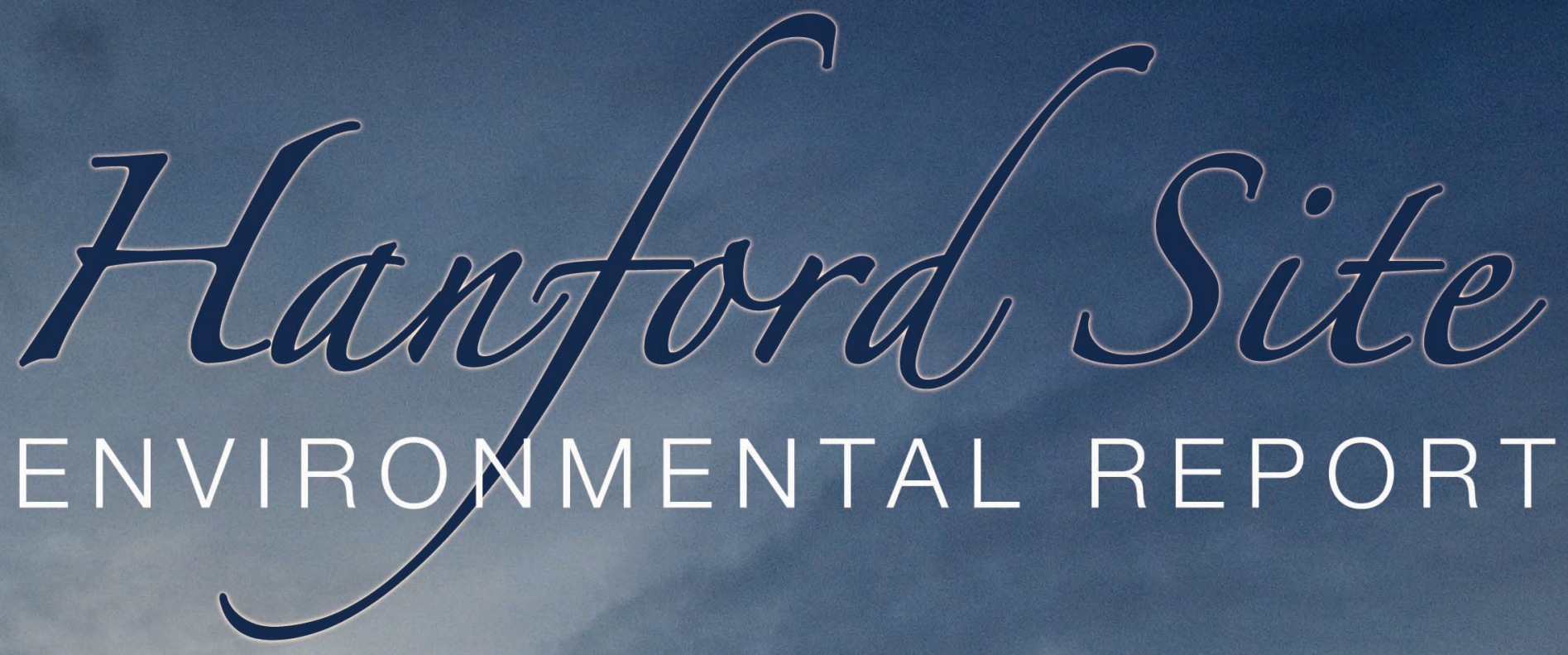
2. $\longrightarrow$ -x........ $=$

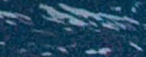




\title{
DISCLAIMER
}

This report was prepared as an account of work sponsored by an agency of the United States Government. Reference herein to any specific commercial product, process, or service by trade name, trademark, manufacturer, or otherwise does not necessarily constitute or imply its endorsement, recommendation, or favoring by the United States Government or any agency thereof, or Battelle Memorial Institute. This report is a summary of major or significant activities occurring at the Hanford Site only, and is not a full disclosure of all details associated with Hanford-related activities, nor a substitute for legally required information subject to reporting requirements regarding releases, violations, etc.

\author{
PACIFIC NORTHWEST NATIONAL LABORATORY \\ operated by \\ BATTELLE \\ for the \\ UNITED STATES DEPARTMENT OF ENERGY \\ under Contract DE-AC05-76RL01830
}

Printed in the United States of America

May be available to DOE and DOE contractors from the

Office of Scientific and Technical Information,

P.O. Box 62, Oak Ridge, TN 37831-0062;

ph: (865) $576-8401$

fax: (865) 576-5728

email: reports@adonis.osti.gov

Available to the public from the National Technical Information Service, U.S. Department of Commerce, 5285 Port Royal Rd., Springfield, VA 22161

ph: (800) 553-6847

fax: (703) 605-6900

email: orders@ntis.fedworld.gov

online ordering: http://www.ntis.gov/ordering.htm

The cover photo shows the setting winter sun trying to penetrate a thick layer of altocumulus and cirrus clouds, providing a dramatic backdrop for Rattlesnake Mountain. Warming temperatures have melted recent snow, leaving a stark contrast in the foreground. Photo is courtesy of S Butner, Pacific Northwest National Laboratory, Richland, Washington. The cover design is by SB Colson, Pacific Northwest National Laboratory, Richland, Washington. 


\section{HANFORD SITE ENVIRONMENTAL REPORT}

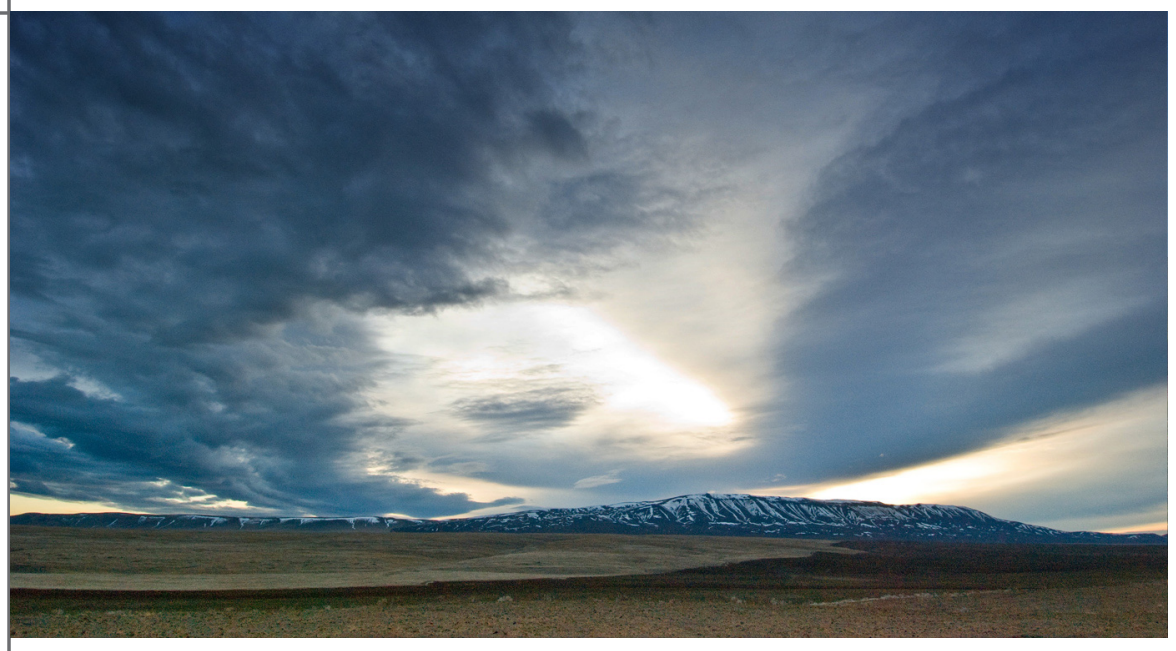

\section{for Calendar Year 2009}

(Including Some Early 2010 Information)

Editors

TM Poston

JP Duncan

RL Dirkes

September 2010

Prepared for the U.S. Department of Energy by personnel from the Pacific Northwest National Laboratory under contract DE-AC05-76RL01830, with contributions from Advanced Technologies and Laboratories International, Inc.; Bechtel National, Inc.;

CH2M HILL Plateau Remediation Company;

Mission Support Alliance, LLC;

Washington Closure Hanford, LLC; and Washington River Protection Solutions LLC

Pacific Northwest National Laboratory Richland, Washington 


\section{Preface}

The Hanford Site environmental report is prepared annually for the U.S. Department of Energy (DOE) in accordance with the requirements in DOE Manual 231.1-1A, "Environment, Safety, and Health Reporting Manual," and DOE Order 231.1A, "Environment, Safety, and Health Reporting." The report provides an overview of activities at the Hanford Site; demonstrates the status of the site's compliance with applicable federal, state, and local environmental laws and regulations, permits, executive orders, and DOE policies and directives; and summarizes environmental data that characterize site environmental management performance. The report also highlights significant environmental and public protection programs and efforts. Some historical and early 2010 information is included where appropriate. More detailed environmental compliance, monitoring, and surveillance information is provided in reports referenced in the text.

Although this report was primarily written to meet DOE reporting requirements and guidelines, it is also intended to provide a broad spectrum of environmental information to DOE managers, the public, Native Americans, public officials, regulatory agencies, Hanford Site contractors, and elected officials. Appendix A lists helpful information to aid the reader, including scientific notation, units of measure, unit conversion information, and nomenclature. Appendix B is a glossary of terms.

The Pacific Northwest National Laboratory's Public Safety and Resource Protection Project produced this report for the DOE Richland Operations Office. Battelle Memorial Institute (Battelle) operates the Pacific Northwest National Laboratory for DOE. Battelle is a non-profit, independent, science and technology contract research institute. Staff from the Pacific Northwest National Laboratory and Mission Support Alliance, LLC wrote major portions of the report. Washington Closure Hanford, LLC; Bechtel National, Inc.; CH2M HILL Plateau Remediation Company; Washington River Protection Solutions LLC; and Advanced Technologies and Laboratories International, Inc. also provided input.

Inquiries regarding this environmental report should be directed to DC (Dana) Ward, DOE Richland Operations Office, P.O. Box 550, MS A5-15, Richland, Washington, 99352 (dana.ward@rl.doe.gov) or to RL (Roger) Dirkes, Pacific Northwest National Laboratory, P.O. Box 999, MS K6-75, Richland, Washington, 99352 (rl.dirkes@pnl. gov).

\section{Report Availability}

This environmental report was produced in both paper and electronic formats. The paper formats include this technical report, two supplemental data appendixes, and a less-detailed summary report (PNNL-19455-SUM). The report is available in portable document format (PDF) on compact disk and electronically at the following website: http://hanford-site.pnl.gov/envreport. Report copies are also available at libraries in communities near the Hanford Site, at several university libraries in Washington and Oregon, and at the DOE's Public Reading Room located at the Washington State University Tri-Cities Consolidated Information Center in Richland, Washington. All versions of the report can be obtained from JP (Joanne) Duncan, Pacific Northwest National Laboratory, P.O. Box 999, MS K6-85, Richland, Washington, 99352 (joanne.duncan@pnl.gov), while supplies last. 


\title{
Summary
}

\author{
JP Duncan
}

Each year, the U.S. Department of Energy (DOE) prepares this integrated Hanford Site Environmental Report in accordance with DOE Order 231.1A, "Environment, Safety and Health Reporting." This report is designed to inform the public, regulators, stakeholders, and other interested parties about Hanford Site environmental performance for the 2009 calendar year. Individual sections provide detail on the following:

- Hanford Site and its mission

- Hanford Site compliance with all applicable DOE, federal, state, and local regulations

- Status and results of Hanford Site cleanup and remediation activities

- Hanford Site environmental management performance

- Hanford Site environmental and groundwater monitoring programs and monitoring data findings

- Potential radiation doses to onsite Hanford Site staff and the public residing in the vicinity

- Data quality assurance methods.

DOE's current mission at the Hanford Site includes site cleanup and remediation and reduction in the amount of land directly controlled by DOE. DOE directs that all activities be performed in compliance with applicable federal, state, and local laws and regulations; DOE Orders; Secretary of Energy Notices; and directives, policies, and guidelines from DOE Headquarters.

\section{Compliance with Federal, State, and Local Laws and Regulations in 2009}

A key feature in the Hanford Site compliance program is the Hanford Federal Facility Agreement and Consent Order, also known as the Tri-Party Agreement. The Tri-Party Agreement is an agreement among the Washington State Department of Ecology, the U.S. Environmental Protection Agency (EPA), and DOE to achieve compliance with the remedial action provisions in the Comprehensive Environmental Response, Compensation, and Liability Act of 1980 (CERCLA) and with treatment, storage, and disposal unit regulations and corrective action provisions in the Resource Conservation and Recovery Act of 1976 (RCRA). The TriParty Agreement has evolved to meet changing conditions as Hanford Site cleanup requirements have progressed. During 2009, there were 55 specific Tri-Party cleanup milestones scheduled for completion: 46 were completed on or before their required due dates; 1 was completed beyond the established due date; 5 were extended beyond 2009, and 3 were not yet complete at the end of the year. Twenty-four negotiated change requests to the Tri-Party Agreement were approved in 2009 (Section 3.0).

RCRA Compliance. Three RCRA non-compliance documents were received at the Hanford Site in 2009; all were resolved with no impact to the environment (Section 5.1.3).

CERCLA Compliance. Field inspections of institutional controls were conducted in 2009 at waste sites on the Hanford Site. No public trespass events occurred and all approved excavation permits were current (Section 5.1.1). 
Pollution Prevention Program. The Pollution Prevention Program (Section 5.6.2) is an organized and continuing effort to reduce the quantity and toxicity of hazardous, radioactive, mixed, and sanitary waste generated at the Hanford Site.

In fiscal year 2009 (October 2008 through September 2009), approximately 4,000 metric tons (4,400 tons) of sanitary and hazardous wastes were recycled through Hanford Sitewide programs administered through the Mission Support Contract.

The Hanford Site Solid Waste Information Tracking System database indicates 197 cubic meters (6,960 cubic feet) of cleanup and stabilization waste (i.e., low-level, mixed low-level, transuranic, and mixed waste as defined by the Toxic Substances Control Act) was generated during fiscal year 2009 with 2.68 metric tons (2.95 tons) of non-radioactive hazardous and Toxic Substances Control Act cleanup and stabilization waste. In fiscal year 2009, 68 metric tons (75 tons) of electronic equipment was transferred or donated for reuse and 61 metric tons (67 tons) were recycled.

Environmental Occurrences. Environmental releases of radioactive and regulated materials from the Hanford Site are reported to DOE and other federal and state agencies as legally required. Six significance categories have been established: operational emergency; recurring; Category 1 (significant impact); Category 2 (moderate impact); Category 3 (minor impact); and Category 4 (some impact). In 2009, two Category 4 events occurred at the Hanford Site (Section 5.7).

Compliance with Cultural Resources Statutes. Cultural resource reviews are performed prior to any federal activity at the Hanford Site. In 2009, two unauthorized excavation incidents were documented as violations of the Archaeological Resources Protection Act of 1979 (Section 8.15).

Table S.1 summarizes Hanford Site work activity compliance with federal statutes in 2009. Chapters 3 and 5 of this report describe compliance in more detail.

\section{Hanford Site Cleanup Operations}

In 1996, when Hanford Site cleanup activities began, the primary focus was on former liquid effluent sites. Progress has reduced the number of liquid effluent sites requiring remediation, allowing current cleanup activities to shift to the remediation of waste burial grounds. The volume of contamination in waste burial grounds is generally less than at liquid effluent waste sites; however, identification, characterization, and disposal of the wastes may involve additional time and scope. During 2009, remediation activities continued in the 100, 200, and 300 Areas, and for Hanford Site groundwater and vadose zone sediments.

Remediation of 100 Areas Waste Sites. Remediation in the 100 Areas during 2009 focused on waste burial grounds and miscellaneous waste sites in the 100-B/C, 100-D, and 100-H Areas (Section 6.1.2.1). A total of 580,500 metric tons (639,900 tons) of contaminated soil from the 100 Areas remediation activities were disposed of at the Environmental Restoration Disposal Facility (near the 200-West Area) during 2009. The majority of the contaminated soil was from the 100-D and 100-H Areas.

Pump-and-treat systems continued to help remove contaminants from the groundwater beneath the 100 Areas in 2009 (Table S.2).

K Basins Closure Activities. For nearly 30 years, the K Basins stored 2,100 metric tons (2,300 tons) of Hanford $\mathrm{N}$ Reactor spent fuel and a small quantity of irradiated fuel from older Hanford Site reactors. The fuel was removed by 2004, but fuel corrosion over the years left behind sludge and debris. During 2009, K Basins cleanup continued with debris removal from both the K-East and K-West Basins. The K-East Basin was demolished in September 2009; the entire structure and basins were removed and disposed of at the Environmental Restoration Disposal Facility. The former site is undergoing active soil remediation. 


\section{Table S.1. Status of Compliance with Federal Acts on the Hanford Site in 2009}

\section{Regulation}

American Indian Religious Freedom

Act; Antiquities Act of 1906

Archaeological and Historic

Preservation Act of 1974;

Archaeological Resources Protection

Act of 1979; Historic Sites Act

Preservation Act of 1966; and

Native American Graves Protection

and Repatriation Act of 1990

Atomic Energy Act of 1954

Atomic Energy Act of 1954

Clean Air Act

Point-source discharges to

U.S. surface waters.

Proper management of radioactive materials.

Air quality, including emissions from facilities and unmonitored sources. of 1935; National Historic

Clean Water Act of 1977

\section{Status}

During 2009, 167 cultural resource reviews were requested on the Hanford Site. DOE determined that 154 activities would not affect cultural resources and were exempt from further review; the remaining 13 requests required full reviews. Fifty-one cultural resources sites were visited in 2009 to assess the effects of erosion, weathering, and unauthorized excavation and collection. Ten new archaeological sites or new isolated finds were recorded on the Hanford Site in 2009

Two unauthorized excavation incidents were documented as Archaeological Resources Protection Act of 1979 violations.

In 2009, two DOE regulations and directives pertaining to the management and control of radioactive materials on the Hanford Site were issued or underwent significant revision. In addition, five technical standards or handbooks underwent revision.

In coordination with the Washington State Department of Health and the Benton Clean Air Agency, the Washington State Department of Ecology issued Renewal 1 of the Hanford Site air operating permit for a period of 5 years, effective January 1, 2007. One revision to the air operating permit was approved in 2009. The Washington State Department of Health, the Washington State Department of Ecology, and the Benton Clean Air Agency conducted over 25 inspections in 2009; all were in compliance.

The Hanford Site has one National Pollutant Discharge Elimination System permit, one storm water permit, and several state sanitary wastewater discharge permits. There were no permit violations in 2009.

Comprehensive Environmental Response, Compensation, and

Sites already contaminated by hazardous materials.

Institutional controls are implemented and maintained in accordance with CERCLA decision documents. During 2009, field inspections of institutional controls at waste sites were performed in the 100-B/C 100-D, 100-H, 100-N Areas, and the 618-13 waste site in the 300 Area. Warning sign information was updated at the 100-D Area in response to these inspections. No public trespass events occurred in 2009, and approved excavation permits were in use.

Emergency Planning and Community Right-to-Know Act of 1986
The public's right to information about hazardous materials in the community and the establishment of emergency planning procedures.
In early 2010, Hanford Site officials issued the 2009 Hanford Site Tier Two Emergency and Hazardous Chemical Inventory report to the Washington State Department of Ecology's Community RightTo-Know Unit; local emergency planning committees for Benton, Franklin, and Grant Counties; and both the city of Richland and Hanford Site fire departments. The 2009 Hanford Site Toxic Chemical Release Inventory was released June 24, 2010.

Numerous plants and animals on the Hanford Site are federal- or state-listed as endangered, threatened, sensitive, or candidate species. Ecological compliance reviews are conducted prior to project initiation on the Hanford Site to prevent adverse impacts to biological resources, including listed species. In 2009, 286 reviews were performed, including 164 ecological compliance reviews for general site activities and 122 reviews for environmental restoration activities.

Federal Insecticide, Fungicide, and Storage and use of pesticides. Rodenticide Act

Migratory Bird Treaty Act
Migratory birds or their feathers, nests, or eggs.
On the Hanford Site, pesticides are applied by commercial pesticide operators licensed by the state.

All Hanford Site projects with a potential to affect federal- or statelisted species of concern complied with the requirements of this Act by using the ecological compliance review process to minimize adverse impacts to migratory birds. 
Table S.1. (contd)

\begin{tabular}{|c|c|c|}
\hline Regulation & What It Covers & 2009 Status \\
\hline $\begin{array}{l}\text { National Environmental Policy Act of } \\
1969 \text { (NEPA) }\end{array}$ & $\begin{array}{l}\text { Environmental impact statements for } \\
\text { major federal projects that have the } \\
\text { potential to significantly affect the } \\
\text { quality of the human environment. }\end{array}$ & $\begin{array}{l}\text { In October 2009, DOE released the Draft Tank Farm Closure and } \\
\text { Waste Management Environmental Impact Statement for the Hanford } \\
\text { Site, Richland, Washington for review and comment. Scope includes } \\
\text { tank waste treatment, single-shell tank closure, reanalysis and } \\
\text { integration of groundwater impacts, reanalysis of onsite disposal } \\
\text { alternatives, and decommissioning of the Fast Flux Test Facility. }\end{array}$ \\
\hline Pollution Prevention Act of 1990 & $\begin{array}{l}\text { Reduction or prevention of wastes } \\
\text { by treatment, control, reuse, } \\
\text { and/or recycling. }\end{array}$ & $\begin{array}{l}\text { In } 2009,3,990 \text { metric tons ( } 4,400 \text { tons) of sanitary and hazardous } \\
\text { wastes were recycled through side-wide programs administered } \\
\text { through the Mission Support Contract on the Hanford Site. }\end{array}$ \\
\hline $\begin{array}{l}\text { Resource Conservation and } \\
\text { Recovery Act of } 1976 \text { (RCRA) }\end{array}$ & $\begin{array}{l}\text { Tracking hazardous waste from } \\
\text { generator to treatment, storage, or } \\
\text { disposal (referred to as cradle-to- } \\
\text { grave management). }\end{array}$ & $\begin{array}{l}\text { DOE is operating under an expired facility RCRA permit at the } \\
\text { Hanford Site while the Washington State Department of Ecology } \\
\text { drafts a new permit. During 2009, two revisions to the Hanford } \\
\text { Facility RCRA Permit Part A Form were submitted to the state for } \\
\text { review and approval. Washington State Department of Ecology } \\
\text { performed } 10 \text { RCRA inspections on the Hanford Site during } 2009 \text { to } \\
\text { assess compliance with applicable requirements. Three RCRA non- } \\
\text { compliance documents were received at the Hanford Site in 2009: } \\
\text { 1) Notice of Non-Compliance at the } 331 \text {-C Facility regarding training } \\
\text { and dangerous waste record-keeping; 2) Notice of Non-Compliance } \\
\text { for failure to provide secondary containment at the Waste Receiving } \\
\text { and Processing Facility; and 3) violations regarding labeling and } \\
\text { dating of recyclables at the } 616 \text { Waste Handling Facility. All issues } \\
\text { were resolved with no impact to the environment. }\end{array}$ \\
\hline Safe Drinking Water Act of 1974 & Drinking water systems. & $\begin{array}{l}\text { There were nine drinking water systems on the Hanford Site in } \\
2009 \text {. The systems were monitored for radiological and chemical } \\
\text { contaminants and disinfection residuals and byproducts. There } \\
\text { were no microbiological detections during } 2009 \text {, and all chemical } \\
\text { concentrations in Hanford Site drinking water were well below } \\
\text { the maximum contaminant levels established by the EPA. Systems } \\
\text { demonstrated compliance with the filtration and disinfection treat- } \\
\text { ment technique requirements and limits for disinfectant residuals and } \\
\text { disinfection byproducts. }\end{array}$ \\
\hline Toxic Substances Control Act & $\begin{array}{l}\text { Hazardous chemical regulation and } \\
\text { tracking; primarily polychlorinated } \\
\text { biphenyls (PCBs). }\end{array}$ & $\begin{array}{l}\text { During 2009, the } 2008 \text { PCB annual document log report for the } \\
\text { Hanford Site and a } 2008 \text { PCB annual report were submitted to } \\
\text { the EPA as required. EPA-approved risk-based disposal approvals } \\
\text { were used in } 2009 \text { for retrieving waste from selected single-shell } \\
\text { underground waste storage tanks; for the management of sludge } \\
\text { from the K Basins; and continued storage of two water tower tanks } \\
\text { containing PCB-contaminated paint. }\end{array}$ \\
\hline
\end{tabular}

DOE = U.S. Department of Energy.

$\mathrm{EPA}=$ U.S. Environmental Protection Agency.

The K-West Basin is undergoing cleanout that involves the removal of radioactive contaminated sludge and debris as a precursor to facility deactivation and demolition. Floor and pit sludge was containerized and stored in underwater containers in the basin. Sludge characterization and removal alternatives for K-West Basin were evaluated in 2009. Further information on $\mathrm{K}$ Basins remediation and closure activities is in Section 6.1.2.2.

\section{Remediation of Waste Sites on the Central Plateau.}

Remedial investigation or feasibility study activities continued on waste sites at the Hanford Site Central Plateau in 2009. Pipeline sampling, geophysical logging, direct-push technology evaluations, and characterization drilling were performed at several operable units, and feasibility studies and proposed plans were issued for several sites. Descriptions of these activities are in Section 6.1.1. 
Pump-and-treat systems and a soil-vapor extraction system continued to remove contaminants from the groundwater and vadose zone beneath the 200 Areas in 2009 (Table S.2).

Remediation of 300 Area Waste Sites. Remediation efforts in 2009 focused on the 300-FF-2 Operable Unit waste sites; activities at these waste sites began in 2002. In 2009, 8,650 metric tons (95,300 tons) of contaminated soil from the 300-FF-2 Operable Unit was removed and disposed of at the Environmental Restoration Disposal Facility. Remediation of the 618-1 Burial Ground, located in the northern 300 Area, continued and is scheduled for completion in 2010. Non-intrusive characterization field activities were conducted at the 618-10 Burial Ground, located west of the 300 Area, in 2009. Descriptions of these activities are in Section 6.1.3.

\section{Facility Decommissioning and Deactivation Activities}

Decommissioning of 100 Areas Facilities. During 2009, 100 Areas deactivation, decontamination, decommissioning, and demolition activities focused on the 100-N Area, where several buildings, a lift station, tower, and above and below grade rooms of the 105-N/109-N Reactor Building Complex were demolished. In addition, safe storage enclosure preparations for the 105-N/109-N Reactor Building Complex continued through 2009 (Section 6.2.4).

Table S.2. Summary of Groundwater Pump-and-Treat Systems and a Vadose Zone Soil-Vapor Extraction System

\begin{tabular}{|c|c|c|c|c|}
\hline Location & $\begin{array}{l}\text { Startup } \\
\text { Date }\end{array}$ & $\underline{\text { Contaminant }}$ & $\begin{array}{l}\text { Mass Removed } \\
\underline{\underline{2009}}\end{array}$ & $\begin{array}{l}\text { Mass Removed } \\
\text { Since Startup }\end{array}$ \\
\hline $\begin{array}{l}\text { 100-D Area (100-DR-5 Pump- } \\
\text { and-Treat System) }\end{array}$ & 2004 & Chromium & $\begin{array}{l}44.2 \text { kilograms } \\
\text { (97.4 pounds) }\end{array}$ & $\begin{array}{l}251.3 \text { kilograms } \\
\text { (554 pounds) }\end{array}$ \\
\hline $\begin{array}{l}\text { 100-D and 100-H Areas } \\
(100-H R-3 \text { Pump-and-Treat } \\
\text { System })^{(a)}\end{array}$ & 1997 & Chromium & $\begin{array}{l}15.9 \text { kilograms } \\
\text { (35.1 pounds) }\end{array}$ & $\begin{array}{l}362 \text { kilograms } \\
\text { (798 pounds) }\end{array}$ \\
\hline $\begin{array}{l}\text { 100-K Area (100-KR-4 } \\
\text { Pump-and-Treat System) }\end{array}$ & 1997 & Chromium & $\begin{array}{l}7.78 \text { kilograms } \\
\text { (17.2 pounds) }\end{array}$ & $\begin{array}{l}347.5 \text { kilograms } \\
\text { (766.1 pounds) }\end{array}$ \\
\hline $\begin{array}{l}\text { 100-K Area (KX Pump-and- } \\
\text { Treat System) }\end{array}$ & 2008 & Chromium & $\begin{array}{l}39.7 \text { kilograms } \\
\text { (87.5 pounds) }\end{array}$ & $\begin{array}{l}43.6 \text { kilograms } \\
\text { (96.1 pounds) }\end{array}$ \\
\hline $\begin{array}{l}\text { 100-K Area (Pump-and-Treat } \\
\text { System near K-West Reactor) }\end{array}$ & 2007 & Chromium & $\begin{array}{l}49.25 \text { kilograms } \\
\text { (108.6 pounds) }\end{array}$ & $\begin{array}{l}83.28 \text { kilograms } \\
\text { (183.6 pounds) }\end{array}$ \\
\hline $\begin{array}{l}\text { 200-West Area (200-ZP-1 } \\
\text { Pump-and-Treat System) }\end{array}$ & 1994 & Carbon tetrachloride & $\begin{array}{l}374 \text { kilograms } \\
\text { (825 pounds) }\end{array}$ & $\begin{array}{l}11,960 \text { kilograms } \\
(26,400 \text { pounds) }\end{array}$ \\
\hline $\begin{array}{l}\text { 200-West Area (241-T Pump- } \\
\text { and-Treat System) }\end{array}$ & 2007 & Technetium-99 & $\begin{array}{l}22.7 \text { grams } \\
\text { (0.8 ounce) }\end{array}$ & $\begin{array}{l}48.25 \text { grams } \\
\text { (1.7 ounces) }\end{array}$ \\
\hline \multirow[t]{4}{*}{$\begin{array}{l}\text { 200-West Area (200-UP-1 } \\
\text { Pump-and-Treat System) }\end{array}$} & 1994 & Carbon tetrachloride & $\begin{array}{l}2.58 \text { kilograms } \\
\text { (5.7 pounds) }\end{array}$ & $\begin{array}{l}40.33 \text { kilograms } \\
\text { (88.9 pounds) }\end{array}$ \\
\hline & & Nitrate & $\begin{array}{l}6,044 \text { kilograms } \\
(13,300 \text { pounds })\end{array}$ & $\begin{array}{l}47,575 \text { kilograms } \\
(104,900 \text { pounds })\end{array}$ \\
\hline & & Technetium-99 & $\begin{array}{l}2.5 \text { grams } \\
\text { (0.09 ounce) }\end{array}$ & $\begin{array}{l}126 \text { grams } \\
(0.28 \text { pound })\end{array}$ \\
\hline & & Uranium & $\begin{array}{l}2.98 \text { kilograms } \\
\text { (6.6 pounds) }\end{array}$ & $\begin{array}{l}219.5 \text { kilograms } \\
\text { (484 pounds) }\end{array}$ \\
\hline $\begin{array}{l}\text { Waste Management } \\
\text { Area S-SX Extended Purging }\end{array}$ & 2003 & Technetium-99 & $\begin{array}{c}0.116 \text { gram } \\
\text { (0.004 ounce) }\end{array}$ & $\begin{array}{l}0.495 \text { gram } \\
\text { (0.02 ounce) }\end{array}$ \\
\hline $\begin{array}{l}\text { 200-West Area (Soil-Vapor } \\
\text { Extraction System) }\end{array}$ & 1991 & Carbon tetrachloride & $\begin{array}{l}177 \text { kilograms } \\
\text { (390.2 pounds) }\end{array}$ & $\begin{array}{l}79,557 \text { kilograms } \\
\text { (175,393 pounds) }\end{array}$ \\
\hline
\end{tabular}

(a) The 100-HR-3-D and 100-HR-3-H pump-and-treat systems were combined in 2009 and designated as 100-HR-3 (DOE/RL-2010-11, Rev. 0). 


\section{Decommissioning of Facilities on the Central Plateau.} The transition and decommissioning of facilities on the Central Plateau continued in 2009. Activities at the Plutonium Finishing Plant included de-inventory of all special nuclear materials; continued cleanout of contaminated equipment; and disposition of excess chemical items and removable combustibles (Section 6.2.1.1). Additional activities conducted on the Central Plateau included surveillance, maintenance, and decontamination or stabilization of over 1,000 waste sites, including former waste disposal cribs, ponds, ditches, trenches, unplanned release sites, and waste burial grounds in the 200-East, 200-West, and 200-North Areas and the Fitzner/Eberhardt Arid Lands Ecology Reserve Unit. Periodic surveillances, radiation surveys, and herbicide and pesticide applications were also conducted (Section 6.2.1.2).

Decommissioning of $\mathbf{3 0 0}$ Area Facilities. During 2009, 300 Area deactivation, decontamination, decommissioning, and demolition activities continued to focus on removing physical barriers to performing remedial actions in the 300-FF-2 Operable Unit. Eight facilities and buildings were demolished in the 300 Area in 2009 (Section 6.2.2).

\section{Deactivation of 400 Area Facilities - Fast Flux Test}

Facility. After multiple studies, a final decision was made by DOE to complete facility deactivation, including removing all nuclear fuel, draining the sodium systems, and deactivating systems and equipment to place the facility in a low-cost, long-term surveillance and maintenance condition, which was completed in June 2009. Deactivation activities included shipment of a polychlorinated biphenyl (PCB)-laden transformer for disposal; shipment of irradiated waste to the Environmental Restoration Disposal Facility; the shutdown of operating systems (electric, fire suppression, water, ventilation, etc.); and cleanout and closure of the reactor containment building and supporting facilities (Section 6.2.3).

\section{Waste Management}

Hanford Site cleanup activities generate non-regulated, radioactive, non-radioactive, mixed, and hazardous waste (Chapter 6). Mixed waste contains both radioactive and hazardous non-radioactive substances. Hazardous waste contains either dangerous waste or extremely hazardous waste, or both. This waste is handled and prepared for safe storage onsite or shipped to offsite facilities for treatment and disposal. Table S.3 provides a summary of waste stored, generated, and treated at the Hanford Site or received from offsite sources in 2009.

In addition to newly generated waste, significant quantities of legacy waste remain from years of nuclear materials production and waste management activities. Most legacy waste from past operations at the Hanford Site resides in RCRA-compliant waste sites or is stored in places pending treatment and ultimate safe storage or disposal. Examples include high-level radioactive waste stored in single-shell and double-shell underground waste storage tanks, and transuranic waste stored in vaults and on storage pads (Sections 6.3 and 6.4).

Solid Waste Management. Waste management at the Hanford Site in 2009 included the treatment, storage, and disposal of solid waste at many site locations (Section 6.3.3). Onsite solid waste facilities include the Central Waste Complex, Waste Receiving and Processing Facility, T Plant Complex, Environmental Restoration Disposal Facility, low-level burial grounds, and the Waste Encapsulation and Storage Facility.

The Central Waste Complex, located in the 200-West Area, receives waste from Hanford Site sources and any offsite sources authorized by DOE to ship waste to the site for treatment, storage, and disposal. Ongoing cleanup and research and development activities at the Hanford Site generate most of the waste received at the Central Waste Complex. Waste received includes low-level, transuranic, or mixed waste, and radioactive waste contaminated with PCBs.

The Central Waste Complex can store as much as 20,800 cubic meters (735,000 cubic feet) of low-level mixed waste and transuranic waste (Section 6.3.3.1). This capacity is adequate to store generated waste volumes, assuming on-schedule treatment of the stored waste. Treatment reduces the amount of waste in storage and makes room for newly generated mixed waste. The dangerous waste designation for each waste container is established at the point-of-origin based on process knowledge or sample analysis. The volume of waste stored at this complex in 2009 totaled approximately 2,900 cubic meters (102,800 cubic feet). 
Table S.3. Hanford Site Waste Summary for 2009

Activity

Solid waste generated during onsite cleanup activities
Waste Type

Solid mixed waste

Radioactive waste

Solid mixed waste

Solid waste received at the Hanford Site from offsite (includes Hanford Site generated waste treated by an offsite contractor and returned to the site as newly generated waste)

\begin{tabular}{|c|c|}
\hline Waste Type & Amount \\
\hline \multirow[t]{2}{*}{ Solid mixed waste } & 255,000 kilograms \\
\hline & (281 tons) \\
\hline \multirow[t]{2}{*}{ Radioactive waste } & 632,000 kilograms \\
\hline & (696 tons) \\
\hline \multirow[t]{2}{*}{ Solid mixed waste } & 233,000 kilograms \\
\hline & (257 tons) \\
\hline \multirow[t]{2}{*}{ Radioactive waste } & 178,000 kilograms \\
\hline & (196 tons) \\
\hline \multirow{2}{*}{$\begin{array}{l}\text { Containerized waste } \\
\text { (dangerous waste only) }\end{array}$} & 42,800 kilograms \\
\hline & (47 tons) \\
\hline \multirow[t]{2}{*}{ Bulk solids } & 74,800 kilograms \\
\hline & (83 tons) \\
\hline \multirow[t]{2}{*}{ Bulk liquids } & 2,050 kilograms \\
\hline & (2 tons) \\
\hline \multirow[t]{2}{*}{ Liquid waste } & 386 thousand liters \\
\hline & (102 thousand gallons) \\
\hline \multirow[t]{2}{*}{ Liquid waste } & 112 million liters \\
\hline & (29.7 million gallons) \\
\hline \multirow[t]{2}{*}{ Liquid waste } & 1,230 thousand liters \\
\hline & (325 thousand gallons) \\
\hline \multirow[t]{2}{*}{ Liquid waste } & 98.3 million liters \\
\hline & (26.0 million gallons) \\
\hline \multirow[t]{2}{*}{ Solid waste } & 164 cubic meters \\
\hline & (5,800 cubic feet) \\
\hline \multirow[t]{2}{*}{ Mixed low-level solid waste } & 1,000 cubic meters \\
\hline & $(35,500$ cubic feet) \\
\hline \multirow[t]{2}{*}{ Solid waste } & 844,000 metric tons \\
\hline & (930,000 tons) \\
\hline \multirow{2}{*}{$\begin{array}{l}\text { Wastewater containing low levels } \\
\text { of organic compounds and tritium }\end{array}$} & 96.2 million liters \\
\hline & (25.4 million gallons) \\
\hline \multirow{2}{*}{$\begin{array}{l}\text { Wastewater containing toxic } \\
\text { metals, radionuclides, ammonia, } \\
\text { and organic compounds }\end{array}$} & 83 million liters \\
\hline & (22 million gallons) \\
\hline \multirow{2}{*}{$\begin{array}{l}\text { Liquid waste from single-shell } \\
\text { tanks }\end{array}$} & 3.6 million liters \\
\hline & (960 thousand gallons) \\
\hline \multirow{2}{*}{$\begin{array}{l}\text { Uncontaminated, treated liquid } \\
\text { waste }\end{array}$} & 1,300 million liters \\
\hline & (340 million gallons) \\
\hline \multirow[t]{2}{*}{ Industrial wastewater } & 98 million liters \\
\hline & (26 million gallons) \\
\hline
\end{tabular}

Waste volume pumped from underground single-shell waste storage tanks to double-shell waste storage tanks (includes flush/dilution water)

Waste volume in underground single-shell waste storage tanks at the end of 2009

Waste added to underground double-shell waste storage tanks

Waste volume in underground double-shell waste storage tanks at the end of 2009

Waste dispositioned and shipped offsite from the Waste Receiving and Processing Facility

Waste treated or directly disposed of in Trenches 31 and 34

a

Dangerous waste shipped off the Hanford Site

\section{Containerized waste}

Bulk solids

Bulk liquids

Liquid waste

112 million liters

1,230 thousand liters

325 thousand gallons

98.3 million liters

164 cubic meters

$(5,800$ cubic feet

Waste disposed of at the Environmental Restoration Disposal Facility

Volume of aqueous waste received at the Liquid Effluent Retention Facility

Volume of liquid effluent treated at the Effluent Treatment Facility

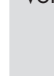

Volume of wastewater treated (evaporated) at the 242-A Evaporator

Volume of effluent disposed of at the 200 Area Treated Effluent Disposal Facility

Volume of wastewater treated and disposed of at the 300 Area Treated

Effluent Disposal Facility

1,000 cubic meters

4,000 metric ton

96.2 million liters

83 million liters

3.6 million liters thousand gallons

1,300 million liters

98 million liters

(26 million gallons) 
Waste destined for the Waste Receiving and Processing Facility includes stored waste as well as newly generated waste from current Hanford Site cleanup activities. The waste consists primarily of contaminated cloth, paper, rubber, metal, and plastic. This facility, which began operating in 1997, dispositioned and shipped 164 cubic meters (5,800 cubic feet) of waste offsite in 2009 (Section 6.3.3.2).

The T Plant Complex in the 200-West Area provides waste treatment, storage, and decontamination services for the Hanford Site, as well as for offsite facilities (Section 6.3.3.3). In 2009, nine hundred and forty-nine 208-liter (55-gallon) drum equivalents of transuranic waste were repackaged to meet offsite waste acceptance criteria.

The Environmental Restoration Disposal Facility serves as the central disposal site for contaminated waste removed during Hanford Site cleanup operations conducted under CERCLA regulations. During 2009, approximately 844,000 metric tons (930,000 tons) of remediation waste were disposed of at the Environmental Restoration Disposal Facility. Approximately 8 million metric tons $(9$ million tons) of remediation waste have been disposed of from initial operations startup through 2009 (Section 6.3.3.4).

The low-level burial grounds consist of eight burial grounds located in the 200-East and 200-West Areas that are used for disposal of low-level waste and mixed waste (i.e., lowlevel radioactive waste with a dangerous waste component). The low-level burial grounds have been operational under a RCRA Part A permit since 1985. Transuranic waste has not been placed in the low-level burial grounds without specific DOE approval since August 19, 1987. On June 23, 2004, DOE issued a record of decision for the Solid Waste Program at the Hanford Site. Part of the record of decision stated that DOE will dispose of low-level waste in lined disposal facilities. Only two of the low-level burial ground trenches are lined (Trenches 31 and 34); therefore, since that date, all low-level waste as well as mixed low-level waste has been disposed of in these two trenches. Disposal of U.S. Navy reactor compartments (Section 6.3.3.7) in the low-level burial grounds is not affected by this record of decision. In 2009, a total of 1,000 cubic meters (35,500 cubic feet) of waste was disposed of in Trenches 31 and 34 , and 675 cubic meters (23,000 cubic feet) of retrievably stored waste were retrieved from the low-level burial grounds (Section 6.3.3.5).
The Waste Encapsulation and Storage Facility stores strontium and cesium encapsulated salts in double containment stainless-steel capsules in underwater pool cells, providing safe storage. The water provides cooling and shielding for the capsules that are considered sealed sources. As a storage-only unit, the Waste Encapsulation and Storage Facility did not generate regulated wastes in 2009 (Section 6.3.3.6).

Two defueled reactor compartment from the U.S. Navy were shipped to Trench 94 in the 200-East Area in 2009, bringing the total number of U.S. Navy reactor compartments received to 120 (Section 6.3.3.7).

The Integrated Disposal Facility (currently not operational), located in the south-central 200-East Area, is an expandable RCRA hazardous waste-compliant landfill. The facility will receive immobilized low-activity tank waste and other lowlevel radioactive waste from the Hanford Tank Waste Treatment and Immobilization Plant. Waste disposal capacity is approximately 163,000 cubic meters (5.76 million cubic feet) (Section 6.3.3.8).

Liquid Waste Management. Liquid effluent is managed in facilities to comply with federal and state regulations and facility permits (Section 6.3.4).

The Effluent Treatment Facility in the 200-East Area treats liquid effluent to remove toxic metals, radionuclides, and ammonia, and destroy organic compounds. The treated effluent is stored in tanks, sampled and analyzed, and discharged to the State-Approved Land Disposal Site (also known as the 616-A Crib). The volume of wastewater treated and disposed of in 2009 was approximately 83 million liters (22 million gallons) (Section 6.3.4.1).

Approximately 64 million liters (17 million gallons) of liquid waste were stored at the Liquid Effluent Retention Facility at the end of 2009 (Section 6.3.4.2). The volume of wastewater received for interim storage in 2009 was approximately 96 million liters ( 25 million gallons). The volume of wastewater transferred from this facility to the Effluent Treatment Facility for treatment in 2009 was approximately 84 million liters ( 22 million gallons).

In 2009, the 200 Area Treated Effluent Disposal Facility disposed of 1,300 million liters (340 million gallons) of 
unregulated effluent. The major source of this effluent was uncontaminated cooling water from various Hanford Site facilities and steam condensate from the 242-A Evaporator (Section 6.3.4.3).

Industrial wastewater generated primarily from laboratories, research facilities, and office buildings in the 300 Area is collected and treated in the 300 Area Treated Effluent Disposal Facility (Section 6.3.4.4). The wastewater consists of cooling water, steam condensate, and other industrial wastewater. The volume of industrial wastewater treated and disposed of during 2009 was 98 million liters (26 million gallons). This facility was permanently shut down in September 2009.

The 242-A Evaporator in the 200-East Area concentrates diluted liquid tank waste by evaporation. This reduces the volume of liquid waste sent to the double-shell tanks for storage and reduces the potential need for more doubleshell tanks (Section 6.3.4.5). In 2009, the 242-A Evaporator completed a successful operating campaign that reduced the volume of waste in two double-shell storage tanks by more than 3.6 million liters (960,000 gallons).

Underground Waste Storage Tanks. In 2009, 386,000 liters (102,000 gallons) of liquid waste (including water used in waste retrieval activities) were pumped from the single-shell tanks to the double-shell tanks, leaving 112 million liters (30 million gallons) of waste remaining in the single-shell tanks. At the end of 2009, there were 98 million liters (26 million gallons) of waste in the doubleshell tanks (Section 6.4).

\section{Hanford Tank Waste Treatment and Immobilization} Plant. The Hanford Tank Waste Treatment and Immobilization Plant is being built on 26 hectares (65 acres) adjacent to the 200-East Area to treat radioactive and hazardous waste currently stored in 177 underground tanks. Four major facilities are being constructed: a pretreatment facility, a high-level waste vitrification facility, a low-activity waste vitrification facility, and an analytical laboratory, as well as supporting facilities. Construction of these facilities continued in 2009 (Section 6.5).

\section{Radiological Release of Property from the Hanford Site}

No property with detectable residual radioactivity above authorized levels was released from the Hanford Site in 2009 (Section 7.0.1).

Radiological Clearance for Ion-Exchange Resin for Offsite Shipment and Regeneration. Ion-exchange resin is currently in use to remove hexavalent chromium from groundwater. Once saturated, the spent resin — which may contain radioactive elements - is removed and readied for shipment to an offsite facility for regeneration and reuse. In 2009 , approximately 62,500 kilograms ( 138,000 pounds) of resin was shipped offsite for regeneration under authorized limits (Section 7.0.1.2).

Radiological Clearance for Granular Activated Carbon for Offsite Shipment and Regeneration. A soil-vapor extraction system that uses granular activated carbon to remove carbon tetrachloride from groundwater in the unconfined aquifer has been operational for over 10 years. When the granulated activated carbon canister has reached volatile organic compound saturation, it is removed from the system and shipped to an offsite facility for regeneration and reuse. In 2009, 16,400 kilograms (36,000 pounds) of granular activated carbon was shipped offsite for regeneration under authorized limits (Section 7.0.1.3).

\section{Columbia River Corridor Assessment and Integration}

Sampling of upland, riparian, and near-shore environments for the River Corridor Baseline Risk Assessment was conducted in 2006 and 2007. Results are being used to prepare the River Corridor Baseline Risk Assessment (Draft B), which is scheduled for regulatory and stakeholder review in 2010 (Section 7.0.2.1). An enhanced characterization of risks associated with groundwater will also be included in the report that support recommendations for final cleanup decisions at source and groundwater units within the River Corridor. 
A remedial investigation under CERCLA has been initiated to evaluate the potential impacts to the Columbia River from Hanford Site-related hazardous substances. Following completion of field work and compilation of all analytical data, baseline ecological and human-health risk assessments will be conducted to estimate the current risk to humans, animals, and plants; determine any potential impacts from Hanford Site-related contaminants; and whether cleanup actions are needed (Section 7.0.2.1).

\section{Columbia River Corridor Long-Term Stewardship}

Columbia River Corridor long-term stewardship focuses on achieving end-state closure and transition of the River Corridor. Elements include risk assessment activities, orphan site evaluations, remedial action reports, and long-term stewardship plans that will provide a basis for independent closure reviews of the 100 and 300 Areas by independent experts. In 2009, orphan site evaluations were completed and reports issued for the 100-D Area, 100-K Area, 100-H Area, 100-N Area, and the 100-IU-2 and 100-IU-6 Operable Units. Evaluations were also initiated for the 300 Area, 400 Area, and Inter-Areas Segments 1 and 2.

\section{Environmental and Resource Protection Programs}

DOE Orders require that environmental monitoring programs be conducted at the Hanford Site to verify protection of the public and site workers, comply with government regulations, and protect the site's environmental and cultural resources. Programs and projects include Effluent and NearFacility Environmental Monitoring Programs, Public Safety and Resource Protection Projects, the Soil and Groundwater Remediation Project, the Drinking Water Monitoring Project, the Biological Control Program, and the Washington State Department of Health Oversight Monitoring Program (Section 8.0; Table S.4).

\section{Air Emissions}

Hanford Site contractors monitor airborne emissions from site facilities to assess the effectiveness of emission treatment and control systems, pollution management practices, and determine compliance with state and federal regulatory requirements. Small quantities of tritium, strontium-90, iodine-129, cesium-137, plutonium-238, plutonium-239/240, plutonium-241, americium-241, and a few other isotopes are released at state and federally permitted discharge points (usually stacks or vents) in the 100,200,300, 400, and 600 Areas of the Hanford Site (Section 8.1.1).

Non-radioactive air pollutants are emitted from powergenerating and chemical-processing facilities. These facilities are monitored when activities are known to generate potential pollutants of concern, which include carbon monoxide, gaseous ammonia, lead, nitrogen oxides, particulate matter, sulfur oxides, and volatile organic compounds (Section 8.1.2).

Air emissions data collected in 2009 were comparable to those collected in 2008.

\section{Ambient-Air Monitoring}

Radioactive constituents in air are monitored on the Hanford Site near facilities and operations, at site-wide locations away from facilities, and offsite around the site perimeter and in nearby and distant communities.

Ambient-Air Monitoring Near Facilities and Operations. In 2009, ambient air was monitored at 84 locations on the Hanford Site near facilities and operations (Section 8.2.1). Samplers were located primarily at or within approximately 500 meters (1,640 feet) of sites or facilities having the potential for, or a history of, environmental releases. Samples were collected biweekly and analyzed. The 2009 data indicate a large degree of variability by location.

Samples collected from locations at or directly adjacent to Hanford Site facilities had higher radionuclide concentrations than samples collected farther away. In general, analytical results for most radionuclides were at or near Hanford Site background levels, which are much less than EPA concentration limits but greater than those measured offsite. The data also show that concentrations of certain radionuclides were higher and widely variable within different onsite operational areas. Naturally occurring beryllium-7 and potassium- 40 were routinely identified.

Several samples from the $100-\mathrm{K}$ and 200 Areas had results greater than $10 \%$ of EPA's concentration values. Elevated 
Table S.4. Summary of Contaminant Monitoring On and Around the Hanford Site, 2009

\section{What Was Monitored?}

Rir Radioactive and non-radioactive emissions were
monitored at Hanford Site facilities. Air particles
and gases were monitored for radioactivity onsite
near facilities and offsite. Ambient-air samples were
collected at 84 locations near Hanford Site facilities,
at 23 locations around the site away from facilities,
at 11 site perimeter locations, at 7 nearby community
locations, and at 1 distant community location.

Columbia River Water and Sediment

Columbia River water and sediment samples were collected from multiple Hanford Reach sampling points and from locations upstream and downstream of the Hanford Site. The samples were analyzed for radioactive and chemical contaminants.

Columbia River Shoreline Spring Water and

Sediment

Groundwater beneath the Hanford Site discharges to the Columbia River along the Hanford Site shoreline. Discharges above the water level of the river are identified as shoreline springs. Samples of spring water and sediment were collected at locations along the Hanford Reach.

\section{The Bottom Line}

Radionuclide levels near facilities in 2009 were generally similar to measurements from previous years. One cesium-137 result from the 200-East Area, two plutonium-239/240 results from the 200-West Area, as well as strontium-90, cesium-137, plutonium-239/240, and americium-241 results from the $100-\mathrm{K}$ Area were greater than $10 \%$ of EPA's concentration values, requiring notifications to the Washington State Department of Health. All measurements of radioactive materials in air around the Hanford Site away from facilities were below DOE-derived concentration guides.

As in past years, small amounts of radioactive materials were detected downriver from the Hanford Site. However, the amounts were far below federal and state limits. During 2009, there was no indication of any deterioration of Columbia River water or sediment quality resulting from operations at the Hanford Site.

Measurements of radiological contaminants in samples collected at the shoreline springs were less than applicable DOE-derived concentration guides. Most of the 2009 chemical sample results were similar to those previously reported. Concentrations of volatile organic compounds were near or below their detection limits in all samples. Trace amounts of chlorinated organic compounds were observed at some locations. Concentrations of most metals were below Washington State ambient surface-water chronic toxicity levels.

Radionuclide concentrations measured in shoreline sediment samples were similar to concentrations measured in Columbia River sediment, with the exception of the 300 Area where uranium concentrations were above the background concentration measured in the sediments from the reservoir behind Priest Rapids Dam. Metals concentrations in all samples were also similar to concentrations measured in Hanford Reach Columbia River sediment samples.

$\begin{array}{ll}\text { Food and Farm Products } & \begin{array}{l}\text { Samples of alfalfa, apples, leafy vegetables, milk, } \\ \text { potatoes, tomatoes, and wine were collected from } \\ \text { locations upwind and downwind of the Hanford Site. }\end{array} \\ \text { Fish and Wildlife } & \begin{array}{l}\text { Game animals and other animals of interest on the } \\ \text { Hanford Site and fish from the Hanford Reach of } \\ \text { the Columbia River were monitored. Carcass, liver, } \\ \text { and muscle samples were analyzed to evaluate } \\ \text { radionuclide and metals concentrations. }\end{array}\end{array}$

Radionuclide concentrations in samples of food and farm products were at normal environmental levels.

Samples of whitefish and Canada geese were collected and analyzed. Radionuclide levels in wildlife samples were well below levels that are estimated to cause adverse health effects to animals or to the people who may consume them. Most trace metal concentrations in liver samples were similar to or less than concentrations measured in background samples. Onsite wildlife samples had elevated maximum values for some trace metals.

In general, radionuclide concentrations in routine samples collected from or adjacent to waste disposal facilities in 2009 were higher than concentrations measured in distant communities in previous years. There were 28 instances of radiological contamination in soil samples investigated in 2009. Of the 28 , 26 were cleaned up and 2 were controlled in a posted area.

Segetation
Hanford Site facilities and operations in 2009 and
analyzed for radiological contaminants. Samples of
wild chives were collected from the Hanford Reach
and analyzed for radiological and metal
concentrations.

Concentrations of radionuclides were comparable to those from previous years and elevated in vegetation samples collected near facilities and operations when compared to concentrations in samples from distant communities collected in previous years. Wild chive samples had no detectable radionuclides except for naturally occurring potassium- 40 . Metals concentrations were highest in chive root subsamples.

$\mathrm{DOE}=$ U.S. Department of Energy.

$\mathrm{EPA}=$ U.S. Environmental Protection Agency. 
results at 100-K East included strontium-90, cesium-137, plutonium-239/240, and americium-241. At 100-K West, cesium-137 was elevated. Results for cesium-137 and plutonium-239/240, were elevated from the 200-East and 200-West Areas, respectively.

Hanford Site-Wide and Offsite Ambient-Air Monitoring. During 2009, samples were collected at 42 continuously operating locations: 23 onsite (site-wide), 11 perimeter locations, 7 in nearby communities, and 1 in a distant community (Section 8.2.2). Airborne particle samples were collected at each station biweekly and monitored for gross alpha and gross beta concentrations. Biweekly samples were combined into quarterly composite samples and analyzed for gamma-emitting radionuclides. Samples of atmospheric water vapor were collected every 4 weeks and analyzed for tritium at 20 locations in 2009. All sample results showed very low radiological concentrations. All radionuclide concentrations in air samples collected in 2009 were below levels comparable to the EPA Clean Air Act dose standard of 10 millirem (100 microsievert) per year (Section 8.2.2.2).

\section{Liquid Effluent Monitoring}

Liquid effluents are discharged from some facilities at the Hanford Site. Effluent streams were sampled for gross alpha and gross beta concentrations, as well as for concentrations of selected radionuclides. In 2009, facilities in the 200 Areas discharged radioactive liquid effluent to the ground at a single location, the State-Approved Land Disposal Site. Liquid effluent from the 100 Areas, primarily secondary cooling water from the $100-\mathrm{K}$ Area, was discharged to the Columbia River via a permitted outfall. Non-radioactive hazardous materials in liquid effluent were monitored in the 100, 200, 300, and 400 Areas to determine compliance with permits before discharging to the State-Approved Land Disposal Site or the Columbia River. Discharges were in compliance with National Pollutant Discharge Elimination System and state waste discharge permit limitations (Section 8.3).

\section{Surface Water and Sediment Monitoring}

Samples of surface water and sediment on and near the Hanford Site were collected and analyzed to determine the concentrations of radiological and chemical contaminants from the site. Surface water bodies included the Columbia River, onsite ponds, and offsite irrigation sources. Aquatic sediment monitoring was conducted for the Columbia River and one onsite pond (Section 8.4).

Columbia River Water. During 2009, Columbia River water samples were collected with automated samplers at fixed-location monitoring stations at Priest Rapids Dam and the city of Richland, Washington, and analyzed for radionuclides. Samples were also taken from cross-river transects and near-shore locations near the 100-N Area, Vernita Bridge, Hanford town site, the 300 Area, and the city of Richland and analyzed for both radionuclides and chemicals. Transect samples were collected at multiple locations on a line across the Columbia River and at several near-shore locations. Radiological constituents of interest included gamma-emitting radionuclides, tritium, strontium-90, technetium-99, uranium-234, uranium-235, uranium-238, plutonium-238, and plutonium-239/240. Gross beta and gross alpha concentrations were also monitored. Chemicals of interest included metals and anions. All radiological contaminant concentrations measured in Columbia River water at the fixed sampling locations during 2009 were less than 1/25th of the concentrations comparable to the DOE-derived concentration guide (effective dose equivalent of less than 100 millirem [1 microsievert] per year). Tritium, uranium-234, uranium-238, and naturally occurring potassium-40 were consistently measured in transect and near-shore samples, but all measured concentrations were less than applicable Washington State ambient surface-water quality criteria. Metals and anions were detected in Columbia River transect water samples both upstream and downstream of the Hanford Site. All concentrations measured in 2009 were below regulatory limits (Section 8.4.1).

Columbia River Sediment. During 2009, samples of the surface layer of Columbia River sediment were collected from the Priest Rapids Dam, McNary Dam, and Ice Harbor Dam reservoirs; slack-water areas along the Hanford Reach; and the city of Richland shoreline. Radionuclides consistently detected in Columbia River sediment in 2009 included naturally occurring potassium-40, cesium-137, uranium-234, uranium-235, uranium-238, plutonium-238, plutonium-239/240, and daughter products from naturally occurring radionuclides. Detectable amounts of most metals 
were in all river sediment samples; however, there are no Washington State freshwater sediment quality criteria for comparison to the measured values (Section 8.4.2).

Pond Water and Sediment. Two onsite ponds, West Lake and the Fast Flux Test Facility Pond, were sampled in 2009. Water samples were obtained quarterly from both ponds and sediment samples were obtained semiannually from West Lake. All samples were analyzed for tritium, and samples from the Fast Flux Test Facility Pond were also analyzed for gross alpha, gross beta, and gamma-emitting radionuclides. All radionuclide concentrations in onsite pond water samples were less than applicable DOE-derived concentration guides and Washington State ambient surface-water quality criteria. Concentrations in sediment samples were similar to concentrations measured in prior years (Section 8.4.3).

Offsite Irrigation Water. In 2009, samples were collected from an irrigation canal in the Riverview area of Pasco (east of the Columbia River and downstream from the Hanford Site) and from an irrigation water supply in Benton County near the southern boundary of the Hanford Site. All radionuclide concentrations were below applicable DOE-derived concentration guides and Washington State ambient surface-water quality criteria. With the exception of tritium and uranium results obtained from the Horn Rapids irrigation pumping station, all radionuclide concentrations were detected at the same levels detected in Columbia River water obtained upstream of the Hanford Site (Section 8.4.4).

\section{Columbia River Shoreline Springs Monitoring}

Samples of Columbia River shoreline spring water and sediment were collected along the Hanford Reach and analyzed for Hanford Site-associated radiological and chemical contaminants present in groundwater beneath the site (Section 8.5).

Columbia River Shoreline Springs Water. Samples were obtained from numerous locations in the fall of 2009 when Columbia River flows were low. Most samples were analyzed for gamma-emitting radionuclides, gross alpha, gross beta, and tritium. Samples from selected springs were analyzed for strontium-90, technetium-99, uranium-234, uranium-235, and uranium-238. Most samples were also analyzed for metals and anions. Samples from some locations were monitored for volatile organic compounds. All radiological contaminants measured in shoreline springs during 2009 were less than applicable DOE concentration guidelines, but exceeded the Washington State ambient water quality criteria for gross alpha at some 300 Area locations and for tritium at the Hanford town site. In addition, uranium concentrations at some 300 Area locations exceeded the drinking water standard (Section 8.5.1.2). For most locations, the 2009 chemical sample results were similar to those previously reported. Concentrations of volatile organic compounds were near or below the analytical laboratory's required detection limits in all samples. Trace amounts of chlorinated organic compounds were observed at some locations. The concentrations of most metals measured in spring water samples in 2009 were below Washington State ambient surface-water chronic toxicity levels. However, the maximum concentrations of dissolved chromium in water at some locations were above the Washington State ambient surface-water chronic and acute toxicity levels. Concentrations of arsenic in all samples were below the Washington State ambient surface-water chronic toxicity level, but exceeded the EPA limit for the protection of human health for the consumption of water and organisms (Section 8.5.1).

Columbia River Shoreline Springs Sediment. During 2009, shoreline springs sediment samples were collected in the $100-\mathrm{B}, 100-\mathrm{H}$, and 100-F Areas, the 300 Area, and at the Hanford town site. Radionuclide concentrations were similar to concentrations measured in Columbia River sediment, with the exception of the 300 Area where uranium concentrations were above the background concentration measured in the sediment from the reservoir behind Priest Rapids Dam. Metals concentrations in all samples were similar to concentrations measured in Columbia River sediment samples (Section 8.5.2).

\section{Radiological Monitoring of Hanford Site Drinking Water}

Samples of treated drinking water were collected monthly at facilities in the 100-K, 100-N, 200-West, and 400 Areas. Water treated from the $100-\mathrm{K}, 100-\mathrm{N}$, and $200-$ West Areas 
is obtained from the Columbia River; water used in the 400 Area is pumped from wells. Water samples were analyzed for gross alpha, gross beta, tritium, and strontium-90. During 2009, annual average concentrations of all monitored radionuclides in Hanford Site drinking water were below federal and state maximum allowable contaminant levels (Section 8.6).

\section{Groundwater Monitoring}

At the Hanford Site, liquid waste released to the ground over many years has reached the groundwater. Hazardous chemicals in the groundwater include carbon tetrachloride, chromium, and cyanide. Radioactive contaminants include tritium, strontium-90, technetium-99, iodine-129, and uranium. Currently, groundwater contaminant levels are greater than drinking water standards beneath $11.3 \%$ of the Hanford Site. Site groundwater is not a source of public drinking water and does not significantly affect offsite drinking water sources, such as the Columbia River and city wells. There are, however, possible near-shore effects where Hanford Site groundwater flows into the Columbia River (Section 8.7).

\section{Food and Farm Products Monitoring}

During 2009, food and farm products including alfalfa, apples, leafy vegetables, milk, potatoes, tomatoes, and wine were collected at locations near the Hanford Site and analyzed for radiological contaminants. The concentrations of most radionuclides in food and farm product samples in 2009 were below levels that could be detected by the analytical laboratories. However, tritium and uranium-234 were detected in low levels in some samples, as was naturally occurring potassium-40 (Section 8.8).

\section{Soil Monitoring}

In 2009, soil samples were collected near facilities and operations at the Hanford Site to detect potential contaminant migration, to monitor the deposition of onsite facility emissions, and to evaluate long-term trends in the environmental accumulation of radioactive materials. Samples were analyzed for radionuclides expected to occur in the areas sampled. In general, radionuclide concentrations in soil samples collected from or adjacent to waste disposal facilities in 2009 were higher than the concentrations in samples collected farther away and were significantly higher than concentrations measured offsite in previous years. The data also show that concentrations of certain radionuclides in 2009 were higher within different operational areas when compared to concentrations measured in distant communities in previous years. Generally, the predominant radionuclides detected were activation and fission products in the 100 Areas, fission products in the 200 and 600 Areas, and uranium in the 300 and 400 Areas (Section 8.9).

\section{Contaminant Monitoring of Plant and Animal Communities}

Section 8.10 presents contaminant monitoring of plant, fish, and wildlife populations on and around the Hanford Site in 2009. The section also includes the control of contaminated or unwanted vegetation and pests and contaminated biota on the site.

Vegetation Monitoring Near Hanford Site Facilities and Operations. Vegetation samples were collected on or adjacent to former waste disposal sites, and from locations downwind and near or within the boundaries of operating facilities and remedial action sites to monitor for radionuclide contaminants. In general, radionuclide concentrations in vegetation samples collected from, or adjacent to, waste disposal facilities in 2009 were higher than concentrations in samples collected farther away, including concentrations measured offsite. Generally, the predominant radionuclides detected were activation and fission products in the $100-\mathrm{N}$ Area, fission products in the 200 and 600 Areas, and uranium in the 300 and 400 Areas (Section 8.10.1).

Investigations of Radioactivity in Vegetation Near Hanford Site Facilities and Operations. During 2009, radiological contamination was detected in 109 vegetation samples. One sample was rabbitbrush and 108 were tumbleweeds (Russian thistle) or tumbleweed fragments; all were disposed of at an onsite licensed facility (Section 8.10.1.3). 
Environmental Surveillance - Special Study. In 2009, wild chives growing along the Hanford Reach of the Columbia River were sampled to evaluate plant tissues for radionuclide and metals contamination. Naturally occurring potassium-40 was the only radionuclide detected in all samples; trace metals were detected in samples collected from Locke Island and the 100-H Area (Section 8.10.2.1).

Vegetation Control Activities. Vegetation control at the Hanford Site consists of cleaning up or removing contaminated plants that can be a threat to site workers or the public, controlling or preventing the growth or re-growth of plants in contaminated or potentially contaminated areas on the site, and monitoring and removing the 10 high-priority noxious plant species (Section 8.10.3).

Monitoring Fish and Wildlife for Hanford-Produced Contaminants. In 2009, Canada geese and whitefish were collected at locations on and around the Hanford Site (Section 8.10.4). Tissue samples were monitored for strontium-90 contamination and gamma emitters, including cesium-137. Cesium-137 was below detection limits in all samples in 2009. Strontium-90 was not found above the analytical detection limit in the whitefish samples collected during 2009, but was detected in two goose bone samples at levels similar to or less than values reported since 1999. Liver tissues from most organisms were monitored for up to 17 trace metals that have the potential to accumulate in certain tissues and are potential contaminants of concern. Beryllium was not detected in any whitefish or goose samples. Maximum concentrations of aluminum, chromium, and mercury were higher in whitefish samples collected at Wanapum Dam than samples collected between 100-N and 100-D Areas during 2009. Maximum concentrations of the remaining 13 trace metals were higher in whitefish samples collected between the 100-N and 100-D Areas than maximum concentrations of samples collected from the background location. Antimony was not detected in any goose samples in 2009. Aluminum, arsenic, cadmium, lead, mercury, nickel, selenium, thallium, thorium, uranium, and zinc were elevated in goose samples collected in the Hanford Reach compared to concentrations of these metals detected in geese collected near Desert Aire, Washington, in 2009. Concentrations of chromium, manganese, and silver were elevated in samples collected near Desert Aire compared to samples collected in the Hanford Reach.
Control of Pests and Contaminated Biota. Animal species must be controlled when they become a nuisance, present health problems, or are radioactivity contaminated. Biological control personnel responded to approximately 26,000 animal control requests from Hanford Site employees in 2009, ranging from requests to remove animals within radioactive waste facilities to insect invasions of work areas. There were 33 contaminated animals or animal-related materials discovered during 2009 (Section 8.10.5).

\section{External Radiation Monitoring}

In 2009, external radiation at the Hanford Site was monitored onsite in relative close proximity to known or potential radiation sources (Section 8.11). The Harshaw thermoluminescent dosimeter system is used to measure external radiation at the Hanford Site. Additionally, radiation surveys were conducted at some locations using portable instruments to monitor and detect contamination, providing a coarse screening for external radiation fields.

\section{External Radiation Monitoring Near Hanford Site} Facilities and Operations. During 2009, external radiation fields were monitored at 119 locations near onsite facilities and operations. Measured radiation levels in the 100-K West Area, $100-\mathrm{N}$ shoreline area, the 200 Areas, 300 Area, and 400 Area were similar to or lower than levels measured in 2008. Increased dose rate levels were observed in the 100-K Area (primarily K-East), 100-N Area, and at the Environmental Restoration Disposal Facility in 2009 (Section 8.11.1).

Radiological Surveys at Active and Inactive Waste Disposal Sites. During 2009, 560 environmental radiological surveys were conducted at active and inactive waste disposal sites and the terrain surrounding them to detect and characterize radioactive surface contamination. Vehicles equipped with radiation detection devices and global positioning systems were used to accurately measure the extent of contamination. Routine radiological survey locations included former waste disposal cribs and trenches, retention basin perimeters, ditch banks, solid waste disposal sites (e.g., burial grounds), unplanned release sites, tank farm perimeters, stabilized waste disposal sites, roads, and firebreaks in and around Hanford Site operational areas. During 2009, the Hanford Site had approximately 
3,580 hectares ( 8,850 acres) of outdoor contaminated areas of all types and approximately 580 hectares (1,430 acres) that contained underground radioactive materials, not including active facilities. No new areas of significant size were discovered during 2009. Approximately 8 hectares (20 acres) of previously posted contamination and/or underground radioactive materials areas underwent remediation and were closed for the interim in 2009 (Section 8.11.1.2). An aerial radiological survey of the $\mathrm{BC}$ Controlled Area and West Lake area was conducted in September 2009. Gross count and exposure rate results were comparable to previous survey results (Section 6.1.1).

\section{Potential Radiological Doses from 2009 Hanford Site Operations}

During 2009, potential radiological doses to the public and biota from Hanford Site operations were evaluated in detail to determine compliance with pertinent regulations and limits (Section 8.12). Doses were assessed in terms of 1) total dose (multiple pathways) to the hypothetical, maximally exposed individual at an offsite location (0.12 millirem [1.2 microsievert] per year at Sagemoor in Franklin County, approximately 1.4 kilometers [0.8 mile] east of the Hanford Site across the Columbia River); 2) average dose to the collective population living within 80 kilometers (50 miles) of Hanford Site operating areas (1.0 person-rem [0.01 person-sievert] per year); 3) dose to a maximally exposed individual for air pathways using EPA methods (excluding radon equals 0.032 millirem [0.32 microsievert] per year at Sagemoor, including radon equals 0.047 millirem $[0.47$ microsievert $]$ per year at Sagemoor); 4) annual dose to site workers consuming drinking water (0.03 millirem [0.3 microsievert] per year); 5) dose from non-DOE industrial sources on and near the Hanford Site (0.007 millirem [0.07 microsievert] per year); and 6) absorbed dose received by aquatic organisms exposed to contaminants released to the Columbia River and in onsite surface water bodies (less than dose limits and guidelines). Estimated dose to a member of the public for radionuclides released from all potential sources of airborne radionuclides (diffuse sources) was 0.021 millirem (0.21 microsievert) at Sagemoor.

\section{Endangered and Threatened Species}

Two fish species (spring-run Chinook salmon and steelhead) listed under the Endangered Species Act of 1973 as endangered or threatened are found on the Hanford Site; two plant species (Umtanum desert buckwheat and White Bluffs bladderpod), one mammal (Washington ground squirrel), and one bird species (greater sage grouse) are candidates for listing. In addition, 13 plant species and 4 bird species are listed as either endangered or threatened by Washington State (Section 8.13).

\section{Ecological Monitoring on the Hanford Site}

Plant and animal species on the Hanford Site are monitored to assess abundance, condition, and population distributions. Data collection and analysis are integrated with environmental monitoring of biotic and abiotic media and analytical results are used to characterize potential risks or impacts.

Plant Communities and Population Surveys. More than 100 plant populations of 53 different taxa listed by Washington State as endangered, threatened, or sensitive, and species listed as review group 1 are found on the Hanford Site. Plant monitoring data are used to develop baseline information and to monitor for changes resulting from Hanford Site operations. Several species were monitored during 2009 including Umtanum buckwheat, a candidate for federal listing, and Columbia yellowcress, a federal species of concern (Section 8.14.1).

Wildlife Population Monitoring. Four fish and wildlife species on the Hanford Site are monitored annually: fall Chinook salmon, steelhead, bald eagles, and mule deer (Section 8.14.1). The number of fall Chinook salmon redds in the Hanford Reach is estimated by aerial surveys. The peak redd count in the fall of 2009 was estimated at 4,995 redds, lower than the 2008 count of 5,588, and 1,430 redds lower than the previous 5 -year average. Two aerial observation flights were flown over the Hanford Reach to document the occurrence of any steelhead spawning along the shoreline regions; none were found. 
Seventy-eight eagles (49 adults and 29 juveniles) were observed during 12 driving surveys in 2009. Roadside surveys were conducted for mule deer on the Hanford Site to assess age and sex ratios and the frequency of testicular atrophy in males. A combined total of 414 deer observations were made over 5 repeated surveys during November 2009 to mid-December 2009, which included multiple observations of the same animals in some cases.

In 2009, surveys were conducted to monitor breeding bird population abundance and habitat usage, and Rocky Mountain elk population abundance and movements. Nearly 120 species of birds have been observed on the Hanford Site in surveys conducted during the breeding season (April to June) from 1988 through 2009. Species abundance has declined from a high in 1989 of nearly 19 species per survey to approximately 7 species per survey in 2008 and 2009 (Section 8.14.1.5). The Rocky Mountain elk population in 2009 was estimated to be 677 elk (Section 8.14.1.7).

\section{Monitoring and Evaluation of Habitat and Species Characterizations}

In 2009, monitoring and assessment efforts focused on sampling plant communities subject to herbicide application and wildfires, and evaluating habitat features associated with burrowing owl nests. Two long-term monitoring plots established in 1996 that were aerially sprayed with herbicides in 2003 and 2006 were re-surveyed in 2009. Results indicate that native forb cover decreased significantly after herbicide treatment compared to forb cover measured in 2001 and 2002. A second survey compared data collected within areas previously treated with herbicides with surveys of similar untreated habitats. Results indicate that both the number of native forbs and canopy cover is lower in the treated areas (Section 8.14.2.1). Regions of the Hanford Site burned by wildfires in 2007 were seeded with perennial bunchgrasses and forbs as protection from wind erosion. In 2009 , preliminary surveys of vegetation in seeded and nonseeded areas showed that native grasses were recovering from the effects of wildfires; measures of exotic grass cover were approximately the same in seeded and unseeded areas (Section 8.14.2.2). Burrowing owl habitat surveys in 2009 indicated that burrowing owls are less abundant on the Hanford Site than in nearby urban and agricultural areas. Nests are more common in sandy loam soils, and $71 \%$ of surveyed burrowing owl nests were located in abandoned badger burrows (Section 8.14.2.3).

\section{Cultural and Historic Resources}

DOE is responsible for managing and protecting the Hanford Site's cultural and historic resources. The Hanford Cultural and Historic Resources Program, which is managed by DOE, ensures cultural and historic resources entrusted to DOE are managed responsibly and in accordance with applicable regulatory requirements (Section 8.15).

Cultural resources reviews must be conducted before a federally funded, federally assisted, or federally licensed ground disturbance or building alteration/demolition project can occur. During 2009, 167 cultural resource reviews were requested by Hanford Site contractors. Thirteen of these required full reviews to identify cultural resources that might be affected by the activity, assess impacts, and develop mitigation measures, if necessary.

In 1987, a monitoring program to assess the effects of weathering and erosion or unauthorized excavation and artifact collection of Hanford Site's cultural resources was established. In 2009, 51 sites were visited and minor impacts due to recreation, natural erosion, and animal activity were recorded.

In 2009, two incidents of unauthorized excavation occurred and were documented as Archaeological Resources Protection Act of 1979 violations (Section 8.15.2).

\section{Climate and Meteorology}

Meteorological measurements support Hanford Site emergency preparedness and response, site operations, and atmospheric dispersion calculations. Activities include weather forecasting and maintaining and distributing climatological data (Section 8.16).

During 2009, average temperature and precipitation totals were below normal. The average temperature for 2009 was $11.6^{\circ} \mathrm{C}\left(52.8^{\circ} \mathrm{F}\right)$, which was $0.4^{\circ} \mathrm{C}\left(0.8^{\circ} \mathrm{F}\right)$ below 
normal $\left(12.0^{\circ} \mathrm{C}\left[53.6^{\circ} \mathrm{F}\right]\right)$. Six months during 2009 were warmer than normal, and 6 months were cooler than normal. Precipitation during 2009 totaled 13.9 centimeters ( 5.47 inches), which is $78 \%$ of normal (17.7 centimeters [6.98 inches]). Snowfall for 2009 totaled 35.3 centimeters (13.9 inches), compared to normal snowfall of 39.1 centimeters (15.4 inches).

The average wind speed during 2009 was 3.4 meters per second ( 7.8 miles per hour), which was 0.09 meter per second ( 0.2 mile per hour) above normal. The peak gust for the year was 27.3 meters per second (61 miles per hour) on March 15 . Four dust storms were recorded at the Hanford Meteorology Station during 2009, less than the five per year average for the entire period on record (1945-2009).

\section{Quality Assurance}

Comprehensive quality assurance programs, which include various quality control practices and methods to verify data, are maintained by monitoring and surveillance projects to assure data quality (Section 8.17). The programs are implemented through quality assurance plans designed to meet requirements of the American National Standards Institute, the American Society of Mechanical Engineers, and DOE Orders. Quality assurance plans are maintained for all activities, and auditors verify conformance. Samples are collected and analyzed according to documented standard procedures. Analytical data quality was verified by a continuing program of internal laboratory quality control, participation in inter-laboratory crosschecks, replicate sampling and analysis, submittal of blind standard samples and blanks, and splitting samples with other laboratories. 


\section{Acknowledgments}

The production of this report was managed by the Pacific Northwest National Laboratory's Public Safety and Resource Protection Project under the direction of Roger L. Dirkes.

The authors appreciate the comprehensive review of the draft report by Christopher Brown (Pacific Northwest National Laboratory). The authors also would like to acknowledge R. Scott Butner (Pacific Northwest National Laboratory) for the cover photograph.

We also thank the U.S. Department of Energy and Hanford Site contractor personnel that contributed and provided reviews to this report.
The report was prepared by Pacific Northwest National Laboratory staff: Hope E. Matthews, lead text editor, with support from Wayne C. Cosby, and Kathy R. Neiderhiser, text processor. Shannon B. Colson (Pacific Northwest National Laboratory) designed the report cover and layout. Duplicating and printing arrangements were managed by Lara R. Ortega, who was supported by Connie J. Perkins, Cindy D. Hernandez, Kevin M. Santo Pietro, Toni L. Dudley, Rosa Linda Armijo, and Steve B. Paxton. This report was produced using Adobe ${ }^{\circledR}$ InDesign and formatted for the Internet by Susan J. Widener. 


\section{Contents}

Preface.

Summary

Acknowledgments

1.0 Introduction

xxiii

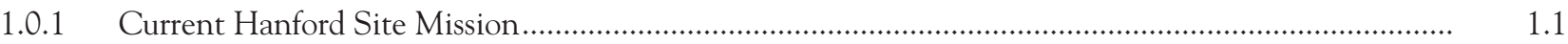

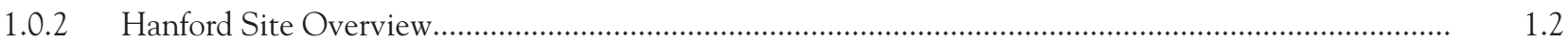

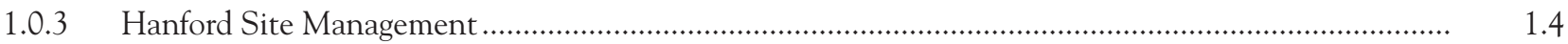

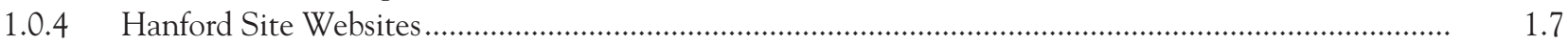

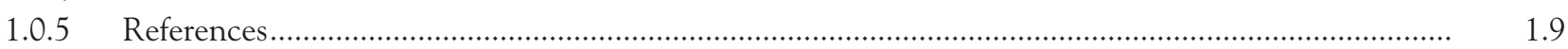

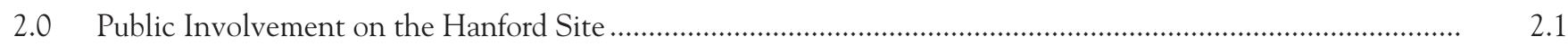

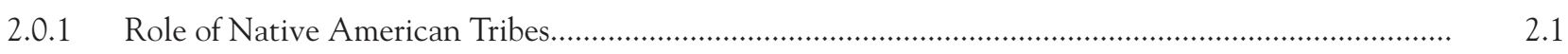

2.0.2 Consultations and Meetings with Tribes, Interested Parties, and the State Historic

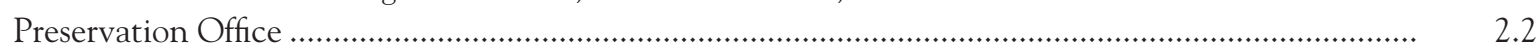

2.0.3 Hanford Natural Resource Trustee Council................................................................................... 2.2

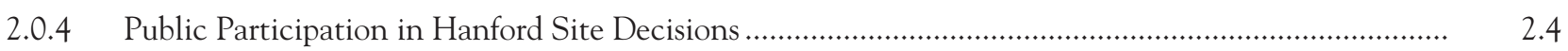

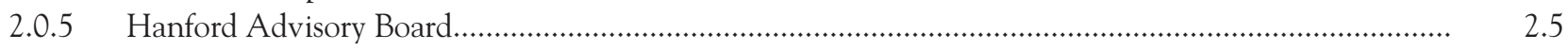

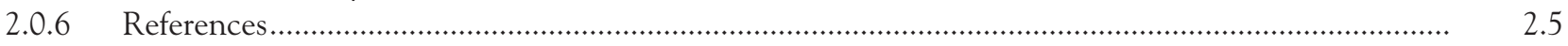

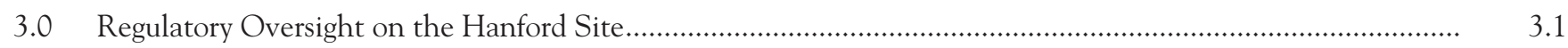

3.0.1 Hanford Federal Facility Agreement and Consent Order ....................................................................

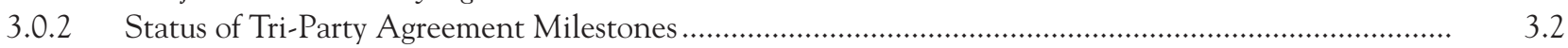

3.0.3 Approved Modifications to the Tri-Party Agreement..........................................................................

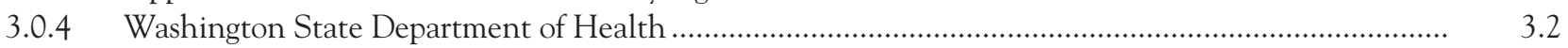

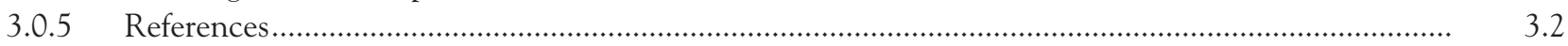

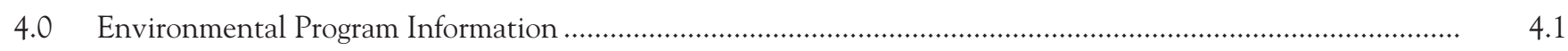

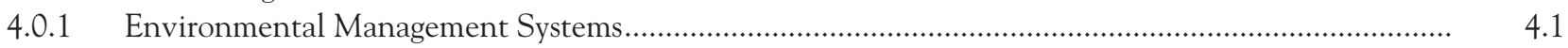

4.0.1.1 Environmental Performance Measures.................................................................................... 4.4

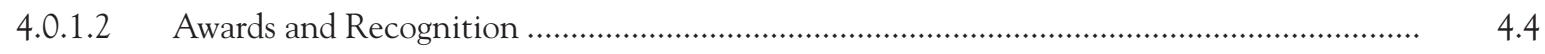

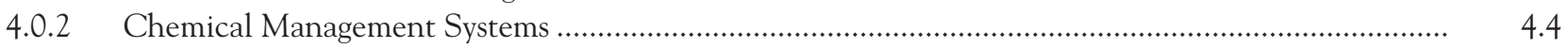

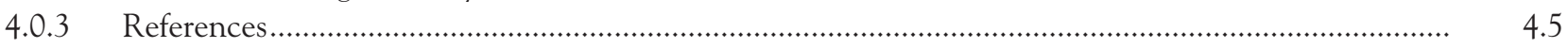

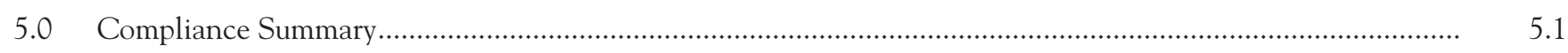

5.1 Statutes Related to Environmental Restoration and Waste Management ...................................................... 5.3

5.1.1 Comprehensive Environmental Response, Compensation, and Liability Act of 1980 .................................

5.1.1.1 Hanford Site Institutional Controls Plan.......................................................................... 5.5

5.1.1.2 CERCLA and Washington State Dangerous Waste/Hazardous Substance
Reportable Releases to the Environment...................................................................... 5.6 


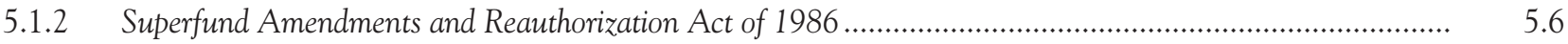

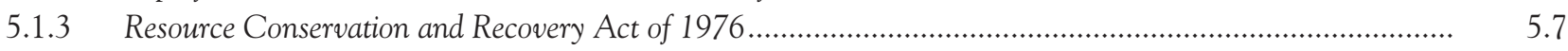

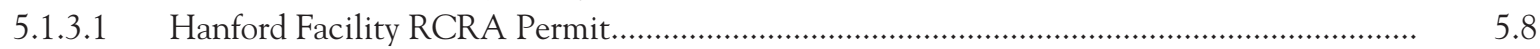

5.1.3.2 RCRA/Dangerous Waste Permit and Closure Plan ................................................................ 5.8

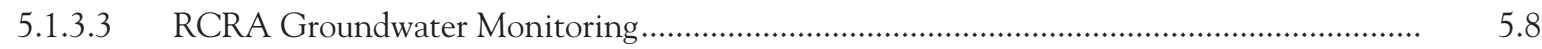

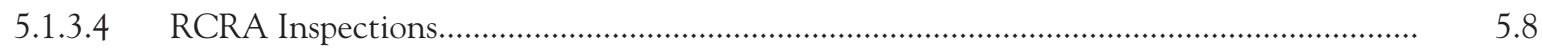

5.1.3.5 Washington Administrative Code Groundwater Monitoring ................................................... 5.10

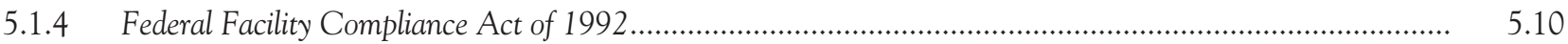

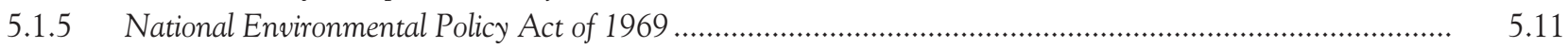

5.1.5.1 Hanford Site Environmental Impact Statements ................................................................ 5.12

5.1.5.2 Hanford Site Environmental Assessments.......................................................................... 5.13

5.1.5.3 Hanford Site Categorical Exclusions................................................................................ 5.14

5.1.6 Toxic Substances Control Act .............................................................................................................. 5.15

5.1.7 Federal Insecticide, Fungicide, and Rodenticide Act ...................................................................... 5.16

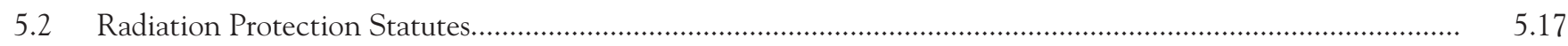

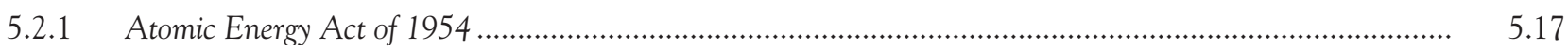

5.2.2 DOE Order 5400.5, "Radiation Protection of the Public and the Environment"................................ 5.17

5.2.3 DOE Order 435.1, "Radioactive Waste Management" .......................................................................... 5.18

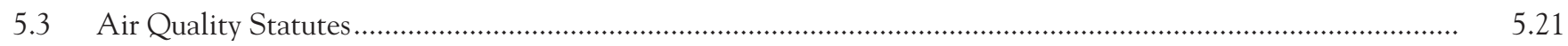

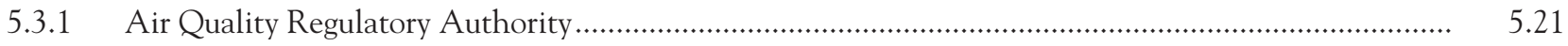

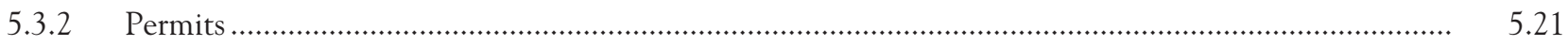

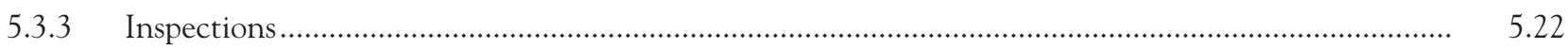

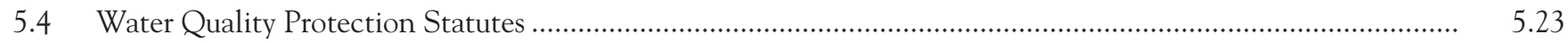

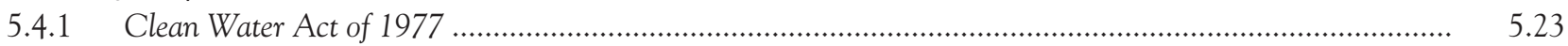

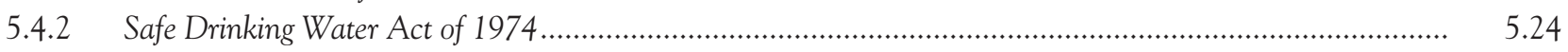

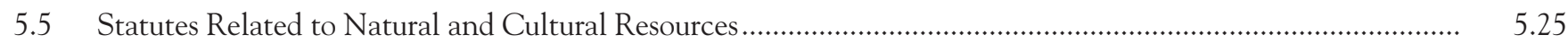

5.5.1 Ecological Compliance ............................................................................................................... 5.25

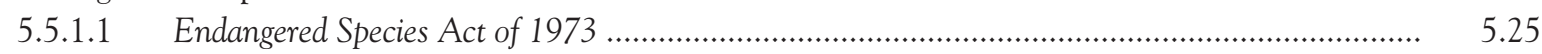

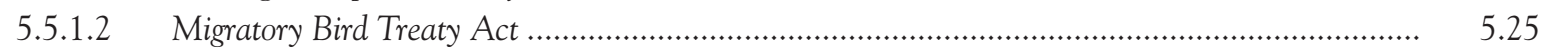

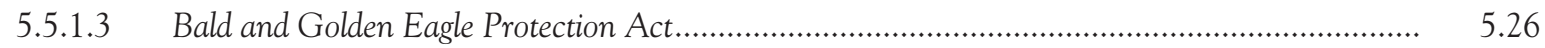

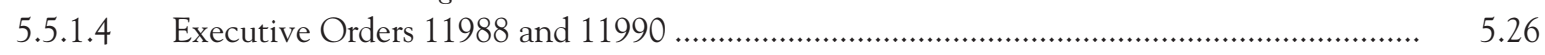

5.5.2 Cultural Resource Compliance ……........................................................................................... 5.26

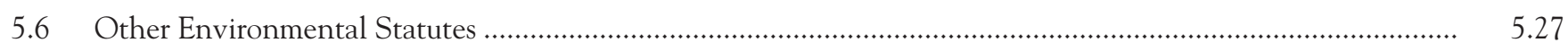

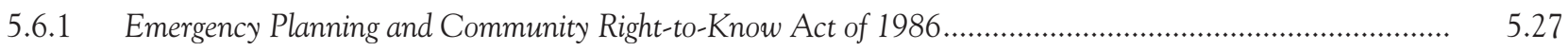

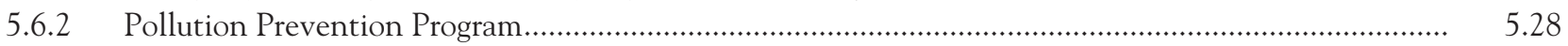

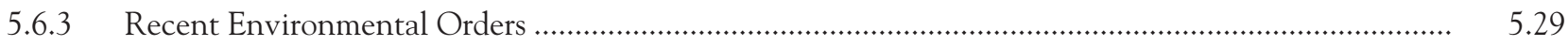

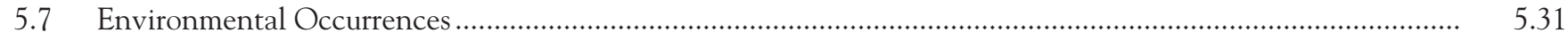

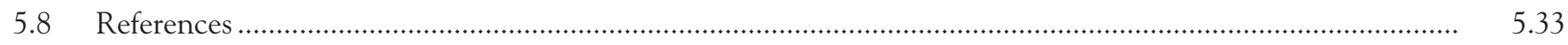

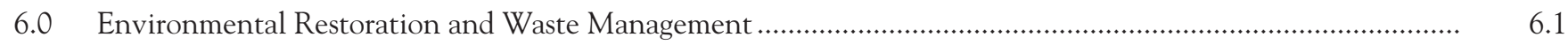

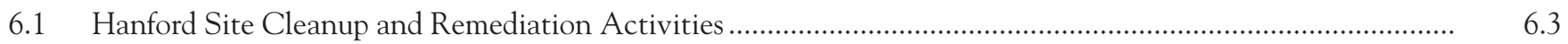

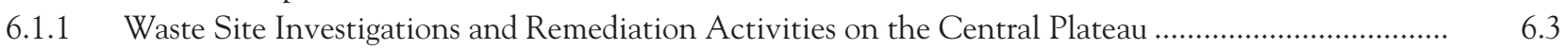

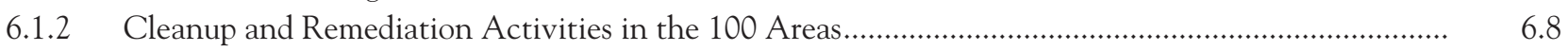

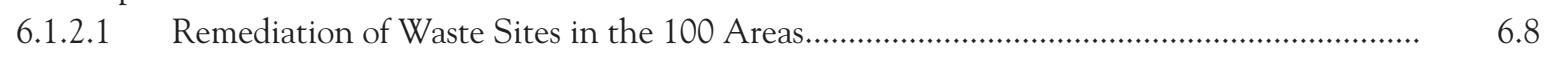

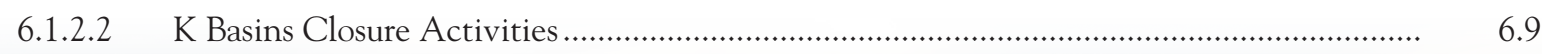




\subsubsection{DOE Richland Operations Office Progress on Defense Nuclear Facilities Safety}

Board Recommendations Regarding K Basins .......................................................................... 6.11

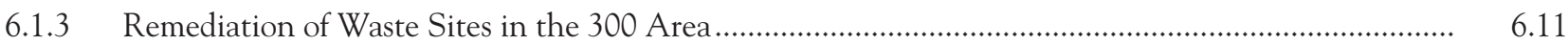

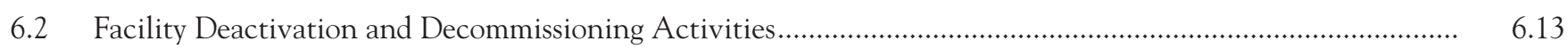

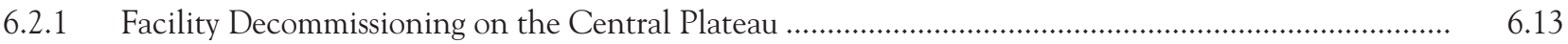

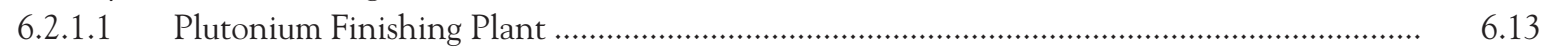

6.2.1.2 Surveillance, Maintenance, and Deactivation Activities on the Central Plateau and on the Fitzner/Eberhardt Arid Lands Ecology Reserve Unit .......................................... 6.13

6.2.1.3 Investigating the Potential for Using the 200 Areas Chemical Separations Plants

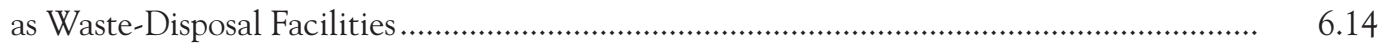

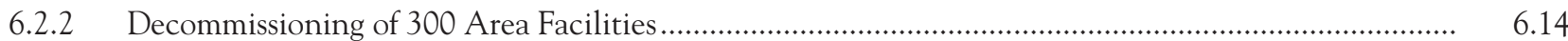

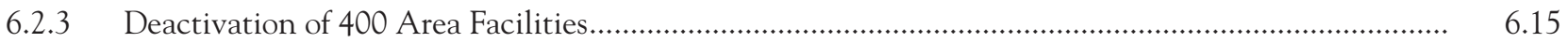

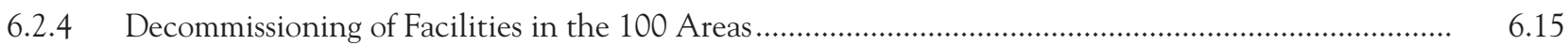

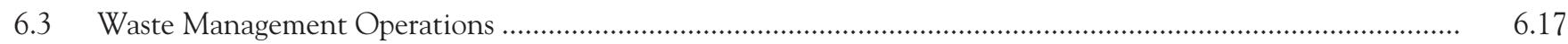

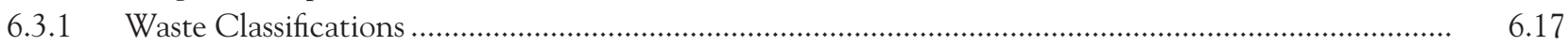

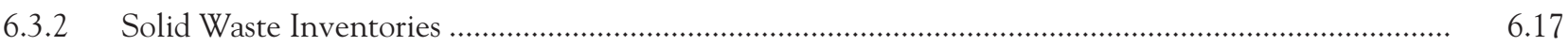

6.3.3 Solid Waste Management..............................................................................................................

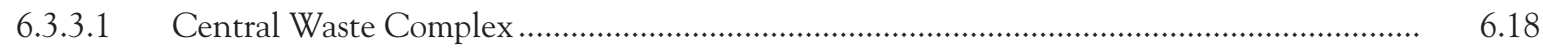

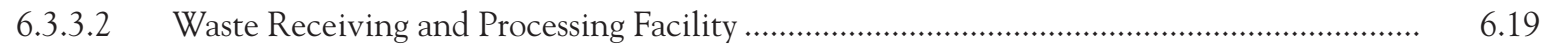

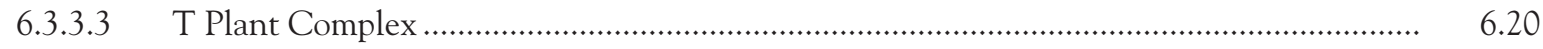

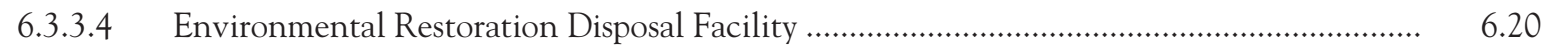

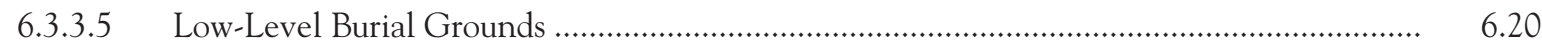

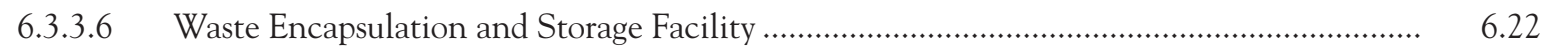

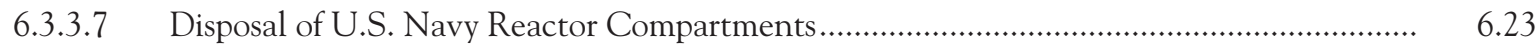

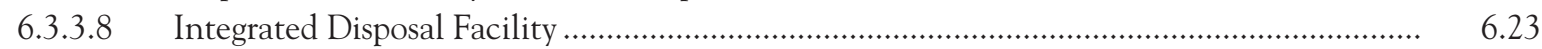

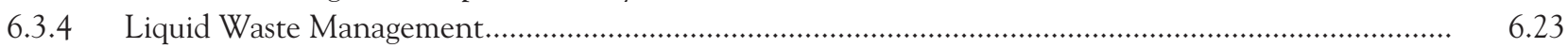

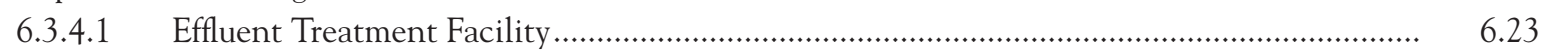

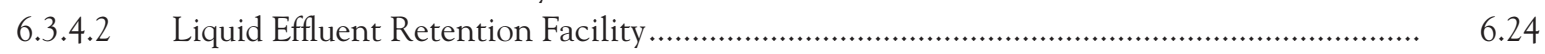

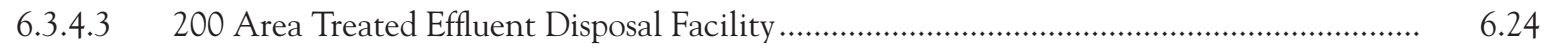

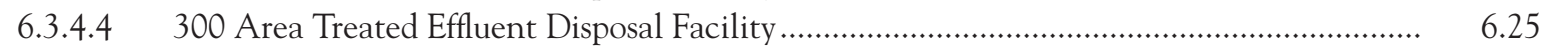

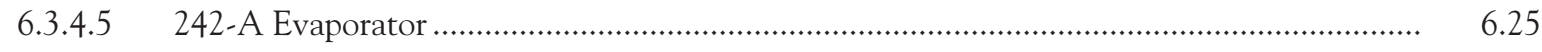

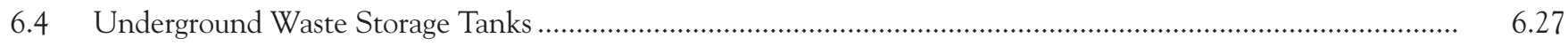

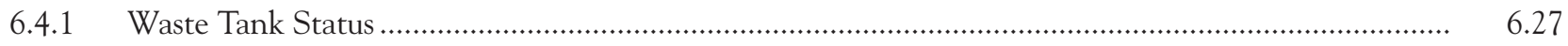

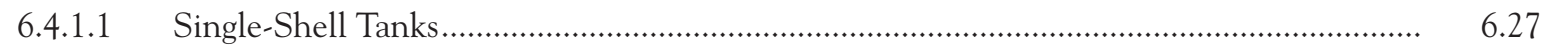

6.4.1.2 Vadose Zone Program .......................................................................................................... 6.28

6.4.1.3 Double-Shell Tanks ........................................................................................................... 6.28

6.4.2 DOE Office of River Protection Progress on Defense Nuclear Facilities Safety Board

Recommendations Regarding the Underground Waste Storage Tanks................................................... 6.29

6.5 Hanford Tank Waste Treatment and Immobilization Plant...................................................................................

6.6 DOE Office of River Protection Progress on Defense Nuclear Facilities Safety Board Recommendations .......... 6.33

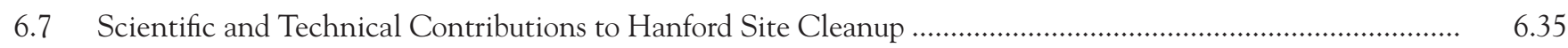

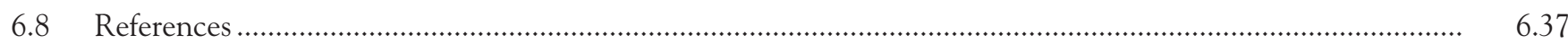


7.0 Hanford Site Closure Activities

7.0.1 Radiological Release of Property from the Hanford Site .................................................................

7.0.1.1 Radiological Clearance for Personal Property Potentially Contaminated with Hard-to-Detect Radionuclides

7.0.1.2 Radiological Clearance for Ion-Exchange Resin for Offsite Shipment and

7.0.1.3 Radiological Clearance for Granular Activated Carbon for Offsite Shipment and Regeneration.

7.0.2 Columbia River Corridor Mission Completion ...................................................................................

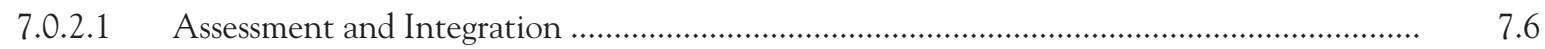

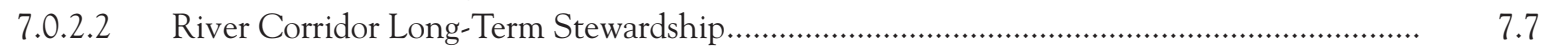

\subsubsection{References.....}

8.0 Environmental and Resource Protection Programs.......

8.0.1 Effluent and Near-Facility Environmental Monitoring Programs ........................................................

8.0.1.1 Liquid Effluent and Airborne Emissions Monitoring ............................................................ 8.2

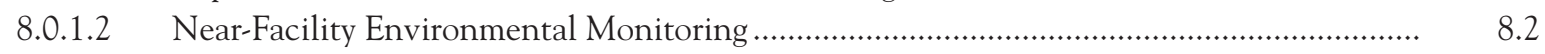

8.0.2 Public Safety and Resource Protection Program Projects ........................................................................

8.0.2.1 Meteorological and Climatological Services Project .............................................................

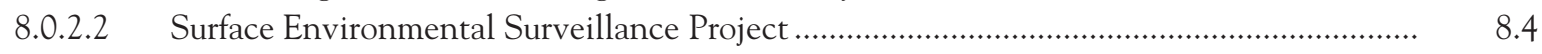

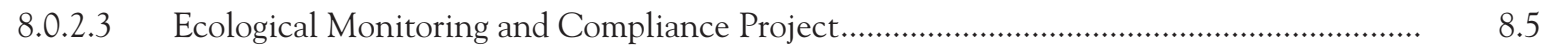

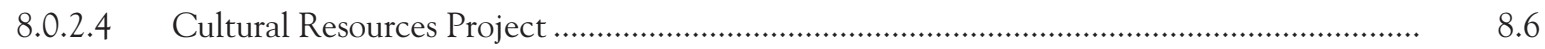

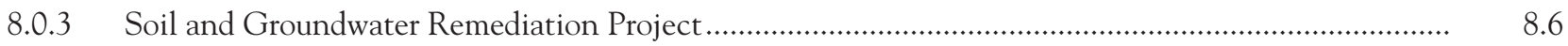

8.0.4 Drinking Water Monitoring Project .......................................................................................... 8.7

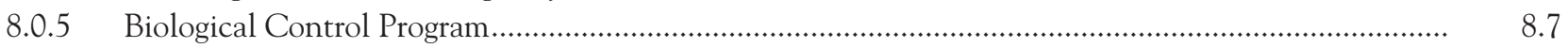

8.0.6 Washington State Department of Health Oversight Monitoring ......................................................

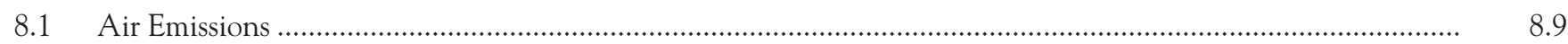

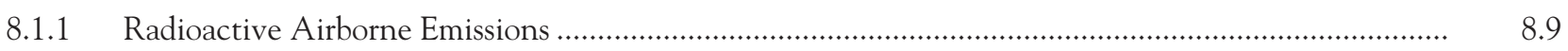

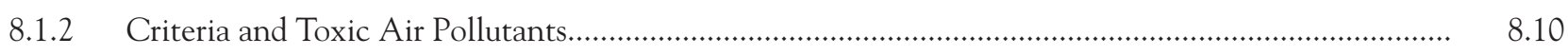

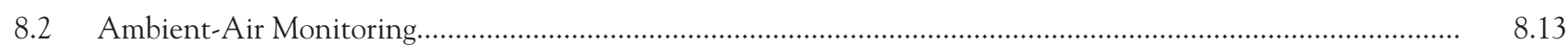

8.2.1 Ambient-Air Monitoring Near Facilities and Operations................................................................... 8.13

8.2.2 Site-Wide and Offsite Ambient-Air Monitoring................................................................................ 8.17

8.2.2.1 Collection of Site-Wide and Offsite Ambient-Air Samples and Analytes Tested............... $\quad 8.17$

8.2.2.2 Ambient-Air Monitoring Results for Site-Wide and Offsite Samples ................................ $\quad 8.20$

8.3 Liquid Effluent from Hanford Site Facilities................................................................................................. 8.25

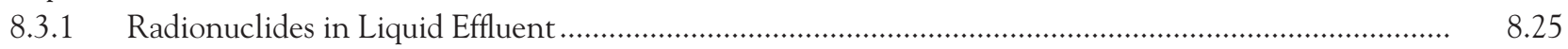

8.3.2 Non-Radioactive Hazardous Materials in Liquid Effluent .................................................................... 8.25

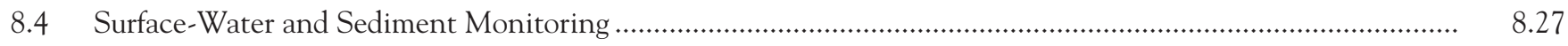

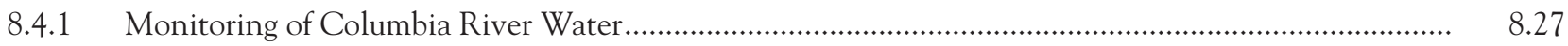

8.4.1.1 Collection of Columbia River Water Samples and Analytes of Interest.............................. $\quad 8.31$

8.4.1.2 Radiological Results for Columbia River Water Sample Analyses....................................... 8.32

8.4.1.3 Chemical and Physical Water Quality Results for Columbia River Water Samples............ 8.36

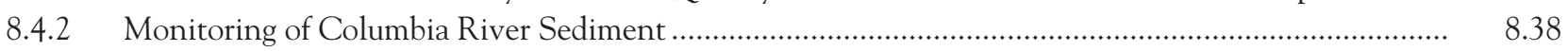

8.4.2.1 Collection of Columbia River Sediment Samples and Analytes of Interest ....................... $\quad 8.39$

8.4.2.2 Radiological Results for Columbia River Sediment Sample Analyses ................................. 8.40

8.4.2.3 Chemical Results for Columbia River Sediment Sample Analyses....................................... 8.40 
8.4.3 Monitoring of Onsite Pond Water and Sediment...............................................................................

8.4.3.1 Collection of Pond Water, Sediment Samples, and Analytes of Interest............................ $\quad 8.40$

8.4.3.2 Radiological Results for Pond Water and Sediment Sample Analyses................................ $\quad 8.41$

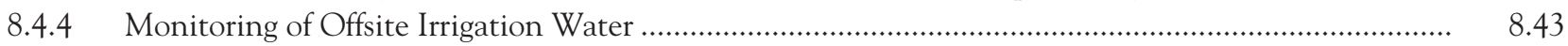

8.4.4.1 Collection and Analysis of Offsite Irrigation Water Samples................................................. $\quad 8.43$

8.4.4.2 Analytical Results for Offsite Irrigation Water Samples....................................................... 8.43

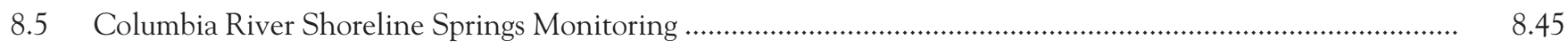

8.5.1 Water Monitoring at Columbia River Shoreline Springs.................................................................... 8.45

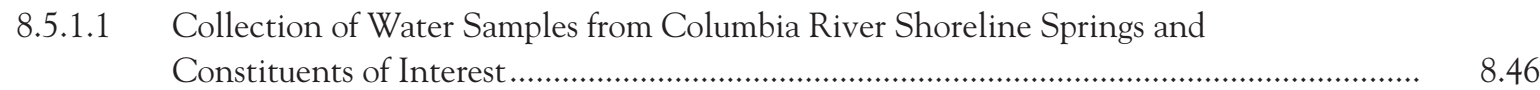

8.5.1.2 Radiological Results for Water Samples from Columbia River Shoreline Springs............... 8.47

8.5.1.3 Chemical Results for Water Samples from Columbia River Shoreline Springs .................... $\quad 8.50$

8.5.2 Monitoring Columbia River Shoreline Springs Sediment ............................................................... 8.50

8.5.2.1 Radiological Results for Sediment Samples from Columbia River Shoreline Springs......... $\quad 8.52$

8.5.2.2 Chemical Results for Sediment Samples from Columbia River Shoreline Springs ............. $\quad 8.52$

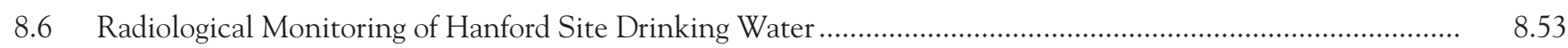

8.6.1 Hanford Site Drinking Water Systems............................................................................................... 8.53

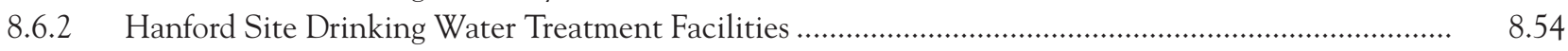

8.6.3 Collection of Drinking Water Samples and Analytes of Interest ........................................................ 8.55

8.6.4 Radiological Results for Hanford Site Drinking Water Samples ............................................................ 8.55

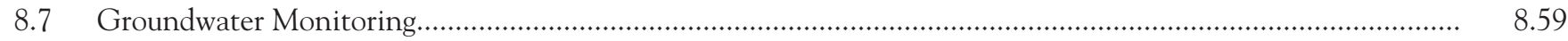

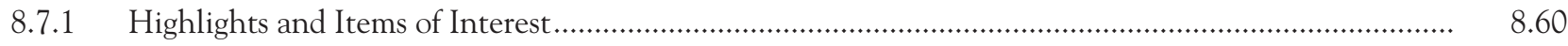

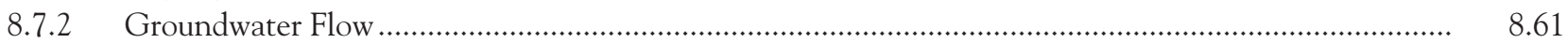

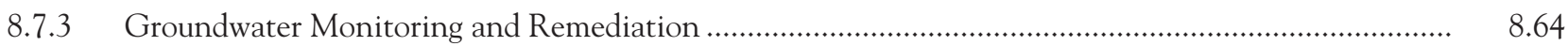

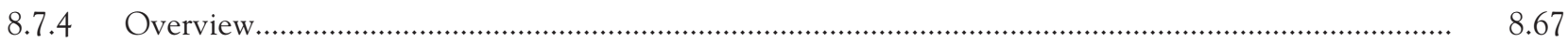

8.7.4.1 Groundwater Monitoring Results for the 100-BC-5 Operable Unit ................................... 8.70

8.7.4.2 Groundwater Monitoring Results for the 100-KR-4 Operable Unit .................................... 8.70

8.7.4.3 Groundwater Monitoring Results for the 100-NR-2 Operable Unit.................................... 8.71

8.7.4.4 Groundwater Monitoring Results for the 100-HR-3 Operable Unit....................................... 8.72

8.7.4.5 Groundwater Monitoring Results for the 100-FR-3 Operable Unit..................................... 8.74

8.7.4.6 Groundwater Monitoring Results for the 200-ZP-1 Operable Unit ....................................... 8.75

8.7.4.7 Groundwater Monitoring Results for the 200-UP-1 Operable Unit .................................... 8.76

8.7.4.8 Groundwater Monitoring Results for the 200-BP-5 Operable Unit..................................... 8.78

8.7.4.9 Groundwater Monitoring Results for the 200-PO-1 Operable Unit ..................................... 8.80

8.7.4.10 Groundwater Monitoring Results for the 300-FF-5 Operable Unit ...................................... 8.81

8.7.4.11 Groundwater Monitoring Results for the 1100-EM-1 Groundwater Interest Area ............. 8.83

8.7.4.12 Groundwater Monitoring Results for the Confined Aquifers ................................................ 8.83

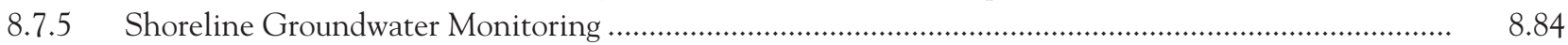

8.7.6 Well Installation, Maintenance, and Decommissioning ................................................................. 8.85

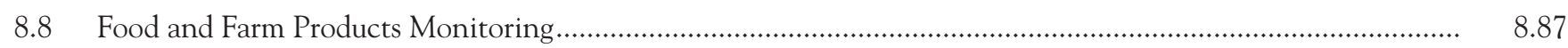

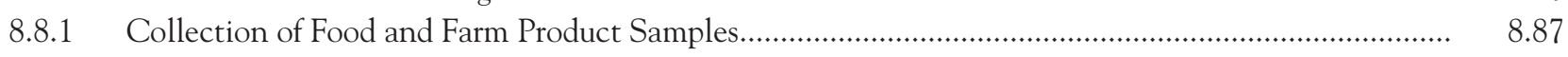

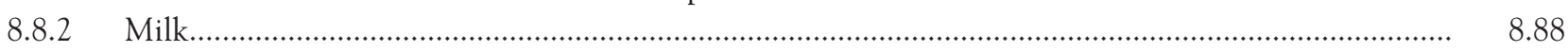

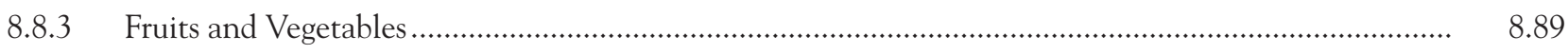

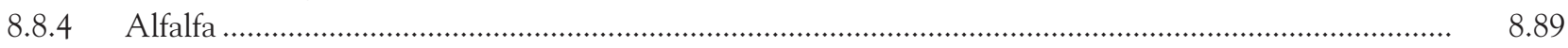

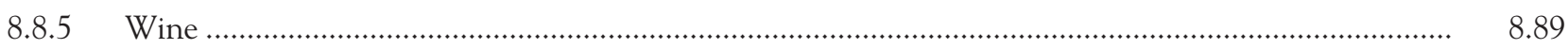




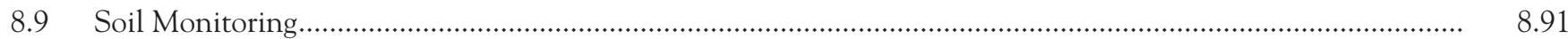

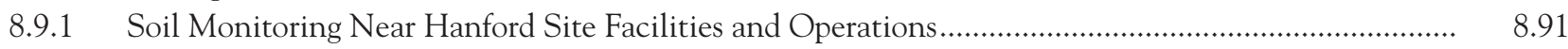

8.9.1.1 Soil Sampling Near Hanford Site Facilities and Operations............................................

8.9.1.2 Analytical Results for Soil Samples Collected Near Hanford Site Facilities and Operations.

8.9.1.3 Investigations of Radioactive Contamination in Soil Near Hanford Site Facilities

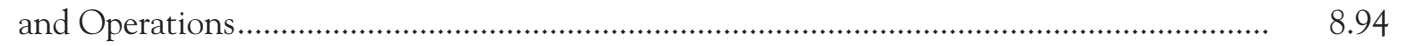

8.9.2 Soil Monitoring at Hanford Site-Wide and Offsite Locations ....................................................... 8.98

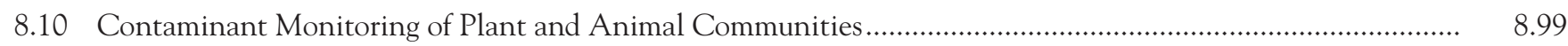

8.10.1 Vegetation Monitoring Near Hanford Site Facilities and Operations............................................... 8..99

8.10.1.1 Vegetation Sampling Near Hanford Site Facilities and Operations .................................. 8.99

8.10.1.2 Analytical Results for Vegetation Samples Collected Near Hanford Site Facilities

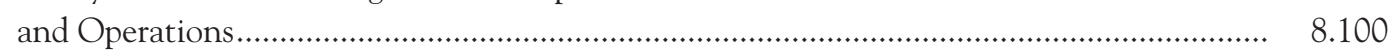

8.10.1.3 Investigations of Radioactive Contamination in Vegetation Near Hanford Site Facilities and Operations ..................................................................................... 8.104

8.10.2 Vegetation Monitoring at Hanford Site-Wide and Offsite Locations .................................................. 8.104

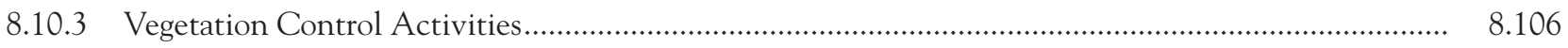

8.10.3.1 Waste Site Contamination Control and Revegetation During 2009 .............................. 8.106

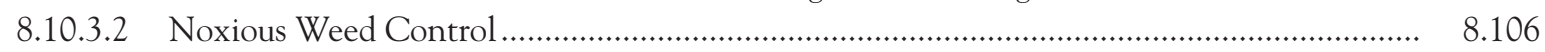

8.10.4 Monitoring of Fish and Wildlife for Hanford Site-Produced Contaminants ................................... 8.108

8.10.4.1 Analytical Results for Fish Samples....................................................................... 8.111

8.10.4.2 Analytical Results for Goose Samples ...................................................................... 8.112

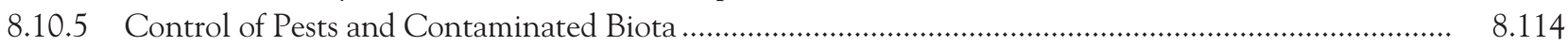

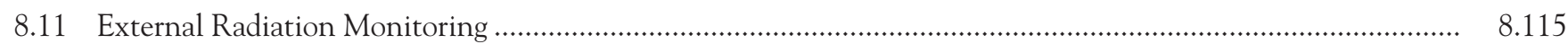

8.11.1 External Radiation Monitoring Near Hanford Site Facilities and Operations .................................. 8.115

8.11.1.1 External Radiation Measurements Onsite Near Facilities and Operations ......................... 8.115

8.11.1.2 Radiological Surveys at Active and Inactive Waste Disposal Sites .................................. 8.118

8.11.2 External Radiation Monitoring at Hanford Site-Wide and Offsite Locations ................................... 8.118

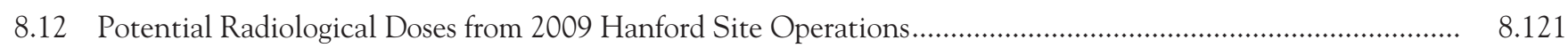

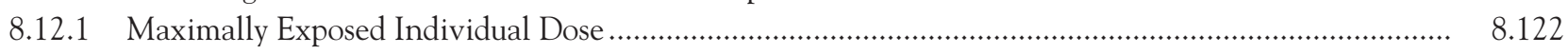

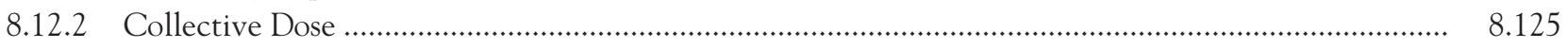

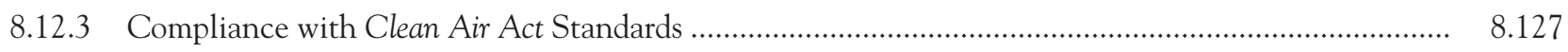

8.12.3.1 Dose to an Offsite Maximally Exposed Individual ...................................................... 8.128

8.12.3.2 Maximum Dose to Non-U.S. Department of Energy Workers at the Hanford Site ............ 8.128

8.12.3.3 Dose from Diffuse and Fugitive Radionuclide Emissions .............................................. 8.129

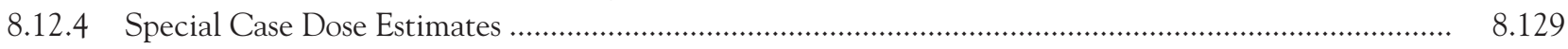

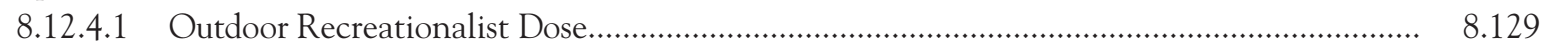

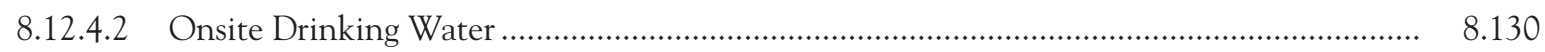

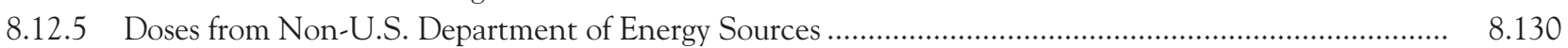

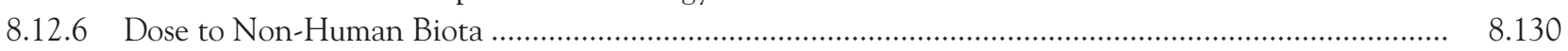

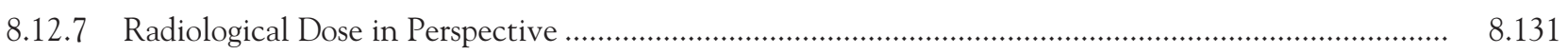

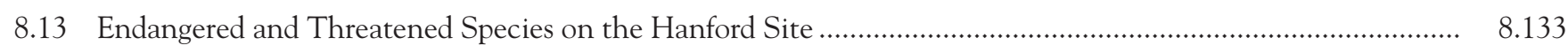

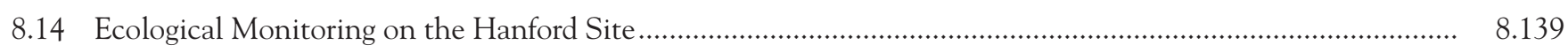

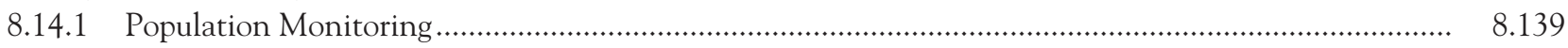

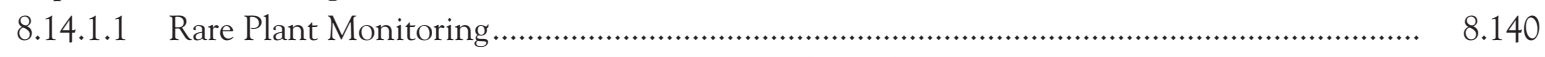

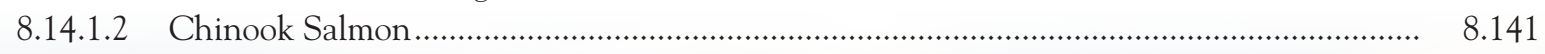




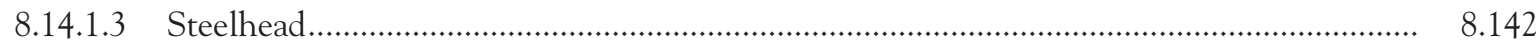

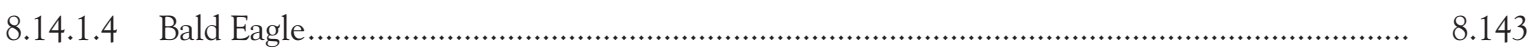

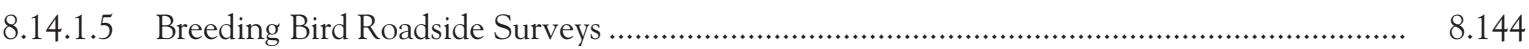

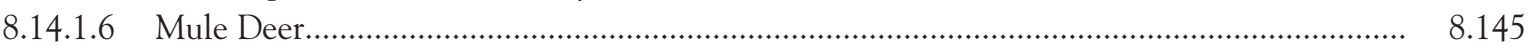

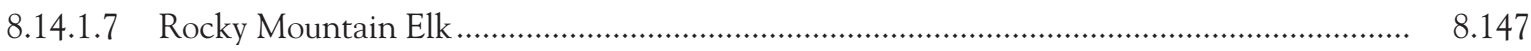

8.14.2 Monitoring and Evaluation of Habitat and Species Characterizations ............................................... 8.147

8.14.2.1 Effects of Herbicide on Plant Communities ....................................................................... 8.148

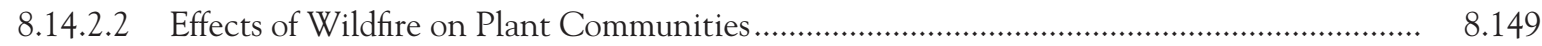

8.14.2.3 Burrowing Owls...................................................................................................... 8.150

8.15 Cultural and Historic Resources Monitoring ........................................................................................ 8.151

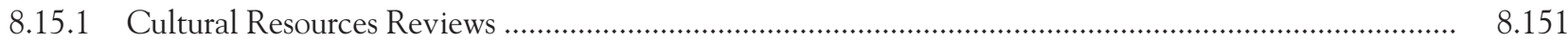

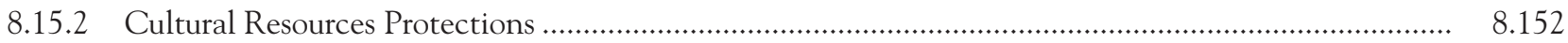

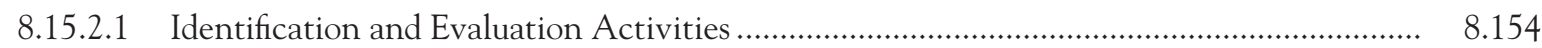

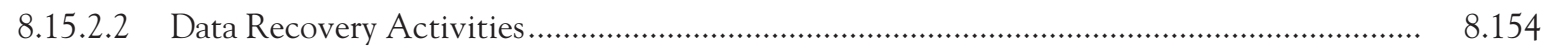

8.15.2.3 Management of Artifact and Data Collections .............................................................. 8.154

8.15.3 Cultural Resources Consultations and Public Involvement ................................................................. 8.155

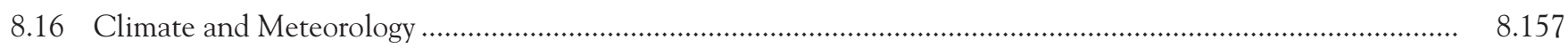

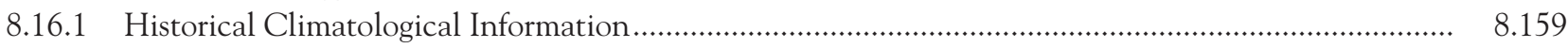

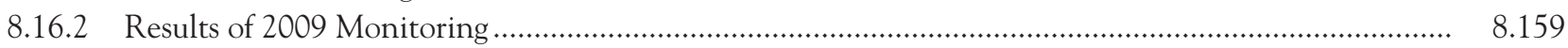

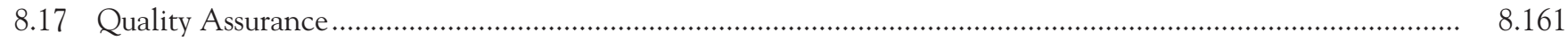

8.17.1 Hanford Site-Wide and Offsite Environmental Surveillance and Environmental Monitoring............. 8.161

8.17.1.1 Project Management Quality Assurance.......................................................................... 8.161

8.17.1.2 Sample Collection Quality Assurance and Quality Control ............................................... 8.161

8.17.1.3 Analytical Results Quality Assurance and Quality Control................................................ 8.163

8.17.1.4 U.S. Department of Energy and U.S. Environmental Protection Agency

Comparison Studies........................................................................................................... 8.164

8.17.1.5 Pacific Northwest National Laboratory Evaluations........................................................ 8.166

8.17.1.6 Laboratory Internal Quality Assurance Programs ............................................................... 8.167

8.17.1.7 Media Audits and Comparisons ....................................................................................... 8.170

8.17.2 Effluent Monitoring and Environmental Monitoring Near Facilities and Operations Quality

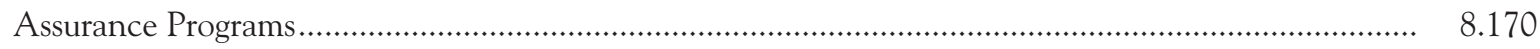

8.17.2.1 Sample Collection Quality Assurance ............................................................................. 8.170

8.17.2.2 Analytical Results Quality Assurance.......................................................................... 8.170

8.18 References

8.175

Appendix A - Helpful Information

Appendix B - Glossary

Appendix C - Additional Monitoring Results for 2009

Appendix D - Standards and Permits

Appendix E - Dose Calculations

Appendix F - Radionuclides Measured by Gamma Spectroscopy 


\section{Figures}

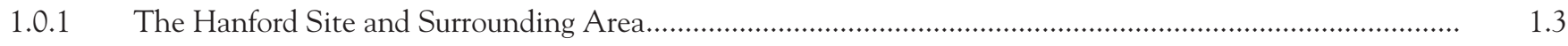

1.0.2 Management Units on the Hanford Reach National Monument ….............................................................

8.2.1 Average Concentrations of Selected Radionuclides in Ambient-Air Samples Collected on the Hanford Site Near Facilities and Operations Compared to Those Collected in Distant Communities, 2005 Through 2009

8.2.2 Hanford Site-Wide and Offsite Ambient-Air Sampling Locations During 2009.....

8.2.3 Gross Alpha Concentrations in Airborne Particulate Samples Collected at Hanford Site-Wide and Distant Locations During 2009 and Early 2010 ......

8.2.4 Gross Beta Concentrations in Airborne Particulate Samples for all Hanford Site-Wide and Offsite

Sampling Locations in 2009 and Early 2010 and Continuous 14-day Average Wind Speeds at the

Hanford Meteorology Station

8.4.1 Surface-Water and Sediment Sampling Locations On and Around the Hanford Site, 2009......

8.4.2 Monthly Average, Maximum, and Minimum Columbia River Flow Rates at Priest Rapids Dam, Washington, 2009

8.4.3 Annual Average Gross Alpha Concentrations in Columbia River Water Upstream and Downstream of the Hanford Site, 2004 Through 2009

8.4.4 Annual Average Gross Beta Concentrations in Columbia River Water Upstream and Downstream of the Hanford Site, 2004 Through 2009.

8.4.5 Annual Average Tritium Concentrations in Columbia River Water Upstream and Downstream of the Hanford Site, 2004 Through 2009.

8.4.6 Annual Average Strontium-90 Concentrations in Columbia River Water Upstream and Downstream of the Hanford Site, 2004 Through 2009.

8.4.7 Annual Average Total Uranium Concentrations in Columbia River Water Upstream and Downstream of the Hanford Site, 2004 Through 2009

8.4.8 Annual Average Iodine-129 Concentrations in Columbia River Water Upstream and Downstream of the Hanford Site, 2004 Through 2009.

8.4.9 Tritium Concentrations in Cross-River Transect Water Samples from the Hanford Reach of the Columbia River, September 2009

8.4.10 U.S. Geological Survey Water Quality Measurements for the Columbia River Upstream and Downstream of the Hanford Site, 2004 Through 2009

8.4.11 Average, Maximum, and Minimum Concentrations of Selected Radionuclides Measured in Columbia River Sediment, 2004 Through 2009

8.4.12 Average, Maximum, and Minimum Concentrations of Selected Metals Measured in Columbia River Sediment, 2009 .

8.4.13 Average, Maximum, and Minimum Gross Beta and Tritium Concentrations in Water Samples from the Fast Flux Test Facility Pond on the Hanford Site, 2004 Through 2009 
8.4.14 Average, Maximum, and Minimum Concentrations of Tritium in Water Samples from West Lake on the Hanford Site, 2004 Through 2009

8.5.1 Concentrations of Selected Radionuclides in Water from Columbia River Shoreline Springs Near the Hanford Site's 300 Area, 2004 Through 2009

8.5.2 Concentrations of Selected Radionuclides in Columbia River Shoreline Springs Water at the Hanford town site, 2004 Through 2009

8.6.1 Hanford Site Drinking Water Treatment Facilities and Sampling Locations, 2009

8.6.2 Tritium Concentrations in Drinking Water from Three Wells in the Hanford Site 400 Area, 1984 Through 2009

8.7.1 Water-Table Elevation and Inferred Flow Direction for the Unconfined Aquifer on the Hanford Site, March 2009

8.7.2 Groundwater Operable Units and Groundwater Interest Areas on the Hanford Site

8.7.3 Locations of the Resource Conservation and Recovery Act of 1976 Units on the Hanford Site

8.7.4 Major Contaminant Plumes in Hanford Site Groundwater at Concentrations Above Drinking

Water Standards During 2009

8.7.5 Chromium Concentrations in Hanford Site's 100-K Area Groundwater, 1996 and 2009.

8.7.6 Strontium-90 Concentrations in Hanford Site's 100-N Area Groundwater, 1996 and 2009.

8.7.7 Chromium Concentrations in Hanford Site's 100-D Area Groundwater, 1999 and 2009.

8.7.8 Chromium Concentrations in Hanford Site's 100-H Area Groundwater, 1996 and 2009

8.7.9 Carbon Tetrachloride Concentrations in Hanford Site's 200-West Area Groundwater, 1996 and 2009

8.7.10 Technetium-99 Concentrations in Hanford Site's 200-UP-1 Operable Unit, 1995 and 2009 ...................... 8.77

8.7.11 Uranium Concentrations in Hanford Site's 200-UP-1 Operable Unit, 1995 and 2009................................ 8.78

8.7.12 Uranium Concentrations in Hanford Site's 200-BP-5 Operable Unit Groundwater, 1997 and 2009............ 8.79

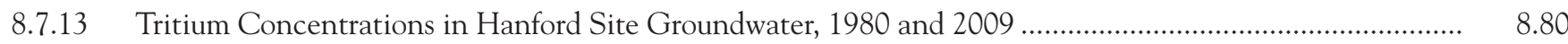

8.7.14 Uranium Concentrations in Hanford Site’s 300-FF-5 Operable Unit Groundwater, 1996 and 2009............. 8.82

8.8.1 Food and Farm Product Sampling Locations, 2009

8.9.1 Average Concentrations of Selected Radionuclides in Soil Samples Collected on the Hanford Site Near Facilities and Operations, 2005 Through 2009, and Those Collected in Distant Communities, 2008

8.10.1 Average Concentrations of Selected Radionuclides in Vegetation Samples Collected Near Hanford Site Facilities and Operations, 2005 Through 2009, and Those Collected in Distant Communities, 2008

8.10.2 Concentrations of Cadmium, Chromium, and Titanium in Wild Chive Subsamples of Root, Bulb, and Leaf Material from Shoreline Locations Within the Hanford Reach and a Reference Location Upriver of the Vernita Bridge, Spring 2009 
8.10.4 Median and Maximum Strontium-90 Concentrations in Hanford Site and Background Canada Goose Bone Samples, 2009 Compared to Previous Years

8.11.1 Annual Average Thermoluminescent Dosimeter Results in Selected Areas Near Facilities and Operations on the Hanford Site, 1996 Through 2009

8.12.1 Locations Important to Dose Calculations at the Hanford Site, 2009.

8.12.2 Calculated Dose to the Hypothetical, Maximally Exposed Individual Near the Hanford Site, 2005 Through 2009

8.12.3 Collective Dose to the Population within 80 Kilometers of Hanford Site Operating Areas, 2005 Through 2009

8.12.4 Annual National Average Radiological Doses from Various Sources.

8.14.1 Survey Locations for Columbia Yellowcress Monitoring Along the Hanford Reach.................................... 8.141

8.14.2 Number of Fall Chinook Salmon Redds in the Hanford Reach of the Columbia River, 1948-2009.............. 8.142

8.14.3 Major Fall Chinook Salmon Spawning Areas in the Hanford Reach of the Columbia River........................ 8.143

8.14.4 Location of Bald Eagle Protection Areas on the Hanford Site .................................................................... 8.144

8.14.5 Estimates of the Number of Fawns per 100 Mule Deer Does in the Post-Hunting Period on the Hanford Site, 1994 Through 2009

8.14.6 Percent of Male Mule Deer on the Hanford Site Showing Signs of Abnormal Antler Growth, 1994 Through 2009 .....

8.14.7 Native Forb Species Richness and Canopy Cover Measured in 2009 on Untreated Areas Compared to Areas with Herbicides Applied Annually 2004-2007 by Soil Type

8.14.8 Comparison of Native and Exotic Grass Cover Within the Wautoma Fire Footprint on Seeded Transects and Not Seeded Transects

8.14.9 Number of Located Burrowing Owl Nests in Relationship to Proximity from Roads .................................... 8.150

8.15.1 Number of Activities Determined Not to be the Type with Potential to Cause Effects to Hanford Site Cultural Resources in 2009.

8.16.1 Hanford Meteorological Monitoring Network Wind Roses, 2009

A.1 A Graphical Representation of Maximum, Median, and Minimum Values.

A.2 Data Plotted Using a Linear Scale..

A.3 Data Plotted Using a Logarithmic Scale 


\section{Tables}

S.1 Status of Compliance with Federal Acts on the Hanford Site in 2009

S.2 Summary of Groundwater Pump-and-Treat Systems and a Vadose Zone Soil-Vapor Extraction System

S.3 Hanford Site Waste Summary for 2009

S.4 Summary of Contaminant Monitoring On and Around the Hanford Site, 2009

4.0.1 Hanford Site Contractor Environmental Management System Internet Links

5.6.1 Emergency Planning and Community Right-to-Know Act of 1986 Compliance Reporting on the Hanford Site, 2009.

5.6.2 Average Quantity of the Ten Hazardous Chemicals Stored in Greatest Quantities on the Hanford Site, 2009.

5.6.3 Hanford Site Sanitary and Hazardous Waste Recycled in 2009

6.3.1 Quantities of Solid Waste Generated on the Hanford Site, 2005 Through 2009

6.3.2 Quantities of Solid Waste Received on the Hanford Site from Offsite Sources, 2005 Through 2009

6.3.3 Quantities of Dangerous Waste Shipped Off the Hanford Site, 2005 Through 2009.

6.4.1 Quantities of Liquid Waste Generated and Stored Within the Tank Farm System on the Hanford Site During 2009 and the Previous 5 Years in Liters

7.0.1 Approved Authorized Limits for Select Hard-to-Detect Radionuclides for Residual Beta-Gamma

Surface Contamination

7.0.2 Approved Authorized Limits for Offsite Shipment and Regeneration of Ion-Exchange Resin

7.0.3 Approved Authorized Limits for Offsite Shipment and Regeneration of Granular Activated Carbon.

8.0.1 Routine Environmental Monitoring Samples and Locations Near Hanford Site Facilities and Operations, 2009.

8.0.2 Types and General Locations of Samples Collected for Site-Wide and Offsite Environmental Surveillance in 2009

8.1.1 Radionuclides Discharged to the Atmosphere on the Hanford Site, 2009

8.1.2 Criteria and Toxic Air Pollutants Discharged to the Atmosphere on the Hanford Site, 2009.

8.2.1 Monitoring Locations and Analyses for Ambient-Air Monitoring Samples Collected Near

Hanford Site Facilities and Operations, 2009

8.2.2 Site-Wide and Offsite Ambient-Air Sampling Locations, Sample Composite Groups, and Analytes, 2009

8.2.3 Airborne Radionuclide Concentrations in the Environs of the Hanford Site, 2009 Compared to Previous Years

8.3.1 Radionuclides in 200 Areas Liquid Effluent Discharged to the State-Approved Land Disposal Site on the Hanford Site, 2009 
8.3.2 Radionuclides in Liquid Effluent from the 100-K Area Discharged to the Columbia River, 2009 .................. 8.25

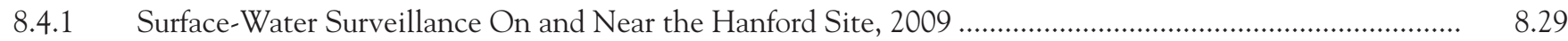

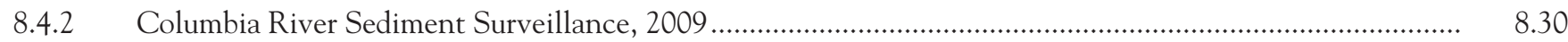

8.5.1 Hanford Reach Shoreline Springs Water Monitoring, 2009 ......................................................................... 8.46

8.5.2 Hanford Reach Shoreline Springs Sediment Monitoring, 2009 ..................................................................... 8.47

8.5.3 Concentration Ranges for Selected Chemicals in Water Monitoring Samples from Columbia River Shoreline Springs on the Hanford Site, 2004 Through 2009 ............................................................... 8.51

8.6.1 Hanford Site Drinking Water Systems and System Operators .....................................................................

8.6.2 Annual Average Concentrations of Selected Radiological Constituents in Hanford Site Drinking Water, 2009

8.6.3 Tritium Concentrations in Hanford Site 400 Area Drinking Water Wells, 2009 ………............................... 8.56

8.7.1 A Summary of Hanford Site Groundwater Monitoring by Groundwater Interest Area, 2009 ...................... 8.61

8.7.2 A Summary of Hanford Site Groundwater Monitoring by Monitoring Purpose, 2009.................................. 8.62

8.7.3 Resource Conservation and Recovery Act of 1976 Units Requiring Groundwater Monitoring on the

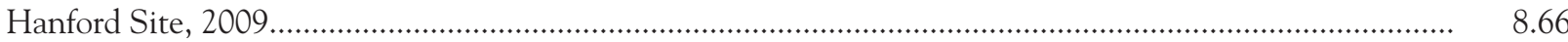

8.7.4 Areas of Contaminant Plumes on the Hanford Site at Levels Above Drinking Water Standards, 2009 ....... 8.69

8.7.5 Summary of Maximum Contaminant Concentrations in Hanford Site Wells by Groundwater Interest Area, 2009

8.8.1 Sampling Locations and Analytes for Food and Farm Products Sampled Around the Hanford Site in 2009

8.9.1 Number and Locations of Soil Samples Collected Near Hanford Site Facilities and Operations, 2009 ........ 8.91

8.9.2 Accessible Soil Concentration Limits for Selected Radionuclides.................................................................. 8.92

8.9.3 Concentrations of Selected Radionuclides in Near-Facility Soil Samples, 2009 Compared to

Previous Years

8.9.4 Radionuclide Concentrations in Environmental Restoration Contractor Field Remediation Projects' Soil Samples, 2009

8.9.5 Number and Locations of Soil Contamination Incidents Investigated Near Hanford Site Facilities and Operations, 2009

8.9.6 Annual Number of Soil Contamination Incidents Investigated Near Hanford Site Facilities and Operations, 1998 Through 2009

8.10.1 Number and Locations of Vegetation Samples Collected Near Hanford Site Facilities and Operations in 2009

8.10.2 Concentrations of Selected Radionuclides in Near-Facility Vegetation Samples, 2009 Compared to Previous Years

8.10.3 Number of Vegetation Contamination Incidents Investigated Near Hanford Site Facilities and Operations, 2009 
8.10.4 Annual Number of Vegetation Contamination Incidents Investigated Near Hanford Site Facilities and Operations, 1998 Through 2009

8.10.5 Number of Fish and Wildlife Sampling Locations and Analyses On and Around the Hanford Site, 2009

8.11.1 Thermoluminescent Dosimeter Results Near Hanford Site Operations in 2008 and 2009 _......................... 8.116

8.11.2 Status of Outdoor Contamination Areas on the Hanford Site, 2009 …….................................................... 8.119

8.11.3 Change in Status of Outdoor Contamination Areas on the Hanford Site, 2009........................................ 8.119

8.12.1 Dose to the Hypothetical, Maximally Exposed Individual Residing at Sagemoor from 2009 Hanford Site Operations

8.12.2 Collective Dose to the Population from 2009 Hanford Site Operations.

8.12.3 Comparison of 2009 Doses to the Public from Hanford Site Effluent and Emissions to Federal Standards and Natural Background Levels

8.12.4 Results of Using the RESRAD-BIOTA Computer Code to Estimate Radiological Doses to Biota On and Around the Hanford Site, Using 2009 Onsite Pond Water, Columbia River Shoreline Spring Water, and River and Pond Sediment

8.12.5 Estimated Risk from Various Activities and Exposures

8.12.6 Activities Comparable in Risk to the 0.12-mrem Dose Calculated for the Hanford Site Maximally Exposed Individual in 2009

8.13.1 Federal and Washington State Listed Endangered, Threatened, Sensitive, and Candidate Species Occurring or Potentially Occurring on the Hanford Site

8.13.2 Washington State Monitor Species Occurring or Potentially Occurring on the Hanford Site .......

8.13.3 Washington State Review and Watch List Plant Species Potentially Found on the Hanford Site

8.14.1 Number of Columbia Yellowcress Stems Counted Along the Hanford Reach of the Columbia River in Surveys Conducted from 1994 Through 2009

8.15.1 Full Cultural Resources Reviews Conducted on the Hanford Site in 2009......

8.16.1 Monthly and Annual Climatological Data for 2009 from the Hanford Meteorology Station

8.17.1 Summary of Field Duplicate Sample Results for Samples Submitted to General Engineering Laboratories, LLC, Charleston, South Carolina, for the Surface Environmental Surveillance Project, 2009

8.17.2 Summary of Battelle's Marine Sciences Laboratory Performance on Laboratory Sample Duplicates for Inductively Coupled Plasma Metals Collected for the Surface Environmental Surveillance Project, 2009

8.17.3 Summary of Battelle's Marine Sciences Laboratory Performance on NSI Solutions, Inc. Proficiency Testing Program Samples, 2009.

8.17.4 Summary of Chemical Results for General Engineering Laboratories, LLC, Charleston, South Carolina, Performance on Eight Environmental Resource Associates', One Resource Technology Corporation's, and Four New York State Department of Health Environmental Laboratory Approved Program's Proficiency Testing Samples, 2009 
8.17.5 Summary of General Engineering Laboratories, LLC, Charleston, South Carolina, Performance on Eight Performance Evaluation Program Samples Provided by the DOE Mixed Analyte Performance Evaluation Program, 2009

8.17.6 Summary of General Engineering Laboratories, LLC, Charleston, South Carolina, Performance on One Multimedia Radiochemistry Performance Testing Sample and One RadChem Proficiency

Testing Sample Provided by the Environmental Resource Associates Proficiency Testing

Program, 2009

8.17.7 Summary of General Engineering Laboratories, LLC, Charleston, South Carolina, Performance on Double-Blind Spiked Samples Submitted by Pacific Northwest National Laboratory for the Surface Environmental Surveillance Project, 2009.

8.17.8 A Summary of Hanford Site Laboratories Used by Site Contractors and Types of Effluent Monitoring and Near-Facility Monitoring Samples Analyzed, 2009.

8.17.9 The Hanford Site's Waste Sampling and Characterization Facility Performance on RAD, DOE Mixed Analyte Performance Evaluation Program Samples, and National Institute of Standards and Technology Radiochemistry Intercomparison Program Samples, 2009

8.17.10 The Hanford Site's 222-S Laboratory Performance on DOE's Mixed Analyte Performance Evaluation Program Samples, 2009

8.17.11 The Hanford Site's 222-S Laboratory Performance on EPA Laboratory Water Pollution Inorganic and Organic Studies, 2009.

A.1 Names and Symbols for Units of Measure.

A.2 Conversion Table

A.3 Names and Symbols for Units of Radioactivity .........

A.4 Conversions for Radioactivity Units.

A.5 Conversions for Radiological Dose Units.

A.6 Names and Symbols for Units of Radiation Dose or Exposure .

A.7 Radionuclides and Their Half-Lives.

A.8 Elemental and Chemical Constituent Nomenclature ......

C.1 Concentrations of Selected Radionuclides in Near-Facility Air Samples, 2009 Compared to Previous Years.....

C.2 Selected U.S. Geological Survey Columbia River Water Quality Data for Vernita Bridge and Richland, Washington, 2009

C.3 Radionuclide Concentrations in Columbia River Water Samples Collected at Priest Rapids Dam,

Washington, 2009 Compared to Previous 5 Years

C.4 Radionuclide Concentrations in Columbia River Water Samples Collected at Richland,

Washington, 2009 Compared to Previous 5 Years

C.5 Radionuclide Concentrations Measured in Columbia River Water Samples Collected Along Transects of the Hanford Reach, 2009

C.6 Radionuclide Concentrations Measured in Columbia River Water Samples Collected at Near-Shore Locations in the Hanford Reach, 2009 
C.7 Concentrations of Dissolved Metals in Columbia River Transect and Near-Shore Water Samples Collected Near the Hanford Site, September 2009

C.8 Radionuclide and Total Organic Carbon Concentrations in Sediment from the Columbia River Near the Hanford Site, 2009 Compared to Previous 5 Years

C.9 Range of Metal Concentrations in Sediment Samples Collected from the Columbia River Near the Hanford Site, 2009.

C.10 Radionuclide Concentrations Measured in Columbia River Water Samples Collected from Shoreline Springs Along the Hanford Site, 2009 Compared to Previous 5 Years.

C.11 Radionuclide Concentrations in Columbia River Shoreline Sediment for 2009 Compared to Previous 5 Years

C.12 Mean Concentrations of Chemical Constituents in Wild Chive Subsamples from the 100-H Area and Locke Island Compared to Reference Samples from Upriver of Vernita Bridge, Spring 2009

C.13 Concentrations of Metals in Livers from Whitefish Collected from the Hanford Reach of the Columbia River and at an Upriver Reference Location Below Wanapum Dam in 2009

C.14 Concentrations of Metals in Livers from Canada Geese Collected from the Hanford Reach of the

Columbia River and at a Reference Location Near Desert Aire, Washington, in 2009

D.1 Environmental Permits

D.2 Selected DOE-Derived Concentration Guides

D.3 Washington State Water Quality Criteria for the Hanford Reach of the Columbia River.

D.4 Selected Drinking Water Standards

D.5 Selected Surface Freshwater Quality Criteria for Toxic Pollutants .......

D.6 Radiation Standards for Protection of the Public from all Routine DOE Concentrations

E.1 Food Pathway Parameters Used in Hanford Site Dose Calculations, 2009 ......

E.2 Dietary Parameters Used in Hanford Site Dose Calculations, 2009

E.6

E.3 Residency Parameters Used in Hanford Site Dose Calculations, 2009

E.6

E.4 Columbia River Recreational Parameters Used in Hanford Site Dose Calculations, 2009 .

E.6

E.5 Technical Details of Airborne Release Dose Calculations for the Hanford Site, 2009.

E.7

E.6 Technical Details of Liquid Release Dose Calculations for the Hanford Site, 2009

E.7 Dose to the Hypothetically, Maximally Exposed Individual Residing at Sagemoor from 2009 Hanford Site Operations

E.8 Collective Dose to the Population from 2009 Hanford Site Operations................................................... E. E

E.9 Annual Dose to 400 Area Workers from Ingestion of Onsite Drinking Water, 2009 .................................. E. E

F.1 Radionuclides Measured by Gamma Spectroscopy . 


\subsection{Introduction}

This environmental report, published annually since 1959 (http://hanford-site.pnl.gov/envreport), provides information and analytical data related to the Hanford Site for the 2009 calendar year, including a brief history of the site and its mission; compliance with applicable federal, state, and local environmental laws, regulations, permits, Executive Orders, and U.S. Department of Energy (DOE) policies and directives; and descriptions and summary data from environmental-related programs.

Included are sections that describe the following:

- Site compliance with local, state, and federal environmental standards and requirements

- Site operations, including environmental restoration efforts and cleanup and closure activities

- Environmental management performance

- Environmental occurrences and responses

- Effluent and emissions from site facilities

- Results of onsite and offsite environmental and groundwater monitoring efforts

- Cultural and biological resource assessments.

Readers interested in more detail than is provided in this environmental report should consult the technical documents cited in text and listed in the reference sections. Descriptions of specific analytical and sampling methods used in the monitoring efforts are contained in the Environmental Monitoring Plan, United States Department of Energy, Richland Operations Office (DOE/RL-91-50, Rev. 4).

\subsubsection{Current Hanford Site Mission}

Prior to 1988, the primary Hanford Site mission was the production of plutonium for national defense purposes. The current primary Hanford Site mission is environmental remediation and cleanup, including the remediation of contaminated areas and the decontamination and decommissioning of Hanford Site facilities.

The Performance Management Plan for the Accelerated Cleanup of the Hanford Site (DOE/RL-2002-47, Rev. D) describes the cleanup mission, which includes six strategies:

1. Restore the Columbia River Corridor by remediating Hanford Site sources of radiological and chemical contaminants that threaten the air, groundwater, or the Columbia River by 2012.

2. Complete tank waste treatment by 2028 by increasing the capacity of the Hanford Tank Waste Treatment and Immobilization Plant (under construction in 2009) and using supplemental technologies for waste treatment and stabilization; accelerate waste retrieval and close the double-shell tank farms, ending the tank waste program by 2033.

3. Clean up other Hanford Site facilities that are considered urgent risks.

4. Treat and dispose of mixed low-level waste, including retrieval of transuranic waste and its shipment offsite.

5. Clean up excess facilities on the Central Plateau.

6. Monitor, isolate, and remediate groundwater contamination sources beneath the Hanford Site. 
The main goal of these strategies is to expedite completion of Hanford Site cleanup in a cost-effective manner that protects the environment and the health and safety of the public and site workers.

\subsubsection{Hanford Site Overview}

The Hanford Site lies within the semi-arid Pasco Basin of the Columbia Plateau in southeastern Washington State (Figure 1.0.1). The site occupies an area of approximately 1,517 square kilometers (586 square miles) north of the city of Richland (DOE/EIS-0222-F). This area has restricted public access and provides a buffer for areas on the site that were used for nuclear materials production, waste storage, and waste disposal. The Columbia River flows eastward through the northern part of the site and then turns south, forming part of the eastern site boundary.

Major DOE operational, research, and administrative areas within and around the Hanford Site (Figure 1.0.1) include the following:

- 100 Areas - The 100 Areas, consisting of six distinct sites, are situated along the shore of the Columbia River in the northern portion of the site. These areas were the location of nine nuclear reactors that have since been retired. Collectively, the 100 Areas occupy approximately 11 square kilometers (4 square miles). The B Reactor, a National Historic Landmark, is located in the 100-B Area. The world's first industrial-scale nuclear reactor, it is where plutonium was produced for the first atomic explosion (the Trinity Test) and the Nagasaki, Japan, atomic bomb. DOE offers scheduled tours of the facility.

- 200 Areas - The 200-East and 200-West Areas, covering approximately 16 square kilometers (6 square miles), are located on the Central Plateau, approximately 8 and 11 kilometers (5 and 7 miles) south and west, respectively, of the Columbia River. The plateau surface is approximately 100 meters (328 feet) above the level of the Columbia River and about 85 meters (280 feet) above the underlying water table. These areas contain underground waste storage tanks and housed facilities (known as "separations plants") that extracted plutonium from dissolved irradiated fuel. The 200-North Area, now considered part of the 600 Area, is located near Gable Mountain, north of the 200 Areas and approximately 7 to 12 kilometers (4 to 7.5 miles) south of the 100 Areas. Covering approximately 23.7 hectares (58.6 acres), operations were mainly related to irradiated nuclear fuel interim storage. Thermal cooling of the spent fuel required water, which was disposed of at several sites within the 200-North Area. Remediation of these sites is ongoing.

- 300 Area - The 300 Area is located just north of the city of Richland and covers approximately 1.5 square kilometers (0.6 square mile). From the early 1940s until the advent of the cleanup mission, nuclear fuel fabrication and research and development activities on the Hanford Site were performed in the 300 Area. Remediation of waste sites and decommissioning of 300 Area facilities continued in 2009.

- 400 Area - The 400 Area is located northwest of the 300 Area, and covers approximately 0.61 square kilometer $(0.23$ square mile). This area includes the Fast Flux Test Facility, a nuclear reactor designed and used to test various types of nuclear fuel, produce medical and industrial isotopes, and conduct cooperative international research. The facility has not operated since 1992 and was placed into low-cost, long-term surveillance and maintenance condition during 2009.

- 600 Area - The 600 Area includes all of the Hanford Site not occupied by the 100, 200, 300, and 400 Areas.

- Former 1100 Area - The former 1100 Area is located between the 300 Area and the city of Richland and covers 3.1 square kilometers (1.2 square miles). In October 1998, this area was transferred to the Port of Benton as part of DOE's Richland Operations Office economic diversification efforts and is no longer part of the Hanford Site. However, DOE contractors continue to lease facilities in this area.

- Richland North Area (offsite) - This area includes the Environmental Molecular Sciences Laboratory, Pacific Northwest National Laboratory, and other DOE and contractor facilities (mostly office buildings), generally located in the northern part of the city of Richland.

- 700 Area (offsite) - The 700 Area includes DOE administrative buildings in the central region of the city of Richland.

- Volpentest Hazardous Materials Management and Emergency Response Training and Education Center (also called HAMMER) - This worker safety 


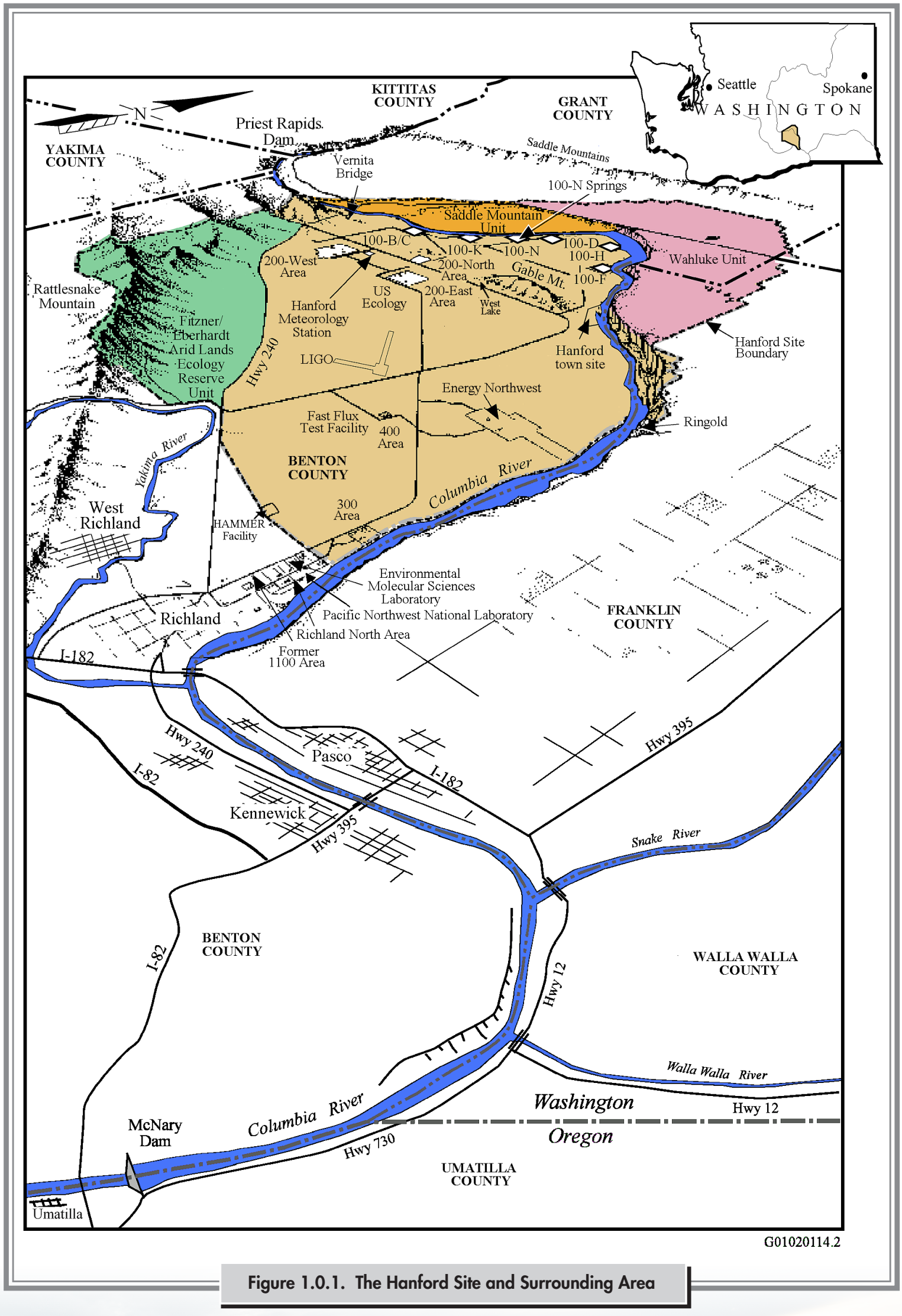


training facility, used by site contractors, federal and state agencies, tribal governments, and private industries, is located on the Hanford Site near the city of Richland. It consists of a 0.31-square-kilometer (0.12-square-mile) main site and a 40.4-square-kilometer (15.6-squaremile) law enforcement and security training site. The facility, owned by DOE, was managed by Fluor Hanford, Inc. from January to late August 2009, then subsequently by Mission Support Alliance, LLC.

\section{Non-DOE Operations and Activities on Hanford Site}

Leased Land - These include commercial power production by Energy Northwest at the Columbia Generating Station (440 hectares [1,090 acres]) and operation of a commercial low-level radioactive waste burial site by US Ecology Washington, Inc. (40 hectares [99 acres]). The Laser Interferometer Gravitational-Wave Observatory (60 hectares [148 acres]), located west of the 400 Area, is sponsored by the National Science Foundation and operated jointly by the California Institute of Technology and the Massachusetts Institute of Technology.

Rattlesnake Mountain - Much of the Rattlesnake Mountain summit is DOE-owned land, but is managed by the U.S. Fish and Wildlife Service as part of the Hanford Reach National Monument. DOE has leased this land to public and private agencies, including public utility districts, communication businesses, emergency management facilities, Energy Northwest, Battelle Memorial Institute, the Alliance for the Advancement of Science through Astronomy, and others for decades. In March 2008, the DOE Richland Operations Office announced it would not renew existing permits, licenses, and easements on Rattlesnake Mountain, and that structures would be removed, returning much of the land to natural conditions. The Rattlesnake Mountain Observatory was removed in June 2009; it was built in 1971 by Battelle using privately donated funds for astronomical research and donated by Battelle to the Alliance for the Advancement of Science through Astronomy in 2005.

In July 2009, an environmental assessment was completed (DOE/EA-1660F) regarding consolidating communications operations and removing excess facilities, infrastructure, and debris from the Fitzner/Eberhardt Arid Lands Ecology Reserve on Rattlesnake Mountain. The proposed actions would reduce the physical footprint, improve the landscape, and minimize impacts to cultural and biological resources. The evaluation determined that DOE could proceed with the construction of the Combined Community Communication Facility, demolition of unneeded structures, and debris cleanup. Construction of the facility and the communication antenna towers were completed in 2009. Demolition of surplus infrastructure and debris cleanup is planned for 2010.

Non-DOE Nuclear Operations Near the City of Richland - Immediately adjacent to the southern boundary of the Hanford Site, AREVA NP, Inc. operates a commercial nuclear fuel fabrication facility, and Perma-Fix Northwest, Inc. operates a low-level and mixed low-level radioactive waste processing facility. Westinghouse Electric Company operates the Richland Service Center, located in north Richland, which provides chemical cleaning, decontamination, and other waste processing services to the nuclear industry.

Hanford Reach National Monument - The 789-squarekilometer (305-square-mile) Hanford Reach National Monument (Figure 1.0.2) was established on the Hanford Site by a Presidential Proclamation in June 2000 (65 FR 37253). The purpose of the monument is to protect the nation's only non-impounded stretch of the Columbia River upstream of Bonneville Dam in the United States, and the remaining shrub-steppe ecosystem that once blanketed the Columbia River Basin.

\subsubsection{Hanford Site Management}

DOE is responsible for operating the Hanford Site. The DOE Richland Operations Office and DOE Office of River Protection jointly manage the Hanford Site through several contractors and their subcontractors. Each contractor is responsible for safe, environmentally sound maintenance and management of its activities or facilities; waste management; evaluation and determination of all discharges to the environment; and for monitoring any potential effluent to assure environmental regulatory compliance. DOE, the U.S. Fish and Wildlife Service, and the Washington Department of Fish and Wildlife each manage portions of the Hanford Reach National Monument. 


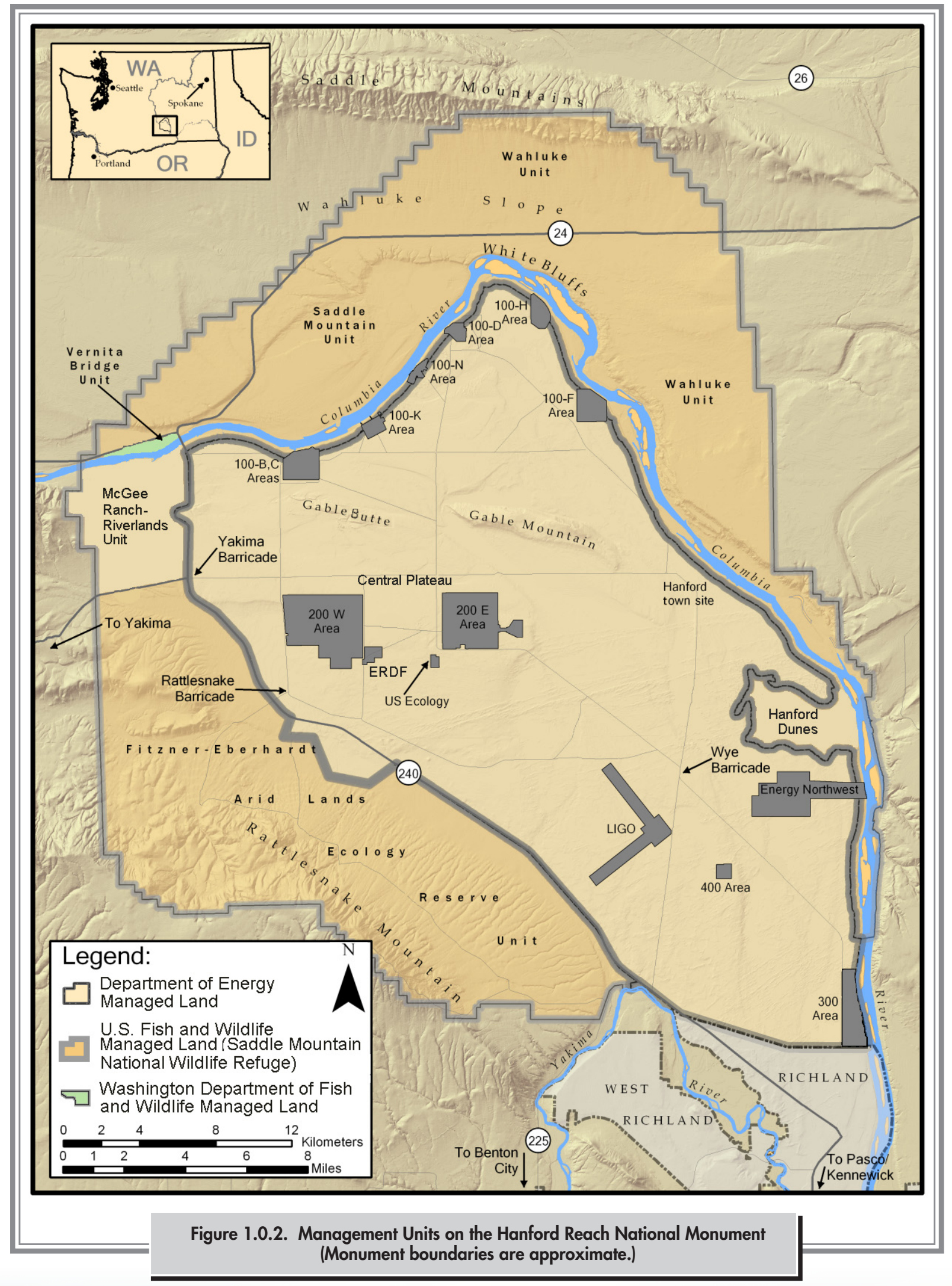


DOE Richland Operations Office. The DOE Richland Operations Office serves as landlord of the Hanford Site and manages cleanup of legacy waste, related research, and other programs. During 2009, the principal contractors for the DOE Richland Operations Office and their respective responsibilities included the following:

- Mission Support Alliance, LLC - In 2009, this contractor became the mission support contractor for the Hanford Site. The scope of work for the Mission Support Contract includes Hanford Site infrastructure and support services including safety, security, and environment; site infrastructure and utilities; site business management; information resources and content management; and portfolio management. Mission Support Alliance, LLC, is a limited liability company operated by Lockheed Martin, LLC; Jacobs Engineering Group, Inc.; and Wackenhut Services, Inc, with subcontractors Abadan; Akima Facilities Management; Dade Moeller \& Associates; HPM Corporation; Longenecker and Associates; Protection Strategies; R. J. Lee Group; Vivid Learning Systems; Westech International; TestAmerica; and Lampson International.

- Washington Closure Hanford, LLC - This contractor was awarded the River Corridor Closure Contract in March 2005. This contractor is a limited liability company owned by Washington Division of URS Corporation; Bechtel National, Inc.; and CH2M HILL Hanford Group, Inc. The scope of work includes clean up of waste sites and environmental restoration along the Columbia River Corridor, an area roughly 544 square kilometers (210 square miles) along the Benton County side of the Columbia River's Hanford Reach. Work includes placing the remaining deactivated plutonium-production reactors in interim safe storage (also known as "cocooning"), continuing cleanup of the remaining waste sites located near the Columbia River, demolishing contaminated facilities, and operating the Environmental Restoration Disposal Facility. The principle subcontractor to Washington Closure Hanford, LLC, is Eberline Services Hanford, Inc.

- CH2M HILl Plateau Remediation Company - This contractor became the plateau remediation contractor for the Hanford Site in 2008 and is responsible for safe environmental cleanup of the Central Plateau. The Plateau Remediation Contract scope of work includes environmental remediation, groundwater monitoring and remediation, waste site characterization, nontank farm waste disposal, Fast Flux Test Facility maintenance and shutdown, environmental monitoring and maintenance, and completion of the Plutonium Finishing Plant closure project. The CH2M HILL Plateau Remediation Company team includes CH2M HILL Constructors, Inc.; AREVA Federal Services, LLC; East Tennessee Materials and Energy Corporation, Inc.; Fluor Federal Services, Inc.; ARES Corporation; Babcock Services; GEM Technology International; INTERA, Inc.; ENREP, Inc.; Ascendent Engineering and Safety Solutions; Cavanagh Services Group; and Project Services Group.

- AdvanceMed Hanford - This contractor was the occupational health contractor on the Hanford Site in 2009. The company provides occupational medicine and nursing; medical surveillance and evaluations; ergonomics assessment; exercise physiology; case management; psychology counseling and evaluations; fitness-for-duty evaluations; health education; infection control; immediate health care; industrial hygiene; and health, safety, and risk assessments.

The DOE Richland Operations Office also manages portions of the Hanford Reach National Monument. The portion of the monument administered by the DOE Richland Operations Office includes the 36.4-square-kilometer (14-square-mile) McGee Ranch/Riverlands Unit (north and west of State Highway 24 and south of the Columbia River) in Benton County, and the Columbia River Corridor Unit, which includes the Hanford Reach islands in Benton County and a 0.4-kilometer- $(0.25$-mile-) wide strip of land along the Hanford Reach shoreline from the Vernita Bridge to just north of the 300 Area. This 101-squarekilometer (39-square-mile) unit in Benton, Franklin, and Grant Counties also includes the 25.6-square-kilometer (9.9-square-mile) Hanford Site dunes area north of Energy Northwest (Figure 1.0.2).

DOE Office of River Protection. The DOE Office of River Protection was established by Congress in 1998 as a field office to manage Hanford Site tank-waste storage, 
retrieval, treatment, and disposal. During 2009, the principal contractors for the DOE Office of River Protection and their respective responsibilities included the following:

- Bechtel National, Inc. - This contractor's mission is to design, build, and initiate the operation of the Hanford Tank Waste Treatment and Immobilization Plant, located on a 0.26-square-kilometer (0.1-square-mile) site on the Central Plateau of the Hanford Site. This facility is designed to convert liquid radioactive waste into a stable glass form (vitrification). The 10-year contract for this work was awarded in December 2000.

- Washington River Protection Solutions LLC - This contractor was awarded the Tank Operations Contract for the Hanford Site in 2008. The scope of work includes base operations of the tanks, analytical laboratory support, single-shell tank retrieval and closure, Hanford Tank Waste Treatment and Immobilization Plant support, and supplemental treatment. Hanford Site tank farms contain 210 million liters (56 million gallons) of radioactive and chemically hazardous waste stored in 177 underground tanks generated from more than three decades of plutonium production. Washington River Protection Solutions LLC was formed by the Washington Division of URS Corporation and EnergySolutions, with AREVA Federal Services, LLC serving as a subcontractor.

- Advanced Technologies and Laboratories International, Inc. - This contractor provides analytical services to Hanford Site cleanup and restoration contractors. Located in the 200-West Area, this laboratory is equipped and staffed to receive, analyze, and store samples and report analytical results to the appropriate contractor.

DOE Office of Science. The Pacific Northwest Site Office of the DOE Office of Science oversees Pacific Northwest National Laboratory (including the Environmental Molecular Sciences Laboratory) to support DOE's science and technology programs, goals, and objectives. Pacific Northwest National Laboratory, a DOE facility in Richland, Washington, is operated by Battelle for the DOE's national security and energy missions. Pacific Northwest National Laboratory delivers scientific solutions by using interdisciplinary teams from multiple scientific disciplines to solve energy, environmental, and national security challenges.
U.S. Fish and Wildlife Service. The U.S. Fish and Wildlife Service, under permits and memoranda of agreement with DOE, manages regions of the Hanford Reach National Monument. During 2009, the U.S. Fish and Wildlife Service administered three major management units (Figure 1.0.2) totaling about 668 square kilometers (258 square miles). These included the following:

- The Fitzner/Eberhardt Arid Lands Ecology Reserve Unit, a 311-square-kilometer (120-square-mile) tract of land in Benton County with no general public access located in the southwestern portion of the Hanford Site.

- The Saddle Mountain Unit, a 130-square-kilometer (50-square-mile) tract of land in Grant County with no general public access located north-northwest of the Columbia River.

- The Wahluke Unit, a 230-square-kilometer (89-squaremile) tract of land located north of the Columbia River with public access and adjacent to (east of) the Saddle Mountain Unit.

These land units have served as a safety and security buffer zone for Hanford Site operations since 1943, resulting in an ecosystem that has been relatively untouched for more than 60 years. Together, these units comprise the Saddle Mountain National Wildlife Refuge.

Washington Department of Fish and Wildlife. This department manages the Vernita Bridge Unit of the Hanford Reach National Monument, occupying approximately 3.2-square-kilometers (1.25-square-miles) along the north side of the Columbia River, west of the Vernita Bridge, and south of State Highway 243 in Grant County. This unit is open to the public year round.

\subsubsection{Hanford Site Websites}

Additional information about Hanford Site management and contractors can be accessed at the following websites:

- AdvanceMed Hanford: http://www.hanford.gov/amh/

- Advanced Technologies and Laboratories International, Inc.: http://www.atlintl.com/

- Bechtel National, Inc.: http://www.hanfordvitplant.com/ 
- CH2M HILL Plateau Remediation Company: http://www.plateauremediation.hanford.gov/

- DOE Office of River Protection: http://www.hanford.gov/orp/

- DOE Office of Science: http://www.er.doe.gov/

- DOE Richland Operations Office: http://www.hanford.gov/rl/

- DOE Science and Technology: http://www.energy.gov/sciencetech/

- Eberline Services Hanford, Inc.: http://www.eberlineservices.com/page_field.htm

- EnergySolutions: http://www.energysolutions.com/?id=OTUy

- Environmental Molecular Sciences Laboratory: http://www.emsl.pnl.gov/

- Environmental Restoration Disposal Facility: http://www.hanford.gov/page.cfm/ERDF

- Fast Flux Test Facility: http://www.hanford.gov/page.cfm/FFTF

- Hanford Reach National Monument: http://www.fws.gov/hanfordreach

- Hanford Site Tours: http://www.hanford.gov/page.cfm/HanfordSiteTours

- Laser Interferometer Gravitational-Wave Observatory: http://www.ligo.caltech.edu/

- Lockheed Martin Corporation: http://www.lockheedmartin.com/

- Mission Support Alliance, LLC: http://www.msa-hanford.com

- Pacific Northwest National Laboratory: http://www.pnl.gov/

- Pacific Northwest Site Office of the DOE Office of Science: http://pnso.oro.doe.gov/

- URS Corporation: http://www.urscorp.com/

- Volpentest Hazardous Materials Management and Emergency Response Training \& Education Center (HAMMER): http://www.hammertraining.com/

- Washington Closure Hanford, LLC: http://www.washingtonclosure.com/
- Washington River Protection Solutions LLC: http://www.wrpstoc.com/

Additional information about the local area and region can be accessed at the following websites:

- City of Kennewick: http://www.ci.kennewick.wa.us/

- City of Pasco: http://www.pasco-wa.gov/

- City of Richland: http://www.ci.richland.wa.us/

- City of West Richland: http://www.westrichland.org/

- Columbia River Basin: http://yosemite.epa.gov/r10/ecocomm.nsf/Columbia/ Columbia

- Geology of Washington - Columbia Basin: http://www.dnr.wa.gov/ResearchScience/Topics/ GeologyofWashington/Pages/columbia.aspx

- Port of Benton: http://www.portofbenton.com/

- Tri-Cities Visitor \& Convention Bureau: http://www.visittri-cities.com/

- U.S. Fish and Wildlife Service: http://www.fws.gov/

- Washington Department of Fish and Wildlife: http://wdfw.wa.gov/

Additional information about other companies in the area can be accessed at the following websites:

- AREVA NP Inc.: http://www.us.areva-np.com/careers/locations/richland. htm

- Battelle Memorial Institute: http://www.battelle.org/

- Energy Northwest, Columbia Generating Station: http://www.energy-northwest.com/generation/cgs/ index.php

- Perma-Fix Northwest, Inc.: http://www.perma-fix.com/northwest

- US Ecology, Inc.: http://www.americanecology.com/richland.htm

- Westinghouse Richland Service Center: http://www.westinghousenuclear.com/Products_\&_ Services/Nuclear_Services/richland_service_center. shtm 


\subsubsection{References}

65 FR 37253. 2000. "Establishment of the Hanford Reach National Monument." Proclamation 7319 of June 9, 2000, by the President of the United States of America. Federal Register, Office of the President.

DOE/EA-1660F. 2009. Environmental Assessment: Combined Community Communications Facility and Infrastructure Cleanup on the Fitzner/Eberhardt Arid Lands Ecology Reserve, Hanford Site, Richland, Washington. U.S. Department of Energy, Richland, Washington.

DOE/EIS-0222-F. 1999. Final Hanford Comprehensive LandUse Plan Environmental Impact Statement. U.S. Department of Energy, Washington, D.C. Accessed on May 17, 2010, at http://nepa.energy.gov/nepa_documents/EIS/eis0222/ eis0222.html.
DOE/RL-91-50, Rev. 4. 2008. Environmental Monitoring Plan, United States Department of Energy, Richland Operations Office. U.S. Department of Energy, Richland Operations Office, Richland, Washington.

DOE/RL-2002-47, Rev. D. 2002. Performance Management Plan for the Accelerated Cleanup of the Hanford Site. U.S. Department of Energy, Richland Operations Office, Richland, Washington. Accessed on May 17, 2010, at http:// www.hanford.gov/rl/uploadfiles/Perf_Mang_rl-2002-47.pdf. 


\title{
2.0 Public Involvement on the Hanford Site
}

\author{
JP Duncan
}

The U.S. Department of Energy (DOE) encourages information exchange and public involvement in discussions and decision making regarding Hanford Site cleanup and remediation actions. Active participants include the public; Native American tribes; local, state, and federal government agencies; advisory boards; activist groups; and other entities in the public and private sectors. The roles and association of selected stakeholders are described in the following sections.

\subsubsection{Role of Native American Tribes}

\section{JA Conrad}

Native American tribes are involved in many aspects of the Hanford Site, including participation in site activities and planning meetings. The Hanford Site is located on land formerly occupied by Native American tribes. The Confederated Tribes and Bands of the Yakama Nation, Confederated Tribes of the Umatilla Indian Reservation, and the Nez Perce Tribe negotiated treaties with the U.S. government in 1855. The Yakama and the Umatilla tribes ceded land to the government and the Nez Perce ceded rights on the Columbia River. All of the Treaties of 1855 (Treaty with the Nez Perce, 1855; Treaty with the Walla Walla, Cayuse, etc., 1855; Treaty with the Yakama, 1855) include provisions that the tribes reserved the right to fish at all usual and accustomed places, to hunt, gather roots and berries, and pasture horses and cattle on open and unclaimed land. The Wanapum, now located in Priest Rapids, once resided on the lands that are now the Hanford Site and have historic ties to the site. The Confederated Tribes of the Colville Reservation, whose descendants also used Hanford Site land, also have historic ties to the site.
The U.S. government has a unique political and legal relationship with tribal governments as defined by treaties, the Constitution, court decisions defining the federal trust responsibility, and Executive Orders. Additional federal laws and regulations requiring DOE to consult with tribes on certain issues include the American Indian Religious Freedom Act, the National Environmental Policy Act of 1969, the Archaeological Resources Protection Act of 1979, the National Historic Preservation Act of 1966, and the Native American Graves Protection and Repatriation Act of 1990. As Hanford Site cleanup progresses, the tribes review various aspects of cleanup activities, including how these activities will affect past cultural resources and any future ability to use and consume the natural resources that once existed at the site.

Native American tribes have been involved at the Hanford Site since the Basalt Waste Isolation Pilot Project in the 1980s. Tribal review of site activities has increased with the environmental restoration and waste management mission at the Hanford Site. The U.S. Department of Energy American Indian 8 Alaska Native Tribal Government Policy (DOE 2006) guides DOE's collaborative interaction with tribes regarding site-related plans and activities. The policy states the following:

"The Department will consult with any American Indian or Alaska Native tribal government with regard to any property to which that tribe attaches religious or cultural importance which might be affected by a DOE action." (DOE 2006)

In 2009, DOE incorporated the U.S. Department of Energy American Indian 83 Alaska Native Tribal Government Policy (DOE 2006) within DOE Order 144.1, "Department of Energy American Indian Tribal Government Interactions 
and Policy," communicating departmental, programmatic, and field responsibilities for interacting with American Indian governments.

DOE provides financial assistance through cooperative agreements with the Confederated Tribes and Bands of the Yakama Nation, the Confederated Tribes of the Umatilla Indian Reservation, and the Nez Perce Tribe to support their involvement in environmental management activities, and cultural resources review and involvement at the Hanford Site. Funding enables tribes to retain staff to facilitate reviews and comment on site-related draft documents and plans, as well as participate in meetings and activities. Representatives from the Confederated Tribes and Bands of the Yakama Nation, Confederated Tribes of the Umatilla Indian Reservation, and $\mathrm{Nez}$ Perce Tribe participate in DOEsupported groups such as the State and Tribal Government Working Group, the Hanford Natural Resources Trustee Council, and the Hanford Cultural and Historic Resources Program.

\subsubsection{Consultations and Meetings with Tribes, Interested Parties, and the State Historic Preservation Office}

\section{EP Kennedy}

Federal legislation and policies require DOE to consult with the Washington State Historic Preservation Office, Native American tribes, and interested parties on cultural resource matters. Specifically, Section 106 of the National Historic Preservation Act of 1966 requires DOE to seek and gather input from tribes and interested parties, and obtain concurrence from the Washington State Historic Preservation Office on the identification of cultural resources, evaluation of the significance of these resources, and assessment of impacts of DOE undertakings on cultural resources. DOE's Cultural and Historic Resources Program routinely consults with the Washington State Historic Preservation Office, the Confederated Tribes of the Umatilla Indian Reservation, the Confederated Tribes and Bands of the Yakama Nation, the Confederated Tribes of the Colville Reservation, the Nez Perce Tribe, and the Wanapum. Program officials also consult with parties that express an interest in cultural resources located on the Hanford Site. These include groups such as the B Reactor Museum Association, the White Bluffs Pioneers, the Benton County Historical Society, the East Benton County Historical Museum, and the Franklin County Museum. Program officials also conduct regular meetings with tribal cultural resources personnel. Discussions focus on cultural resource reviews and issues regarding the protection of Hanford Site cultural resources. Program officials hold meetings with interested parties on an as-needed basis. Section 8.15 of this report further addresses cultural and historic resource activities.

\subsubsection{Hanford Natural Resource Trustee Council}

\section{Ward}

The Comprehensive Environmental Response, Compensation, and Liability Act of 1980 (CERCLA) and the implementing regulations established in 40 CFR 300, "National Oil and Hazardous Substances Pollution Contingency Plan" establish DOE as both the CERCLA lead response agency on departmental facilities and a trustee for natural resources under its jurisdiction. As the lead response agency, DOE is mandated to carry out response actions to correct or mitigate threats to human health and the environment that have resulted from the release of hazardous substances during the execution of its assigned missions. CERCLA also provides authority for assessment and restoration of natural resources that have been damaged by a hazardous substance release or response.

Under CERCLA, as amended, the United States is liable for damages or injury to, destruction of, or loss of natural resources resulting from release of hazardous substances or from removal or remedial activities made necessary because of such releases, including the cost of assessing such damage. The President of the United States, by Executive Order 12580, "Superfund Implementation" (52 FR 2923), appointed the Secretary of Energy as the primary trustee for all natural resources located on, over, or under land administered by DOE, including the Hanford Site.

Designated federal trustees for Hanford Site natural resources include the U.S. Department of the Interior represented by the U.S. Fish and Wildlife Service, and the 
U.S. Department of Commerce represented by the National Oceanic and Atmospheric Administration. CERCLA $\S 107(\mathrm{f})(2)(B)$ authorizes state governors to designate a state trustee to coordinate all state trustee responsibilities. State organizations include the Washington State Department of Ecology and the Oregon Department of Energy. Native American tribes also participate as members of the Hanford Natural Resource Trustee Council. Tribes include the Confederated Tribes and Bands of the Yakama Nation, the Confederated Tribes of the Umatilla Indian Reservation, and the Nez Perce Tribe.

The Hanford Natural Resource Trustee Council was established in 1996 via a Memorandum of Agreement (DOE/RL 1996) and is a voluntary association of trust organizations. Members collaborate and coordinate on many issues, documents, and actions concerning natural resources. The primary purpose of the council is to facilitate the coordination and cooperation of the trustees in their efforts to mitigate the effects to natural resources that result from either hazardous substance releases on the Hanford Site or remediation of those releases. The council has adopted bylaws to direct the process of arriving at consensus on all substantive decisions.

During 2009, the trustees met as a formal council six times to discuss CERCLA natural resource issues for the Hanford Site. The senior trustees (upper-management level representatives from each trust organization) conducted two conference calls in 2009 to discuss policy, management, and budget issues.

During 2009, several trust organizations of the Hanford Natural Resource Trustee Council added staff members experienced in natural resource damage assessments to aid in the injury assessment process in support of removal and remedial actions. In addition, a statement of work was prepared to employ a project coordinator to assist the trustees in planning and executing activities, including the injury assessment process.

The Hanford Natural Resource Council also performed the following actions in 2009:

- Held training on resource valuation

- Completed Phase I (conceptual site model) for the Hanford Injury Assessment Plan
- Organized and held meetings for each of six technical work groups

- Completed a statement of work for Phase II of the Hanford Injury Assessment Plan and proceeded with a request for proposals

- Evaluated a Hanford Site natural resource damage assessment process, developed an initial project scope and timeline, and agreed to formalize a proposed schedule

- Held exploratory discussions with the U.S. Fish and Wildlife Service and National Fish and Wildlife Foundation about additional U.S. Fish and Wildlife Service assistance

- Developed council budgets for natural resource injury assessment activities

- Supported funding for injury assessment in the President's budget request to Congress

- Prepared a statement of work for and obtained facilitator services to assist the trustees in planning and conducting Hanford Natural Resource Trustee Council administrative business

- Received regular briefings on ongoing and planned cleanup activities, including remedial investigation and feasibility study plans and results

- Held a second workshop to plan sturgeon sampling for the River Corridor Baseline Risk Assessment and provided input to DOE and Washington Closure Hanford, LLC fish sampling plans

- Influenced the Washington Closure Hanford, LLC decision to characterize groundwater upwelling in the Columbia River

- Provided (as individual organizations) comments to DOE on cleanup activities including draft plans (e.g., Environmental Restoration and Disposal Facility expansion, 100 Area remedial investigation/feasibility study plans)

- Participated in several workshops to discuss revision of the Hanford Site Biological Resource Management Plan (DOE/RL 96-32, Rev. 0).

Information about the Hanford Natural Resource Trustee Council, including its history and projects, is on the following website: http://www.hanford.gov/page.cfm/HNRTC. 


\subsubsection{Public Participation in Hanford Site Decisions}

\section{PK Call}

DOE's Richland Operations Office and Office of River Protection believe public involvement is essential to the ultimate success of Hanford Site cleanup. These offices coordinate, plan, and schedule public participation activities for DOE on the Hanford Site.

The Hanford Site Tri-Party Agreement Public Involvement Community Relations Plan (DOE/RL 2002) outlines the public participation processes used by the Tri-Party Agreement agencies (Washington State Department of Ecology, U.S. Environmental Protection Agency [EPA], and DOE) and identifies various ways the public can participate in Hanford Site cleanup decisions (see Section 3.0.1). The first plan was developed and approved with public input in 1990 and has since been revised four times; January 2002 is the most current revision. It is available on the following website: http://www.hanford.gov/?page=89. Presently, the plan is undergoing revisions and will tentatively be available for review and comment in mid to late 2010.

A key goal of public involvement is to facilitate broad-based participation and obtain stakeholder and public perspectives on Hanford Site cleanup decisions. DOE uses various forums to inform the public of upcoming public involvement and participation opportunities. These include, but are not limited to, the following:

- The Hanford Cleanup Line - The Hanford Cleanup Line (800-321-2008) responds to information requests about the Hanford Federal Facility Agreement and Consent Order (Tri-Party Agreement [Ecology et al. 1989]) cleanup activities. The Tri-Party Agreement agencies strive to provide a timely response to all requests. The line is advertised frequently in a variety of ways, including all Tri-Party Agreement announcements, media information such as newspaper notices, brochures, meeting notices, and Hanford Site fact sheets.

- Mailing List - The Tri-Party Agreement agencies maintain a mailing list of about 3,000 individuals who have expressed interest in Hanford Site cleanup issues.
The mailing list is used to provide information to the public on upcoming cleanup decisions and activities. Information can be received by mail or electronically. To be added to the list, call the Hanford Cleanup Line at (800) 321-2008.

- Hanford Site Public Involvement Activities - A Hanford Site Event Calendar is available on the following website: http://www.hanford.gov/pageAction.cfm/ calendar. The calendar provides an overview of public involvement opportunities for the coming months and identifies current forums and emerging opportunities to inform and involve stakeholders and the public.

- Hanford Site Informational Links - Information concerning Hanford Site events, issues, cleanup activities, and public involvement opportunities is available on the following website: http://www.hanford.gov/.

- Meeting Summaries - Summaries of certain public meetings are available upon request from DOE's Public Reading Room located at the Washington State University Tri-Cities Consolidated Information Center, 2710 University Drive, Richland, Washington. Further information regarding the DOE Public Reading Room is available on the following website: http://readingroom.pnl.gov/.

- Comment and Response Documents - Following a DOE or Tri-Party Agreement public comment period, a comment and response document is developed to record public comments received on an issue. Comment and response documents are distributed to those members of the public who provide comments or request copies. The documents are posted in DOE's Public Reading Room, in the Tri-Party Agreement's Administrative Record as part of the decision documentation, and are available on the following website: www.hanford.gov/page.cfm/ TriParty.

- Informational Public Meetings - All Tri-Party Agreement quarterly public involvement planning meetings, semiannual meetings, special meetings, and workshops are open to the public. In addition, the Tri-Party Agreement agencies welcome opportunities for co-sponsoring meetings organized by local, state, and tribal governments and citizen groups. 
Hanford Site cleanup documents are also available to the general public through the Tri-Party Agreement's Administrative Record and Public Information Repository available on the following website: http://www5.hanford. gov/arpir/.

The public is provided a variety of opportunities to offer input and influence Hanford Site cleanup decisions. These opportunities include informal and formal public comment periods, such as those described in the Tri-Party Agreement (Ecology et al. 1989), CERCLA, the Resource Conservation and Recovery Act of 1976 (RCRA), and the National Environmental Policy Act of 1969; Hanford Advisory Board meetings; annual state of the site and budget meetings; and other Hanford Site-related public involvement/information meetings, workshops, or activities.

\section{State of Oregon}

DOE recognizes the State of Oregon's unique role and interests at the Hanford Site, and its concerns to protect the resources of the Columbia River. DOE is interested in sharing, facilitating, and accommodating the exchange of information with the State of Oregon. DOE's Richland Operations Office and Office of River Protection entered into a Memorandum of Understanding (DOE/RL 2004) with Oregon to consult, and whenever possible, cooperate on Hanford Site environmental issues. DOE will consult with and include the Oregon Department of Energy in planning and conducting Hanford Site-related public involvement activities in the State of Oregon.

For more information about Hanford Site cleanup activities, contact the Tri-Party Agreement agencies at the following contact numbers:

- DOE Richland Operations Office

- DOE Office of River Protection

- Hanford Site Cleanup Line/Ecology

- EPA

(509) 376-8631

To view public involvement and outreach activities conducted by the Tri-Party Agreement agencies, visit the Hanford Site website: http://www.hanford.gov.

\subsubsection{Hanford Advisory Board PK Call}

The Hanford Advisory Board is a broadly representative body consisting of a balanced mix of the diverse interests affected by Hanford Site cleanup decisions. The board was created in 1994 by the Tri-Party Agreement agencies and ultimately chartered as one of nine environmental management site-specific advisory boards across the country. The board is composed of 31 members and their alternates, including representatives from the Nez Perce Tribe and the Confederated Tribes and Bands of the Yakama Nation. A representative of the Confederated Tribes of the Umatilla Indian Reservation participates on the board in an ex-officio status. Current members with their affiliations are on the following website: http://www.hanford.gov/page.cfm/hab.

The Hanford Advisory Board assists the broader public in becoming more informed and meaningfully involved in Hanford Site cleanup decisions through its open public meetings. Board members' formal advice on cleanup issues reflects the values of its constituents. Copies of their advice and DOE's responses are on the following website: http:// www.hanford.gov/?page $=453$.

Information about the Hanford Advisory Board, including its charter (operating ground rules) are on the following website: http://www.hanford.gov/?page=449.

\subsubsection{References}

40 CFR 300. 2009. "National Oil and Hazardous Substances Pollution Contingency Plan." Code of Federal Regulations, U.S. Environmental Protection Agency. Source: 59 Federal Register 47416, September 15, 1994.

52 FR 2923. January 23, 1987. Executive Order 12580. "Superfund Implementation." Federal Register, Office of the President.

American Indian Religious Freedom Act. 1978. Public Law 95-341, as amended, 42 USC 1996 et seq.

Archaeological Resources Protection Act of 1979. 1979. Public Law 96-95, as amended, 16 USC 470aa et seq. 
Comprehensive Environmental Response, Compensation, and Liability Act of 1980. 1980. Public Law 96-510, as amended, 42 USC 9601 et seq. Accessed May 17, 2010, at http:// www.epa.gov/lawsregs/laws/cercla.html.

DOE. 2006. U.S. Department of Energy American Indian Eु Alaska Native Tribal Government Policy. Office of Congressional \& Intergovernmental Affairs, U.S. Department of Energy, Washington, D.C. Accessed May 17, 2010, at http://apps1.eere.energy.gov/tribalenergy/pdfs/doe_indian_ policy2006.pdf.

DOE Order 144.1. 2009. "Department of Energy American Indian Tribal Government Interactions and Policy." U.S. Department of Energy, Washington, D.C.

DOE/RL. 1996. Memorandum of Agreement Among the United States Department of Energy, United States Department of the Interior, Nez Perce Tribe, State of Oregon, Confederated Tribes of the Umatilla Indian Reservation, State of Washington (including the Departments of Ecology and Fish and Wildlife), and the Confederated Tribes and Bands of the Yakama Indian Nation. U.S. Department of Energy, Richland Operations Office, Richland, Washington. Accessed May 17, 2010, at http://www.hanford.gov/?page=651\&parent $=0$.

DOE/RL. 2002. Hanford Site Tri-Party Agreement Public Involvement Community Relations Plan. Washington State Department of Ecology, U.S. Environmental Protection Agency, and U.S. Department of Energy. Prepared by the U.S. Department of Energy, Richland Operations Office, Richland, Washington. Assessed May 17, 2010, at http:// www.hanford.gov $/$ ?page $=89$.

DOE/RL. 2004. Memorandum of Understanding between the U.S. Department of Energy's Richland Operations Office and Office of River Protection and the State of Oregon. U.S. Department of Energy, Richland Operations Office, Richland, Washington.
DOE/RL 96-32, Rev. 0. 2001. Hanford Site Biological Resources Management Plan. U.S. Department of Energy, Richland Operations Office, Richland, Washington.

Ecology - Washington State Department of Ecology, U.S. Environmental Protection Agency, and U.S. Department of Energy. 1989. Hanford Federal Facility Agreement and Consent Order (The Tri-Party Agreement). Document No. 89-10, as amended, Olympia, Washington. Accessed May 17, 2010, at http://www.hanford.gov/?page=81.

National Environmental Policy Act of 1969. 1969. Public Law 91-190, as amended, 42 USC 4321 et seq.

National Historic Preservation Act of 1966. 1966. Public Law 89-665, as amended, 16 USC 470 et seq.

Native American Graves Protection and Repatriation Act of 1990. 1990. Public Law 101-601, as amended, 25 USC 3001 et seq.

Resource Conservation and Recovery Act of 1976. 1976. Public Law 94-580, as amended, 42 USC 6901 et seq. and 42 USC 6927(c) et seq. Accessed May 17, 2010, at http:// www.epa.gov/lawsregs/laws/rcra.html.

Treaty with the Nez Perce, 1855. June 11, 1855. 12 Stat. 957, Vol. 2, 702; 165 U.S. 359.

Treaty with the Walla Walla, Cayuse, etc., 1855. June 9, 1855. 12 Stat. 945-951, Vol. 2, 694; 194 U.S. 401.

Treaty with the Yakama, 1855. June 9, 1855. 12 Stat. 951, Vol. 2, 698; 198 U.S. 371; 215 U.S. 291; 227 U.S. 355; 241 U.S. 556; and 249 U.S. 194. 


\title{
3.0 Regulatory Oversight on the Hanford Site
}

\author{
TG Beam
}

Several federal, state, and local regulatory agencies are responsible for monitoring and enforcing compliance with applicable environmental regulations on the Hanford Site. These agencies include the U.S. Environmental Protection Agency (EPA); the Washington State Department of Ecology; the Washington State Department of Health, and the Benton Clean Air Agency. EPA is the primary federal regulatory agency that develops, promulgates, and enforces environmental regulations and standards as directed in statutes enacted by Congress. In some instances, EPA has authorized the state program to operate in lieu of the federal program when the state's program meets or exceeds EPA requirements. In other activities, the state program is assigned direct environmental oversight of the U.S. Department of Energy (DOE) program, as provided by federal law. Where federal regulatory authority is not delegated or only partially authorized to the state, the EPA Pacific Northwest Regional Office (Region 10) is responsible for reviewing and enforcing compliance with EPA regulations as they pertain to the Hanford Site. EPA periodically reviews state environmental programs and may directly enforce Federal environmental regulations.

\subsubsection{Hanford Federal Facility Agreement and Consent Order (Tri-Party Agreement)}

\section{TW Noland}

The Hanford Federal Facility Agreement and Consent Order (also known as the Tri-Party Agreement [Ecology et al. 1989]) is an agreement among the Washington State Department of Ecology, EPA, and DOE (Tri-Party
Agreement agencies) to achieve environmental regulation compliance on the Hanford Site with the Comprehensive Environmental Response, Compensation, and Liability Act of 1980 (CERCLA), and the Resource Conservation and Recovery Act of 1976 (RCRA) treatment, storage, and disposal unit regulations and corrective action provisions. The Tri-Party Agreement is an interagency agreement (also known as a federal facility agreement) under Section 120 of CERCLA, a corrective action order under RCRA, and a consent order under the Washington State Hazardous Waste Management Act of 1976 that 1) defines RCRA and CERCLA cleanup commitments, 2) establishes responsibilities, 3) provides a basis for budgeting, and 4) reflects a concerted goal to achieve regulatory compliance and remediation with enforceable milestones. A companion document to the Tri-Party Agreement is the Hanford Site Tri-Party Agreement Public Involvement Community Relations Plan (DOE/RL 2002). This plan describes how public information and involvement activities are conducted for Tri-Party Agreement decisions.

The Tri-Party Agreement (Ecology et al. 1989) has evolved as Hanford Site cleanup has progressed. The Tri-Party Agreement agencies have negotiated changes to the agreement since its publication in 1989 to meet the changing conditions and needs of cleanup on the Hanford Site. All significant changes undergo a process of public involvement that enhances communication and addresses public concerns prior to final approvals. As changes are approved through the Tri-Party Agreement change control process, they are incorporated into the Tri-Party Agreement and displayed on the Internet electronic version, which is maintained at the following website: http://www.hanford. gov/?page $=81$. Printed copies of Revision 7 of the Tri-Party Agreement, which is current as of July 23, 2007, are 
publicly available at DOE's Public Reading Room located in the Washington State University Tri-Cities Consolidated Information Center, 2770 University Drive, Richland, Washington, and at public information repositories in Seattle and Spokane, Washington, and Portland, Oregon.

To be placed on the mailing list to obtain Tri-Party Agreement information, contact EPA or DOE directly, or call the Hanford Cleanup Line at (800) 321-2008.

\subsubsection{Status of Tri-Party Agreement Milestones}

\section{TW Noland}

The Tri-Party Agreement (Ecology et al. 1989) commits DOE to comply with the remedial action provisions of CERCLA as well as with RCRA treatment, storage, and disposal unit regulations and corrective-action provisions, including Washington State's implementing regulations (WAC 173-303, "Dangerous Waste Regulations"). From 1989 through 2009, a total of 1,067 Tri-Party Agreement milestones were completed and 306 target dates were met. During 2009, 55 specific cleanup milestones were scheduled for completion; 43 were completed early, 3 were completed on time, 1 was completed late, 5 were extended to beyond 2009 , and 3 were not yet complete at the end of the year.

\subsubsection{Approved Modifications to the Tri-Party Agreement}

\section{TW Noland}

During 2009, 24 negotiated change requests to the Tri-Party Agreement were approved; these changes can be viewed at the Tri-Party Agreement website: http://www.hanford.gov/ c.cfm/tpa/.

\subsubsection{Washington State Department of Health}

\section{TG Beam}

The Washington State Department of Health has regulatory authority to enforce federal and state standards applicable to all sources of ionizing radiation in the state. EPA provided delegation of authority to the Washington
State Department of Health to implement and enforce the federal standards and requirements in 40 CFR 61, Subparts A and H. Subpart H of 40 CFR 61, which covers radioactive air emissions, is enforced along with the state standards and requirements of WAC 246-247, "Radiation Protection-Air Emissions," and WAC 173-480, "Ambient Air Quality Standards and Emission Limits for Radionuclides," issued under the authority of the Washington Clean Air Act. These regulations include requirements to obtain Washington State Department of Health approval before constructing any new or modified sources of airborne radionuclide emissions, and for the Washington State Department of Health to issue and enforce the resulting licenses covering construction and operation. The Washington State Department of Health also inspects emission sources within the state that may emit airborne radioactive material to verify that the operations, emissions, and record keeping and reporting are in compliance with all applicable licenses and federal and state regulations. To protect public health with an adequate margin of safety, the state enforces an "as low as reasonably achievable" environmental approach to minimizing airborne emissions. The Washington State Department of Health maintains an office in Richland, Washington, with staff assigned to oversee Hanford Site operations.

\subsubsection{References}

40 CFR 61, Subpart A. 2009. "National Emission Standards for Hazardous Air Pollutants." Subpart A, "General Provisions." Code of Federal Regulations, U.S. Environmental Protection Agency. Accessed May 17, 2010, at http://www. gpoaccess.gov/cfr/index.html.

40 CFR 61, Subpart H. 2009. "National Emission Standards for Hazardous Air Pollutants." Subpart H, "National Emission Standards for Emissions of Radionuclides Other Than Radon from Department of Energy Facilities." Code of Federal Regulations, U.S. Environmental Protection Agency. Accessed May 17, 2010, at http://www.gpoaccess.gov/cfr/ index.html.

Comprehensive Environmental Response, Compensation, and Liability Act of 1980. 1980. Public Law 96-510, as amended, 42 USC 9601 et seq. Accessed May 17, 2010, at http:// www.epa.gov/lawsregs/laws/cercla.html. 
DOE/RL. 2002. Hanford Site Tri-Party Agreement Public Involvement Community Relations Plan. Washington State Department of Ecology, U.S. Environmental Protection Agency, and U.S. Department of Energy. Prepared by the U.S. Department of Energy, Richland Operations Office, Richland, Washington. Assessed May 17, 2010, at http:// www.hanford.gov/?page $=89$.

Ecology - Washington State Department of Ecology, U.S. Environmental Protection Agency, and U.S. Department of Energy. 1989. Hanford Federal Facility Agreement and Consent Order (Tri-Party Agreement). Document No. 89-10, as amended, Olympia, Washington. Accessed May 17, 2010, at http://www.hanford.gov/?page=81.

Hazardous Waste Management Act of 1976. 1976. RCW 70.105, as amended. Revised Code of Washington, Olympia, Washington.

Resource Conservation and Recovery Act of 1976. 1976. Public Law 94-580, as amended, 42 USC 6901 et seq. and 42 USC 6927(c) et seq. Accessed May 17, 2010, at http:// www.epa.gov/lawsregs/laws/rcra.html.
WAC 173-303. 2009. "Dangerous Waste Regulations." Washington Administrative Code, Olympia, Washington. Accessed May 17, 2010, at http://apps.leg.wa.gov/wac/.

WAC 173-480. 2007. "Ambient Air Quality Standards and Emission Limits for Radionuclides." Washington Administrative Code, Olympia, Washington. Accessed May 17, 2010, at http://apps.leg.wa.gov/wac/.

WAC 246-247. 2005. "Radiation Protection - Air Emissions." Washington Administrative Code, Olympia, Washington. Accessed May 17, 2010, at http://apps.leg.wa.gov/ wac/.

Washington Clean Air Act. RCW 70.94, as amended. Revised Code of Washington, Olympia, Washington. 


\subsection{Environmental Program Information}

The U.S. Department of Energy (DOE) requires that all Hanford Site contractors develop and operate under an Integrated Safety Management System that includes an Environmental Management System consistent with the Organization for Standardization's 14001:2004(E) International Standard - Environmental Management Systems Requirements with Guidance for Use (ISO 14001:2004[E]). The Environmental Management System requires that a Chemical Management System address management of the procurement, use, and disposal of chemicals, with an emphasis on the procurement of environmentally friendly chemicals. The following sections provide information on these systems.

\subsubsection{Environmental Management Systems}

\section{AS Nagel}

Hanford Site contractors have established Integrated Safety Management Systems as mandated by their contracts with DOE. These systems are intended to protect workers, the public, and the environment by integrating environmental, safety, and health considerations into the way work is planned, performed, and improved. DOE verified that all Hanford Site entities under DOE Policy 450.4, "Safety Management System Policy," had incorporated the requirement within DOE Order 450.1, "Environmental Protection Program," to establish an Environmental Management System within their Integrated Safety Management System prior to December 31, 2005. Washington Closure Hanford, LLC began implementation of the River Corridor Closure Project Contract on August 27, 2005, and in November 2007, completed full implementation of its Integrated Safety Management System.
Recent contract awards also required that DOE verify its new contractors have an Integrated Safety Management System in place. Washington River Protection Solutions LLC began implementation of the Tank Operations Contract at the Hanford Site on October 1, 2008, and in September 2009, completed full implementation of its Integrated Safety Management System. CH2M HILL Plateau Remediation Company began implementation of the Plateau Remediation Contract at the Hanford Site on October 1, 2008, and in November 2009 completed full implementation of its Integrated Safety Management System. Mission Support Alliance, LLC completed work scope transition from Fluor Hanford, Inc. and began implementation of the Mission Support Contract at the Hanford Site on August 24, 2009. A management review Phase I audit of its Integrated Safety Management System was conducted in January 2010 and a Phase II verification audit of the Mission Support Alliance, LLC Integrated Safety Management System is planned for 2010.

DOE Order 450.1A, "Environmental Protection Program," was issued June 4, 2008, and superseded DOE Order 450.1. DOE Order 450.1A requires implementation of an Environmental Management System that is integrated into the site's Integrated Safety Management System and reflects the elements and framework found in the International Organization for Standardization's 14001:2004(E) International Standard (ISO 14001:2004[E]). Elements of ISO 14001 include a defined environmental policy; planning, including environmental aspects, legal and other environmental requirements, and environmental objectives, targets and programs; implementation and operations, including resources, roles, responsibility and authority, competence, training and awareness, communication, documentation, document control, operational control, and emergency 
preparedness and response; checking, including monitoring and measuring, evaluation of compliance, nonconformity, corrective and preventative action, records control, and internal audit; and management review.

DOE Order 450.1A further states that each Environmental Management System must include policies, procedures, and training to identify operations and activities with significant environmental impacts; to manage, control, and mitigate impacts; and to assess performance, implement corrective actions where needed, and to ensure continual environmental improvement. In addition, the Environmental Management System must address sustainable practices for enhancing environmental, energy and transportation performance required by Executive Order 13423, "Strengthening Federal Environmental, Energy and Transportation Management" (72 FR 3919) and DOE Order 430.2B, "Departmental Energy, Renewable Energy and Transportation Management" (see Section 5.6.3); protection of public health and the environment; wildland fire protection; natural and cultural resource protection and stewardship; effluent and environmental monitoring; quality of analytical data; assessment of engineered nanomaterials hazards; and identification of opportunities to implement additional sustainable practices. Implementing an Environmental Management System provides further assurance that contractors are employing sound stewardship practices that are protective of the air, water, land, and other natural and cultural resources potentially impacted by their operations.

In 2009, DOE offices at the Hanford Site required several contractors to implement the requirements of DOE Order 450.1A. With the exception of Pacific Northwest National Laboratory, which established an ISO 14001-based Environmental Management System in 1996 and has maintained a registration of that system since 2002, Hanford Site ISO 14001-based Environmental Management Systems were either implemented in 2009 or are under development.

Pacific Northwest National Laboratory, operated by Battelle Memorial Institute for the DOE Office of Science's Pacific Northwest Site Office, currently has a mature, robust Environmental Management System that was established in 1996. Pacific Northwest National Laboratory has maintained ISO 14001 certification since 2002. In 2008, Pacific Northwest National Laboratory received direction from the
DOE Office of Science's Pacific Northwest Site Office to implement the requirements of DOE Order 450.1A, DOE Order 430.2B, and Executive Order 13423 (72 FR 3919). Auditing has verified that the Pacific Northwest National Laboratory Environmental Management System is fully integrated into its Integrated Safety Management System and meets the requirements of DOE Order 450.1A, and as such, the DOE Office of Science's Pacific Northwest Site Office was able to declare Pacific Northwest National Laboratory in conformance with DOE Order 450.1A in June 2009. The 2009 Environmental Management System Scorecard developed by the DOE Office of Science's Pacific Northwest Site Office rates Pacific Northwest National Laboratory's performance as "Green," which is the highest ranking and includes achieving the highest rankings for all performance metrics except sustainable practices, which achieved the second highest ranking.

In June 2009, Fluor Hanford Inc., CH2M HILL Plateau Remediation Company, and Washington Closure Hanford, LLC received direction from the DOE Richland Operations Office to implement the requirements of DOE Order 450.1A, DOE Order 430.2B, and Executive Order 13423 (72 FR 3919). On August 24, 2009, Mission Support Alliance, LLC assumed the role of integration contractor from Fluor Hanford Inc. and was also directed to implement the requirements of these Orders. The three companies, Mission Support Alliance, LLC; CH2M HILL Plateau Remediation Company; and Washington Closure Hanford, LLC were each successful in developing an ISO 14001-based Environmental Management System that was integrated into their respective Integrated Safety Management System. Auditing, along with approved corrective action plans, verified that each Environmental Management System met the requirements of DOE Order 450.1A and as such, each contractor notified the DOE Richland Operations Office that they were able to declare their Environmental Management System "fully implemented" in conformance with DOE Order 450.1A. Washington Closure Hanford, LLC declared conformance in September 2009; CH2M HILL Plateau Remediation Company in November 2009; and Mission Support Alliance, LLC in December 2009. Following review and approval of these declarations, the DOE Richland Operations Office was able to declare each Environmental Management System 
was in conformance with DOE Order 450.1A, ahead of their renegotiated due date of December 31, 2009. DOE Order 450.1A required Environmental Management Systems to be "fully implemented" by June 30, 2009; however, issues in awarding the Mission Support Alliance, LLC contract necessitated a renegotiated implementation date. AdvanceMed Hanford, at the direction of the DOE Richland Operations Office, also began implementation of an Environmental Management System in 2009. The DOE Richland Operations Office prepared the 2009 Environmental Management System Scorecard and rated its performance as "Yellow," which is the second highest ranking.

Washington River Protection Solutions LLC; Bechtel National, Inc.; and Advanced Technologies and Laboratories International, Inc. perform work at the Hanford Site under the direction of the DOE Office of River Protection. In October 2008, Washington River Protection Solutions LLC was directed to implement the requirements of DOE Order 450.1A, DOE Order 430.2B, and Executive Order 13423 (72 FR 3919). Washington River Protection Solutions LLC was successful in developing an ISO 14001 based Environmental Management System that was integrated into their Integrated Safety Management System. Auditing, along with an approved corrective action plan, verified that the Washington River Protection Solutions LLC Environmental Management System met the requirements of DOE Order 450.1A and as such, in August 2009, Washington River Protection Solutions LLC notified the DOE Office of River Protection that it was able to declare its Environmental Management System in conformance with DOE Order 450.1A. Following review and approval of these declarations, the DOE Office of River Protection was able to declare the Washington River Protection Solutions LLC's Environmental Management System in conformance with DOE Order 450.1A in September 2009. In November 2009, Advanced Technologies and Laboratories International, Inc. was directed to implement DOE Order 450.1A. In December 2009, Bechtel National, Inc. was directed to develop a detailed proposal for implementation of DOE Order 450.1A, DOE Order 430.2B, Executive Order 13423, and Executive Order 13514, "Federal Leadership in Environmental, Energy and Economic Performance" (74 FR 52117) (see Section 5.6.3), including full implementation of an Environmental Management System within 2 years of contract direction. The DOE Office of River Protection prepared the 2009 Environmental Management System Scorecard and rated its performance as "Yellow," which is the second highest ranking.

In February 2010, the DOE Richland Operations Office directed Mission Support Alliance, LLC; Washington Closure Hanford, LLC; and CH2M HILL Plateau Remediation Company to develop a proposal for implementation of Executive Order 13514 (74 FR 52117). The DOE Office of River Protection directed Washington River Protection Solutions LLC to develop a proposal for implementation of Executive Order 13514, also in February 2010. Executive Order 13514 enhances the requirements of Executive Order 13423 (72 FR 3919) by making reduction of greenhouse gas emissions a priority for federal agencies.

Mission Support Alliance, LLC, as the services and infrastructure contractor at the Hanford Site, is in the process of developing a Hanford Site Executable Plan. The plan will describe the energy management program; identify planned energy efficiency, water conservation, transportation fleet management and sustainable buildings activities; and include an Emergency Conservation Plan, as required by DOE Order 430.2B and Executive Order 13423 (72 FR 3919). Development of these environmental objectives is scheduled to be complete in 2010, as are updated or new plans for recycling, ozone-depleting substance management, environmentally preferred procurement management, and electronic asset stewardship.

Several contractors have made their environmental policy and environmental aspects available to the public through company Internet sites (Table 4.0.1). Benefits of implementing the systematic approach of an Environmental Management System as reported by Hanford Site contractors include enhanced public perception as a "good neighbor"; reduced operational costs; use of upfront planning to identify waste disposal pathways and reduce volume; early requirements identification and avoiding project delay; high level of integration with existing programs to reduce administrative burden; more efficient systems; cooperation with key stakeholders; fewer environmental violations; improvements in business practices and staff awareness; reduced water use; improvement in groundwater quality; 


\begin{tabular}{|c|c|c|}
\hline \multicolumn{2}{|c|}{ Table 4.0.1. Hanford Site Contractor Environmental Management System Internet Links } & \multirow[b]{2}{*}{ Category } \\
\hline$\underline{\text { Contractor }}$ & $\underline{\text { Website }}$ & \\
\hline \multirow[t]{2}{*}{ Pacific Northwest National Laboratory } & http://www.pnl.gov/about/environmental.asp & Policy \\
\hline & http://www.pnl.gov/ems/env_impacts.asp & Aspects \\
\hline Washington River Protection Solutions LLC & http://www.wrpstoc.com/what_we_do/environmental_management & Policy, Aspects \\
\hline Mission Support Alliance, LLC & http://www.msa-hanford.com/filedisplay.cfm?fileid=1158 & Policy, Aspects \\
\hline CH2M HILL Plateau Remediation Company & https://www.plateauremediation.com/index.aspx?section=194 & Policy \\
\hline Washington Closure Hanford, LLC & http://www.washingtonclosure.com/about_us/environmental_stewardship & Policy, Aspects \\
\hline
\end{tabular}

reduction in energy needs through building removal; efficient environmental sampling; increased recycling; and more efficient waste disposal.

\subsubsection{Environmental Performance Measures}

Mission Support Alliance, LLC began the process of developing environmental performance measures for the Hanford Site in October 2009. Measures were developed to address the goals of DOE Order 450.1A, DOE Order 430.2B, and Executive Order 13423 (72 FR 3919), and will be updated in 2010 to address those of Executive Order 13514 (74 FR 52117). The measures required by these Executive Orders and DOE Orders include reduction in greenhouse gas emissions through energy efficiency; addition of new renewable energy sources; reduction of water consumption; use of sustainable environmental practices in the acquisition of goods and services; reduction in the quantity of toxic and hazardous chemicals and materials acquired; compliance with Leadership in Energy and Environmental Design guiding principles in new construction or major modifications of government buildings; reduction in vehicle consumption of petroleum products; and acquisition of Electronic Products Environmental Assessment Tool-registered electronic products. Where available, baseline data were collected in 2009 and continued in 2010. Performance measurement data will be used as a tool to ensure environmental goals within the DOE Orders are appropriately managed. In addition, individual contractors have established companyspecific performance measures within their Environmental Management Systems.

Hanford Site officials coordinate with the U.S. Department of Defense, as required by DOE Order 450.1A, when ozone-depleting substances are removed from refrigerant systems that are being decommissioned or taken out of service. The Hanford Site Ozone-Depleting-Substance Control and Phase-Out Plan (DOE/RL-94-86) will be updated in 2010 to reflect the phase out of procurement of all Class I ozone-depleting substances. Non-ozone-depleting substance substitutes are evaluated and considered before the procurement of any new refrigerant material.

\subsubsection{Awards and Recognition}

The Hanford Site received no DOE or other federal agency, state agency, or industry-sponsored environmental awards or recognition in 2009. As part of their Environmental Management System, several Hanford Site contractors have developed an environmental awards program to recognize leadership in environmental, energy, and transportation stewardship.

\subsubsection{Chemical Management Systems}

\section{RE Johnson}

The Emergency Planning and Community Right-to-Know Act of 1986 (Section 5.6.1) and Title III of the Superfund Amendments and Reauthorization Act of 1986 (Section 5.1.2) require officials managing federal facilities that use, produce, or store extremely hazardous substances in quantities that exceed specific release thresholds to report these inventories and planned or accidental environmental releases to federal, state, and local emergency planning authorities. Hanford Site contractors developed and documented formal systems to manage chemicals in 1997 that are still in use today. Chemical Management Systems apply to the acquisition, use, 
storage, transportation, and final disposition of chemicals, including hazardous chemicals as defined in 29 CFR 1910, Subpart Z, "Occupational Safety and Health Standards" (Appendices A and B). The Chemical Management Systems are reviewed periodically and improvements are made as needed. Section 5.6.1 provides details on the inventories of hazardous chemicals stored on the Hanford Site in 2009.

\subsubsection{References}

29 CFR 1910, Subpart Z. 2009. "Occupational Safety and Health Standards." Subpart Z, "Toxic and Hazardous Substances." Code of Federal Regulations, U.S. Department of Labor. Accessed May 17, 2010, at http://www.gpoaccess. gov/cfr/index.html.

72 FR 3919. January 26, 2007. Executive Order 13423. "Strengthening Federal Environmental, Energy and Transportation Management." Federal Register, Office of the President.

74 FR 52117. October 5, 2009. Executive Order 13514. "Federal Leadership in Environmental, Energy, and Economic Performance." Federal Register, Office of the President.

DOE Order 430.2B. 2008. "Departmental Energy, Renewable Energy and Transportation Management.” U.S. Department of Energy, Washington, D.C.
DOE Order 450.1. 2003. "Environmental Protection Program." Superseded by DOE Order 450.1A. U.S. Department of Energy, Washington, D.C.

DOE Order 450.1A. 2008. "Environmental Protection Program.” U.S. Department of Energy, Washington, D.C.

DOE Policy 450.4. 1996. "Safety Management System Policy." U.S. Department of Energy, The Office of Environment, Safety and Health, Washington, D.C.

DOE/RL-94-86. 1994. Ozone-Depleting-Substance Control and Phase-Out Plan. U.S. Department of Energy, Richland Operations Office, Richland, Washington.

Emergency Planning and Community Right-to-Know Act of 1986. 1986. Public Law 99-499, as amended, 42 USC 11001 et seq.

ISO 14001:2004(E). 2004. Environmental Management Systems - Requirements with Guidance for Use. International Organization for Standardization, Geneva.

Superfund Amendments and Reauthorization Act of 1986. 1986. Public Law 99-499, as amended, 42 USC 9601 et seq. 


\title{
5.0 Compliance Summary
}

\author{
JP Duncan
}

U.S. Department of Energy (DOE) policy mandates that all DOE activities on the Hanford Site are performed in compliance with applicable federal, state, and local environmental laws and regulations; DOE and Executive Orders; Secretary of Energy Notices; and DOE Headquarters and site operations office directives, policies, and guidance. This includes specific requirements, actions, plans, and schedules in the Hanford Federal Facility Agreement and Consent Order (also known as the Tri-Party Agreement [Ecology et al. 1989]) and other compliance or consent agreements. Both the DOE Richland Operations Office and the DOE Office of River Protection recognize the importance of maintaining a proactive program of selfassessment and regulatory reporting to assure environmental compliance is achieved and maintained on the Hanford Site. Additionally, DOE Order 231.1A, Chg 1, "Environment, Safety and Health Reporting," includes the requirement for reporting annual compliance status with environmental standards and requirements, which this site environmental report describes.

This section summarizes the various laws and regulations that impact Hanford Site activities, such as federal environmental protection statutes and associated state and local environmental regulations. Permits required under specific environmental protection regulations are also described, as well as notices of violations and notices of non-compliance issued by the U.S. Environmental Protection Agency (EPA) or the Washington State Department of Ecology. Notices of violation are the regulatory means of informing organizations that their work activities are not meeting requirements. Notices of non-compliance are informal notifications of regulatory violations. 


\subsection{Statutes Related to Environmental Restoration and Waste Management}

This section provides compliance information regarding federal environmental statutes and regulations related to hazardous materials and waste management at the Hanford Site.

\subsubsection{Comprehensive Environmental Response, Compensation, and Liability Act of 1980}

\section{JW Cammann}

The Comprehensive Environmental Response, Compensation, and Liability Act of 1980 (CERCLA) was enacted in 1980 to address response, compensation, and liability for past releases or potential releases of hazardous substances, pollutants, and contaminants to the environment. CERCLA was amended by the Superfund Amendments and Reauthorization Act of 1986 (Section 5.1.2), which made several important changes and additions, including clarification that federal facilities are subject to the same provisions of CERCLA as any non-governmental entity. Federal facilities identified on the EPA National Priorities List, which is EPA's list of the uncontrolled hazardous substance releases in the United States that are priorities for long-term remedial evaluation and response, must enter into an interagency agreement with EPA to remediate the sites. Under CERCLA, two kinds of response actions are authorized: 1) short-term removal actions to address releases or threatened releases requiring prompt response; and 2) long-term remedial response actions that permanently and significantly reduce the dangers associated with releases or threats of releases of hazardous substances that are serious, but not immediately life threatening.
The Hanford Site was divided into four aggregate areas when it was placed on EPA's National Priorities List on November 3, 1989, pursuant to CERCLA. The four sites included the 100 Areas, 200 Areas (i.e., Central Plateau), 300 Area, and 1100 Area of the Hanford Site. DOE and its contractors have made considerable progress in cleaning up the Hanford Site. Progress includes deletion of portions of the 100 Areas from the EPA's National Priorities List, including the Wahluke Slope north of the Columbia River, and the entire 1100 Area. EPA is responsible for oversight of DOE implementation of CERCLA regulations.

There can be significant overlap between the Resource Conservation and Recovery Act of 1976 (RCRA) corrective action program (Section 5.1.3) and the CERCLA remediation program. Many waste management units on the Hanford Site could potentially be subject to cleanup under both programs. The CERCLA program is implemented through 40 CFR 300, "National Oil and Hazardous Substances Pollution Contingency Plan," which establishes procedures for characterization, evaluation, and remediation. The Tri-Party Agreement (Ecology et al. 1989) addresses implementation of both CERCLA and RCRA corrective action provisions on the Hanford Site through administrative application of either program while meeting the technical requirements of both.

Executive Order 12580, "Superfund Implementation" (52 FR 2923) directs that DOE, as the lead agency, must conduct response actions (removal and/or remedial) on the Hanford Site. The CERCLA regulatory framework for both removal and remedial actions consists of five general activities that include 1) investigation, 2) evaluation, 3) decision, 4) implementation, and 5) closeout. 
For remedial actions during the investigation phase, the lead agency conducts a preliminary assessment and site inspection following the discovery of a release or the threat of release to the environment. Upon determination that the site of the release meets the criteria for inclusion on the National Priorities List, the lead agency conducts more detailed site characterization in accordance with a remedial investigation and feasibility study work plan; data quality objectives, sampling, and analysis plan; field work plan; and quality assurance plan. The evaluation phase includes development of alternatives to eliminate the release or threat of release; the lead agency then considers the results of site characterization as documented in remedial investigation reports used to support feasibility studies of candidate remedial technologies. During the decision phase, the lead agency documents implementation of the preferred alternative, obtains regulatory approval, and seeks public involvement through issuance of a proposed plan that is made available for public review and a record of decision that defines the action(s) that will be taken to mitigate the threat to human health and the environment caused by the release of a hazardous substance or substances. During the implementation phase, the lead agency executes the preferred alternative and involves preparation of a remedial design and remedial action work plan, remedial design report, air monitoring plan, waste management plan, mitigation action plan, and operations and maintenance plan. Finally, during the closeout phase the lead agency issues a remedial site verification package that documents remedial action goals, objectives, and applicable or relevant and appropriate requirements achieved in accordance with the record of decision.

There are three types of removal actions under CERCLA: 1) emergency, 2) time-critical, and 3) non-time-critical. Emergency removals must be initiated within hours or days in response to acute problems and may involve fires, explosions, imminent contamination of water supplies, or the release or imminent release of hazardous substances. Timecritical removals are conducted in response to releases requiring onsite action within 6 months (e.g., removal of drums or small volumes of contaminated soil). Non-timecritical removals are conducted in response to releases where a planning period of at least 6 months is available before onsite activities must begin and the need is less immediate. The majority of removal actions conducted on the Hanford Site is non-time-critical.

Non-time-critical removal actions most often remove or reduce the threat caused by a release of a hazardous substance such that no further action is necessary to be protective of human health and the environment. When a removal action is unsuccessful in reaching a protective situation, it may be followed by a remedial action to complete the site response. Non-time-critical removal actions can provide substantial risk reduction by addressing specific problems without requiring the more time consuming remedial investigation and feasibility study process associated with CERCLA remedial actions.

As with remedial actions, non-time-critical removal actions include activities involving investigation, evaluation, decision, implementation, and closeout. Upon completion of an initial evaluation to develop an understanding of the threat posed by a release, the lead agency initiates an engineering evaluation and cost analysis process. The engineering evaluation and cost analysis process involves preparation of an engineering evaluation and cost analysis, conducting community relations activities, and documentation of the removal action decision in an action memorandum. The engineering evaluation and cost analysis process is comparable to the remedial investigation and feasibility study process, but it is less comprehensive. The action memorandum is comparable to a remedial action record of decision; however, it is less elaborate. A removal action work plan is prepared to implement the decisions in the action memorandum. Closeout of the non-time-critical removal process ensures that all removal action objectives have been met and that threats to human health and the environment have been mitigated. If the removal action location is within the boundaries of a National Priorities List site operable unit, the remedy selected for the removal action must be consistent with the final remedy for the entire operable unit.

CERCLA requires a status review of response actions (removal and remedial) for contaminated waste sites no less frequently than once every 5 years to determine whether selected actions remain protective of human health and the environment. EPA initiated the first CERCLA 5-year review 
in fiscal year 2000. This 5-year review addressed all portions of the Hanford Site for which a decision document (i.e., record of decision, action memorandum) has been issued and covered areas that contain hazardous substances, pollutants, or contaminants that will be remediated under CERCLA (EPA 2001). DOE considered the first CERCLA 5-year review, issued by the EPA in April 2001, as the starting point for subsequent 5 -year reviews. The first CERCLA 5 -year review evaluated the performance of the response actions selected in records of decision and action memoranda, including existing institutional controls preventing exposure to the public and the environment (Section 5.1.1.1). EPA concluded the selected response actions were protective, or would be protective upon completion of the remedial or removal actions. EPA identified deficiencies and corrective actions to address the deficiencies. In conducting the second CERCLA 5-year review in 2005 and 2006, DOE applied the same approach EPA used and followed EPA and DOE guidance on how to conduct CERCLA 5-year reviews (DOE/RL-2006-20, Rev. 1).

DOE began planning the third CERCLA 5-year review in 2009, including initial coordination with the EPA (Region 10) and the Washington State Department of Ecology. A CERCLA Five-Year Review Assessment and Communications Plan (http://www.hanford.gov/page.cfm/ CERCLA) was completed and submitted to DOE for future incorporation into the third CERCLA 5-year review document. A Federal Integrated Project Team that included DOE, DOE contractors, and regulatory agency participants was formed and convened several times to facilitate the planning process. Future efforts will concentrate on obtaining input from Hanford Site contractors engaged in CERCLA response actions and determining the adequacy of those actions with respect to protecting human health and the environment in accordance with response action goals, objectives, and applicable or relevant and appropriate requirements. Interactions with Native American tribes, the Hanford Natural Resource Trustees Council, Hanford Advisory Board, Oregon Hanford Cleanup Board, and other stakeholders and interested parties will be conducted to keep them informed of the status of the CERCLA 5-year review process and solicit comments. The third CERCLA 5 -year review is scheduled for completion and issuance by November 6, 2011.

\subsubsection{Hanford Site Institutional Controls Plan}

\section{R Ranade}

The Sitewide Institutional Controls Plan for Hanford CERCLA Response Actions (DOE/RL-2001-41, Rev. 2) describes the institutional controls for the Hanford Site and how they are implemented and maintained in accordance with CERCLA decision documents. The decision documents present the selected remedial actions chosen in accordance with CERCLA, as amended by the Superfund Amendments and Reauthorization Act of 1986 and implemented under 40 CFR 300. CERCLA decision documents are developed as part of the cleanup mission on the Hanford Site, which began in 1989 following the end of the national defense mission. The selected remedies chosen may include institutional controls. CERCLA decision documents identify specific requirements for institutional controls.

Institutional controls are primarily administrative in nature and are typically used to augment the engineered components of a selected remedy to minimize the potential for human exposure to contamination. Active institutional controls, such as controlling access to the Hanford Site or activities that may affect remedial action, are generally employed during remediation. After remediation is completed, the lead agency employs passive institutional controls such as permanent markers, retaining public records and archives, or sustaining regulations regarding land or resource use. Some active institutional controls, such as monitoring and controlling access to the site, may also be employed after remediation is completed.

Section 4.2 of DOE/RL-2001-41, Revision 2, requires DOE to conduct a Hanford Site-wide assessment every 5 years coinciding with the CERCLA 5-year review. The next site-wide institutional control review is scheduled in 2011. In addition, several CERCLA decision documents require annual reviews of institutional controls for specific areas. Annual reviews of these institutional controls are reported in the unit manager's meeting each September. Minutes from the unit manager's meeting are in the Tri-Party Agreement's Administrative Record and can be accessed at the following website: http://www5.hanford.gov/arpir. 
The River Corridor Project has a number of institutional controls in both interim action and final record of decision documents. Washington Closure Hanford, LLC, which manages the River Corridor Project, reported no public trespass events on Washington Closure Hanford-managed projects during 2009. Approved excavation permits were in place for all active remediation. Correction of signage to the 618-7 waste site and 618-10 and 618-11 Burial Grounds, identified during the 2008 institutional controls assessment (DOE/RL-2001-41, Rev. 4), were completed. Field inspection of required signage on entrances to active 100 Areas waste sites within 100-B/C, 100-D, 100-H, and 100-N Areas, and on the entrance to the 618-13 waste site in the 300 Area were conducted. Inspections indicated that all required signage was in place except for one entrance to the 100-D Area. Warning signs at the 100-D Area entrance were subsequently installed. The Central Plateau Project, managed by CH2M HILL Plateau Remediation Company, also has a number of institutional controls in both interim and final record of decision documents. In February 2009, DOE, EPA, and the Washington State Department of Ecology (Tri-Party Agreement agencies) published the Explanation of Significant Differences for the Interim Action Record of Decision for the 200-UP-1 Groundwater Operable Unit, Hanford Site, Benton County Washington, February 2009 (Ecology et al. 2009), identifying required institutional controls. The Sitewide Institutional Controls Plan for Hanford CERCLA Actions was revised in August 2009 to include institutional controls identified in the 200-UP-1 Groundwater Operable Unit explanation of significant differences document (DOE/RL-2001-41, Rev. 4).

\subsubsection{CERCLA and Washington State Dangerous Waste/Hazardous Substance Reportable Releases to the Environment}

\section{JK Perry}

Federal regulations establish reporting requirements for certain environmental releases. As required, releases are reported to the National Response Center, the federal central point of contact for reporting hazardous substances and oil spills. Reportable releases include spills or discharges of hazardous substances to the environment, other than releases permitted under state or federal law. CERCLA
Section 103 requires that releases of hazardous substances that equal or exceed specified reportable quantities, including releases that are continuous and stable in quantity and rate but exceed specified limits, must be reported. During calendar year 2009, hazardous substance releases were conservatively assessed in accordance with 40 CFR 302, "Designation, Reportable Quantities, and Notification" and notifications were provided to the National Response Center. These releases have been or are being appropriately addressed consistent with the Tri-Party Agreement (Ecology et al. 1989).

Washington State regulations (WAC 173-303-145) also require that spills or non-permitted discharges of dangerous waste or hazardous substances to the environment be reported. The requirement applies to spills or discharges onto the ground, into groundwater or surface water (e.g., the Columbia River), or in the air such that human health or the environment are threatened, regardless of the quantity of dangerous waste or hazardous substance.

During calendar year 2009, hazardous substance releases were conservatively assessed under WAC 173-303-145, and notifications were provided to the Washington State Department of Ecology for various minor spills. These spills were cleaned up, and materials were disposed of in accordance with applicable requirements.

\subsubsection{Superfund Amendments and Reauthorization Act of 1986}

\section{JW Cammann}

The Superfund hazardous substance cleanup program was created by CERCLA (Section 5.1.1). It was expanded and reauthorized by the Superfund Amendments and Reauthorization Act of 1986.

Congress passed RCRA in 1976 to govern how hazardous wastes were to be treated, stored, and disposed of to minimize the present and future threat to human health and the environment. However, RCRA did not address prior activities or abandoned contaminated sites. Therefore, federal, state, and local authorities did not have guidelines for addressing or cleaning up properties contaminated by hazardous substances from past practices. 
On December 11, 1980, Congress enacted CERCLA to provide the means to identify responsible parties, fund the cleanup of impacted sites under the "polluter pays principle," and address the dangers of past-practice hazardous waste sites that create significant risk to public health and the environment. On October 17, 1986, the Superfund Amendments and Reauthorization Act of 1986 was enacted amending and reauthorizing CERCLA. The Act reflected EPA's experience in administering the complex Superfund program during its first 6 years and made several important changes and additions to the program. Changes and additions under the Superfund Amendments and Reauthorization Act of 1986 are as follows:

- Stressed the importance of permanent remedies and innovative treatment technologies in cleaning up hazardous waste sites

- Required Superfund actions to consider and generally comply with the standards and requirements found in other state and federal environmental laws and regulations

- Provided new enforcement authorities and settlement tools

- Increased state involvement in every phase of the Superfund program

- Increased the focus on human health problems posed by hazardous waste sites

- Encouraged greater citizen participation in making decisions on how sites should be cleaned up

- Increased the size of the cleanup trust fund to $\$ 8.5$ billion.

The Superfund Amendments and Reauthorization Act of 1986 also required EPA to revise its hazard ranking system to ensure that it accurately assessed the relative degree of risk to human health and the environment posed by uncontrolled hazardous waste sites that may be placed on the EPA's National Priorities List.

The Superfund Amendments and Reauthorization Act of 1986 attempted to accelerate the cleanup of hazardous waste sites and resolve questions of jurisdiction. Section 120 of the Act establishes a timetable and requires participation in the planning and cleanup selection process by state and local officials and the public. In cases where a federal government agency and EPA disagree on the proposed remedy at a site, EPA is to make the selection. Although subsection ( $g$ ) of the Act prohibits the transfer of EPA's authorities under this section to any other agency or person, Executive Order 12580 signed by President Reagan on January 23, 1987 (52 FR 2923), gives the Office of Management and Budget the final authority in cases where the EPA and another federal government agency disagree on the remedy selection.

In May and June 1988, EPA concurred with the U.S. Department of Defense and DOE on model language to be inserted in all federal facility cleanup agreements at Superfund sites owned by the two departments. The model language provides for and recognizes 1) EPA's authority to assess penalties in the case of non-compliance with the agreement; 2) the departments' commitment to study and perform EPA-approved cleanups at the facilities; 3) EPA's commitment to review and comment on the departments' studies and plans; 4) a mechanism for resolving disputes, with final authority resting with the EPA Administrator when staff of the agency and the departments cannot reach agreement on selection of the final remedy; and 5) enforceability of the agreements by states and citizens. The Superfund Amendments and Reauthorization Act of 1986 also places restrictions on the sale of federal government property to ensure that any hazardous waste sites will be cleaned up prior to sale. A number of new statutory authorities, such as the Emergency Planning and Community Right-To-Know Act of 1986, were also established by the Superfund Amendments and Reauthorization Act of 1986 (Section 5.6.1).

\subsubsection{Resource Conservation and Recovery Act of 1976}

\section{Wollam}

RCRA was enacted in 1976 with the objective of protecting human health and the environment. In 1984, the Hazardous and Solid Waste Amendments of 1984 reauthorized RCRA, imposing new requirements on hazardous waste management. The central principle of RCRA is its establishment of cradle-to-grave management to track hazardous waste from its generation to treatment, storage, and disposal. The Washington State Department of Ecology has the 
authority to enforce RCRA requirements in the state under WAC 173-303, "Dangerous Waste Regulations." The Hanford Site is subject to RCRA corrective action authority because the site has been issued a single permit that will eventually contain all applicable treatment, storage, and disposal units.

\subsubsection{Hanford Facility RCRA Permit SA Thompson}

The Washington State Department of Ecology issued the Hanford Facility RCRA Permit on September 27, 1994 (Ecology 1994). The permit is the foundation for RCRA permitting on the Hanford Site in accordance with provisions established in the Tri-Party Agreement (Ecology et al. 1989) and WAC 173-303. The permit is issued to eight permittees: the DOE Richland Operations Office and the DOE Office of River Protection as the owners/operators of the Hanford Site and six of their contractors: Bechtel National, Inc.; CH2M HILL Plateau Remediation Company; Mission Support Alliance, LLC; Pacific Northwest National Laboratory; Washington Closure Hanford, LLC; and Washington River Protection Solutions LLC, as co-operators. The Hanford Facility RCRA Permit expired on September 27, 2004; however, DOE continues to operate under the expired permit until a new permit is in effect. The Washington State Department of Ecology is working on a draft of the new permit.

\subsubsection{RCRA/Dangerous Waste Permit and Closure Plan}

\section{SA Thompson}

The Hanford Site is considered a single facility for RCRA and WAC 173-303 regulatory purposes and is comprised of 43 treatment, storage, and disposal units. The Tri-Party Agreement (Ecology et al. 1989) agencies recognized that not all of the units could be issued dangerous waste permits simultaneously, and a schedule (Tri-Party Agreement M-20 Milestones) was established to submit unit-specific permit applications and closure plans to the Washington State Department of Ecology. The last Tri-Party Agreement M-20 Milestone for the 242-CX Tank System was completed on December 22, 2008, and the Washington State Department of Ecology is in the process of preparing the draft Hanford
Facility RCRA Permit, WA7890008967, Revision 9, to incorporate the 43 treatment, storage, and disposal units.

During 2009, two revisions to the Hanford Facility RCRA Permit, WA7890008967 Part A Form (Ecology 1994), were submitted to the Washington State Department of Ecology for review and approval. Both concern the 200 Areas:

- Double-Shell Tanks System and 204-AR Waste Unloading Station

- Single-Shell Tank System.

\subsubsection{RCRA Groundwater Monitoring SP Luttrell}

RCRA groundwater monitoring is part of the Hanford Site Soil and Groundwater Remediation Project (Section 8.7). In 2009, 14 RCRA sites were monitored to determine whether they were contaminating groundwater with hazardous constituents. Seven sites were monitored to assess the extent of known contaminants, and two were monitored to determine the progress of groundwater contamination cleanup activities. The Liquid Effluent Retention Facility and active Trenches 31,34, and 94 within the low-level burial grounds are scheduled to receive permits as operating RCRA facilities. The Integrated Disposal Facility received a RCRA operating permit in June 2006 and is under a unitspecific groundwater monitoring plan, although the site is not yet operational. The other sites monitored under RCRA are scheduled for closure under the Hanford Facility RCRA Permit (Ecology 1994). A summary of groundwater monitoring activities for these sites during 2009 is provided in Section 8.7; more detailed information is available in the Hanford Site Groundwater Monitoring and Performance Report for Calendar Year 2009 (DOE/RL-2010-11, Rev. 0).

\subsubsection{RCRA Inspections DL Hagel}

The Washington State Department of Ecology performed 10 RCRA inspections on the Hanford Site during 2009 to assess compliance with applicable requirements. Hanford Site contractors and DOE worked to resolve any notices of violation and warning letters of non-compliance that were received from the Washington State Department of Ecology 
based on those inspections. These documents identified conditions that were alleged to be non-compliant with RCRA requirements. The following three items summarize the RCRA non-compliance and notice of violation documents received in 2009.

Notice of Non-Compliance Resulting from the 331-C Facility Dangerous Waste Inspection on November 5, 2008. The Washington State Department of Ecology sent a Notice of Non-Compliance on February 18, 2009, in response to a dangerous waste compliance inspection of the 331-C Facility conducted on November 5, 2008.

The inspection identified two violations of the Hanford Facility RCRA Permit regarding training and weekly inspection recordkeeping. Two concerns were also identified that related to personnel training.

Pacific Northwest National Laboratory personnel revised applicable sections of its training plan, performed additional training for affected staff, and documented the missing inspection checklist to address the issues identified.

On March 19, 2009, the DOE Richland Operations Office transmitted an unpublished report to the Washington State Department of Ecology identifying all completed actions and provided requested information. (a) On June 4, 2009, the Washington State Department of Ecology sent a letter to the DOE Richland Operations Office accepting the corrective actions. ${ }^{(b)}$ This action is closed.

Notice of Non-Compliance Resulting from the Waste Receiving and Processing Facility Dangerous Waste Inspection of April 14, 2009. The Washington State Department of Ecology sent a Notice of Non-Compliance on June 19, 2009, in response to a dangerous waste compliance inspection of the Waste Receiving and Processing Facility conducted on April 14, 2009.

The inspection identified one violation for failure to provide separate secondary containment for two drums of unknown waste, and one concern regarding universal waste management at the facility.

CH2M HILL Plateau Remediation Company took immediate steps to provide separate secondary containment for the two drums, resulting in Washington State Department of Ecology's decision to withhold formal enforcement in this case. Washington State Department of Ecology also acknowledged that a management plan for the Centralized Consolidation/Recycling Center was under revision and its intention to review the plan when submitted to EPA.

The DOE Office of River Protection submitted a formal response to EPA on May 8, 2009, identifying proposed corrective actions to resolve the Notice of Non-Compliance. Revision 3 of the Management Plan for Recyclable Materials Administered by Hanford's Centralized Consolidation/Recycling Center (CCRC) was submitted to EPA on October 7, 2009 (HNF-EP-0863, Rev. 3). EPA responded with its acceptance on January 26, 2010. This action is closed.

Notice of Violation of RCRA Requirements for Universal Waste Management at $\mathbf{6 1 6}$ Waste Handling Facility. A notice of violation was received from EPA on March 9, 2009, based on observations made during an inspection of the 616 Waste Handling Facility in September 2008, which was managed by the previous tank farms contractor, CH2M HILL Hanford Group. EPA alleged four violations of the universal waste requirements regarding the labeling and dating of batteries and lamps being accumulated for recycling.

The DOE Office of River Protection submitted a formal response to EPA on May 8, 2009, identifying proposed corrective actions to resolve the notice of violation, which included revisions to the management plan for the Centralized Consolidation/Recycling Center (HNF-EP-0863, Rev. 3). The plan contains guidance on the management of universal wastes. The DOE Office of River Protection coordinated efforts with DOE offices and site contractors

(a) 09-EMD-0055. 2009. Responses to Violations and Concerns. U.S. Department of Energy, Richland Operations Office, Richland, Washington.

(b) Mason EV. 2009. "USDOE Response to Ecology, Dated February 18, 2009, Notice of Non-Compliance." Letter to DA Brockman (U.S. Department of Energy, Richland Operations Office, Richland, Washington) from EV Mason (Washington State Department of Ecology, Olympia, Washington), dated June 4, 2009. 
to revise the management plan for the Centralized Consolidation/Recycling Center and submit it to EPA for approval. Revision 3 of the plan was submitted to EPA on October 7, 2009 (HNF-EP-0863, Rev. 3). EPA responded with its acceptance on January 26, 2010. This action is closed.

\subsubsection{Washington Administrative Code Groundwater Monitoring}

\section{SP Luttrell}

Groundwater monitoring was required for three regulated, non-RCRA waste facilities in 2009. The 200 Area Treated Effluent Disposal Facility and the State-Approved Land Disposal Site are monitored under state discharge permits (WAC 173-216). The Solid Waste Landfill is monitored for compliance with requirements in WAC 173-304, "Minimum Functional Standards for Solid Waste Handling." Wells near these facilities were monitored in 2009 for waste constituents specified in the facility permits.

Section 8.7 summarizes groundwater monitoring activities for these sites during 2009; more detailed information is available in DOE/RL-2010-11, Rev. 0.

\subsubsection{Federal Facility Compliance Act of 1992}

\section{Wollam}

The Federal Facility Compliance Act of 1992, enacted by Congress on October 6, 1992, amends Section 6001 of RCRA to specify that the United States waives sovereign immunity from civil and administrative fines and penalties for RCRA violations. In addition, RCRA requires EPA to conduct annual inspections of all federal facilities (42 USC 6927(c)). Authorized states are also given authority to conduct inspections of federal facilities to enforce compliance with state hazardous waste programs.

The Federal Facility Compliance Act of 1992 was effective upon enactment on October 6, 1992, with the exception that "departments, agencies, and instrumentalities of the executive branch of the Federal Government" would not be subject to the sovereign immunity waiver "with respect to civil, criminal, and administrative penalties and fines (as added by the amendments made by subsection (a))" until 3 years after enactment for violations of RCRA section 3004(j) "involving storage of mixed waste that is not subject to an existing agreement, permit, or administrative or judicial order, so long as such waste is managed in compliance with all other applicable requirements." This section forbids the storage of hazardous waste prohibited from land disposal unless the storage is for accumulating such quantities as necessary to facilitate proper recovery, treatment, or disposal.

After October 6, 1995, the provisions added to RCRA's existing waiver of sovereign immunity by the Federal Facility Compliance Act of 1992 with respect "to civil, criminal, and administrative penalties and fines" shall still not apply to $\mathrm{DOE}$ as long as DOE is in compliance with both a plan that has been submitted and approved and an order requiring compliance with such a plan. The required plan calls for the development of treatment capacities and technologies to treat all mixed wastes at each DOE facility.

The Federal Facility Compliance Act of 1992 further amends RCRA by imposing several new reporting requirements on DOE related to mixed waste. The Secretary of Energy must submit reports containing a national inventory of mixed wastes on a state-by-state basis, and a national inventory of mixed waste treatment capacities and technologies to the EPA administrator and the governors of states in which DOE stores or generates mixed wastes. The mixed waste inventory must describe each mixed waste type, list the amount currently stored, and estimate the amount of each type of mixed waste expected to be generated in the next 5 years at each DOE facility. Wastes not characterized by sampling and analysis also had to be described. The inventory of treatment capacities and technologies is required to contain an estimate of available treatment capacity for each waste category described in the waste inventory. DOE submitted its initial draft "Interim Mixed Waste Inventory Report: Waste Streams, Treatment Capacities and Technologies" in April 1993 (58 FR 25822). Also, the Secretary of Energy was directed to prepare and submit plans for developing treatment capacities and technologies for all facilities generating or storing mixed waste that are not subject to any permit, agreement, or order. These plans would include schedules for developing treatment capacity where treatment technologies exist and schedules for identifying and 
developing treatment technologies where none is currently available. These plans would be reviewed and approved either by EPA or the states, depending on whether the state is authorized to regulate mixed waste.

In 2009, these reporting requirements were met by the Calendar Year 2008 Hanford Site Mixed Waste Land Disposal Restrictions Summary Report (DOE/RL-2009-27, Rev. 0).

\subsubsection{National Environmental Policy Act of 1969}

\section{JW Cammann}

The National Environmental Policy Act of 1969 (NEPA) requires that an environmental impact statement be prepared for major federal agency actions that have the potential to significantly affect the quality of the human environment. A record of decision documents decisions concerning a proposed action for which an environmental impact statement has been prepared.

An environmental assessment is prepared when it is uncertain if a proposed action would require the preparation of an environmental impact statement. A "finding of no significant impact" may be issued to present the reasons why an action will not have a significant effect on the human environment, and therefore, will not require preparation of an environmental impact statement.

A mitigation action plan, prepared in accordance with NEPA regulations (10 CFR 1021.331), describes a plan for implementing commitments made in an environmental impact statement and its associated record of decision, or when appropriate, an environmental assessment, to mitigate adverse environmental impacts associated with a proposed action.

Occasionally, special environmental analyses may be prepared after consulting with the Council on Environmental Quality for alternative arrangements under 40 CFR 1506.11, which apply where emergency circumstances make it necessary to take action without preparing an environmental impact statement. The special environmental analysis examines the environmental impacts of the emergency action and considers alternatives that include mitigation measures.
A supplement analysis, prepared in accordance with NEPA regulations (10 CFR 1021.314(c)), is used to determine whether a supplemental or new environmental impact statement should be prepared pursuant to Council on Environmental Quality NEPA regulations (40 CFR 1502.9(c)). A supplement analysis is prepared to consider new information developed since issuance of an environmental impact statement and record of decision. The supplement analysis determines if the proposed action is still bound by the original environmental impact statement and record of decision, or if a supplemental environmental impact statement and amended record of decision are required.

A Notice of Intent is a formal announcement of intent to prepare an environmental impact statement, which is published in the Federal Register in accordance with DOE NEPA regulations (10 CFR 1021.311). The EPA Notice of Availability is the official public notification published in the Federal Register to announce the issuance and public availability of a draft or final environmental impact statement.

Additionally, certain actions may be categorized into classes that have already been analyzed and determined to not normally result in a significant environmental impact (10 CFR 1021, Subpart D, Appendix A and B). Known as categorical exclusions, these actions are exempt from NEPA environmental assessment or environmental impact statement requirements if eligibility criteria are met. Some categorical exclusions are applicable to general DOE actions and do not require written documentation for application. These categorical exclusions are administrative in nature and are listed in 10 CFR 1021, Subpart D, Appendix A. Other categorical exclusions are applicable to specific DOE actions and must be documented in writing when applied. These categorical exclusions are listed in 10 CFR 1021, Subpart D, Appendix B.

Action-specific categorical exclusions listed in 10 CFR 1021, Subpart D, Appendix B must be reviewed and approved by the DOE NEPA Compliance Officer prior to their citation in meeting NEPA requirements. At the Hanford Site, some categorical exclusions that are action-specific and apply to routinely conducted activities have been pre-approved by the DOE NEPA Compliance Officer as site-wide categorical exclusions. Site-wide categorical exclusions may be applied 
to proposed actions by NEPA-trained individuals without approval by the DOE NEPA Compliance Officer.

There are four conditions that must be met in order to apply all categorical exclusions to proposed actions. The proposed action must 1) fit within the scope described in the categorical exclusion; 2) have no extraordinary circumstances that may impact the significance of the environmental effects of the proposed action; 3) not be "connected" to other actions with potentially significant impacts, not be related to other proposed actions with cumulatively significance impacts, and not be precluded by 40 CFR 1506.1 or 10 CFR 1021.211; and 4) meet the integral elements of 10 CFR 1021 and not violate regulatory requirements; not require construction of waste treatment, storage, and disposal facilities; not disturb hazardous substances that could result in an uncontrolled release; and not adversely affect environmentally sensitive resources (i.e., historic properties, cultural resources, ecological resources, wilderness areas, wild and scenic areas, sole source aquifers, wellhead protection areas, etc.).

Hanford Site NEPA documents are prepared and approved in accordance with NEPA regulations and their implementing procedures. DOE activities conducted under CERCLA requirements incorporate NEPA values including analysis of cumulative, offsite, ecological, cultural, and socioeconomic impacts to the extent practicable in work planning documents in lieu of preparing separate NEPA documentation.

On October 2, 2009, the Deputy Secretary of Energy issued a memorandum to the Heads of Departmental Elements. ${ }^{(c)}$ This memorandum reaffirms President Obama's commitment to creating an unprecedented level of openness in government. The President specifically called on executive agency leaders to make information about agency operations and decisions available to the public online, in a form that is easy to find and use, to encourage transparency, participation, and collaboration. Such openness is especially important when the information relates to DOE's compliance with NEPA requirements.
Therefore, to further transparency and openness in DOE's implementation of the NEPA process, a new policy was established with regard to the online posting of certain categorical exclusion determinations made by DOE NEPA Compliance Officers. Under the new policy, each Program and Field Office is required to document and post online all categorical exclusion determinations involving classes of actions listed in Subpart D, Appendix B of DOE's NEPA implementing procedures (10 CFR 1021). DOE Order 451.1B, "National Environmental Policy Act Compliance Program," will be revised to be consistent with this new policy.

Posted categorical exclusion determinations do not disclose classified, confidential, or other information that DOE would not disclose pursuant to the Freedom of Information Act. This policy became effective November 2, 2009. NEPA documentation for the Hanford Site is available at the following website: http://www.hanford.gov/page.cfm/ OfficialDocuments.

\subsubsection{Hanford Site Environmental Impact Statements}

Draft Tank Farm Closure and Waste Management Environmental Impact Statement for the Hanford Site, Richland, Washington (DOE/EIS-0391). In February 2006, DOE announced its intent to prepare a new environmental impact statement for the Hanford Site pursuant to NEPA requirements titled, "Notice of Intent to Prepare the Tank Closure and Waste Management Environmental Impact Statement for the Hanford Site, Richland, Washington" (71 FR 5655).

DOE/EIS-0391, in addition to tank waste treatment and single-shell tank closure, had the scope increased to revise, update, and reanalyze groundwater impacts previously addressed in the Final Hanford Site Solid (Radioactive and Hazardous) Waste Program Environmental Impact Statement, Richland, Washington (DOE/EIS-0286F), and provide a single, integrated analysis of groundwater for all waste types on the Hanford Site. DOE/EIS-0391 included a reanalysis

(c) Memorandum from Deputy Secretary of Energy to Heads of Departmental Elements, "NEPA Process Transparency and Openness," dated October 2, 2009. Accessed May 17, 2010, at http://nepa.energy.gov/DOEPolicyonNEPAProcessTransparencyandOpenness_10_02_09.pdf. 
of onsite disposal alternatives for the Hanford Site's lowlevel radioactive and mixed low-level radioactive wastes, and similar wastes from other DOE sites. DOE analyzed alternatives for the retrieval, treatment, storage, and disposal of underground tank wastes and closure of underground single-shell tanks. Included is the scope of the Fast Flux Test Facility Decommissioning Environmental Impact Statement, which was terminated prior to completion in February 2006. DOE/EIS-0391 presents reasonable foreseeable future activities related to cleanup on the Hanford Site.

A Notice of Availability of the Draft Tank Closure and Waste Management Environmental Impact Statement for the Hanford Site, Richland, Washington (DOE/EIS-0391) for review and comment was issued in the Federal Register on October 30, 2009 (74 FR 56194). The comment period was to end on March 19, 2010. The comment period was extended in the Federal Register on March 19, 2010 (75 FR 13268), an additional 45 days for a total of 185 days to May 3, 2010. DOE announced a series of public hearings on the draft DOE/EIS-0391 in two Federal Register announcements: one on January 8, 2010 (75 FR 1048) and a second on January 25, 2010 (75 FR 3902).

\subsubsection{Hanford Site Environmental Assessments}

Environmental Assessment: Upgrades and Life Extension of the 242-A Evaporator, Hanford Site, Richland, Washington Conducted Under the American Recovery and Reinvestment Act of 2009 (DOE/EA-1682). On February 5, 2009, DOE determined that an environmental assessment was needed to evaluate proposed upgrades and a life extension of the 242-A Evaporator in the 200-East Area of the Hanford Site. This interim action environmental assessment was prepared to determine if the proposed upgrades to extend the life of the 242-A Evaporator would potentially cause significant adverse impacts to the environment or limit the choice of actions among the reasonable alternatives for the facility being considered in the ongoing DOE/EIS-0391 draft report.

The current and future mission of the 242-A Evaporator is to support environmental restoration and remediation of the Hanford Site by optimizing the 200 Area double-shell tank waste volumes in support of the tank farms contractor and Hanford Tank Waste Treatment and Immobilization Plant contractor. The proposed actions will be conducted using funding provided under the American Recovery and Reinvestment Act of 2009.

DOE/EA-1682 analyzed a "no action" alternative and the proposed action. The proposed action included upgrades in the leak detection system for the discharge pipeline from the 242-A Evaporator to the Liquid Effluent Retention Facility; upgrades to flow, pressure, weight factor, and density measuring and transmitting instrumentation in the 242-A Evaporator; and upgrades to the heating, ventilation, and air conditioning system. Proposed actions and associated upgrades will support continued operation of the 242-A Evaporator through the year 2032.

During 2009, work continued on the environmental assessment. DOE/EA-1682 was issued with a "finding of no significant impact" on February 3, 2010. Procurement and construction activities are planned during fiscal year 2010.

Environmental Assessment: Combined Community Communications Facility and Infrastructure Cleanup on the Fitzner/Eberhardt Arid Lands Ecology Reserve, Hanford Site, Richland, Washington (DOE/EA-1660F). DOE/EA-1660F was issued in July 2009, and a "finding of no significant impact" was issued on July 20, 2009, approving the proposed action.

DOE/EA-1660F provides information and analysis of proposed DOE activities to consolidate existing facilities and reduce the footprint of facilities and infrastructure within the Fitzner/Eberhardt Arid Lands Ecology Reserve and analyzed a "no action alternative" and the proposed action. Three alternatives were considered but not evaluated in detail.

Under the no-action alternative, a Combined Community Communication Facility would not be constructed. Communications users would continue to use the seven towers, associated infrastructure, and the telephone facility located on the ridgeline of Rattlesnake Mountain. DOE would continue to maintain and operate the towers, feeder roads, telephone cable, and power lines to satisfy emergency management and commercial communications requirements. The access road to the ridgeline would be maintained 
to allow users to access and maintain the communications equipment. The surplus facilities at the base areas and ridgeline would remain in place with little maintenance. The boundary fence would not be maintained and debris located across Fitzner/Eberhardt Arid Lands Ecology Reserve would be left in place.

DOE's proposed action was to demolish most of the facilities on Fitzner/Eberhardt Arid Lands Ecology Reserve except those needed by DOE, U.S. Fish \& Wildlife Service, and communications providers. Existing emergency communications capability would be maintained. A facility would be constructed to combine communications operations at a single site to allow the demolition of most of the existing antennas and radio repeaters on the ridgeline. In addition, DOE would remove miscellaneous debris from past activities across the site and repair the fence on the boundary of the Fitzner/Eberhardt Arid Lands Ecology Reserve.

The availability of American Recovery and Reinvestment Act of 2009 funding has provided DOE the opportunity to identify actions that could be accelerated and accomplished earlier than planned. DOE's construction of the Combined Community Communication Facility ensures continued emergency communications for Energy Northwest, local, and regional agencies, and reduced the physical footprint by consolidating communications facilities and removing surplus facilities and infrastructure located on the Fitzner/ Eberhardt Arid Lands Ecology Reserve. The proposed action also fulfilled DOE's responsibility to preserve and protect important cultural, historical, and ecological resources on the Hanford Site. Construction of the Combined Community Communication Facility was completed in 2009, along with installation of the communication antenna towers. Demolition of surplus infrastructure and debris cleanup is anticipated for completion in 2010.

\subsubsection{Hanford Site Categorical Exclusions}

During 2009, the DOE NEPA Compliance Officer approved the following categorical exclusions for activities that correspond to the classes of actions described in 10 CFR 1021, Subpart D, Appendix B. Categorical exclusions encompass classes of actions that do not individually or cumulatively have a significant effect on the human environment, and for which neither an environmental assessment nor an environmental impact statement is required.

Limited Prescribed Burning on the Hanford Site during October, November, and December 2009 to Maintain Critical Fire Breaks. This categorical exclusion covers the limited prescribed burning of approximately 81 hectares (200 acres) on the Hanford Site. Prescribed burning helps maintain critical fire breaks along several Hanford Site roadways and the fenced perimeter of several major operating areas to mitigate the potential impacts of wildland fires. Prescribed burning was conducted in a controlled and deliberate manner by the Hanford Fire Department and in accordance with a DOE-approved prescribed burn plan and burn permit issued by the Benton Clean Air Agency.

\section{Purgewater Storage and Treatment Facility Unit \#1}

Closure. This categorical exclusion covers the closeout of a 3.79-million-liter (1-million-gallon) surface impoundment used as a purgewater storage and treatment facility (Modular Tank Unit \#1) in the 600 Area of the Hanford Site. Modular Tank Unit \#1 contains well water and sediment from various groundwater well drilling operations and has been in operation since 1990. The facility has reached the end of its design life.

\section{Modifications to the Maintenance and Storage Facility.} This categorical exclusion covers modifications to the existing Maintenance and Storage Facility for cold mockup testing in support of Hanford Site sludge disposition. The Maintenance and Storage Facility cold mockup facility will be used to confirm treatment technologies and support design readiness of systems and components before being deployed for removal of sludge from the 105-K West Basin and sludge treatment. Testing will be conducted using non-radioactive sludge stimulants that bound expected physical properties of the actual radioactive sludge that will be removed.

\section{Facility Upgrades at 222-S Laboratory Complex.}

This categorical exclusion covers facility upgrades, system upgrades, and analytical instrument upgrades at the 222-S Laboratory Complex on the Hanford Site. Facility upgrades include, but are not limited to, roof repairs, mobile office and storage facility modifications, stairway improvements, relocation of laboratory functions, and 
landscaping around facilities. System upgrades include, but are not limited to, heating, ventilation, and air conditioning; the local area computer network; lighting fixtures; phone system; and electrical drawings. Also included is procurement of a backup air-dryer. Analytical instrument upgrades include, but are not limited to an alpha energy analyzer, gamma energy analyzer, liquid chromatograph/mass spectrometer, ion chromatograph, microwave digestion system, inductively coupled plasma-atomic emissions spectrometer, gas chromatograph/mass spectrometer, inductively coupled plasma-mass spectrometer, viscometer, particle size distribution analyzer, and associated software and hardware upgrades.

Proposed upgrades will provide the capability to maintain compliance with regulatory and customer requirements with high reliability. Analytical instrument upgrades will be performed using American Recovery and Reinvestment Act of 2009 funding. All other upgrades will be performed using baseline funding appropriated for 222-S Laboratory Complex maintenance and operations activities.

Construction of 241-TY Interim Surface Barrier. This categorical exclusion covers the construction of an interim surface barrier over the 241-TY Tank Farm in the 200-West Area of the Hanford Site. The surface barrier is being constructed as a RCRA interim corrective measure. A 10.2-centimeter (4-inch) nominal thickness modified asphalt barrier will be constructed over an area of approximately 7,430 square meters ( 80,000 square feet). Collected meteoric precipitation will be routed from the modified asphalt surface barrier to an evapotranspiration basin. The evapotranspiration basin will be lined with a geomembrane, covered with 0.91 meter ( 3 feet) of fine-grained soil, and revegetated with native plants to facilitate recycle of collected moisture to the atmosphere by evaporation and plant transpiration. The purpose of the RCRA interim corrective measure is to reduce the infiltration of meteoric precipitation in the 241-TY Tank Farm, which provides the primary driving force for contaminant migration towards groundwater.

\subsubsection{Toxic Substances Control Act}

\section{Wollam}

Toxic Substances Control Act requirements that apply to the Hanford Site primarily involve regulation of polychlorinated biphenyls (PCBs). Federal regulations for PCB use, storage, and disposal are provided in 40 CFR 761, "Polychlorinated Biphenyls (PCBs) Manufacturing, Processing, Distribution in Commerce, and Use Prohibitions." PCB wastes on the Hanford Site are stored and/or disposed of in accordance with 40 CFR 761. Some radioactive PCB waste remains in storage onsite pending the development of adequate treatment and disposal technologies and capacities. Electrical equipment that might contain PCBs is also maintained and serviced in accordance with 40 CFR 761.

During 2009, the DOE Richland Operations Office submitted both the 2008 Hanford Site Polychlorinated Biphenyl Annual Document Log (DOE/RL-2009-51, Rev. 0) and a 2008 Hanford Site Polychlorinated Biphenyl Annual Report (DOE/RL-2009-50, Rev. 0) to EPA as required by 40 CFR 761.180. These documents describe the PCB waste management and disposal activities occurring on the Hanford Site. The Framework Agreement for Management of Polychlorinated Biphenyls (PBCs) in Hanford Tank Waste (Ecology et al. 2000), signed on August 31, 2000, resulted in EPA, the Washington State Department of Ecology, and DOE and its Hanford Site contractors working together to resolve the regulatory issues associated with managing PCB waste at 1) the Hanford Tank Waste Treatment and Immobilization Plant (currently under construction); 2) the waste tank farms; and 3) affected waste management units adjacent to the waste tank farms. The 1998 PCB disposal amendments in 40 CFR 761 allow for necessary storage and the expedited disposal of PCB waste regulated under the Toxic Substances Control Act.

During 2009, single-shell tank waste retrieval activities continued in accordance with EPA Phase I and II risk-based disposal approvals for the use of double-shell tank PCB remediation waste in accordance with 40 CFR 761.61(c). 
Phase I identifies general conditions that apply to the overall strategy and retrieval process and Phase II identifies tank-specific conditions. Approvals have been received for the eight single-shell tanks classified as integrally sound.

Other risk-based disposal approvals are being implemented on the Hanford Site. K Basins sludge continued to be managed through 2009, and a risk-based disposal approval for continued storage of two water tower tanks at the Hanford Site remains in place. The paint on the tanks' interior walls contains PCBs greater than 500 parts per million and the tanks will be disposed of as PCB bulk product waste. The riskbased disposal approval will allow continued storage of the tanks while disposal plans are developed and implemented.

\subsubsection{Federal Insecticide, Fungicide, and Rodenticide Act}

\section{JM Rodriguez}

The Federal Insecticide, Fungicide, and Rodenticide Act is administered by EPA. The standards administered by the Washington State Department of Agriculture to regulate implementation of the Act in the state include the Washington Pesticide Control Act, the Washington Pesticide Application Act, and rules relating to general pesticide use codified in WAC 16-228, "General Pesticide Rules." On the Hanford Site, commercial pesticides are applied by commercial pesticide operators that are listed on one of two commercial pesticide applicator licenses, and by a licensed private commercial applicator. 


\subsection{Radiation Protection Statutes}

The Hanford Site is subject to radiation protection statutes and regulations designed to protect the health and safety of the public, the workforce, and the environment.

\subsubsection{Atomic Energy Act of 1954}

\section{WM Glines}

The Atomic Energy Act of 1954 was promulgated to assure the proper management of radioactive materials. The Act and its amendments include provisions to delegate the roles and responsibilities for the control of radioactive materials and nuclear energy primarily to DOE, the U.S. Nuclear Regulatory Commission, and EPA. Under the Act, DOE regulates the control of radioactive materials under its authority, including the treatment, storage, and disposal of low-level radioactive waste from its operations. Sections of the Act authorize DOE to set radiation protection standards for itself and its contractors. Accordingly, DOE promulgated a series of regulations (e.g., 10 CFR 820, 10 CFR 830, and 10 CFR 835) and directives (e.g., DOE Order 435.1, Chg 1 [Section 5.2.3] and DOE Order 5400.5, Chg 2 [Section 5.2.2]) to protect public health and the environment from potential risks associated with radioactive materials. Hanford Site operations are subject to the requirements in these regulations and directives. In 2009, the following DOE regulations or directives that potentially impact the management and control of radioactive materials were issued or underwent significant revision:

- DOE Notice 251.76, "Extension of DOE N 234.1, Reporting of Radioactive Sealed Sources"

- DOE Order 410.2, "Management of Nuclear Materials."
In addition, in 2009 the following DOE technical standards or handbooks pertaining to the management and control of radioactive materials were issued or underwent significant revision:

- DOE-HDBK-1104-2009, Review and Approval of Nuclear Facility Safety Basis and Safety Design Basis Documents.

- DOE-HDBK-1122-2009, Radiological Control Technician Training

- DOE-HDBK-1130-2008, Radiological Worker Training

- DOE-STD-1083-2009, Processing Exemptions to Nuclear Safety Rules and Approval of Alternative Methods for Documented Safety Analyses

- DOE-STD-1136-2009, Guide of Good Practices for Occupational Radiological Protection in Uranium Facilities

Directives, regulations, standards, and handbooks issued in 2009 may be accessed via the DOE Office of Health, Safety, and Security website at http://www.hss.energy.gov/ nuclearsafety/ns/techstds/standard/standard.html.

\subsubsection{DOE Order 5400.5, "Radiation Protection of the Public and the Environment"}

\section{WM Glines}

DOE Order 5400.5, "Radiation Protection of the Public and the Environment," was initially issued in February 1990, and underwent minor revisions in June 1990 (Change 1) and January 1993 (Change 2). The purpose of this directive is to establish standards and requirements for conduct of DOE and DOE contractor operations with respect to radiological 
protection of the public and the environment. This directive integrated, consolidated, and updated portions of previous DOE directives that had addressed public and environmental radiation protection standards and control practices. This directive was developed and issued consistent with DOE's policy to implement legally applicable radiation protection requirements; to consider and adopt, as appropriate, recommendations by authoritative organizations (e.g., the National Council on Radiation Protection and Measurements and the International Commission on Radiological Protection); and to adopt and implement standards generally consistent with those of the U.S. Nuclear Regulatory Commission for DOE facilities and activities not subject to U.S. Nuclear Regulatory Commission authority. Specifically, relative to guidance, standards, and regulatory requirements existing at the time of its issuance, this directive adopted applicable standards issued by the International Commission on Radiological Protection and the National Council on Radiation Protection and Measurements, incorporated regulatory requirements applicable to DOE operations, and consolidated and upgraded DOE guidance for contaminated property.

DOE Order 5400.5, Chg 2 applies to all DOE elements and contractors performing work for DOE, as provided by law and/or contract, and as implemented by the appropriate contracting officer. This directive was developed and issued under the authority of the Atomic Energy Act of 1954, as amended, which authorizes DOE to provide for the radiological health and safety of the public for operations conducted under DOE direction.

Relative to the radiological health and safety of the public, the objectives of DOE Order 5400.5, Chg 2 are to ensure that DOE operations achieve the following:

- Radiation exposures to the public are maintained within established limits.

- Radioactive contamination is controlled through the management of real and personal property.

- Potential exposures to the public are as far below established limits as is reasonably achievable.

- DOE facilities have the capabilities, consistent with the types of operations conducted, to monitor routine and non-routine releases and to assess doses to the public.
In addition to providing radiological protection to the public, the objective of DOE Order 5400.5 is to provide radiological protection of the environment to the extent practical.

DOE Order 5400.5, Chg 2 also provides derived concentration guide values as reference values for conducting radiological environmental protection programs at operational DOE facilities and sites. These DOE-derived concentration guide values are based on a committed dose standard of 100 millirem (1 millisievert) due to ingestion, inhalation, or direct exposure during a given year, and are provided for three exposure pathways: 1) ingestion of water; 2) inhalation of air; and 3) immersion in a gaseous cloud. This directive also provides radiological protection requirements and guidelines for cleanup of residual radioactive material, management of the resulting wastes and residues, and clearance of property. These requirements and guidelines are applicable at the time the property is released.

In 2008, DOE initiated a comprehensive revision and update to DOE Order 5400.5, Chg 2. This effort continued in 2009, and a draft revision to this directive (re-numbered DOE Order 458.1) was issued for comment in October 2009. Following resolution of comments, a final revision of DOE Order 5400.5, Chg 2 is expected to be issued as DOE Order 458.1 in mid-2010.

\subsubsection{DOE Order 435.1, "Radioactive Waste Management"}

\section{MS Collins}

The purpose of DOE Order 435.1, "Radioactive Waste Management," is to establish requirements to ensure DOE radioactive waste is managed in a manner that is protective of worker and public health and safety, and the environment. The Order takes a "cradle-to-grave" approach to managing waste and includes requirements for waste generation, storage, treatment, disposal, and post-closure monitoring of facilities. 
Radioactive waste shall be managed such that the requirements of other DOE Orders, standards, and regulations are met, including the following:

- 10 CFR 835, "Occupational Radiation Protection"

- DOE Order 440.1A, "Worker Protection Management for DOE Federal and Contractor Employees"

- DOE Order 450.1A, "Environmental Protection Program"

- DOE Order 5400.5, Chg 2, "Radiation Protection of the Public and the Environment."
DOE Order 435.1 establishes requirements for the management of high-level waste, transuranic waste, and low-level waste. It also covers mixed waste (i.e., highlevel waste, transuranic waste, and low-level waste that also contain chemically hazardous constituents). DOE Order 435.1, approved in 1999, superseded a previous set of requirements (DOE Order 5820.2A, dated September 26, 1988) for managing radioactive waste. DOE Order 435.1, Chg 1, approved in 2001, includes minor revisions to the original Order. 


\title{
5.3 Air Quality Statutes
}

\author{
TG Beam
}

This section provides information on federal, state, and local statutes applicable to the Hanford Site air quality program.

\subsubsection{Air Quality Regulatory Authority}

The federal Clean Air Act was enacted to protect and enhance air quality and is the legal basis for federal, state, and local air quality regulations. The law, originally passed in 1967, has been revised extensively on numerous occasions. The Clean Air Act Amendments of 1990 is the most recent revision and is the framework for a significant portion of the current federal air quality regulations. The Washington Clean Air Act parallels and supplements federal law. It has been revised periodically to keep pace with changes at the federal level.

EPA provides high-level programmatic oversight of the air quality program on the Hanford Site, but has delegated authority for implementing applicable Clean Air Act regulations to designated state and local regulatory agencies.

The Washington State Department of Health regulates radioactive air emissions on the Hanford Site by enforcing applicable federal requirements in 40 CFR 61, Subparts A and $\mathrm{H}$, as well as the state requirements in WAC 173-480 and WAC 246-247. The federal regulations contained in 40 CFR 61, Subpart H, which is part of the Federal National Emission Standards for Hazardous Air Pollutants (NESHAP), are collectively referred to on the Hanford Site as "Rad NESHAP" because they provide regulations for radioactive air emissions.

The Washington State Department of Ecology regulates criteria and toxic air pollutant emissions on the Hanford
Site by enforcing the applicable federal requirements in 40 CFR 52, 40 CFR 60, 40 CFR 61, 40 CFR 63, 40 CFR 68, and 40 CFR 82 as well as the state requirements in WAC 173-400, WAC 173-460, WAC 173-480, and WAC 173-491. Criteria and toxic air pollutant emissions are often referred to as "non-radioactive" air emissions on the Hanford Site. Criteria pollutants are particulate matter, nitrogen oxides, sulfur oxides, carbon monoxide, lead, and volatile organic compounds. Toxic pollutants are other chemical contaminants as regulated by Washington State.

The Benton Clean Air Agency regulates demolition and asbestos renovation activities on the Hanford Site in accordance with federal requirements in 40 CFR 61, Subpart M. The Benton Clean Air Agency also regulates outdoor burning activities on the Hanford Site in accordance with state requirements in WAC 173-425.

\subsubsection{Permits}

Hanford Site contractors evaluate each proposed new or modified emission unit using the new source review requirements of radioactive air emissions (WAC 246-247), criteria pollutants (WAC 173-400-110), and/or toxic air pollutants (WAC 173-460-040) to determine whether a notice of construction application must be submitted to the Washington State Department of Health and/or the Washington State Department of Ecology, as applicable, for approval before construction or operation of the proposed source.

Hanford Site radioactive air emission sources are operated in accordance with the Department of Energy Hanford Site Radioactive Air Emissions License \#FF-01 issued by the Washington State Department of Health (2007). The FF-01 license is a compilation of all applicable radioactive 
air emission requirements and is renewed every 5 years. For each emission unit, the FF-01 license includes either 1) an approval to modify/construct, or 2) an operating license. Overall, Hanford Site radioactive air emissions are controlled to sufficiently low levels to ensure the resultant exposure to any offsite individual remains well below the 10 millirem (100 microsievert) per year standard specified in 40 CFR 61.92. Hanford Site radioactive air emissions data are published annually in the radionuclide air emissions report (DOE/RL-2010-17).

As a major source of air pollutants, the Hanford Site is subject to the operating permit requirements of 40 CFR 70 and WAC 173-401. In coordination with the Washington State Department of Health and the Benton Clean Air Agency, the Washington State Department of Ecology issued Renewal 1 of the Hanford Site air operating permit for a period of 5 years, effective January 1, 2007. The air operating permit is a compilation of applicable Clean Air Act requirements for both radioactive and criteria/toxic air pollutant emissions, including the Hanford Site air emissions license \#FF-01 issued by the Washington State Department of Health (2007) and notice of construction approval orders issued by the Washington State Department of Ecology. Provisions in the air operating permit require that semiannual reports documenting the status of required monitoring and any identified permit deviations be submitted to the regulatory agencies (DOE/RL-2009-04,
Rev. 0; DOE/RL-2010-01, Rev. 0). An annual report that documents the compliance status of Hanford Site emission sources against applicable Clean Air Act requirements is also required (DOE/RL-2010-02), as well as an annual report that documents total emissions of criteria and toxic pollutants on the Hanford Site (DOE/RL-2010-20, Rev. 0). The air operating permit was revised once in 2009 to incorporate new Washington State Department of Health and Washington State Department of Ecology air emission licenses, approval orders, and updated regulatory requirements. Revision E was issued on December 18, 2009.

\subsubsection{Inspections}

The Washington State Department of Health, the Washington State Department of Ecology, and the Benton Clean Air Agency conduct regular inspections of Hanford Site emission sources to verify compliance with applicable Clean Air Act requirements. Hanford Site contractors and DOE actively work to resolve any potential compliance issues identified during these inspections. During 2009, the regulatory agencies conducted over 25 Clean Air Act inspections on the Hanford Site. None of the inspections resulted in the issuance of any notice of non-compliance (or similar correspondence) or formal enforcement action on the part of the regulatory agencies. 


\subsection{Water Quality Protection Statutes}

This section provides information on federal, state, and local statutes and permits related to Hanford Site water quality.

\subsubsection{Clean Water Act of 1977 R Ranade}

The Clean Water Act of 1977 applies to point-source discharges to surface waters in the United States. At the Hanford Site, regulations are applied through the "EPA Administered Permit Programs: The National Pollutant Discharge Elimination System" (40 CFR 122) permit that governs effluent discharges to the Columbia River. There is one National Pollutant Discharge Elimination System (NPDES) permit (WA-002591-7) issued by EPA for the Hanford Site (Appendix D, Table D.1). The NPDES permit covers three outfalls: one outfall for the 300 Area Treated Effluent Disposal Facility, and two outfalls in the 100-K Area. CH2M HILL Plateau Remediation Company is the holder of this permit. During 2009, the outfall for the 300 Area Treated Effluent Disposal Facility was removed from the permit because the facility was shut down.

CH2M HILL Plateau Remediation Company held a 2000 Multi-Sector General Permit for Hanford Site 100-K Area stormwater discharges during early 2009. This permit established the terms and conditions under which stormwater discharges associated with industrial activity were authorized. CH2M HILL Plateau Remediation Company filed a notice of termination for its coverage under this permit on June 22, 2009, following approval and coverage of a NPDES Construction General Permit that began on June 3, 2009.

\section{State Waste Discharge Permits}

The Washington State Department of Ecology has a State Wastewater Discharge Permit Program that regulates ground discharges. Five Washington State Department of Ecology state waste discharge permits were in effect during 2009 (ST-4500, ST-4501, ST-4502, ST-4507, and ST-4511). DOE is the holder of all the state waste discharge permits. A permit renewal application for ST-4511 was filed with the Washington State Department of Ecology in August 2009.

Throughout the Hanford Site there are numerous sanitary waste discharges to the ground. Sanitary wastewater from the 400 Area is discharged to a treatment facility at Energy Northwest's Columbia Generating Station in Richland, Washington. Sanitary wastewater from the 300 Area, the former 1100 Area, and other facilities north of and in the city of Richland is discharged to the city's treatment facility. Sanitary wastewater in the 100 Areas and Central Plateau is treated primarily in a series of onsite sewage systems. Placement of these sewage systems is based on population centers and facility locations. In recent years, extensive efforts have been made to regionalize the onsite sewage systems. Larger sewage systems replaced many of the small onsite sewage systems. These larger sewage systems (with design capacities of 13,300 to 55,000 liters [3,500 to 14,500 gallons] per day) operate under permits issued by the Washington State Department of Health and treat wastewater from several facilities rather than a single facility (Appendix D, Table D.1). Holding-tank sewage systems are also used to dispose of sanitary wastewater. The Washington State Department of Health issues an annual permit to DOE for the operation of Hanford Site sewage systems, which include holding-tank sewage systems. 
There were no permit violations on the Hanford Site during 2009.

\subsubsection{Safe Drinking Water Act of 1974}

\section{R Ranade and LM Kelly}

The Safe Drinking Water Act of 1974 established a cooperative program among local, state, and federal agencies to institute drinking water regulations applicable to all public water systems in the United States. States were granted primary responsibility, known as primacy, for administering and enforcing the Safe Drinking Water Act of 1974. To obtain primacy, states were required to meet certain criteria, including adoption of regulations equal to or more stringent than EPA regulations.

Washington State was awarded primacy in 1978. The State Board of Health and the Washington State Department of Health became partners in developing and enforcing state drinking water regulations. Hanford Site water systems were designated as public water systems in 1986 and became formally registered as public systems under the jurisdiction of the Washington State Department of Health in 1987.

The Safe Drinking Water Act of 1974 was amended in 1986 and 1996 (Safe Drinking Water Act Amendments). While the 1986 amendments included provisions that emphasized treatment to ensure safe drinking water, the 1996 amendments focused on source water protection, funding for water system improvements, operator training, public information, and the strengthening of EPA's scientific work, including the use of risk and cost benefit analysis in establishing drinking water standards. Between 1975 and 2006, the amendments have resulted in the development of 18 new drinking water regulations. Post-1996 regulations have included more complex compliance determinations and more advanced treatment technologies. Based on site-specific conditions, many public water systems are either employing or investigating the use of new treatment technologies to comply with the increasingly complex requirements.
The Microbial and Disinfection Byproduct Rules address acute threats from microbial contamination and chronic threats from disinfectant residuals and disinfection byproducts. The first phase of the rulemaking strategy resulted in the "Disinfectants and Disinfection Byproduct Rule" (63 FR 69389), the "Interim Enhanced Surface Water Treatment Rule" (63 FR 69477), and the "Long Term 1 Enhanced Surface Water Treatment Rule" (67 FR 1811), which strengthened microbial controls for small (less than 10,000 people) water systems. These rules limit disinfectant residuals and disinfection byproducts in the distribution systems while improving particle removal in the drinking water treatment plants.

In 2006, EPA published the "National Primary Drinking Water Regulations: Long Term 2 Enhanced Surface Water Treatment Rule; Final Rule" (71 FR 653) and the "National Primary Drinking Water Regulations: Stage 2 Disinfectants and Disinfection Byproducts Rule" (71 FR 387). These rules build upon previously issued rules to strengthen protection against microbial contaminants, and in parallel, reduce potential health risks from disinfectant byproducts. Compliance deadlines are based on system size as established by EPA. In 2009, affected Hanford Site systems demonstrated compliance with the filtration and disinfection treatment technique requirements and limits for disinfectant residuals and disinfection byproducts. EPA also published the "Ground Water Rule" (71 FR 65574) in 2006 to provide increased protection against microbial pathogens in water systems that use groundwater sources.

To protect the health of workers using public water supplies on the Hanford Site, water systems were monitored during 2009 for microbiological, chemical, physical, and radiological constituents. There were no microbiological detections during the 2009 monitoring cycle, and all chemical concentrations in Hanford Site drinking water were well below the maximum contaminant levels established by EPA. Analytical results for 2009 radiological monitoring are summarized in Section 8.6. 


\subsection{Statutes Related to Natural and Cultural Resources}

This section provides information on federal statutes and assessments related to ecological and cultural resource compliance on the Hanford Site.

\subsubsection{Ecological Compliance}

\section{MR Sackschewsky}

DOE policies require that all Hanford Site projects with the potential to adversely affect biological resources have an ecological compliance review conducted before the project starts. Regulators use the review to determine if the project will comply with the Endangered Species Act of 1973, the Migratory Bird Treaty Act, and the Bald and Golden Eagle Protection Act, as well as Executive Orders 11988 (42 FR 26951) and 11990 (42 FR 26961). The review also addresses whether other significant resources such as Washington State-listed species of concern, wetlands, and native shrub-steppe habitats are adequately considered during the project planning process. Where adverse effects are identified, mitigation actions are prescribed. Mitigation actions can include avoidance, minimization, rectification, or compensation.

Because many projects occur during periods of the year when plants are not growing and are difficult to identify or evaluate, each of the operational areas (200-East, 200-West, $100-\mathrm{K}$, and 300 Areas) are surveyed each spring. All habitat areas within these areas are surveyed, and each building is inspected for nests of migratory birds. These baseline visual surveys provide information about habitat types and species inventories and abundances, which can be used throughout the year to assess potential impacts to resources. These data are also used to support ecological inventory and data requirements for ecological risk evaluations. Examples of the baseline survey maps are available at http://www.pnl.gov/ ecomon/compliance.asp. There were 286 reviews performed during 2009, including 164 ecological compliance reviews to support general Hanford Site activities, and 122 reviews for environmental restoration activities.

\subsubsection{Endangered Species Act of 1973}

Several protected species of plants and animals exist on the Hanford Site and along the Hanford Reach of the Columbia River. Steelhead trout (Oncorhynchus mykiss) and springrun Chinook salmon (Oncorhynchus tshawytscha) are listed under the Endangered Species Act of 1973 as either threatened or endangered (50 CFR 17, Subpart B) and occur onsite. DOE has a management plan in place for these species (DOE/RL-2000-27, Rev. 0). Other species on the Hanford Site are listed by the Washington Department of Fish and Wildlife as endangered, threatened, or sensitive (see Section 8.13).

\subsubsection{Migratory Bird Treaty Act}

The Migratory Bird Treaty Act prohibits taking or disturbing specified migratory birds or their feathers, eggs, or nests. Over 100 species of birds that regularly occur on the Hanford Site are protected by the Migratory Bird Treaty Act. All Hanford Site projects with a potential to affect federal or state-listed species of concern complied with the requirements of this Act by using the ecological compliance review process as described in the Hanford Site Biological Resources Management Plan (DOE/RL 96-32, Rev. 0). When applicable, ecological reviews produce recommendations to minimize adverse impacts to migratory birds, such as performing work outside of the nesting season and minimizing the loss of habitat. 


\subsubsection{Bald and Golden Eagle Protection Act}

The Bald and Golden Eagle Protection Act provides for the protection of the bald eagle and the golden eagle by prohibiting, except under certain specified conditions, the taking, possession, or commerce of such birds. A revised Bald Eagle Site Management Plan for the Hanford Site, South Central Washington was published in 2009 to direct Hanford Site activities in accordance with current federal and state regulations and guidelines (DOE/RL-94-150, Rev. 1). This management plan outlines seasonal access restrictions around documented nesting and communal roosting sites at the Hanford Site between November 15 and March 15, and establishes guidelines for the protection of perches, roosts, and alternative nest sites. When applicable, ecological reviews have produced recommendations to minimize adverse impacts to bald eagles including performing work outside of the winter season; staying out of established buffer areas; or entering buffer areas at mid-day, minimizing impacts by avoiding eagle roosting periods.

\subsubsection{Executive Orders 11988 and 11990}

Executive Order 11990, "Protection of Wetlands" (42 FR 26961), and Executive Order 11988, "Floodplain Management" (42 FR 26951), require federal agencies to minimize the loss or degradation of wetlands on federal lands, and account for floodplain management when developing water-and land-use plans, respectively. DOE implements the requirements of these two Executive Orders through 10 CFR 1022, "Compliance with Floodplain and Wetlands Environmental Review Requirements." It is DOE policy to 1) restore and preserve natural and beneficial values served by floodplains; 2) minimize the destruction, loss, or degradation of wetlands; and 3) preserve and enhance the natural and beneficial value of wetlands. On the Hanford Site, compliance with these Executive Orders, as well as the wetland provisions of the Clean Water Act are implemented through the ecological compliance review process in conjunction with the appropriate site Environmental Compliance Officers. The compliance process includes the identification, protection, and when necessary, mitigation of wetlands and floodplains on the Hanford Site.

\subsubsection{Cultural Resource Compliance}

\section{EP Kennedy}

DOE's policy is to comply with all cultural resource-related laws and regulations (DOE Policy 141.1). On the Hanford Site, cultural resources are subject to the provisions of laws, regulations, Executive Orders, and proclamations. Laws include the American Indian Religious Freedom Act; Antiquities Act of 1906; Archaeological and Historic Preservation Act of 1974; Archaeological Resources Protection Act of 1979; Historic Sites Act of 1935; National Environmental Policy Act of 1969; National Historic Preservation Act of 1966; and Native American Graves Protection and Repatriation Act of 1990. Regulations applicable to cultural resources include the following: 36 CFR 79, "Curation of Federally-Owned and Administered Archaeological Collections"; 36 CFR 65, "National Historic Landmarks Program"; 36 CFR 60, "National Register of Historic Places"; 36 CFR 63, "Determinations of Eligibility for Inclusion in the National Register of Historic Places"; 43 CFR 10, "Native American Graves Protection and Repatriation and Regulations"; 43 CFR 7, "Protection of Archaeological Resources"; and 36 CFR 800, "Protection of Historic Properties." Executive Orders include Executive Order 11593, "Protection and Enhancement of the Cultural Environment" (36 FR 8921); Executive Order 13007, "Indian Sacred Sites" (61 FR 26771); Executive Order 13287, "Preserve America" (68 FR 10635); and Presidential Proclamation 7319, "Establishment of the Hanford Reach National Monument” (65 FR 37253).

In 2009, two unauthorized excavation incidents occurred on the Hanford Site and were documented as Archaeological Resources Protection Act of 1979 violations.

See Section 8.15 for details regarding Hanford Site cultural resource programs. 


\title{
5.6 Other Environmental Statutes
}

\author{
JP Duncan
}

The Emergency Planning and Community Right-to-Know Act of 1986 requires federal, state, and local emergency planning authorities are informed regarding the presence and storage of hazardous substances, as well as planned or unplanned releases to the environment.

The Pollution Prevention Act of 1990 requires that pollution be prevented or reduced at the source whenever possible, and pollution that cannot be prevented be recycled or treated in an environmentally safe manner. The Hanford Site Pollution Prevention Program was created to address these requirements.

Recent legislation has imposed additional environmental protection orders intended to promote increased environmental protection and management at federal facilities. The establishment of responsibilities, requirements, and goals with respect to improved energy efficiency, pollution prevention, and sustainable practices for energy, the environment, and transportation at DOE facilities and other federal agencies are addressed in recent DOE and Presidential Executive Orders.

Information regarding these additional statutes is presented in the following sections.

\subsubsection{Emergency Planning and Community Right-to- Know Act of 1986}

\section{RE Johnson}

The Emergency Planning and Community Right-to-Know Act of 1986 requires each state to establish an emergency response commission and local emergency planning committees, and develop a process to distribute information on hazardous chemicals present in local facilities. These committees gather information and develop emergency plans for local planning districts. Personnel from facilities that produce, use, or store extremely hazardous substances in quantities above threshold planning quantities (quantities that trigger notifications to the state and local emergency response organizations) must identify their facilities to the state emergency response commission and the local emergency planning committee. Facility personnel must periodically provide information to support the emergency planning process. The threshold planning quantities are predetermined amounts established by state and local authorities. Facility personnel must also notify the state emergency response commission and local emergency planning committee immediately after an accidental release of any extremely hazardous substance (40 CFR 355, Appendices $\mathrm{A}$ and $\mathrm{B}$ ) over the reportable quantity. Two annual reports are required by the Emergency Planning and Community Right-to-Know Act of 1986: 1) a Tier Two Emergency and Hazardous Chemical Inventory, which contains information about hazardous chemicals stored at each facility in amounts exceeding minimum threshold levels; and 2) a Toxic Chemical Release Inventory, which contains information about total annual releases of certain toxic chemicals and associated waste management activities.

On February 24, 2010, Hanford Site officials issued the 2009 Hanford Site Tier Two Emergency and Hazardous Chemical Inventory report (DOE/RL-2010-19, Rev. 0) to the Washington State Department of Ecology's Community Right-To-Know Unit; local emergency planning committees for Benton, Franklin, and Grant Counties; and both the city of Richland and Hanford Site fire departments. The 2009 Hanford Site Toxic Chemical Release Inventory (DOE/RL-2010-21, Rev. 0), which includes releases and 
waste management activities involving the metal lead, naphthalene, and propylene, was submitted to the DOE Richland Operations Office on June 17, 2010, and was electronically transmitted to EPA and the Washington State Department of Ecology on June 24, 2010. Table 5.6.1 provides an overview of 2009 reporting under the Emergency Planning and Community Right-to-Know Act of 1986.
Types, quantities, and locations of hazardous chemicals are tracked through Chemical Management System requirements that are specific to prime contractors (Section 4.0.2). Table 5.6.2 summarizes the information reported and lists the average quantities of the 10 hazardous chemicals stored in greatest quantity on the Hanford Site in 2009.

Table 5.6.1. Emergency Planning and Community Right-to-Know Act of 1986
Compliance Reporting on the Hanford Site, 2009
302-303: Planning notification
304: Extremely hazardous substances release notification
311-312: Material safety data sheet/chemical inventory
313: Toxic chemical release inventory reporting
(a) "Yes" indicates that notifications were provided and/or reports were issued under the applicable provisions.
"No" indicates that notifications or reports should have been provided but were not. "Not Required" indicates
that no actions were required under the applicable provisions, either because releases were too small to require
action or no releases occurred.
(b) These notifications apply to the Hanford Site but were completed prior to 2009.

\section{Table 5.6.2. Average Quantity of the Ten Hazardous Chemicals ${ }^{(a)}$ Stored in Greatest Quantities on the Hanford Site, 2009}

\section{Hazardous Chemical}

Sodium

Mineral oil

Diesel fuel (grades 1 and 2)

Lead acid batteries

Portland cement

Fly ash (class F)

Propane

Gasoline

Petroleum distillates (unspecified)

Ethyl alcohol
Average

$1,240,000(2,730,000)$

$1,100,000(2,420,000)$

$383,000(842,000)$

$225,000(495,000)$

$165,000(362,000)$

$156,000(343,000)$

$144,000(317,000)$

$97,700(215,000)$

$82,700(182,000)$

$51,000(112,000)$ Quantity, kg (lb)

(a) Includes chemicals defined as hazardous under "Hazard Communication" (29 CFR 1910.1200(c)) .

\subsubsection{Pollution Prevention Program}

\section{DS Garrison}

The DOE Richland Operations Office is responsible for the Hanford Site Pollution Prevention Program and provides program implementation guidance to Hanford Site contractors. The Pollution Prevention Program reflects federal and DOE policies to reduce, reuse, and/or recycle wastes, as established by the Pollution Prevention Act of 1990.

DOE Order 450.1A, "Environmental Protection Program," established new pollution prevention and environmental stewardship goals that enhanced the pollution prevention and Environmental Management System provisions in DOE Order 450.1A, and Executive Order 13423, "Strengthening Federal Environmental, Energy, and Transportation Management" (72 FR 3917). These goals are implemented by Hanford Site contractors. 
In fiscal year 2009 , a total of 3,990 metric tons (4,400 tons) of sanitary and hazardous wastes were recycled through Hanford Site-wide programs administered through the Mission Support Contract (formerly the Project Hanford Management Contract) (Table 5.6.3). The Hanford Site Solid Waste Information Tracking System database indicates 197 cubic meters (6,960 cubic feet) of cleanup and stabilization waste (i.e., low-level, mixed low-level, transuranic, and mixed waste as defined by the Toxic Substances Control Act) was generated during fiscal year 2009 with 2.68 metric tons (2.95 tons) of non-radioactive hazardous and Toxic Substances Control Act cleanup and stabilization waste. Ninety-nine percent of information technology equipment (computers, laptops, and monitors) was within Electronic Products Environmental Assessment Tool classification of silver and gold categories and had Energy Star ${ }^{\circledR}$ power management features. In fiscal year 2009, approximately

\begin{tabular}{|c|c|}
\hline \multicolumn{2}{|c|}{$\begin{array}{l}\text { Table 5.6.3. Hanford Site Sanitary and } \\
\text { Hazardous Waste Recycled in } 2009\end{array}$} \\
\hline Waste & $\begin{array}{l}\text { Quantity, } \\
\text { metric tons (tons) }\end{array}$ \\
\hline \multicolumn{2}{|l|}{ Sanitary Waste } \\
\hline Appliances and furniture & $29.0(32.0)$ \\
\hline Ballasts & $1.27(1.4)$ \\
\hline Computers and electronics & $129(142)$ \\
\hline Used oil (engine, machinery) & $38.5(42.4)$ \\
\hline Iron and steel & $274(302)$ \\
\hline Office and mixed paper & $415(457)$ \\
\hline Corrugated cardboard & $7.45(8.21)$ \\
\hline Non-ferrous metal (copper) & $4.07(4.49)$ \\
\hline Stainless steel & $32.5(35.8)$ \\
\hline Software & $7.6(8.38)$ \\
\hline Tires & $15.5(17.1)$ \\
\hline Toner cartridges & $17.7(19.5)$ \\
\hline \multicolumn{2}{|l|}{ Hazardous Waste } \\
\hline Antifreeze & $431(475)$ \\
\hline Batteries & $17.5(19.3)$ \\
\hline Diesel fuel & $2,546^{(a)}$ \\
\hline Lamps & $2.28(2.51)$ \\
\hline PCB oil (b) & $26.1(28.8)$ \\
\hline Shop towels & $0.45(0.496)$ \\
\hline \multicolumn{2}{|c|}{$\begin{array}{l}\text { (a) } 699,953 \text { gallons. } \\
\text { (b) Less than } 50 \text { ppm PCB oil recycled for energy recovery. } \\
\text { PCB = Polychlorinated biphenyl. } \\
\text { ppm = Parts per million. }\end{array}$} \\
\hline
\end{tabular}

68 metric tons (75 tons) of electronic equipment was transferred or donated for reuse and 61 metric tons (67 tons) were sent for recycling.

\subsubsection{Recent Environmental Orders}

\section{AS Nagel and TG Beam}

The Hanford Site must comply with environmental protection orders including two recent DOE Orders and two Presidential Executive Orders.

Executive Order 13423 (72 FR 3917) established a policy for federal agencies to conduct legally, environmentally, economically, and fiscally sound environmental, transportation, and energy-related activities in an integrated, efficient, continuously improving, and sustainable manner. The Order set goals for the following areas: improved energy efficiency; reduced greenhouse gas emissions; use of renewable energy sources; renewable energy generation; reduced water consumption; acquisition of goods and services; reduced use of toxic and hazardous chemicals and materials; increased waste minimization, prevention and recycling; use of sustainable building practices; reduced use of petroleum products for vehicles; and electronics stewardship. In addition, Executive Order 13423 requires that an Environmental Management System be established as the mechanism for managing environmental goals, as well as other impacts to the environment from Hanford Site operations, and establishing environmental objectives and targets. The Order also requires establishment of environmental management training, environmental compliance review and auditing, and leadership awards to recognize outstanding environmental, energy, or transportation management performance.

Executive Order 13514, "Federal Leadership in Environmental, Energy and Economic Performance" (74 FR 52117), states that federal agencies "shall increase energy efficiency; measure, report, and reduce their greenhouse gas emissions from direct and indirect activities; conserve and protect water resources through efficiency, reuse, and stormwater management; eliminate waste, recycle, and prevent pollution; leverage agency acquisitions to foster markets for sustainable technologies and environmentally preferable 
materials, products, and services; design, construct, maintain, and operate high performance sustainable buildings in sustainable locations; strengthen the vitality and livability of the communities in which Federal facilities are located; and inform Federal employees about and involve them in the achievement of these goals." Requirements of this Order include establishment of targets for baseline Scope 1 (generated from site operations and activities) and Scope 2 (associated with the purchase of energy [electricity, heat, or steam] used by site contractors) greenhouse gas emissions, along with 2020 reduction targets, be established by January 2010. Similar numbers for Scope 3 (emissions associated with ancillary activities related to site operations, including business travel, employee commuting, vendor activities, delivery services, etc.) emissions will be established by June 2010. Executive Order 13514 also sets goals for the following areas: improved water use efficiency and management; promotion of pollution prevention and waste elimination; advancement of regional and local integrated planning; implementation of sustainable building lifecycle management practices; advancement of sustainable acquisition; and promotion of electronics stewardship. The Order also requires continued implementation of a formal sustainable Environmental Management System.

DOE Order 430.2B, "Departmental Energy, Renewable Energy and Transportation Management," provides requirements and responsibilities for managing energy, buildings, and vehicle fleets at all DOE facilities, laboratories, and sites. The Order implements the requirements of Executive Orders 13423 (72 FR 3917) and 13514 (74 FR 52117) including the establishment of an Environmental Management System that includes environmental, energy and transportation objectives and targets.

DOE Order 450.1A, "Environmental Protection Program," requires implementation of an Environmental Management System that is integrated into the Integrated Safety Management System and reflects the elements and framework found in the International Organization for Standardization's 14001:2004(E) International Standard (ISO 14001:2004(E)), Environmental Management Systems Requirements with Guidance for Use. The Order states that each Environmental Management System include policies, procedures and training to identify operations and activities with significant environmental impacts; to manage, control, and mitigate impacts; and to assess performance, implement corrective actions where needed, and to ensure continual environmental improvement. In addition, the Environmental Management System must address sustainable practices for enhancing environmental, energy, and transportation performance required by Executive Order 13423 (72 FR 3917) and DOE Order 430.2B; protecting public health and the environment; wildland fire protection; natural and cultural resource protection and stewardship; monitoring effluent and environmental data; providing quality analytical data; assessing engineered nanomaterials hazards; and identifying opportunities to implement sustainable practices.

Implementation of DOE and Executive Orders by Hanford Site contractors is addressed in Section 4.0.1.

Mission Support Alliance, LLC, as the services and infrastructure contractor for the Hanford Site, is in the process of developing a Hanford Site Executable Plan. The plan will describe the energy management program; identify planned energy efficiency, water conservation, transportation fleet management, and sustainable buildings activities; and include an Emergency Conservation Plan, as required by DOE Order 430.2B and Executive Order 13423 (72 FR 3917). Development of these environmental objectives is scheduled to be completed in 2010, as are updated or new plans for recycling, ozone-depleting substance management, environmentally preferred procurement management, and electronic asset stewardship. 


\title{
5.7 Environmental Occurrences
}

\author{
BG Fritz
}

Releases of radioactive and regulated materials to the environment are reported to DOE and other federal and state agencies as required by law. The specific agencies notified depend on the type, amount, and location of each release event. This section addresses releases or potential releases to the environment that may not be documented by other reporting mechanisms. All Hanford Site occurrences are reported to the Occurrence Notification Center and subsequently recorded in the Occurrence Reporting and Processing System. This system is a DOE electronic database that tracks occurrence reports across the DOE complex (DOE Manual 231.1-2). The following sections summarize occurrences that occurred in 2009 that may have impacted the Hanford Site environment. The occurrences are arranged according to significance category, which are assigned based on the nature and severity of the occurrence. The categories include Operational Emergency; Recurring; Category 1 (significant impact); Category 2 (moderate impact); Category 3 (minor impact); and Category 4 (some impact). In 2009, there were no Hanford Site environmental occurrences ranked as Operational Emergency, Recurring, Category 1, Category 2, or Category 3.

\section{Category 4 - Some Impact}

Category 4 occurrences are defined as having some impact on safe facility operations, worker or public safety and health, regulatory compliance, or public and business interests. Two Category 4 occurrences with potential environmental implications occurred on the Hanford Site in 2009 and are summarized below. Other discoveries of legacy contamination are also briefly summarized.

Radionuclide Discharge to Columbia River. In February 2009, analysis results for gross beta samples collected in January from the $1908-\mathrm{K}$ outfall were noted to be approximately 100 times greater than normal. These results prompted additional sampling and the February composite sample to be collected early (February 13). This sample had gross beta concentrations approximately 300 times greater than normal. While the water from this outfall discharges to the Columbia River, the concentrations measured did not require formal notification. However, EPA, the Washington State Department of Health, and the Washington State Department of Ecology were notified as a courtesy.

Brush Fires. Several small brush fires were reported in 2009. One occurred on June 22 southwest of the 300 Area. The cause of the fire was determined to be an ember from controlled burns conducted earlier that day. High winds up to 32.2 kilometers ( 20 miles) per hour during the afternoon resulted in the fire burning an estimated 23 hectares (57 acres). Another brush fire occurred on August 12 between the 100-KX Pump-and-Treat Facility and the Columbia River, burning 1.8 hectares ( 4.5 acres); the cause of the fire was unknown. On August 20, nine wild fires were started on the Hanford Site as a result of lightning strikes. These fires were identified and extinguished by the Hanford Fire Department. Two power poles were damaged by lightning strikes, resulting in power loss to several 200-East Area facilities for less than 1 hour as power was re-routed around the damaged poles.

Discovery of Legacy Contamination. Each year on the Hanford Site, legacy contamination is spread as a result of environmental conditions. Some of this contamination is discovered during routine survey work. Biological vectors also spread contamination; tumbleweeds, rabbits, and mud daubers (wasps) are all common biological vectors. Tumbleweeds have a deep taproot that can sequester contamination from below the soil surface into the plant body on the surface. Rabbits could eat vegetation located 
in contaminated areas, and then deposit contaminated feces outside of the contaminated area. Mud daubers build nests from mud and occasionally use mud from contaminated areas, resulting in the transfer of contamination to uncontaminated areas. Of these three biological vectors, contaminated tumbleweeds occur most frequently and have the potential to transfer contamination the farthest distance from their original locations. High winds may contribute to the spread of legacy contamination beyond posted areas. Reports of legacy contamination discovered throughout the year are consolidated into quarterly reports. In 2009, 81 occurrences of legacy contamination were documented. 


\subsection{References}

10 CFR 820. 2009. "Procedural Rules for DOE Nuclear Activities." Code of Federal Regulations, U.S. Department of Energy. Accessed May 17, 2010, at http://www.gpoaccess. gov/cfr/index.html.

10 CFR 830. 2009. "Nuclear Safety Management." Code of Federal Regulations, U.S. Department of Energy. Accessed May 17, 2010, at http://www.gpoaccess.gov/cfr/index.html.

10 CFR 835. 2009. "Occupational Radiation Protection." Code of Federal Regulations, U.S. Department of Energy. Accessed May 17, 2010, at http:/www.gpoaccess.gov/cfr/ index.html.

10 CFR 1021. 2009. "National Environmental Policy Act Implementing Procedures." Code of Federal Regulations, U.S. Department of Energy. Accessed May 17, 2010, at http://www.gpoaccess.gov/cfr/index.html.

10 CFR 1021.211. 2009. "National Environmental Policy Act Implementing Procedures: Interim Actions: Limitations on Actions During the NEPA Process." Code of Federal Regulations, U.S. Department of Energy. Accessed May 17, 2010, at http://www.gpoaccess.gov/cfr/index.html.

10 CFR 1021.311. 2009. "National Environmental Policy Act Implementing Procedures: Notice of Intent and Scoping." Code of Federal Regulations, U.S. Department of Energy. Accessed May 17, 2010, at http://www.gpoaccess. gov/cfr/index.html.

10 CFR 1021.314(c). 2009. "National Environmental Policy Act Implementing Procedures: Supplemental Environmental Impact Statements." Code of Federal Regulations, U.S. Department of Energy. Accessed May 17, 2010, at http://www.gpoaccess.gov/cfr/index.html.
10 CFR 1021.331. 2009. "National Environmental Policy Act Implementing Procedures: Mitigation Action Plans." Code of Federal Regulations, U.S. Department of Energy. Accessed May 17, 2010, at http://www.gpoaccess.gov/cfr/ index.html.

10 CFR 1021, Subpart D, Appendix A. 2009. "National Environmental Policy Act Implementing Procedures," Subpart D, Appendix A, "Typical Classes of Actions; Categorical Exclusions Applicable to Specific Agency Actions." Code of Federal Regulations, U.S. Department of Energy. Accessed May 17, 2010, at http://www.gpoaccess. gov/cfr/index.html.

10 CFR 1021, Subpart D, Appendix B. 2010. "National Environmental Policy Act Implementing Procedures." Subpart D, Appendix B, "Categorical Exclusions Applicable to Specific Agency Actions." Code of Federal Regulations, U.S. Department of Energy. Accessed May 17, 2010, at http://www.gpoaccess.gov/cfr/index.html.

10 CFR 1022. 2009. "Compliance with Floodplain and Wetlands Environmental Review Requirements." Code of Federal Regulations, U.S. Department of Energy. Accessed May 17, 2010, at http://www.gpoaccess.gov/cfr/index.html.

29 CFR 1910.1200(c). 2009. "Occupational Safety and Health Standards, Hazard Communication: Definitions." Code of Federal Regulations, U.S. Department of Labor. Accessed May 17, 2010, at http://www.gpoaccess.gov/cfr/ index.html.

36 CFR 60. 2009. "National Register of Historic Places." Code of Federal Regulations, U.S. National Park Service. Accessed May 17, 2010, at http://www.gpoaccess.gov/cfr/ index.html. 
36 CFR 63. 2009. "Determinations of Eligibility for Inclusion in the National Register of Historic Places." Code of Federal Regulations, U.S. National Park Service. Accessed May 17, 2010, at http://www.gpoaccess.gov/cfr/index.html.

36 CFR 65. 2009. "National Historic Landmarks Program." Code of Federal Regulations, U.S. National Park Service. Accessed May 17, 2010, at http://www.gpoaccess.gov/cfr/ index.html.

36 CFR 79. 2009. "Curation of Federally-Owned and Administered Archaeological Collections." Code of Federal Regulations, U.S. National Park Service. Accessed May 17, 2010, at http://www.gpoaccess.gov/cfr/index.html.

36 CFR 800. 2009. "Protection of Historic Properties." Code of Federal Regulations, Advisory Council on Historic Preservation. Accessed May 17, 2010, at http://www. gpoaccess.gov/cfr/index.html.

40 CFR 52. 2009. "Approval and Promulgation of Implementation Plans." Code of Federal Regulations, U.S. Environmental Protection Agency. Accessed May 17, 2010, at http://www.gpoaccess.gov/cfr/index.html.

40 CFR 60. 2009. "Standards of Performance for New Stationary Sources." Code of Federal Regulations, U.S. Environmental Protection Agency. Accessed May 17, 2010, at http://www.gpoaccess.gov/cfr/index.html.

40 CFR 61. 2009. "National Emission Standards for Hazardous Air Pollutants." Code of Federal Regulations, U.S. Environmental Protection Agency. Accessed May 17, 2010, at http://www.gpoaccess.gov/cfr/index.html.

40 CFR 61.92. 2009. "National Emission Standards for Hazardous Air Pollutants." Subpart H, "National Emission Standards for Emissions of Radionuclides Other Than Radon from Department of Energy Facilities." Part 92, "Standard." Code of Federal Regulations, U.S. Environmental Protection Agency. Accessed May 17, 2010, at http://www. gpoaccess.gov/cfr/index.html.

40 CFR 61, Subpart A. 2009. "National Emission Standards for Hazardous Air Pollutants." Subpart A, "General Provisions." Code of Federal Regulations, U.S. Environmental Protection Agency. Accessed May 17, 2010, at http://www. gpoaccess.gov/cfr/index.html.
40 CFR 61, Subpart H. 2009. "National Emission Standards for Hazardous Air Pollutants." Subpart H, "National Emission Standards for Emissions of Radionuclides Other Than Radon from Department of Energy Facilities." Code of Federal Regulations, U.S. Environmental Protection Agency. Accessed May 17, 2010, at http://www.gpoaccess.gov/cfr/ index.html.

40 CFR 61, Subpart M. 2009. "National Emission Standards for Hazardous Air Pollutants." Subpart M, "National Emission Standard for Asbestos." Code of Federal Regulations, U.S. Environmental Protection Agency. Accessed May 17, 2010, at http://www.gpoaccess.gov/cfr/index.html.

40 CFR 63. 2009. "National Emissions Standards for Hazardous Air Pollutants for Source Categories." Code of Federal Regulations, U.S. Environmental Protection Agency. Accessed May 17, 2010, at http://www.gpoaccess.gov/cfr/ index.html.

40 CFR 68. 2009. "Chemical Accident Prevention Provisions." Code of Federal Regulations, U.S. Environmental Protection Agency. Accessed May 17, 2010, at http://www. gpoaccess.gov/cfr/index.html.

40 CFR 70. 2009. "State Operating Permit Programs." Code of Federal Regulations, U.S. Environmental Protection Agency. Accessed May 17, 2010, at http://www.gpoaccess. gov/cfr/index.html.

40 CFR 82. 2009. "Protection of Stratospheric Ozone." Code of Federal Regulations, U.S. Environmental Protection Agency. Accessed May 17, 2010, at http://www.gpoaccess. gov/cfr/index.html.

40 CFR 122. 2009. "EPA Administered Permit Programs: The National Pollutant Discharge Elimination System." Code of Federal Regulations, U.S. Environmental Protection Agency. Accessed May 17, 2010, at http://www.gpoaccess. gov/cfr/index.html.

40 CFR 300. 2009. "National Oil and Hazardous Substances Pollution Contingency Plan." Code of Federal Regulations, U.S. Environmental Protection Agency. Accessed May 17, 2010, at http://www.gpoaccess.gov/cfr/index.html. 
40 CFR 302. 2009. "Designation, Reportable Quantities, and Notification." Code of Federal Regulations, U.S. Environmental Protection Agency. Accessed May 17, 2010, at http://www.gpoaccess.gov/cfr/index.html.

40 CFR 355, Appendices A and B. 2009. "Emergency Planning and Notification: The List of Extremely Hazardous Substances and Their Threshold Planning Quantities." Code of Federal Regulations, U.S. Environmental Protection Agency. Accessed May 17, 2010, at http://www.gpoaccess. gov/cfr/index.html.

40 CFR 761. 2009. "Polychlorinated Biphenyls (PCBs) Manufacturing, Processing, Distribution in Commerce, and Use Prohibitions." Code of Federal Regulations, U.S. Environmental Protection Agency. Accessed May 17, 2010, at http://www.gpoaccess.gov/cfr/index.html.

40 CFR 761.61(c). 2009. "Polychlorinated Biphenyls (PCBs) Manufacturing, Processing, Distribution in Commerce, and Use Prohibitions; PCB Remediation Waste: Risk-Based Disposal Approval." Code of Federal Regulations, U.S. Environmental Protection Agency. Accessed May 17, 2010, at http://www.gpoaccess.gov/cfr/index.html.

40 CFR 761.180. 2009. "Polychlorinated Biphenyls (PCBs) Manufacturing, Processing, Distribution in Commerce, and Use Prohibitions: Records and Monitoring." Code of Federal Regulations, U.S. Environmental Protection Agency. Accessed May 17, 2010, at http://www.gpoaccess.gov/cfr/ index.html.

40 CFR 1502.9(c). 2009. "Environmental Impact Statement: Draft, Final, and Supplemental Statements: Agencies." Code of Federal Regulations, Council on Environmental Quality. Accessed May 17, 2010, at http://www. gpoaccess.gov/cfr/index.html.

40 CFR 1506.1. 2009. "Other Requirements of NEPA: Limitations on Actions during NEPA Process." Code of Federal Regulations, Council on Environmental Quality. Accessed May 17, 2010, at http://www.gpoaccess.gov/cfr/ index.html.

40 CFR 1506.11. 2009. "Other Requirements of NEPA: Emergencies." Code of Federal Regulations, Council on Environmental Quality. Accessed May 17, 2010, at http:// www.gpoaccess.gov/cfr/index.html.
43 CFR 7. 2009. "Protection of Archaeological Resources." Code of Federal Regulations, U.S. Department of the Interior. Accessed May 17, 2010, at http://www.gpoaccess.gov/cfr/ index.html.

43 CFR 10. 2009. "Native American Graves Protection and Repatriation Regulations." Code of Federal Regulations, U.S. Department of the Interior. Accessed May 17, 2010, at http://www.gpoaccess.gov/cfr/index.html.

50 CFR 17, Subpart B. 2008. "Endangered and Threatened Wildlife and Plants." Subpart B, "Lists." Code of Federal Regulations, U.S. Fish and Wildlife Service and U.S. Department of the Interior. Accessed May 17, 2010, at http://www. gpoaccess.gov/cfr/index.html.

36 FR 8921. May 13, 1971. Executive Order 11593. "Protection and Enhancement of the Cultural Environment." Federal Register, Office of the President.

42 FR 26951. May 24, 1977. Executive Order 11988. "Floodplain Management." Federal Register, Office of the President.

42 FR 26961. May 24, 1977. Executive Order 11990. "Protection of Wetlands." Federal Register, Office of the President.

52 FR 2923. January 23, 1987. Executive Order 12580. "Superfund Implementation." Federal Register, Office of the President.

58 FR 25822. April 23, 1993. "Interim Mixed Waste Inventory Report: Waste Streams, Treatment Capacities and Technologies." Federal Register, U.S. Department of Energy.

61 FR 26771. May 29, 1996. Executive Order 13007. "Indian Sacred Sites." Federal Register, Office of the President.

63 FR 69390. December 16, 1998. "National Primary Drinking Water Regulations: Disinfectants and Disinfection Byproducts." Federal Register, U.S. Environmental Protection Agency. 
63 FR 69478. December 16, 1998. "National Primary Drinking Water Regulations: Interim Enhanced Surface Water Treatment." Federal Register, U.S. Environmental Protection Agency.

65 FR 37253. 2000. "Establishment of the Hanford Reach National Monument." Proclamation 7319 of June 9, 2000, by the President of the United States of America. Federal Register, Office of the President.

67 FR 1811. January 14, 2002. "National Primary Drinking Water Regulations: Long Term 1 Enhanced Surface Water Treatment Rule." Federal Register, U.S. Environmental Protection Agency.

68 FR 10635. March 5, 2003. Executive Order 13287. "Preserve America." Federal Register, Office of the President.

71 FR 387. January 4, 2006. "National Primary Drinking Water Regulations: Stage 2 Disinfectants and Disinfection Byproducts Rule." Federal Register, U.S. Environmental Protection Agency.

71 FR 653. January 5, 2006. "National Primary Drinking Water Regulations: Long Term 2 Enhanced Surface Water Treatment Rule; Final Rule.” Federal Register, U.S. Environmental Protection Agency.

71 FR 5655. February 2, 2006. "Notice of Intent to Prepare the Tank Closure and Waste Management Environmental Impact Statement for the Hanford Site, Richland, Washington." Federal Register, U.S. Department of Energy.

71 FR 65574. November 8, 2006. "National Primary Drinking Water Regulations: Ground Water Rule." Federal Register, U.S. Environmental Protection Agency.

72 FR 3917. January 26, 2007. Executive Order 13423. "Strengthening Federal Environmental, Energy, and Transportation Management." Federal Register, Office of the President.

73 FR 10962. January 24, 2007. Executive Order 13423, "Strengthening Federal Environmental, Energy, and Transportation Management." Federal Register, Office of the President.
74 FR 52117. October 5, 2009. Executive Order 13514 "Federal Leadership in Environmental, Energy, and Economic Performance." Federal Register, Office of the President.

74 FR 56194. October 30, 2009. "Environmental Impacts Statements; Motive of Availability." Federal Register, U.S. Environmental Protection Agency.

75 FR 1048. January 8, 2010. "Notice of Public Hearings on the Draft Tank Closure and Waste Management Environmental Impact Statement for the Hanford Site, Richland, WA." Federal Register, U.S. Department of Energy.

75 FR 3902. January 25, 2010. "Notice of Public Hearings on the Draft Tank Closure and Waste Management Environmental Impact Statement for the Hanford Site, Richland, WA." Federal Register, U.S. Department of Energy.

75 FR 13268. March 19, 2010. "Extension of the Public Comment Period for the Draft Tank Closure and Waste Management Environmental Impact Statement for the Hanford Site, Richland, WA." Federal Register, U.S. Environmental Protection Agency.

American Indian Religious Freedom Act. 1978. Public Law 95-341, as amended, 42 USC 1996 et seq.

American Recovery and Reinvestment Act of 2009. 2009. Public Law 111-5, as amended, 26 USC 1 et seq.

Antiquities Act of 1906. 1906. Ch. 3060, 34 Stat. 225, 16 USC 431 et seq.

Archaeological and Historic Preservation Act of 1974. 1974. Public Law 93-291, as amended, 16 USC 469 et seq.

Archaeological Resources Protection Act of 1979. 1979. Public Law 96-95, as amended, 16 USC 470aa et seq.

Atomic Energy Act of 1954. 1954. Chapter 724, 60 Stat. 755, 42 USC 2011 et seq.

Bald and Golden Eagle Protection Act. 1940. Public Law 87-884, as amended, 16 USC 688 et seq.

Comprehensive Environmental Response, Compensation, and Liability Act of 1980. 1980. Public Law 96-510, as amended, 42 USC 9601 et seq. Accessed May 17, 2010, at http:// www.epa.gov/lawsregs/laws/cercla.html. 
Clean Air Act. 1986. Public Law 88-206, as amended, 42 USC 7401 et seq.

Clean Air Act Amendments of 1990. 1990. Public Law 101-549, as amended, 42 USC 7401 et seq.

Clean Water Act of 1977. 1977. Public Law 95-217, as amended, 33 USC 1251 et seq.

DOE/EA-1660F. 2009. Environmental Assessment: Combined Community Communications Facility and Infrastructure Cleanup on the Fitzner/Eberhardt Arid Lands Ecology Reserve, Hanford Site, Richland, Washington. U.S. Department of Energy, Richland, Washington.

DOE/EA-1682. 2010. Environmental Assessment: Upgrades and Life Extension of the 242-A Evaporator, Hanford Site, Richland, Washington Conducted Under the American Recovery and Reinvestment Act of 2009. U.S. Department of Energy, Richland, Washington.

DOE/EIS-0286F. 2004. Final Hanford Site Solid (Radioactive and Hazardous) Waste Program Environmental Impact Statement, Richland, Washington. U.S. Department of Energy, Richland Operations Office, Richland, Washington.

DOE/EIS-0391. 2009. Draft Tank Farm Closure and Waste Management Environmental Impact Statement for the Hanford Site, Richland, Washington. U.S. Department of Energy, Washington, D.C.

DOE/EIS-0423D. 2010. Draft Long-Term Management and Storage of Elemental Mercury: Environmental Impact Statement. U.S. Department of Energy, Washington, D.C.

DOE-HDBK-1104-2009. 2009. Review and Approval of Nuclear Facility Safety Basis and Safety Design Basis Documents. U.S. Department of Energy, Washington, D.C.

DOE-HDBK-1122-2009. 2009. Radiological Control Technician Training. U.S. Department of Energy, Washington, D.C.

DOE-HDBK-1130-2008. 2008. Radiological Worker Training. U.S. Department of Energy, Washington, D.C.

DOE Manual 231.1-2. 2003. "Occurrence Reporting and Processing of Operations Information." Office of Environment, Safety and Health, U.S. Department of Energy, Washington, D.C.
DOE Notice 251.76. 2009. "Extension of DOE N 234.1, Reporting of Radioactive Sealed Sources." U.S. Department of Energy, Washington, D.C.

DOE Order 231.1A, Chg. 1. 2004. "Environment, Safety and Health Reporting." U.S. Department of Energy, Washington, D.C.

DOE Order 410.2. 2009. "Management of Nuclear Materials." U.S. Department of Energy, Washington, D.C.

DOE Order 430.2B. 2008. "Departmental Energy, Renewable Energy, and Transportation Management." U.S. Department of Energy, Washington, D.C.

DOE Order 435.1. 1999. "Radioactive Waste Management.” U.S. Department of Energy, Washington, D.C.

DOE Order 435.1, Chg 1. 2001. "Radioactive Waste Management.” U.S. Department of Energy, Washington, D.C.

DOE Order 440.1A. 2007. "Worker Protection Management for DOE Federal and Contractor Employees." U.S. Department of Energy, Washington, D.C.

DOE Order 450.1A. 2008. "Environmental Protection Program.” U.S. Department of Energy, Washington, D.C.

DOE Order 451.1B. 2000. "National Environmental Policy Act Compliance Program.” U.S. Department of Energy, Washington, D.C.

DOE Order 458.1, Draft. 2009. "Radiation Protection of the Public and Environment." U.S. Department of Energy, Washington, D.C.

DOE Order 462.1. 2008. "Import and Export of Category 1 and 2 Radioactive Sources and Aggregated Quantities." U.S. Department of Energy, Washington, D.C.

DOE Order 5400.5. 1990. "Radiation Protection of the Public and the Environment." U.S. Department of Energy, Washington, D.C.

DOE Order 5400.5, Chg 1. 1990. "Radiation Protection of the Public and the Environment." U.S. Department of Energy, Washington, D.C. 
DOE Order 5400.5, Chg 2. 1993. "Radiation Protection of the Public and the Environment." U.S. Department of Energy, Washington, D.C.

DOE Order 5820.2A. 1988. "Radioactive Waste Management.” U.S. Department of Energy, Washington, D.C.

DOE Policy 141.1. 2001. "Department of Energy Management of Cultural Resources." U.S. Department of Energy, Washington, D.C.

DOE/RL-94-150, Rev. 1. 2009. Bald Eagle Management Plan for the Hanford Site, South-Central Washington. U.S. Department of Energy, Richland Operations Office, Richland, Washington.

DOE/RL 96-32, Rev. 0. 2001. Hanford Site Biological Resources Management Plan. U.S. Department of Energy, Richland Operations Office, Richland, Washington.

DOE/RL-2000-27, Rev. 0. 2000. U.S. Department of Energy, Hanford Site Threatened and Endangered Species Management Plan: Salmon and Steelhead. U.S. Department of Energy, Richland Operations Office, Richland, Washington.

DOE/RL-2001-41, Rev 2. 2007. Sitewide Institutional Controls Plan for Hanford CERCLA Response Actions. U.S. Department of Energy, Richland Operations Office, Richland, Washington.

DOE/RL-2001-41, Rev 4. 2009. Sitewide Institutional Controls Plan for Hanford CERCLA Response Actions. U.S. Department of Energy, Richland Operations Office, Richland, Washington.

DOE/RL-2006-20, Rev 1. 2006. The Second CERCLA FiveYear Review Report for the Hanford Site. U.S. Department of Energy, Richland Operations Office, Richland, Washington.

DOE/RL-2009-04, Rev. 0. 2009. Hanford Site Air Operating Permit Semiannual Report for the Period January 1, 2009 through June 30, 2009. U.S. Department of Energy, Richland Operations Office, Richland, Washington.

DOE/RL-2009-27, Rev. 0. 2009. Calendar Year 2008 Hanford Site Mixed Waste Land Disposal Restrictions Summary Report. U.S. Department of Energy, Richland Operations Office, Richland, Washington.
DOE/RL-2009-50, Rev 0. 2009. 2008 Hanford Site Polychlorinated Biphenyl Annual Report. U.S. Department of Energy, Richland Operations Office, Richland, Washington.

DOE/RL-2009-51, Rev 0. 2009. 2008 Hanford Site Polychlorinated Biphenyl Annual Document Log. U.S. Department of Energy, Richland Operations Office, Richland, Washington.

DOE/RL-2010-01, Rev. 0. 2009. Hanford Site Air Operating Permit Semiannual Report for the Period July 1, 2009 through December 31, 2009. U.S. Department of Energy, Richland Operations Office, Richland, Washington.

DOE/RL-2010-02. 2010. Hanford Site Air Operating Permit Annual Compliance Certification Report for the Period January 1, 2009 through December 31, 2009. U.S. Department of Energy, Richland Operations Office, Richland, Washington.

DOE/RL-2010-11, Rev. 0. 2010. Hanford Site Groundwater Monitoring and Performance Report for Calendar Year 2009. U.S. Department of Energy, Richland Operations Office, Richland, Washington.

DOE/RL-2010-17. 2010. Radionuclide Air Emissions Report for the Hanford Site, Calendar Year 2009. U.S. Department of Energy, Richland Operations Office, Richland, Washington.

DOE/RL-2010-19, Rev. 0. 2010. 2009 Hanford Site Tier Two Emergency and Hazardous Chemical Inventory. U.S. Department of Energy, Richland Operations Office, Richland, Washington.

DOE/RL-2010-20, Rev. 0. 2010. Calendar Year 2009 Criteria and Toxic Air Pollutants Air Emissions Inventory. U.S. Department of Energy, Richland Operations Office, Richland, Washington.

DOE/RL-2010-21, Rev. 0. 2010. 2009 Hanford Site Toxic Chemical Release Inventory. U.S. Department of Energy, Richland Operations Office, Richland, Washington.

DOE-STD-1083-2009. 2009. Processing Exemptions to Nuclear Safety Rules and Approval of Alternative Methods for Documented Safety Analyses. U.S. Department of Energy, Washington, D.C. 
DOE-STD-1136-2009. 2009. Guide of Good Practices for Occupational Radiological Protection in Uranium Facilities. U.S. Department of Energy, Washington, D.C.

Ecology. 1994. Dangerous Waste Portion of the Resource Conservation and Recovery Act Permit for the Treatment, Storage, and Disposal of Dangerous Waste. Permit Number WA-7890008967, as amended. Washington State Department of Ecology, Olympia, Washington.

Ecology - Washington State Department of Ecology, U.S. Environmental Protection Agency, and U.S. Department of Energy. 1989. Hanford Federal Facility Agreement and Consent Order (Tri-Party Agreement). Document No. 89-10, as amended, Olympia, Washington. Accessed May 17, 2010, at http://www.hanford.gov/?page=81.

Ecology - Washington State Department of Ecology; U.S. Environmental Protection Agency, Region 10; U.S. Department of Energy, Richland Operations Office; and U.S. Department of Energy, Office of River Protection. 2000. Framework Agreement for Management of Polychlorinated Biphenyls (PCBs) in Hanford Tank Waste. Olympia, Washington.

Ecology - Washington State Department of Ecology, U.S. Environmental Protection Agency, and U.S. Department of Energy. 2009. Explanation of Significant Differences for the Interim Action Record of Decision for the 200-UP-1 Groundwater Operable Unit, Hanford Site, Benton County, Washington, February 2009. Accessed May 17, 2010, at http://www5.hanford.gov/pdw/fsd/AR/FSD0001/FSD0049/ 0903110450/[0903110450].pdf.

Emergency Planning and Community Right-to-Know Act of 1986. 1986. Public Law 99-499, as amended, 42 USC 11001 et seq.

Endangered Species Act of 1973. 1973. Public Law 93-205, as amended, 16 USC 1531 et seq.

EPA. 2001. USDOE Hanford Site First Five-Year Review Report. U.S. Environmental Protection Agency, Region 10, Hanford Project Office, Seattle, Washington.

Federal Facility Compliance Act of 1992. 1992. Public Law 102-386, as amended, 106 Stat. 1505 et seq.
Federal Insecticide, Fungicide, and Rodenticide Act. 1975. Public Laws 94-51, as amended, 7 USC 136 et seq.

Freedom of Information Act. 1966. Public Law 89-554, as amended, 5 USC 552 et seq.

Hazardous and Solid Waste Amendments of 1984. 1984. Public Law 98-616, as amended, 42 USC 6901 et seq.

HNF-EP-0863, Rev. 3. 2009. Management Plan for Recyclable Materials Administered by Hanford's Centralized Consolidation/ Recycling Center (CCRC). Mission Support Alliance, LLC, Richland, Washington.

Historic Sites Act of 1935. 1935. 49 Stat. 666, 16 USC 461 et seq.

ISO 14001:2004(E). 2004. Environmental Management Systems - Requirements with Guidance for Use. International Organization for Standardization, Geneva.

Migratory Bird Treaty Act. 1918. 40 Stat. 755, as amended, 16 USC 710.

National Environmental Policy Act of 1969. 1969. Public Law 91-190, as amended, 42 USC 4321 et seq.

National Historic Preservation Act of 1966. 1966. Public Law 89-665, as amended, 16 USC 470 et seq.

Native American Graves Protection and Repatriation Act of 1990. 1990. Public Law 101-601, as amended, 25 USC 3001 et seq.

Pollution Prevention Act of 1990. 1990. Public Law 101-508, as amended, 42 USC 13101 et seq.

Resource Conservation and Recovery Act of 1976. 1976. Public Law 94-580, as amended, 42 USC 6901 et seq. and 42 USC 6927(c) et seq. Accessed May 17, 2010, at http:// www.epa.gov/lawsregs/laws/rcra.html.

Safe Drinking Water Act of 1974. 1974. Public Law 93-523, as amended, 42 USC 201 et seq.

Safe Drinking Water Act Amendments of 1986. 1986. Public Law 99-339, as amended, 42 USC 201 et seq.

Safe Drinking Water Act Amendments of 1996. 1996. Public Law 104-182, as amended, 42 USC 201 et seq. 
Superfund Amendments and Reauthorization Act of 1986. 1986. Public Law 99-499, as amended, 42 USC 9601 et seq.

Toxic Substances Control Act. 1976. Public Law 94-469, as amended, 15 USC 2601 et seq.

WAC 16-228. 2007. "General Pesticide Rules." Washington Administrative Code, Olympia, Washington. Accessed May 17, 2010, at http://apps.leg.wa.gov/wac/.

WAC 173-216. 2006. "State Waste Discharge Permit Program." Washington Administrative Code, Olympia, Washington. Accessed May 17, 2010, at http://apps.leg.wa.gov/ wac/.

WAC 173-303. 2009. "Dangerous Waste Regulations." Washington Administrative Code, Olympia, Washington. Accessed May 17, 2010, at http://apps.leg.wa.gov/wac/.

WAC 173-304. 1988. "Minimum Functional Standards for Solid Waste Handling." Washington Administrative Code, Olympia, Washington. Accessed May 17, 2010, at http:// apps.leg.wa.gov/wac/.

WAC 173-303-145. 2007. "Dangerous Waste Regulations: Spills and Discharges into the Environment." Washington Administrative Code, Olympia, Washington. Accessed May 17, 2010, at http://apps.leg.wa.gov/wac/.

WAC 173-400. 2009. "General Regulations for Air Pollution Sources." Washington Administrative Code, Olympia, Washington. Accessed May 17, 2010, at http://apps.leg. wa.gov/wac/.

WAC 173-400-110. 2007. "General Regulations for Air Pollution Sources: New Source Review." Washington Administrative Code, Olympia, Washington. Accessed May 17, 2010, at http://apps.leg.wa.gov/wac/.

WAC 173-401. 2002. "Operating Permit Regulation." Washington Administrative Code, Olympia, Washington. Accessed May 17, 2010, at http://apps.leg.wa.gov/wac/.
WAC 173-425. 2000. "Outdoor Burning." Washington Administrative Code, Olympia, Washington. Accessed May 17, 2010, at http://apps.leg.wa.gov/wac/.

WAC 173-460. 1998. "Controls for New Sources of Toxic Air Pollutants." Washington Administrative Code, Olympia, Washington. Accessed May 17, 2010, at http:// apps.leg.wa.gov/wac/.

WAC 173-460-040. 1998. "New Source Review; Controls for New Sources of Toxic Air Pollutants." Washington Administrative Code, Olympia, Washington. Accessed May 17, 2010, at http://apps.leg.wa.gov/wac/.

WAC 173-480. 2007. "Ambient Air Quality Standards and Emission Limits for Radionuclides." Washington Administrative Code, Olympia, Washington. Accessed May 17, 2010, at http://apps.leg.wa.gov/wac/.

WAC 173-491. 2007. "Emission Standards and Controls for Sources Emitting Gasoline Vapors." Washington Administrative Code, Olympia, Washington. Accessed May 17, 2010, at http://apps.leg.wa.gov/wac/.

WAC 246-247. 2005. "Radiation Protection - Air Emissions." Washington Administrative Code, Olympia, Washington. Accessed May 17, 2010, at http://apps.leg. wa.gov/wac/.

Washington Clean Air Act. RCW 70.94, as amended. Revised Code of Washington, Olympia, Washington.

Washington Pesticide Application Act. RCW 17.21, as amended. Revised Code of Washington, Olympia, Washington.

Washington Pesticide Control Act. RCW 15.58, as amended. Revised Code of Washington, Olympia, Washington.

Washington State Department of Health. 2007. The Department of Energy Hanford Site Radioactive Air Emissions License \#FF-01. Washington State Department of Health, Olympia, Washington. 


\title{
6.0 Environmental Restoration and Waste Management
}

\author{
JP Duncan
}

Environmental cleanup, deactivation, and decommissioning activities continued on the Hanford Site during 2009. The following sections describe ongoing environmental restoration and mitigation, facility decommissioning activities, and waste management on the Hanford Site. This section also describes the status of underground waste storage tanks, construction of the Hanford Tank Waste Treatment and Immobilization Plant and its associated facilities, and research activities related to waste cleanup. 


\subsection{Hanford Site Cleanup and Remediation Activities}

The following sections describe ongoing cleanup and remediation activities on the Hanford Site.

\subsubsection{Waste Site Investigations and Remediation Activities on the Central Plateau}

\section{SS Lowe}

Remedial investigation/feasibility study activities continued during 2009 at Central Plateau waste sites. Work was performed within the characterization and regulatory framework defined in the 200 Areas Remedial Investigation/Feasibility Study Implementation Plan - Environmental Restoration Program (DOE/RL-98-28, Rev. 0). Work was performed at a number of operable unit groups, which were in various stages of the Comprehensive Environmental Response, Compensation, and Liability Act of 1980 (CERCLA) remedial investigation/ feasibility study process. The following summarizes activities performed in 2009.

200-CW-1 Operable Unit. The 200-CW-1 Operable Unit consists of former ponds and ditches located within the 200-East Area and north and east of the 200-East Area. The 200-CW-1 Operable Unit consists of waste sites that received cooling water from facilities such as the ReductionOxidation (REDOX) Plant, T Plant, Plutonium Uranium Extraction (PUREX) Plant, and B Plant. Supplemental remedial investigation activities were conducted during 2008, including using direct-push technology and borehole installation, and are being incorporated into Draft B of the feasibility study report (DOE/RL-2002-69, Draft A) and proposed plan (DOE/RL-2003-06, Draft A), currently in production. Both reports will be submitted to the Washington State Department of Ecology and the
U.S. Environmental Protection Agency (EPA) per the Hanford Federal Facility Agreement and Consent Order (also known as the Tri-Party Agreement [Ecology et al. 1989]) Interim Milestone M-015-38B, by November 30, 2011.

Tri-Party Agreement change number M-15-08-07 was approved by the U.S. Department of Energy (DOE), EPA, and the Washington State Department of Ecology in August 2009 to extend the due date of Milestone M-015-38B to November 30, 2010. The extension allows for the submission of a revised feasibility study report and revised proposed plan for the 200-CW-1 Operable Unit waste sites in the Central Plateau Outer Area to the Washington State Department of Ecology. This revised proposed plan may be used as a basis for a record of decision of the Central Plateau Outer Area. The Central Plateau Outer Area contains some waste sites included in the 200-MG-1, 200-MG-2, 200-IS-1, 200-UR-1, 200-CS-1, 200-SW-2, 100-IU-6, 200-UW-1, 200-CW-1, 200-CW-3, 200-MW-1, and 200-MW-2 Operable Units. Consolidation of these operable units into the Central Plateau Outer Area is described in the Central Plateau Cleanup Completion Strategy (DOE/RL-2009-81, Rev. 0).

200-CS-1 Operable Unit. The 200-CS-1 Operable Unit consists of waste sites that received sewer wastewater containing chemicals from major plant facilities in both the 200-West and 200-East Areas. A remedial investigation/ feasibility study work plan (DOE/RL-99-44, Rev. 0) was implemented in 2000 to characterize four representative waste sites of the operable unit: the 216-S-10 Pond, 216-S-10 Ditch, 216-B-63 Trench, and 216-A-29 Ditch. Drafts A and B of the feasibility study (DOE/RL-2005-63, Draft A; DOE/RL-2005-63, Draft B) and proposed plan (DOE/RL-2005-64, Draft A; DOE/RL-2005-64, Draft B) were submitted to the Washington State Department of 
Ecology and EPA in 2006 and 2007, respectively. Most of the waste sites in the 200-CS-1 Operable Unit are projected to be included in the Central Plateau Outer Area as discussed in DOE/RL-2009-81, Rev. 0.

200-CW-5 Operable Unit. The 200-CW-5 Operable Unit consists of waste sites that received cooling water and chemical sewer waste from facilities in the 200-West Area, including the Plutonium Finishing Plant and associated facilities. The remedial investigation included pipeline sampling, geophysical logging of shallow drive-point casings, and characterization drilling to the water table to determine vadose zone contamination. Primary contaminants of concern included strontium-90, cesium-137, americium-241, plutonium isotopes, nitrite, and polychlorinated biphenyls (PCBs). A feasibility study (DOE/RL-2004-24, Draft A) and proposed plan (DOE/RL-2004-26, Draft A) were issued to the Tri-Party Agreement agencies (Washington State Department of Ecology, EPA, and DOE) in October 2004 (Tri-Party Agreement Interim Milestone M-015-40C [Ecology et al. 1989]). Discussions among the Tri-Party Agreement agencies and CH2M HILL Plateau Remediation Company have determined that additional characterization information is not required at this operable unit. The Draft B feasibility study (DOE/RL-2004-24, Draft B) and proposed plan (DOE/RL-2004-26, Draft B) were submitted to EPA on July 30, 2008 (Tri-Party Agreement Interim Milestone M-015-40D [Ecology et al. 1989]). Draft C of the feasibility study will be submitted to the agencies in 2010. A combined proposed plan for the 200-CW-5 Operable Unit and the 200-PW-1, 200-PW-3, and 200-PW-6 Operable Units is scheduled for submittal to DOE, EPA, and Washington State Department of Ecology in 2010.

200-CW-3 Operable Unit. The 200-CW-3 Operable Unit consists of waste sites that received cooling water from fuel storage basins in the 200-North Area. The Remedial Design/ Remedial Action Work Plan for 200 North Area Waste Sites Located in the 200-CW-3 Operable Unit (DOE/RL-2007-55, Rev. 0) and the Sampling and Analysis Plan for Remediation of 200 North Area Waste Sites Located in the 200-CW-3 Operable Unit (DOE/RL-2007-54) were completed in 2008. Associated field sampling activities of the remaining waste sites occurred in 2009. Some waste sites in the 200-CW-3 Operable Unit are now included in the Central Plateau Outer Area.
200-SC-1 Operable Unit. Waste sites in the 200-SC-1 Operable Unit received steam condensate liquid decontamination wastes from 200-East and 200-West facilities, including the Reduction-Oxidation (REDOX) Plant, T Plant, and the Plutonium Uranium Extraction (PUREX) Plant. Supplemental characterization of the 216-A-30, 216-B-55, and 216-S-6 waste sites was completed in 2008 in accordance with the waste sites work plan (DOE/RL2007-02, Rev. 0). Characterization boreholes were drilled and soil samples obtained from the vadose zone for chemical and radiochemical analyses. Geophysical logging of the boreholes was also conducted. Primary contaminants of concern included tritium, strontium-90, cesium-137, plutonium isotopes, uranium, fluoride, and nitrate. A data quality assessment was performed in 2009 that determined the data are generally of sufficient quality and quantity to supplement existing data for use in development of a feasibility study and proposed plan (SGW-39742).

\section{0-TW-1, 200-TW-2, and 200-PW-5 Operable Units.}

The 200-TW-1 Operable Unit consists of waste sites (mostly cribs and trenches) that received waste associated with uranium recovery activities at the U Plant. The 200-TW-2 Operable Unit consists of waste sites (mostly cribs and trenches) that received waste from decontamination processes at the B Plant and T Plant. The 200-PW-5 Operable Unit waste sites received fission product-rich wastes that were generated during the fuel-rod enrichment cycle and released when the fuel elements were decladded or dissolved in sodium hydroxide or nitric acid. DOE approved a supplemental remedial investigation work plan (DOE/RL-2007-02, Rev. 0) to collect additional data required for decision making purposes regarding the 200-TW-1, 200-TW-2, and 200-PW-5 Operable Units. Supplemental data collection began in fiscal year 2008 with three direct-push boreholes at the 216-T-18 site, as well as borehole geophysical logging (HGLP-LDR-309). Additional supplemental characterization is planned for these operable units starting in 2011.

Two boreholes installed as part of the 200-BP-5 Operable Unit groundwater remedial investigation in the vicinity of the 216-B-43 Crib (200-TW-1 Operable Unit) included collection of vadose zone characterization data as specified in Table $\mathrm{C}-2$ of the site sampling field plans report (DOE/RL-2007-02, Rev. 0). The borehole summary report, issued in 2009, includes information on the vadose zone samples collected (SGW-39626). 
200-PW-1, 200-PW-3, and 200-PW-6 Operable Units.

The 200-PW-1 Operable Unit contains waste sites that received significant quantities of carbon tetrachloride and plutonium, as well as other contaminants associated with process waste from the Plutonium Finishing Plant. The 200-PW-3 Operable Unit waste sites received organic rich plutonium-uranium extraction process waste from the Plutonium Uranium Extraction (PUREX) Plant. The 200-PW-6 Operable Unit waste sites received plutoniumrich waste from the Plutonium Finishing Plant complex, but did not receive organic-rich wastes. This operable unit group also includes carbon tetrachloride in the vadose zone that has migrated beyond the waste site boundaries. The work plan for the plutonium/organic-rich operable unit group (200-PW-1, 200-PW-3, and 200-PW-6 Operable Units) was approved by the Tri-Party Agreement agencies in 2004 (DOE/RL-2001-01, Rev. 1), and remedial investigation field activities were completed in 2006. CERCLA remedial investigation of the 200-PW-1 Operable Unit was completed in 2007.

Data from these remedial investigation activities, as well as existing data, were included in Revision 0 of the remedial investigation report issued in September 2007 (DOE/RL2006-51, Rev. 0). These data were used to support the evaluation of remedial alternatives in the feasibility study for the 200-PW-1, 200-PW-3, and 200-PW-6 Operable Unit waste sites. Draft A of the feasibility study (DOE/RL2007-27, Draft A) and proposed plan (DOE/RL-2007-40, Draft A) were submitted to EPA in September 2007 in fulfillment of Tri-Party Agreement Interim Milestone M-015-45B (Ecology et al. 1989). The Draft B (reissue) of the feasibility study was submitted to EPA in March 2009 (DOE/RL-2007-27, Draft B) and Draft C of the feasibility study is in preparation for submittal to the Tri-Party Agreement agencies during 2010. A combined proposed plan for the 200-PW-1, 200-PW-3, and 200-PW-6 Operable Units and the 200-CW-5 Operable Unit will address all the waste sites collectively; Draft A is scheduled for submittal to the Tri-Party Agreement agencies during 2010.

200-PW-2 and 200-PW-4 Operable Units. Waste sites in the 200-PW-2 Operable Unit received uranium-rich condensate and process waste, primarily from waste streams generated at the U Plant, Reduction-Oxidation (REDOX) Plant, Plutonium Uranium Extraction (PUREX) Plant,
B Plant, and semi-works facilities. Waste sites in the 200-PW-4 Operable Unit received mostly process drainage, process distillate discharge, and miscellaneous condensates from the same facilities, including condensates from the S and A Tank Farms and 242-A Evaporator. Site-specific sampling and analysis plans associated with field activities conducted at the 216-S-1\&2 Crib and the 216-A-5 Crib were approved in 2008 and four direct-push boreholes (one at the 216-A-5 Crib and three at the 216-S-1\&2 Crib) and a deep vadose zone borehole at the 216-A-5 Crib were drilled (SGW-38991).

In fall 2009, installation of the new groundwater monitoring well 299-E24-25 (C7514 or "L" well) for the 200-BP-5 Groundwater Operable Unit began near waste site 216-C-1, located within the former hot semi-works area. Vadose zone soil is being sampled and analyzed in conjunction with the drilling of the $\mathrm{L}$ well to provide subsurface characterization data. These data will be used in the evaluation of the nature and extent of potential contaminants discharged to the 216-C-1 Crib.

200-LW-1 and 200-LW-2 Operable Units. Waste sites in the 200-LW-1 and 200-LW-2 Operable Units received liquid waste resulting from 300 Area process laboratory operations that supported radiochemistry metallurgical experiments. These waste sites also received liquid waste resulting mainly from laboratory operations on the Central Plateau that supported the major chemical processing facilities and equipment decontamination at T Plant.

In fall 2009, installation of a new groundwater monitoring well (C5860 or "K" well) was initiated for the 200-BP-5 Groundwater Operable Unit near the 216-B-6 reverse well, which is a 200-LW-2 Operable Unit soil waste site. Vadose zone soil is being sampled and analyzed in conjunction with the drilling of $\mathrm{K}$ well to provide subsurface characterization data. These data will be used to evaluate the nature and extent of potential contaminants discharged to the 216-B-6 reverse well.

200-MW-1 Operable Unit. Waste sites in the 200-MW-1 Operable Unit consist mainly of cribs, trenches, and reverse wells that received moderate- to low-volume equipment decontamination waste and ventilation system waste. The initial work plan for the 200-MW-1 Operable Unit was approved in 2002 (DOE/RL-2001-65, Rev. 0). The 
200-MW-1 Operable Unit later incorporated seven additional waste sites. Some 200-MW-1 waste sites are now included in the Central Plateau Outer Area.

Supplemental field investigations were completed at the 216-A-2, 216-A-4, and 216-A-21 Cribs and 200-E-102 Trench following a supplemental work plan (DOE/RL2007-02, Rev. 0). These characterization activities included subsurface geophysical logging and sediment and groundwater sampling (as applicable) at four shallow direct-push boreholes and two deep drilled boreholes at 200-MW-1 Operable Unit sites south of the Plutonium Uranium Extraction (PUREX) Plant. One borehole was completed as a new groundwater monitoring well near the 216-A-4 Crib (299-E24-23).

During 2009, the remedial investigation report summarizing and evaluating data collected at the 216-A-2, 216-A-4, and 216-A-21 Cribs and 200-E-102 Trench and feasibility study reports supporting remedial decision making for waste sites in the 200-MW-1 Operable Unit were combined into a single remedial investigation/feasibility study. The decisional draft was submitted to DOE in November 2009. During review, DOE requested that the risk assessment scenarios be modified to address the most recent risk assessment strategy. The Draft A report was completed in January 2010 (DOE/RL2008-38, Draft A), which met Tri-Party Agreement Interim Milestone M-015-44B .

200-SW-1 and 200-SW-2 Operable Units. The 200-SW-1 Operable Unit includes two non-radioactive landfills in the 600 Area: the Nonradioactive Dangerous Waste Landfill and the Solid Waste Landfill. These are now being managed as part of the Central Plateau Outer Area. The 200-SW-2 Operable Unit includes 25 landfills located in the 200-East and 200-West Areas. Initial non-intrusive (Phase I-A) field characterization, completed in fiscal year 2006, included geophysical investigation, passive organic-vapor sampling, radiation surveys, and additional historical information research (D\&D-28283). A remedial investigation/feasibility study work plan was finalized and approved by DOE and the Washington State Department of Ecology in December 2008 (DOE/RL-2004-60, Rev. 0). A portion of the Phase I-B remedial investigation scope (i.e., surface geophysics [SGW-43771] and passive organic vapor sampling [SGW-42563]) were completed in 2009.
200-IS-1 Operable Unit. The 200-IS-1 Operable Unit consists of pipelines, diversion boxes, catch tanks, and related structures used to transfer single-shell tank waste within and between the 200 Areas. These facilities are the responsibility of the tank operations contractor, Washington River Protection Solutions LLC, and the plateau remediation contractor, CH2M HILL Plateau Remediation Company. One pipeline in the 200-IS-1 Operable Unit is included in the Central Plateau Outer Area.

Five Resource Conservation and Recovery Act of 1976 (RCRA) treatment, storage, and disposal unit tanks managed by CH2M HILL Plateau Remediation Company are also included in this operable unit: 241-CX-70, 241-CX-71, 241-CX-72, 276-S-141, and 276-S-142. The 200-IS-1 Operable Unit Work Plan and Sampling and Analysis Plan (DOE/RL-2002-14, Rev. 1, Draft B) was approved in 2008 and implementation was initiated with borehole geophysical logging at 68 locations across the Central Plateau (SGW-39648). In addition, the 241-CX Tank System Closure Plan (DOE/RL-2008-51, Rev. 0) was submitted to the Washington State Department of Ecology on December 22, 2008, which met Tri-Party Agreement Milestone M-020-54 and closed out Milestones M-020-00 and M-020-00B (Ecology et al. 1989). The closure plan was approved and publicly released in August 2009 (DOE/ RL-2008-51, Rev. 0). Additional field work at the Gable Mountain pipeline (200-E-127 PL) is planned in 2010.

200-MG-1 and 200-MG-2 Operable Units. In 2005, EPA and the Washington State Department of Ecology identified a need for additional characterization for many of the Central Plateau waste sites that were being evaluated through the remedial investigation/feasibility study process. The Tri-Party Agreement agencies initiated a supplemental data quality objectives process to evaluate data needs, and to concur on a path forward for supplemental data collection that would augment the waste site database.

Through the supplemental characterization effort, the Model Group 1 waste site group was designated. Model Group 1 contained waste sites with shallow or readily addressed contamination; decision making for these waste sites was determined to be straightforward and supplemental data were not required (Ecology et al. 2006). This model group included 266 waste sites, which were assigned to two 
new operable units. Waste sites in Model Group 1, for which the Washington State Department of Ecology is the lead regulatory agency, are now included in the new 200-MG-1 Operable Unit (193 waste sites). Model Group 1 sites, for which EPA is the lead regulatory agency, are in the new 200-MG-2 Operable Unit (73 waste sites). Waste sites include unplanned releases, shallow leaks from pipelines or tanks, and contamination spread by burrowing wildlife.

In 2008, DOE determined that the 200-MG-1 and 200-MG-2 Operable Unit waste sites contain the potential to release CERCLA hazardous substances and that a nontime-critical removal action, pursuant to authority delegated under Executive Order 12580, "Superfund Implementation" (52 FR 2923) and Section 7.2.4 of the Hanford Federal Facility Agreement and Consent Order Action Plan (Ecology et al. 1989) is warranted to mitigate the threat of contaminant release.

In 2009, DOE issued two non-time-critical removal action engineering evaluation/cost analysis documents that address the disposition of contaminated soil and other materials from waste sites in the 200-MG-1 and 200-MG-2 Operable Units (DOE/RL-2008-44, Rev. 0 and DOE/RL-2008-45, Rev. 0, respectively). The engineering evaluation/cost analyses evaluated removal action alternatives for each site, including no action; confirmatory sampling/no action; removal, treatment, and disposal; and maintain existing soil cover/institutional controls/monitored natural attenuation. In 2009, DOE also issued two action memorandum documents for selected sites within the 200-MG-1 and 200-MG-2 Operable Units (DOE/RL-2009-48, Rev. 0 and DOE/RL2009-37, Rev. 0, respectively). The Removal Action Work Plan for the 11 Waste Sites in the 200-MG-1 Operable Unit was also issued in 2009 (DOE/RL-2009-53, Rev. 0). Removal action on eleven 200-MG-1 Operable Unit sites began in 2009.

200-UR-1 Operable Unit. The 200-UR-1 Operable Unit was re-evaluated during 2008, resulting in the removal of 21 sites from this operable unit. The sites were either rejected or consolidated into other operable units.

Two major sites within this operable unit have unique site conditions and occupy relatively large geographical areas. The BC Controlled Area, located south of the 200-East Area, encompasses a geographic area approximately equal to the 200-West and 200-East Areas combined (approximately 31 square kilometers [12 square miles]) and can be divided into two regions (Zone A and Zone B). The balance of the BC Controlled Area is largely uncontaminated, with the few minor contamination sites characterized as radiologically contaminated non-liquid media (i.e., windblown particulates, plant material, and/or animal waste) occupying a thin layer on the surface.

West Lake, the second major unplanned release waste site, is located approximately 2.9 kilometers ( 1.8 miles) north of the 200-East Area and includes an area of approximately 7.7 hectares (19 acres). West Lake is an intermittent pond located in a natural surface depression; water levels in the pond change in response to water-table fluctuations. Elevated levels of certain radionuclides have been detected in West Lake in the past and deposits of minerals can be seen around the pond's edge. In 2009, the West Lake sampling plan was updated (DOE/RL-2009-121, Draft A).

An aerial radiological survey was conducted of the BC Controlled Area and West Lake area in September 2009 to update previous surveys of these areas. The survey was performed from a helicopter using an Aerial Measuring System Radiation and Environmental Data Acquisition and Recorder, Version V, with an array of 12 detectors. Data were also geo-referenced using a differential global positioning system. Gamma energy spectra were collected every second during the survey and gross counts, inferred exposure rates, manmade activity, and cesium-138 and americium-241 activity, as calculated from the aerial data that were presented in the form of contoured isopleth maps superimposed on imagery of the surveyed areas. Gross count and exposure rate results were comparable to the 1996 survey results and several areas of surface contamination were tentatively identified (SGW-45563).

BC Cribs and Trenches Area. Three boreholes were drilled and sampled in 2008 to aid in the interpretation of the electrical resistivity characterization data (ground truth) in the BC Cribs and Trenches Area (200-BC-1 Operable Unit). A report was completed in June 2009 (PNNL-17821), concluding the following:

- Surface-based electrical resistivity characterization data were sufficient to indicate lateral and to some extent vertical distribution of mobile constituents. 
- Separate contaminant plumes exist for the cribs and trenches.

- Outside the facility footprint (lateral and vertical), the vadose sediments do not appear to contain chemical or radionuclide contaminants above background with the exception of nitrate, sodium, sulfate, and technetium-99.

An excavation-based treatability test initiated in 2007 at the 216-B-26 Trench was completed in 2009. The objective of the treatability test was to evaluate worker dose and remediation costs for the removal and disposal of the contaminated (primarily strontium-90 and cesium-137) surface soil. Work included excavation and soil sampling of one-third of the near-surface contamination from the 216-B-26 Trench, as well as further characterization of the 216-B-26 and 216-B-53A Trenches, and the 216-B-14 Crib using direct-push technology with borehole geophysical logging. A treatability test report was issued in December 2009 (DOE/RL-2009-36). The study concluded that the actual potential dose to workers was less than half that predicted in the focused feasibility study (DOE/RL-2004-66, Draft A), and that while the actual cost for excavation and characterization were higher than those predicted, the higher cost could be mitigated by process efficiencies. In October 2009, work began on the BC-1 Cribs and Trenches feasibility study, scheduled for completion in September 2010.

Preparations for a deep vadose zone treatability test began in 2008 following approval of the Deep Vadose Zone Treatability Test Plan for the Hanford Central Plateau (DOE/RL2007-56, Rev. 0). Initial testing will focus on soil desiccation (moisture extraction) as a potential remedy to protect groundwater from technetium-99 contamination. A soil desiccation pilot test will be conducted in the cribs region of the 200-BC-1 Cribs and Trenches Area to evaluate the dynamics of soil pore-water extraction and its impact on slowing contaminant transport using a combination of field work and laboratory experiments. Activities in 2009 focused on characterization of the pilot test site and the detailed test design; the pilot test will follow in 2010. Laboratory experiments performed in 2009 focused on gas-delivered reactants having the potential to immobilize uranium associated with pore water and concluded that ammonia injection into the vadose zone has the best potential to reduce the mobile uranium fraction.
Central Plateau Ecological Risk Assessment. Initiated in 2002, the Central Plateau Ecological Risk Assessment task was designed to evaluate the potential ecological risks associated with Central Plateau waste sites. A data evaluation report was initiated in 2002, with data quality objectives development and sample planning beginning in 2004. Sampling for Phases I and II was conducted in fiscal year 2005, focusing on background site characterization, a subset of waste sites, and the BC Controlled Area. Phase III data quality objectives development and sample planning activities were conducted in fiscal year 2006, along with associated sampling in the non-waste site areas around the 200-East and 200-West Areas. In November 2006, additional Phase III sampling was performed to fill data gaps observed in the Phase I and II characterization efforts and to supplement data collected from two reference sites located off the Hanford Site. Data from all phases were compiled and evaluated in the Central Plateau Terrestrial Ecological Risk Assessment report (DOE/RL-2007-50, Draft A, Reissue) published in 2008. In 2009, DOE began document revisions to incorporate comments from the regulatory agencies and to address the proposed Central Plateau Cleanup Completion Strategy. When completed, the Central Plateau ecological risk assessment report will support the remedial investigation/ feasibility study process for the Central Plateau.

\subsubsection{Cleanup and Remediation Activities in the 100 Areas}

This section describes ongoing cleanup and remediation activities in the 100 Areas.

\subsubsection{Remediation of Waste Sites in the 100 Areas}

\section{DG Saueressig}

Full-scale remediation of waste sites in the 100 Areas began in 1996. Figure 1.0.1 shows the 100 Areas former-reactor region along the Columbia River. Remediation activities in 2009 were performed in multiple locations in the 100 Areas, including the 100-B/C, 100-D, and 100-H Areas. Activities included sampling to determine if suspected waste sites exceeded cleanup objectives; sampling to confirm that cleanup objectives had been met; physical excavation 
operations; waste sorting and segregation; waste treatment; and waste disposal, backfill, and revegetation.

Waste sites vary in complexity and waste type. Typical waste sites include waste burial grounds, liquid effluent waste sites, burn pits, retired septic systems, piping systems, and miscellaneous waste sites. The primary focus early in the cleanup process was to address waste sites receiving liquid waste because those sites generally contained significant quantities of contaminants and served as potential sources for groundwater contamination.

In 2009, remediation activities focused on waste burial grounds and miscellaneous waste sites. Waste burial grounds require cleanup but also present a significant health and safety risk to workers due to incomplete disposal records and the potential for discovering unknown material from past disposal practices. For example, unknown materials or containers with no marking or labeling could be discovered during cleanup that would require further characterization. Characterization of unknown material is critical to ensure worker safety and the proper management of the waste for potential treatment and disposal. Discovery of an unknown material requires additional time and planning to ensure proper protective gear is used in the field when characterizing the material, and to verify that limits and controls identified in approved authorization documents required by DOE are adequate for the work scope. If authorization documents do not adequately cover the material discovered, work is stopped until documentation can be revised and work safely restarted. Based on characterization results, additional waste treatment may be required before disposal.

Miscellaneous waste sites vary in the nature and extent of contamination and are generally smaller-sized areas when compared to waste burial grounds. Sampling requirements for determining if a miscellaneous waste site requires cleanup or is in compliance with post-cleanup goals can vary significantly from one waste site to another.

The 100 Areas waste sites are authorized for remediation activities through records of decision approved by EPA, DOE, and the Washington State Department of Ecology. Waste generated from the cleanup of waste sites is disposed of at the Environmental Restoration Disposal Facility located in the 200 Areas. This centralized disposal facility is the primary disposal pathway, but other disposal options are available if the material does not meet the waste acceptance criteria for the facility.

During 2009, a total of 580,500 metric tons (639,900 tons) of contaminated soil from 100 Areas remediation activities were disposed at the Environmental Restoration Disposal Facility. Quantities and respective locations are as follows:

- 42,500 metric tons (46,900 tons) from the $100-\mathrm{B} / \mathrm{C}$ Area

- 200,000 metric tons (221,000 tons) from 100-H Area

- 338,000 metric tons (372,000 tons) from the 100-D Area.

\subsubsection{K Basins Closure Activities DJ Watson and BM Barnes}

CH2M HILL Plateau Remediation Company managed 100-K Area remediation activities during 2009 that included 1) facility demolition, 2) waste site remediation, 3) cleanout of the 105-K West Basin, and 4) groundwater pump-andtreat operations.

American Recovery and Reinvestment Act of 2009 funding made possible increased decontamination and demolition of structures within the $100-\mathrm{K}$ Area. One of the most significant accomplishments was demolition of the 105-K East Basin in September 2009. The entire structure, including the basins, were removed and disposed of at the Environmental Restoration Disposal Facility. The site where the 105-K East Basin was located is now undergoing active soil remediation. The 105-K West Basin and the Cold Vacuum Drying Facility are the only remaining operating nuclear facilities. The 105-K West Basin is undergoing cleanout that involves the removal of radioactive contaminated sludge and debris as a precursor to facility deactivation and demolition. For nearly 30 years, the basins stored 2,100 metric tons (2,300 tons) of Hanford Site N Reactor spent fuel and a small quantity of slightly irradiated single-pass reactor fuel (fuel from other Hanford Site reactors). The fuel was removed in a major cleanup effort that ended in October 2004.

Corrosion of the fuel during storage, as well as sludge generated during the fuel washing and packaging process, 
left behind approximately 28 cubic meters $(989$ cubic feet) of sludge. Sludge was segregated into four streams for subsequent removal and disposition: 1) K-East Basin floor and pit sludge, which was transferred to underwater storage containers in the K-West Basin; 2) K-West Basin floor and pit sludge, which is currently being stored in underwater storage containers in the K-West Basin; 3) K-West Basin knock-out-pot sludge, generated during the fuel washing and packaging process, and currently stored in underwater containers in the K-West Basin; and 4) settler tube sludge, also generated during the fuel washing and packaging process, currently stored underwater in the settler tubes in the K-West Basin.

Floor and pit sludge is a non-homogenous mixture of debris that includes windblown sand and environmental particulates; concrete fragments from the basin walls; corrosion products from fuel canisters and fuel racks; fuel cladding pieces; tiny pieces of corroded uranium (uranium oxides, hydrates, and hydrides); ion-exchange resin beads; PCBs; and fission products. Sludge has been defined as any material that is less than or equal to 0.64 centimeter ( 0.25 inch) in size. The means by which sludge will be treated, and at which national repository it will be disposed of, will be described in the project's CERCLA remedial design documentation. The K-West Basin fuel cleaning system transferred sludge to either knock-out pots or settler tanks. Knock-out pots collect particles greater than 500 microns ( 0.02 inch) in size by using either a downstream strainer or an internal screen. Settler tanks, a series of horizontal tubes downstream of the knock-out pots, allow particles less than 500 microns $(0.02$ inch) to settle out and not be re-circulated.

During 2009, the following lists progress and accomplishments in remediation of the 100-K Area:

- Completed a report in February 2009 delineating a Tentative Agreement on Hanford Federal Facility Agreement and Consent Order Modifications Regarding Accelerated Groundwater and Soils Milestones/FY 2009 Funding/ Waste Management/K Basins and Other Issue Solutions (Ecology et al. 2009). The report included associated changes in Tri-Party Agreement milestones and was submitted for public review and comment. Following the comment period, associated change packages were finalized and approved. The M-34 series milestones for remediation of the $\mathrm{K}$ Basins were deleted and the remaining work scope was moved to the M-16 series to promote integration with other $100-\mathrm{K}$ Area closure activities.

- Completed demolition of the 105-K East Basin structure. Building and basin debris was collected and shipped to the Environmental Restoration Disposal Facility for permanent disposal.

- Initiated efforts to characterize the 105-K East Reactor Core to facilitate eventual demolition of the facility.

- Completed hose-in-hose system removal activities. The hose-in-hose system was used to transfer sludge materials from the 105-K East Basin to the 105-K West Basin. The hose-in-hose system was disposed of at the Environmental Restoration Disposal Facility.

- Demolished and disposed of the following:

- 110-KE Gas Storage Facility

- 1706-KE, 1706-KEL, and 1706-KER above-grade structures

- 1713-KE warehouse

- 1714-KE oil and paint storage shed

- 118-KE-2 horizontal control rod storage cave

- 119-KE Exhaust Air Sampling Building.

- Completed RCRA closure of the 1706-K Waste Treatment System.

- Demolished and/or removed the following mobile office structures for reuse:

- MO-048

- MO-060

- MO-101

- MO-102

- MO-214

- MO-382

- MO-401

- MO-402

- MO-907

- MO-928

- MO-969. 
- Continued testing of systems and components at Hanford's Maintenance and Storage Facility in the 400 Area for deployment in the 105-K West Basin for sludge retrieval and handling (e.g., the system that will be used to retrieve and transfer settler tank sludge into underwater containers, and sludge retrieval and transfer from storage containers into shipping containers).

- Sampled sludge from underwater containers in the 105-K West Basin for laboratory analysis at Pacific Northwest National Laboratory to support design and waste management information needs. Analyses are in progress.

- Completed in-pool characterization of the knock-out pot sludge in the 105-K West Basin to support system designs to be used in its processing and removal for interim storage at Hanford's 200 Area as spent nuclear fuel.

- Completed an analysis of alternatives for the disposition of $\mathrm{K}$ Basin sludge. Disposition will occur in two phases: the first is removal from the basin and transfer to another Hanford Site facility for interim storage, and the second is treatment and packaging for disposal at a national repository.

- Increased groundwater pumping and treatment capacity.

\subsubsection{DOE Richland Operations Office Progress on Defense Nuclear Facilities Safety Board Recommendations Regarding K Basins \\ SM Hahn}

In a December 1, 2009 letter, ${ }^{(a)}$ the DOE Richland Operations Office revised the K-Basins Sludge Treatment Project commitment dates contained in the DOE Implementation Plan (DOE 2002) and its revision (DOE 2005) for stabilization of the nuclear materials identified in Defense Nuclear Facilities Safety Board Recommendation 2000-1 (DNFSB 2000). The implementation plan commitment date of November 2009 for completion of K Basins sludge treatment and packaging is being revised due to the technical complexity and characterization of the sludge material. The dates provided in the December 2009 letter are based on DOE's best estimate and will be validated in 2010 .

Removal and treatment of engineered container and settler tube sludge will be completed in two phases. The first phase involves removing the sludge from K-West Basin to T Plant, located on the Central Plateau, for interim storage. The second phase involves sludge treatment and packaging, and subsequent shipping to the appropriate facility for final disposal. An 18-month Phase II alternative analysis has been initiated to identify and develop treatment and packaging technologies.

Knock-out pot sludge will be processed in the K-West Basin. The coarse sludge will be separated from the finer sludge material, packaged into multi-canister overpacks, and transferred to the Canister Storage Building for interim storage, until it is disposed of with other spent nuclear fuel. The fine knock-out pot sludge material will be processed in the same manner as the engineered container and settler tube sludge, using the two-phase approach.

\subsubsection{Remediation of Waste Sites in the 300 Area}

\section{DE Faulk}

Full-scale remediation work began in the 300 Area in 1997, focusing on the 300-FF-1 Operable Unit waste sites. Remediation of the 300-FF-1 Operable Unit waste sites was completed in February 2004, including backfill and revegetation. Remediation efforts in 2009 focused on 300-FF-2 Operable Unit waste sites. The 300-FF-2 Operable Unit record of decision (EPA/ROD/R10-01-119) authorized remediation activities for the 300-FF-2 Operable Unit, which began in September 2002. Remediation activities included sampling to determine if suspected waste sites exceeded cleanup objectives; sampling to confirm that cleanup objectives were met; conducting physical excavation operations; sorting and segregating waste; sampling, treating, and disposing of waste; and backfilling and revegetating affected sites.

(a) Triay IR. 2009. Letter to The Honorable JE Mansfield (Defense Nuclear Facilities Safety Board, Washington, D.C.) from IR Triay (Assistance Secretary for Environmental Management, U.S. Department of Energy, Washington, D.C.), dated December 1, 2009. Accessed May 17, 2010, at http://www.hss.energy.gov/deprep/2009/TB09D01A.htm. 
Waste burial grounds require cleanup but also present a significant health and safety risk to workers as a result of incomplete waste-disposal records and the potential for discovering unknown material from past disposal practices. This unknown material may require further characterization. Characterization is critical to ensure worker safety and proper management of waste for potential treatment and disposal. Discovery of unknown material requires additional time and planning to ensure proper protective gear is used in the field when characterizing the material, and to verify that limits and controls identified in approved work authorization documents (as required by DOE) are adequate for the work scope. If work authorization documents do not adequately cover the material discovered, work is stopped until the documents can be revised and work can be safely restarted. Based on the characterization results, additional waste treatment may be required before disposal.

Waste generated from the cleanup of waste sites in the 300-F-2 Operable Unit is disposed of at the Environmental Restoration Disposal Facility (Section 6.3.3.4) located on the Central Plateau and other EPA-approved disposal facilities. More than 8,650 metric tons (95,300 tons) of contaminated soil from the 300-FF-2 Operable Unit was disposed at the Environmental Restoration Disposal Facility in 2009.

Remediation of the 618-1 Burial Ground continued throughout 2009 and is scheduled for completion in 2010. The 618-1 Burial Ground is located in the northern 300 Area and operated from 1945 to 1951 . Remediation of additional waste sites within the northern part of the 300 Area began in 2009 and is ongoing.
The 618-10 Burial Ground, located just west of Route 4 South, operated from 1954 to 1963 and is approximately 2.1 hectares (5.2 acres) in size. The 618-11 Burial Ground, located close to the Energy Northwest Columbia Generating Station in Richland, Washington, operated from 1962 to 1967 and is approximately 3.5 hectares ( 8.6 acres) in size. Both burial grounds received waste including transuranic material from the 300 Area laboratory facilities. The burial grounds consist of multiple trenches, vertical pipe units, and caissons.

Significant challenges for remediation are present at the 618-10 and 618-11 Burial Grounds. In August 2005, responsibility for remediating these two waste sites was transferred from Fluor Hanford, Inc. to Washington Closure Hanford, LLC. After the transfer, Washington Closure Hanford, LLC developed a design solution for the sites, evaluating waste removal and packaging technologies and disposal pathways to determine the most cost-effective methods, which was submitted to DOE on December 31, 2006. DOE evaluated the design solution and determined characterization was needed prior to proceeding with remediation. Washington Closure Hanford, LLC prepared a sampling and analysis plan in 2008 to address nonintrusive characterization of the 618-10 Burial Ground (DOE/RL-2008-27, Rev. 0). Non-intrusive characterization field activities began in 2009 and will conclude in 2010. Intrusive characterization of $618-10$ disposal trenches involving the construction of a series of test pits designed to investigate waste forms and validate planned remediation methods is scheduled for 2010. 


\subsection{Facility Deactivation and Decommissioning Activities}

This section provides information regarding the transition of Hanford Site facilities from stabilization to surveillance and maintenance, and eventual decommissioning. Decommissioning activities include the interim safe storage of plutonium production reactors; and deactivation and decommissioning facilities in the 100, 200, 300, and 400 Areas and ancillary reactor facilities.

\subsubsection{Facility Decommissioning on the Central Plateau}

This section provides information about the transition and decommissioning of Central Plateau facilities.

\subsubsection{Plutonium Finishing Plant WG Cox}

During 1949, the Plutonium Finishing Plant began processing plutonium nitrate solutions into metallic plutonium for shipment to nuclear weapons-production facilities. Operation of this plant continued into the late 1980s. In 1990, DOE issued a shutdown order for the Plutonium Finishing Plant and in 1996, authorized deactivation and transition of the plutonium-processing portions of the facility in preparation for decommissioning.

In 2004, Fluor Hanford, Inc. workers at the Plutonium Finishing Plant complex completed a large and multi-faceted effort to stabilize, immobilize, repackage, and/or properly dispose of nearly 18 metric tons (19.8 tons) of plutoniumbearing materials in the plant. Workers then focused on decontaminating and deactivating the processing facilities, while still providing for the safe and secure storage of nuclear materials until final disposition.
CH2M HILL Plateau Remediation Company achieved the following significant accomplishments at the Plutonium Finishing Plant during 2009:

- Completed de-inventory of all special nuclear materials and security downgrade

- Removed 45 gloveboxes and hoods from the process and laboratory areas of the 234-5Z Building

- Completed process equipment removal from the 236-Z Building 18.3-meter (60-foot) long first-floor west gallery glovebox

- Removed 360 cubic meters (12,700 cubic feet) of combustibles from the 234-5Z Building

- Dispositioned over 700 excess chemical items.

6.2.1.2 Surveillance, Maintenance, and Deactivation Activities on the Central Plateau and on the Fitzner/Eberhardt Arid Lands Ecology Reserve Unit

\section{GJ LeBaron}

Disposition of Central Plateau facilities includes the surveillance, maintenance, and deactivation of buildings and waste sites in the 200-East, 200-West, and 200-North Areas, and on the Fitzner/Eberhardt Arid Lands Ecology Reserve. Facilities include interim-status RCRA treatment, storage, and disposal units awaiting closure; the canyon facilities (Plutonium Uranium Extraction [PUREX] Plant, B Plant, Reduction-Oxidation [REDOX] Plant, and U Plant); three operating major air emission stacks; and two operating minor emission stacks. 
Surveillance, maintenance, and decontamination or stabilization of over 1,000 waste sites continued in 2009, including former waste disposal cribs, ponds, ditches, trenches, unplanned release sites, and waste burial grounds. Periodic surveillances, radiation surveys, and pesticide and herbicide applications were performed at these sites, as well as at buildings on the Fitzner/Eberhardt Arid Lands Ecology Reserve. Timely responses to identified problems were initiated. The overall objective was to maintain these sites in safe and stable conditions and prevent contaminants at these sites from spreading in the environment.

Facilities and waste sites are remediated as funding is available and in accordance with requirements and agreements with the regulatory agencies.

\subsubsection{Investigating the Potential for Using the 200 Areas Chemical} Separations Plants as Waste-Disposal Facilities

\section{CB Walker}

The Canyon Disposition Initiative was created to investigate the potential for using the five canyon buildings (B Plant, T Plant, U Plant, Plutonium Uranium Extraction [PUREX] Plant, and Reduction-Oxidation [REDOX] Plant) on the Hanford Site as disposal facilities for Hanford Site remediation waste, rather than demolishing the structures. The U Plant was selected as the pilot project for the Canyon Disposition Initiative. The remaining canyon buildings are to be addressed on a case-by-case basis, building on previous canyon disposition work.

Planning and sampling activities to support preparation of a CERCLA feasibility study for implementation of the Canyon Disposition Initiative at U Plant began in the mid-1990s. In December 2004, the Canyon Disposition Initiative (221-U Facility) final feasibility study (DOE/RL2001-11, Rev. 1) and the associated proposed plan (DOE/RL2001-29, Rev. 0) were released for public review. These documents examine seven alternatives for remediation of the 221-U Facility: 1) no action, 2) full removal and disposal, 3) decontaminate and leave in place, 4) entombment with internal waste disposal, 5) entombment with internal and external waste disposal, 6) close in place-standing structure, and 7) close in place-partially demolished structure. In fall 2005, the EPA issued the 221-U Facility (Canyon Disposition Initiative) record of decision (DOE et al. 2005), selecting the close in place-partially demolished structure alternative. In accordance with the record of decision, process equipment already in the plant will be consolidated into the belowground plant process cells; the cells, galleries, and other void spaces will be filled with grout; the exterior walls and roof will be collapsed in place; and the site will be covered with a barrier.

In December 2006, DOE issued the first draft of the Remedial Design/Remedial Action Work Plan for the 221-U Facility for review by the regulatory agencies; final approval was achieved in December 2008 (DOE/RL-2006-21, Draft B). A report summarizing some pertinent lessons learned from the 221-U Facility regulatory document process titled Project Experience Report, Canyon Disposition Initiative (221-U Facility) was completed in January 2009 (D\&D-35827).

Current plans do not include waste importation as part of U Plant remedial actions. While U Plant remediation is a prototype for the remaining canyon buildings, remedial action decisions will be reached independently for each of the remaining canyon buildings, taking into account each building's significant differences.

Implementation of the selected alternative for the 221-U Facility (close in place-partially demolished structure) began in 2009. Process equipment in the plant has been preliminarily targeted to specific belowground cells within the canyon structure for final disposition. Actual movement of equipment into the targeted cells has been initiated in accordance with the Remedial Design/Remedial Action Work Plan for the 221-U Facility (DOE/RL-2006-21, Draft B). To date, no waste importation options have been evaluated for the 221-U Facility.

\subsubsection{Decommissioning of 300 Area Facilities}

\section{CP Strand}

During 2009, deactivation, decontamination, decommissioning, and demolition activities in the 300 Area continued to focus on removing physical barriers to perform remedial 
actions in the 300-FF-2 Operable Unit. These activities were conducted as non-time-critical removal actions under CERCLA in accordance with Memorandum \#1 for the 300 Area Facilities (DOE and EPA 2005) and Memorandum \#3 for the 300 Area Facilities (DOE and EPA 2006b). Additionally, Memorandum \#2 for the 300 Area Facilities (DOE and EPA 2006a) was issued, which authorizes deactivation, decontamination, decommissioning, and demolition activities for the 324 and 327 Facility complexes.

The following 300 Area buildings and structures were demolished during 2009:

- 321 Cold Chemical Semi-Works Complex (321, 321B, 321C, and 321D)

- 323 Mechanical Properties Laboratory

- 332 Packaging Test Facility

- 335 Fast Reactor Thermal Engineering Facility

- 337 Boiler Annex.

Facility deactivation, characterization, and demolition planning is ongoing for many other buildings located in the 300 Area.

\subsubsection{Deactivation of 400 Area Facilities}

\section{LE Harville}

The Fast Flux Test Facility is a DOE-owned, formerly operating 400-megawatt (thermal) liquid-metal cooled (sodium) research and test reactor located at the 400 Area on the Hanford Site. Built in the late 1970s, the original purpose of the facility was to develop and test advanced fuels and materials for the Liquid Metal Fast Breeder Reactor Program, and to serve as a prototype facility for future Liquid Metal Fast Breeder Reactor Program facilities; other missions were subsequently pursued. The Fast Flux Test Facility operated from April 1982 to April 1992 and provided the nuclear industry with significant advances in fuel performance, medical isotope production, material performance, and passive and active safety systems testing. The reactor was placed in a standby mode in December 1993. After multiple studies, a final decision was made to complete facility deactivation, including removing all nuclear fuel, draining the sodium systems, and deactivating systems and equipment to place the facility in a low-cost, long-term surveillance and maintenance condition, which was completed in June 2009.

Two disposable solid waste casks were used to ship irradiated waste from the Interim Examination and Maintenance Cell to the Environmental Restoration Disposal Facility in March 2009. Since 2008, a total of three disposable solid waste casks have been used to ship irradiated waste for burial. Two empty casks remain in storage at the 400 Area Interim Storage Area.

The last PCB-laden transformer was removed and shipped for disposal in February 2009. Other deactivation activities during 2009 included the shutdown of operating systems (electric, fire suppression, water, ventilation, etc.) and cleanout and closure of the reactor containment building and supporting facilities, culminating in turnover to longterm, low-cost surveillance and maintenance. Three TriParty Agreement (Ecology et al. 1989) milestones were completed as part of these activities: Milestone M-8100A-T05, "Complete Auxiliary Plant Systems Shutdown" was completed on April 28, 2009; Milestone M-81-15, "Submit FFTF [Fast Flux Test Facility] Surveillance and Maintenance Plan" was completed on May 14, 2009; and Milestone M-81-00A, "Complete FFTF [Fast Flux Test Facility] Transition and Initiate Surveillance and Maintenance Phase" was completed on June 1, 2009.

Final decommissioning of the Fast Flux Test Facility depends on the outcome of the Draft Tank Farm Closure and Waste Management Environmental Impact Statement for the Hanford Site, Richland, Washington (DOE/EIS-0391). The resultant record of decision will determine the final end-state for the Fast Flux Test Facility.

\subsubsection{Decommissioning of Facilities in the 100 Areas}

\section{McCurley}

During 2009, 100 Areas deactivation, decontamination, decommissioning, and demolition activities focused on the 
100-N Area. These activities were conducted as non-timecritical removal actions under CERCLA. The following 100-N Area buildings were demolished during 2009:

- Various rooms (above and below grade) along the east and south sides of the 105-N/109-N Reactor Building Complex including the 109-N Turbine Bay Room, 105-N Control Room, 105-N Switch Gear Room, and 105-N Supply Fan Room

- 107-N Basin Recirculating/Cooling Building (above grade)

- 1310-N Radioactive Liquid and Waste Treatment Facility (above grade)

- 1706-N Lift Station

- 1112-N Document Control Building

- 1112-NA Microwave Tower.
Pre-demolition work began on the following facilities:

- 105-NE Fission Products Trap

- 117-N Exhaust Air Filter House

- 181-N River Pumphouse

- 1310-N Radioactive Liquid and Waste Treatment Facility - Silo

- 1902-D Water Tower.

In addition, safe storage enclosure preparations for the 105-N/109-N Reactor Building Complex continued through 2009. 


\subsection{Waste Management Operations}

This section provides information regarding liquid and solid waste management at the Hanford Site.

\subsubsection{Waste Classifications}

\section{WE Toebe and JO Skolrud}

Hanford Site cleanup operations result in the generation of solid wastes that must be evaluated for proper management. Solid wastes are reviewed against procedures in WAC 173-303-070(3) and are classified as dangerous when the criteria for this classification are met. The radionuclides in solid waste are exempt from evaluation under WAC 173-303-070(3), but are subject to evaluation and categorization as transuranic, high-level, or low-level under the Atomic Energy Act of 1954. Wastes that contain constituents regulated under both WAC 173-303 and the Atomic Energy Act of 1954 are classified as mixed wastes.

Radioactive and/or mixed wastes are currently managed in several ways. High-level waste is stored in large underground single- and double-shell tanks, or in capsules. Low-level waste is typically stored in either tanks or containers. The method used to store low-level waste depends on the source, composition, and waste concentration. Transuranic waste is stored in vaults or on above ground storage pads, or stored in a manner to allow its retrieval. A DOE annual report lists the dangerous and mixed wastes that are generated, treated, and disposed of onsite or shipped offsite (DOE/RL-2010-08, Rev. 0). Dangerous and mixed wastes are treated, stored, and prepared for disposal at several Hanford Site facilities. Dangerous waste generated at the site is also shipped offsite for treatment and/or disposal. Some types of dangerous waste, such as used lead-acid batteries and aerosol products (e.g., spray paint), are shipped offsite for recycling.
Waste that does not contain hazardous or radioactive substances is non-regulated waste. Non-regulated waste generated at the Hanford Site was historically disposed onsite. Beginning in 1999, non-regulated waste including refuse, asbestos-containing waste, and drummed non-hazardous waste has been disposed of at municipal or commercial solid waste disposal facilities. Since 1996, medical waste has been shipped to a commercial medical waste treatment and disposal facility. Non-regulated waste originates at several areas across the Hanford Site. Examples include construction debris, office trash, cafeteria waste, and packaging materials. Other materials and items classified as nondangerous waste are solidified filter backwash and sludge from the treatment of Columbia River water, failed and broken equipment and tools, air filters, uncontaminated used gloves and other clothing, and certain chemical precipitates (such as oxalates). Non-regulated demolition waste from 100 Areas decommissioning projects is buried in situ (in place) or in designated disposal locations on the Hanford Site.

\subsubsection{Solid Waste Inventories}

\section{$\mathrm{N}$ Weston}

The Solid Waste Information and Tracking System is a computer database used to track a portion of mixed and radioactive waste at the Hanford Site, primarily nonCERCLA containerized waste managed by CH2M HILL Plateau Remediation Company; Fluor Hanford, Inc. and subsequently Mission Support Alliance, LLC; and Washington River Protection Solutions LLC. The database does not include all waste from Washington Closure Hanford, LLC; the Environmental Restoration Disposal Facility; or any Pacific Northwest National Laboratory 
wastes. The database also does not include high-level radioactive waste volumes managed at Hanford Site tank farms.

Quantities for both mixed and radioactive wastes generated onsite or received from offsite sources and disposed of at the Hanford Site from 2005 through 2009, as tracked by the Solid Waste Information and Tracking System database, are shown in Tables 6.3.1 and 6.3.2. Quantities of dangerous waste shipped offsite from 2005 through 2009, as tracked by the database, are shown in Table 6.3.3. Hanford Site solid waste management is discussed in Section 6.3.3.

\subsubsection{Solid Waste Management}

Solid waste management includes the treatment, storage, and/or disposal of solid waste produced as a result of Hanford Site operations, or received from offsite sources authorized by DOE to ship waste to the site. These facilities are operated and maintained in accordance with state and federal regulations and facility permits. The following sections describe specific waste treatment, storage, or disposal locations at the Hanford Site.

\subsubsection{Central Waste Complex JF Ollero}

The Central Waste Complex, a solid waste storage facility located in the 200-West Area, receives waste from sources on the Hanford Site and offsite sources that are authorized by DOE to ship waste to the Hanford Site for treatment, storage, and disposal. The majority of wastes received at the Central Waste Complex are from ongoing cleanup, research, and development activities generated at the Hanford Site. Waste types stored include low-level, mixed low-level waste, transuranic waste, and radioactive waste contaminated with PCBs. The current volume of waste stored totals approximately 8,900 cubic meters ( 314,200 cubic feet).

The Central Waste Complex can store as much as 20,800 cubic meters $(735,000$ cubic feet $)$ of waste. This capacity is adequate to store the projected volumes of waste

\begin{tabular}{|lccccc|}
\hline \multicolumn{5}{|c|}{ Table 6.3.1. Quantities of Solid Waste ${ }^{\text {(a) }}$ Generated on the Hanford Site, $\mathbf{2 0 0 5}$} & Through 2009, kg (tons) \\
\hline Waste Category & $\underline{\mathbf{2 0 0 5}}$ & $\underline{\mathbf{2 0 0 6}}$ & $\underline{\mathbf{2 0 0 7}}$ & $\underline{\mathbf{2 0 0 8}}$ & $\underline{\mathbf{2 0 0 9}}$ \\
\hline Mixed & 349,000 & 315,000 & 235,000 & 314,000 & 255,000 \\
& $(385)$ & $(347)$ & $(259)$ & $(346)$ & $(281)$ \\
Radioactive & $1,190,000$ & 465,000 & 300,000 & 361,000 & 632,000 \\
& $(1,310)$ & $(513)$ & $(330)$ & $(398)$ & $(696)$ \\
& & & & \\
\hline (a) Solid waste includes containerized liquid waste. & & & \\
\hline
\end{tabular}

Table 6.3.2. Quantities of Solid Waste ${ }^{(a)}$ Received on the Hanford Site from Offsite Sources, 2005 Through 2009, $\mathrm{kg}$ (tons)

\begin{tabular}{|c|c|c|c|c|c|}
\hline \multirow[b]{2}{*}{ Waste Category } & \multicolumn{5}{|c|}{$\begin{array}{l}\text { Quantities of Solid Waste }{ }^{(a)} \text { Received on the Hanford Site from Offsite Sources, } \\
22005 \text { Through 2009, kg (tons) }\end{array}$} \\
\hline & $\underline{2005}$ & $\underline{2006}$ & 2007 & $\underline{2008}$ & 2009 \\
\hline Mixed $^{(\mathrm{b})}$ & $\begin{array}{l}190,000 \\
(209)\end{array}$ & $\begin{array}{l}152,000 \\
(168)\end{array}$ & $\begin{array}{l}177,000 \\
(195)\end{array}$ & $\begin{array}{l}416,000 \\
(459)\end{array}$ & $\begin{array}{l}233,000 \\
(257)\end{array}$ \\
\hline Radioactive $^{(\mathrm{b})}$ & $\begin{array}{l}83,100 \\
(92)\end{array}$ & $\begin{array}{l}71,200 \\
(79)\end{array}$ & $\begin{array}{c}168,000 \\
(185)\end{array}$ & $\begin{array}{l}404,000 \\
(445)\end{array}$ & $\begin{array}{l}178,000 \\
(196)\end{array}$ \\
\hline \multicolumn{6}{|c|}{$\begin{array}{l}\text { (a) Solid waste includes containerized liquid waste. Solid waste quantities do not include U.S. Navy reactor } \\
\text { compartments. } \\
\text { (b) Total includes Hanford Site-generated waste treated by an offsite contractor and returned as newly generated } \\
\text { waste. }\end{array}$} \\
\hline
\end{tabular}




\begin{tabular}{|c|c|c|c|c|c|}
\hline \multirow[b]{2}{*}{ Waste Category } & \multicolumn{4}{|c|}{$\begin{array}{l}\text { Quantities of Dangerous Waste }{ }^{(a)} \text { Shipped Off the Hanford Site, } \\
2005 \text { Through 2009, kg (tons) }\end{array}$} & \multirow[b]{2}{*}{$\underline{2009}$} \\
\hline & $\underline{2005}$ & $\underline{2006}$ & $\underline{2007}$ & $\underline{2008}$ & \\
\hline \multirow[t]{2}{*}{ Containerized } & $\begin{array}{l}71,600^{(b)} \\
(79)\end{array}$ & $\begin{array}{l}18,700^{(b)} \\
\quad(21)\end{array}$ & $\begin{array}{l}48,000^{(b)} \\
\quad(53)\end{array}$ & $\begin{array}{l}116,000^{(b)} \\
(128)\end{array}$ & $\begin{array}{l}42,800^{(\mathrm{b})} \\
(47)\end{array}$ \\
\hline & $\begin{array}{l}61,400^{(c)} \\
\quad(68)\end{array}$ & $\begin{array}{l}33,300^{(\mathrm{c})} \\
\quad(37)\end{array}$ & $\begin{array}{l}35,100^{(c)} \\
\quad(39)\end{array}$ & $\begin{array}{l}50,900^{(c)} \\
\quad(56)\end{array}$ & $\begin{array}{l}71,300^{(c)} \\
(79)\end{array}$ \\
\hline Bulk Solids - Total & 0 & 0 & 0 & 0 & $\begin{array}{c}74,800 \\
(83)\end{array}$ \\
\hline Dangerous & & & & & $\begin{array}{l}3,430 \\
(3.8)\end{array}$ \\
\hline Non-radioactive or dangerous & & & & & $\begin{array}{l}71,400 \\
(79)\end{array}$ \\
\hline Bulk Liquids - Total & $\begin{array}{l}49,200^{(d)} \\
\quad(54)\end{array}$ & $\begin{array}{c}917^{(\mathrm{d})} \\
(1)\end{array}$ & $\begin{array}{c}96,700^{(d)} \\
(107)\end{array}$ & $\begin{array}{c}201,000^{(\mathrm{d})} \\
\quad(221)\end{array}$ & $\begin{array}{c}2,050^{(\mathrm{d})} \\
(2)\end{array}$ \\
\hline Dangerous & & & $\begin{array}{c}14,300 \\
(16)\end{array}$ & $\begin{array}{c}51,900 \\
(57)\end{array}$ & $\begin{array}{c}2,050 \\
(2)\end{array}$ \\
\hline Non-radioactive or dangerous & & & $\begin{array}{c}82,400 \\
(91)\end{array}$ & $\begin{array}{c}149,000 \\
(164)\end{array}$ & $\begin{array}{l}0 \\
0\end{array}$ \\
\hline Total & $\begin{array}{c}182,0000 \\
(201)\end{array}$ & $\begin{array}{c}52,900 \\
(58)\end{array}$ & $\begin{array}{c}180,000 \\
(198)\end{array}$ & $\begin{array}{c}367,000 \\
(405)\end{array}$ & $\begin{array}{c}191,000 \\
(211)\end{array}$ \\
\hline \multicolumn{6}{|c|}{$\begin{array}{l}\text { (a) Does not include Toxic Substances Control Act waste. } \\
\text { (b) Dangerous waste only. } \\
\text { (c) Mixed waste (radioactive and dangerous). } \\
\text { (d) Bulk liquid classifications are not readily available prior to } 2007 .\end{array}$} \\
\hline
\end{tabular}

to be generated from the activities identified above, assuming on-schedule treatment and disposal of the stored waste.

An outdoor storage area was constructed in 2007 to store large containers of suspect transuranic waste from waste retrieval operations. The volume of waste currently stored in the outdoor expansion area is 2,900 cubic meters (102,800 cubic feet).

The Central Waste Complex is currently operating under RCRA interim status, while DOE and the Washington State Department of Ecology develop a final status permit.

\subsubsection{Waste Receiving and Processing Facility}

\section{PW Martin}

The Waste Receiving and Processing Facility began operating in 1997 with the mission to analyze, characterize, and prepare drums and boxes of low-level, mixed, and transuranic wastes for disposal. The 4,800 square-meter (52,000 square-foot) facility, along with two 2,000 squaremeter (21,500 square-foot) storage buildings, is located north of the Central Waste Complex on the Central Plateau.

Waste destined for the Waste Receiving and Processing Facility includes stored waste as well as newly generated waste from current Hanford Site cleanup activities. The waste consists primarily of contaminated cloth, paper, rubber, metal, and plastic (i.e., debris). Processed waste that qualifies as low-level radioactive waste and meets disposal requirements is buried at the Hanford Site. Low-level radioactive waste not meeting burial requirements is processed at the Waste Receiving and Processing Facility for onsite burial or prepared for future treatment at other onsite or offsite treatment, storage, and disposal facilities. Waste determined at the facility to be transuranic is certified and packaged for 
shipment to the Waste Isolation Pilot Plant in Carlsbad, New Mexico, for permanent disposal. Other waste materials requiring further processing to meet disposal criteria are retained pending treatment.

In 2009, the Waste Receiving and Processing Facility dispositioned and shipped 164 cubic meters (5,800 cubic feet) of mixed waste offsite for treatment. The treated waste was then returned to the Hanford Site for disposal. There were no shipments of transuranic waste to the Waste Isolation Pilot Plant in 2009.

\subsubsection{T Plant Complex JF Ollero}

The T Plant Complex, located in the 200-West Area, provides solid waste treatment, storage, and decontamination services for the Hanford Site, as well as for offsite facilities. The following activities occurred at the T Plant Complex during 2009:

- Numerous containers and boxes of waste were sampled, characterized, treated, and repackaged to meet waste acceptance criteria and land disposal restrictions requirements.

- Nine hundred and forty-nine 208-liter containers (55-gallon drum equivalents) of transuranic waste were repackaged to meet offsite waste acceptance criteria and eventual disposal at the Waste Isolation Pilot Plant in Carlsbad, New Mexico.

- Eight hundred and eighty-two empty waste containers were crushed by a super-compactor located in the 221-T Canyon, conserving landfill space in onsite disposal units.

The T Plant Complex is currently operating under RCRA interim status. Drafting of the T Plant RCRA Part B permit application for final status began in June 2008. Review, approval, and issuance by the Washington State Department of Ecology are expected in 2010.

\subsubsection{Environmental Restoration Disposal Facility}

\section{MA Casbon}

The Environmental Restoration Disposal Facility is located near the 200-West Area. The facility began operations in July 1996 and serves as the central disposal site for contaminated waste removed during Hanford Site cleanup operations conducted under CERCLA regulations. To provide a barrier to prevent contaminant migration from the in-ground facility, the Environmental Restoration Disposal Facility was constructed to RCRA Subtitle C minimum technology requirements, which include a double liner and leachate collection system (40 CFR 264.301). Remediation waste disposed in the facility includes soil, rubble, or other solid waste materials contaminated with hazardous, low-level radioactive, or mixed (combined hazardous and radioactive) low-level waste.

There are currently eight waste cells within the Environmental Restoration Disposal Facility. Construction of cells 1 and 2 was completed in 1996 and waste placement in these cells is complete. An interim cover has been placed over cells 1 and 2. Cells 3 and 4, constructed while cells 1 and 2 were being filled, have also reached their operational capacity and cells 5 and 6 are nearing capacity. Construction of cells 7 and 8 was completed in 2009; these two cells have been receiving waste since June 2009. All eight cells are roughly equal in size, each holding approximately 1.27 metric tons (1.4 million tons) or approximately 0.61 million cubic meter ( 0.8 million cubic yard). Two additional cells are being constructed. The new "super" cells are each the size of two conventional cells, making the two under construction equivalent to four conventional cells. These are scheduled for completion in 2011 and will expand capacity to 14.9 metric tons (16.4 million tons).

In 2009 , approximately 844,000 metric tons (930,000 tons) of remediation waste were disposed at the facility. Approximately 8 million metric tons ( 9 million tons) of remediation waste have been placed in the Environmental Restoration Disposal Facility from initial operations start-up through 2009. The total available expansion area of the Environmental Restoration Disposal Facility site was authorized in a 1995 record of decision (EPA/ROD/R10-95/100) to cover as much as 4.1 square kilometers (1.6 square miles).

\subsubsection{Low-Level Burial Grounds LC Petersen, JF Ollero, and DE Nester}

The low-level burial grounds consist of eight separate burial grounds; two in the 200-East Area and six in the 200-West 
Area. They are regulated under the Atomic Energy Act of 1954. Trenches that contain mixed low-level waste are also regulated under RCRA. Two of the burial grounds are presently being used for the disposal of low-level waste and mixed waste (i.e., low-level radioactive waste with a dangerous waste component regulated by WAC 173-303). The first is designated as low-level waste burial ground 218-W-5, which is located in the 200-West Area and contains Trenches 31 and 34. The second, located in the 200-East Area, is low-level burial ground 218-E-12B, which includes Trench 94. This trench is dedicated for the disposal of defueled U.S. Navy reactor compartments (Section 6.3.3.7). Five of the burial grounds in the 200-West Area were previously used for disposal of low-level waste and/or retrievable storage of transuranic waste, as well as portions of the 218-E-12B Burial Ground. The 218-W-6 Burial Ground has never received waste.

The low-level burial grounds have been under a RCRA Part A interim status permit since 1985. A draft revision to the subsequent RCRA Part B final permit application for the low-level burial grounds was submitted to the Washington State Department of Ecology in June 2002. Discussions between DOE and the Washington State Department of Ecology concerning the Part B permit application are ongoing. In addition, the low-level burial grounds are included in the 200-SW-1 Nonradioactive Landfills and Dumps Group Operable Unit and 200-SW-2 Radioactive Landfills and Dumps Group Operable Units Remedial Investigation/ Feasibility Study Work Plan (DOE/RL-2004-60, Rev. 0). The plan outlines proposed characterization and remediation activities for specified burial grounds in the 200-East and 200-West Areas.

On June 23, 2004, DOE issued a record of decision (69 FR 39449-39456) for the Solid Waste Program on the Hanford Site. Part of the record of decision stated that DOE will dispose of low-level waste in lined disposal facilities. Disposal of U.S. Navy reactor compartments in Trench 94 was not affected by this record of decision.

While some of the low-level burial grounds contain only low-level waste and mixed low-level waste, suspect transuranic waste had previously been placed in retrievable storage in four of these burial grounds. Since August 19, 1987, no transuranic waste has been placed in the low-level burial grounds without specific DOE approval.
Retrieval of suspect transuranic retrievably stored waste in the 218-W-4C Burial Ground was initiated in October 2003 in accordance with the Tri-Party Agreement (Change Number M-91-03-01 [Ecology et al. 1989]), and removal of waste from trenches in this burial ground was completed in May 2008. Retrieval of suspect transuranic retrievably stored waste in the 218-W-4B Burial Ground was initiated in January 2007. Retrieval of suspect transuranic retrievably stored waste in the 218-W-3A Burial Ground was initiated in August 2007. Retrieval of suspect transuranic retrievably stored waste in the 218-W-4B and 218-W-3A Burial Grounds continues in accordance with Tri-Party Agreement Milestone M-91-40 (Ecology et al. 1989).

In 2009, 675 cubic meters (23,000 cubic feet) of retrievably stored waste were retrieved from the low-level burial grounds. Preparations began in 2009 for removal of retrievably stored suspect transuranic waste from the 218-E-12B Burial Ground, using the next-generation retrieval approach. With this approach, venting, assaying, nondestructive examination, and processing of retrieved containers are performed closer to the retrieval location. This approach reduces the number of waste transfers and waste handling necessary for processing in preparation for certification and transport to the Waste Isolation Pilot Plant.

\section{Low-Level Waste Burial Ground 218-W-5, Trenches 31}

and 34. Trenches 31 and 34 are rectangular landfills with approximate base dimensions of 76 by 30 meters ( 250 by 100 feet). The floor of the excavation slopes slightly (nominally 1:3), giving a variable depth of 9 to 12 meters (30 to 40 feet). These trenches comply with Washington Administrative Code requirements for double liners and leachate removal/collection systems. The floor and sides of the trenches are covered with a layer of soil 1 meter (3.3 feet) deep to protect the liner system during landfill operations. There is a recessed section at the end of each excavation that houses a sump for leachate collection. Vehicle access to the bottom of each trench is provided by ramps along the perimeter walls.

These lined disposal units were originally designated for disposal of mixed low-level waste only. On June 23, 2004, disposal of low-level waste in the unlined trenches on the Hanford Site ceased. Since that date, Trenches 31 and 34 
have accepted low-level waste and mixed low-level wastes for disposal. Disposal in Trench 31 began in May 2005 and disposal in Trench 34 began in September 1999.

In 2009, a total of 1,000 cubic meters (35,500 cubic feet) of waste was disposed in Trenches 31 and 34. In Trench 34, there are approximately 5,140 cubic meters $(181,000$ cubic feet) of disposed waste in 5,226 waste packages. During summer 2004, the first operational layer of waste packages was covered with compacted gravel and soil, and the second waste layer was initiated. At the end of 2009, Trench 34 was filled to approximately $80 \%$ capacity. There are approximately 3,150 cubic meters (111,000 cubic feet) of waste disposed in 2,438 waste packages in Trench 31. During summer 2009, the first operational layer of waste packages was covered with compacted gravel and soil, and the second waste layer was started. Trench 31 is filled to approximately $20 \%$ capacity.

Treatment of legacy mixed low-level waste continued at the Hanford Site during 2009. Treatment of the majority of wastes occurred offsite and following treatment, the waste was returned to the Hanford Site for disposal in Trenches 31 and 34. A small volume of treated wastes was disposed of at an offsite commercial disposal unit. On a pretreatment volume basis, 1,270 cubic meters ( 44,700 cubic feet) of waste was treated prior to disposal.

In 2009, treatment of mixed wastes at offsite commercial waste processors completed the following Tri-Party Agreement milestones:

- Milestone M-091-42(f) - Complete treatment of 7,600 cubic meters (268,000 cubic feet) of small package contact-handled mixed low-level waste; met on August 22, 2009 (Ecology et al. 1989)

- Milestone M-091-43(d) - Complete treatment of 600 cubic meters (21,200 cubic feet) of large package and/or remote-handled mixed low-level waste; met on August 31, 2009 (Ecology et al. 1989).

\subsubsection{Waste Encapsulation and Storage Facility}

\section{FM Simmons}

The Waste Encapsulation and Storage Facility, located in the 200-East Area, was constructed in 1970-1971 on the west end of B Plant and became operational in 1974. The mission of the Waste Encapsulation and Storage Facility was encapsulation and storage of cesium chloride and strontium fluoride salts that had been separated from the Hanford Site's high-level radioactive tank waste. The facility is a two-story, 1,860 square-meter (20,000 square-foot) building, 48 meters ( 157 feet) long and 12 meters ( 40 feet) high, constructed of steel reinforced concrete and partitioned into seven hot cells, a hot cell service area, operating areas, building service areas, and a pool cell area. The hot cells are labeled A through $G$ and activities within the hot cells are performed remotely using manipulators. Waste and drum load out can be performed in hot cell A. Hot cells B through $\mathrm{E}$ have been placed in cold standby status. Only hot cells $F$ and $G$ remain active for cesium and strontium capsule storage. The operating areas and other building service areas associated with the hot cells provide areas for instrumentation monitoring, utility support, or manipulator repair as required.

The Waste Encapsulation and Storage Facility currently stores strontium and cesium encapsulated salts in double containment stainless-steel capsules in underwater pool cells, providing safe storage. The water provides cooling and shielding for the capsules that are considered sealed sources. As a storage-only unit, the facility does not currently generate regulated wastes.

\section{DOE Richland Operations Office Progress on Defense Nuclear Facilities Safety Board Recommendations Regarding the Waste Encapsulation and Storage Facility}

\section{SM Hahn}

DOE Richland Operations Office is providing support to DOE-Headquarters to respond to Defense Nuclear Facilities Safety Board Recommendation 2004-2, "Active Confined Systems," which notes concerns with the safety system strategy used for several facilities to confine radioactive materials during or following accidents. The DOEHeadquarters technical advisory board review of DOE Richland Operations Office's Recommendation 2004-2, "WESF [Waste Encapsulation and Storage Facility] Ventilation System Evaluation," concluded that the Waste Encapsulation and Storage Facility confinement ventilation system, including the gap analysis and cost benefit analysis, 
be re-evaluated. This Waste Encapsulation and Storage Facility-specific report was submitted to the Defense Nuclear Facility Safety Board in February 2010 (CHPRC 2010).

\subsubsection{Disposal of U.S. Navy Reactor Compartments}

\section{SG Arnold}

In 2009, two defueled U.S. Navy reactor compartments were received and placed in Trench 94 of the 218-E-12B Burial Ground, bringing the total number of reactor compartments received to 120. All U.S. Navy reactor compartments shipped to the Hanford Site for disposal originated from decommissioned nuclear-powered submarines or cruisers. Decommissioned submarine reactor compartments are approximately 10 meters (33 feet) in diameter, 14.3 meters (47 feet) long, and weigh between 900 and 1,400 metric tons (1,000 and 1,500 tons). Decommissioned cruiser reactor compartments are approximately 10 meters (33 feet) in diameter, 12.8 meters ( 42 feet) high, and weigh approximately 1,362 metric tons ( 1,500 tons).

\subsubsection{Integrated Disposal Facility PW Martin}

The Integrated Disposal Facility is a newly constructed, unused landfill that is not yet actively operated. Located in the south central part of the 200-East Area, the landfill is an expandable RCRA hazardous waste compliant unit (i.e., a double high-density polyethylene-lined trench with leachate collection and a leak detection system). The landfill is divided lengthwise (north to south) into two distinct cells: the east cell for disposal of low-level radioactive waste (nonRCRA-permitted), and the west cell for disposal of low-level mixed waste (radioactive and RCRA-regulated hazardous waste). The constructed landfill is approximately 442 meters ( 1,450 feet) wide by 160 meters ( 525 feet) long and up to 15 meters (49 feet) deep. When operational, the landfill will have four waste container layers separated vertically by 0.9 meter ( 3 feet) of soil. The current waste disposal capacity is approximately 163,000 cubic meters (5.76 million cubic feet). The Integrated Disposal Facility is referenced in the draft Environmental Impact Statement for Tank Farm Closure and Waste Management (DOE/EIS-0391) as a future disposal option for Hanford Site wastes.

\subsubsection{Liquid Waste Management}

Facilities are operated on the Hanford Site to store, treat, reduce, and dispose of various types of liquid effluent generated by site cleanup activities. These facilities are operated and maintained in accordance with state and federal regulations and facility permits.

\subsubsection{Effluent Treatment Facility HC Boynton}

The Effluent Treatment Facility, located in the 200-East Area, treats liquid effluent to remove toxic metals, radionuclides, and ammonia, in addition to destroying organic compounds. The treatment process constitutes best available technology and includes $\mathrm{pH}$ adjustment, filtration, ultra-violet light and peroxide oxidation to destroy organic compounds, reverse osmosis to remove dissolved solids, and ion exchange to remove the last traces of contaminants. The facility began operating in December 1995 and has a maximum treatment capacity of 570 liters ( 150 gallons) per minute. Storage and treatment activities are managed in compliance with the facility RCRA permit and effluent discharges comply with the limitations set forth in State Waste Discharge Permit ST-4500 and with the 200 Area Effluent Treatment Facility delisting requirements and modifications.

The treated effluent is stored in tanks, sampled and analyzed, and discharged via a dedicated pipeline to the StateApproved Land Disposal Site (also known as the 616-A Crib). This disposal site is located just north of the 200-West Area and is an underground drain field. The percolation rates for the field have been established by site testing and evaluation of soil characteristics. Tritium in the liquid effluent from the Effluent Treatment Facility cannot be practically removed, and the location of the disposal site maximizes the time for migration of the tritium to the Columbia River to allow for radioactive decay (the half-life of tritium is 12.35 years).

The volume of wastewater treated and disposed of in 2009 was approximately 83 million liters (22 million gallons). 
This was primarily CERCLA-regulated wastewater (groundwater from the 200-UP-1 and 200-ZP-1 Operable Units in the 200-West Area).

\subsubsection{Liquid Effluent Retention Facility \\ HC Boynton}

The Liquid Effluent Retention Facility, located in the 200-East Area, consists of three RCRA-compliant surface basins used to temporarily store process condensate from the 242-A Evaporator and other aqueous waste. The Liquid Effluent Retention Facility provides a steady flow and consistent $\mathrm{pH}$ for the feed to the Effluent Treatment Facility. Each basin has a maximum capacity of 29.5 million liters (7.8 million gallons). Generally, spare capacity is maintained in each basin in the event a leak should develop in an operating basin. Each basin is constructed of two flexible, high-density polyethylene membrane liners. A system is provided to detect, collect, and remove leachate from between the primary and secondary liners in the event of leakage. Beneath the secondary liner is a soil and bentonite clay barrier, should both the primary and secondary liners fail. Each basin has a floating membrane cover constructed of very low-density polyethylene to keep out windblown soil and weeds, and to minimize evaporation of small amounts of organic compounds and tritium that may be present in the basin contents. The facility began operating in April 1994 and receives liquid waste from both RCRAand CERCLA-regulated cleanup activities. Typically, RCRA and CERCLA wastewater were segregated in the surface basins and processed with different disposal destinations. However, in 2007, the Environmental Restoration Disposal Facility record of decision was amended to allow receipt of all RCRA and CERCLA waste (EPA 2007). Therefore, segregation of RCRA and CERCLA wastewater is currently no longer required. Treatment and storage activities at the Liquid Effluent Retention Facility are managed in accordance with the facility RCRA permit.

The volume of wastewater received for interim storage in 2009 was approximately 96.2 million liters (25.4 million gallons). This included approximately 5.7 million liters (1.5 million gallons) of RCRA-regulated wastewater from 242-A Evaporator process condensate and approximately 3.8 million liters (1.0 million gallons) of CERCLA-regulated wastewater from Environmental Restoration Disposal Facility leachate. The majority of wastewater received at the Liquid Effluent Retention Facility was pipeline-transported contaminated groundwater from 200-UP-1 and 200-ZP-1 wells, totaling approximately 84.0 million liters (22.2 million gallons). Approximately 2.4 million liters (0.63 million gallons) of wastewater were received from various facilities by tanker trucks that included approximately 0.9 million liter ( 0.24 million gallon) of water purged from wells prior to sampling. The wastewater volume transferred to the Effluent Treatment Facility for treatment and disposal in 2009 was 82.5 million liters (21.8 million gallons).

The volume of wastewater being stored in the Liquid Effluent Retention Facility at the end of 2009 was 64.4 million liters (17.0 million gallons).

\subsubsection{200 Area Treated Effluent Disposal Facility HC Boynton}

The 200 Area Treated Effluent Disposal Facility, located east of the 200-East Area, is a collection and disposal system for non-RCRA-permitted waste streams. The individual waste streams must be treated or otherwise comply with best available technology and all known available and reasonable treatment methods in accordance with "Submission of Plans and Reports for Construction of Wastewater Facilities" (WAC 173-240), which is the responsibility of the generating facility. Effluent discharges comply with the limitations established in State Waste Discharge Permit ST-4502.

The 200 Area Treated Effluent Disposal Facility consists of approximately 18 kilometers (11 miles) of buried pipelines connecting three pumping stations, the 6653 Building (known as the disposal sample station), and two 2-hectare (5-acre) disposal ponds. The facility began operating in April 1995 and has a capacity of 12,900 liters (3,400 gallons) per minute. The volume of unregulated effluent disposed of in 2009 was 1,300 million liters (340 million gallons). The major source of this effluent was uncontaminated cooling water and steam condensate from the 242-A Evaporator, with various other uncontaminated waste streams received from other Hanford Site facilities. 


\subsubsection{300 Area Treated Effluent Disposal Facility}

\section{Halgren}

Industrial wastewater generated throughout the Hanford Site is collected and treated in the 300 Area Treated Effluent Disposal Facility, which began operation in December 1994. The primary sources of the wastewater are laboratories, research facilities, and office buildings in the 300 Area. The wastewater consists of once-through cooling water, steam condensate, and other industrial wastewater. Potentially contaminated wastewater is collected in the nearby 307 Retention Basins where it is monitored and released to the 300 Area process sewer for treatment by the 300 Area Treated Effluent Disposal Facility.

This facility has a storage capacity of up to 5 days at the design flow rate of 1,100 liters (300 gallons) per minute. The treatment process includes iron co-precipitation to remove heavy metals, ion exchange to remove mercury, and ultra-violet light and peroxide oxidation to destroy organics and cyanide. The treated liquid effluent is monitored and discharged through an outfall to the Columbia River under a National Pollutant Discharge Elimination System permit. The volume of industrial wastewater treated and disposed of during 2009 was 98 million liters (26 million gallons). The 300 Area Treated Effluent Disposal Facility was permanently shut down on September 2, 2009. The facility has completed terminal cleanout and all process systems have been deactivated in preparation for decommissioning and destruction.

\subsubsection{242-A Evaporator GM Crummel}

The 242-A Evaporator, located in the 200-East Area, concentrates dilute liquid tank waste by evaporation. The resultant water vapor is captured, condensed, filtered, sampled, and sent to the nearby Liquid Effluent Retention Facility for further treatment and disposal before being returned to the double-shell tanks. This reduces the volume of liquid waste sent to double-shell waste storage tanks for storage and reduces the potential need for additional doubleshell tanks.

In 2009, planning and design activities to upgrade and extend the 242-A Evaporator service life through 2032 occurred using American Recovery and Reinvestment Act of 2009 funding. Procurement and construction activities are planned for 2010. Upgrades will include the following:

- Discharge pipeline leak detection system upgrades from the 242-A Evaporator to the Liquid Effluent Retention Facility

- Instrumentation replacement (transmitters)

- Heating, ventilation, and air conditioning exhaust upgrades.

In 2009, the 242-A Evaporator completed a successful operating campaign that reduced the volume of waste in two double-shell storage tanks by more than 3.6 million liters (960,000 gallons). 


\subsection{Underground Waste Storage Tanks}

\section{GM Crummel}

Most Hanford Site waste is stored in 149 large underground single-shell (single-walled) and 28 double-shell (doublewalled) tanks located on the Central Plateau near the center of the site. A grouping of tanks is referred to as a farm. The 149 single-shell tanks were constructed in the late 1940s and early 1950s; 67 are assumed to have leaked in the past. Pumpable liquids in the single-shell tanks were transferred to the newer and safer double-shell tanks several years ago under the Interim Stabilization Program to help prevent additional environmental releases. The following sections summarize waste tank-related activities that occurred in 2009.

\subsubsection{Waste Tank Status}

\section{GM Crummel}

This section provides information about the single-shell and double-shell tanks on the Hanford Site, and activities that occurred in 2009 related to their operation and closure. Quantities of liquid waste generated in 2009 and stored in underground storage tanks are provided in the Hanford Facility Annual Dangerous Waste Report Calendar Year 2009 (DOE/RL-2010-08, Rev. 0). Table 6.4.1 summarizes the liquid waste generated and stored from 2004 through 2009 in underground storage tanks.

\subsubsection{Single-Shell Tanks GM Crummel}

During 2009, approximately 386,000 liters (102,000 gallons) of radioactive and hazardous waste were removed from single-shell Tank 241-C-110 and transferred to safer doubleshell tank storage. At the end of 2009, there was approximately 112 million liters (29.7 million gallons) of waste remaining in the single-shell tanks.

\begin{tabular}{|c|c|c|c|c|c|c|c|}
\hline \multirow{2}{*}{\multicolumn{2}{|c|}{ Type of Waste }} & \multicolumn{6}{|c|}{$\begin{array}{l}\text { Quantities of Liquid Waste }{ }^{(a)} \text { Generated and Stored Within the Tank Farm System on } \\
\text { the Hanford Site During } 2009 \text { and the Previous } 5 \text { Years in Liters (gallons) }{ }^{(b)}\end{array}$} \\
\hline & & $\underline{2004}$ & 2005 & $\underline{2006}$ & 2007 & $\underline{2008}$ & 2009 \\
\hline \multicolumn{2}{|c|}{$\begin{array}{l}\text { Volume of waste added } \\
\text { to double-shell tanks }\end{array}$} & $\begin{array}{l}3,316 \\
(876)\end{array}$ & $\begin{array}{l}3,668 \\
(969)\end{array}$ & $\begin{array}{l}3,547 \\
(937)\end{array}$ & $\begin{array}{c}5,901 \\
(1,559)\end{array}$ & $\begin{array}{l}322 \\
(85)\end{array}$ & $\begin{array}{l}1,230 \\
(325)\end{array}$ \\
\hline \multicolumn{2}{|c|}{$\begin{array}{l}\text { Total volume in double- } \\
\text { shell tanks (year end) }\end{array}$} & $\begin{array}{l}95,275 \\
(25,169)\end{array}$ & $\begin{array}{l}98,943 \\
(26,138)\end{array}$ & $\begin{array}{l}101,411 \\
(26,790)\end{array}$ & $\begin{array}{l}101,052 \\
(26,695)\end{array}$ & $\begin{array}{l}101,366 \\
(26,778)\end{array}$ & $\begin{array}{c}98,311 \\
(25,971)\end{array}$ \\
\hline \multicolumn{2}{|c|}{$\begin{array}{l}\text { Volume evaporated at } \\
\text { 242-A Evaporator }\end{array}$} & $\begin{array}{c}734 \\
(194)\end{array}$ & $\begin{array}{c}707 \\
(187)\end{array}$ & $\begin{array}{l}1,052 \\
(278)\end{array}$ & $\begin{array}{c}4,500 \\
(1,189)\end{array}$ & $\begin{array}{c}0 \\
(0)\end{array}$ & $\begin{array}{l}3,634 \\
(960)\end{array}$ \\
\hline \multicolumn{2}{|c|}{$\begin{array}{l}\text { Volume pumped from } \\
\text { single-shell tanks }\end{array}$} & $\begin{array}{l}2,778^{(\mathrm{c})} \\
(734)^{(\mathrm{c})}\end{array}$ & $\begin{array}{l}888^{(\mathrm{c})} \\
(235)^{(\mathrm{c})}\end{array}$ & $\begin{array}{l}2,953^{(\mathrm{d})} \\
(780)^{(\mathrm{d})}\end{array}$ & $\begin{array}{l}4,342^{(\mathrm{d})} \\
(1,147)^{(\mathrm{d})}\end{array}$ & $\begin{array}{l}262^{(\mathrm{d})} \\
(69)^{(\mathrm{d})}\end{array}$ & $\begin{array}{l}386^{(\mathrm{d})} \\
(102)^{(\mathrm{d})}\end{array}$ \\
\hline \multicolumn{8}{|c|}{$\begin{array}{l}\text { (a) Quantity of liquid waste is defined as liquid waste } \\
\text { to the nearest } 1,000 \text {. This does not include conta } \\
\text { (b) Multiply volumes shown by } 1,000 \text {. } \\
\text { (c) Volume does not include dilution or flush water. } \\
\text { (d) Volume does include dilution or flush water. }\end{array}$} \\
\hline
\end{tabular}




\subsubsection{Vadose Zone Program}

\section{DA Myers and DL Parker}

The Vadose Zone Program is responsible for implementing the Tank Farm RCRA Corrective Action Program through field characterization, laboratory analyses, technical analyses, risk assessment for past tank leaks, and installation of interim measures that will reduce the threat from contaminants until permanent solutions can be found. Results of vadose zone investigations and interim measures conducted the first 10 years of the project are documented in the RCRA Facility Investigation Report for Hanford Single-Shell Tank Waste Management Areas (DOE/ORP-2008-01, Rev. 0).

In 2009, Vadose Zone Program workers installed several direct-push boreholes for soil sampling and geophysical logging in the C and SX Tank Farms and completed surface geophysical surveys at Waste Management Area SX. Monitoring was conducted at the interim surface barrier that covers a portion of the 241-T Tank Farm to reduce infiltration of precipitation through the remnants of the 1973 release from Tank T-106. Planning was initiated for an interim barrier that will cover the TY farm.

\section{Direct-Push Boreholes and Sampling}

Direct-push technology, using the hydraulic hammer unit to evaluate subsurface contamination in the vadose zone, was deployed in two tank farms during 2009. Several directpush boreholes were made in the C Tank Farm as part of the Phase II RCRA investigation of that waste management area. The hydraulic hammer unit was also deployed in the SX Tank Farm to assess the extent of contamination in support of a proposed interim barrier in that farm.

\section{Surface Geophysical Exploration}

Surface geophysical exploration is a combination of surfacedeployed geophysical techniques, including pole-to-pole electrical resistivity, electro-magnetic induction, magnetic gradiometry, and ground-penetrating radar, used to help define the presence and distribution of buried infrastructure, so that those features may be considered during resistivity data analysis. The depth to which the resistivity measurements interrogate the subsurface is determined by the distance between electrode pairs (the farther apart, the deeper the interrogation). Because resistivity is an indirect measure of several subsurface phenomena (e.g., moisture distribution, saline contaminants, and soil texture), the greater the depth of interrogation, the lower the resolution of the analysis. During 2009, surface geophysical exploration was performed in Waste Management Area S-SX (RPP-RPT42513). In addition, analysis of the first-ever fully threedimensional surface geophysical exploration survey with buried electrodes (UPR-200-E-81, near the 241-C Tank Farm) was completed during the period (RPP-RPT-41236).

\section{Interim Surface Barriers}

Effectiveness of the T Tank Farm interim surface barrier at reducing infiltration is assessed through a barrier monitoring program (PNNL-16538). Pre-barrier data were collected and a monitoring report for fiscal year 2007 was issued in January 2008 (PNNL-17306). The most recent post-barrier data were compiled into a fiscal year 2009 monitoring report, issued in January 2010 (PNNL-19123). Barrier monitoring is ongoing.

The design of a second interim barrier, at TY Tank Farm, was developed and approved by the Washington State Department of Ecology. Lessons learned through the T Farm barrier were applied in the design:

- An evapotranspiration facility will be constructed to divert any intercepted water back to the atmosphere

- The tank farm surface will consist of a modified asphalt, testing this surface's ability to redirect water

- Monitoring instruments have been modified.

\subsubsection{Double-Shell Tanks GM Crummel}

The tank farms contain 28 double-shell tanks with a storage capacity of approximately 126 million liters (33 million gallons), which store radioactive and chemical waste. The tanks were built between 1968 and 1986 and contain both liquids and settled solids from past nuclear operations, including waste transfers from older single-shell tanks. The storage space within the double-shell tank system is being managed to store waste pending treatment by the Hanford Tank Waste Treatment and Immobilization Plant or a supplemental treatment process, and includes emergency pumping space available at all times for 3.8 million liters (1 million gallons). 
At the end of 2009, there were 98 million liters (26.0 million gallons) of waste in the double-shell tanks.

\subsubsection{DOE Office of River} Protection Progress on Defense Nuclear Facilities Safety Board Recommendations Regarding the Underground Waste Storage Tanks

\section{LJ Croy}

Throughout 2009, the DOE Office of River Protection and its contractors met with and provided information to the
Defense Nuclear Facilities Safety Board and its technical staff to resolve commitments regarding Hanford Site underground storage tank farm projects. The following technical topics were completed in 2009:

- A combined phase Integrated Safety Management System review of the tank farm operations contractor's processes and activities to ensure that the Integrated Safety Management System review is effectively implemented to ensure mission success

- Reviews of Specific Administrative Control implementation credited in their facility safety bases in response to Defense Nuclear Facilities Safety Board Recommendation 2002-3 Requirements for the Design, Implementation, and Maintenance of Administrative Controls (DNFSB 2002). 


\title{
6.5 Hanford Tank Waste Treatment and Immobilization Plant
}

\author{
JF Brown
}

The Hanford Tank Waste Treatment and Immobilization Plant is being built on 26 hectares (65 acres) located on the Central Plateau at the 200-East Area to treat radioactive and hazardous waste currently stored in 177 underground tanks. The plant comprises four major facilities now under construction (Pretreatment Facility, High-Level Waste Vitrification Facility, Low-Activity Waste Vitrification Facility, and Analytical Laboratory), along with 20 support buildings and the associated underground utilities.

During 2009, significant progress was made on the Hanford Tank Waste Treatment and Immobilization Plant Project. For the Pretreatment Facility, the first concrete slab was placed at the 23-meter (77-foot) elevation, and crews began installing a 1-1/2-meter- (5-foot-) wide heating, ventilation, and air conditioning duct that will span the facility's 122-meter- (400-foot-) long hot cell. The High-Level Waste Vitrification Facility's crews installed a 38-metric ton (42-ton) door liner, which will hold two shield doors in the facility's filter cave. Two large mixing vessels were installed in the Low-Activity Waste Vitrification Facility, designed to blend dry glass-forming materials before being combined with waste product and melted. The Analytical Laboratory crews continued to install hot cell partition dividers and air handling systems. In the Balance of Facilities, structural steel was installed around glass-former hoppers and the cathodic protection system was put into service, which protects miles of underground piping from corrosion.

The overall project is approximately $52 \%$ complete, including the following:

- Approximately 78\% design complete

- Approximately $56 \%$ construction complete on the Balance of Facilities
- Approximately 57\% construction complete on the Low-Activity Waste Vitrification Facility

- Approximately 59\% construction complete on the Analytical Laboratory

- Approximately 29\% construction complete on the Pretreatment Facility

- Approximately $24 \%$ construction complete on the High-Level Waste Vitrification Facility.

Phase I testing was completed at the Pretreatment Engineering Platform, a one-quarter-scale demonstration facility built to confirm the efficiency and throughput of select pretreatment processes. The Pretreatment Engineering Platform is the second largest processing system at the Hanford Site. Its Phase I testing confirmed that the ultrafiltration process will effectively separate the solid and liquid waste, and that the leaching process will dissolve a sufficient amount of aluminum to reduce the overall quantity of highlevel waste glass produced.

Another testing facility, the M3 Mixing Test Platform, has been constructed and is being used to confirm key pretreatment vessel mixing system technologies. The platform is designed to test the effectiveness of the Hanford Tank Waste Treatment and Immobilization Plant's pulse-jet mixers for specific vessels, which are essential to keep waste solids suspended throughout the pretreatment process.

From project inception through 2009, the Hanford Tank Waste Treatment and Immobilization Plant placed 148,000 cubic meters (5.20 million cubic feet) of concrete; erected 13,500 metric tons (14,900 tons) of structural steel; and installed 80,000 meters (264,000 linear feet) of pipe and 77,000 meters $(253,000$ linear feet $)$ of cable and wire. 
In 2009, the Hanford Tank Waste Treatment and Immobilization Plant donated 776 computers and 160 monitors to the community for reuse; purchased 29,100 liters (7,700 gallons) of bio-diesel; specified 30\% recycled paper content for new purchases; and recycled approximately:

- 39 metric tons (43 tons) of glass media for surface blasting and cutting operations

- 23.5 metric tons (25.9 tons) of paper

- 5.7 metric tons (6.28 tons) of stainless steel
- 297 metric tons (327 tons) of steel

- 17 metric tons (18.7 tons) of batteries

- 10.9 metric tons (12 tons) of engine oil.

In April 2009, the Hanford Tank Waste Treatment and Immobilization Plant was awarded the DOE Voluntary Protection Program Merit status in recognition of the site's highly evolved worker safety and health culture, and in 2009 achieved the best safety record since the project's inception. 


\title{
6.6 DOE Office of River Protection Progress on Defense Nuclear Facilities Safety Board Recommendations
}

\author{
LJ Croy
}

Throughout 2009, the DOE Office of River Protection and its contractors met with and provided information to the Defense Nuclear Facility Safety Board and its technical staff to resolve commitments and review the following technical topics regarding Hanford Tank Waste Treatment and Immobilization Plant projects:

- Completed the commitment in the January 8, 2009, Defense Nuclear Facility Safety Board letter requesting the DOE Office of River Protection validate that a design basis fire would not result in unacceptable toxicological consequences under the current plan for fire protection coating of structural steel in Hanford Tank Waste Treatment and Immobilization Plant facilities (Eggenberger 2009). The Defense Nuclear Safety Board concluded the planned fireproof coating is adequate to prevent a structural collapse that would release hazardous chemicals in the event of a design basis fire. This commitment was closed in March 2009.
- Started evaluations to resolve Defense Nuclear Facility Safety Board commitment SL09-014, dated December 2, 2009, to assess the adequacy of the structuralsteel design and determine if design changes are required to Hanford Tank Waste Treatment and Immobilization Plant facilities.

- Established two task teams to determine whether alternative design approaches are needed for the Pretreatment Facility and High-Level Waste Vitrification Facility to simplify the facilities for construction and operation while maintaining necessary conservatism and adequate safety assurance.

- Conducted scaled and prototypic testing to aid in the resolution of pulse-jet mixer technical issues for completion of vessel design, fabrication, and modifications. 


\title{
6.7 Scientific and Technical Contributions to Hanford Site Cleanup
}

\author{
PR Bredt and MD Freshley
}

In 2009, Pacific Northwest National Laboratory addressed Hanford Site challenges in chemical and nuclear waste processing, and subsurface science and remediation. Pacific Northwest National Laboratory researchers supported DOE and its contractors, as well as the DOE Office of Science and DOE Office of Technology Innovation and Development by performing evaluations, analyzing data, providing reviews, preparing and operating special facilities, and creating new technologies to address site cleanup challenges.

Pacific Northwest National Laboratory continued to provide support to the Hanford Tank Waste Treatment and Immobilization Plant by resolving waste processing and performance issues. Staff completed the first phase of testing on the Pretreatment Engineering Platform, an approximate quarter-scale prototype of the Hanford Tank Waste Treatment and Immobilization Plant sludge treatment system that will confirm waste processing approaches and design for the full-scale plant. Three integrated tests simulating aluminum leaching, chrome oxidation, and ultrafiltration were completed; over 38,000 liters (10,000 gallons) of simulated Hanford Site tank waste were processed. Using the test results, researchers were able to resolve the external flowsheet review team's concern over undemonstrated leaching at the Hanford Tank Waste Treatment and Immobilization Plant.

Progress was made on the Hanford Tank Waste Treatment and Immobilization Plant waste feed delivery process. Pacific Northwest National Laboratory researchers developed a flow loop test strategy for Washington River Protection Solutions LLC, providing certification that waste transfers from the tank farms to the Hanford Tank Waste Treatment and Immobilization Plant will comply with feed requirements. Staff identified instruments that will provide physical characterization of the waste during pipe flow. Initial tests will evaluate pipe plugging potential during waste transfer.

Pacific Northwest National Laboratory researchers continued to make advances in waste solidification and immobilization. This included delivery of a Hanford Site waste roadmap to identify the risks and uncertainties associated with the treatment and disposal of Hanford Tank Waste Treatment and Immobilization Plant secondary wastes, identifying candidate waste forms, and beginning a series of performance tests. A report (PNNL-18501) summarizing available data on waste glass composition and properties, and proposing models to fit the data for key glass properties was issued. These models will feed the Hanford Site tank waste optimization simulator, a tool that the tank operations contractor is using to optimize cost, schedule, and canister count (for both high-level waste and low-activity waste), as well as provide retrieval sequencing and blending options.

In addition, Pacific Northwest National Laboratory completed the next stage of $\mathrm{K}$ Basin sludge characterization. These data are being used to establish the nuclear material accountability values for the K-West Basin floor and pit sludge inventory, and to support the final design of equipment for sludge disposition.

In the area of subsurface science and remediation, Pacific Northwest National Laboratory researchers completed several investigations to assist with remediation of contaminated soils and groundwater at the Hanford Site. Pacific Northwest National Laboratory conducted geochemical studies and soil column tests that provided insights into the movement of chromium in the vadose zone. Researchers also investigated biostimulation as a way to increase the effectiveness of a previously installed underground chemical 
barrier that reduces chromium in contaminated groundwater. Two approaches were evaluated for creating a biological treatment barrier upgradient of the chemical barrier; one using injection of molasses into the aquifer, and one using injection of a vegetable oil emulsion. The biological barrier enhanced the effectiveness of the downgradient chemical barrier reducing oxygen, nitrate, and chromium concentrations in the groundwater (PNNL-18784).

Pacific Northwest National Laboratory researchers completed studies to assist with development and design of a treatability test to address deep vadose zone contamination on the Hanford Site Central Plateau. Studies included intermediate-scale laboratory testing of soil desiccation components, development of approaches for uranium sequestration, and modeling to support field test design for soil desiccation. Pacific Northwest National Laboratory assisted CH2M HILL Plateau Remediation Company with fieldscale characterization. The project will implement a fieldscale desiccation test in 2010-2011. Through funding from the DOE Office of Technology Innovation and Development, Pacific Northwest National Laboratory developed approaches for using foam as a medium for delivering reactive media to the vadose zone. In 2009, laboratory testing of several different foams was completed and approaches for modeling foam transport were developed. Pacific Northwest National Laboratory also developed and published a methodology for measuring vapor-phase vadose zone contamination and its impact on groundwater (Truex et al. 2009). These efforts are supporting remediation activities for carbon tetrachloride vadose zone contamination in the 200-West Area.

Pacific Northwest National Laboratory researchers are developing a method for infiltrating polyphosphate for treatment of uranium contamination in 300 Area groundwater. During 2009, a series of laboratory investigations were conducted resulting in the 1) determination of the reaction between uranium-bearing solid phases and aqueous polyphosphate remediation technology as a function of polyphosphate composition and concentration, and 2) determination of the mechanism of autunite formation through the reaction of solid-phase calcite-bound uranium and aqueous polyphosphate remediation technology. A book chapter (Wellman et al. 2008a) and book (Wellman et al. 2008b) that describes this technology were published in late
2008. This technology will be used in a field demonstration for CH2M HILL Plateau Remediation Company following development of a field test plan.

Pacific Northwest National Laboratory is also developing a method for infiltrating citrate-phosphate solutions to treat strontium-90 in the $100-\mathrm{N}$ Area. Laboratory investigations in 2009 determined that 1) calcium-citrate-phosphate solutions form apatite at low water saturations, and 2) the best strategy for the infiltration of the apatite-forming solution is rapid infiltration of the solution, followed by slow water infiltration. Low-conductivity zones were treated in laboratory and intermediate-scale experiments using this strategy. Treatment of high-conductivity zones may require other emplacement techniques, such as foam. A final report was published in March 2009 (PNNL-18143). An upcoming field demonstration for CH2M HILL Plateau Remediation Company will further evaluate this technology.

Pacific Northwest National Laboratory researchers are testing phytoextraction using willow shrubs for potential use at the $100-\mathrm{N}$ Area for extracting strontium- 90 from the riparian zone. Results showed that coyote willows could be effective at producing enough biomass to efficiently remove strontium-90 from the riparian zone along the Columbia River. In the third year of growth (2009), the biomass of the willows exceeded projected growth by more than a factor of three. A final report was published in January 2010 (PNNL-19120).

Pacific Northwest National Laboratory continued research in the 300 Area as part of the DOE Office of Science's Environmental Remediation Science Program to characterize the uranium-contaminated subsurface, examine fundamental science issues important to contaminant transport and groundwater remediation, and support future cleanup decisions at the Hanford Site and other DOE sites. Progress in 2009 included completion of several field experiments, geophysical characterization, and modeling. Field experiments focused on well field characterization using tracer experiments and geophysics; passive monitoring to characterize the release of uranium to the aquifer during rise and fall of the river stage during spring runoff; and a reactive tracer experiment to study the release of sorbed uranium. Results are being used to update the conceptual model for uranium contamination in the 300 Area subsurface and will provide the technical basis for remediation strategies. 


\subsection{References}

40 CFR 264.301. 2010. "Standards for Owners and Operators of Hazardous Waste Treatment, Storage, and Disposal Facilities; Design and Operating Requirements." Code of Federal Regulations, U.S. Environmental Protection Agency. Accessed May 17, 2010, at http://www.gpoaccess. gov/cfr/index.html.

52 FR 2923. January 23, 1987. Executive Order 12580. "Superfund Implementation." Federal Register, Office of the President.

69 FR 39449. June 30, 2004. "Record of Decision for the Solid Waste Program, Hanford Site, Richland, WA: Storage and Treatment of Low-Level Waste and Mixed Low-Level Waste; Disposal of Low-Level Waste and Mixed LowLevel Waste, and Storage, Processing, and Certification of Transuranic Waste for Shipment to the Waste Isolation Pilot Plant." Federal Register, U.S. Department of Energy.

American Recovery and Reinvestment Act of 2009. 2009. Public Law 111-5, as amended, 26 USC 1 et seq.

Atomic Energy Act of 1954. 1954. Chapter 724, 60 Stat. 755, 42 USC 2011 et seq.

CHPRC. 2010. DNFSB Recommendation 2004-2 WESF Ventilation System Evaluation. CH2M HILL Plateau Remediation Company, Richland, Washington.

Comprehensive Environmental Response, Compensation, and Liability Act of 1980. 1980. Public Law 96-510, as amended, 42 USC 9601 et seq. Accessed May 17, 2010, at http:// www.epa.gov/lawsregs/laws/cercla.htm.

D\&D-28283. 2006. Sampling and Analysis Instruction for Nonintrusive Characterization of Bin 3A and Bin 3B Waste Sites in the 200-SW-2 Operable Unit. Fluor Hanford, Inc., Richland, Washington.
D\&D-35827. 2009. Project Experience Report, Canyon Disposition Initiative (221-U Facility). Fluor Hanford, Inc., Richland, Washington.

DNFSB. 2000. Prioritization for Stabilizing Nuclear Materials. Recommendation 2000-1, Defense Nuclear Facilities Safety Board, Washington, D.C.

DNFSB. 2002. Requirements for the Design, Implementation, and Maintenance of Administrative Controls. Recommendation 2002-3, Defense Nuclear Facilities Safety Board, Washington, D.C.

DNFSB. 2004. Active Confined Systems. Recommendation 2004-2, Defense Nuclear Facilities Safety Board, Washington, D.C.

DOE. 2002. An Implementation Plan for Stabilization and Storage of Nuclear Material. The Department of Energy Plan in Response to DNFSB Recommendation 2000-1, Revision 2. U.S. Department of Energy, Washington, D.C.

DOE. 2005. Prioritization for Stabilizing Nuclear Materials; DNFSB Recommendation 2000-1; Implementation Plan; Revision to Section 5.1 Hanford. U.S. Department of Energy, Washington, D.C.

DOE and EPA. 2005. Action Memorandum \#1 for the 300 Area Facilities. U.S. Department of Energy, Richland Operations Office, Richland, Washington, and U.S. Environmental Protection Agency, Region 10, Seattle, Washington.

DOE and EPA. 2006a. Action Memorandum \#2 for the 300 Area Facilities. U.S. Department of Energy, Richland Operations Office, Richland, Washington; and U.S. Environmental Protection Agency, Region 10, Seattle, Washington. 
DOE and EPA. 2006b. Action Memorandum \#3 for the 300 Area Facilities. U.S. Department of Energy, Richland Operations Office, Richland, Washington; and U.S. Environmental Protection Agency, Region 10, Seattle, Washington.

DOE, EPA, and Ecology. 2005. Record of Decision for the 221-U Facility (Canyon Disposition Initiative) and Responsiveness Summary. U.S. Department of Energy, Richland Operations Office, Richland, Washington; U.S. Environmental Protection Agency, Region 10, Seattle, Washington; and Washington State Department of Ecology, Olympia, Washington.

DOE/EIS-0391. 2009. Draft Tank Farm Closure and Waste Management Environmental Impact Statement for the Hanford Site, Richland, Washington. U.S. Department of Energy, Washington, D.C.

DOE/ORP-2008-01, Rev. 0. 2008. RCRA Facility Investigation Report for Hanford Single-Shell Tank Waste Management Areas. U.S. Department of Energy, Office of River Protection, Richland, Washington.

DOE/RL-98-28, Rev. 0. 1999. 200 Areas Remedial Investigation/Feasibility Study Implementation Plan - Environmental Restoration Program. U.S. Department of Energy, Richland Operations Office, Richland, Washington.

DOE/RL-99-44, Rev. 0. 2000. 200-CS-1 Operable Unit RI/FS Work Plan and RCRA TSD Unit Sampling Plan. U.S. Department of Energy, Richland Operations Office, Richland, Washington.

DOE/RL-2001-01. 2004. Plutonium/Organic-Rich Process Condensate/Process Waste Group Operable Unit RI/FS Work Plan: Includes 200-PW-1, 200-PW-3, and 200-PW-6 Operable Units. Re-issue, U.S. Department of Energy, Richland Operations Office, Richland, Washington.

DOE/RL-2001-11, Rev. 1. 2004. Final Feasibility Study for the Canyon Disposition Initiative (221-U Facility). U.S. Department of Energy, Richland Operations Office, Richland, Washington.
DOE/RL-2001-29, Rev. 0. 2004. Proposed Plan for Remediation of the 221-U Facility (Canyon Disposition Initiative). U.S. Department of Energy, Richland Operations Office, Richland, Washington.

DOE/RL-2001-65, Rev. 0. 2002. 200-MW-1 Miscellaneous Waste Group Operable Unit RI/FS Work Plan. U.S. Department of Energy, Richland Operations Office, Richland, Washington.

DOE/RL-2002-14, Rev. 1, Draft B. 2007. Tanks/Lines/ Pits/Boxes/Septic Tank and Drainfields Waste Group Operable Unit RI /FS Work Plan and RCRA TSD Unit Sampling Plan: Includes: 200-IS-1 and 200-ST-1 Operable Units. U.S. Department of Energy, Richland Operations Office, Richland, Washington.

DOE/RL-2002-69, Draft A. 2003. Feasibility Study for the 200-CW-1 and 200-CW-3 Operable Units and the 200 North Area Waste Sites. U.S. Department of Energy, Richland Operations Office, Richland, Washington.

DOE/RL-2003-06, Draft A. 2003. Proposed Plan for the 200-CW-1 and 200-CW-3 Operable Units and the 200 North Area Waste Sites. U.S. Department of Energy, Richland Operations Office, Richland, Washington.

DOE/RL-2004-24, Draft A. 2004. Feasibility Study for the 200-CW-5 (U Pond/Z Ditches Cooling Water Waste Group), 200-CW-2 (S Pond and Ditches Cooling Water Waste Group), 200-CW-4 (T Pond and Ditches Cooling Water Waste Group), and 200-SC-1 (Steam Condensate Waste Group) Operable Units. Reissue, U.S. Department of Energy, Richland Operations Office, Richland, Washington.

DOE/RL-2004-24, Draft B. 2008. Feasibility Study for the 200-CW-5 Cooling Water Operable Unit. U.S. Department of Energy, Richland Operations Office, Richland, Washington.

DOE/RL-2004-26, Draft A. 2004. Proposed Plan for 200-CW-5, 200-CW-2, 200-CW-4, and 200-SC-1 Operable Units. Reissue, U.S. Department of Energy, Richland Operations Office, Richland, Washington.

DOE/RL-2004-26, Draft B. 2008. Proposed Plan for 200-CW-5 Cooling Water Operable Unit. U.S. Department of Energy, Richland Operations Office, Richland, Washington. 
DOE/RL-2004-60, Rev 0. 2008. 200-SW-1 Nonradioactive Landfills and Dumps Group Operable Unit and 200-SW-2 Radioactive Landfills and Dumps Group Operable Unit Remedial Investigation/Feasibility Study Work Plan. U.S. Department of Energy, Richland Operations Office, Richland, Washington.

DOE/RL-2004-66, Draft A. 2005. Focused Feasibility Study for the BC Cribs and Trenches Area Waste Sites. U.S. Department of Energy, Richland Operations Office, Richland, Washington.

DOE/RL-2005-63, Draft A. 2006. Feasibility Study for the 200-CS-1 Chemical Sewer Group Operable Unit. U.S. Department of Energy, Richland Operations Office, Richland, Washington.

DOE/RL-2005-63, Draft B. 2007. Feasibility Study for the 200-CS-1 Chemical Sewer Group Operable Unit. U.S. Department of Energy, Richland Operations Office, Richland, Washington.

DOE/RL-2005-64, Draft A. 2007. Proposed Plan for the 200-CS-1 Chemical Sewer Group Operable Unit. U.S. Department of Energy, Richland Operations Office, Richland, Washington.

DOE/RL-2005-64, Draft B. 2007. Proposed Plan for the 200-CS-1 Chemical Sewer Group Operable Unit. Reissue, U.S. Department of Energy, Richland Operations Office, Richland, Washington.

DOE/RL-2006-21, Draft B. 2007. Remedial Design/Remedial Action Work Plan for the 221-U Facility. U.S. Department of Energy, Richland Operations Office, Richland, Washington.

DOE/RL-2006-51, Rev. 0. 2007. Remedial Investigation Report for the Plutonium/Organic Rich Process Condensatel Process Waste Group Operable Unit: Includes the 200-PW-1, 200-PW-3, and 200-PW-6 Operable Units. U.S. Department of Energy, Richland Operations Office, Richland, Washington.

DOE/RL-2007-02-VOLII-ADD3, Rev 0. 2008. Site-Specific Field-Sampling Plans for 216-B-42 Trench, 216-S-13 Crib, 216-S-21 Crib, 216-T-18 Crib, and 216-T-19 Crib and Tile Field in 200-TW-1/200-PW-5 Operable Units. U.S. Department of Energy, Richland Operations Office, Richland, Washington.
DOE/RL-2007-27, Draft A. 2007. Feasibility Study for the Plutonium/Organic-Rich Process Condensate/Process Waste Group Operable Units: Includes the 200-PW-1, 200-PW-3, and 200-PW-6 Operable Units. U.S. Department of Energy, Richland Operations Office, Richland, Washington.

DOE/RL-2007-27, Draft B. 2009. Feasibility Study for the Plutonium/Organic-Rich Process Condensate/Process Waste Group Operable Unit: Includes the 200-PW-1, 200-PW-3, and 200-PW-6 Operable Units. Reissue, U.S. Department of Energy, Richland Operations Office, Richland, Washington.

DOE/RL-2007-40, Draft A. 2007. Proposed Plan for the 200-PW-1, 200-PW-3, and 200-PW-6 Operable Units. U.S. Department of Energy, Richland Operations Office, Richland, Washington.

DOE/RL-2007-50, Draft A, Reissue. 2008. Central Plateau Terrestrial Ecological Risk Assessment. U.S. Department of Energy, Richland Operations Office, Richland, Washington.

DOE/RL-2007-54. 2008. Sampling and Analysis Plan for Remediation of 200 North Area Waste Sites Located in the 200-CW-3 Operable Unit. U.S. Department of Energy, Richland Operations Office, Richland, Washington.

DOE/RL-2007-55, Rev. 0. 2008. Remedial Design/Remedial Action Work Plan for 200 North Area Waste Sites Located in the 200-CW-3 Operable Unit. U.S. Department of Energy, Richland Operations Office, Richland, Washington.

DOE/RL-2007-56, Rev. 0. 2008. Deep Vadose Zone Treatability Test Plan for the Hanford Central Plateau. U.S. Department of Energy, Richland Operations Office, Richland, Washington.

DOE/RL-2008-27, Rev. 0. 2009. Sampling and Analysis Plan for 618-10 and 618-11 Nonintrusive Sampling. U.S. Department of Energy, Richland Operations Office, Richland, Washington.

DOE/RL-2008-38, Draft A. 2010. Remedial Investigation/ Feasibility Study for the 200-MW-1 Miscellaneous Waste Sites Operable Unit. U.S. Department of Energy, Richland Operations Office, Richland, Washington. 
DOE/RL-2008-44, Rev. 0. 2009. Engineering Evaluation/ Cost Analysis for the 200-MG-1 Operable Unit. U.S. Department of Energy, Richland Operations Office, Richland, Washington.

DOE/RL-2008-45, Rev. 0. 2009. Engineering Evaluation/ Cost Analysis for the 200-MG-2 Operable Unit Waste Sites. U.S. Department of Energy, Richland Operations Office, Richland, Washington.

DOE/RL-2008-51, Rev 0. 2008. 241-CX Tank System Closure Plan. U.S. Department of Energy, Richland Operations Office, Richland, Washington.

DOE/RL-2009-36. 2009. BC Cribs and Trenches Excavation-Based Treatability Test Report. Revision 0. Reissue, U.S. Department of Energy, Richland Operations Office, Richland, Washington.

DOE/RL-2009-37, Rev. 0. 2009. Action Memorandum for Non-Time-Critical Removal Action for 200-MG-2 Operable Unit. U.S. Department of Energy, Richland Operations Office, Richland, Washington.

DOE/RL-2009-48, Rev. 0. 2009. Action Memorandum for Non-Time-Critical Removal Action for 11 Waste Sites in the 200-MG-1 Operable Unit. U.S. Department of Energy, Richland Operations Office, Richland, Washington.

DOE/RL-2009-53, Rev. 0. 2009. Removal Action Work Plan for 11 Waste Sites in the 200-MG-1 Operable Unit. U.S. Department of Energy, Richland Operations Office, Richland, Washington.

DOE/RL-2009-81, Rev. 0. 2009. Central Plateau Cleanup Completion Strategy. U.S. Department of Energy, Richland Operations Office, Richland, Washington.

DOE/RL-2009-121, Draft A. 2010. Sampling and Analysis Plan for the West Lake Site. U.S. Department of Energy, Richland Operations Office, Richland, Washington.

DOE/RL-2010-08, Rev. 0. 2010. Hanford Facility Annual Dangerous Waste Report Calendar Year 2009. JO Skolrud, U.S. Department of Energy, Richland Operations Office, Richland, Washington.
Ecology - Washington State Department of Ecology, U.S. Environmental Protection Agency, and U.S. Department of Energy. 1989. Hanford Federal Facility Agreement and Consent Order (Tri-Party Agreement). Document No. 89-10, as amended, Olympia, Washington. Accessed May 17, 2010, at http://www.hanford.gov/?page=81.

Ecology - Washington State Department of Ecology, U.S. Environmental Protection Agency, and U.S. Department of Energy. 2009. Tentative Agreement on Hanford Federal Facility Agreement and Consent Order Modifications Regarding Accelerated Groundwater and Soils Milestones/ FY 2009 Funding/Waste Management/K Basins and Other Issue Solutions. Olympia, Washington.

Eggenberger AJ. 2009. "Defense Nuclear Facilities Safety Board." Letter to Dr. Ines Triay, U.S. Department of Energy, Washington, D.C., from AJ Eggenberger, Defense Nuclear Facilities Safety Board Chairman, Washington, D.C., dated January 8, 2009.

EPA. 2007. U.S. Department of Energy Environmental Restoration Disposal Facility Hanford Site - 200 Area Benton County, Washington Amended Record of Decision, Decision Summary and Responsiveness Summary. U.S. Environmental Protection Agency, Region 10, Seattle, Washington.

EPA/ROD/R10-01-119. 2001. EPA Superfund Record of Decision: Hanford 300-Area (USDOE), EPA ID: WA2890090077, OU 03, Benton County, WA. U.S. Environmental Protection Agency, Washington State Department of Ecology, and U.S. Department of Energy, Richland Operations Office, Richland, Washington. Accessed August 17, 2010, at http://www.epa.gov/superfund/ sites/rods/fulltext/r1001119.pdf.

EPA/ROD/R10-95/100. 1995. EPA Superfund Record of Decision: Hanford 200-Area (USDOE), EPA ID: WA1890090078, OU 14, Benton County, WA. U.S. Environmental Protection Agency, Washington State Department of Ecology, and U.S. Department of Energy, Richland Operations Office, Richland, Washington. Accessed August 17, 2010, at http://www.epa.gov/superfund/ sites/rods/fulltext/r1095100.pdf. 
HGLP-LDR-309, Rev. 0. 2009. Geophysical Investigation Report Small Diameter Logging Results 200-TW-1, Operable Unit Site Characterization, February 2009, Hanford Geophysical Logging Project. S.M. Stoller Corporation, Richland, Washington.

PNNL-16538. 2007. T Tank Farm Interim Surface Barrier Demonstration - Vadose Zone Monitoring Plan. ZF Zhang, JM Keller, and CE Strickland, Pacific Northwest National Laboratory, Richland, Washington.

PNNL-17306. 2008. T Tank Farm Interim Surface Barrier Demonstration - Vadose Zone Monitoring FY07 Report. ZF Zhang, CE Strickland, JM Keller, CD Wittreich, and HA Sydnor, Pacific Northwest National Laboratory, Richland, Washington.

PNNL-17821. 2009. Electrical Resistivity Correlation to Vadose Zone Sediment and Pore-Water Composition for the BC Cribs and Trenches Area. RJ Serne, AL Ward, W Um, BN Bjornstad, and DF Rucker, Pacific Northwest National Laboratory, Richland, Washington.

PNNL-18143. 2009. Research Plan: Foam Delivery of Remedial Amendments to Deep Vadose Zone for Metals and Radionuclides Remediation. L Zhong, AT Hart, JE Szecsody, ZF Zhang, VL Freedman, M Ankeny, L Hull, M Oostrom, MD Freshley, and DM Wellman, Pacific Northwest National Laboratory, Richland, Washington.

PNNL-18501. 2009. Glass Property Data and Models for Estimating High-Level Waste Glass Volume. JD Vienna, A Fluegel, DS Kim, and PR Hrma, Pacific Northwest National Laboratory, Richland, Washington.

PNNL-18784. 2009. Hanford 100-D Area Biostimulation Treatability Test Results. MJ Truex, VR Vermeul, BG Fritz, RD Mackley, DP Mendoza, RP Elmore, AV Mitroshkov, DS Sklarew, CD Johnson, M Oostrom, DR Newcomer, FJ Brockman, CL Bilskis, SS Hubbard, JE Peterson, KH Williams, E Gasperikova, and J Ajo-Franklin, Pacific Northwest National Laboratory, Richland, Washington.

PNNL-19120. 2010. 100-N Area Strontium-90 Treatability Demonstration Project: Phytoextraction Along the 100-N Columbia River Riparian Zone - Field Treatability Study. RJ Fellows, JS Fruchter, CJ Driver, and CA Ainsworth, Pacific Northwest National Laboratory, Richland, Washington.
PNNL-19123. 2010. T Tank Farm Interim Surface Barrier Demonstration - Vadose Zone Monitoring FY09 Report. ZF Zhang, CE Strickland, JG Field, and DL Parker, Pacific Northwest National Laboratory, Richland, Washington.

Resource Conservation and Recovery Act of 1976. 1976. Public Law 94-580, as amended, 42 USC 6901 et seq. and 42 USC 6927(c) et seq. Accessed May 17, 2010, at http:// www.epa.gov/lawsregs/laws/rcra.html.

RPP-RPT-41236. 2009. Surface Geophysical Exploration of UPR 200-E-81 Near the C Tank Farm. M Levitt, Washington River Protection Solutions LLC, Richland, Washington.

RPP-RPT-42513. 2009. Surface Geophysical Exploration of the SX Tank Farm at the Hanford Site. M Levitt, Washington River Protection Solutions LLC, Richland, Washington.

SGW-38991, Rev 0. 2009. Borehole Summary Report for 216-A-5 and 216-S1/S2 Cribs Supplemental Characterization: Boreholes C6551, C6552, C6553, C6554, and C6835, 200-PW-2, and 200-PW-4 Operable Units. CH2M HILL Plateau Remediation Company, Richland, Washington.

SGW-39626, Rev. 0. 2009. Borehole Summary Report for the Installation of Seven Groundwater Monitoring Wells at the 200-BP-5 Operable Unit, CY2008. CH2M HILL Plateau Remediation Company, Richland, Washington.

SGW-39648, Rev. 0. 2009. Summary Report - Direct Push Technology Boreholes for Geophysical Logging 200-IS-1 Operable Unit FY 2008. CH2M HILL Plateau Remediation Company, Richland, Washington.

SGW-39742, Rev. 0. 2009. Data Quality Assessment for the Supplemental Characterization of the 216-A-30, 216-B-55, and 216-S-6 Waste Sites in the 200-SC-1 Operable Unit. CH2M HILL Plateau Remediation Company, Richland, Washington.

SGW-42563, Rev. 0. 2009. Results from Passive Soil-Vapor Sampling in 200-SW-2 Operable Unit Landfills, September 2009. CH2M HILL Plateau Remediation Company, Richland, Washington.

SGW-43771, Rev. 0. 2009. Geophysical Investigations Summary Report 200 Area Burial Grounds: 218-E-2, 218-E-4, 218-E-9, and 218-W-4A. CH2M HILL Plateau Remediation Company, Richland, Washington. 
SGW-45563, Rev. 0. 2010. An Aerial Radiological Survey of the Hanford BC Controlled Area and West Lake Area. CH2M HILL Plateau Remediation Company, Richland, Washington.

Toxic Substances Control Act. 1976. Public Law 94-469, as amended, 15 USC 2601 et seq.

Truex MJ, M Oostrom, and ML Brusseau. 2009. "Estimating Persistent Mass Flux of Volatile Contaminants from the Vadose Zone to Groundwater." Ground Water Monitoring and Remediation 29(2):63-72.

WAC 173-240. 2009. "Submission of Plans and Reports for Construction of Wastewater Facilities." Washington Administrative Code, Olympia, Washington. Accessed May 17, 2010, at http://apps.leg.wa.gov/wac/.

WAC 173-303. 2009. "Dangerous Waste Regulations." Washington Administrative Code, Olympia, Washington. Accessed May 17, 2010, at http://apps.leg.wa.gov/wac/.
WAC 173-303-070(3). 2009. "Designation of Dangerous Waste; Designation Procedures." Washington Administrative Code, Olympia, Washington. Accessed May 17, 2010, at http://apps.leg.wa.gov/wac/.

Wellman DM, EM Pierce, VR Vermeul, SV Mattigod, EL Richards, MD Williams, JS Fruchter, and JP Icenhower. 2008a. Chapter 1, "In Situ Uranium Stabilization through Polyphosphate Remediation: Development and Demonstration at the Hanford Site 300 Area, Washington State." In Waste Management Research Trends, TV Golush (ed.), Nova Science Publishers, Inc., Hauppauge, New York.

Wellman DM, EM Pierce, VR Vermeul, SV Mattigod, EL Richards, MD Williams, JS Fruchter, and JP Icenhower. 2008b. In Situ Uranium Stabilization through Polyphosphate Remediation. Nova Science Publishers, Inc., Hauppauge, New York. 


\subsection{Hanford Site Closure Activities}

This section provides information on Hanford Site cleanup activities as the U.S. Department of Energy (DOE) progresses toward site closure and the likely transfer of property to other entities.

\subsubsection{Radiological Release of Property from the Hanford Site}

\section{WM Glines}

Principle requirements for the control and release of DOE property containing residual radioactivity are in DOE Order 5400.5, Chg 2, "Radiation Protection of the Public and the Environment." These requirements are designed to ensure the following:

- Property is evaluated, radiologically characterized —and where appropriate—decontaminated before release.

- The level of residual radioactivity in property to be released is as near background levels as is reasonably practicable, as determined through DOE's as low as reasonably achievable process requirements, and meets DOE authorized limits.

- All property releases are appropriately certified, verified, documented, and reported; public participation needs are addressed; and processes are in place to appropriately maintain records.

No property with detectable residual radioactivity above authorized levels was released from the Hanford Site in 2009.

\subsubsection{Radiological Clearance for Personal Property Potentially Contaminated with Hard-to-Detect Radionuclides}

\section{WM Glines}

In the process of performing environmental remediation or related support activities, Hanford Site contractors encounter a wide variety of contaminated personal property including consumables, office items, tools and equipment, and debris. Final disposition of these materials depends on whether the property is considered radiologically contaminated, and whether the disposal of such property is subject to Comprehensive Environmental Response, Compensation, and Liability Act of 1980 (CERCLA) requirements. Radiologically contaminated property is disposed at the Environmental Restoration Disposal Facility if subject to CERCLA requirements, and if not, at the Central Waste Complex in the 200-West Area. Personal property that has contamination levels below approved DOE control and release guidelines (DOE Order 5400.5, Chg 2) are considered for release if the property can be reused. Hanford Site contractors routinely encounter a wide variety of radionuclide mixtures ranging from essentially pure plutonium to fission and activation products. Included in these fission and activation products are low-energy beta emitters, such as carbon-14, iron-55, nickel-59, nickel-63, selenium-79, technetium-99, palladium-107, and europium-155 that are difficult or impossible to detect with routine field-survey methods (i.e., hard-to-detect radionuclides).

Traditionally, field detectable or easy-to-detect radionuclides have been used as an analog for the entire mixture of 
radionuclides encountered during work activities. The control and release criteria (DOE Order 5400.5, Chg 2) have been adjusted downward to account for the portion of the activity that is not detectable by field survey methods. As the ratio of hard-to-detect radionuclides to easy-todetect radionuclides increases, the criteria are reduced to a point where the adjusted limits are difficult or impossible to verify with field survey instruments. Decades of radioactive decay have reduced the contributions of easy-to-detect radionuclides to such low levels that current control and release methodologies are no longer sufficient for verifying that contaminant levels comply with the existing, approved DOE property release guidelines in DOE Order 5400.5, Chg 2.

Accordingly, in May 2006, a request to DOE was submitted by Washington Closure Hanford, LLC, the prime contractor for the River Corridor Closure Contract, to increase the release criteria (authorized limits) for hard-to-detect radionuclides. The requested authorized limits would apply only to beta-gamma surface contamination on potentially contaminated equipment and materials, and exclude volumetric contamination (contamination that is distributed throughout the volume of the property), contamination in or on persons, unrestricted release of metals, and alpha-surface contamination. Detailed radiological analyses were performed to demonstrate that these authorized limits would be protective of human health and the environment. Based on these analyses, the authorized limits would result in a dose of less than 1 millirem ( 10 microsievert) in any year to the maximally exposed individual and a collective dose of less than 10 person-rem ( 0.1 person-sievert) to any exposed population. These authorized limits (Table 7.0.1) were reviewed by the DOE Richland Operations Office and DOE

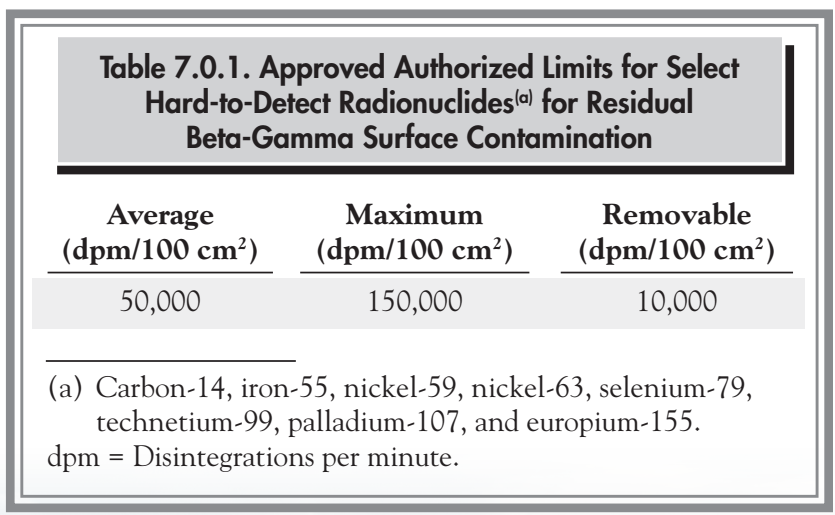

Headquarters personnel and approved for use by Washington Closure Hanford, LLC in May 2007.

In 2008, the DOE Richland Operations Office provided conditional approval to CH2M HILL Plateau Remediation Company and Fluor Hanford, Inc. to use the hard-to-detect authorized limits.

In June 2009, Washington River Protection Solutions LLC submitted a request to the DOE Office of River Protection for approval to use these hard-to-detect authorized limits. The DOE Office of River Protection provided conditional approval for this request in June 2009. In October 2009, Mission Support Alliance, LLC submitted a request to the DOE Richland Operations Office for approval to use these hard-to-detect authorized limits. The DOE Richland Operations Office provided conditional approval for this request in November 2009.

No property with detectable residual radioactivity was released from the Hanford Site in 2009 using these hard-todetect authorized limits.

\subsubsection{Radiological Clearance for lon-Exchange Resin for Offsite Shipment and Regeneration}

\section{WM Glines}

Remedial actions are currently in progress at the Hanford Site for the treatment of groundwater containing hexavalent chromium. Although there are no current unacceptable human health risks from contaminants in the groundwater, primarily because exposure is precluded by DOE Hanford Site controls, a qualitative ecological risk assessment concluded that hexavalent chromium concentrations in groundwater exceeds the U.S. Environmental Protection Agency (EPA) ambient water quality criterion of $10 \mu \mathrm{g} / \mathrm{L}$ $(0.01 \mathrm{ppm})$ for protection of freshwater aquatic life. Therefore, these remedial actions are necessary to protect ecological receptors along the Hanford Reach of the Columbia River.

Remedial actions involve the use of pump-and-treat systems to extract groundwater containing hexavalent chromium from specific target areas. The groundwater is treated using an ion-exchange resin treatment process to remove hexavalent chromium, and the treated groundwater is then 
returned to the aquifer using injection wells. Once saturated, the spent resin is removed from the pump-and-treat system and the resin is prepared for shipment to an offsite facility for regeneration and reuse. Resin regeneration requires chemical washing to release the bound hexavalent chromium.

Based on past Hanford Site activities and the results of characterization sampling, this resin could contain residual radioactivity. Characterization sampling results were also used to determine specific radionuclides of concern for this residual radioactivity. For any potential residual radioactivity, DOE Order 5400.5, Chg 2, requires that the residual radioactivity not exceed established guidelines, or that radiological release criteria (i.e., authorized limits) be developed and submitted to the applicable DOE field office. Guidelines have not been established for volumetric residual radioactivity for the radionuclides of concern for the resin. In January 2007, Fluor Hanford, Inc., the Hanford Site contractor responsible for these remedial actions, submitted a request to the DOE Richland Operations Office for authorized limits to permit offsite shipment and resin regeneration.

Requested authorized limits were developed using realistic and conservative radiation dose analyses based on the "likely use" and "worst-plausible use" scenarios. The expected enduse (i.e., likely use scenario) for this resin was as a filtration media in groundwater remediation. The worst-use scenario was use of the resin in another groundwater remediation system outside of the Hanford Site. Detailed radiological analyses were performed to demonstrate that these authorized limits would be protective of human health and the environment. Based on these analyses, the authorized limits would result in a dose of less than 1 millirem (10 microsievert) in any year to the maximally exposed individual, and a collective dose of less than 10 person-rem ( 0.1 personsievert) to any exposed population.

The DOE Richland Operations Office coordinated review of this authorized limit request with the U.S. Nuclear Regulatory Commission. Based on a review of DOE's process for developing authorized limits, the U.S. Nuclear Regulatory Commission established that coordination was appropriate to ensure that site-specific release limits and survey and review protocols were appropriate and acceptable. The U.S. Nuclear Regulatory Commission indicated that on a case-by-case basis, radioactive material has been transferred to unlicensed entities based on an impact analysis that has demonstrated such a release would result in exposure of less than 1 millirem/year (10 microsievert/year) to any individual and a minimal collective dose. The analyses performed for these authorized limits indicate that any actual releases would meet these criteria. Following review by the DOE Richland Operations Office and DOE Headquarters personnel, these authorized limits (Table 7.0.2) were approved for use by Fluor Hanford, Inc. in August 2007. In October 2008, CH2M HILL Plateau Remediation Company assumed responsibility from Fluor Hanford, Inc. for all Hanford Site groundwater remedial actions. In anticipation of this transfer of responsibility, in September 2008, CH2M HILL Plateau Remediation Company submitted a request to the DOE Richland Operations Office for approval to use the authorized limits for resin previously approved for Fluor Hanford, Inc. The DOE Richland Operations Office approved this request for CH2M HILL Plateau Remediation Company in October 2008.

In 2009 , approximately 62,500 kilograms ( 138,000 pounds) of resin was shipped offsite for regeneration under these approved authorized limits.

\begin{tabular}{|c|c|}
\hline \multicolumn{2}{|c|}{$\begin{array}{l}\text { Table 7.0.2. Approved Authorized Limits for Offsite } \\
\text { Shipment and Regeneration of Ion-Exchange Resin }\end{array}$} \\
\hline$\underline{\text { Radionuclide }}$ & $\begin{array}{l}\text { Authorized Limit } \\
\qquad(\mathrm{pCi} / \mathrm{g})\end{array}$ \\
\hline Tritium & 100,000 \\
\hline Strontium/yttrium-90 & 21,000 \\
\hline Technetium-99 & 400,000 \\
\hline Uranium-233 & 3,700 \\
\hline Uranium-234 & 3,700 \\
\hline Uranium-235 plus short-lived progeny & 390 \\
\hline Uranium-238 plus short-lived progeny & 3,000 \\
\hline
\end{tabular}




\subsubsection{Radiological Clearance for Granular Activated Carbon for Offsite Shipment and Regeneration}

\section{WM Glines}

Carbon tetrachloride was found in the unconfined aquifer beneath the 200-West Area on the Hanford Site in the mid-1980s. Groundwater monitoring indicated the carbon tetrachloride plume was widespread and concentrations were increasing. An expedited response action was initiated in 1992 to extract carbon tetrachloride from the vadose zone in the 200-ZP-2 Operable Unit, currently designated as the 200-PW-1 Operable Unit, in the 200-West Area. The 200-PW-1 Operable Unit soil-vapor extraction system includes vapor-phase granular activated carbon canisters to remove carbon tetrachloride from the extracted vapors prior to discharge. This facility was in full operation by 1995 .

In 1996, workers installed a groundwater pump-and-treat system in a second operable unit (200-ZP-1 Operable Unit) to treat contaminated groundwater in the unconfined aquifer. The system includes an air-stripping unit that volatilizes carbon tetrachloride in the groundwater and then discharges the carbon tetrachloride vapors through granular activated carbon canisters that are identical to the large, carbon-steel granular activated carbon canisters in the 200-PW-1 Operable Unit soil-vapor extraction system.

Each of these systems use granular activated carbon canisters to capture the volatile organic compounds removed during the extraction process. When a granular activated carbon canister has reached volatile organic compound saturation, it is removed from the system and the granular activated carbon is prepared for shipment to an offsite facility for regeneration and reuse. Regeneration of the granular activated carbon requires heating it in a hearth furnace to remove the captured volatile organic compounds.

Based on past Hanford Site activities and the results of characterization sampling, this granular activated carbon could contain residual radioactivity. Characterization sampling results were also used to determine specific radionuclides of concern for this residual radioactivity. For any potential residual radioactivity, DOE Order 5400.5, Chg 2, requires that the residual radioactivity not exceed established guidelines, or that radiological release criteria (i.e., authorized limits) be developed and submitted to the applicable DOE field office. Guidelines have not been established for volumetric residual radioactivity for the radionuclides of concern for the granular activated carbon. Accordingly, in March 2007, Fluor Hanford, Inc., the Hanford Site contractor responsible for these remedial actions, submitted a request to the DOE Richland Operations Office for authorized limits to permit offsite shipment and regeneration of the granular activated carbon.

These requested authorized limits were developed using realistic, yet conservative, radiation dose analyses based on the "likely use" and "worst-plausible use" scenarios. The expected end-use (i.e., likely use scenario) for this granular activated carbon was as a filtration media for pollution controls in industrial processes. The worst-plausible use scenario was use of the granular activated carbon in a home water filtration system. Detailed radiological analyses were performed to demonstrate that these authorized limits would be protective of human health and the environment. Based on these analyses, authorized limits would result in a dose of less than 1 millirem (10 microsievert) in any year to the maximally exposed individual, and a collective dose of less than 10 person-rem (0.1 person-sievert) to any exposed population.

The DOE Richland Operations Office coordinated review of this authorized limit request with the U.S. Nuclear Regulatory Commission. Based on a review of DOE's process for developing authorized limits, the U.S. Nuclear Regulatory Commission established that coordination was appropriate to ensure that site-specific release limits and survey and review protocols were appropriate and acceptable. The U.S. Nuclear Regulatory Commission indicated that on a case-by-case basis, radioactive material is transferred to unlicensed entities based on an impact analysis that demonstrates such a release would result in an exposure of less than 1 millirem/year (10 microsievert/ year) to any individual and a minimal collective dose. The analyses performed for these authorized limits show that any actual releases would meet these criteria. Following review by the DOE Richland Operations Office and DOE Headquarters personnel, these authorized limits were approved for use by Fluor Hanford, Inc. in August 2007 (Table 7.0.3). In October 2008, CH2M HILL Plateau Remediation Company assumed responsibility from Fluor 


\begin{tabular}{|c|c|}
\hline \multicolumn{2}{|c|}{$\begin{array}{l}\text { Table 7.0.3. Approved Authorized Limits for Offsite } \\
\text { Shipment and Regeneration of Granular } \\
\text { Activated Carbon }\end{array}$} \\
\hline$\underline{\text { Radionuclide }}$ & $\begin{array}{l}\text { Authorized Limit } \\
\qquad(\mathrm{pCi} / \mathrm{g})\end{array}$ \\
\hline Tritium & 940,000 \\
\hline Carbon-14 & 10,000 \\
\hline Cobalt-60 & 64 \\
\hline Selenium-79 & 6,200 \\
\hline Strontium-90 & 320 \\
\hline Technetium-99 & 1,600 \\
\hline Iodine-129 & 170 \\
\hline Cesium-137 & 250 \\
\hline Europium-152 & 130 \\
\hline Europium-154 & 120 \\
\hline Europium-155 & 2,100 \\
\hline Protactinium-231 & 38 \\
\hline Thorium-232 plus progeny & 18 \\
\hline Uranium-234 & 360 \\
\hline Uranium-235 & 390 \\
\hline Neptunium-237 & 170 \\
\hline Plutonium-238 & 79 \\
\hline Uranium-238 plus short-lived progeny & 370 \\
\hline Plutonium-239 & 72 \\
\hline Plutonium-240 & 72 \\
\hline Americium-241 & 88 \\
\hline
\end{tabular}

Hanford, Inc. for all Hanford Site groundwater remedial actions. In anticipation of this transfer of responsibility, in September 2008, CH2M HILL Plateau Remediation Company submitted a request to the DOE Richland Operations Office for approval to use the authorized limits for granular activated carbon previously approved for Fluor Hanford, Inc. The DOE Richland Operations Office provided approval for this request to CH2M HILL Plateau Remediation Company in October 2008.

In 2009 , approximately 16,400 kilograms (36,000 pounds) of granular activated carbon was shipped offsite for regeneration under these approved authorized limits.

\subsubsection{Columbia River Corridor Mission Completion}

\section{JA Lerch}

The Columbia River Corridor includes the Hanford Site 100 and 300 Areas, which border the Columbia River. The 100 and 300 Areas include hundreds of contaminated excess facilities, 9 deactivated plutonium-production reactors, and nearly 600 liquid- and solid-waste disposal sites. DOE's award of the River Corridor Closure Contract to Washington Closure Hanford, LLC in 2005 has allowed cleanup actions to continue in the 100 and 300 Areas with completion as a primary focus. The principle goals of DOE's River Corridor Closure Contract are to complete the following:

- Deactivate, decontaminate, decommission, and demolish excess facilities

- Place former production reactors in an interim safe and stable condition

- Remediate liquid-and solid-waste disposal sites

- Meet all regulatory requirements

- Determine the adequacy of the current cleanup criteria in protecting human health and the environment

- Prepare the Hanford Site's River Corridor for transfer to long-term stewardship.

The last two items are being addressed under the River Corridor Closure Contract by the Environmental Protection Mission Completion Project. Key project scope includes assessment and integration activities (http://www. washingtonclosure.com/projects/environmental_protection/ mission_completion/assessment_integration/) and long-term stewardship support (http://www.washingtonclosure.com/ projects/environmental_protection/mission_completion/ long-term-stewardship/). Ongoing, open communication among the many parties interested in Hanford Site cleanup continued in 2009 as work progressed in these areas. 


\subsubsection{Assessment and Integration}

\section{JA Lerch}

River Corridor Baseline Risk Assessment. DOE's cleanup plans for the Columbia River Corridor are based on CERCLA requirements. In 1991, DOE, EPA, and the Washington State Department of Ecology (Tri-Party Agreement agencies) agreed that interim remedial actions in the 100 and 300 Areas could be implemented by relying on streamlined qualitative risk assessments rather than a quantitative baseline risk assessment. Waste-site cleanup under interim action records of decision was initiated during the mid-1990s and is planned for completion by Washington Closure Hanford, LLC by 2015. The contractor's current focus is on completing the remedial actions so the Tri-Party Agreement agencies can proceed to final CERCLA closeout of the 100 and 300 Areas. A critical step in proceeding toward final CERCLA closeout is completing the River Corridor Baseline Risk Assessment, a quantitative baseline risk assessment that Washington Closure Hanford, LLC is conducting.

Collection of environmental and biological samples to support development of the River Corridor Baseline Risk Assessment was initiated in 2005 and completed in 2006. Additional sampling for the riparian and near-shore environments of the River Corridor within the reactor and operational areas was conducted in 2006 and 2007. Results from these sampling efforts, combined with relevant existing data, are being used in the preparation of the River Corridor Baseline Risk Assessment (Draft B), which is scheduled for regulatory and stakeholder review in 2010. At the direction of the Tri-Party Agreement agencies and in response to stakeholder feedback, an enhanced characterization of risks associated with groundwater will also be included in the River Corridor Baseline Risk Assessment Draft B report. The report will support recommendations for final cleanup decisions at source and groundwater units within the River Corridor.

\section{Remedial Investigation of Hanford Site Releases to the} Columbia River. A remedial investigation under CERCLA has been initiated to evaluate the potential impacts to the Columbia River from Hanford Site-related hazardous substances released from waste sites along the River Corridor and to support final cleanup decisions. Approval of the
Remedial Investigation Work Plan for Hanford Site Releases to the Columbia River (DOE/RL-2008-11) to perform field sampling was completed in October 2008, followed by the initiation of sampling activities. The extent of the remedial investigation includes locations above the Wanapum Dam, focuses on areas within the Hanford Reach and Lake Wallula downstream to McNary Dam, and includes some sampling in the vicinity of the Bonneville Dam. Activities include sampling of Columbia River water and incoming irrigation return discharges; pore water, sediment, soils on islands throughout the Hanford Reach; and collection and analysis of six different fish species. A majority of the sampling was completed by June 2009; fish collection is ongoing.

In 2008, workers initiated an evaluation of groundwater upwelling within the Hanford Reach of the Columbia River from the 100 Areas downriver to the 300 Area. The initial phases completed in 2009 included measurements of porewater specific conductance, temperature, and a screening analysis of key Hanford Site indicator contaminants. The final phase of sampling of pore water, sediment, and river water at selected locations was initiated in fall 2009 and is scheduled to be completed in 2010 .

Following completion of field work and compilation of all analytical data, workers will conduct baseline ecological and human-health risk assessments to estimate the current risk to humans, animals, and plants; potential impacts from Hanford Site-related contaminants; and determine whether cleanup actions are needed.

\section{River Corridor Remedial Investigation/Feasibility}

Study Process. In 2009, Washington Closure Hanford, LLC supported the development of integrated source and groundwater remedial investigation/feasibility study work plans and sampling and analysis plans for the six River Corridor decision areas (100-B/C, 100-K, 100-N, 100-D/H, and 100-F/IU-2/IU-6), and the 300 Area. The integrated work plans include summaries of current information and future data needs for both soil and groundwater. Draft work plans and sampling and analysis plans for each decision area were distributed to EPA and the Washington State Department of Ecology for review in 2009. Approval of the work plans and sampling and analysis plans are expected in 2010, with field data collection and remedial investigation/ feasibility study report preparation extending through 2011. 


\subsubsection{River Corridor Long-Term Stewardship CS Cearlock}

The long-term stewardship task is focused on achieving end-state closure and transition of the River Corridor to long-term stewardship. Within the River Corridor Closure Contract, key elements of the long-term stewardship work include the preparation of remedial action reports for each CERCLA-source operable unit and development of a draft long-term stewardship plan. Preparation for transition to long-term stewardship also includes "orphan site" evaluations. These evaluations include a systematic approach to review land parcels and identify potential waste sites (orphan sites) in the River Corridor that are not currently listed in existing CERCLA decision documents. Orphan site evaluations consist of comprehensive reviews of historical documentation, field investigations, and geophysical surveys.

In 2009, workers completed orphan site evaluations and issued reports for the 100-D Area (OSR-2006-0001, Rev. 0), 100-K Area (OSR-2008-0003, Rev. 0), 100-H Area (OSR-2008-0002, Rev. 0), 100-N Area (OSR-2009-0001, Rev. 0), and the 100-IU-2 and 100-IU-6 Operable Units (OSR-2008-0001, Rev. 0). Workers also initiated evaluations for the 300 Area, 400 Area, and Inter-Areas Segments 1 and 2 .

The results of risk assessment activities, orphan site evaluations, remedial action reports, and long-term stewardship plans will provide a basis for independent closure reviews of the 100 and 300 Areas by independent experts. The independent closure reviews will assure that implemented remedies meet the remedial action objectives established in the source operable unit records of decision, and that no further action is needed to protect human health and the environment. These activities will culminate in development of a final long-term stewardship plan that will contain a proposed finding of suitability to transfer property in accordance with CERCLA Section 120(h) and the final criteria for long-term stewardship.

\subsubsection{References}

Comprehensive Environmental Response, Compensation, and Liability Act of 1980. 1980. Public Law 96-510, as amended, 42 USC 9601 et seq. Accessed May 17, 2010, at http:// www.epa.gov/lawsregs/laws/cercla.html.

DOE Order 5400.5, Chg 2. 1993. "Radiation Protection of the Public and the Environment." U.S. Department of Energy, Washington, D.C.

DOE/RL-2008-11. 2008. Remedial Investigation Work Plan for Hanford Site Releases to the Columbia River. U.S. Department of Energy, Richland Operations Office, Richland, Washington.

OSR-2006-0001, Rev. 0. 2009. 100-D Area Orphan Sites Evaluation Report. Washington Closure Hanford, LLC, Richland, Washington.

OSR-2008-0001, Rev. 0. 2009. 100-IU-1 and 100-IU-6 Areas Orphan Sites Evaluation Report. Washington Closure Hanford, LLC, Richland, Washington.

OSR-2008-0002, Rev. 0. 2009. 100-H Area Orphan Sites Evaluation Report. Washington Closure Hanford, LLC, Richland, Washington.

OSR-2008-0003, Rev. 0. 2009. 100-K Area Orphan Sites Evaluation Report. Washington Closure Hanford, LLC, Richland, Washington.

OSR-2009-0001, Rev. 0. 2009. 100-N Area Orphan Sites Evaluation Report. Washington Closure Hanford, LLC, Richland, Washington. 


\subsection{Environmental and Resource Protection Programs}

U.S. Department of Energy (DOE) Orders 450.1A and 5400.5, Chg 2 require that environmental monitoring programs be conducted on the Hanford Site to verify protection of the site's environmental and cultural resources, the public, and workers at the site. These monitoring activities support the site's Integrated Safety Management System Policy (DOE Policy 450.4) and its component Environmental Management System (Section 4.0.1). Component systems are tools for achieving site and contractor compliance with environmental, public health, and resource protection laws, regulations, and DOE Orders.

The Environmental Monitoring Plan United States Department of Energy, Richland Operations Office (DOE/RL-91-50, Rev. 4) provides implementation guidance for Hanford Site monitoring programs and projects. The plan contains the rationale for the required programs and projects, including design criteria, sampling locations and schedules, quality assurance requirements, program and project implementation procedures, analytical procedures, and reporting requirements. The early identification of-and appropriate response to- potentially adverse environmental and resource effects associated with DOE operations are confirmed by the following:

- Pre-operational environmental characterization, assessments, and evaluations

- Effluent and emissions monitoring

- Environmental monitoring and surveillance (as defined in DOE Order 5400.5, Chg 2 and in Appendix B of this report, "Glossary")

- Cultural resources monitoring

- Controlling and monitoring of contaminated and undesirable biota.
Objectives of the monitoring programs include the following:

- Detecting, characterizing, and responding to contaminant releases from Hanford Site DOE facilities and operations

- Providing data to assess the human health and ecological impacts of Hanford Site-produced contaminants

- Estimating contaminant dispersal patterns in the environment

- Characterizing pathways of exposure to the public and biota

- Characterizing exposures and doses to individuals, nearby populations, and biota

- Evaluating potential impacts to biota (and the Columbia River) in the vicinity of DOE Hanford Site activities

- Verifying that environmental monitoring programs are conducted in an integrated fashion to preclude collecting duplicative environmental data

- Verifying early identification of, and appropriate response to, the potentially adverse environmental impact associated with DOE operations

- Promoting long-term stewardship of Hanford Site natural and cultural resources

- Protecting natural and cultural resources.

Other important reasons for conducting these monitoring activities include the following:

- Complying with and confirming site compliance with DOE Orders and local, state, and federal laws and regulations 
- Verifying the efficacy of waste-management practices on the Hanford Site

- Providing information to reassure the public that Hanford Site facilities and operations are not adversely affecting people or the environment

- Answering questions or providing information to stakeholders, activist organizations, and the public

- Supporting DOE decisions

- Providing information to support DOE in environmental litigations.

Brief summaries of DOE environmental monitoring programs and projects, including Effluent and Near-Facility Environmental Monitoring Programs, Public Safety and Resource Protection Projects, the Soil and Groundwater Remediation Project, the Drinking Water Monitoring Project, the Biological Control Program, and the Washington State Department of Health Oversight Monitoring Program, are provided in the following subsections. Subsections within this chapter address specific media and programs that interrelate with these programs.

\subsubsection{Effluent and Near- Facility Environmental Monitoring Programs}

\section{JJ Dorian}

Effluent and near-facility environmental monitoring on the Hanford Site consists of 1) liquid effluent and airborne emissions monitoring at site facilities and operations, and 2) environmental monitoring near facilities and operations that have the potential to discharge, or have discharged, stored, or been a disposal site for radioactive and hazardous materials. Categories of effluent that normally or potentially contain radionuclides or hazardous materials include cooling water, steam condensates, process condensates, and wastewater from laboratories and chemical sewers. Airborne emissions can include both radioactive and non-radioactive particulate, and gaseous or volatilized materials from facility stacks and vents.

\subsubsection{Liquid Effluent and Airborne Emissions Monitoring}

Hanford Site contractors perform real-time monitoring of liquid effluent and airborne emissions at each facility to assess the effectiveness of effluent and emissions treatment and control systems as well as pollution-management practices. Monitoring is also conducted to determine facility and site compliance with state and federal regulatory requirements. Section 8.3 and an annual environmental release report (e.g., HNF-EP-0527-19) summarize information on effluent discharged from Hanford Site facilities in 2009. Section 8.1 and other reports (e.g., DOE/RL-2010-17) summarize air emissions data for 2009.

\subsubsection{Near-Facility Environmental Monitoring}

Near-facility environmental monitoring is conducted near DOE facilities and operations on the Hanford Site that have the potential to discharge, or have discharged, stored, or been a disposal site for radioactive or hazardous contaminants. Monitoring locations are associated with nuclear facilities, such as the Canister Storage Building; inactive nuclear facilities, such as N Reactor, the Plutonium Finishing Plant, and the Plutonium Uranium Extraction (PUREX) Plant; and active and inactive waste storage or disposal facilities, such as burial grounds, cribs, ditches, ponds, underground waste storage tanks, and trenches. Much of the monitoring program includes collecting and analyzing environmental samples and conducting radiological surveys in areas near facilities. The program also evaluates and reports analytical data, determines the effectiveness of facility effluent monitoring and controls, measures the adequacy of containment at waste-disposal sites, and detects and monitors unusual conditions. The program implements applicable portions of DOE Orders 435.1, 450.1A, and 5400.5, Chg 2; DOE Manual 231.1-1A; 10 CFR 835 and 40 CFR 61; and WAC 246-247.

Several types of environmental media are sampled routinely near Hanford Site facilities, and various radiological and non-radiological measurements are taken. The media sampled include air, soil, and vegetation. Surface contamination and external radiation levels are also monitored. 
Media samples are collected from known or expected emissions and effluent pathways, which are generally downwind of potential or actual airborne releases and downgradient of liquid discharges.

Active and inactive waste disposal sites and the terrain surrounding them are surveyed to detect and characterize radioactive surface contamination. Routine radiological survey locations include former waste disposal cribs and trenches; retention-basin perimeters; ditch banks; solid waste disposal sites (e.g., burial grounds); unplanned release sites; tank-farm perimeters; stabilized-waste disposal sites; roads; and firebreaks in and around the site operational areas. Investigations of contaminated biota, soil, and other materials are conducted in the operational areas to monitor the presence or movement of radioactive or hazardous materials around areas of known or suspected contamination, or to verify radiological conditions at specific project (e.g., cleanup or construction) sites. Investigations for contaminants are conducted for at least one of the following reasons:

- To follow up on surface radiological surveys that had indicated radioactive contamination was present

- To conduct pre-operational surveys to characterize the radiological and chemical conditions at a site before facility construction, operation, or ultimate remediation

- To determine if biotic intrusion (e.g., animal burrows or deep-rooted vegetation) had created a potential for contaminants to spread

- To determine the integrity of waste-containment systems.
Contamination incidents investigated in 2009 focused on soil, vegetation, wildlife, and wildlife-related materials (e.g., bird nests, animal feces). Most materials were surveyed in the field to detect radioactive contamination. Some materials were sampled, and the samples were submitted for laboratory analysis. Laboratory analysis results and fieldsurvey readings for contamination incidents investigated in 2009 are provided in a separate appendix (PNNL-19455, APP. 2).

Sections 8.2, 8.9, 8.10, 8.11, and 8.17 summarize information on contaminant concentrations or radiation levels measured onsite near facilities and operations during 2009. Additional data may be found in PNNL-19455, APP. 2. Table 8.0.1 summarizes the type and general locations of samples collected for near-facility monitoring during 2009. Sections 8.9 and 8.10 summarize information on contamination incidents investigated during 2009.

\subsubsection{Public Safety and Resource Protection Program Projects}

\section{JP Duncan}

The Public Safety and Resource Protection Program for the Hanford Site is managed by Pacific Northwest National Laboratory for the DOE Richland Operations Office. Projects include the Ecological Monitoring and Compliance Project, the Meteorological and Climatological Services Project, the Surface Environmental Surveillance Project, and the Cultural Resources Project. These projects are designed to monitor the Hanford Site environment;

\begin{tabular}{|c|c|c|c|c|c|c|c|c|c|c|}
\hline \multirow[b]{3}{*}{ Sample Type } & \multicolumn{8}{|c|}{$\begin{array}{l}\text { Table 8.0.1. Routine Environmental Monitoring Samples and Locations } \\
\text { Near Hanford Site Facilities and Operations, } 2009\end{array}$} & & \\
\hline & \multirow{2}{*}{$\begin{array}{l}\text { No. of Sample } \\
\text { Locations }\end{array}$} & \multicolumn{9}{|c|}{ Operational Area } \\
\hline & & $\underline{100-K}$ & $\underline{100-\mathrm{N}}$ & $\underline{100-D}$ & $\underline{100-H}$ & 200-East & 200-West & $\underline{300 / 400}$ & $\underline{600}$ & $\underline{E R D F}^{(a}$ \\
\hline Air & 84 & 10 & 3 & 4 & 4 & 21 & 24 & 7 & 8 & 3 \\
\hline Soil & 73 & 0 & 0 & 0 & 4 & 13 & 26 & 14 & 15 & 1 \\
\hline Vegetation & 58 & 0 & 3 & 0 & 0 & 8 & 18 & 14 & 15 & 0 \\
\hline External radiation & 119 & 18 & 5 & 0 & 0 & 43 & 24 & 25 & 1 & 3 \\
\hline
\end{tabular}


reassure the public that the Hanford Site is operating in compliance with applicable environmental regulations; and conduct impact assessments to protect the public, worker safety, and cultural and ecological resources. Surveillance data concerning environmental effects as related to public health are collected by an independent contractor not associated with facility contractors or subcontractors, enabling DOE to manage environmental risks on the Hanford Site.

Information summarizing the Public Safety and Resource Protection Program projects is provided in the following sections.

\subsubsection{Meteorological and Climatological Services Project}

The Meteorological and Climatological Services Project provides support to DOE and Hanford Site contractors to reassure the public that activities conducted on the site that may be impacted by adverse meteorological conditions (e.g., thunderstorms, strong winds, dense fog, blowing dust, and snowstorms) are conducted in as safe and efficient a manner as possible. The project measures, analyzes, and archives meteorological data, including wind direction, wind speed, temperature, precipitation, atmospheric pressure, and humidity, from monitoring stations positioned on and around the Hanford Site. The project also provides meteorological response in the event of a suspected or actual release of hazardous or radioactive material to the atmosphere, contributing to appropriate and timely decisions.

Comprehensive meteorological records are maintained for other applications as well, including environmental impact statements, dose reconstruction, post-accident analyses, or building design. Section 8.16 summarizes meteorological data for 2009, including some historical climatological information.

\subsubsection{Surface Environmental Surveillance Project}

Surface Environmental Surveillance Project personnel are responsible for measuring the concentrations of radiological and non-radiological contaminants in environmental media onsite within the 600 Area (site-wide) and offsite at perimeter, community, and distant locations, and to determine the potential effects of these materials on the environment and to the public. Samples of agricultural products, air, fish and wildlife, soil, surface water and sediment, water and sediment from Columbia River shoreline springs, and vegetation are collected routinely and are analyzed for radionuclides and chemicals, including metals, organics, and anions.

Project monitoring activities focus on routine releases from DOE facilities on the Hanford Site. However, the project also conducts sampling and analysis in response to known unplanned releases and releases from non-DOE operations on and near the site. Monitoring results are provided to DOE and the public annually through this Hanford Site environmental report series. Unusually high contaminant concentrations, should they occur, are reported to the DOE Richland Operations Office and the appropriate facility managers on a timely basis.

Through the Surface Environmental Surveillance Project, personnel follow general requirements and objectives: monitor routine and non-routine contaminant releases to the environment from DOE facilities and operations, assess doses to members of the public, monitor potential impacts of contaminants on other biota, and alert DOE to the possible need for corrective action (DOE Orders 450.1A and 5400.5, Chg 2; Environmental Regulatory Guide for Radiological Effluent Monitoring and Environmental Surveillance [DOE/EH-0173T]).

Specific objectives of the monitoring activities include the following:

- Collecting and analyzing samples, reviewing and interpreting analytical data, and maintaining and overseeing a long-term computer database for trend analysis

- Determining compliance with applicable environmental quality standards, public exposure limits, and applicable laws and regulations; requirements of DOE Orders; and environmental commitments made in environmental impact statements, environmental assessments, safety analysis reports, or other official DOE documents

- Performing pre-operational assessments 
- Assessing radiological doses to the public and environment

- Assessing doses from other local sources

- Reporting alarm levels and potential doses exceeding exposure limits

- Determining contaminant background levels and site contributions of contaminants in the environment

- Determining long-term accumulations of siterelated contaminants in the environment and trend predictions

- Characterizing and defining trends in the physical, chemical, and biological conditions of environmental media

- Determining the effectiveness of treatments and controls in reducing effluents and emissions

- Determining the validity and effectiveness of models in predicting environmental pollutant concentrations

- Detecting and quantifying unplanned releases

- Identifying and quantifying new environmental quality problems

- Maintaining the capability to assess the consequences of accidental contaminant releases

- Reassuring the public and addressing issues of concern to the public, stakeholders, regulatory agencies, and business community

- Increasing public understanding of site environmental issues, primarily through public involvement, and providing environmental information to the public

- Providing environmental data and assessments to assist DOE and its contractors in environmental management of the site.

Annual project reviews are performed to verify that the project 1) is aligned with current operations and missions, 2) is focused on those contaminants having the greatest contribution to the potential offsite dose, and 3) provides the greatest amount of useful information for the waste management, cleanup, and environmental assessment activities planned or ongoing on the Hanford Site. Site-wide and offsite surveillance are closely related to, and coordinated with, the Near-Facility Environmental Monitoring Program described in Section 8.0.1.2 and the Soil and Groundwater Remediation Project (Section 8.0.3).
Sections 8.2, 8.4, 8.5, 8.8, 8.10, 8.11, and 8.12 summarize information on contaminant concentrations in project samples collected at site-wide and offsite locations during 2009. More detailed contaminant data are provided in the Hanford Site Environmental Surveillance Data Report for Calendar Year 2009 (PNNL-19455, APP. 1). The types and general locations of samples collected for site-wide and offsite environmental surveillance during 2009 are summarized in Table 8.0.2.

\subsubsection{Ecological Monitoring and Compliance Project}

The Ecological Monitoring and Compliance Project has multiple objectives that support both activity-specific ecological compliance requirements and site-wide requirements to verify that natural resources on the Hanford Site are protected. Project personnel monitor the abundance, vigor, and distribution of plant and animal populations on the site and evaluate the cumulative impact of Hanford Site operations on these resources. In addition, project researchers perform baseline ecological resource surveys to document the occurrence of protected resources. The surveys help researchers evaluate and document impacts to protected species and habitats as required by the National Environmental Policy Act of 1969 and the Endangered Species Act of 1973, facilitate cost-effective regulatory compliance, and make sure that DOE fulfills its responsibilities to protect natural resources. This project also supports multiple objectives for completing the Hanford Site waste management and environmental restoration mission through the following activities:

- Verifying Hanford Site operational compliance with laws and regulations, including the Endangered Species Act of 1973, the Bald and Golden Eagle Protection Act, and the Migratory Bird Treaty Act

- Identifying biotic contaminant transport pathways and characterization of risks

- Providing data for environmental impact and ecological risk assessments

- Providing maps and information useful for mitigating the impact on biological resources during facility expansions and decommissioning activities

- Supporting Hanford Site land-use planning and stewardship. 


\begin{tabular}{|c|c|c|c|c|c|c|c|c|}
\hline \multirow[b]{4}{*}{ Type } & \multicolumn{7}{|c|}{$\begin{array}{c}\text { Table 8.0.2. Types and General Locations of Samples Collected for Site-Wide and } \\
\text { Offsite Environmental Surveillance in } 2009\end{array}$} & \\
\hline & \multirow{3}{*}{$\begin{array}{c}\text { Total } \\
\text { Number of } \\
\underline{\text { Locations }}\end{array}$} & \multicolumn{7}{|c|}{ Sampling Locations } \\
\hline & & \multirow[b]{2}{*}{ Onsite $^{(\mathrm{a})}$} & \multirow[b]{2}{*}{$\begin{array}{l}\text { Site } \\
\text { Perimeter }^{(\mathbf{b})}\end{array}$} & \multirow[b]{2}{*}{$\underline{\text { Nearby }}^{(\mathbf{c})}$} & \multirow[b]{2}{*}{$\underline{\text { Distant }}^{(\mathbf{c})}$} & \multicolumn{3}{|c|}{ Columbia River } \\
\hline & & & & & & $\underline{\text { Upstream }}^{(\mathrm{c})}$ & $\begin{array}{l}\text { Hanford } \\
\underline{\text { Reach }}^{(\mathbf{b})}\end{array}$ & $\underline{\text { Downstream }}^{(\mathrm{c})}$ \\
\hline Air & 42 & 23 & 11 & 7 & 1 & & & \\
\hline Spring water & 17 & & & & & & 16 & 1 \\
\hline Spring sediment & 10 & & & & & & 9 & 1 \\
\hline $\begin{array}{l}\text { Columbia River } \\
\text { water }\end{array}$ & 46 & & & & & 5 & 30 & 11 \\
\hline Irrigation water & 2 & & & 2 & & & & \\
\hline Drinking water & 4 & 4 & & & & & & \\
\hline River sediment & 8 & & & & & 2 & 3 & 3 \\
\hline Ponds & 2 & 2 & & & & & & \\
\hline Pond sediment & 1 & 1 & & & & & & \\
\hline Foodstuffs & 9 & & 6 & 3 & & & & \\
\hline Wildlife & 3 & 2 & & & 1 & & & \\
\hline Aquatic biota & 2 & & & & & 1 & 1 & \\
\hline $\begin{array}{ll}\text { (a) Surveillanc } \\
\text { (b) Surveillanc } \\
\text { (c) Surveillanc }\end{array}$ & $\begin{array}{l}\text { one } 1 \text { (between } \\
\text { one } 2 \text { (near or ju } \\
\text { one } 3 \text { (in and be }\end{array}$ & $\begin{array}{l}\text { the Near-Fa } \\
\text { st inside th } \\
\text { tween com }\end{array}$ & $\begin{array}{l}\text { lity Environme } \\
\text { site boundary). } \\
\text { unities within a }\end{array}$ & 80-kilomet & $\begin{array}{l}\text { g Program sa } \\
\text { [50-mile] ra }\end{array}$ & $\begin{array}{l}\text { npling location } \\
\text { ius of the site's }\end{array}$ & $\begin{array}{l}\text { and the sit } \\
\text { ndustrial ar }\end{array}$ & $\begin{array}{l}\text { perimeter). } \\
\text { as). }\end{array}$ \\
\hline
\end{tabular}

These activities are intended to help protect the natural resources within the DOE-operated portions of the Hanford Site, including the DOE-managed portion of the Hanford Reach National Monument, as well as to provide information useful to Hanford Site natural resource stakeholders and the public on the status of some of the site's most highly valued biological resources. Information concerning endangered and threatened species on the Hanford Site is summarized in Section 8.13. Ecosystem and compliance monitoring information for 2009 for Hanford Site plant and animal species and communities is summarized in Section 8.14.

\subsubsection{Cultural Resources Project}

The Cultural Resources Project operates the Hanford Cultural Resources Laboratory for DOE. Project personnel perform baseline cultural resource surveys to document the occurrences of protected resources, evaluate and document impacts to protected resources as required by federal laws, facilitate regulatory compliance, and make sure that DOE fulfills its responsibilities to protect cultural resources. A summary of Hanford Site cultural resource monitoring activities conducted in 2009 is provided in Section 8.15.

\subsubsection{Soil and Groundwater Remediation Project}

\section{LC Swanson}

DOE, with the concurrence of the Washington State Department of Ecology and the U.S. Environmental Protection Agency (EPA), issued the Hanford Site Groundwater Strategy: Protection, Monitoring, and Remediation (DOE/RL2002-59) (henceforth known as the Hanford Site Groundwater Strategy) in February 2004. The document was prepared as a collaborative effort to present "a strategy for multiple regulatory authorities and government agencies to effectively protect and restore groundwater at the Hanford Site."

The Hanford Site Groundwater Strategy focuses on three key areas: groundwater protection, groundwater monitoring, and remediation of contaminated groundwater. All three of these strategic areas are implemented through the Soil and Groundwater Remediation Project. Activities performed by the project include an ongoing monitoring and assessment program to determine the distribution and 
movement of existing radiological and chemical contamination in the soil and groundwater beneath the Hanford Site. The project identifies and characterizes potential and emerging groundwater contamination problems in areas of interest that have been organized and referred to as operable units. Monitoring activities in and around these operable units are conducted to comply with a variety of state and federal regulations, including the Atomic Energy Act of 1954, the Resource Conservation and Recovery Act of 1976 (RCRA), the Comprehensive Environmental Response, Compensation, and Liability Act of 1980 (CERCLA), DOE Orders (e.g., 5400.5, Chg 2), and Washington State regulations, as well as requirements for operational monitoring around retired reactors and chemical-processing facilities and requirements for environmental surveillance.

Groundwater samples were collected from 11 groundwater operable units and other portions of the Hanford Site, including 918 monitoring wells and 317 shoreline aquifer tubes during the 2009 reporting period. As a result of changing from fiscal year to calendar year reporting, the 2009 reporting period covers from October 1, 2008, to December 31, 2009. Section 8.7 summarizes groundwater monitoring activities and analytical results for the reporting period.

\subsubsection{Drinking Water Monitoring Project}

\section{GW Patton and LM Kelly}

Public drinking water supplies on sites operated by DOE or a DOE contractor are regulated by EPA. Radiation dose limits are directed by DOE Order 5400.5, Chg 2, which restricts levels to those mandated by law in 40 CFR 141, "National Primary Drinking Water Regulations"-the federal drinking water standards. State governments administer and enforce EPA limits through their health departments and environmental agencies. The Washington State Department of Health enforces federal drinking water laws through state administrative codes. The Drinking Water Monitoring Project conducts routine monitoring of drinking water supplies on the Hanford Site. Water supplies on the site are provided by the city of Richland and by DOE-owned, contractor-operated, water treatment systems that use water from the Columbia River and wells. Although the city of Richland water supplies are not monitored through the Drinking Water Monitoring Project, the city drinking water intake on the Columbia River is monitored. Section 8.6 summarizes radiological monitoring results for the Hanford Site drinking water systems in 2009.

\subsubsection{Biological Control Program}

\section{AR Johnson}

Biological control is any activity to prevent, limit, clean up, or remediate the impact to the environment or human health and safety from radioactively contaminated (contaminated) or undesirable plants or animals. Biological Control Program personnel are responsible for integrating 1) expanded radiological surveillance to determine the extent of contaminated biota and soil, 2) control of undesirable plants and animals, including noxious weeds, 3) cleanup of contamination spread by biotic vectors, and 4) revegetation of areas affected by radioactive contamination spread by plants and animals as well as blowing dust or sand, and recovery from wildland fires or prescribed burns.

The control of weeds and pests is an important part of the Biological Control Program. Weeds on industrial sites on the Hanford Site threaten to accumulate radionuclides, become fire hazards, or interfere with work or machinery. On the Hanford Site, weed control occurs at tank farms (groups of underground radioactive waste storage tanks); radioactive waste pumping installations; industrial sites; power stations; along transmission lines, buildings, storage and work areas; and along fence lines. Pest control prevents, limits, or removes undesirable plants or animals by applying chemicals or by cultural or mechanical methods.

Noxious weeds are controlled onsite to prevent their spread and reduce or eliminate their populations. A noxious weed is a legal and administrative category designated by federal or state regulatory agencies (e.g., the U.S. Department of Agriculture or Washington State Department of Agriculture). Noxious weeds are non-native, aggressively invasive, and hard to control. Damage to natural ecosystems and loss of productive agricultural lands can occur unless control 
measures are taken. Control measures can be mechanical, chemical, or biological. Biological control may include preventive measures or measures in response to existing contamination spread.

Activities to prevent the spread of contamination include radiological surveys, preventive controls (e.g., herbicide spraying), revegetation of eroding areas, and the placement of engineered barriers. If contamination has already spread, typical response measures may include posting the area with radiation-indicating signs, stabilizing the contamination to keep it from spreading, and cleaning up or removing the contamination to an approved disposal location.

In some cases, revegetation is necessary following cleanup and removal of contamination. Revegetation is a common activity on the Hanford Site but has specific meanings and limitations when applied to biological control. Revegetation may include removing and replacing soil, revegetating the soil surface, or placing engineered barriers to stop biological intrusion (biological barriers). Such revegetation on radioactive waste sites is typically performed to prevent recurrence of surface radioactive contamination or colonization by unwanted biota. Section 8.10 provides a description of activities conducted for the Biological Control Program in 2009.

\subsubsection{Washington State Department of Health Oversight Monitoring}

\section{JJ Dorian}

The Environmental Radiation Monitoring and Assessment section of the Washington State Department of Health conducts an independent oversight program on Hanford Site environmental radiation monitoring conducted by DOE contractors. During most of 2009, the contractors were Pacific Northwest National Laboratory, EnergySolutions, and Fluor Hanford, Inc. The environmental monitoring scope performed by EnergySolutions and Fluor Hanford, Inc. was taken over by Mission Support Alliance, LLC on August 24, 2009, maintaining involvement of the same personnel. The main objectives of the Washington State Department of Health oversight program are to verify the quality of contractor monitoring programs and to make sure the programs are adequate to protect public health.

The objectives of the Washington State Department of Health oversight program are achieved through split sampling with the contractors and independent sampling at contractor sampling sites. Washington State Public Health Laboratory personnel provide a check on contractor analyses and analyze Washington State Department of Health samples. Each year, the Washington State Department of Health compares the radioactivity measurements in Washington State Department of Health and contractor samples in a quantitative manner to determine the accuracy and reliability of contractor monitoring. The results of the Washington State Department of Health oversight program are published in the Hanford Environmental Oversight Program data summary report (e.g., DOH 320-051). 


\title{
8.1 Air Emissions
}

\author{
DJ Rokkan
}

Hanford Site contractors monitor airborne emissions from site facilities to determine compliance with state and federal regulatory requirements as well as to assess the effectiveness of emission control equipment and pollution management practices. Measuring devices quantify most facility emission flows while other emission flows are calculated using process information or fan manufacturers' specifications. Most facility radioactive air emission units are actively ventilated stacks that are sampled either continuously or periodically. Airborne emissions with a potential to contain radioactive materials at prescribed threshold levels are measured for gross alpha and gross beta concentrations and, as warranted, specific radionuclides. Non-radioactive constituents and parameters are monitored directly, sampled and analyzed, or estimated based upon inventory usage.

Emission data are documented in this and other reports, all of which are available to the public. For instance, DOE annually submits to EPA and the Washington State Department of Health a report of radionuclide air emissions from the site (DOE/RL-2010-17) in compliance with 40 CFR 61, Subpart H, and with WAC 246-247.

\subsubsection{Radioactive Airborne Emissions}

Small quantities of particulate and volatilized forms of radionuclides are emitted to the environment through state and federally permitted radioactive emission point sources (i.e., stacks). Tritium (i.e., hydrogen-3), strontium-90, iodine-129, cesium-137, plutonium-238, plutonium-239/240, plutonium-241, and americium-241 are the isotopes most commonly measured in the emissions. Emission points are monitored continuously if they have the potential to exceed $1 \%$ of the standard for public dose -10 millirem (100 microsievert) per year.

Distinguishing Hanford Site-produced radionuclides in the environment is challenging because concentrations of emissions from site stacks are comparable to widespread background concentrations of radionuclides that originated from historical atmospheric nuclear weapons testing. Gross alpha and gross beta concentrations in stack emissions are on average equivalent to concentrations in the environment, including concentrations at distant locations upwind of the Hanford Site. Radioactive emissions decreased on the Hanford Site largely because the production and processing of nuclear materials ceased.

The continuous monitoring of radioactive emissions from facilities requires analyzing samples collected at points of discharge to the environment, usually a stack. Samples are analyzed for gross alpha and gross beta as well as for selected radionuclides. Specific radionuclides are selected for sampling, analysis, and reporting based on 1) an evaluation of the hypothetical maximum potential of emissions of known radionuclide inventories in a facility or an outside activity occurring under normal operating conditions with the calculated effect of pollution-abatement equipment removed; 2) the sampling criteria provided in contractor environmental compliance manuals; and 3) the potential of each radionuclide to contribute to the public dose. Continuous air monitoring systems with alarms are also used at selected emission points when the potential exists for radioactive emissions to exceed normal operating ranges to levels that require immediate personnel alert. 
Radioactive emission points are located in the 100, 200, 300, 400, and 600 Areas of the Hanford Site. For 2009, the prime sources of emissions and the number of emission points by operating area are as follows:

- In the 100 Areas, five radioactive emission points were active. Emissions originated from normal evaporation and cleanup activities at the water-filled 100-K West Fuel Storage Basin, which in previous years contained irradiated nuclear fuel; the Cold Vacuum Drying Facility; and the 107-N Basin Recirculation Building.

- In the 200 Areas, 46 radioactive emission points were active. The primary sources of these emission points were the Plutonium Finishing Plant, the T Plant, the Waste Encapsulation and Storage Facility, underground tanks storing high-level radioactive waste, waste evaporators, the Waste Receiving and Processing Facility, and the inactive Plutonium Uranium Extraction (PUREX) Plant.

- In the 300 Area, 10 radioactive emission points were active. The primary sources of these emissions were laboratories and research facilities, including the 324 Waste Technology Engineering Laboratory, 325 Applied Chemistry Laboratory, 331 Life Sciences Laboratory, and 340 Complex Vault and Tanks.

- In the 400 Area, five radioactive emission points were active. The sources of these emissions are three facilities that have been shut down: the Fast Flux Test Facility, the Maintenance and Storage Facility, and the Fuels and Materials Examination Facility.

- In the 600 Area, two radioactive emission points were active at the Waste Sampling and Characterization Facility where low-level radiological and chemical analyses are performed on various types of samples (e.g., particulate air filters, liquids, soil, and vegetation).

Air emissions data collected in 2009 were comparable to those collected in 2008. Table 8.1.1 summarizes Hanford Site radioactive airborne emissions in 2009.

\subsubsection{Criteria and Toxic Air Pollutants}

Criteria and toxic air pollutants emitted from chemicalprocessing and power-generating facilities are monitored when activities at a facility are known to generate potential pollutants of concern. Table 8.1.2 summarizes the emissions of non-radioactive pollutants discharged to the atmosphere on the Hanford Site during 2009. (Note: the 100 and 400 Areas have no criteria and toxic air pollutants of regulatory concern).

In previous years, gaseous ammonia has been emitted from the Plutonium Uranium Extraction (PUREX) Plant, the 242-A Evaporator, the AP Tank Farm, and the AW Tank Farm, all located in the 200-East Area. Ammonia emissions are tracked only when activities at these facilities are capable of generating them. Table 8.1.2 also summarizes reportable ammonia emissions during 2009, which were only produced in the tank farms located in the 200 Areas.

Onsite diesel-powered electricity-generating plants emitted particulate matter, sulfur oxides, nitrogen oxides, volatile organic compounds, carbon monoxide, and lead. Total annual releases of these constituents are reported in accordance with the air quality standards established in "General Regulations for Air Pollution Sources” (WAC 173-400). Based on the quantities of fossil fuel consumed at Hanford Site power plants, the resulting emissions are calculated using EPA-approved formulas (Compilation of Air Pollutant Emission Factors, Volume I: Stationary Point and Area Sources, AP-42).

Release totals are immediately reported to EPA if work activities result in chemical emissions in excess of quantities reportable under CERCLA. If the emissions remain stable at predicted levels, they may be reported annually with EPA approval. 


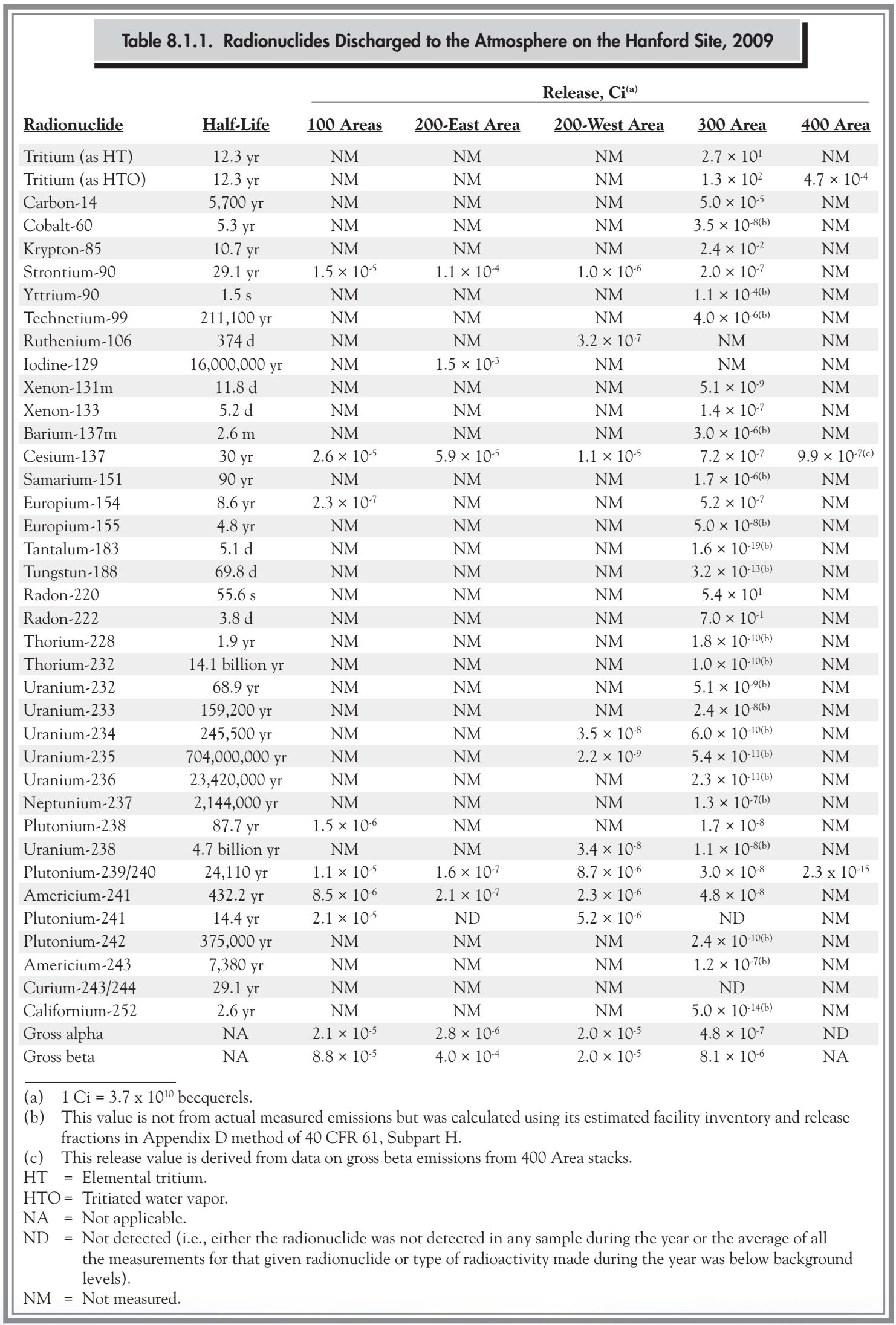


Table 8.1.2. Criteria and Toxic Air Pollutants Discharged to the Atmosphere on the Hanford Site, 2009

\begin{tabular}{|c|c|c|c|}
\hline & \multicolumn{3}{|c|}{$\begin{array}{l}\text { Table 8.1.2. Criteria and Toxic Air Pollutants Discharged } \\
\text { to the Atmosphere on the Hanford Site, } 2009\end{array}$} \\
\hline \multirow{2}{*}{\multicolumn{2}{|c|}{$\begin{array}{l}\text { Constituent } \\
\text { Particulate matter-total }\end{array}$}} & \multicolumn{2}{|c|}{$\underline{\text { Release, kg (lb) }}$} \\
\hline & & 1,800 & $(4,000)$ \\
\hline \multicolumn{2}{|c|}{ Particulate matter-10 } & 900 & $(2,000)$ \\
\hline \multicolumn{2}{|c|}{ Particulate matter-2.5 } & 0 & $(0)$ \\
\hline \multicolumn{2}{|c|}{ Nitrogen oxides } & 14,000 & $(30,000)$ \\
\hline \multicolumn{2}{|c|}{ Sulfur oxides } & 0 & $(0)$ \\
\hline \multicolumn{2}{|c|}{ Carbon monoxide } & 12,000 & $(26,000)$ \\
\hline \multicolumn{2}{|c|}{ Lead } & 0.45 & (1) \\
\hline \multicolumn{2}{|c|}{ Volatile organic compounds ${ }^{(\mathrm{a}, \mathrm{b})}$} & 11,000 & $(24,000)$ \\
\hline \multicolumn{2}{|c|}{ Ammonia $^{(c)}$} & 5,500 & $(12,000)$ \\
\hline \multicolumn{2}{|c|}{ Total criteria pollutants ${ }^{(\mathrm{d})}$} & 38,000 & $(84,000)$ \\
\hline \multicolumn{2}{|c|}{$\begin{array}{l}\text { (a) The estimate of volatile or } \\
\text { from certain laboratory op }\end{array}$} & loes not in & emissions \\
\hline (b) & $\begin{array}{l}\text { From burning petroleum tc } \\
\text { tors; release value also incl } \\
\text { and } 200 \text {-West Areas tank } \\
200 \text { Area Effluent Treatme } \\
\text { Complex, and Waste Rece }\end{array}$ & $\begin{array}{l}\text { d to powe } \\
\text { imates fro } \\
\text { losses fron } \\
\text { Waste C } \\
\text { ig Facility }\end{array}$ & $\begin{array}{l}\text { rical genera- } \\
\text { 200-East } \\
\text { dispensing, } \\
\text { x, T Plant }\end{array}$ \\
\hline (c) & $\begin{array}{l}\text { Ammonia releases are calc } \\
\text { Areas tank farms and the } 2 \\
\text { value also includes ammon } \\
\text { and to power electrical gen }\end{array}$ & $\begin{array}{l}\mathrm{m} \text { the } 200 \\
\text { reatment } \\
\text { troleum } \mathrm{t}\end{array}$ & $\begin{array}{l}\text { and } 200 \text {-West } \\
\text { y; the release } \\
\text { uce steam }\end{array}$ \\
\hline (d) & $\begin{array}{l}\text { Criteria pollutants include } \\
\text { sulfur oxides, carbon mono }\end{array}$ & $\begin{array}{l}\text { - total, } \mathrm{n} \\
\text { atile orga }\end{array}$ & $\begin{array}{l}\text { oxides, } \\
\text { mpounds. }\end{array}$ \\
\hline
\end{tabular}




\title{
8.2 Ambient-Air Monitoring
}

\author{
BG Fritz and CJ Perkins
}

Atmospheric releases of radioactive materials from Hanford Site facilities and operations to the surrounding region are potential sources of human exposure. On the Hanford Site, radioactive constituents in air are monitored onsite near facilities and operations, at site-wide locations away from facilities, and offsite around the site perimeter as well as in nearby and distant communities. Information about these ambient-air monitoring efforts, including detailed descriptions of air-sampling and analysis techniques, is provided in DOE's Hanford Site environmental monitoring plan (DOE/RL-91-50, Rev. 4). Section 8.0 of this report briefly summarizes the ambient-air monitoring objectives and the projects that support them.

Comparing measured radionuclide concentrations from locations on and around the Hanford Site to concentrations measured at upwind locations assumed to be uninfluenced by Hanford Site operations provides an evaluation of the impact of radionuclide air emissions from the Hanford Site on surrounding ambient air. Complete listings of all radiological analytical results summarized in the following sections are reported separately (PNNL-19455, APP. 1; PNNL-19455, APP. 2).

In addition to the radiological monitoring networks, a small non-radiological air-monitoring system is operated onsite. This system measures concentrations of atmospheric particulate matter (dust) at a few locations on the Hanford Site. Results are primarily used for scientific studies in an attempt to better understand windblown dust on and around the Hanford Site.

\subsubsection{Ambient-Air Monitoring Near Facilities and Operations}

\section{CJ Perkins}

During 2009, a network of continuously operating samplers at 84 locations across the Hanford Site (sampling locations are illustrated in PNNL-19455, APP. 2) was used to monitor radioactive materials in air near site facilities and operations (Table 8.2.1). Most air samplers were located at or within approximately 500 meters (1,640 feet) of sites and facilities having the potential for, or a history of, environmental releases. The samplers were primarily located in the prevailing downwind direction. Samples were collected according to a schedule established prior to the 2009 monitoring year. Airborne particle samples were collected at each location by drawing air through a glass-fiber filter. The filters were collected biweekly, field-surveyed for gross radioactivity, held for at least 7 days, and then analyzed for gross alpha and beta activity. The 7-day holding period was necessary to allow for the decay of naturally occurring, short-lived radionuclides that would otherwise obscure the detection of longer lived radionuclides associated with emissions from nuclear facilities. The gross radioactivity measurements were used to indicate changes in trends in the near-facility environment.

For most specific radionuclide analyses, the amount of radioactive material collected on a single filter during a 2-week period was too small to be measured accurately. The samples were combined into either quarterly or semiannual composite samples for each location to increase the 


\begin{tabular}{|c|c|c|c|c|}
\hline \multirow[b]{3}{*}{$\underline{\text { Site }}$} & \multicolumn{4}{|c|}{$\begin{array}{l}\text { - Monitoring Locations and Analyses for Ambient-Air Monitoring Samples } \\
\text { Collected Near Hanford Site Facilities and Operations, } 2009\end{array}$} \\
\hline & \multirow{2}{*}{$\begin{array}{l}\text { Number of } \\
\text { Samplers }\end{array}$} & \multirow[b]{2}{*}{$\underline{\text { EDP Code }}^{(\mathrm{a})}$} & \multicolumn{2}{|c|}{ Analyses } \\
\hline & & & Biweekly & Composite $^{(b)}$ \\
\hline $\begin{array}{l}\text { 100-D Area Field Remediation } \\
\text { Project }^{(c)}\end{array}$ & 4 & N467, N468, N514, N515 & $\begin{array}{l}\text { Gross alpha, } \\
\text { gross beta }\end{array}$ & $\begin{array}{l}\mathrm{GEA},{ }^{90} \mathrm{Sr}, \mathrm{Pu} \text {-iso, U-iso } \\
{ }^{241} \mathrm{Am}\end{array}$ \\
\hline $\begin{array}{l}\text { 100-H Area Field Remediation } \\
\text { Project }{ }^{(c)}\end{array}$ & 4 & N508, N509, N510, N574 & $\begin{array}{l}\text { Gross alpha, } \\
\text { gross beta }\end{array}$ & GEA, ${ }^{90} \mathrm{Sr}, \mathrm{Pu}$-iso, U-iso \\
\hline $\begin{array}{l}\text { 100-K Basins Closure } \\
\text { (100-K Area) }\end{array}$ & 8 & $\begin{array}{l}\text { N401, N402, N403, (d) N404, N476, } \\
\text { N477, N478, N479 }\end{array}$ & $\begin{array}{l}\text { Gross alpha, } \\
\text { gross beta }\end{array}$ & $\begin{array}{l}\text { GEA, }{ }^{90} \mathrm{Sr}, \mathrm{Pu} \text {-iso, U-iso } \\
{ }^{241} \mathrm{Am},{ }^{241} \mathrm{Pu}\end{array}$ \\
\hline $\begin{array}{l}\text { 118-K-1 Field Remediation } \\
\text { Project }(100-\mathrm{K} \text { Area })^{(c)}\end{array}$ & 3 & N403, N534, N535 & $\begin{array}{l}\text { Gross alpha, } \\
\text { gross beta }\end{array}$ & GEA, ${ }^{90} \mathrm{Sr}$, Pu-iso, U-iso \\
\hline 100-N Area D4 Project & 3 & N102, N103, N106 & $\begin{array}{l}\text { Gross alpha, } \\
\text { gross beta }\end{array}$ & $\begin{array}{l}\mathrm{GEA},{ }^{90} \mathrm{Sr}, \mathrm{Pu} \text {-iso, U-iso } \\
{ }^{241} \mathrm{Am}\end{array}$ \\
\hline 200-East Area & 17 & $\begin{array}{l}\text { N019, N158, N498, N499, N957, } \\
\text { N967, N968, N969, N970, N972, } \\
\text { N973, N976, N977, N978, N984, } \\
\text { N985, N999 }\end{array}$ & $\begin{array}{l}\text { Gross alpha, } \\
\text { gross beta }\end{array}$ & GEA, ${ }^{90} \mathrm{Sr}$, Pu-iso, U-iso \\
\hline $\begin{array}{l}\text { BC Controlled Area } \\
\text { ( } 600 \text { Area) }\end{array}$ & 4 & N572, N573, N957, N978 & $\begin{array}{l}\text { Gross alpha } \\
\text { gross beta }\end{array}$ & $\begin{array}{l}\text { GEA, }{ }^{90} \mathrm{Sr}, \mathrm{Pu} \text {-iso, U-iso } \\
{ }^{241} \mathrm{Am},{ }^{241} \mathrm{Pu}\end{array}$ \\
\hline $\begin{array}{l}\text { Canister Storage Building } \\
\text { (200-East Area) }\end{array}$ & 2 & N480, N481 & $\begin{array}{l}\text { Gross alpha, } \\
\text { gross beta }\end{array}$ & $\begin{array}{l}\mathrm{GEA},{ }^{90} \mathrm{Sr}, \mathrm{Pu} \text {-iso, U-iso } \\
{ }^{241} \mathrm{Am},{ }^{241} \mathrm{Pu}\end{array}$ \\
\hline $\begin{array}{l}\text { Integrated Disposal Facility } \\
\text { (200-East Area) }\end{array}$ & 2 & N532, N559 & $\begin{array}{l}\text { Gross alpha, } \\
\text { gross beta }\end{array}$ & GEA, ${ }^{90} \mathrm{Sr}$, Pu-iso, U-iso \\
\hline 200-West Area & 24 & $\begin{array}{l}\text { N155, N161, N165, (d) N168, N200, } \\
\text { N304, N433, N441, N442, N449, } \\
\text { N456, N457, N551, N554, N555, } \\
\text { N956, N963, N964, N965, N966, } \\
\text { N974, N975, N987, N994 }\end{array}$ & $\begin{array}{l}\text { Gross alpha, } \\
\text { gross beta }\end{array}$ & GEA, ${ }^{90} \mathrm{Sr}$, Pu-iso, U-iso \\
\hline $\begin{array}{l}\text { 200-North Decontamination } \\
\text { and Demolition Project }\end{array}$ & 4 & N563, N564, N567, N568 & $\begin{array}{l}\text { Gross alpha, } \\
\text { gross beta }\end{array}$ & GEA, ${ }^{90} \mathrm{Sr}, \mathrm{Pu}$-iso, U-iso \\
\hline $\begin{array}{l}\text { 200-UW-1 Decontamination } \\
\text { and Demolition Project } \\
\text { (200-West Area) }\end{array}$ & 4 & N168, N550, N956, N963 & $\begin{array}{l}\text { Gross alpha, } \\
\text { gross beta }\end{array}$ & GEA, ${ }^{90} \mathrm{Sr}, \mathrm{Pu}$-iso, $\mathrm{U}$-iso \\
\hline $\begin{array}{l}300 \text { Area Decontamination and } \\
\text { Demolition Project }^{(c)}\end{array}$ & 1 & N557 & $\begin{array}{l}\text { Gross alpha, } \\
\text { gross beta }\end{array}$ & GEA, ${ }^{90} \mathrm{Sr}$, Pu-iso, U-iso \\
\hline $\begin{array}{l}\text { 300-FF-2 Field Remediation Project } \\
(300 \text { Area })^{(c)}\end{array}$ & 6 & $\begin{array}{l}\text { N130, N527, N537, N538, N539, } \\
\text { N540 }\end{array}$ & $\begin{array}{l}\text { Gross alpha, } \\
\text { gross beta }\end{array}$ & GEA, ${ }^{90} \mathrm{Sr}, \mathrm{Pu}$-iso, U-iso \\
\hline $\begin{array}{l}\text { Environmental Restoration } \\
\text { Disposal Facility (200-West Area) }\end{array}$ & 5 & N482, ${ }^{(d)}$ N517, N518, N550, N963 & $\begin{array}{l}\text { Gross alpha, } \\
\text { gross beta }\end{array}$ & GEA, ${ }^{90} \mathrm{Sr}, \mathrm{Pu}$-iso, $\mathrm{U}$-iso \\
\hline 600 Area (Wye Barricade) & 1 & N981(e) & $\begin{array}{l}\text { Gross alpha, } \\
\text { gross beta }\end{array}$ & GEA, ${ }^{90} \mathrm{Sr}, \mathrm{Pu}$-iso, $\mathrm{U}$-iso \\
\hline \multicolumn{5}{|c|}{$\begin{array}{l}\text { (a) Environmental data point (EDP) code = Sampler location code. See PNNL-19455, APP. } 2 . \\
\text { (b) GEA = Gamma energy analysis; Pu-iso = isotopic plutonium }\left({ }^{238} \mathrm{Pu},{ }^{23924240} \mathrm{Pu}\right) \text {; U-iso = isotopic uranium }\left({ }^{234} \mathrm{U},{ }^{235} \mathrm{U},{ }^{238} \mathrm{U}\right) \text {. } \\
\text { (c) Pacific Northwest National Laboratory air sampling station(s) provide supplemental air monitoring data. See Table 8.2.2 for a listing of locations. } \\
\text { (d) Collocated sampling location with Washington State Department of Health. } \\
\text { (e) Collocated sampling location with Washington State Department of Health and Pacific Northwest National Laboratory. }\end{array}$} \\
\hline
\end{tabular}


accuracy of the analysis. Composite samples were routinely analyzed for gamma-emitting isotopes, strontium-90, uranium-234, uranium-235, plutonium-238, uranium-238, and plutonium-239/240. In addition, americium-241 and plutonium-241 were analyzed at locations associated with spent nuclear fuel processing (Table 8.2.1).

Figure 8.2.1 shows the annual average air concentrations of selected radionuclides in the 100 and 200/600 Areas compared to EPA concentration values and air concentrations measured in distant communities. The EPA concentration values for environmental compliance (40 CFR 61, Appendix E, Table 2) are dose-based reference values used as indices of performance. The concentration values are concentrations that would result in a dose of 10 millirem (100 microsievert) per year under conditions of continuous exposure. The 2009 data indicate a large degree of variability by location. Air samples collected from locations at or directly adjacent to Hanford Site facilities had higher radionuclide concentrations than samples collected farther away. In general, analytical results for most radionuclides were at or near Hanford Site background levels, which are much less than EPA concentration values but greater than those measured offsite. The data also show that concentrations of certain radionuclides were higher and widely variable within different onsite operational areas. Naturally occurring radionuclides beryllium- 7 and potassium- 40 were routinely identified. Appendix C, Table C.1 shows the annual average and maximum concentrations of radionuclides in air samples collected near facilities and operations during 2009.

Ambient-air was monitored at four locations at the 100-D Field Remediation Project in 2009. Results were similar to those observed in previous years; only uranium-234 and uranium-238 were consistently detected.

Ambient-air was monitored at four locations at the $100-\mathrm{H}$ Field Remediation Project. Results were similar to those observed in previous years; uranium-234, uranium-238, and americium-241 were consistently detected.

During 2009, ambient-air was monitored at eight locations in the 100-K Area (four stations each at the 100-K East and 100-K West Areas). Several sample results were greater than $10 \%$ of EPA's concentration values (40 CFR 61, Appendix E, Table 2) and were reported to the Washington
State Department of Health. At 100-K East, the elevated results included strontium-90, cesium-137, plutonium239/240, and americium-241. At 100-K West, the elevated results were for cesium-137 in three of the four stations during the second-half of the year. Corresponding biweekly air sample results observed during the year included several statistically elevated alpha and beta concentrations. The elevated results were attributable to ongoing demolition activities at this facility. For the overall 100-K Area during 2009, cesium-137 and americium-241 were detected in $100 \%$ of the samples, and uranium-234, uranium-238, and plutonium-239/240 were detected in over $75 \%$ of the samples. Strontium-90, which has been detected in approximately $30 \%$ of the $100-\mathrm{K}$ Area air samples during the previous 10 years, was detected in over $60 \%$ of the samples in 2009.

In early October, ambient-air monitoring was reinitiated at two downwind locations at the 118-K-1 Field Remediation Project (100-K Area). Uranium-234 was detected in one of the samples at a level similar to previous measurements.

Analytical results from three ambient-air sampling locations at the $100-\mathrm{N}$ D4 Project site (100-N Area) in 2009 were similar to those measured in previous years. Americium-241 was detected in all of the samples, and uranium-234 and uranium-238 were detected in approximately $85 \%$ and $67 \%$ of the composite samples, respectively.

Air sampling was conducted at 21 locations in the 200-East Area during 2009. Radionuclide levels measured in the 200-East Area ambient-air composite samples in 2009 were generally similar to those measured in previous years. Uranium-234 and uranium-238 were detected in approximately $85 \%$ of the samples, and americium-241 and cesium-137 were detected in approximately $25 \%$ and $20 \%$ of the composite samples, respectively. During the second half of 2009 , one cesium- 137 result $\left(2.3 \mathrm{E}-03 \mathrm{pCi} / \mathrm{m}^{3}\right)$ at air sampling location N019 (located near B Plant) was greater than $10 \%$ of EPA's concentration value $\left(1.9 \mathrm{E}-02 \mathrm{pCi} / \mathrm{m}^{3}\right)$ (40 CFR 61, Appendix E, Table 2) and was reported to the Washington State Department of Health. A review of the biweekly air sample results during the period did not reveal statistically elevated alpha or beta concentrations. The two stations near the Canister Storage Building showed that uranium-234 and uranium-238 were present in each of the 2009 composite samples. 


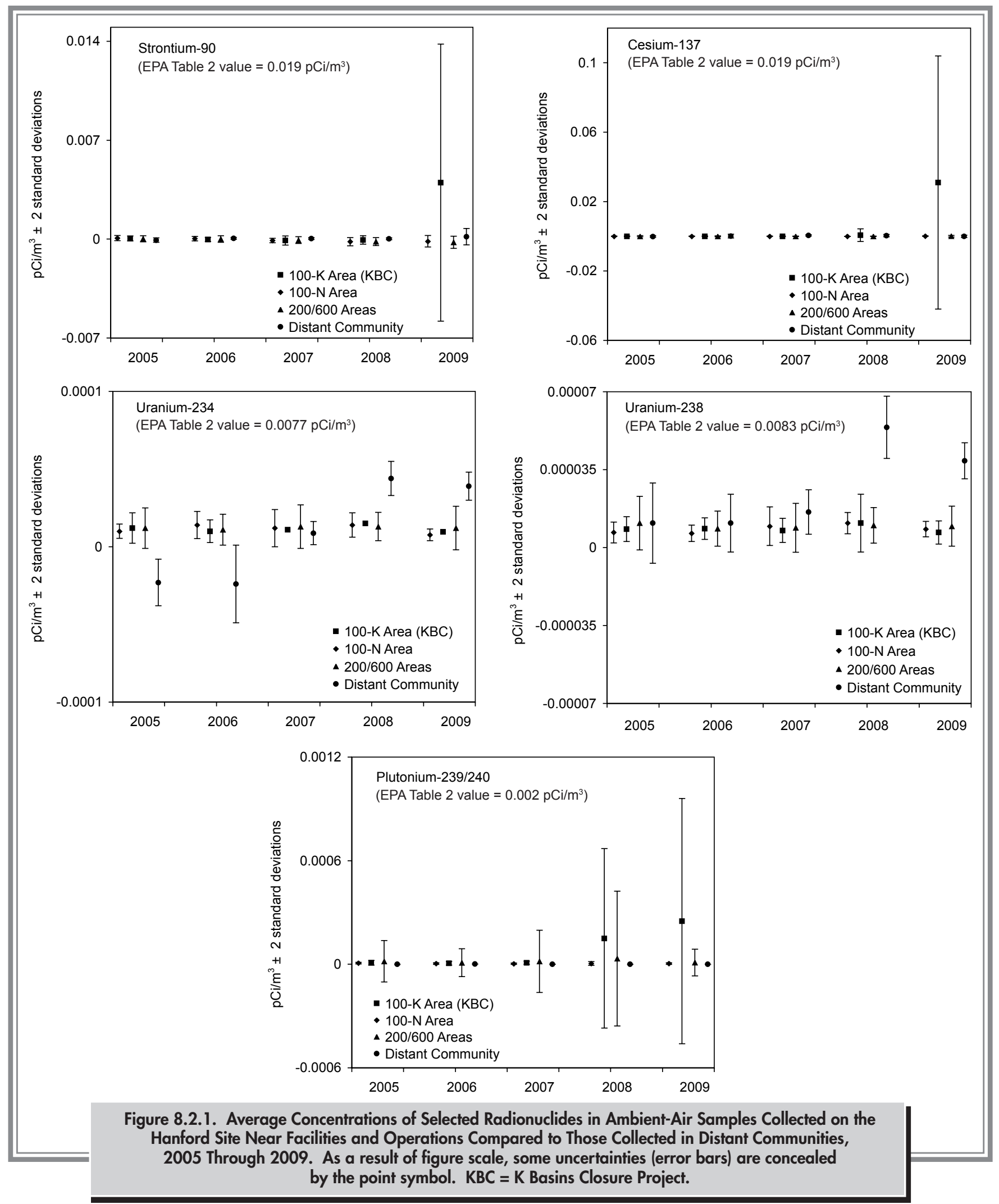


In May 2009, ambient-air monitoring was initiated at four locations at the 200-North decontamination and demolition project. Uranium-234 was detected in 100\% of the samples, and uranium-238 and plutonium-239/240 were detected in approximately $30 \%$ of the samples.

During 2009, air sampling in support of deactivation and decontamination activities at the 200-UW-1 Operable Unit was conducted at four ambient-air monitoring stations. Uranium-234 and uranium-238 were detected in 100\% of the samples, and cesium-137 was detected in $50 \%$ of the samples.

Air sampling was conducted at 24 locations in the 200-West Area during 2009. Generally, radionuclide levels measured in the 200-West Area were similar to results for previous years. Uranium-234 and uranium-238 were detected in approximately $90 \%$ of the samples. Plutonium-239/240 was detected in approximately $33 \%$ of the samples. The plutonium-239/240 concentrations at air-sampling locations N165 (near the 216-Z-9 Trench) and N987 (near the 241 TY Tank Farm) were greater than 10\% of the EPA concentration value (40 CFR 61, Appendix E, Table 2) for the composite samples collected during the first-half of 2009. Required notifications were made to the Washington State Department of Health. The elevated plutonium value at N165 is believed to originate from the nearby retired 216-ZP-9 Trench that received liquid waste from the Plutonium Finishing Plant until 1995. No attributable cause was specifically identified for the elevated plutonium value at $\mathrm{N} 987$.

Air sampling in support of decontamination and decommissioning activities in the 300 Area continued at one location in 2009. Results from the quarterly composited samples showed that only uranium-234 and uranium-238 were detected with any consistency (100\% of the samples).

Air sampling was conducted during 2009 in support of remediation work in the 300-FF-2 Operable Unit (near the 300 Area) at six ambient-air monitoring stations. Uranium-234 and uranium-238 were detected in 75\% and $62 \%$ of the samples, respectively.

Ambient-air monitoring was reinitiated in July 2009 at four locations at the BC Controlled Area site in the 600 Area. Generally, radionuclide levels measured at this site were similar to typical Hanford Site levels. Uranium-234 and uranium-238 were detected in $83 \%$ and $67 \%$ of the air samples, respectively.

Air sampling was conducted at five locations in 2009 at the Environmental Restoration Disposal Facility (200-West Area). The 2009 analytical results were comparable to those obtained in previous years. Uranium-234 and uranium-238 were detected in $100 \%$ of the samples, and cesium-137, uranium-235, and plutonium-239/240 were detected in 30\% of the samples.

\subsubsection{Site-Wide and Offsite Ambient-Air Monitoring}

\section{BG Fritz}

During 2009, airborne radionuclide samples were collected by 42 continuously operating samplers on the Hanford Site. The sampling stations were grouped into four location classifications: site-wide (onsite; 23 stations), perimeter (11 stations), nearby communities ( 7 stations), and distant community (1 station) (Figure 8.2.2 and Table 8.2.2). Air samplers on the Hanford Site were located primarily around major operational areas to maximize the capability to detect radiological contaminants resulting from site operations. Perimeter samplers were located around the site boundary with emphasis on the prevailing downwind directions to the south and east. Samplers located in Basin City, Benton City, Kennewick, Mattawa, Othello, Pasco, and Richland, Washington, provided data for the nearest population centers. A sampler in Yakima, Washington, provided background data from a community essentially unaffected by Hanford Site operations.

\subsubsection{Collection of Site-Wide and Offsite Ambient-Air Samples and Analytes Tested}

Samples were collected according to a schedule established prior to the monitoring year (PNNL-18177) and were analyzed for up to eight constituents (Table 8.2.2). Airborne particle samples were collected biweekly at each location by continuously drawing air through a glass-fiber filter. The filter samples were transported to an analytical laboratory and stored for at least 72 hours. The storage period is 


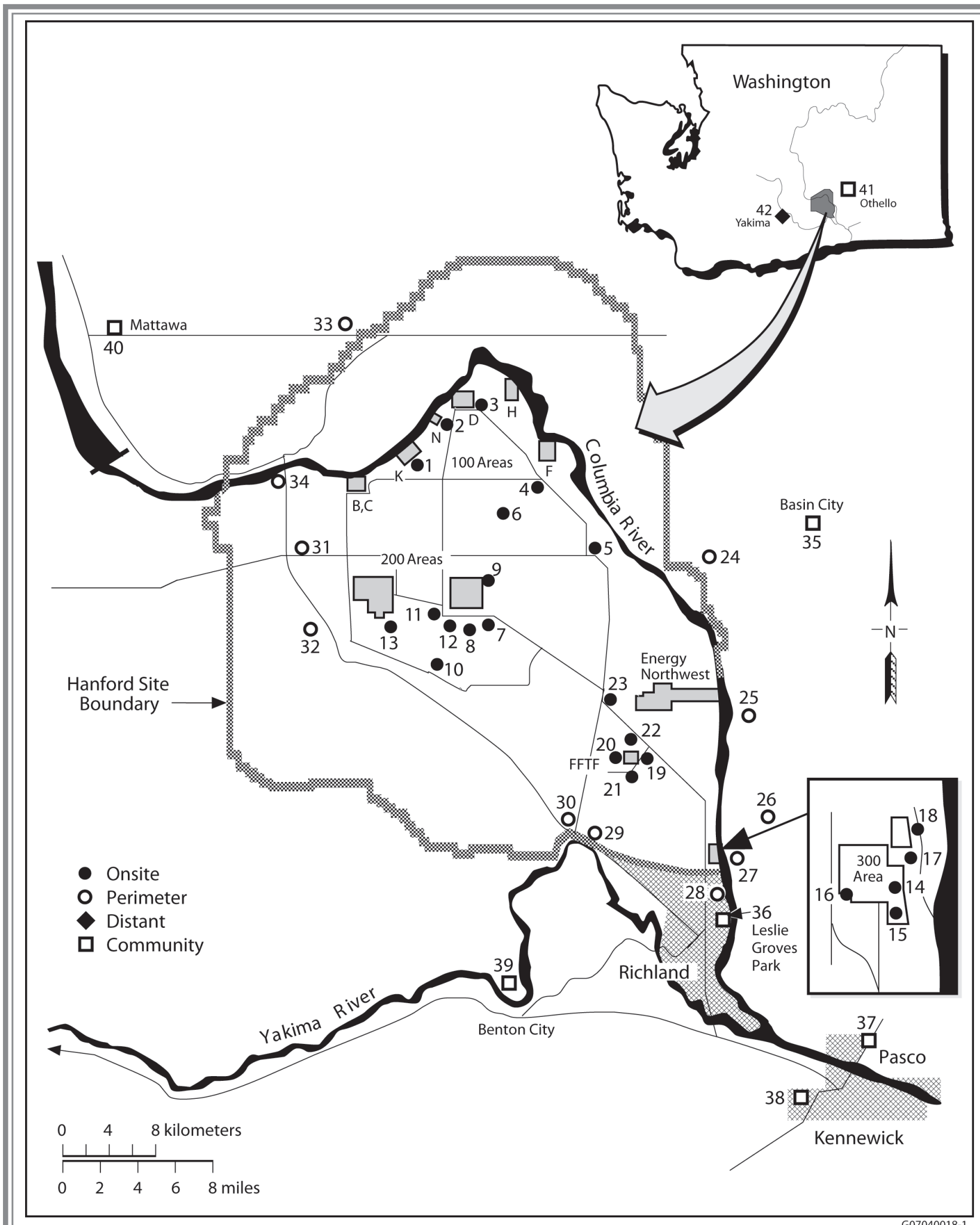

G07040018-1

Figure 8.2.2. Hanford Site-Wide and Offsite Ambient-Air Sampling Locations During 2009 (see Table 8.2.2 for location names) 
Table 8.2.2. Site-Wide and Offsite Ambient-Air Sampling Locations, Sample Composite Groups, and Analytes, 2009

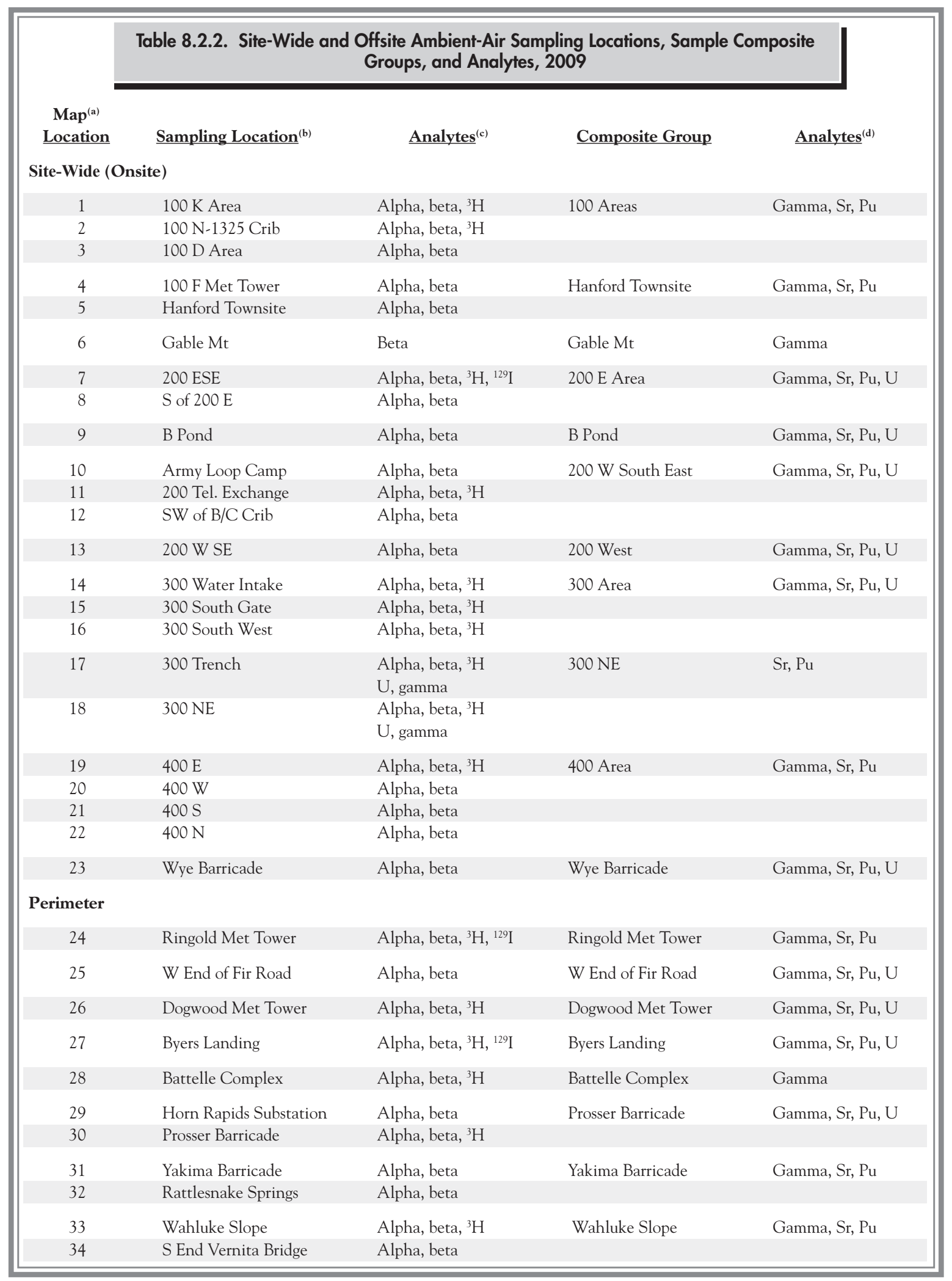




\section{Table 8.2.2. (contd)}

\begin{tabular}{|c|c|c|c|c|c|}
\hline \multirow{2}{*}{\multicolumn{2}{|c|}{$\operatorname{Map}^{(a)}$}} & \multicolumn{3}{|c|}{ Table 8.2.2. (contd) } & \multirow[b]{2}{*}{$\underline{\text { Analytes }}^{(\mathrm{d})}$} \\
\hline & & $\underline{\text { Sampling Location }}^{(\mathbf{b})}$ & $\underline{\text { Analytes }}^{(\mathrm{c})}$ & Composite Group & \\
\hline \multicolumn{6}{|c|}{ Nearby Communities } \\
\hline & 35 & Basin City School & Alpha, beta, ${ }^{3} \mathrm{H}$ & Basin City School & Gamma, Sr, Pu, U \\
\hline & 36 & Leslie Groves-Richland & Alpha, beta, ${ }^{3} \mathrm{H}$ & Leslie Groves-Richland & Gamma, Sr, Pu, U \\
\hline & 37 & Pasco & Beta & Tri-Cities & Gamma, Sr, Pu \\
\hline & 38 & Kennewick & Alpha, beta & & \\
\hline & 39 & Benton City & Beta & Benton City & Gamma \\
\hline & 40 & Mattawa & Beta & Mattawa & Gamma \\
\hline & 41 & Othello & Beta & Othello & Gamma \\
\hline \multicolumn{6}{|c|}{ Distant Communities } \\
\hline & 42 & Yakima & Alpha, beta, ${ }^{3} \mathrm{H},{ }^{129} \mathrm{I}$ & Yakima & Gamma, Sr, Pu, U \\
\hline \multicolumn{6}{|c|}{$\begin{array}{l}\text { (a) See Figure 8.2.2. } \\
\text { (b) Sampling location names are derived from the Hanford Environmental Information System database. } \\
\text { (c) Alpha (gross) and beta (gross) samples were collected and analyzed every } 2 \text { weeks; }{ }^{3} \mathrm{H} \text { samples were collected and analyzed } \\
\text { every } 4 \text { weeks; and }{ }^{129} \mathrm{I} \text { samples were collected every } 4 \text { weeks but were not analyzed because of an equipment problem at } \\
\text { the analytical laboratory. } \\
\text { (d) Gamma spectroscopy, strontium-90, isotopic plutonium }\left({ }^{238} \mathrm{Pu},{ }^{239 / 240} \mathrm{Pu} \text { ), and isotopic uranium }\left({ }^{234} \mathrm{U},{ }^{235} \mathrm{U},{ }^{238} \mathrm{U}\right) \text { analyses }\right. \\
\text { were performed on quarterly composite samples. }\end{array}$} \\
\hline
\end{tabular}

necessary to allow for the decay of short-lived, naturally occurring radionuclides (e.g., radon gas decay products) that would otherwise obscure the detection of longer lived radionuclides potentially present from Hanford Site emissions. The filters were then analyzed for gross beta radiation. Selected filters were also analyzed for gross alpha radiation. Historically, for most radionuclides, the amount of radioactive material collected on a filter during a 2-week period has been too small to accurately analyze individual radionuclides of concern. Biweekly samples were combined into quarterly composite samples to increase the sensitivity and accuracy of the analysis. The compositing procedure results in a 12-week average concentration for specific radionuclides present in the atmosphere as particulates. The quarterly composite samples were analyzed for gammaemitting radionuclides, and most were also analyzed for strontium-90, uranium-234, uranium-235, plutonium-238, uranium-238, and plutonium-239/240.

Atmospheric water vapor was collected for tritium analysis at 20 locations in 2009 by continuously drawing air through multi-column samplers containing adsorbent silica gel. The water-vapor samplers were exchanged every 4 weeks to prevent loss of the sample as a result of breakthrough (i.e., oversaturation). The collection efficiency of the silica gel adsorbent is discussed in Patton et al. (1997). The collected water was distilled from the silica gel and analyzed for its tritium content.

\subsubsection{Ambient-Air Monitoring Results for Site-Wide and Offsite Samples}

All sample results showed very low radiological concentrations in air during 2009. All radionuclide concentrations (Table 8.2.3) were less than their respective DOE-derived concentration guide (Appendix D, Table D.2). The derived concentration guides are concentrations that would result in a dose of 100 millirem ( 1 millisievert) per year under conditions of continuous exposure. A more conservative dose standard is the EPA Clean Air Act standard of 10 millirem (100 microsievert) per year from airborne radiological material. Again, all radionuclide concentrations in air samples collected in 2009 were low enough to meet the EPA standard. 
Table 8.2.3. Airborne Radionuclide Concentrations in the Environs of the Hanford Site, 2009 Compared to Previous Years

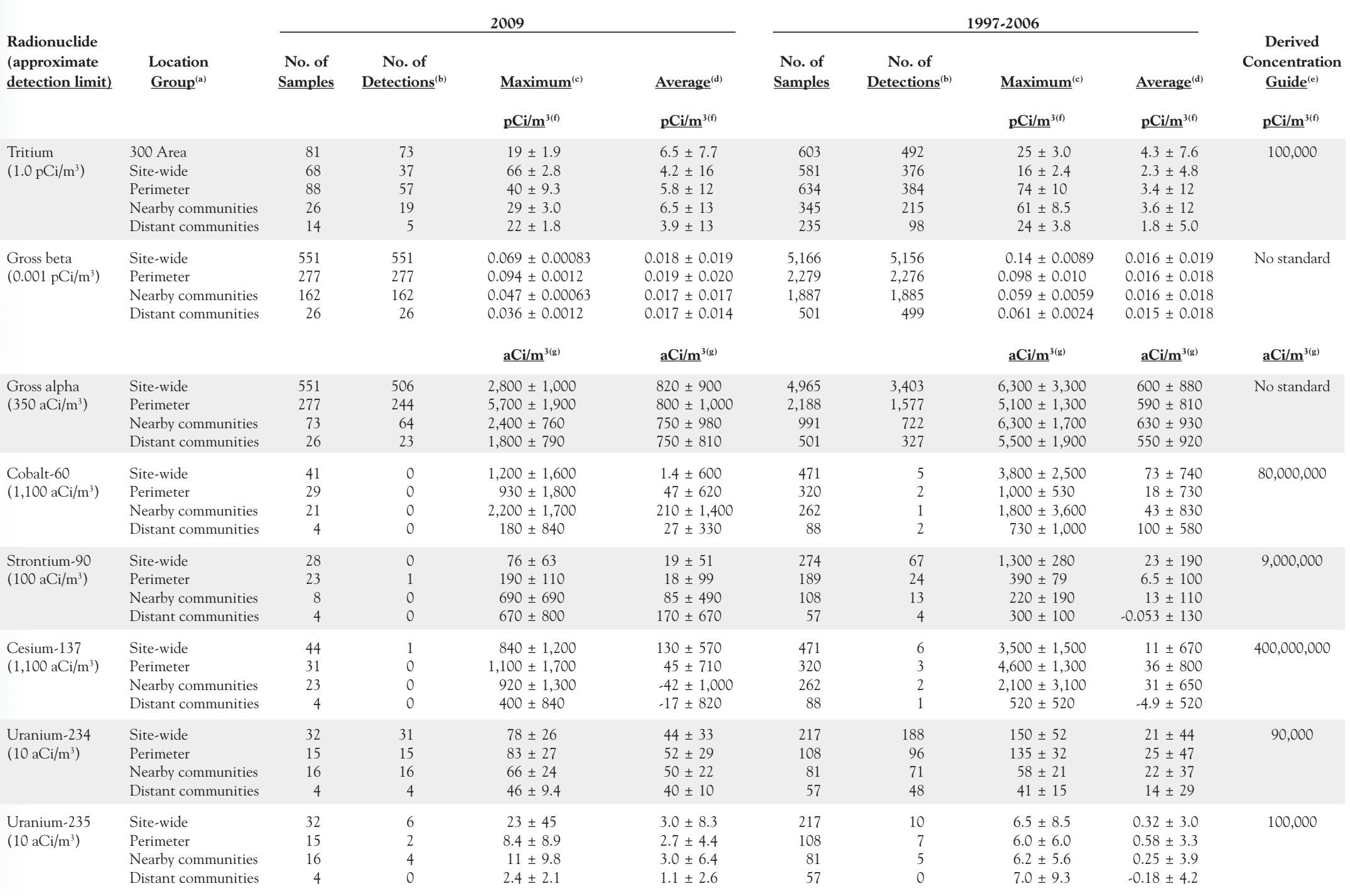


Table 8.2.3. (contd)

\begin{tabular}{|c|c|c|c|c|c|c|c|c|c|c|}
\hline \multirow[b]{2}{*}{$\begin{array}{l}\text { Radionuclide } \\
\text { (approximate } \\
\text { detection limit) }\end{array}$} & \multirow[b]{2}{*}{$\begin{array}{l}\text { Location } \\
\text { Group }^{(a)}\end{array}$} & \multicolumn{4}{|c|}{2009} & \multicolumn{4}{|c|}{$1997-2006$} & \multirow[b]{2}{*}{$\begin{array}{c}\text { Derived } \\
\text { Concentration } \\
\text { Guide }^{\left(e^{()}\right.}\end{array}$} \\
\hline & & $\begin{array}{c}\begin{array}{c}\text { No. of } \\
\text { Samples }\end{array} \\
\end{array}$ & $\begin{array}{c}\text { No. of } \\
\text { Detections }^{(b)}\end{array}$ & $\underline{\text { Maximum }}^{(c)}$ & $\underline{\text { Average }}^{(\mathrm{d})}$ & $\begin{array}{c}\begin{array}{c}\text { No. of } \\
\text { Samples }\end{array} \\
\end{array}$ & $\begin{array}{c}\text { No. of } \\
\text { Detections }^{(b)}\end{array}$ & Maximum $^{(\mathrm{c})}$ & Average $^{(\mathrm{d})}$ & \\
\hline & & & & ${\underline{\underline{\mathbf{a C i}} / \mathbf{m}^{3(\mathrm{~g})}}}$ & ${\underline{\mathbf{a C i} / \mathbf{m}^{3(\mathrm{~g})}}}$ & & & ${\underline{\mathbf{a C i} / \mathbf{m}^{3(\mathrm{~g})}}}$ & ${\underline{\mathrm{aCi} / \mathbf{m}^{3(\mathrm{~g})}}}$ & ${\underline{\mathbf{a C i} / \mathbf{m}^{3(\mathrm{~g})}}}$ \\
\hline \multirow{4}{*}{$\begin{array}{l}\text { Plutonium-238 } \\
\left(3 \mathrm{aCi} / \mathrm{m}^{3}\right)\end{array}$} & Site-wide & 44 & 4 & $4.3 \pm 3.2$ & $0.60 \pm 2.1$ & 274 & 16 & $13 \pm 3.9$ & $0.095 \pm 2.3$ & \multirow[t]{4}{*}{30,000} \\
\hline & Perimeter & 24 & 3 & $4.0 \pm 2.7$ & $0.69 \pm 1.9$ & 189 & 1 & $1.9 \pm 1.4$ & $-0.11 \pm 1.1$ & \\
\hline & Nearby communities & 12 & 4 & $5.7 \pm 3.2$ & $1.6 \pm 4.1$ & 108 & 2 & $3.7 \pm 3.6$ & $0.0061 \pm 1.5$ & \\
\hline & Distant communities & 4 & 2 & $2.4 \pm 1.7$ & $1.0 \pm 2.0$ & 57 & 0 & $0.98 \pm 1.4$ & $-0.32 \pm 1.1$ & \\
\hline \multirow{4}{*}{$\begin{array}{l}\text { Uranium-238 } \\
\left(10 \mathrm{aCi} / \mathrm{m}^{3}\right)\end{array}$} & Site-wide & 32 & 31 & $71 \pm 13$ & $45 \pm 27$ & 217 & 201 & $160 \pm 37$ & $22 \pm 40$ & \multirow[t]{4}{*}{100,000} \\
\hline & Perimeter & 15 & 15 & $89 \pm 28$ & $52 \pm 25$ & 108 & 105 & $140 \pm 32$ & $27 \pm 37$ & \\
\hline & Nearby communities & 16 & 16 & $96 \pm 30$ & $55 \pm 35$ & 81 & 78 & $56 \pm 18$ & $24 \pm 22$ & \\
\hline & Distant communities & 4 & 4 & $44 \pm 18$ & $39 \pm 9.4$ & 57 & 56 & $33 \pm 15$ & $17 \pm 13$ & \\
\hline Plutonium- & Site-wide & 44 & 11 & $7.9 \pm 3.4$ & $1.4 \pm 3.9$ & 274 & 74 & $36 \pm 6.4$ & $1.4 \pm 7.0$ & \multirow[t]{4}{*}{20,000} \\
\hline $239 / 240$ & Perimeter & 24 & 4 & $55 \pm 12$ & $3.2 \pm 22$ & 189 & 13 & $5.2 \pm 2.5$ & $0.31 \pm 1.7$ & \\
\hline \multirow{2}{*}{$\left(3 \mathrm{aCi} / \mathrm{m}^{3}\right)$} & Nearby communities & 12 & 4 & $16 \pm 4.3$ & $2.2 \pm 9.1$ & 108 & 7 & $3.2 \pm 4.6$ & $0.39 \pm 1.4$ & \\
\hline & Distant communities & 4 & 0 & $0.32 \pm 0.62$ & $0.22 \pm 0.29$ & 57 & 2 & $3.2 \pm 2.9$ & $0.29 \pm 1.7$ & \\
\hline
\end{tabular}

(a) Location groups are identified in Table 8.2.2.

(b) Detection is defined as a value reported above the minimum detectable activity and above the total propagated analytical uncertainty.

(c) Maximum single sample result \pm total analytical uncertainty. Negative concentration values are explained in Appendix A.

(d) Average of all samples \pm 2 times the standard deviation.

(e) DOE-derived concentration guide (see Appendix D, Table D.2)

(f) $1 \mathrm{pCi}=0.037 \mathrm{~Bq}$

(g) There are 1 million attocuries $(\mathrm{aCi})$ in 1 picocurie $(\mathrm{pCi})$. 
Gross alpha concentrations were essentially the same at Hanford Site-wide and offsite locations during 2009 (Figure 8.2.3). There were no statistically significant differences (two-sample means t-test, 95\% confidence level) in the average gross alpha concentrations measured at the different distance classes. The highest 2-week average gross alpha concentration for 2009 was observed at a perimeter location $\left(5,700 \mathrm{aCi} / \mathrm{m}^{3}\left[210 \mu \mathrm{Bq} / \mathrm{m}^{3}\right]\right)$. The average gross alpha concentrations observed in individual location groups during 2009 were higher than the 10-year average concentrations observed from 1997 through 2006, while the maximum concentrations measured were generally lower than the maximum concentrations observed from 1997 through 2006 (Table 8.2.3). This increase in average concentrations probably resulted from a different analytical laboratory used in 2009 and between 1997 and 2006 rather than any real change in atmospheric concentrations of radionuclides across the Hanford Site. A fixed 10-year window (1997-2006) was used as a comparison to the current year's results, providing a sizable time period so annual variations in long-term average concentrations are minimized. This window is used to provide consistent year-toyear "reference" values.

Gross beta concentrations in air peaked during the fall and winter months in 2009 (Figure 8.2.4), repeating a pattern of natural radioactivity fluctuations (Eisenbud
1987). The annual average gross beta concentrations at site-wide locations during 2009 were slightly higher than the concentration measured at the distant location. The differences were small and not statistically significant (twosample means t-test, 95\% confidence level). The average gross beta concentrations reported at each distance class for 2009 were higher than concentrations measured from 1997 through 2006 (Table 8.2.3). In 2004, gross beta concentrations were noted to be inversely proportional to the average wind speed over the sampling period (i.e., as wind speed increased, concentrations decreased). This pattern was evident again in 2009 (Figure 8.2.4), although the relationship was not as strong as in recent years.

Plutonium-238 was detected in 13 air samples collected during 2009 (Table 8.2.3). Most of the samples that were reported with detectable concentrations were collected during the fourth quarter of 2009. The maximum reported plutonium-238 concentration in 2009 was $5.7 \mathrm{aCi} / \mathrm{m}^{3}$ $\left(0.21 \mu \mathrm{Bq} / \mathrm{m}^{3}\right)$, which was reported at a community monitoring location.

The annual average plutonium-239/240 concentration in air samples collected in 2009 at Hanford Site-wide locations was $1.4 \mathrm{aCi} / \mathrm{m}^{3}\left(0.052 \mu \mathrm{Bq} / \mathrm{m}^{3}\right)$. Of the 44 site-wide samples analyzed for plutonium-239/240, 11 had detectable concentrations (Table 8.2.3). The maximum reported

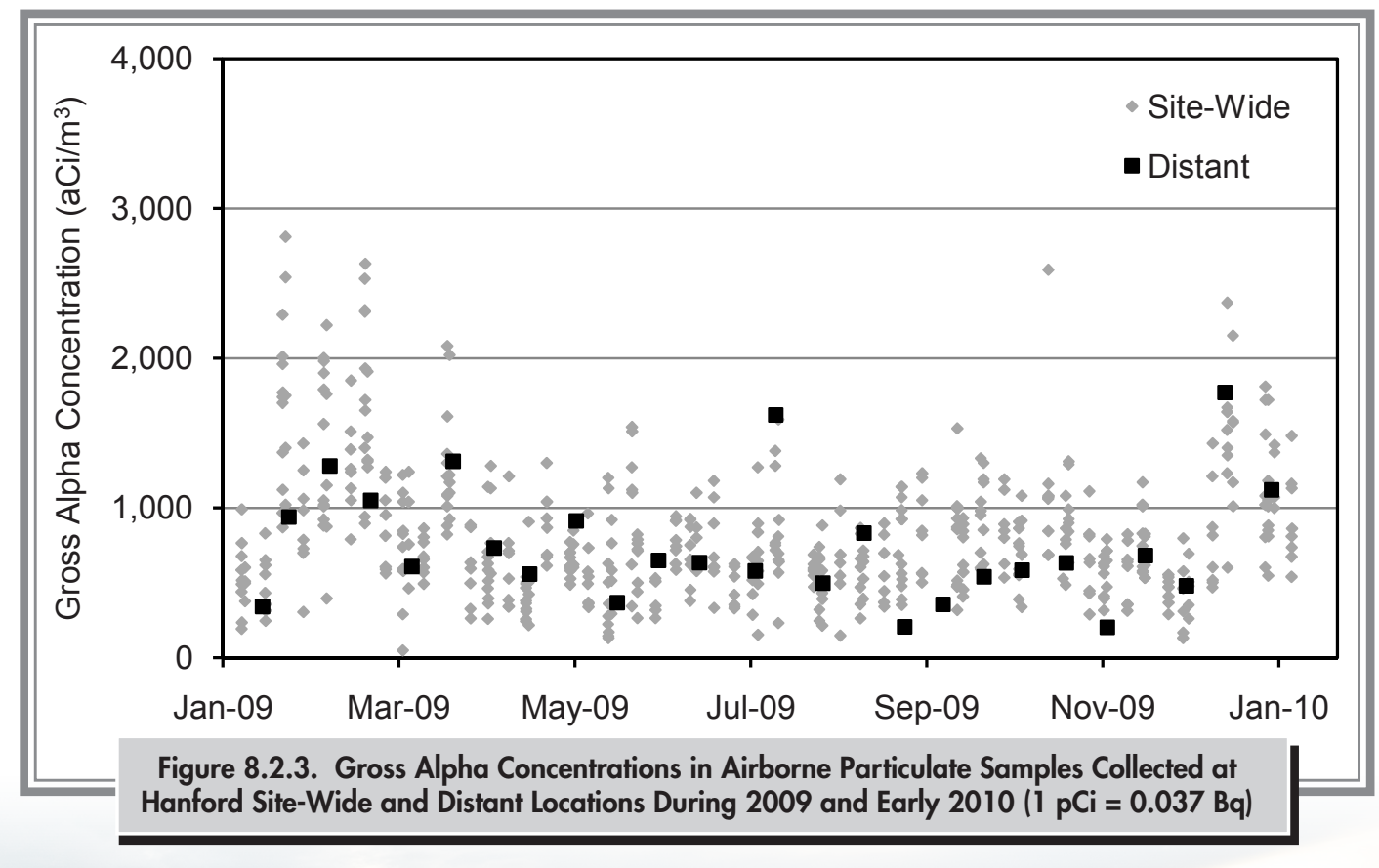




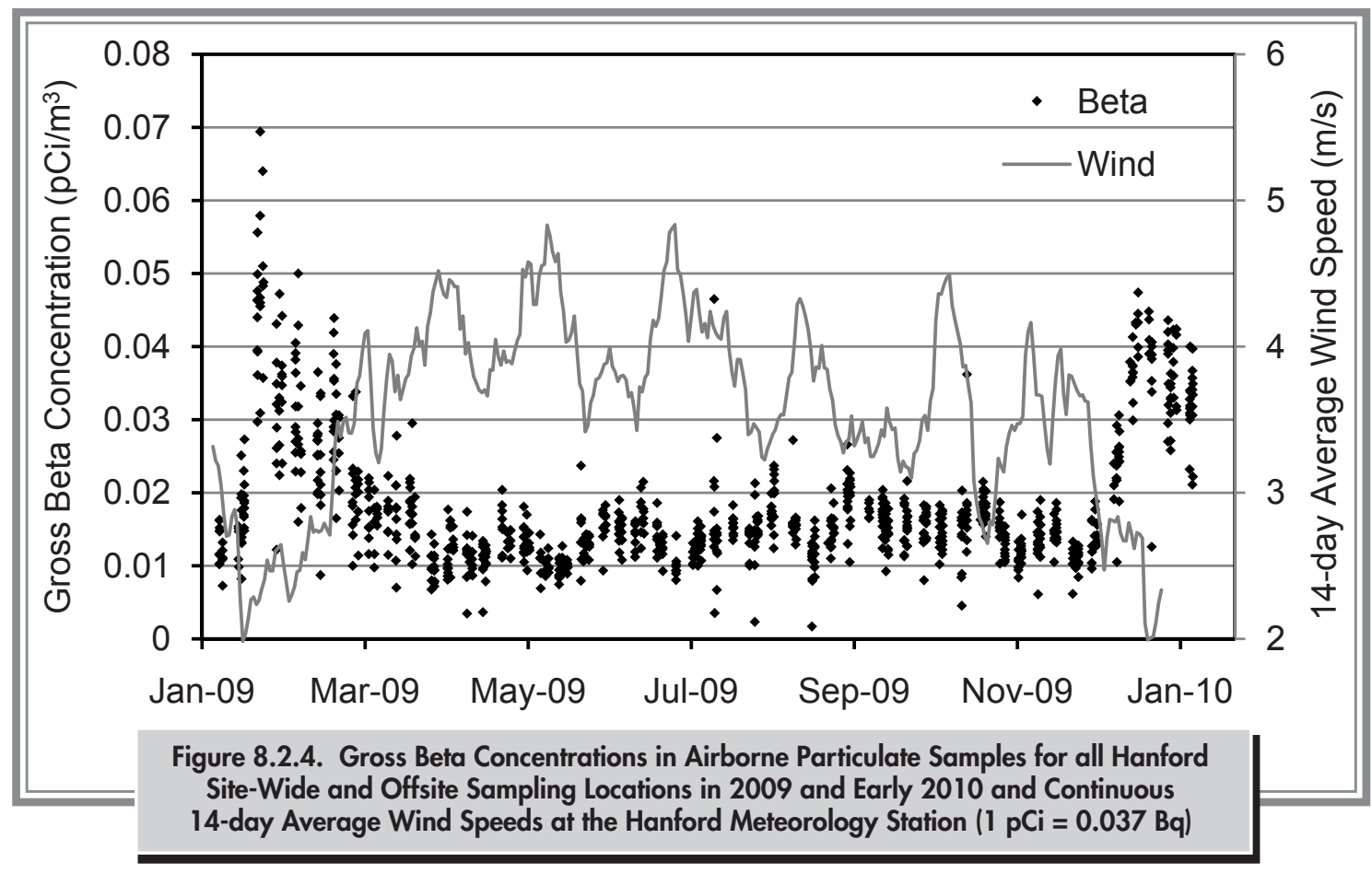

concentration $\left(55 \mathrm{aCi} / \mathrm{m}^{3}\left[2.0 \mu \mathrm{Bq} / \mathrm{m}^{3}\right]\right)$ was 360 times less than the DOE-derived concentration guide $\left(20,000 \mathrm{aCi} / \mathrm{m}^{3}\right.$ $\left.\left[740 \mu \mathrm{Bq} / \mathrm{m}^{3}\right]\right)$ for plutonium-239/240.

Average isotopic uranium concentrations (uranium-234, uranium-235, and uranium-238) in airborne particulate matter in 2009 were higher than average concentrations measured from 1997 through 2006 for all location groups (Table 8.2.3). The 2009 annual average uranium-238 concentration at the site perimeter was $52 \mathrm{aCi} / \mathrm{m}^{3}$ $\left(1.9 \mu \mathrm{Bq} / \mathrm{m}^{3}\right)$. The annual average site-wide and perimeter uranium-238 concentrations were not statistically different from the concentration measured at the distant location (two-sample means t-test, 95\% confidence level). The maximum uranium-238 concentration measured in 2009
(96 $\mathrm{aCi} / \mathrm{m}^{3}\left[3.6 \mu \mathrm{Bq} / \mathrm{m}^{3}\right]$ ) was only $0.045 \%$ of the DOEderived concentration guide for uranium-238.

Sixty-three airborne particulate samples were analyzed for strontium-90 in 2009 (Table 8.2.3). One sample collected on the site perimeter had a detectable concentration.

All quarterly composite samples (102) collected in 2009 were examined with gamma spectroscopy. Naturally occurring beryllium-7 and potassium-40 were occasionally measured with detectable concentrations. The potential Hanford Site-origin, gamma-emitting, radionuclide cesium-137 was detected in a single site-wide sample. No samples had detectable concentrations of cobalt -60 . 


\subsection{Liquid Effluent from Hanford Site Facilities}

DJ Rokkan

Liquid effluents are discharged from a few facilities on the Hanford Site. Effluent streams are sampled for gross alpha and gross beta concentrations, as well as for concentrations of selected radionuclides and non-radioactive hazardous materials.

Contaminant data from liquid effluent sampling and analyses are reported to DOE annually in an environmental release report (e.g., HNF-EP-0527-19). The report includes summaries of monitoring results on liquid effluents discharged to the Columbia River, which are regulated by the National Pollutant Discharge Elimination System (NPDES) (40 CFR 122) permit and reported to EPA, and liquid effluent discharges to the soil, which are regulated by WAC 173-216 and reported to the Washington State Department of Ecology.

\subsubsection{Radionuclides in Liquid Effluent}

During 2009, facilities in the 200 Areas discharged radioactive liquid effluent to the ground at a single location, the 616-A Crib, also known as the State-Approved Land Disposal Site. Table 8.3.1 summarizes this effluent discharge.

Table 8.3.2 summarizes the liquid effluent discharged in the 100 Areas. Generally, this effluent consists of secondary

\begin{tabular}{|c|c|c|}
\hline \multicolumn{3}{|c|}{$\begin{array}{l}\text { Table 8.3.1. Radionuclides in } 200 \text { Areas Liquid } \\
\text { Effluent Discharged to the State-Approved Land } \\
\text { Disposal Site on the Hanford Site, } 2009\end{array}$} \\
\hline Radionuclide & $\underline{\text { Half-Life }}$ & $\underline{\text { Release, } \mathbf{C i}^{(a}}$ \\
\hline Tritium & $12.35 \mathrm{yr}$ & 0.61 \\
\hline
\end{tabular}

cooling water discharged from the $100-\mathrm{K}$ Area to the Columbia River via the NPDES-permitted 1908-K Outfall.

\begin{tabular}{|c|c|c|}
\hline \multicolumn{3}{|c|}{$\begin{array}{l}\text { Table 8.3.2. Radionuclides in Liquid Effluent } \\
\text { from the 100-K Area Discharged to the } \\
\text { Columbia River, } 2009\end{array}$} \\
\hline Radionuclide & Half-Life & Release, $\mathbf{C i}^{(\mathbf{a})}$ \\
\hline Strontium-90 & $29.1 \mathrm{yr}$ & $1.1 \times 10^{-2}$ \\
\hline Cesium-137 & $30 \mathrm{yr}$ & $1.3 \times 10^{-2}$ \\
\hline Plutonium-238 & $87.7 \mathrm{yr}$ & $3.6 \times 10^{-6}$ \\
\hline Plutonium-239/240 & $24,110 \mathrm{yr}$ & $3.0 \times 10^{-5}$ \\
\hline
\end{tabular}

\subsubsection{Non-Radioactive Hazardous Materials in Liquid Effluent}

Non-radioactive hazardous materials in liquid effluents are monitored in the 100, 200, 300, and 400 Areas for selected non-radioactive hazardous materials. These effluents are discharged to the State-Approved Land Disposal Site and to the Columbia River. Effluent entering the environment at designated discharge points is sampled and analyzed to determine compliance with the NPDES (40 CFR 122) and state waste discharge permits (WAC 173-216) for the Hanford Site. The release totals are immediately reported to EPA if chemicals in liquid effluents exceed quantities reportable under CERCLA. If chemicals in effluents remain stable at predicted levels, these levels may be reported annually if EPA has approved this practice. Section 5.4.1 provides a brief synopsis of the NPDES and state waste discharge permits. 


\title{
8.4 Surface-Water and Sediment Monitoring
}

\author{
GW Patton
}

Samples of surface water and sediment on and near the Hanford Site were collected and analyzed to determine the concentrations of radiological and chemical contaminants in the aquatic environment attributed to the Hanford Site. Surface-water bodies monitored included the Columbia River, onsite ponds, and offsite irrigation sources (Figure 8.4.1). Aquatic sediment monitoring was conducted for the Columbia River and one onsite pond. Tables 8.4.1 and 8.4.2 summarize the sampling locations, types, and frequencies, as well as sample analyses included in surfacewater and sediment monitoring during 2009. This section describes the monitoring efforts and summarizes the results for these aquatic environments. Detailed analytical results are reported in PNNL-19455, APP. 1.

\subsubsection{Monitoring of Columbia River Water}

The Columbia River is one of the largest rivers in the continental United States in terms of total flow and is the dominant surface-water body on the Hanford Site. The original selection of the Hanford Site for plutonium production was based partly on the abundant water supply offered by the river. The river flows through the northern portion of the site and forms part of the eastern boundary of the site. The river is used as a source of drinking water for onsite facilities and communities downstream from the Hanford Site. Water removed from the river immediately downstream of the site is also used for crop irrigation in Benton and Franklin Counties. In addition, the Hanford Reach of the Columbia River is used for a variety of recreational activities including hunting, fishing, boating, water skiing, and swimming.
Originating in the Rocky Mountains of eastern British Columbia, the Columbia River and its tributaries drain an area of approximately 670,000 square kilometers (260,000 square miles) before discharging to the Pacific Ocean. Three dams in Canada and 11 dams in the United States regulate the flow of the river; 4 of these dams are downstream of the Hanford Site. Priest Rapids Dam is the nearest upstream dam, and McNary Dam is the nearest downstream dam to the site. The Hanford Reach of the Columbia River extends from Priest Rapids Dam downstream to the head of Lake Wallula, created by McNary Dam, near the city of Richland, Washington. The Hanford Reach is the last stretch of the Columbia River in the United States upstream of Bonneville Dam (the first dam upstream from the ocean) that remains unimpounded.

River flow through the Hanford Reach fluctuates signifcantly and is controlled primarily by operations at upstream dams. The annual average flow of the Columbia River downstream of Priest Rapids Dam is approximately 3,400 cubic meters (120,000 cubic feet) per second (WA-94-1). In 2009, the Columbia River had below-normal flows; the average daily flow rate downstream of Priest Rapids Dam was 2,720 cubic meters $(96,100$ cubic feet) per second. The peak monthly average flow rate occurred during June (4,430 cubic meters $[156,000$ cubic feet] per second) (Figure 8.4.2). The lowest monthly average flow rate occurred during September (1,610 cubic meters [56,900 cubic feet] per second), based on mean daily flows. Daily average flow rates varied from 1,120 to 5,350 cubic meters $(39,600$ to 189,000 cubic feet) per second during 2009. As a result of fluctuation in discharges, the depth of the river varies significantly over time. The river stage (water-surface level) 


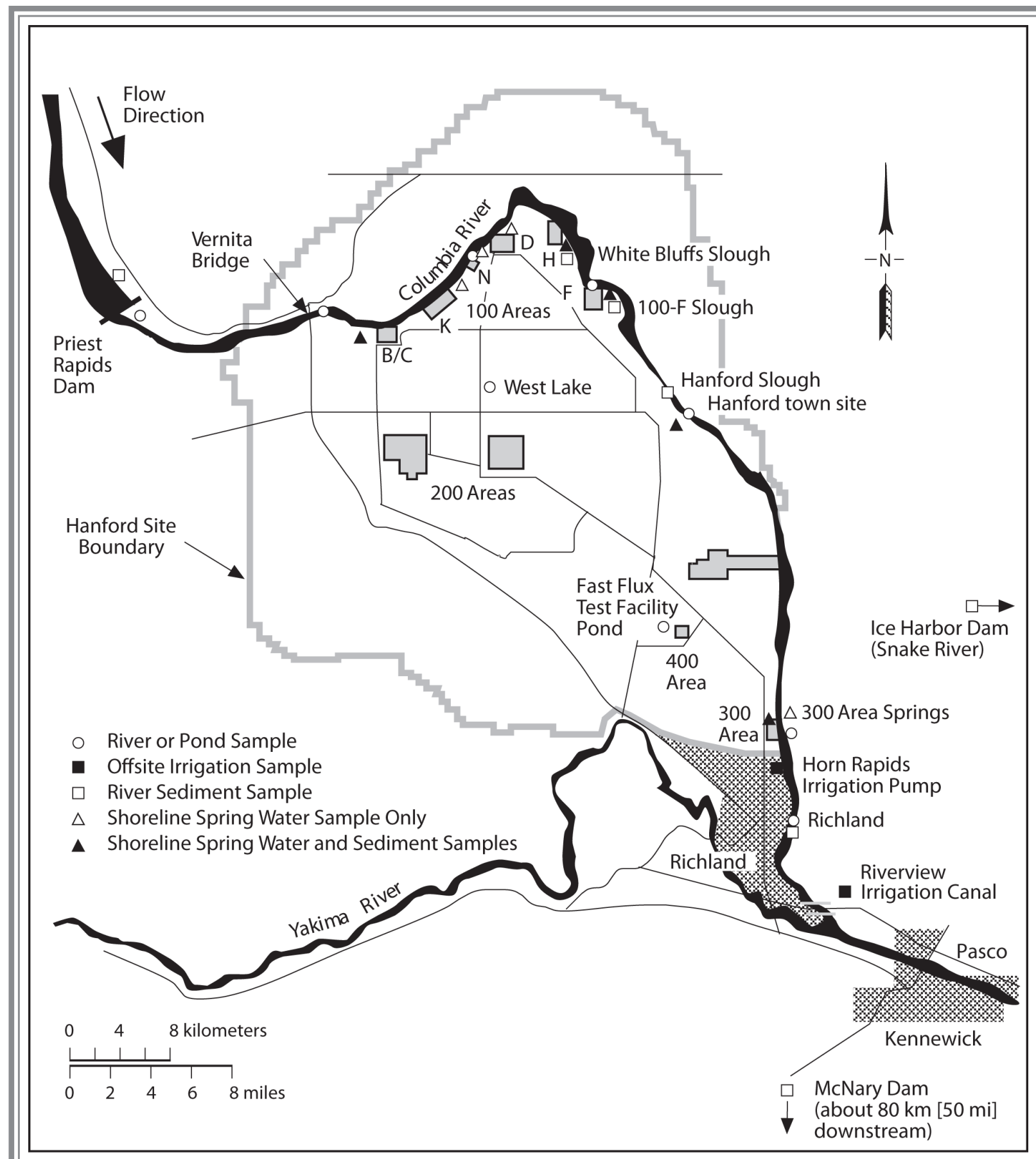

G07040018.25

Figure 8.4.1. Surface-Water and Sediment Sampling Locations On and Around the Hanford Site, 2009 


\begin{tabular}{|c|c|c|c|}
\hline \multicolumn{4}{|c|}{ Table 8.4.1. Surface-Water Surveillance On and Near the Hanford Site, 2009} \\
\hline$\frac{\text { Location }}{\text { Columbia River - Radiological }}$ & \multicolumn{2}{|c|}{ Columbia River - Radiological } & $\underline{\text { Analyses }}$ \\
\hline Priest Rapids Dam and Richland & $\begin{array}{l}\text { Cumulative } \\
\text { Particulate (filter) } \\
\text { Soluble (resin) }\end{array}$ & $\begin{array}{l}\text { M Comp } \\
\text { M Cont }^{(\mathrm{d})} \\
\text { Q Cont } \\
\text { M Cont } \\
\text { Q Cont }\end{array}$ & $\begin{array}{l}\text { Alpha, beta, low }{ }^{3} \mathrm{H},{ }^{(b)}{ }^{90} \mathrm{Sr},{ }^{99} \mathrm{Tc}, \mathrm{U}^{(c)} \\
\mathrm{Gamma} \text { energy analysis } \\
\mathrm{Pu}^{(f)} \\
\text { Gamma energy analysis } \\
\mathrm{Pu}\end{array}$ \\
\hline Vernita Bridge and Richland & Grab (transects) & Quarterly & Low ${ }^{3} \mathrm{H},{ }^{90} \mathrm{Sr}, \mathrm{U}$ \\
\hline $\begin{array}{l}100-\mathrm{N} \text { and } 300 \text { Areas } \\
\text { and Hanford town site }\end{array}$ & Grab (transects) & Annually & Low ${ }^{3} \mathrm{H},{ }^{90} \mathrm{Sr}, \mathrm{U}$ \\
\hline \multicolumn{4}{|l|}{ Columbia River - Chemical } \\
\hline Vernita Bridge and Richland ${ }^{(\mathrm{g})}$ & $\begin{array}{l}\text { Grab } \\
\text { Grab (transects) } \\
\text { Grab (transects) }\end{array}$ & $\begin{array}{l}\text { 3/year } \\
\text { Quarterly } \\
\text { Annually }\end{array}$ & $\begin{array}{l}\text { Temperature, dissolved oxygen, turbidity, } \mathrm{pH} \text {, } \\
\text { alkalinity, anions, suspended solids, dissolved solids, } \\
\left.\text { specific conductance, hardness (as } \mathrm{CaCO}_{3}\right), \mathrm{Ca}, \mathrm{P} \text {, } \\
\mathrm{Cr}, \mathrm{Mg}, \mathrm{N}, \mathrm{Fe}, \mathrm{NH}_{3}, \mathrm{NO}_{3}+\mathrm{NO}_{2} \\
\text { Anions } \\
\text { Metals (filtered and unfiltered), volatile organic } \\
\text { compounds }\end{array}$ \\
\hline $\begin{array}{l}100-\mathrm{N} \text { and } 300 \text { Areas } \\
\text { and Hanford town site } \\
\text { Onsite Ponds }\end{array}$ & Grab (transects) & Annually & Metals (filtered and unfiltered), anions \\
\hline $\begin{array}{l}\text { West Lake } \mathrm{e}^{(\mathrm{h})} \\
\text { Fast Flux Test Facility Pond } \\
\text { Offsite Irrigation Water }\end{array}$ & $\begin{array}{l}\text { Grab } \\
\text { Grab }\end{array}$ & $\begin{array}{l}\text { Quarterly } \\
\text { Quarterly }\end{array}$ & $\begin{array}{l}\text { Alpha, beta, }{ }^{3} \mathrm{H},{ }^{90} \mathrm{Sr},{ }^{99} \mathrm{Tc}, \mathrm{U} \text {, gamma energy analysis } \\
\text { Alpha, beta, }{ }^{3} \mathrm{H} \text {, gamma energy analysis }\end{array}$ \\
\hline $\begin{array}{l}\text { Riverview irrigation canal } \\
\text { Horn Rapids }\end{array}$ & $\begin{array}{l}\text { Grab } \\
\text { Grab }\end{array}$ & $\begin{array}{l}3 / \text { year } \\
3 / \text { year }\end{array}$ & $\begin{array}{l}\text { Alpha, beta, }{ }^{3} \mathrm{H},{ }^{90} \mathrm{Sr}, \mathrm{U} \text {, gamma energy analysis } \\
\text { Alpha, beta, }{ }^{3} \mathrm{H},{ }^{90} \mathrm{Sr}, \mathrm{U} \text {, gamma energy analysis }\end{array}$ \\
\hline $\begin{array}{l}\text { (a) M Comp indicates river wate } \\
\text { (b) Low }{ }^{3} \mathrm{H}=\text { Low-level tritium a } \\
\text { (c) U = Isotopic uranium-234, ut } \\
\text { (d) M Cont = River water was sa } \\
\text { posited monthly for analysis. } \\
\text { (e) Q Cont = River water was sa } \\
\text { posited quarterly for analysis. } \\
\text { (f) Pu = Isotopic plutonium-238 } \\
\text { (g) Numerous water quality anal } \\
\text { Laboratory. } \\
\text { (h) Because of high concentratio } \\
\text { samples. } \\
\text { Comp = Composite. } \\
\text { Cont }=\text { Continuous. } \\
\text { M = Monthly. } \\
\text { Q }=\text { Quarterly. }\end{array}$ & $\begin{array}{l}\text { lected hourly and co } \\
10-\mathrm{pCi} / \mathrm{L} \text { detection } 1 \\
35 \text {, and uranium- } 23 \\
\mathrm{r} 2 \text { weeks by continu } \\
2 \text { weeks by continu } \\
\text { onium-239/240. } \\
\text { erformed by the U.S } \\
\text { ended sediment, W }\end{array}$ & $\begin{array}{l}\text { sited monthly } \\
\text { ), which inclu } \\
\text { flow through } \\
\text { flow through a } \\
\text { alogical Surv } \\
\text { ake water is a }\end{array}$ & $\begin{array}{l}\text { analysis. } \\
\text { an electrolytic preconcentration. } \\
\text { ter and resin column, and multiple samples were com- } \\
\text { ter and resin column, and multiple samples were com- } \\
\text { yzed for tritium; all other analytes are for sediment }\end{array}$ \\
\hline
\end{tabular}

may change along the Hanford Reach by up to 3 meters (10 feet) within a few hours (PNL-10698). Seasonal changes of approximately the same magnitude are also observed. River-stage fluctuations measured at the 300 Area are approximately one-half the magnitude of those measured near the 100 Areas because of the effect of the pool behind McNary Dam (PNL-8580) and the relative distance of each area from Priest Rapids Dam. The width of the river varies from approximately 300 to 1,000 meters (980 to 3,300 feet) as it passes through the Hanford Site.

Pollutants from multiple sources are present in the Columbia River as it passes through the Hanford Reach. These sources include upstream industry, atmospheric fallout that collects in the river's drainage basin, runoff from agricultural operations, and discharge from the aquifers on either side 
Table 8.4.2. Columbia River Sediment Surveillance, 2009

\section{Location $^{(a)}$}

Columbia River

Priest Rapids Dam:

Two locations near the dam

White Bluffs Slough

100-F Slough

Hanford Slough

Richland

McNary Dam:

Two locations near the dam
Frequency

River-sediment analyses included gamma energy analysis, ${ }^{90} \mathrm{Sr}, \mathrm{U},{ }^{(b)} \mathrm{Pu},{ }^{(c)}$ metals, and total organic carbon

Annually

Annually

Annually

Annually

Annually

Annually

(a) See Figure 8.4.1.

(b) $\mathrm{U}=$ Isotopic uranium-234, uranium-235, and uranium-238 analyzed by alpha spectrometry (alpha energy analysis).

(c) $\mathrm{Pu}=$ Isotopic plutonium-238 and plutonium-239/240.

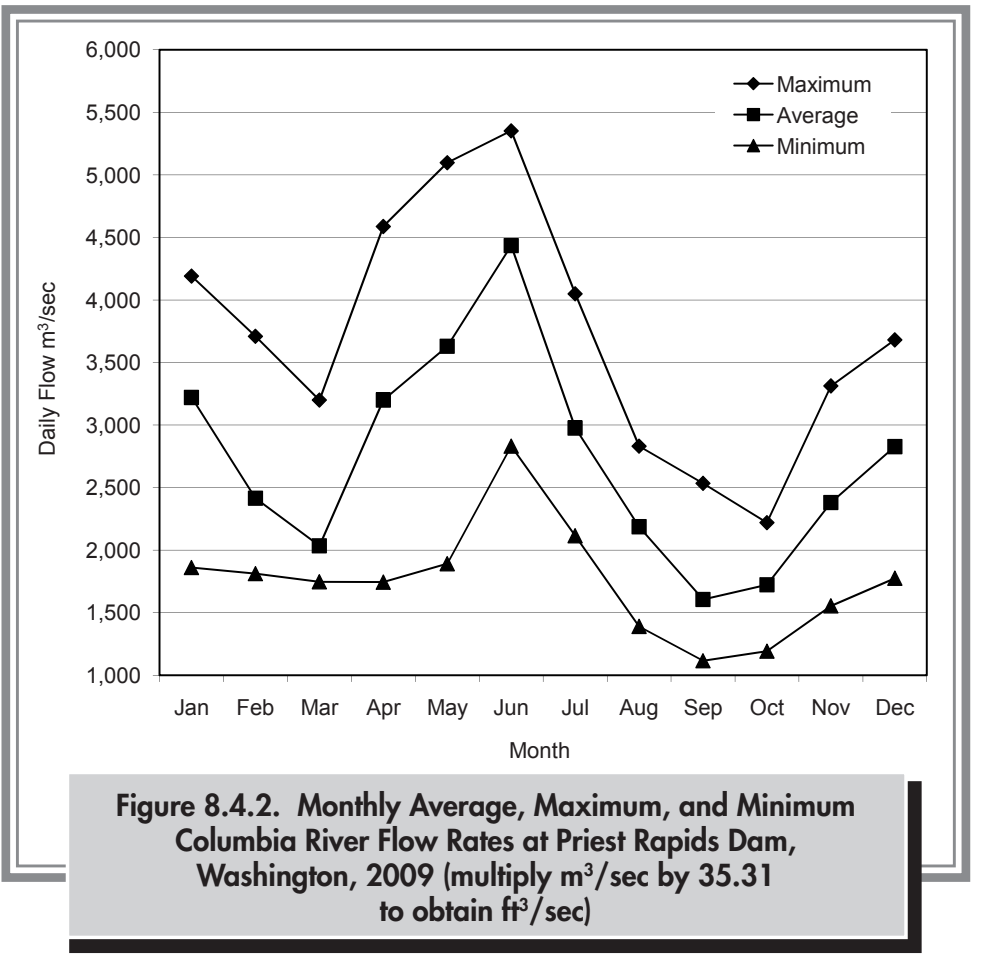

and regulated for non-radiological constituents under the NPDES in compliance with the Clean Water Act of 1977 (Section 5.4.1). In addition to permitted direct discharges of liquid effluent from Hanford Site facilities, groundwater contaminants from past operational releases to the ground discharge into the Columbia River (see Section 8.5 of this report; DOE/RL-92-12, Rev. 1; PNL-5289; PNL-7500; WHC-SD-EN-TI-006). In general, groundwater discharges are considered to be the dominant pathway for Hanford Site contaminants to enter the Columbia River.

Washington State has classified the general wateruse and water quality criteria for the Columbia River downstream from Grand Coulee Dam with an aquatic-life designation of "salmonid spawning, rearing, and migration," which provides for the protection of spawning, rearing, and migration of salmon and trout as well as other associated aquatic life. The recreational uses designation

of the river. Hanford Site pollutants, both radiological and chemical, enter the Columbia River along the Hanford Reach. Effluent from each direct discharge point is monitored routinely and reported by the responsible operating contractor (Section 8.3). Direct discharges are identified for the Columbia River downstream from Grand Coulee Dam is "primary contact," which provides for activities that may involve complete submersion by the participant. The entire Columbia River is designated as suitable for all water supply and miscellaneous uses by Washington State. 


\subsubsection{Collection of Columbia River Water Samples and Analytes of Interest}

During 2009, Columbia River water samples were collected from fixed-location monitoring stations at Priest Rapids Dam and the city of Richland and analyzed for radionuclides. Cross-river transects and near-shore locations near Vernita Bridge, the 100-N Area, the Hanford town site, the 300 Area, and the city of Richland were analyzed for both radionuclides and chemicals (Figure 8.4.1). Samples were collected upstream from Hanford Site facilities at Priest Rapids Dam and Vernita Bridge to provide data from locations unaffected by site operations. Samples were collected from all other locations, including a municipal drinking water supply and points of withdrawal for irrigation water downstream of the Hanford Site, to identify any increase in contaminant concentrations attributable to the site. The sampling of irrigation water systems is discussed in Section 8.4.4.

The fixed-location monitoring stations at Priest Rapids Dam and the city of Richland consist of an automated sampler and a continuous flow system. The automated sampler was used to obtain hourly unfiltered samples of Columbia River water (cumulative samples), which were composited for a period of 7 days. These weekly samples were combined into monthly and quarterly composite samples for radiological analyses (Table 8.4.1). The continuous flow system was used to collect particulate and soluble constituents in Columbia River water by passing water through a filter and then through a resin column. Filter and resin samples were exchanged approximately every 14 days and were combined into quarterly composite samples for radiological analyses. The river sampling locations and the methods used for sample collection are discussed in DOE/RL-91-50, Rev. 4.

Radionuclides of interest were selected for analysis based on the following criteria:

- Their presence in effluent discharged from Hanford Site facilities or in near-river groundwater underlying the site

- Their importance in determining water quality, verifying facility effluent controls and monitoring systems, and determining compliance with applicable water quality standards.
Constituents of interest in Columbia River water samples collected at Priest Rapids Dam and the city of Richland included gamma-emitting radionuclides, tritium, strontium-90, technetium-99, uranium-234, uranium-235, plutonium-238, uranium-238, and plutonium-239/240. River water samples to be analyzed for iodine-129 were not collected in 2009 because the instrument used for this assay was not operational, and an alternative for this ultra-trace measurement capability was not available. Gross alpha and gross beta measurements were made as indicators of the general radiological quality of the river and provided a timely indication of change. Gamma-energy analysis provides the capability to detect numerous specific radionuclides (Appendix F). Analytical detection levels (defined as the laboratory-reported minimum detectable concentration) for all radionuclides were less than or equal to $10 \%$ of their respective Washington State water quality criteria levels (Appendix D, Tables D.3 and D.4). Unless otherwise noted in this section, the statistical tests for differences are paired sample comparisons and two-tailed t-tests, with alpha at a $5 \%$ significance level.

Transect sampling (i.e., multiple samples collected along a line across the Columbia River) was initiated as a result of findings of a special study conducted during 1987 and 1988 (PNL-8531). That study concluded that, under certain flow conditions, contaminants entering the river from the Hanford Site are not completely mixed when sampled at routine monitoring stations located downriver. Incomplete mixing results in a slightly conservative (high) bias in the data generated using the routine, single-point, sampling system at the city of Richland drinking water intake. During 1999, the transect sampling strategy was modified; some of the mid-river sampling points were shifted to near-shore locations in the vicinity of the transect. For example, at the 100-N Area, instead of 10 evenly spaced cross-river transect samples, only 6 cross-river samples were collected, and the other 4 samples were obtained at near-shore locations (typically less than 5 meters [16 feet] from shore). This sampling pattern was used during 2009 and allowed the cross-river concentration profile to be determined and also provided information over a larger portion of the Hanford Site shoreline where the highest contaminant concentrations would be expected. Vernita Bridge and city of Richland transects and near-shore locations were sampled 
quarterly during 2009. Annual transect and near-shore sampling were conducted at the 100-N Area, the Hanford town site, and 300 Area locations in late summer when river flows were low, which provides the highest probability of detecting Hanford Site contaminants carried by groundwater to the Columbia River (PNL-8531).

Columbia River transect water samples collected during 2009 were analyzed for both radiological and chemical contaminants (Table 8.4.1). Specific metals and anions were selected for analysis following reviews of existing surface-water and groundwater data, various remedial investigation/feasibility study work plans, and preliminary Hanford Site risk assessments (DOE/RL-92-67, Draft B; PNL-8073; PNL-8654; PNL-10400; PNL-10535). Grab samples of water collected along transects were radiologically and chemically analyzed. Metals analyses included both unfiltered and filtered samples.

Pacific Northwest National Laboratory also conducted water monitoring for potential Hanford Site contaminants, and the U.S. Geological Survey, under contract to Pacific Northwest National Laboratory, monitored basic water quality parameters (e.g., $\mathrm{pH}$, dissolved oxygen, turbidity) and some chemical constituents. The U.S. Geological Survey collected samples two times per year along Columbia River transects at Vernita Bridge and the city of Richland (Appendix C, Table C.2). Samples were analyzed at the U.S. Geological Survey laboratory in Lakewood, Colorado.

\subsubsection{Radiological Results for Columbia River Water Sample Analyses}

Fixed Location Samples. Results of radiological analyses of Columbia River water samples collected at Priest Rapids Dam and the city of Richland during 2009 are reported in PNNL-19455, APP. 1, and summarized in Appendix C (Tables C.3 and C.4). Appendix C tables list the maximum and average concentrations of selected radionuclides detected in Columbia River water in 2009 and for the previous 5 years. All individual radiological contaminant concentrations measured in Columbia River water during 2009 were less than $1 / 25$ of the concentrations comparable to the DOE-derived concentration guides (DOE Order 5400.5, Chg 2; Appendix D, Table D.2). The DOEderived concentration guides are based on a 100-millirem (1-milliseivert) per year standard; dividing by 25 allows for more direct comparison to the 4-millirem (0.04-milliseivert) per year drinking water standard and Washington State ambient surface water quality criteria (40 CFR 141; WAC 173-201A; Appendix D, Tables D.4 and D.5). Significant results are discussed in the following paragraphs, and comparisons to previous years are provided.

Radionuclide concentrations monitored in Columbia River water were low throughout 2009. Tritium, uranium-234, uranium-238, and naturally occurring potassium-40 were measured consistently in river water at levels greater than their reported minimum detectable concentrations. Strontium-90, uranium-235, plutonium-238, and plutonium-239/240 were occasionally detected, but all values were near the minimum detectable concentrations. Concentrations of all other radionuclides were typically less than the minimum detectable concentrations. Tritium, strontium-90, and plutonium exist in worldwide fallout from historical nuclear weapons testing as well as in effluent from Hanford Site facilities. Tritium and uranium occur naturally in the environment in addition to being present in Hanford Site effluent.

The 2009 average gross alpha and gross beta concentrations measured upstream and downstream of the Hanford Site were similar to those observed during recent years (Figures 8.4.3 and 8.4.4). Statistical comparisons for gross alpha

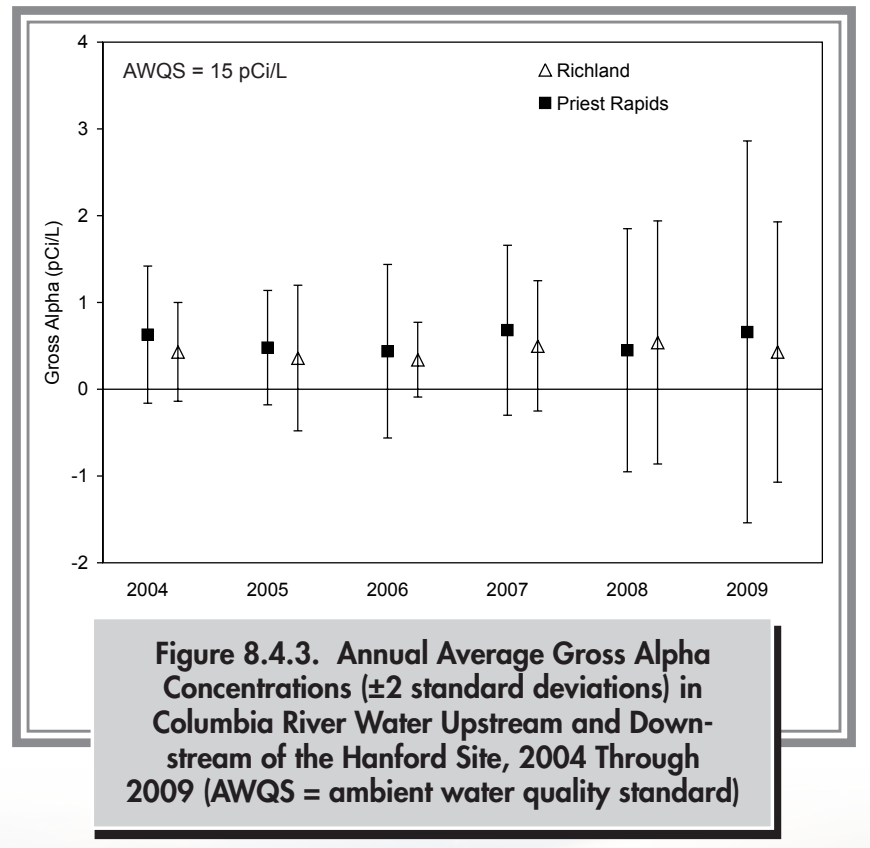




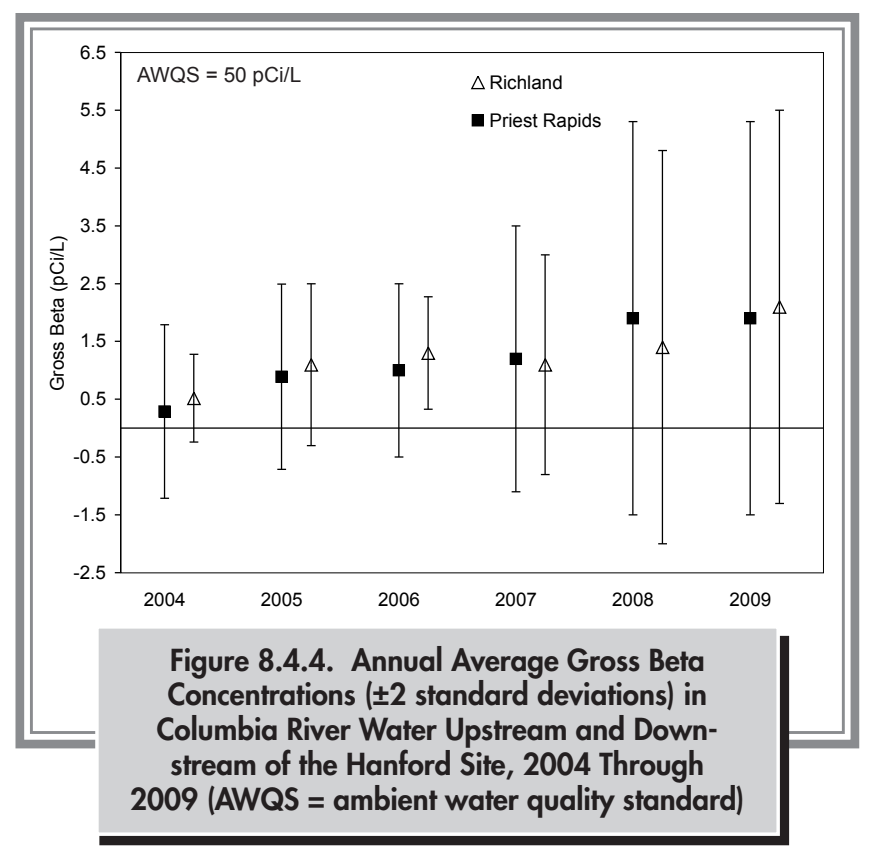

and gross beta concentrations at Priest Rapids Dam and the city of Richland were not performed because most of the concentrations were less than the 1 - and $3-\mathrm{pCi} / \mathrm{L}$ (0.037- and 0.11- $\mathrm{Bq} / \mathrm{L}$ ) minimum detectable concentrations, respectively. The average gross alpha and gross beta concentrations in Columbia River water at the city of Richland during 2009 were less than the Washington State ambient surface water quality criteria of 15 and $50 \mathrm{pCi} / \mathrm{L}(0.56$ and $1.9 \mathrm{~Bq} / \mathrm{L})$, respectively.

The 2009 annual average tritium concentrations measured upstream and downstream of the Hanford Site were similar to concentrations measured in recent years. Statistical analyses indicated that monthly tritium concentrations in river water samples at the city of Richland were higher than concentrations in samples from Priest Rapids Dam (Figure 8.4.5). However, 2009 average tritium concentrations in Columbia River water collected at the city of Richland were only $0.2 \%$ of the Washington State ambient surface water quality criterion of $20,000 \mathrm{pCi} / \mathrm{L}(740 \mathrm{~Bq} / \mathrm{L})$. The onsite source of tritium entering the river is groundwater seepage. Although representative of river water used by the city of Richland for drinking water (first municipal water source downstream from the Hanford Site), tritium concentrations measured at the Richland shoreline tend to be elevated when compared to average tritium concentrations across the river at this location (PNL-8531). This

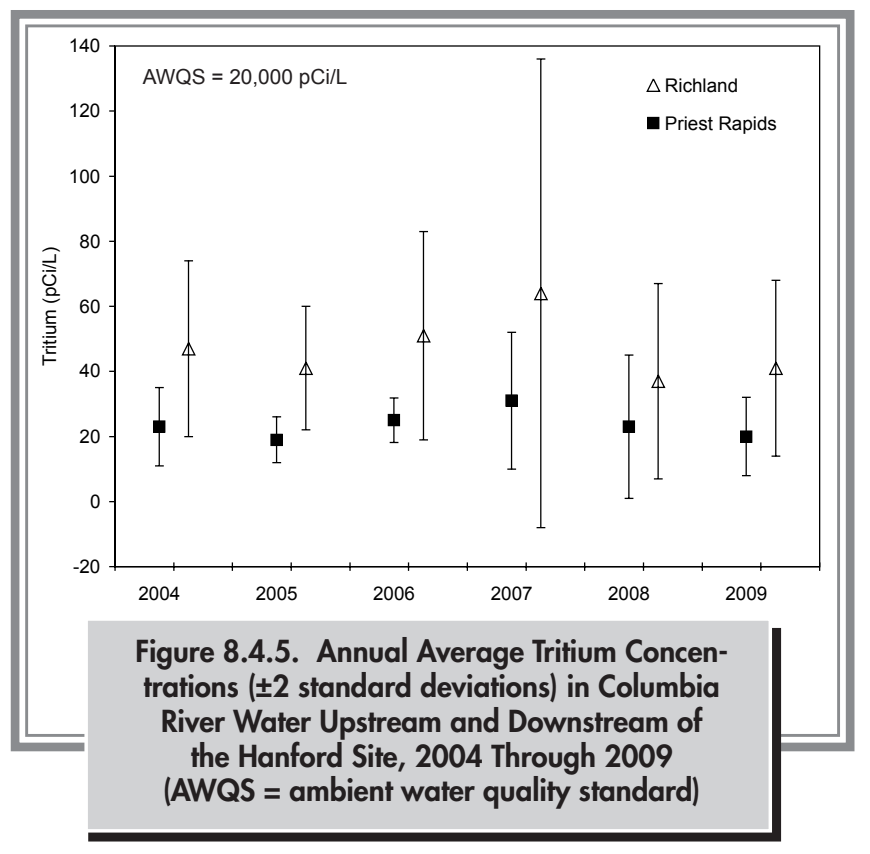

bias is attributable to a groundwater plume (originating from the 200-East Area entering the river along the portion of shoreline extending from the Hanford town site downstream to downstream of the 300 Area), which is relatively close to the city of Richland water intake. This plume is not completely mixed within the Columbia River at the city of Richland. Sampling along cross-river transects at the city of Richland during 2009 confirmed the existence of a concentration gradient in the river under certain flow conditions and is discussed subsequently in this section. The extent to which samples taken at the city of Richland drinking water intake overestimate the average tritium concentrations in the Columbia River at this location is variable and appears to be related to the flow rate of the river just before and during sample collection.

Average strontium-90 levels measured in Columbia River water collected upstream and downstream of the Hanford Site during 2009 were similar to those reported previously (Figure 8.4.6). Groundwater plumes containing strontium-90 enter the Columbia River throughout the 100 Areas. Some of the highest strontium-90 levels that have been found in onsite groundwater are the result of past discharges to the $100-\mathrm{N}$ Area liquid waste disposal facilities. Strontium-90 concentrations at Priest Rapids Dam were not statistically compared with the city of Richland because most of the concentrations were less 


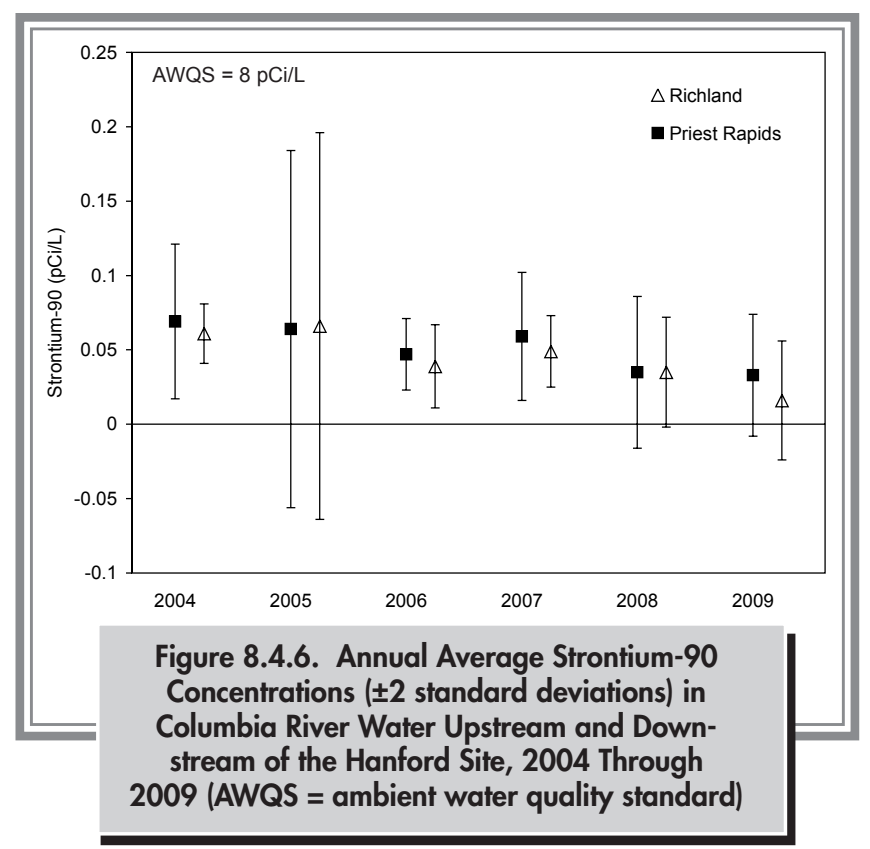

than the minimum detectable concentration. Average strontium-90 concentrations in Columbia River water at the city of Richland were less than $0.2 \%$ of the Washington State ambient surface water quality criterion $(8 \mathrm{pCi} / \mathrm{L}$ $[0.30 \mathrm{~Bq} / \mathrm{L}])$.

Annual average total uranium concentrations (i.e., the sum of uranium-234, uranium-235, and uranium-238) observed in water samples collected upstream and downstream of the Hanford Site during 2009 were similar to those observed during recent years (Figure 8.4.7). Monthly total uranium concentrations measured at the city of Richland during 2009 were significantly higher than those measured at Priest Rapids Dam. Uranium is present in the groundwater beneath the 300 Area as a result of past Hanford Site operations. Uranium has been detected at elevated levels in shoreline springs at the 300 Area in the past (Section 8.5; PNNL-13692; PNNL-16805). Uranium from non-Hanford Site sources, such as fertilizer use, is also known to enter the Columbia River across from the Hanford Site via irrigation return water and groundwater seepage associated with extensive irrigation north and east of the river (PNL-7500). Most phosphate fertilizers contain trace amounts of naturally occurring uranium. There is no Washington State ambient surface water quality criterion directly applicable to uranium. However, total uranium levels in the river during 2009 were well below the EPA

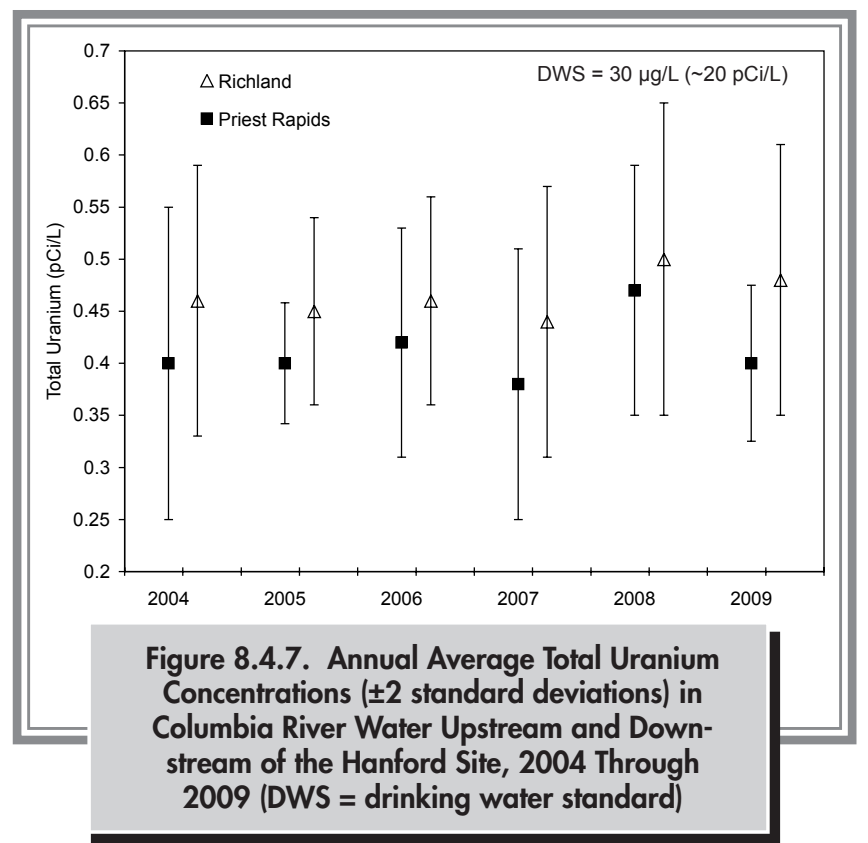

drinking water standard of $30 \mu \mathrm{g} / \mathrm{L}$ (approximately $20 \mathrm{pCi} / \mathrm{L}$ [0.74 Bq/L], Appendix D, Table D.4).

Columbia River water samples were not collected for iodine-129 analysis in 2009 because the unique instrument for this assay was not operational, and an alternative for this ultra-trace measurement capability was not available. The onsite source of iodine-129 to the Columbia River is the discharge of contaminated groundwater along the portion of shoreline downstream of the Hanford town site (Section 8.5.2). The iodine-129 plume originated in the 200 Areas from past waste disposal practices. In previous years, quarterly iodine-129 concentrations in Columbia River water at the city of Richland were significantly higher than those at Priest Rapids Dam, indicating a Hanford Site source of iodine-129. Past results have shown that iodine-129 values at Priest Rapids Dam are largely unaffected by river stages; however, the concentrations measured for river water at the city of Richland are inversely proportional to the river stage (i.e., during lower flow, the concentrations of iodine-129 are higher and vice versa). The influence of river stage on concentrations of iodine-129 at the city of Richland is reflected in the larger standard deviation, compared to the samples from Priest Rapids Dam, for the annual averages for 2004 through 2005 (Figure 8.4.8). 


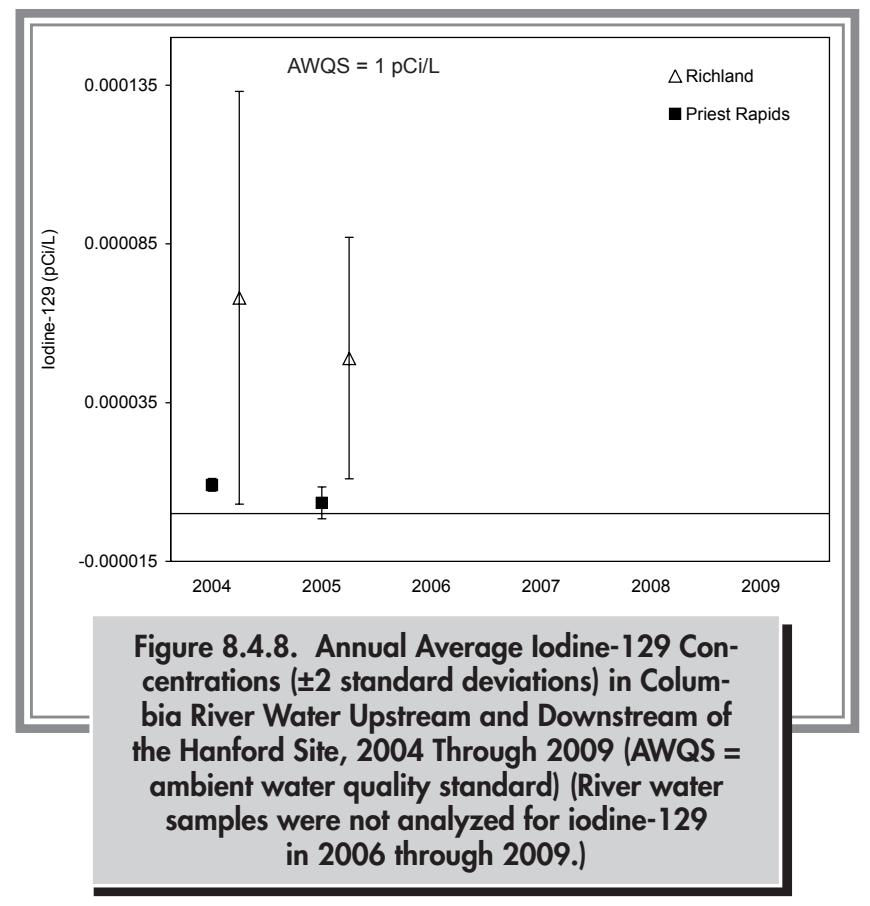

Plutonium-239/240 concentrations for river water samples at the city of Richland were extremely low during 2009. All plutonium concentrations for the filtered fractions of water samples were reported as undetected by the analytical laboratory. Plutonium concentrations for material collected on the resins (dissolved) were above the detection limits in one of four samples at the city of Richland $(0.00016 \pm$ $0.00014 \mathrm{pCi} / \mathrm{L}[5.9 \pm 5.2 \mu \mathrm{Bq} / \mathrm{L}])$ and at Priest Rapids Dam $(0.00011 \pm 0.00011 \mathrm{pCi} / \mathrm{L}[4.1 \pm 4.1 \mu \mathrm{Bq} / \mathrm{L}])$. All concentrations and detection limits were well below the DOEderived concentration guide of $30 \mathrm{pCi} / \mathrm{L}(1.1 \mathrm{E} 6 \mu \mathrm{Bq} / \mathrm{L})$ (Appendix D, Table D.2). No Washington State ambient surface water quality criterion exists for plutonium-239/240. Plutonium concentrations at Priest Rapids Dam were not statistically compared with the city of Richland because most of the concentrations were less than the reported minimum detectable concentrations.

Columbia River Transect and Near-Shore Samples. Radiological results from samples collected along Columbia River transects and at near-shore locations near Vernita Bridge, the $100-\mathrm{N}$ Area, the Hanford town site, the 300 Area, and the city of Richland during 2009 are presented in Appendix C (Tables C.5 and C.6) and PNNL-19455, APP. 1. Sampling locations were documented using a global positioning system receiver. Radionuclides consistently measured at concentrations greater than the minimum detectable activity included tritium, uranium-234, and uranium-238. Strontium-90 and uranium-235 were occasionally detected, but all values were near the minimum detectable concentrations. All measured concentrations of these radionuclides were less than the applicable Washington State ambient surface water quality criteria.

Tritium concentrations measured along Columbia River transects at Vernita Bridge, the 100-N Area, the Hanford town site, the 300 Area, and the city of Richland pump house during September 2009 are depicted in Figure 8.4.9. The transect at Vernita Bridge is the most upstream location. Stations 1 and 10 are located along the Benton County and Grant-Franklin Counties shorelines, respectively. The 100-N Area, the Hanford town site, the 300 Area, and the city of Richland transects have higher tritium concentrations near the Hanford Site shore (Benton County) relative to the opposite shore. The presence of a tritium concentration gradient in the Columbia River at the city of Richland supports previous studies showing that contaminants in the 200 Areas groundwater plume entering the river at, and upstream of, the 300 Area are not completely mixed in the river at the city of Richland (HW-73672; PNL-8531). The gradient is most pronounced during periods of relatively low river flow. Since transect sampling began in 1987 (PNL-8531), the average tritium concentration measured along the city of Richland transect has been less than that measured in monthly composited samples from the fixed-location monitoring station in the city of Richland, illustrating the conservative bias (i.e., overestimate) of the fixed-location monitoring station. For samples collected in 2009 , the highest tritium concentration measured in crossriver transect water was $60 \pm 7.0 \mathrm{pCi} / \mathrm{L}(2.2 \pm 0.26 \mathrm{~Bq} / \mathrm{L})$ at the Hanford town site (Appendix C, Table C.5). The highest tritium concentration measured in near-shore water samples was $180 \pm 72 \mathrm{pCi} / \mathrm{L}(6.7 \pm 2.7 \mathrm{~Bq} / \mathrm{L})$ from a sample collected at the 300 Area (Appendix C, Table C.6). Historically, the highest tritium concentrations for transect and near-shore samples have been measured at the Hanford town site; however, 2009 results for the Hanford town site were not as elevated compared to samples from Vernita Bridge as in past years. The riverbank spring water results (Section 8.5) for 2009 at the Hanford town site continued to show elevated tritium concentrations compared to samples from Vernita 


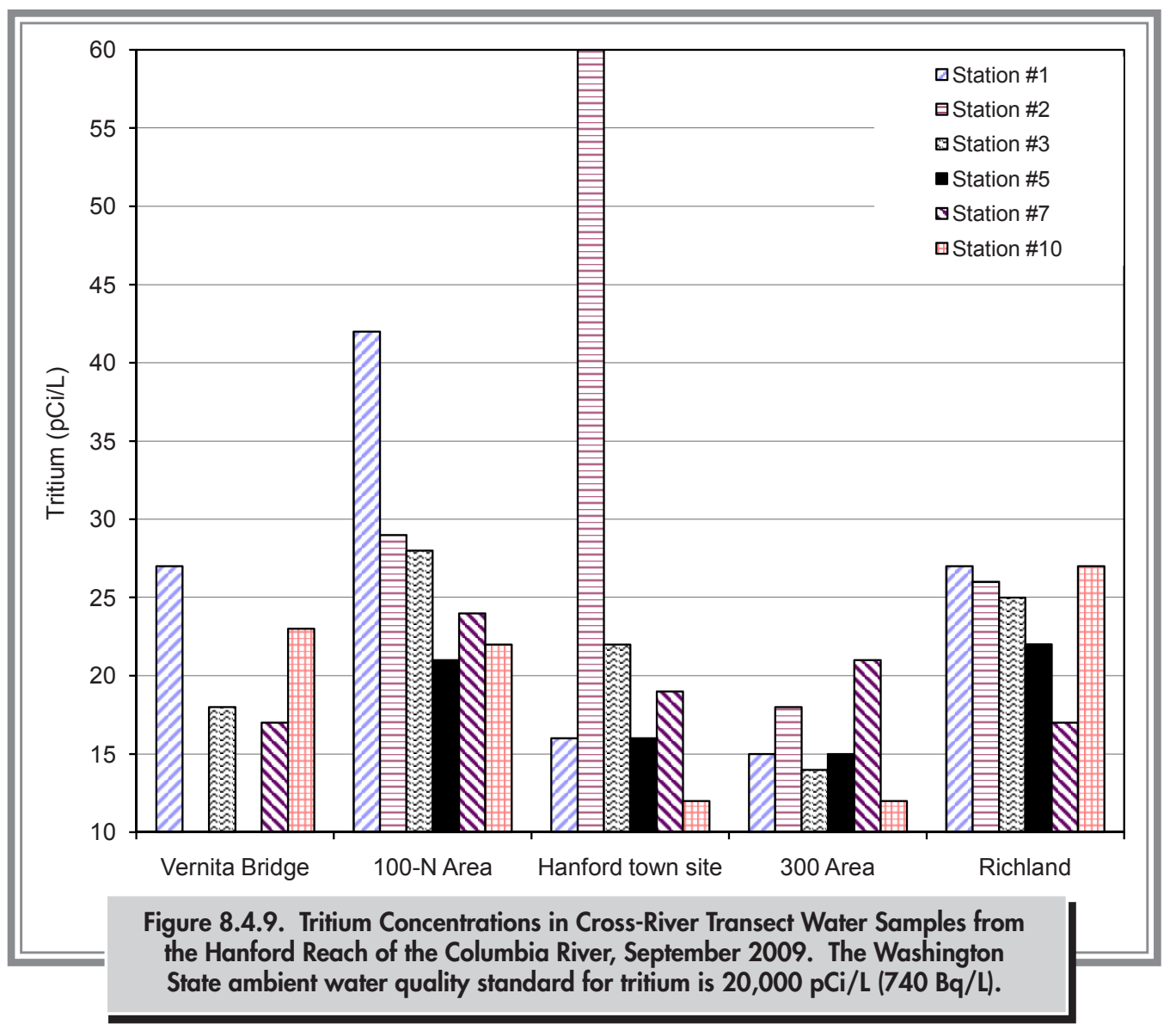

Bridge. Specific conductivity results for the 2009 transect and near-shore water samples collected at the Hanford town site indicate there was only limited mixing of groundwater into the river at the time of sample collection.

During 2009, strontium-90 concentrations in Hanford Reach river water for both transect and near-shore samples were similar to background concentrations for all locations. The maximum strontium-90 concentration for 2009 was $0.056 \pm 0.023 \mathrm{pCi} / \mathrm{L}(0.0021 \pm 0.00085 \mathrm{~Bq} / \mathrm{L})$ for a nearshore water sample collected at the Vernita Bridge transect location. The average strontium-90 concentration found during transect sampling at the city of Richland was similar to those measured in monthly composite samples at the Richland pumphouse.

Total uranium concentrations in Hanford Reach water during 2009 were elevated along both the Benton County and Grant-Franklin Counties shorelines for the transect and near-shore samples. In August 2009, the highest total uranium concentration was measured in samples from the Franklin County shoreline of the Richland transect, with a value of $0.67 \pm 0.10 \mathrm{pCi} / \mathrm{L}(0.025 \pm 0.0037 \mathrm{~Bq} / \mathrm{L})($ Appendix C, Table C.6; PNNL-19455, APP. 1). However, this concentration was well below the drinking water standard. Elevated uranium concentrations on the Franklin County side of the Columbia River likely resulted from groundwater seepage and water from irrigation return canals that had elevated uranium levels from the use of phosphate fertilizers, which contain some uranium (PNL-7500).

\subsubsection{Chemical and Physical Water Quality Results for Columbia River Water Samples}

Pacific Northwest National Laboratory and the U.S. Geological Survey (under contract to Pacific Northwest National Laboratory) compiled chemical and physical water quality data for the Columbia River during 2009. A number of the parameters measured have no regulatory limits; however, 
they are useful as indicators of water quality and contaminants of Hanford Site origin. Potential sources of pollutants not associated with the Hanford Site include irrigation return water; groundwater seepage associated with extensive irrigation north and east of the Columbia River (PNL-7500); and industrial, agricultural, and mining effluent introduced upstream of the Hanford Site.

Pacific Northwest National Laboratory Samples. Results of chemical analyses conducted by Pacific Northwest National Laboratory on water collected at Columbia River transect and near-shore locations at Vernita Bridge, the 100-N Area, the Hanford town site, the 300 Area, and the city of Richland are provided in PNNL-19455, APP. 1. The concentrations of metals and anions observed in river water during 2009 were similar to those observed in the past and remain below regulatory limits. Metals and anions were detected in Columbia River transect samples both upstream and downstream of the Hanford Site. Arsenic, antimony, cadmium, chromium, copper, lead, nickel, selenium, thallium, and zinc were detected in the majority of samples, with similar levels at most locations. Beryllium and silver were below the detection limits for all samples. Washington State ambient surface water quality criteria for cadmium, copper, lead, nickel, silver, and zinc are total-hardness dependent (WAC 173-201A; Appendix D, Table D.5). Increased water hardness (i.e., primarily higher concentrations of calcium and magnesium ions) can reduce the toxicity of some metals by limiting their absorption into aquatic organisms. Criteria for Columbia River water were calculated using a total hardness of $47 \mathrm{mg} / \mathrm{L}$ as calcium carbonate, the lowest value based on U.S. Geological Survey monitoring of Columbia River water near Vernita Bridge and the city of Richland in recent years. The total hardness reported by the U.S. Geological Survey at those locations from 1992 through 2009 ranged from 47 to $77 \mathrm{mg} / \mathrm{L}$ as calcium carbonate. All metal and anion concentrations in river water were less than the Washington State ambient surface water quality criteria for the protection of aquatic life (Appendix C, Table C.7 and Appendix D, Table D.5). Arsenic concentrations exceeded the EPA standard for the protection of human health for the consumption of water and organisms. However, this EPA value is approximately 10,500 times lower than the Washington State chronic toxicity value (Appendix D, Table D.5), and similar concentrations were found at Vernita Bridge and the city of Richland.
For samples collected on the cross-river transects, concentrations of nitrate, chloride, and sulfate were slightly elevated along both shorelines at the 100-N Area. Samples collected and analyzed for anions at the Hanford town site were similar and did not reveal any near-shore gradients. Chloride, nitrate, and sulfate concentrations were elevated along the Franklin County shoreline at the 300 Area and both the Benton County and Franklin County shorelines at the city of Richland compared to mid-river samples. In many cases, the highest anion concentrations are for samples collected along the Franklin County shoreline. These elevated results likely resulted from groundwater seepage associated with extensive irrigation north and east of the Columbia River. Nitrate contamination of some Franklin County groundwater has been documented by the U.S. Geological Survey (1995) and is associated with high fertilizer and water usage in agricultural areas. Numerous wells in western Franklin County exceed the EPA maximum contaminant level for nitrate (40 CFR 141; U.S. Geological Survey Circular 1144). Average quarterly concentrations of chloride and nitrate were higher at the city of Richland transect than in the Vernita Bridge transect. The concentrations of volatile organic compounds in Columbia River water samples (e.g., chlorinated solvents and hydrocarbons) were below the analytical laboratory's contractually required detection limits for all samples, with no indication of a Hanford Site source.

Concentrations of chromium in the Hanford Reach are of interest because groundwater contaminated with chromium above the ambient water quality criterion intersects the Columbia River at several Hanford Site locations (Section 8.7). All river transect and near-shore filtered water samples for 2009 had chromium concentrations below the ambient water quality criterion (Appendix C, Table C.7). Some near-shore water samples collected at the 100-N Area and the Hanford town site had slightly elevated chromium levels compared to upstream samples at Vernita Bridge.

U.S. Geological Survey Samples. Figure 8.4.10 illustrates U.S. Geological Survey Columbia River chemical and physical water quality data for samples collected at Vernita Bridge and the city of Richland for 2004 through 2009 (WDR-US-2007). Results for 2009 are also tabulated in PNNL-19455, APP. 1 and summarized in Appendix C (Table C.2). The 2009 U.S. Geological Survey results were 


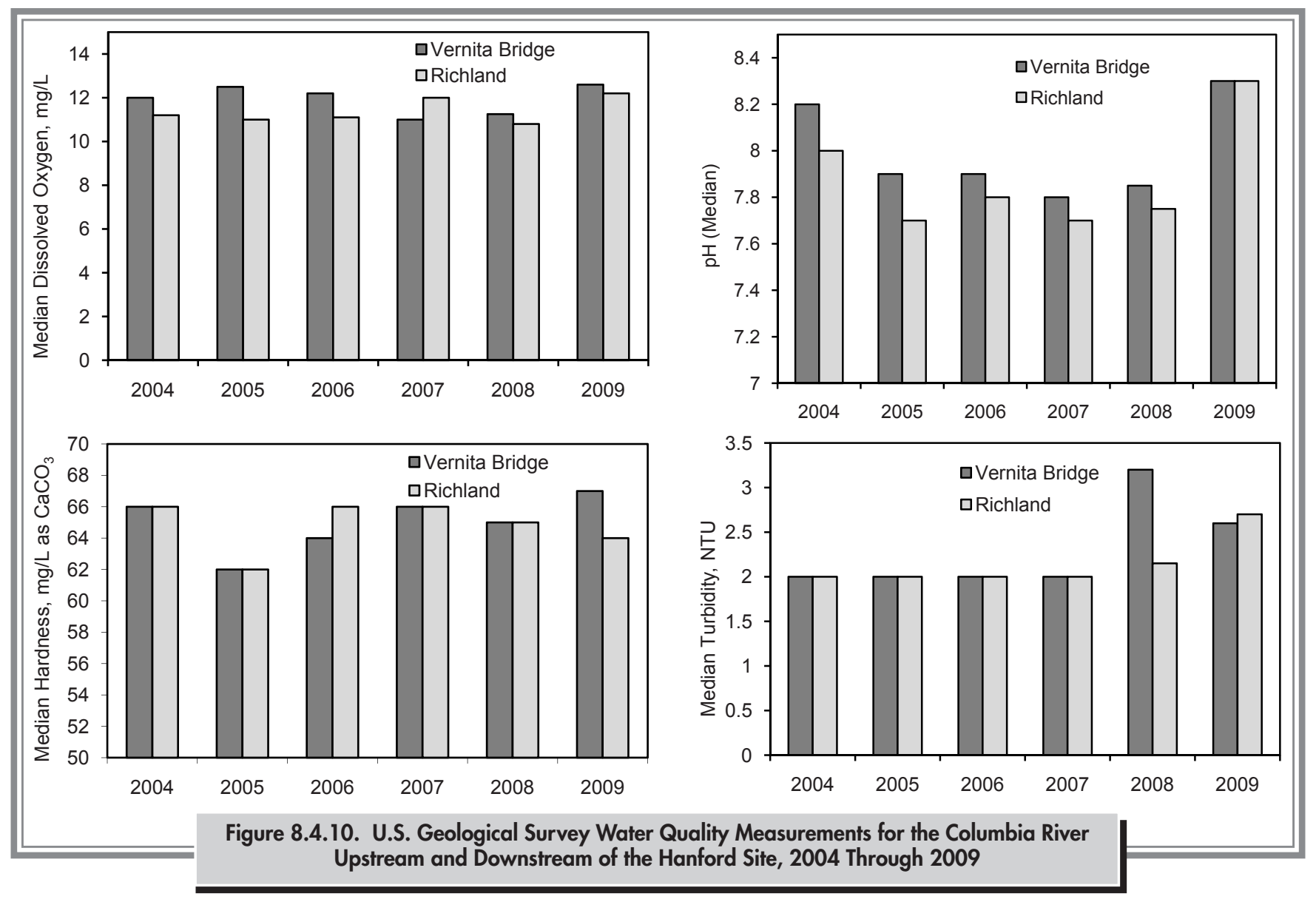

comparable to those reported during the previous 5 years, and applicable Washington State standards for the Columbia River were met. During 2009, there was no indication of any deterioration of water quality along the Hanford Reach of the Columbia River (Appendix D, Table D.3). For 2009, median concentrations of dissolved chromium were similar for water samples collected from near Vernita Bridge and the city of Richland and were well below the ambient water quality criterion.

\subsubsection{Monitoring of Columbia River Sediment}

During peak operating years on the Hanford Site, large amounts of effluents associated with reactor operations were discharged to the Columbia River. Some constituents in these effluents may have become associated with particulate matter that accumulated in riverbed sediment, particularly in slack-water areas and in the reservoirs upstream of the dams. The majority of short-lived radioactive constituents have decayed away, but some longer-lived radionuclides, such as isotopes of cesium, plutonium, strontium, and uranium, are still detectable. Fluctuations in the river flow from the operation of upriver hydroelectric dams, annual spring high river flows, and occasional floods have resulted in resuspension, relocation, and subsequent redeposition of sediment (BNWL-2305). Upper-layer sediment in the Columbia River downstream of the Hanford Site contains low concentrations of radionuclides, metals of Hanford Site origin, and radionuclides from nuclear weapons testing fallout as well as metals and other non-radioactive contaminants from mining and agricultural activities (Beasley et al. 1981; BNWL-2305; Cox et al. 2004; PNL-8148; PNL-10535; PNNL-13417; PNNL-16990). Periodic sediment sampling confirms that concentrations are low and that no significant changes in concentrations have occurred. The accumulation of radioactive materials in sediment can lead to human exposure from ingestion of aquatic organisms associated 
with the sediment or sediment resuspension into drinking water supplies. Sediment with accumulated radioactive materials can be an external radiation source, irradiating people who are fishing, wading, swimming, sunbathing, or participating in other recreational activities associated with the river or shoreline (DOE/EH-0173T).

Since the shutdown of the last single-pass reactor on the Hanford Site in 1971, the contaminant concentrations in Columbia River surface sediment near and downstream of the Hanford Site have been decreasing. This decrease is a result of radioactive decay and the deposition of uncontaminated material on top of the older sediment, which occurs in the reservoirs of the dams downstream of the Hanford Site (Cushing et al. 1981). However, discharges of some pollutants from the Hanford Site to the Columbia River still occur through permit-regulated liquid effluent discharges at the 100-K Area (Section 8.3) and through contaminated groundwater seepage (Section 8.5).

Several studies have been conducted to investigate the difference in sediment grain-size composition and total organic carbon content at routine Columbia River monitoring sites and the effect of grain size and organic content in measured contaminant concentrations (Beasley et al. 1981; PNL-10535; PNNL-13417). Physical and chemical sediment characteristics were found to be highly variable among monitoring sites along the Columbia River. Samples containing the highest percentage of silts, clays, and total organic carbon were generally collected from reservoirs behind dams upstream of the site and from the White Bluffs Slough on the Hanford Reach.

\subsubsection{Collection of Columbia River Sediment Samples and Analytes of Interest}

During 2009, samples of the surface layer of Columbia River sediment were collected at depths of 0 to 10 centimeters (0 to 4 inches) from six river locations that were permanently submerged (some Hanford Reach sampling locations may not be submerged during an extremely low river stage)

(Figure 8.4.1 and Table 8.4.2). Sampling locations were documented using a global positioning system receiver. Surface sediment was collected with a dredge sampler, capturing several years of integrated deposits, including both sediment grains and associated pore water. Gibbons (2000) estimated average sediment deposition rates of 0.723 centimeter ( 0.28 inch) per year for Priest Rapids Dam and 2.25 centimeters ( 0.89 inch) per year for McNary Dam. Assuming a maximum sediment sampling depth of 10 centimeters ( 3.9 inches) with the dredge, the samples would integrate up to 14 years at Priest Rapids Dam and 4.4 years at McNary Dam. Sediment deposition rates have not been estimated for Hanford Reach locations.

Samples were collected upstream of Hanford Site facilities from the Priest Rapids Dam reservoir (the nearest upstream impoundment) to provide data from an area unaffected by site operations. Samples were collected downstream of the Hanford Site above McNary Dam (the nearest downstream impoundment) to identify any increase in contaminant concentrations. Any increases in contaminant concentrations found in sediment above McNary Dam compared to that found above Priest Rapids Dam do not necessarily reflect a Hanford Site source. The confluences of the Columbia River with the Yakima, Snake, and Walla Walla Rivers lie between the Hanford Site and McNary Dam. Several towns, irrigation water returns, and factories in these drainages, as well as atmospheric fallout from nuclear weapons testing, may also contribute to the contaminant load found in McNary Dam sediment. Thus, sediment samples are taken periodically in the reservoir above Ice Harbor Dam (the first dam on the Snake River upstream of the river mouth) to assess Snake River input. Sediment samples were also collected along the Hanford Reach of the Columbia River, from slack-water areas where fine-grained material is known to deposit (e.g., the White Bluffs, 100-F Area, and Hanford Sloughs), and from the publicly accessible city of Richland shoreline that lies within the McNary Dam impoundment.

Monitoring sites in the reservoirs behind McNary and Priest Rapids dams consisted of two stations spaced approximately equidistant on a transect line crossing the Columbia River; the samples were collected near the boat-exclusion buoys immediately upstream of each dam. All other monitoring sites consisted of a single sampling location. Samples were collected using a clam-shell style sediment dredge; this sampling method is discussed in PNNL-16744. All sediment samples were analyzed for gamma-emitting radionuclides (Appendix F), strontium-90, uranium-234, uranium-235, plutonium-238, uranium-238, plutonium-239/240, and 
metals (DOE/RL-91-50, Rev. 4). The specific analytes selected for sediment samples were based on findings of previous Columbia River sediment investigations, reviews of past and present effluent contaminants discharged from site facilities, and reviews of contaminant concentrations observed in Hanford Site groundwater monitoring wells near the river.

\subsubsection{Radiological Results for Columbia River Sediment Sample Analyses}

Radionuclides consistently detected in river sediment adjacent to and downstream of the Hanford Site during 2009 included potassium-40, cesium-137, uranium-234, uranium-235, uranium-238, plutonium-239/240, and daughter products from naturally occurring radionuclides. The concentrations of all other radionuclides, including strontium-90, were below the reported minimum detectable concentrations for most samples (PNNL-19455, APP. 1). Cesium-137 and plutonium isotopes exist in worldwide fallout as well as in effluent from Hanford Site facilities. Potassium-40 and uranium isotopes occur naturally in the environment, and uranium isotopes are also present in Hanford Site effluent. No federal or state freshwater sediment criteria are available to assess the sediment quality of the Columbia River (EPA 822-R-96-001). Radionuclide concentrations reported in river sediment during 2009 were similar to those reported for previous years, with the exception of cesium-137 (Appendix C, Table C.8), and there were no obvious differences between locations. Unusual cesium-137 values for sediment samples for 2004 through 2007, which were roughly two times higher than values from locations above Priest Rapids Dam, were sampled at the White Bluffs Slough. The 2009 values for cesium-137 at the White Bluffs Slough were slightly elevated compared to Priest Rapids Dam but lower than the 2004 through 2007 values. Previous studies of soils from the White Bluffs Slough detected elevated concentrations of cesium-137 (PNL-3127; PNL-8789). Average, maximum, and minimum concentrations of selected radionuclides measured in Columbia River sediment (2004 through 2009) are presented in Figure 8.4.11.

\subsubsection{Chemical Results for Columbia River Sediment Sample Analyses}

Detectable amounts of most metals were found in all river sediment samples (Figure 8.4.12; Appendix C, Table C.9; PNNL-19455, APP. 1). Maximum and average concentrations of most metals were higher for sediment collected in the reservoir upstream of Priest Rapids Dam than in sediment from either the Hanford Reach or McNary Dam. The concentrations of cadmium, lead, nickel, and zinc differed the most between locations and may be associated with upstream mining activity. Currently, there are no Washington State freshwater sediment quality criteria to compare with the measured values.

\subsubsection{Monitoring of Onsite Pond Water and Sediment}

Two onsite ponds, West Lake and the Fast Flux Test Facility Pond (Figure 8.4.1), located near facilities in various stages of remediation, were sampled periodically during 2009. The ponds are accessible to migratory waterfowl, deer, and other wildlife, creating a potential biological pathway for the dispersion of contaminants (PNL-10174). The Fast Flux Test Facility Pond is a disposal site for process water, primarily cooling water drawn from 400 Area groundwater wells. West Lake, the only naturally occurring pond on the site, is located north of the 200-East Area (ARH-CD-775). West Lake has not received direct effluent discharges from Hanford Site facilities, but it is influenced by precipitation and changing water-table elevations that are related to the discharge of water to the ground in the 200 Areas. The water level in West Lake fluctuates, and the lake changes from standing water in winter and spring to dry or nearly dry in summer and fall.

\subsubsection{Collection of Pond Water, Sediment Samples, and Analytes of Interest}

During 2009, grab samples were collected quarterly from the Fast Flux Test Facility Pond (water) and from West Lake (quarterly water and biannual sediment). All water samples were analyzed for tritium. Water samples from the Fast 


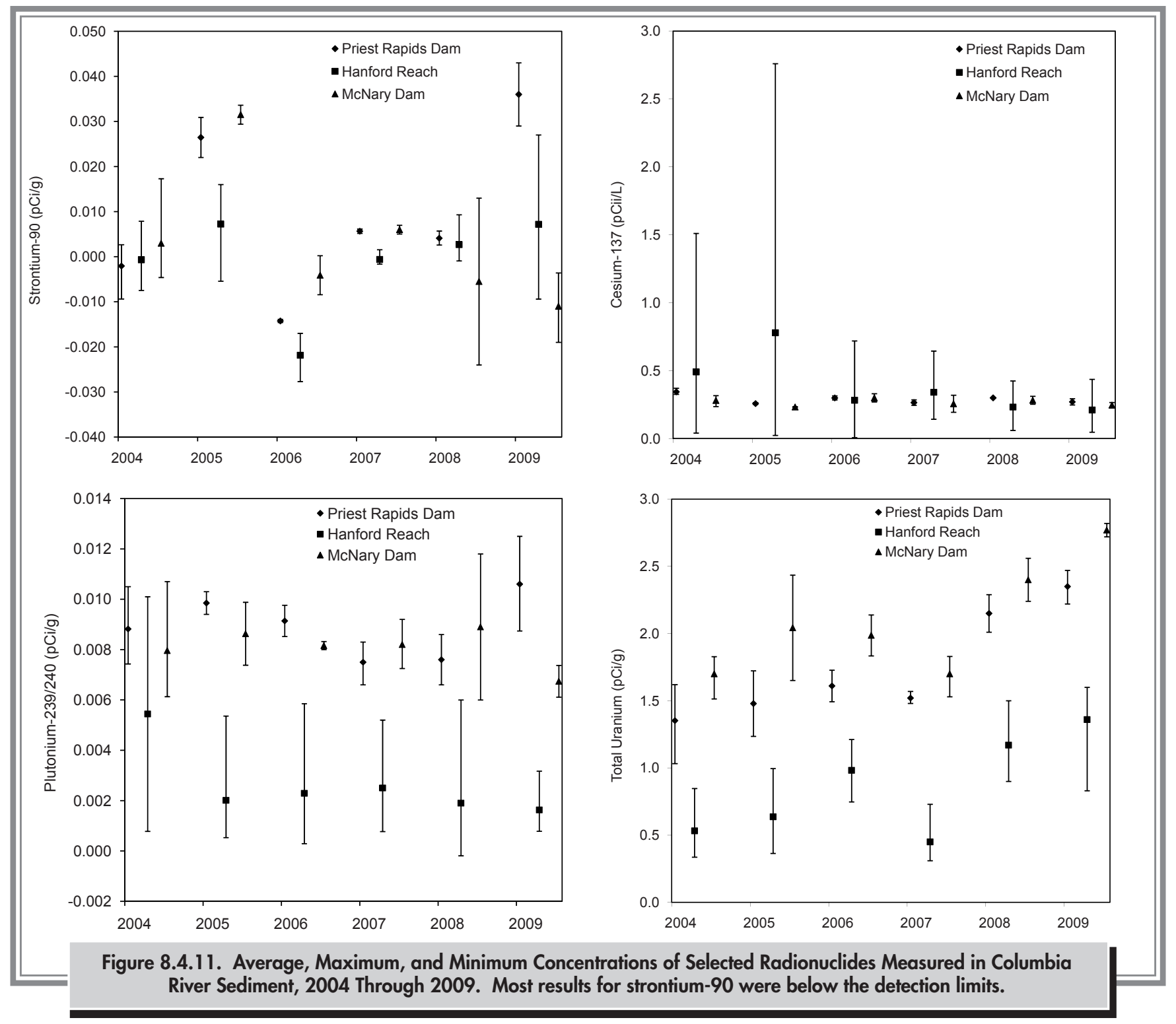

Flux Test Facility Pond were also analyzed for gross alpha and gross beta concentrations as well as gamma-emitting radionuclides. The groundwater table in the 200-East Area has dropped in recent years (Section 8.7), decreasing the size of West Lake and causing the suspended sediment loading to increase. Since 2002, it has not been practical for the analytical laboratory to process West Lake water samples for gross alpha, gross beta, strontium-90, technetium-99, uranium-234, uranium-235, and uranium-238 because of the high sediment load. Consequently, sediment samples were submitted for these analytes. Radionuclides were chosen for analysis based on their presence in local groundwater and their potential to contribute to the overall radiation dose to biota that frequent the ponds.

\subsubsection{Radiological Results for Pond Water and Sediment Sample Analyses}

All radionuclide concentrations in onsite pond water samples were less than applicable DOE-derived concentration guides (DOE Order 5400.5, Chg 2; Appendix D, Table D.2) and Washington State ambient surface water quality criteria (WAC 173-201A; 40 CFR 141; PNNL-19455, APP. 1; Appendix D, Tables D.3 and D.4). 


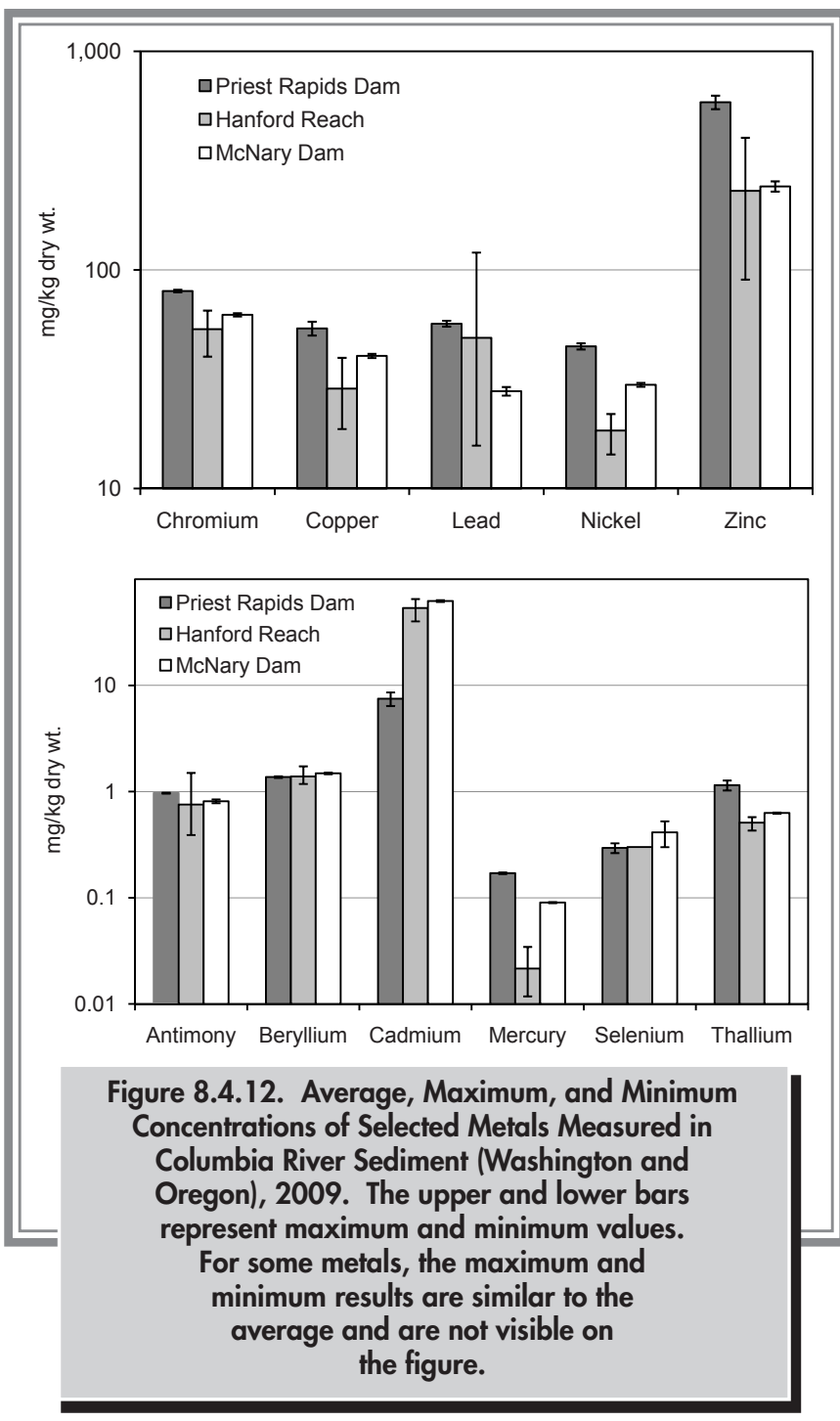

Figure 8.4.13 shows the annual average gross beta and tritium concentrations in Fast Flux Test Facility Pond water from 2004 through 2009. Average levels of both constituents have decreased slightly in recent years. The average tritium concentration in Fast Flux Test Facility Pond water during 2009 was $11 \%$ of the Washington State ambient surface water quality criterion of $20,000 \mathrm{pCi} / \mathrm{L}(740 \mathrm{~Bq} / \mathrm{L})$. The sources of contaminants in the pond water are groundwater contaminant plumes from the 200 Areas that have migrated to wells within the 400 Area that supply water to facility operations.

Tritium concentrations in West Lake water during 2009 were similar to those observed in the past (Figure 8.4.14). All results for 2009 are below the laboratory-reported detection limits.
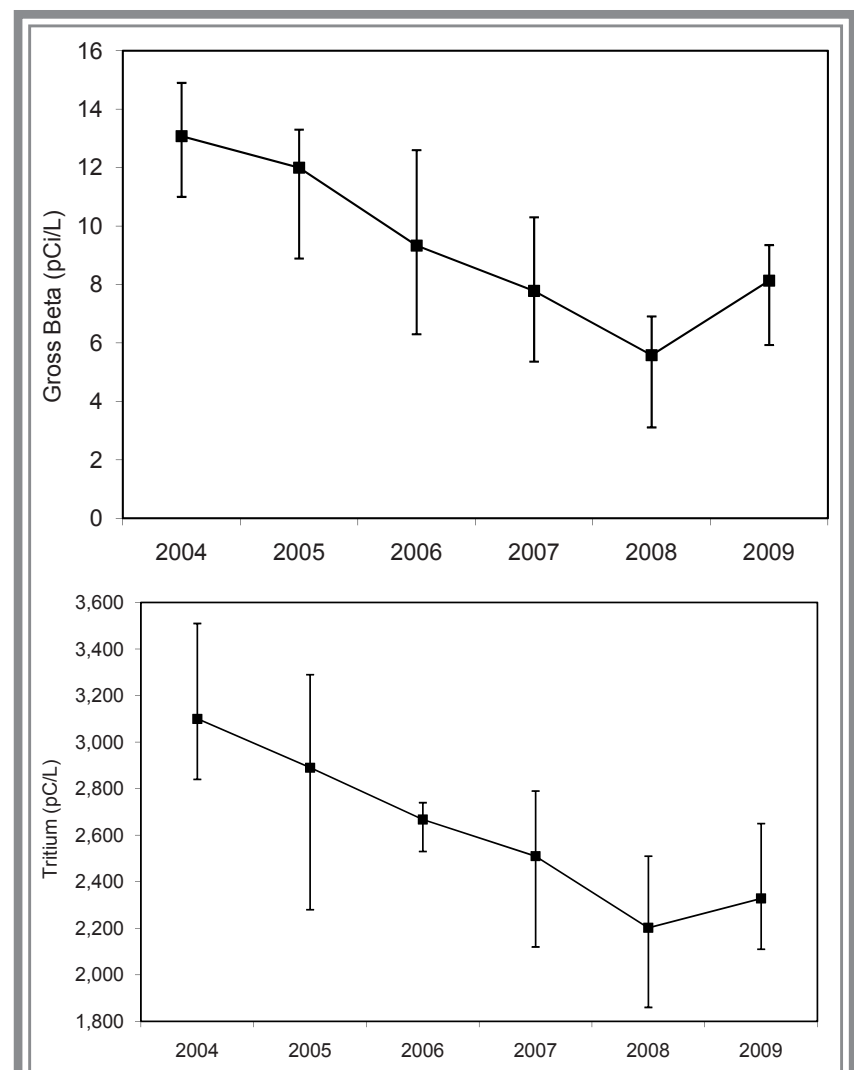

Figure 8.4.13. Average, Maximum, and Minimum Gross Beta and Tritium Concentrations in Water Samples from the Fast Flux Test Facility Pond on the Hanford Site, 2004 Through 2009

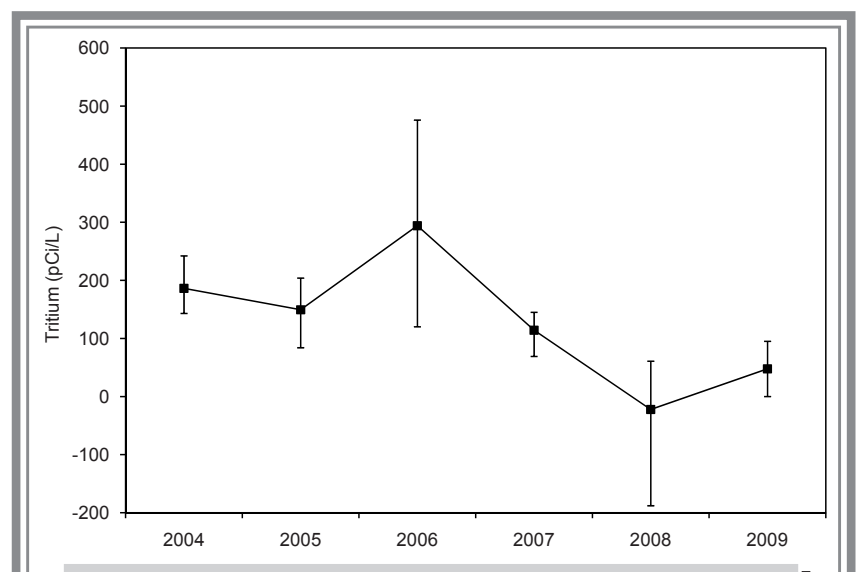

Figure 8.4.14. Average, Maximum, and Minimum Concentrations of Tritium in Water Samples from West Lake on the Hanford Site, 2004 Through 2009 
Samples of West Lake upper-layer sediment in $2009 \mathrm{had}$ the following ranges of values:

- Gross alpha-11 to $12 \mathrm{pCi} / \mathrm{g}$ (0.41 to $0.44 \mathrm{~Bq} / \mathrm{g}$ )

- Gross beta-24 to $31 \mathrm{pCi} / \mathrm{g}$ (0.89 to $1.1 \mathrm{~Bq} / \mathrm{g}$ )

- Potassium-40-12 to $17 \mathrm{pCi} / \mathrm{g}$ (0.44 to $0.63 \mathrm{~Bq} / \mathrm{g}$ )

- Strontium-90-0.30 to 0.38 pCi/g (0.011 to 0.014 Bq/g)

- Cesium-137-1.0 to 1.9 pCi/g (0.037 to $0.070 \mathrm{~Bq} / \mathrm{g}$ )

- Uranium-234-1.9 to $6.4 \mathrm{pCi} / \mathrm{g}$ (0.070 to $0.24 \mathrm{~Bq} / \mathrm{g}$ )

- Uranium-235-0.10 to $0.36 \mathrm{pCi} / \mathrm{g} \quad(0.0037$ to $0.013 \mathrm{~Bq} / \mathrm{g}$ )

- Uranium-238-1.8 to $6.1 \mathrm{pCi} / \mathrm{g}$ (0.067 to $0.23 \mathrm{~Bq} / \mathrm{g}$ ).

West Lake sediment samples were collected with a handscoop near the shoreline as grab samples of upper-layer material. Radionuclide levels in West Lake surface sediments are similar to previous measurements reported (PNL-7662). Uranium concentrations are most likely from naturally occurring uranium in the surrounding soil (BNWL-1979).

\subsubsection{Monitoring of Offsite Irrigation Water}

As a result of public concerns about the potential for Hanford Site associated contaminants in offsite water, sampling was conducted in 2009 to document the levels of radionuclides in water used by the public. The consumption of vegetation irrigated with Columbia River water downstream of the site has been identified as one of the primary pathways contributing to the potential dose to the hypothetical, maximally exposed individual and any other member of the public (Section 8.14).

\subsubsection{Collection and Analysis of Offsite Irrigation Water Samples}

During 2009, water samples were collected from an irrigation canal located east of the Columbia River and downstream from the Hanford Site at Riverview. Samples were also collected from an irrigation water supply on the Benton County shoreline near the southern boundary of the Hanford Site (Horn Rapids irrigation pumping station) (Figure 8.4.1). Water from the Riverview irrigation canal and the Horn Rapids irrigation pumping station was sampled three times during the 2009 irrigation season. Unfiltered samples were analyzed for gross alpha, gross beta, gamma emitters, tritium, strontium-90, uranium-234, uranium-235, and uranium-238.

\subsubsection{Analytical Results for Offsite Irrigation Water Samples}

During 2009, most radionuclide concentrations measured in irrigation water were at the same levels detected in Columbia River water samples collected upstream of the Hanford Site (PNNL-19455, APP. 1). At the Horn Rapids irrigation pumping station, the tritium and uranium results were higher than Columbia River water samples collected upstream of the Hanford Site. All radionuclide concentrations were less than their respective DOEderived concentration guides and Washington State ambient surface water quality criteria (DOE Order 5400.5, Chg 2; WAC 173-201A; 40 CFR 141). 


\title{
8.5 Columbia River Shoreline Springs Monitoring
}

\author{
GW Patton
}

Samples of Columbia River shoreline spring water and associated sediment were collected along the Hanford Reach and analyzed to determine the potential impact of radiological and chemical contaminants from the Hanford Site on the public and the aquatic environment. Sections 8.5.1 and 8.5.2 discuss the collection, analysis, and results for Columbia River shoreline spring water and sediment samples.

\subsubsection{Water Monitoring at Columbia River Shoreline Springs}

The Columbia River is the discharge area for the unconfined aquifer underlying the Hanford Site. Groundwater provides a means for transporting Hanford Site-associated contaminants, which have leached into groundwater from past waste disposal practices, to the Columbia River (DOE/ RL-92-12, Rev. 1; PNL-5289; PNL-7500; WHC-SD-ENTI-006). Contaminated groundwater enters the Columbia River via surface and subsurface discharge. Discharge zones located above the water level of the river are identified in this report as shoreline springs. Routine monitoring of shoreline springs offers the opportunity to characterize the quality of groundwater being discharged to the river and assess the potential human and ecological risk associated with the spring water. In addition, contaminants in groundwater near the Columbia River are monitored using shoreline groundwater-sampling tubes (aquifer tubes) (Section 8.7; BHI-01153, Rev. 0; PNNL-14444; PNNL-16805; PNNL-16894; SGW-41497, Rev. 0).

Shoreline springs were documented along the Hanford Reach long before Hanford Site operations began during World War II (Jenkins 1922). During the early 1980s, researchers walked a 66-kilometer (41-mile) stretch of the Benton County shoreline of the Hanford Reach and identified 115 springs (PNL-5289). They reported that the predominant areas of riverbank springs at that time were in the vicinity of the 100-N Area, Hanford town site, and the 300 Area. In recent years, it has become increasingly difficult to locate shoreline springs in the 100-N Area. Declining water-table elevations, a consequence of the end of $\mathrm{N}$ Reactor operations, have reduced discharge from the 100-N Area springs.

The presence of shoreline springs also varies with river stage (river-level elevation). The water table near the Hanford Reach is strongly influenced by river-stage fluctuations. The river stage in the Hanford Reach is controlled by upriver conditions and operations at upriver dams. As river water levels fluctuate, groundwater levels change, which causes the presence of shoreline springs in the Hanford Reach to vary. At the 300 Area, the river stage is also influenced by the elevation of the McNary Dam pool. Columbia River water moves into the Hanford Site aquifer as the river stage rises (bank storage) and then discharges from the aquifer in the form of shoreline springs as the river stage falls. Following an extended period of low river flow, groundwater discharge zones above the water level of the river may cease to exist when the level of the aquifer comes into equilibrium with the level of the river. Thus, springs are most readily identified immediately following a decline in river stage.

Bank storage of river water also affects the contaminant concentration of the springs. Spring water discharged immediately following a river stage decline generally consists of river water or a mixture of river water and groundwater. The percentage of groundwater in the spring water discharge increases over time following a drop in river stage. Measuring the specific conductance of the spring water 
discharge provides an indicator of the extent of bank storage because Hanford Site groundwater has a higher specific conductance than Columbia River water.

The effect of bank storage on groundwater discharges and contaminant concentration variations in aquifer thickness, porosity, and plume concentrations makes it difficult to accurately estimate the volume of contaminated groundwater discharging via springs to the Columbia River within the Hanford Reach. Studies of shoreline springs conducted during 1983 (PNL-5289), 1988 (PNL-7500), and 1991 (DOE/RL-92-12, Rev. 1; WHC-EP-0609) and results of near-shore studies in 1997 (PNNL-11933) and 2001 (PNNL-13692) noted that discharges from the springs had only localized effects on river contaminant concentrations.

\subsubsection{Collection of Water Samples from Columbia River Shoreline Springs and Constituents of Interest}

Routine monitoring of selected shoreline springs was initiated during 1988. Currently, shoreline spring water samples are collected for contaminant monitoring and to support groundwater operable unit investigations (DOE/RL-91-50, Rev. 4). Tables 8.5.1 and 8.5.2 and Figure 8.4.1 summarize the sampling locations and frequencies, as well as sample types and analyses included in shoreline springs monitoring during 2009. This section describes the monitoring efforts and summarizes the results for these aquatic environments. Detailed analytical results are reported in PNNL-19455, APP. 1. Analytes of interest for samples from shoreline springs were selected based on findings of previous investigations, reviews of contaminant concentrations observed in nearby groundwater monitoring wells, and results of preliminary risk assessments. Sampling is conducted annually when river flows are low, typically in early fall.

The majority of samples collected during 2009 were analyzed for gamma-emitting radionuclides, gross alpha, gross beta, and tritium. Samples from selected springs were analyzed for strontium-90, technetium-99, uranium-234, uranium-235, and uranium-238. Selected riverbank spring water samples were analyzed for iodine-129 using a gamma spectroscopy method. Most samples were analyzed for metals and anions. Samples from selected locations were analyzed for volatile organic compounds. Only unfiltered samples were analyzed, except for metals analyses, in which case both filtered and unfiltered samples were analyzed (Appendix C, Table C.10; PNNL-19455, APP. 1).

\begin{tabular}{|c|c|c|c|}
\hline \multirow[b]{2}{*}{$\begin{array}{c}\text { Spring } \\
\text { Location }^{(a)}\end{array}$} & \multicolumn{3}{|c|}{ Table 8.5.1. Hanford Reach Shoreline Springs Water Monitoring, 2009} \\
\hline & Sample Type & $\begin{array}{l}\text { Sampling } \\
\text { Frequency }\end{array}$ & Analyses \\
\hline 100-B Area & $\mathrm{Grab}$ & Annually & $\begin{array}{l}\text { Alpha, beta, }{ }^{3} \mathrm{H},{ }^{90} \mathrm{Sr},{ }^{99} \mathrm{Tc} \text {, gamma energy analysis, metals } \\
\text { (filtered and unfiltered), anions, VOC }{ }^{(b)}\end{array}$ \\
\hline 100-K Area & Grab & Annually & $\begin{array}{l}\text { Alpha, beta, }{ }^{3} \mathrm{H},{ }^{90} \mathrm{Sr} \text {, gamma energy analysis, metals } \\
\text { (filtered and unfiltered), anions, } \text { VOC }^{(\text {b) }}\end{array}$ \\
\hline 100-N Area & Grab & Annually & $\begin{array}{l}\text { Alpha, beta, }{ }^{3} \mathrm{H},{ }^{90} \mathrm{Sr} \text {, gamma energy analysis, metals } \\
\text { (filtered and unfiltered), anions }\end{array}$ \\
\hline 100-D Area & Grab & Annually & $\begin{array}{l}\text { Alpha, beta, }{ }^{3} \mathrm{H},{ }^{90} \mathrm{Sr} \text {, gamma energy analysis, metals } \\
\text { (filtered and unfiltered), anions }\end{array}$ \\
\hline 100-H Area & Grab & Annually & $\begin{array}{l}\text { Alpha, beta, }{ }^{3} \mathrm{H},{ }^{90} \mathrm{Sr},{ }^{99} \mathrm{Tc}, \mathrm{U}^{(c)} \text { gamma energy analysis, } \\
\text { metals (filtered and unfiltered), anions }\end{array}$ \\
\hline 100-F Area & Grab & Annually & $\begin{array}{l}\text { Alpha, beta, }{ }^{3} \mathrm{H},{ }^{90} \mathrm{Sr}, \mathrm{U},{ }^{(c)} \text { gamma energy analysis, metals } \\
\text { (filtered and unfiltered), anions, } \mathrm{VOC}^{(\mathrm{b})}\end{array}$ \\
\hline Hanford town site & Grab & Annually & $\begin{array}{l}\text { Alpha, beta, }{ }^{3} \mathrm{H},{ }^{99} \mathrm{Tc},{ }^{129} \mathrm{I}, \mathrm{U},{ }^{(c)} \text { gamma energy analysis, } \\
\text { metals (filtered and unfiltered), anions }\end{array}$ \\
\hline 300 Area & Grab & Annually & $\begin{array}{l}\text { Alpha, beta, }{ }^{3} \mathrm{H},{ }^{90} \mathrm{Sr},{ }^{129} \mathrm{I}, \mathrm{U},{ }^{(c)} \text { gamma energy analysis, } \\
\text { metals (filtered and unfiltered), anions, VOC }{ }^{(b)}\end{array}$ \\
\hline \multicolumn{4}{|c|}{$\begin{array}{l}\text { (a) See Figure } 8.4 .1 . \\
\text { (b) VOC = Volatile organic compounds. } \\
\text { (c) U = Isotopic uranium-234, uranium-235, and uranium-238 analyzed by alpha spectrometry (alpha energy analysis). }\end{array}$} \\
\hline
\end{tabular}


Table 8.5.2. Hanford Reach Shoreline Springs Sediment Monitoring, 2009

\begin{tabular}{|c|c|c|}
\hline $\begin{array}{c}\text { Spring } \\
\text { Location }^{(a)}\end{array}$ & $\begin{array}{l}\text { Sampling } \\
\text { Frequency }\end{array}$ & $\underline{\text { Analyses }}$ \\
\hline 100-B Area & Annually & Gamma energy analysis, ${ }^{90} \mathrm{Sr}, \mathrm{U},{ }^{(b)}$ metals \\
\hline 100-H Area & Annually & Gamma energy analysis, ${ }^{90} \mathrm{Sr}, \mathrm{U},{ }^{(b)}$ metals \\
\hline 100-F Area & Annually & Gamma energy analysis, ${ }^{90} \mathrm{Sr}, \mathrm{U}$, (b) metals \\
\hline Hanford town site & Annually & Gamma energy analysis, ${ }^{90} \mathrm{Sr}, \mathrm{U},{ }^{(\mathrm{b})}$ metals \\
\hline 300 Area & Annually & Gamma energy analysis, ${ }^{90} \mathrm{Sr}, \mathrm{U},{ }^{(b)}$ metals \\
\hline
\end{tabular}

(a) See Figure 8.4.1.

(b) $\mathrm{U}=$ Isotopic uranium-234, uranium-235, and uranium-238 analyzed by alpha spectrometry (alpha energy analysis).

riverbank springs are indicators of the contaminated groundwater plume originating at the 300 Area. The elevated tritium levels measured in 300 Area shoreline springs are indicators of the contaminated groundwater plume from the 200 Areas (Section 5.9 in PNL-10698).

Figure 8.5.2 provides concentrations of selected radionuclides in shoreline spring water near the Hanford town site (Spring 28-2 and Spring DR 28-2) from 2004 through 2009. Annual fluctuations in these values reflect the influence of

\subsubsection{Radiological Results for Water Samples from Columbia River Shoreline Springs}

Contaminants of Hanford Site origin continued to be detected in water from shoreline springs entering the Columbia River along the Hanford Site during 2009. Gross alpha, gross beta, tritium, strontium-90, technetium-99, uranium-234, uranium-235, and uranium-238 were detected in spring water (Appendix C, Table C.10). All samples analyzed for iodine-129 in 2009 were below the laboratoryreported detection limit. All radiological contaminant concentrations measured in shoreline springs during 2009 were less than applicable DOE-derived concentration guides, but exceeded the Washington State ambient water quality criteria for gross alpha at some 300 Area locations and for tritium at the Hanford town site. In addition, uranium concentrations at some 300 Area locations exceeded the drinking water standard (DOE Order 5400.5, Chg 2; Appendix D, Table D.2).

Figure 8.5.1 depicts 6-year trend plots of selected radionuclide concentrations in 300 Area shoreline spring water (Spring 42-2 and Spring DR 42-2) from 2004 through 2009. Radionuclide concentrations in 300 Area shoreline springs in 2009 were similar to concentrations measured in previous years. Radionuclide concentrations in shoreline spring water vary over the years with changes in the degree of Columbia River water and groundwater mixing (i.e., bank storage effect). Elevated gross alpha, gross beta, and uranium concentrations measured in the 300 Area bank storage during the sampling period. The elevated radionuclide levels measured in the Hanford town site shoreline springs are indicators of the contaminated groundwater plume from the 200 Areas (Section 5.9 in PNL-10698).

In 2009, gross beta concentrations in shoreline spring water at locations in the 100 Areas, the Hanford town site, and the 300 Area were elevated compared to gross beta concentrations in Columbia River water at Priest Rapids Dam, but were below the Washington State 50-pCi/L (2-Bq/L) ambient water quality criterion. Gross beta concentrations were highest for riverbank spring water at the 300 Area and the Hanford town site.

Tritium concentrations varied widely with location. The highest tritium concentration measured in shoreline springs was at the Hanford town site $(20,400 \pm 3,990 \mathrm{pCi} / \mathrm{L}$ $[755 \pm 148 \mathrm{~Bq} / \mathrm{L}]$ ), which was $102 \%$ of the Washington State ambient surface water quality criterion of $20,000 \mathrm{pCi} / \mathrm{L}$ (740 Bq/L) (WAC 173-201A; 40 CFR 141), followed by $9,066 \pm 1,790 \mathrm{pCi} / \mathrm{L}(335 \pm 66.2 \mathrm{~Bq} / \mathrm{L})$ in the 300 Area, and $6,230 \pm 1,310 \mathrm{pCi} / \mathrm{L}(230 \pm 48.5 \mathrm{~Bq} / \mathrm{L})$ in the 100-D Area. Tritium concentrations in most shoreline spring water samples were elevated compared to the 2009 Columbia River water concentrations at Priest Rapids Dam.

Water samples from shoreline springs were analyzed for strontium-90 in the 100 and 300 Areas. The highest strontium-90 concentration detected in shoreline spring water was at the $100-\mathrm{H}$ Area $(3.0 \pm 0.48 \mathrm{pCi} / \mathrm{L}[0.11 \pm$ $0.018 \mathrm{~Bq} / \mathrm{L}])$. This value was $38 \%$ of the state's ambient 


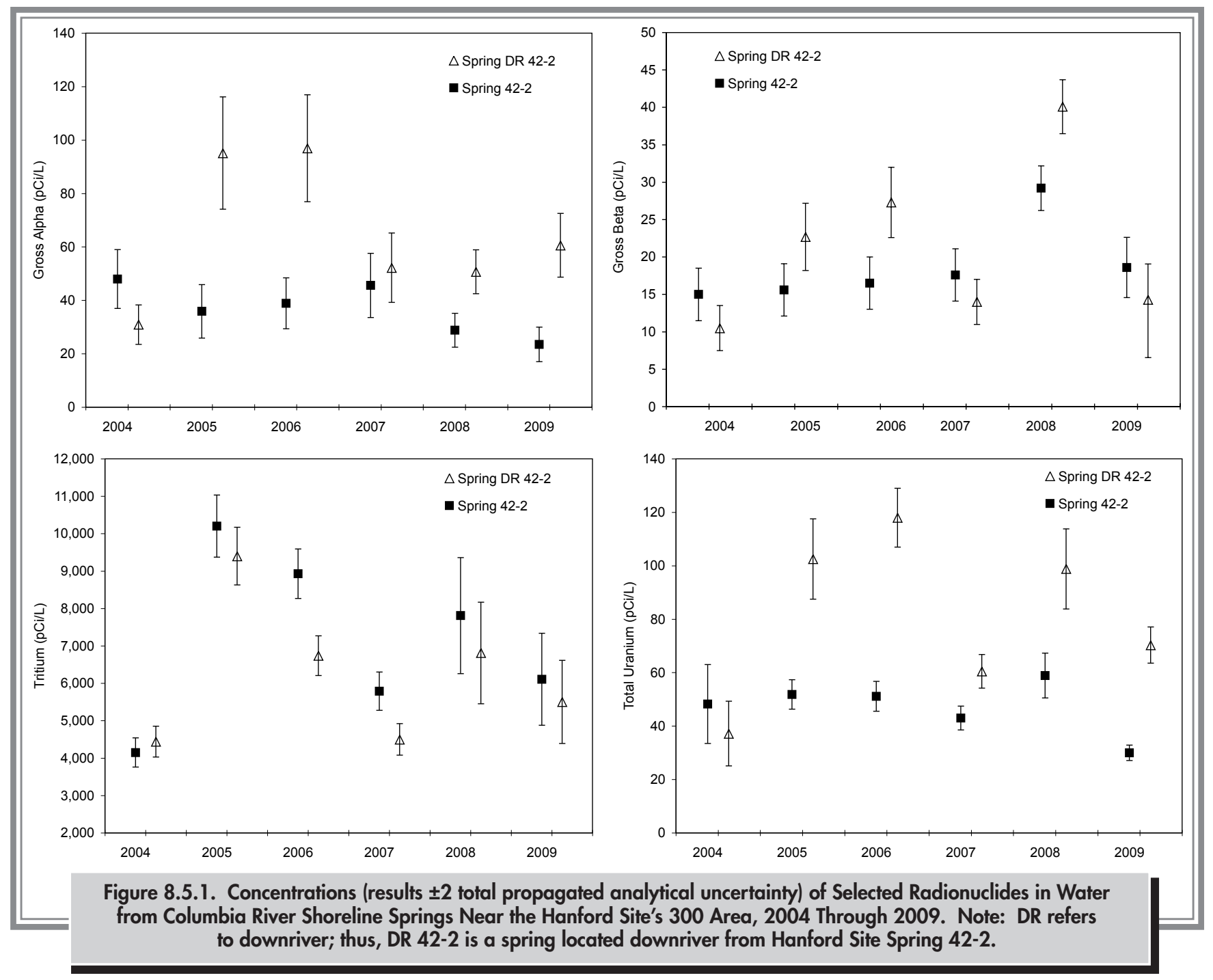

surface water quality criterion of $8 \mathrm{pCi} / \mathrm{L}(0.30 \mathrm{~Bq} / \mathrm{L})$. Groundwater at the 100-N Area historically has had the highest strontium-90 concentrations. However, since 1997, no visible shoreline springs have been observed along the shoreline where strontium-90 concentrations in groundwater are elevated.

Water samples from shoreline springs in the 100-B Area, 100-H Area, and at the Hanford town site were analyzed for technetium-99. All results for technetium-99 were below the EPA drinking water standard of $900 \mathrm{pCi} / \mathrm{L}(33 \mathrm{~Bq} / \mathrm{L})$ (Appendix D, Table D.4). The highest technetium-99 concentration was found in shoreline spring water from the Hanford town site $(35 \pm 4.0 \mathrm{pCi} / \mathrm{L}[1.3 \pm 0.15 \mathrm{~Bq} / \mathrm{L}])$.
Water samples from shoreline springs at the Hanford town site and the 300 Area were collected from 2004 through 2005 and submitted to a laboratory for iodine-129 analyses using a method capable of detecting extremely low concentrations. However, since 2005, the unique instrument used for this assay has not been operational, and an alternative for this ultra-trace measurement capability is not available. The highest concentrations were measured in water samples from the Hanford town site springs from 2004 to 2005, with all values below the state's surface water quality criterion of $1 \mathrm{pCi} / \mathrm{L}(0.037 \mathrm{~Bq} / \mathrm{L}$ ) (Appendix D, Table D.4). Riverbank spring water samples were analyzed for iodine-129 for 2007 to 2009 with traditional gamma spectrometry, 


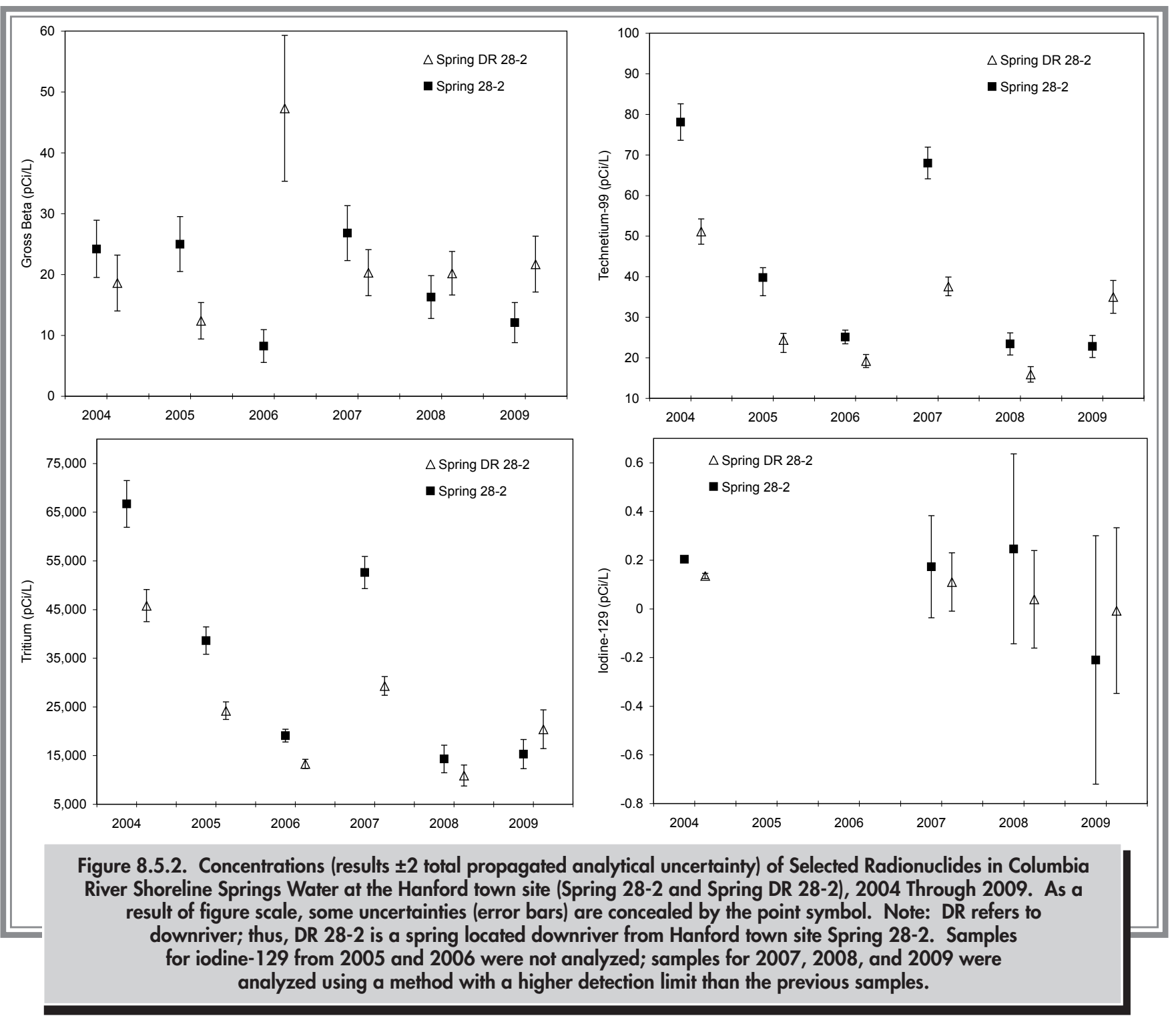

which has a higher detection limit than the ultra-trace method. All samples analyzed for iodine-129 for 2007 to 2009 were below the detection limit of $1 \mathrm{pCi} / \mathrm{L}(0.037 \mathrm{~Bq} / \mathrm{L})$.

Uranium was monitored in shoreline spring water samples from the 100-H Area, 100-F Area, Hanford town site, and 300 Area in 2009 (Figure 8.4.1). The highest total uranium level was found in 300 Area spring water $(70 \pm 4.8 \mathrm{pCi} / \mathrm{L}$ [2.6 $\pm 0.18 \mathrm{~Bq} / \mathrm{L}]$ or approximately $100 \pm 7.2 \mu \mathrm{g} / \mathrm{L})$, which was collected at Spring DR 42-2 downgradient from the retired 300 Area process trenches. The total uranium concentration in this spring exceeded the EPA drinking water standard of $30 \mu \mathrm{g} / \mathrm{L}$ (approximately $20 \mathrm{pCi} / \mathrm{L}[0.74 \mathrm{~Bq} / \mathrm{L}]$ ). Spring DR $42-2$ in the 300 Area had an elevated gross alpha concentration $(61 \pm 12 \mathrm{pCi} / \mathrm{L}[2.3 \pm 0.44 \mathrm{~Bq} / \mathrm{L}])$, which exceeded the Washington State ambient surface water quality criterion of $15 \mathrm{pCi} / \mathrm{L}(0.56 \mathrm{~Bq} / \mathrm{L})$ (Appendix D, Table D.4). Elevated uranium concentrations exist in the unconfined aquifer beneath the 300 Area in the vicinity of former uranium fuel fabrication facilities and inactive waste sites. Gross alpha and gross beta concentrations in 300 Area shoreline spring water from 2004 through 2009 parallel uranium concentrations and are likely associated with its presence. Concentrations of radionuclides in 300 Area 
shoreline springs in 2009 were similar to concentrations measured in previous years and varied with changes in riverbank storage.

\subsubsection{Chemical Results for Water Samples from Columbia River Shoreline Springs}

Chemical contaminants originating from the Hanford Site continued to be detected in water from shoreline springs entering the Columbia River during 2009. Metals and anions of interest (chloride, fluoride, nitrate, and sulfate) were detected in spring water. Concentrations of volatile organic compounds were near or below the analytical laboratory's required detection limits in all samples. Trace amounts of trichloroethene, a chlorinated organic compound, were detected below the analytical laboratory's required detection limit for the $100-\mathrm{K}$ and 300 Areas. Trichloroethene has been consistently detected at trace concentrations in 300 Area shoreline spring water, which is a result of contaminated groundwater in the shallowest part of the unconfined aquifer near the river. Relatively high concentrations recently discovered at depth in the unconfined aquifer, which greatly exceeded regulatory standards (PNNL-16435), were not observed in the riverbank springs.

Table 8.5.3 presents concentration ranges of selected chemicals measured in shoreline spring water during 2004 through 2009. For most locations, the 2009 chemical sample results were similar to those reported previously (PNNL-14687). Nitrate concentrations for 2004 through 2009 were highest in spring water samples from the 100-F

Area. Dissolved chromium concentrations in shoreline springs for 2004 through 2009 were highest in the 100-D, 100-B, and 100-K Areas. Hanford Site groundwater monitoring results for 2009 indicated similar contaminant concentrations at shoreline areas near the discharge locations for the springs (Section 8.7, Figure 8.7.6).

The Washington State ambient surface water quality criteria for cadmium, copper, lead, nickel, silver, and zinc are total-hardness dependent (WAC 173-201A; Appendix D, Table D.5). For comparison purposes, shoreline spring water criteria were calculated using the same $47-\mathrm{mg} / \mathrm{L}$ calcium carbonate hardness given in Appendix D, Table D.5. Concentrations of most metals measured in water collected from springs along the Hanford Site shoreline during 2004 through 2009 were below Washington State ambient surface water chronic toxicity levels (WAC 173-201A). However, for 2004 through 2009, the maximum concentrations of dissolved chromium in shoreline spring water from the 100-B, 100-K, 100-D, 100-H, and 100-F Areas were above the Washington State ambient surface water chronic and acute toxicity levels; concentrations from the 100-N Area were above the Washington State ambient surface water chronic toxicity levels only (Appendix D, Table D.5). For 2009, dissolved chromium was at or above the Washington State ambient surface water level for chronic and acute toxicity levels at the 100-B, 100-K, 100-H, and 100-F Areas. Arsenic concentrations in shoreline spring water were well below the Washington State ambient surface water chronic toxicity level, but concentrations in all samples (including upriver Columbia River water samples) exceeded the EPA limit for the protection of human health for the consumption of water and organisms. Nevertheless, this EPA value is more than 10,500 times lower than the Washington State chronic toxicity standard (40 CFR 141; Appendix D, Table D.5). Nitrate concentrations at all shoreline spring locations were below the drinking water standard (Appendix D, Table D.4).

\subsubsection{Monitoring Columbia River Shoreline Springs Sediment}

Beginning in the 1990s, periodic studies were conducted to collect and analyze sediment from riverbank springs in the 100 Areas and the 300 Area (DOE/RL-92-12, Rev. 1; WHC-EP-0609; WHC-SD-EN-TI-125, Rev. 0; WHC-SDEN-TI-198). Routine sampling of sediment from shoreline springs began during 1993 at the Hanford town site and 300 Area. Sampling of shoreline springs sediment in the 100-B, 100-K, and 100-F Areas began during 1995 and in the 100-H Area in 2004. Substrates at the shoreline springs in the 100-N and 100-D Areas consist predominantly of large cobble, which is unsuitable for sampling. During 2009, sediment samples were collected at shoreline springs in the 100-B, 100-H, 100-F, and 300 Areas and the Hanford town site. 
Table 8.5.3. Concentration Ranges for Selected Chemicals in Water Monitoring Samples from Columbia River Shoreline Springs on the Hanford Site, 2004 Through 2009

\begin{tabular}{|c|c|c|c|c|c|c|c|c|c|}
\hline No. of Samples & $\begin{array}{c}\text { Ambient- } \\
\text { Water Quality } \\
\text { Criterion Level }^{(\mathrm{a})}\end{array}$ & $\frac{\text { 100-B Area }}{10}$ & $\frac{100-K \text { Area }}{7}$ & $\frac{100-N \text { Area }}{6}$ & $\frac{\text { 100-D Area }}{12}$ & $\frac{100-H \text { Area }}{11}$ & $\frac{100-F \text { Area }}{6}$ & $\begin{array}{c}\begin{array}{c}\text { Hanford } \\
\text { town site }\end{array} \\
18\end{array}$ & $\frac{300 \text { Area }}{17}$ \\
\hline \multicolumn{10}{|c|}{ Dissolved Metals $(\mu \mathrm{g} / \mathrm{L})$} \\
\hline Antimony & NA & $0.12-0.25$ & $0.094-0.29$ & $0.16-0.29$ & $0.14-0.30$ & $0.13-0.39$ & $0.099-0.22$ & $0.15-0.29$ & $0.14-0.29$ \\
\hline Arsenic & 190 & $0.42-1.3$ & $0.35-1.8$ & $1.5-2.5$ & $0.54-2.5$ & $0.33-2.6$ & $0.38-2.2$ & $0.99-4.0$ & $0.87-6.3$ \\
\hline Cadmium & 0.59 & $0.0040-0.011$ & $0.0083-0.025$ & $0.0090-0.021$ & $0.0074-0.054$ & $0.0020-0.038$ & $0.074-0.12$ & $0.0073-0.028$ & $0.014-0.038$ \\
\hline Chromium & $10^{(\mathrm{b})}$ & $2.2-18$ & $0.59-72$ & $4.9-11$ & $0.49-54$ & $0.76-37$ & $0.83-16$ & $0.52-2.7$ & $1.5-3.5$ \\
\hline Copper & 6 & $0.20-1.6$ & $0.25-0.73$ & $0.18-0.38$ & $0.32-1.1$ & $0.40-0.89$ & $0.23-0.50$ & $0.24-0.70$ & $0.30-0.47$ \\
\hline Lead & 1.1 & $0.15-1.4$ & $0.14-0.39$ & $0.090-0.24$ & $0.0087-0.91$ & $0.13-1.0$ & $0.051-0.36$ & $0.0060-0.29$ & $0.0040-0.41$ \\
\hline Nickel & 83 & $0.091-1.6$ & $0.11-1.3$ & $0.010-1.7$ & $0.22-6.4$ & $0.099-1.5$ & $0.12-1.7$ & $0.046-1.4$ & $0.17-2.1$ \\
\hline Silver & $0.94^{(\mathrm{c})}$ & $0.0017-0.0050$ & $0.0017-0.0050$ & $0.0017-0.0050$ & $0.0017-0.0050$ & $0.0017-0.0070$ & $0.0017-0.0050$ & $0.0017-0.015$ & $0.0017-0.0050$ \\
\hline Thallium & NA & $0.0010-0.024$ & $0.0038-0.016$ & $0.0028-0.0081$ & $0.0066-0.030$ & $0.0010-0.017$ & $0.0010-0.013$ & $0.0032-0.019$ & $0.0040-0.018$ \\
\hline Zinc & 55 & $0.43-17$ & $1.1-3.1$ & $1.2-1.7$ & $1.5-5.3$ & $0.68-4.8$ & $1.1-4.2$ & $0.74-2.7$ & $0.78-4.1$ \\
\hline No. of Samples & & 10 & 8 & 6 & 12 & 11 & 6 & 17 & 16 \\
\hline \multicolumn{10}{|c|}{ Total Recoverable Metals ( $\mu \mathrm{g} / \mathrm{L}$ ) } \\
\hline Chromium & $96^{(\mathrm{d})}$ & $5.4-250$ & $0.83-74$ & $5.0-13$ & $1.5-270$ & $0.89-58$ & $2.3-59$ & $0.69-24$ & $1.8-30$ \\
\hline Mercury & 0.012 & $0.00038-0.11$ & $0.00071-0.050$ & $0.00040-0.0094$ & $0.00047-0.30$ & $0.00062-0.064$ & $0.0016-0.060$ & $0.00057-0.018$ & $0.00054-0.047$ \\
\hline Selenium & 5 & $0.30-1.3$ & $0.10-2.1$ & $0.65-1.0$ & $0.10-2.4$ & $0.10-1.3$ & $0.16-2.0$ & $0.38-1.7$ & $1.2-3.9$ \\
\hline No. of Samples & & 8 & 6 & 5 & 12 & 11 & 6 & 18 & 22 \\
\hline \multicolumn{10}{|l|}{ Anions (mg/L) } \\
\hline Nitrate & $45^{(\mathrm{e})}$ & $0.37-2.2$ & $0.054-7.1$ & $2.7-4.7$ & $0.10-3.4$ & $0.56-6.9$ & $2.6-10$ & $0.47-5.2$ & $1.7-6.2$ \\
\hline \multicolumn{10}{|c|}{$\begin{array}{l}\text { (a) Ambient water quality criteria values (WAC 173-201 } \\
\text { (b) Value for hexavalent chromium. } \\
\text { (c) Value for acute toxicity; chronic value not available. } \\
\text { (d) Value for trivalent chromium. } \\
\text { (e) Drinking water standard (WAC 246-290). } \\
\text { NA = Not available. }\end{array}$} \\
\hline
\end{tabular}




\subsubsection{Radiological Results for Sediment Samples from Columbia River Shoreline Springs}

Results for 2009 samples were similar to those observed for previous years (PNNL-19455, APP. 1; Appendix C, Table C.11). Potassium-40, cesium-137, and uranium isotopes were the only radionuclides reported above the minimum detectable concentrations. During 2009, radionuclide concentrations in shoreline spring sediment were similar to those observed in Columbia River sediment, with the exception of the 300 Area where uranium concentrations were above the background concentrations measured for sediment from Priest Rapids Dam. Elevated uranium concentrations for 300 Area Spring sediment compared to Priest Rapids Dam sediment have been previously reported (PNNL-14687).

\subsubsection{Chemical Results for Sediment Samples from Columbia River Shoreline Springs}

Concentrations of metals in shoreline spring sediment samples during 2009 were similar to concentrations in Hanford Reach Columbia River sediment samples (PNNL19455, APP. 1; Appendix C, Table C.9). Lead concentrations in riverbank spring sediment were slightly elevated at the 100-H Area, and chromium levels were slightly elevated at the 100-B Area. Currently, there are no Washington State freshwater sediment quality criteria to compare with the measured values. 


\title{
8.6 Radiological Monitoring of Hanford Site Drinking Water
}

\author{
GW Patton and LM Kelly
}

Pacific Northwest National Laboratory scientists conducted radiological monitoring of drinking water supplied to Hanford Site facilities by DOE-owned pumps and water treatment facilities during 2009. Mission Support Alliance, LLC, the site water-compliance organization, conducted routine chemical, physical, and microbiological monitoring of onsite drinking water. Individual water systems operated by Mission Support Alliance, LLC; CH2M HILL Plateau Remediation Company; and Washington Closure Hanford, LLC performed process monitoring (including chemical and physical sampling) at the water treatment plants and distribution systems to determine compliance with applicable regulations.

“Group A Public Water Supplies” (WAC 246-290) requires that all drinking water analytical results be reported routinely to the Washington State Department of Health. Radiological results for Hanford Site drinking water samples are reported to the state through this annual environmental report and through an annual supplemental data compilation (e.g., PNNL-19455, APP. 1). Process monitoring reports are provided directly to the state each month by the contractor responsible for operating the water system. Chemical, physical, and microbiological data are reported to the state directly by the state-accredited laboratory performing the analyses as well as to Mission Support Alliance, LLC, but are not published.

All DOE-owned Hanford Site drinking water systems were in compliance with drinking water standards for radiological, chemical, and microbiological contaminant levels during 2009. Contaminant concentrations measured during the year were similar to those observed in recent years (PNNL-18427; PNNL-17603).

\subsubsection{Hanford Site Drinking Water Systems}

Nine DOE-owned, contractor-operated, public water systems (Table 8.6.1) supplied drinking water during 2009 to DOE facilities on the Hanford Site. Drinking water for the 200-East Area is supplied from the 200-West facility. Eight of the nine systems used water from the Columbia River. The 400 Area system used groundwater from the unconfined aquifer beneath the site. Mission Support Alliance, LLC operated five of the public water systems; two systems were operated by Washington Closure Hanford, LLC; and two systems were operated by CH2M HILL Plateau Remediation Company. The 300 Area system distributed water supplied by the city of Richland. In addition to the 300 Area, the city of Richland provided drinking water to the Richland North Area and the Volpentest Hazardous Materials Management and Emergency Response Training and Education Center (HAMMER) in 2009.

\begin{tabular}{|c|c|}
\hline \multicolumn{2}{|c|}{$\begin{array}{l}\text { Table 8.6.1. Hanford Site Drinking Water } \\
\text { Systems and System Operators }\end{array}$} \\
\hline System $^{(a)}$ & Operator \\
\hline 200-West Area & Mission Support Alliance, LLC \\
\hline 100-K Area & CH2M HILL Plateau Remediation Company \\
\hline 100-N Area & Washington Closure Hanford, LLC \\
\hline 300 Area & Washington Closure Hanford, LLC \\
\hline 400 Area & CH2M HILL Plateau Remediation Company \\
\hline 200-East Area & Mission Support Alliance, LLC \\
\hline 609 Fire Station & Mission Support Alliance, LLC \\
\hline Wye Barricade & Mission Support Alliance, LLC \\
\hline Yakima Barricade & Mission Support Alliance, LLC \\
\hline \multicolumn{2}{|c|}{$\begin{array}{l}\text { (a) } 400 \text { Area system water is from } 400 \text { Area groundwater wells. } \\
\text { Water for all other systems is from the Columbia River. }\end{array}$} \\
\hline
\end{tabular}




\subsubsection{Hanford Site Drinking Water Treatment Facilities}

Raw water was treated at four DOE-owned water treatment facilities in the 100-K, 100-N, 200-West, and 400 Areas (Figure 8.6.1). Water for the 100-K, 100-N, and 200-West
Areas facilities was obtained from the Columbia River. Water treated in the 400 Area was pumped from wells. The 400 Area continued to use well 499-S1-8J (P-16) as the primary drinking water supply well, and wells 499-S0-8 (P-14) and 499-S0-7 (P-15) were designated as emergency backup sources. The three wells furnished water to a common header that supplies two above ground storage tanks.

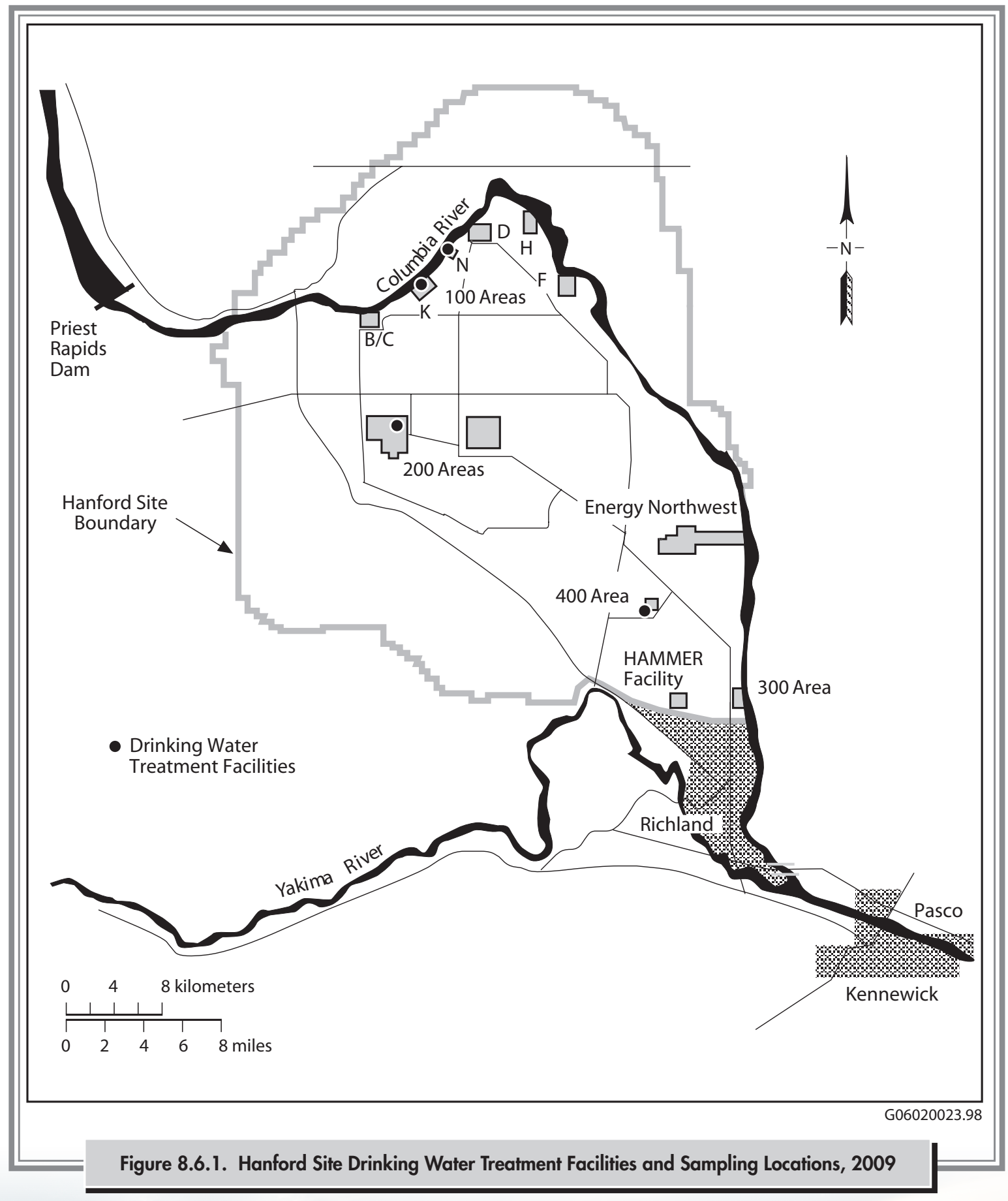


Well P-14 was used in April, July, and December 2009 and supplied approximately 6,130,000 liters (1,619,000 gallons). Well P-15 did not supply water to the 400 Area in 2009.

\subsubsection{Collection of Drinking Water Samples and Analytes of Interest}

Samples at all four drinking water treatment facilities were collected monthly and analyzed either quarterly or annually for radiological contaminants. All were samples of treated water collected before the water was distributed for general use. Drinking water in the 300 Area, Richland North Area, and at the Volpentest Hazardous Materials Management and Emergency Response Training and Education Center (HAMMER) was not routinely monitored for radiological contaminants by DOE contractor personnel. However, personnel from Pacific Northwest National Laboratory's Surface Environmental Surveillance Project routinely collected water samples from the Columbia River at the city of Richland river water intake. The Columbia River is a major source of the city of Richland's drinking water. The radiological analytical results for these river water samples are summarized in Section 8.4 and tabulated in Appendix C (Table C.4). The city of Richland also monitors its water for radiological and chemical contaminants as well as for general water quality. Because it is a community water system, city officials are required to annually report monitoring results and characterize the risks (if any) from exposure to contaminants in the water in what is known as a Consumer Confidence Report. These reports are mailed to all utility consumers as an insert with a monthly utility bill. Results are also made available on the city of Richland website at http://www.ci.richland.wa.us/RICHLAND/Utilities/index. cfm?PageNum=15.

\subsubsection{Radiological Results for Hanford Site Drinking Water Samples}

Drinking water samples collected for radiological analysis in 2009 were analyzed for gross alpha, gross beta, tritium, and strontium-90 (Table 8.6.2). Individual analytical results are reported in PNNL-19455, APP. 1. The maximum amount of beta-gamma radiation from manmade radionuclides allowed in drinking water by Washington State and EPA is an annual average concentration that will not produce an annual dose equivalent to the whole body or any internal organ greater than 4 millirem (0.04 millisievert). Maximum contaminant levels for gross alpha (excluding radon and uranium) and radium-226 and radium-228 (a combined total) are $15 \mathrm{pCi} / \mathrm{L}(0.56 \mathrm{~Bq} / \mathrm{L})$ and $5 \mathrm{pCi} / \mathrm{L}$ $(0.18 \mathrm{~Bq} / \mathrm{L})$, respectively. The maximum allowable annual average limit for tritium is $20,000 \mathrm{pCi} / \mathrm{L}(740 \mathrm{~Bq} / \mathrm{L})$

\begin{tabular}{|c|c|c|c|c|c|c|}
\hline \multirow[b]{3}{*}{ Constituent } & \multicolumn{5}{|c|}{$\begin{array}{l}\text { Table 8.6.2. Annual Average Concentrations }(\mathrm{pCi} / \mathrm{L})^{(\mathrm{a})} \text { of Selected Radiological } \\
\text { Constituents in Hanford Site Drinking Water, } 2009\end{array}$} & \multirow[b]{3}{*}{ Standard } \\
\hline & \multirow{2}{*}{$\begin{array}{l}\text { No. of Samples } \\
\text { Analyzed From } \\
\text { Each Location }\end{array}$} & \multicolumn{4}{|c|}{ Systems } & \\
\hline & & 100-K Area & 100-N Area & 200-West Area & 400 Area & \\
\hline Gross alpha ${ }^{(b)}$ & $4^{(c)}$ & $0.32 \pm 2.4$ & $0.83 \pm 1.3^{(\mathrm{d})}$ & $1.1 \pm 3.1$ & $0.033 \pm 2.2^{(\mathrm{d})}$ & $15^{(e, f)}$ \\
\hline Gross beta $^{(\mathrm{b})}$ & $4^{(\mathrm{g})}$ & $2.1 \pm 1.6^{(\mathrm{d})}$ & $1.4 \pm 2.1^{(\mathrm{d})}$ & $1.8 \pm 4.1$ & $7.2 \pm 4.0$ & $50^{(f)}$ \\
\hline Tritium & $1^{(\mathrm{h})}$ & $-44 \pm 380^{(\mathrm{d}, \mathrm{i})}$ & $-16 \pm 390^{(\mathrm{d}, \mathrm{i})}$ & $-88 \pm 370^{(\mathrm{d}, \mathrm{i})}$ & $2,000 \pm 180^{(b, c)}$ & $20,000^{(f)}$ \\
\hline Strontium-90 & $1^{(\mathrm{h})}$ & $-0.34 \pm 0.47^{(\mathrm{d}, \mathrm{i})}$ & $0.36 \pm 0.84^{(\mathrm{d}, \mathrm{i})}$ & $0.10 \pm 0.90^{(\mathrm{d}, \mathrm{i})}$ & $0.011 \pm 0.58^{(\mathrm{d}, \mathrm{i})}$ & $8^{(\mathrm{e}, \mathrm{f})}$ \\
\hline \multicolumn{7}{|c|}{$\begin{array}{l}\text { (a) Multiply pCi/L by } 0.037 \text { to convert to } \mathrm{Bq} / \mathrm{L} \text {. } \\
\text { (b) Annual average } \pm 2 \text { times the standard deviation. } \\
\text { (c) Samples were collected and analyzed quarterly }(\mathrm{n}=4) \text {. } \\
\text { (d) Analytical results for all samples were below the detection limit. } \\
\text { (e) WAC } 246-290 \text {. } \\
\text { (f) } 40 \text { CFR } 141 . \\
\text { (g) Samples were collected monthly, composited, and analyzed quarterly. } \\
\text { (h) Samples were collected quarterly, composited, and analyzed annually. } \\
\text { (i) Single result } \pm 2 \text { total propagated analytical error. }\end{array}$} \\
\hline
\end{tabular}


(40 CFR 141; WAC 246-290). These concentrations are assumed to produce a total body or organ dose of 4 millirem ( 0.04 millisievert) per year. If two or more radionuclides are present, the sum of their annual dose equivalent to the total body or to any internal organ must not exceed 4 millirem (0.04 millisievert).

Annual average concentrations of all monitored radionuclides in Hanford Site drinking water were below state and federal maximum allowable contaminant levels during 2009. Most gross alpha, gross beta, and tritium results for Columbia River water samples were below their minimum detectable concentrations (i.e., concentrations were too low to measure). Strontium-90 was not detected in any river water samples. Gross beta was found in all 400 Area well water samples. Gross alpha and strontium-90 were not detected in 400 Area well water samples (Table 8.6.2).

Soil and Groundwater Remediation Project personnel collected and analyzed raw (untreated) water samples from all three 400 Area drinking water wells (one primary well and two backup wells). A tritium plume that originates in the 200-East Area extends under the 400 Area and has historically affected tritium concentrations in all 400 Area drinking water wells. During 2009, annual average tritium concentrations in all three wells were below the 20,000-pCi/L (740-Bq/L) state and federal annual average drinking water standard (Table 8.6.3; Figure 8.6.2).

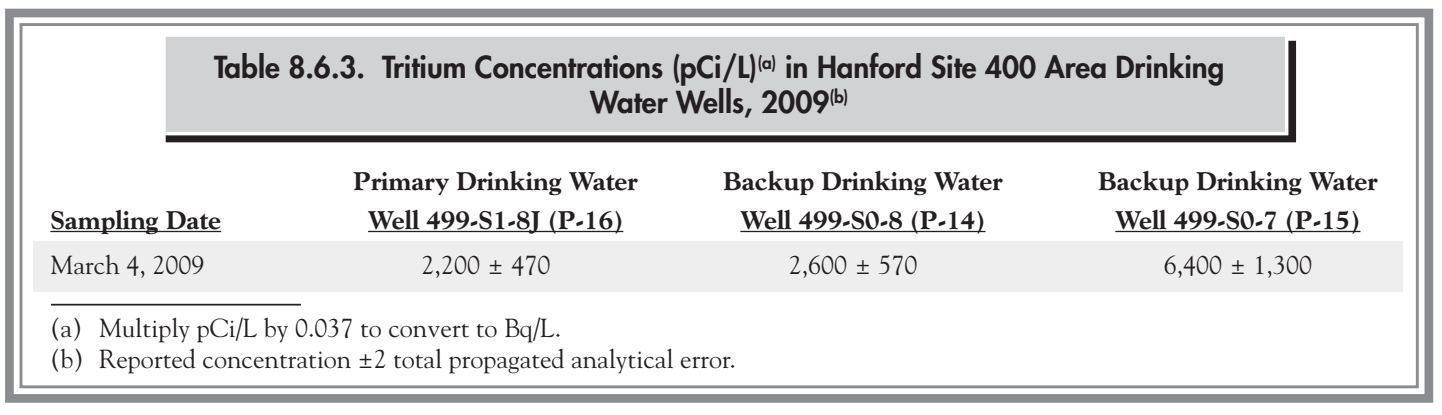




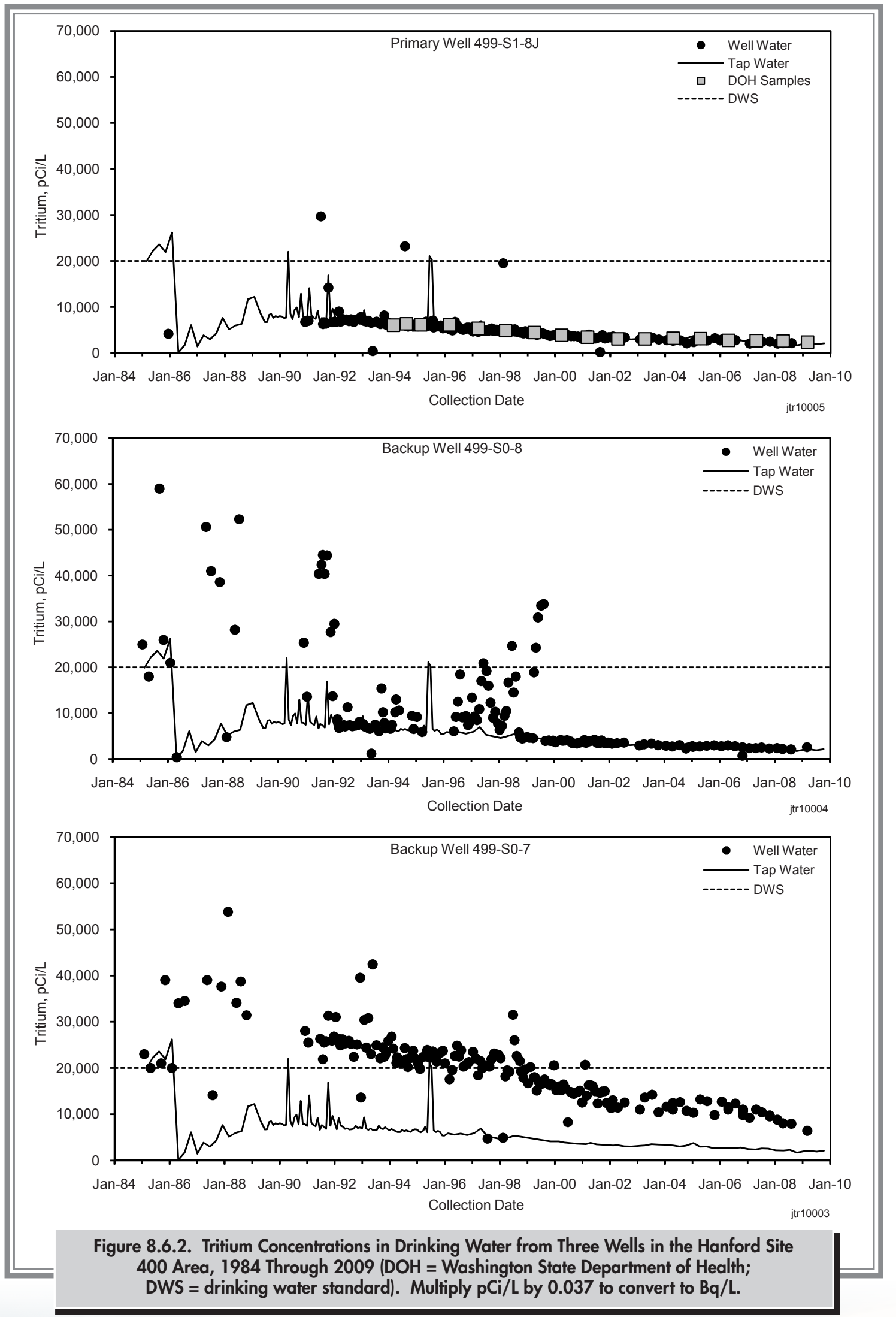




\title{
8.7 Groundwater Monitoring
}

\author{
CJ Martin
}

Groundwater, which is water in layers beneath the earth's surface in the saturation zone, is found in porous materials such as sand, gravel, or fractured rock, and can be extracted for use by pumping to the earth's surface. Where groundwater can be pumped in useable quantities, the porous material and the groundwater within it is defined as an aquifer, which can be found in two conditions: unconfined and confined. In an unconfined aquifer, the groundwater surface (water table) is exposed to the atmosphere through open pores in the porous material. In a confined aquifer, a layer of impermeable geologic material (e.g., clay) occurs between the groundwater surface and the ground surface. This isolates (confines) the aquifer from the atmosphere. Often when a well is drilled into a confined aquifer, the water level in the well will rise above the surrounding unconfined water table.

Hanford Site groundwater has been affected by past industrial activities. Fifty years of nuclear weapons production resulted in approximately 1.7 trillion liters (450 billion gallons) of liquid waste being released to the ground (DOE/RL-2007-20, Rev. 0). Some of the contaminants in this wastewater have reached the groundwater. Hazardous chemicals in the groundwater include carbon tetrachloride, chromium, and cyanide. Radioactive contaminants include tritium, strontium-90, technetium-99, iodine-129, and uranium. Currently, groundwater contaminant levels are greater than drinking water standards beneath approximately $11.3 \%$ of the Hanford Site area and are decreasing with time (DOE/RL-2010-11, Rev. 0).

Groundwater beneath the Hanford Site is currently used as a water supply for drinking water or irrigation in a very limited capacity. Contaminants in groundwater have not been shown to adversely impact offsite sources for water supply, such as the Columbia River and municipal water supply wells. Contaminants carried by groundwater moving from the site can be detected in the near-shore Columbia River environment and, in some locations, at levels that exceed relevant environmental standards.

The Hanford Integrated Groundwater and Vadose Zone Management Plan (DOE/RL-2007-20, Rev. 0) describes steps for cleaning up groundwater and the vadose zone. DOE developed the plan in consultation with EPA and the Washington State Department of Ecology. The primary elements associated with managing the Hanford Site's groundwater and vadose zone are to 1 ) protect the Columbia River and groundwater; 2) develop a cleanup decision process; and 3) attain final cleanup. The following paragraphs describe these elements in further detail.

Protect the Columbia River and Groundwater. Many actions have already been taken to address the principle threats to the Columbia River and groundwater. These actions include the following:

- Discontinuing discharge of all unpermitted liquids in the central Hanford Site

- Cleanup of the former liquid waste sites in the 100 and 300 Areas to reduce the potential for future contamination to groundwater

- Contain groundwater plumes and reduce the mass of primary contaminants through remedial actions such as pump-and-treat systems.

Develop a Process for Cleanup Decisions. Final decisions will be based on processes outlined in CERCLA and/or RCRA. Five key elements will support final decisions:

- Ensure sufficient characterization data is gathered, focusing on waste sites with deep contamination that pose a future risk to groundwater 
- Evaluate the performance of early actions (waste site remediation along the River Corridor and groundwater interim actions) to help guide future cleanup activities

- Identify cleanup goals for waste sites that support longterm groundwater remediation

- Identify new technologies to reduce the mobility of deep contamination and limit its movement to groundwater

- Improve integration of cleanup decisions for waste sites and groundwater.

Attain Final Cleanup. DOE, EPA, and the Washington State Department of Ecology are committed to completing the cleanup of past-practice waste sites by September 2024 . Substantial progress has been made toward cleanup of the 100 and 300 Areas. Strategies used for making final decisions in the 100 and 300 Areas will provide a basis for attaining similar final decisions for the 200 Areas.

The following sections are summarized from the Hanford Site groundwater monitoring report for 2009 (DOE/RL2010-11, Rev. 0).

\subsubsection{Highlights and Items of Interest}

This section briefly describes some of the high-priority groundwater accomplishments and issues for 2009.

River Corridor Baseline Risk Assessment. To support the decision-making process for final CERCLA remedial actions within the Columbia River Corridor, DOE is conducting a CERCLA remedial investigation, including a baseline risk assessment for the River Corridor portion of the Hanford Site. The risk assessment consists of three components: the 100 Area and 300 Area Component (DOE/RL-2005-42, Rev. 1; DOE/RL-2007-21, Draft A); the Inter-Area Component (WCH-274, Rev. 0); and the Columbia River Component (WCH-91, Rev. 0). Data from the 100 Area and 300 Area Component and the Inter-Area Component will be integrated with groundwater data into a series of final CERCLA remedial investigation reports for the operational areas of the River Corridor.

Integrated 100 Area Remedial Investigation/Feasibility Study Work Plan. DOE, EPA, and the Washington State Department of Ecology recently developed a strategy for making final decisions necessary to complete cleanup along the River Corridor. Final decisions for the operable units will address the cleanup of contaminated soil, solid waste burial grounds, groundwater, and releases from reactor buildings. In January 2010, DOE released the Integrated 100 Area Remedial Investigation/Feasibility Study Work Plan (DOE/RL2008-46, Rev. 0). A series of addenda address specific segments of the River Corridor. The integrated work plan, the addenda, and the related sampling and analysis plans identify the data gaps and the data to be collected. These data will be used to develop the remedial investigation/feasibility study.

100-KR-4 Pump-and-Treat Expansion. In 2008, DOE installed new extraction and injection wells and constructed the KX pump-and-treat system with a designed treatment capacity of 2,271 liters (600 gallons) per minute, which began full operation in February 2009. The pumpand-treat system will capture the hexavalent chromium plume nearest the 100-N Area by the 116-K-2 Trench. In addition, the KW pump-and-treat treatment capacity was increased from 379 liters ( 100 gallons) per minute to 787 liters (200 gallons) per minute. Four existing wells were converted for extraction and two new injection wells were drilled to support the revised operations.

100-N Apatite Barrier. Workers performed the last set of injections in injection/barrier wells completed at the top of the unconfined aquifer in 2008. Strontium-90 concentrations initially increased in all wells, but declined over the next year and a half as the remediation took effect. Tests began in December 2009 to emplace apatite into the vadose zone by pulse jet injection. Testing to place apatite by surface infiltration is scheduled to begin in late summer 2010.

100-HR-3 Operable Unit Remedial Process Optimization. In 2009, DOE began to expand and optimize the 100-HR-3 treatment system to provide expanded treatment capacity. Also, a new facility is being constructed in the 100-D Area and a new facility in the 100-H Area is planned in the future.

200-ZP-1 Operable Unit Pump-and-Treat Expansion. During 2009, the 200 West Area 200-ZP-1 Pump-and-Treat Remedial Design/Remedial Action Work Plan (DOE/RL2008-78) was published. This document details the plan and schedule for implementing all tasks to design, install, and operate the pump-and-treat operation. The goal is to 
design a remediation system to remove carbon tetrachloride throughout the vertical extent of the aquifer.

300-FF-5 Studies. In 2009, scientists continued an aggressive campaign to investigate the uranium plume in the 300 Area. Treatability testing using polyphosphate solutions was performed and will continue into 2010 at a second location, focusing on immobilizing uranium in the vadose zone. Work also continued on computer simulations of groundwater flow and uranium transport.

Columbia River Monitoring. DOE and Washington Closure Hanford, LLC are investigating Hanford Site contaminant releases to the Columbia River. The information obtained from this investigation will ultimately be used to help make final cleanup decisions for Hanford Site contaminants that exist in and along the Columbia River. From 2008 through early 2010, Washington Closure Hanford, LLC conducted a study to evaluate groundwater upwelling and river bed porewater within the sediment in the Columbia River. The study areas included all six reactor areas, the Hanford town site, and the 300 Area. Results are scheduled for publication in 2010.

Groundwater Data. Workers sampled 922 monitoring wells and 326 aquifer tubes between October 2008 and
December 2009. Many of the wells and aquifer tubes were sampled more than once during the period; 18,899 sample sets were collected and analyzed. These numbers do not include special groundwater sampling associated with remediation and research. Tables 8.7.1 and 8.7.2 list the number of wells sampled and analyses by groundwater interest area and monitoring purpose.

\subsubsection{Groundwater Flow}

Groundwater flow directions are illustrated on the watertable map for March 2009 (Figure 8.7.1). Groundwater flow directions are inferred from water-table elevations, barriers to flow (e.g., basalt or mud units at the water table), and the distribution of contaminants. Groundwater enters the unconfined aquifer from recharge areas to the west and moves to the east, eventually flowing into the Columbia River. Additional water infiltrates through the vadose zone beneath the Hanford Site. Hydrologists estimate the total discharge of groundwater from the Hanford Site aquifer to the Columbia River is in the range of 1.1 to 2.5 cubic meters (39 to 88 cubic feet) per second. This rate of discharge is small (less than one-tenth of a percent) compared to the average flow of the river, which is approximately 3,400 cubic meters $(120,000$ cubic feet) per second.

\begin{tabular}{|c|c|c|c|c|c|c|c|}
\hline \multicolumn{8}{|c|}{ Table 8.7.1. A Summary of Hanford Site Groundwater Monitoring by Groundwater Interest Area, 2009(a,b) } \\
\hline & Hanford Site & $100-\mathrm{BC}-5$ & 100-FR-3 & 100-HR-3-D & 100-HR-3-H & 100-KR-4 & $100-N R-2$ \\
\hline $\begin{array}{l}\text { Number of wells and } \\
\text { aquifer tubes }\end{array}$ & 1,157 & 46 & 66 & 161 & 107 & 106 & 92 \\
\hline Number of sampling events & 5,246 & 132 & 99 & 1,113 & 354 & 1,152 & 447 \\
\hline Number of analyses & 53,629 & 1,706 & 999 & 7,610 & 3,434 & 5,332 & 3,126 \\
\hline Number of results & 204,028 & 7,985 & 3,866 & 22,209 & 12,975 & 14,212 & 12,338 \\
\hline \multirow[t]{2}{*}{$\begin{array}{l}\text { Percent of results } \\
\text { non-detected }\end{array}$} & 56 & 63 & 51 & 42 & 53 & 44 & 53 \\
\hline & $\underline{1100-E M-1}$ & $\underline{200-B P-5}$ & $\underline{200-P O-1}$ & $\underline{200-U P-1}$ & $\underline{200-Z P-1}$ & 300-FF-5 & \\
\hline $\begin{array}{l}\text { Number of wells and } \\
\text { aquifer tubes }\end{array}$ & 24 & 139 & 139 & 73 & 98 & 106 & \\
\hline Number of sampling events & 31 & 396 & 368 & 260 & 512 & 382 & \\
\hline Number of analyses & 380 & 8,705 & 6,547 & 3,781 & 6,933 & 4,590 & \\
\hline Number of results & 2,054 & 29,562 & 28,126 & 17,771 & 31,608 & 21,322 & \\
\hline $\begin{array}{l}\text { Percent of results } \\
\text { non-detected }\end{array}$ & 66 & 53 & 60 & 59 & 62 & 62 & \\
\hline
\end{tabular}




\begin{tabular}{|c|c|c|c|}
\hline & $\underline{\text { Restoration }}^{(\mathrm{c})}$ & Waste Management $^{(\mathrm{d})}$ & $\underline{\text { Environmental Surveillance }}^{(\mathrm{e})}$ \\
\hline Number of wells and aquifer tubes & 1,207 & 693 & 1,024 \\
\hline Number of sampling events & 3,753 & 1,185 & 1,816 \\
\hline Number of analyses & 30,954 & 20,191 & 21,766 \\
\hline Number of results & 116,539 & 75,983 & 86,226 \\
\hline Percent of results non-detected & 56 & 53 & 57 \\
\hline \multicolumn{4}{|c|}{$\begin{array}{l}\text { (a) Because of the co-sampling among groundwater monitoring programs, the wells monitored, sampling events, analyses, results, and no } \\
\text { detectable results overlap among monitoring purposes. Totals exclude special sampling. } \\
\text { (b) Date range reported is from October 1, } 2008 \text { through December } 31,2009 . \\
\text { (c) Wells associated with remediation activities. } \\
\text { (d) Wells sampled to determine impact, if any, of a waste management unit (e.g., RCRA) on groundwater. } \\
\text { (e) Wells sampled to detect impact, if any, of site operations on groundwater over the entire Hanford Site and adjacent offsite areas. } \\
\text { RCRA = Resource Conservation and Recovery Act of } 1976 .\end{array}$} \\
\hline
\end{tabular}

As seen in Figure 8.7.1, the water table beneath the 200-East Area is relatively flat (no contours). This is because of the highly permeable sediments of the Hanford formation at the water table. Groundwater enters the 200-East Area vicinity from the west and southwest. The flow of groundwater divides, with some flowing to the north through a gap between Gable Butte and Gable Mountain (Gable Gap), and some flowing southeast toward the central part of the Hanford Site. This groundwater divide may be located near the central part of the 200-East Area, but its precise location is unknown. Ongoing studies are helping to determine the direction of groundwater flow in this region. In the southern part of the Hanford Site, groundwater enters the 300 Area from the northwest, west, and southwest.

The natural pattern of groundwater flow was altered during the Hanford Site's operating years by water-table mounds. The mounds were created by the discharge of large volumes of wastewater to the ground surface and were present in each reactor area and beneath the 200 Areas. Since effluent disposal decreased significantly in the 1990s, these mounds have dissipated in the reactor areas and have declined considerably in the 200 Areas. Currently, wastewater is discharged to the ground at two permitted locations: the State-Approved Land Disposal Site, north of the 200-West Area, and at the Treated Effluent Disposal Facility, east of the 200-East Area.

Groundwater flow in the unconfined aquifer is currently altered where extraction or injection wells are used for pump-and-treat systems. Extraction wells in the 100-K, 100-D, 100-H, and 200-West Areas capture contaminated water from the surrounding areas. Water flows away from injection wells, which are upgradient of the contaminant plumes, so the injection increases the groundwater flow toward the extraction wells.

A confined aquifer occurs within sand and gravel of the lowest sedimentary unit of the Ringold Formation. It is confined between the upper-most basalt and a thick layer of silt and clay known as the Ringold Lower Mud Unit. The unconfined aquifer does not extend east of the 200-East Area because of the presence of the Ringold Lower Mud Unit at the water table (Figure 8.7.1), so the Ringold Formation confined aquifer is the uppermost aquifer in this area. Beneath the Ringold Formation confined aquifer is the upper basalt-confined aquifer, which exists mainly in the Rattlesnake Ridge interbed. This is a widespread sedimentary layer between basalt flows. Groundwater within these confined aquifers is influenced by a residual recharge mound near the B Pond. Several wells north and east of the 200-East Area have shown evidence of groundwater exchange (intercommunication) between the upper basaltconfined aquifer and the overlying unconfined aquifer. The intercommunication has been attributed to erosion of the upper Saddle Mountains Basalt and downward groundwater movement. Because upward groundwater movement exists elsewhere in the 200-East Area/Gable Gap region, the upper basalt-confined aquifer likely discharges to the overlying 


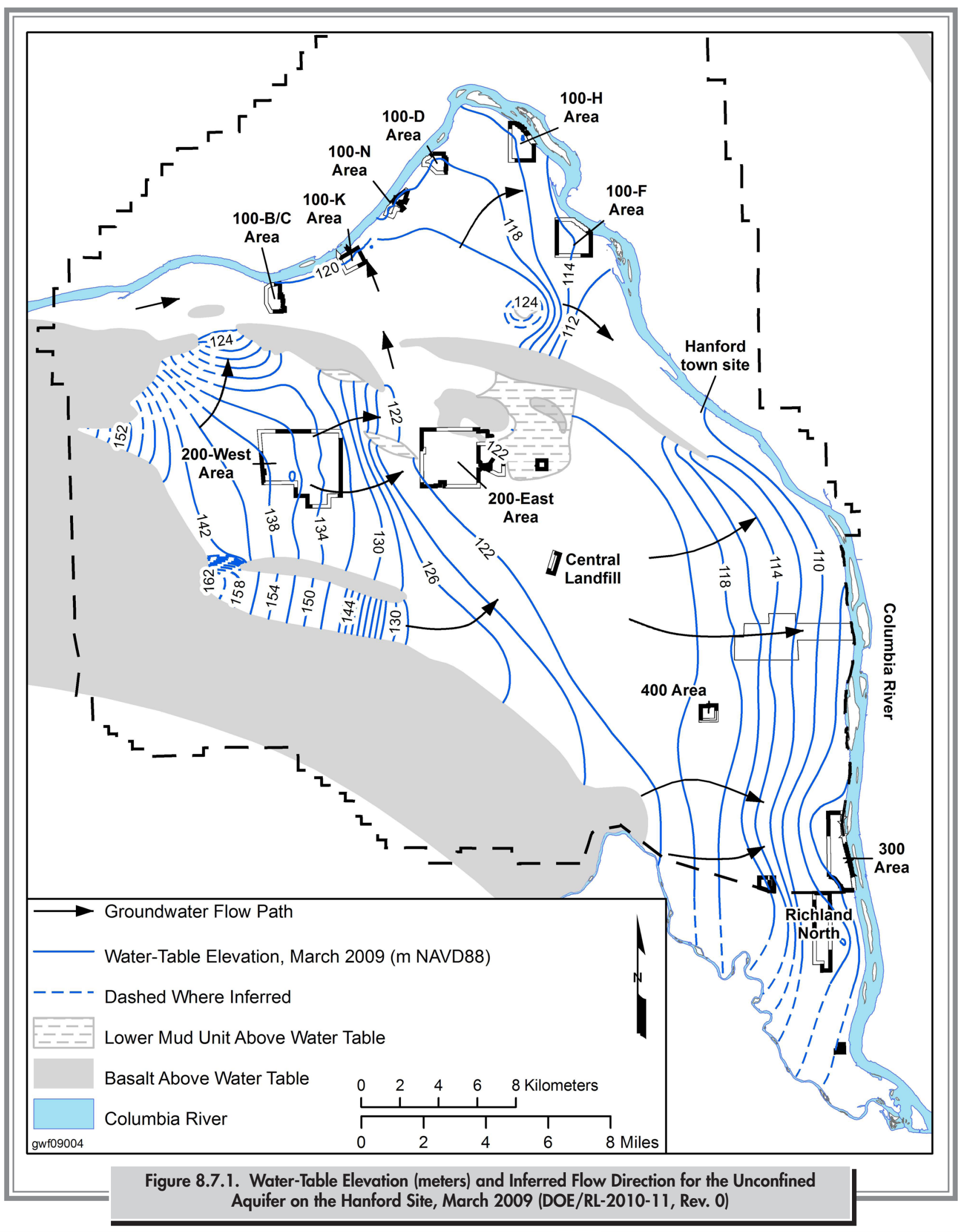


unconfined aquifer, especially within Gable Gap where the Elephant Mountain Basalt was removed by erosion.

\subsubsection{Groundwater}

\section{Monitoring and Remediation}

DOE monitors Hanford Site groundwater to fulfill a variety of state and federal regulations, including the Atomic Energy Act of 1954, RCRA, CERCLA, and various rules of the Washington Administrative Code.

DOE Order 450.1A, "Environmental Protection Program," implements requirements of the Atomic Energy Act of 1954. This Order requires environmental monitoring to detect, characterize, and respond to releases from DOE facilities, assess impacts, and characterize exposure pathways. The Order recommends implementing a site-wide approach for groundwater protection and requires compliance with other applicable environmental protection requirements.

The Hanford Site is divided into groupings of similar waste units within geographic areas (termed an operable unit), so the CERCLA cleanup process can be efficiently implemented. Most operable units are source operable units focusing on areas where waste was actually disposed of while others are groundwater operable units. The concept of the groundwater operable unit was adopted to allow separate characterization of the waste sites and the groundwater. Separate characterization recognizes differences between localized contaminants in the soil column at the disposal sites and the more widespread contamination in groundwater that is often mixed from several disposal sites. Monitoring wells are located and sampled to define the nature and extent of the contamination in the groundwater. Groundwater is also monitored under CERCLA to assess the effectiveness of groundwater remediation. Figure 8.7.2 shows the boundaries of the groundwater operable units. These regulatory-defined groundwater operable units do not cover the entire Hanford Site. Therefore, to provide scheduling, data review, and interpretation for the entire Hanford Site, groundwater staff have defined informal "groundwater interest areas" that include the groundwater operable units and the regions in between (Figure 8.7.2).

The groundwater monitoring requirements for Hanford's RCRA units fall into one of two categories: interim status or final status. A permitted RCRA unit requires final status monitoring as specified in WAC 173-303-645. RCRA units that have not yet been incorporated into permits require interim status monitoring as specified in WAC 173-303-400, which invokes 40 CFR 265.

RCRA groundwater monitoring is conducted under one of three possible phases:

- Contamination Indicator Evaluation (or final status detection) - Initially, researchers use a contamination indicator evaluation program that uses groundwater data for specific contamination indicator parameters to determine and monitor the impact, if any, of the facility on groundwater.

- Assessment (or final status compliance) - If the contamination indicator evaluation monitoring results indicate a statistically significant change in groundwater chemistry, an assessment or compliance phase of monitoring begins. Unlike the contamination indicator evaluation programs where any potential impact from the facility is being monitored, an assessment/compliance program helps researchers confirm that an impact to groundwater has occurred. Therefore, the objectives under the assessment/compliance program change from looking for a problem to assessing the nature and extent of the problem.

- Corrective Action (through administrative order for interim status sites or during final status) - If the source of the contamination is determined to be the RCRA unit and the contaminant concentration(s) exceeds applicable limits, the Washington State Department of Ecology may require corrective action. Groundwater is then monitored to determine if the corrective action has been effective.

In 2009, detection monitoring at three RCRA sites indicated these sites may have affected groundwater quality. Concentrations of the indicator parameter total organic carbon exceeded threshold values at Low-Level Waste Management Area 4 and the Nonradioactive Dangerous Waste Landfill, while the threshold value for specific conductance was exceeded at Waste Management Area C. Assessment monitoring began at these sites in late 2009. Groundwater monitoring at the other RCRA sites continued under previously established programs. Table 8.7.3 lists Hanford Site RCRA units and 2009 status highlights; Figure 8.7.3 shows their locations. 


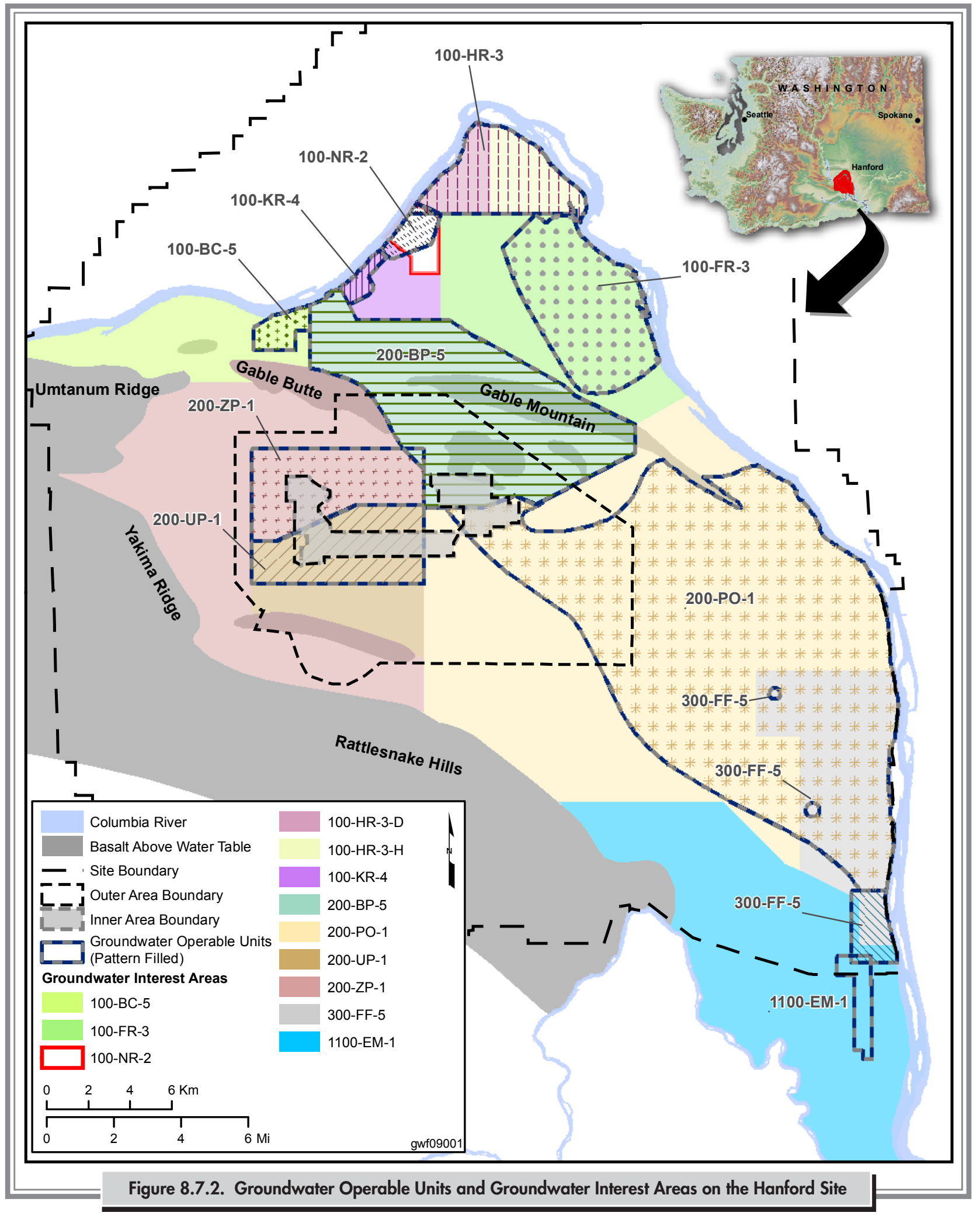




\begin{tabular}{|c|c|}
\hline \multicolumn{2}{|c|}{$\begin{array}{c}\text { Table 8.7.3. Resource Conservation and Recovery Act of } 1976 \text { Units Requiring Groundwater } \\
\text { Monitoring on the Hanford Site, } 2009 \text { (a) }\end{array}$} \\
\hline RCRA Unit & 2009 Status \\
\hline 116-N-1 (1301-N) Facility & Continued indicator evaluation ${ }^{(b)}$ \\
\hline $120-\mathrm{N}-1,120-\mathrm{N}-2(1324-\mathrm{N} / \mathrm{NA})$ Facilities & Continued indicator evaluation ${ }^{(b)}$ \\
\hline $116-N-3(1325-N)$ Facility & Continued indicator evaluation ${ }^{(b)}$ \\
\hline 116-H-6 (183-H) Evaporation Basins & Corrective action alternative program during interim remedial action; chromium and nitrate \\
\hline 216-A-29 Ditch & Continued indicator evaluation ${ }^{(b)}$ \\
\hline 216-B-3 Pond & Continued indicator evaluation ${ }^{(b)}$ \\
\hline 216-B-63 Trench & Continued indicator evaluation ${ }^{(b)}$ \\
\hline 216-S-10 Pond and Ditch & $\begin{array}{l}\text { Continued indicator evaluation; }{ }^{(b)} \text { completion of first year of RCRA analyses for three new } \\
\text { wells; establishment of new background threshold values }\end{array}$ \\
\hline 316-5 (300 Area) Process Trenches & Compliance/corrective action; organics \\
\hline Integrated Disposal Facility & Not yet in use; monitoring results added to background data set \\
\hline Liquid Effluent Retention Facility & $\begin{array}{l}\text { Two new wells monitor the top of the fractured basalt. DOE and Washington State Department } \\
\text { of Ecology pursuing agreement for monitoring }\end{array}$ \\
\hline Low-Level Waste Management Area 1 & Continued indicator evaluation ${ }^{(b)}$ \\
\hline Low-Level Waste Management Area 2 & Continued indicator evaluation ${ }^{(\mathrm{b})}$ \\
\hline Low-Level Waste Management Area 3 & $\begin{array}{l}\text { Statistical evaluations suspended until upgradient wells installed and background values } \\
\text { established }\end{array}$ \\
\hline Low-Level Waste Management Area 4 & $\begin{array}{l}\text { Total organic carbon exceeded threshold value in August 2008. Returned to indicator } \\
\text { evaluation status in 2009. Remaining upgradient wells went dry. }\end{array}$ \\
\hline Nonradioactive Dangerous Waste Landfill & $\begin{array}{l}\text { Total organic carbon exceeded threshold value in August 2008. Returned to indicator } \\
\text { evaluation status in } 2009 .\end{array}$ \\
\hline PUREX Cribs & Continued assessment: nitrate \\
\hline SST Waste Management Area A-AX & Continued assessment (first determination); one year of sample results available from new well \\
\hline SST Waste Management Area B-BX-BY & Continued assessment: cyanide, nitrate \\
\hline SST Waste Management Area C & $\begin{array}{l}\text { Specific conductance exceeded threshold value in July 2009; initiated groundwater quality } \\
\text { assessment monitoring in December 2009; cyanide }\end{array}$ \\
\hline SST Waste Management Area S-SX & Continued assessment: chromium, nitrate \\
\hline SST Waste Management Area T & Continued assessment: chromium, nitrate \\
\hline SST Waste Management Area TX-TY & Continued assessment: chromium, nitrate \\
\hline SST Waste Management Area U & Continued assessment: chromium, nitrate \\
\hline $\begin{array}{l}\text { (a) Date range reported is from October } 1,2 \\
\text { (b) Analysis of RCRA contamination indica } \\
\text { from the unit. } \\
\text { DOE = U.S. Department of Energy. } \\
\text { PUREX = Plutonium Uranium Extraction I } \\
\text { RCRA }=\text { Resource Conservation and Recove } \\
\text { SST } \quad=\text { Single-shell tanks. }\end{array}$ & $\begin{array}{l}8 \text { through December } 31,2009 \text {. } \\
\text { r parameters provided no evidence of groundwater contamination with hazardous constituents } \\
\text { nt. } \\
\text { Act of } 1976 .\end{array}$ \\
\hline
\end{tabular}




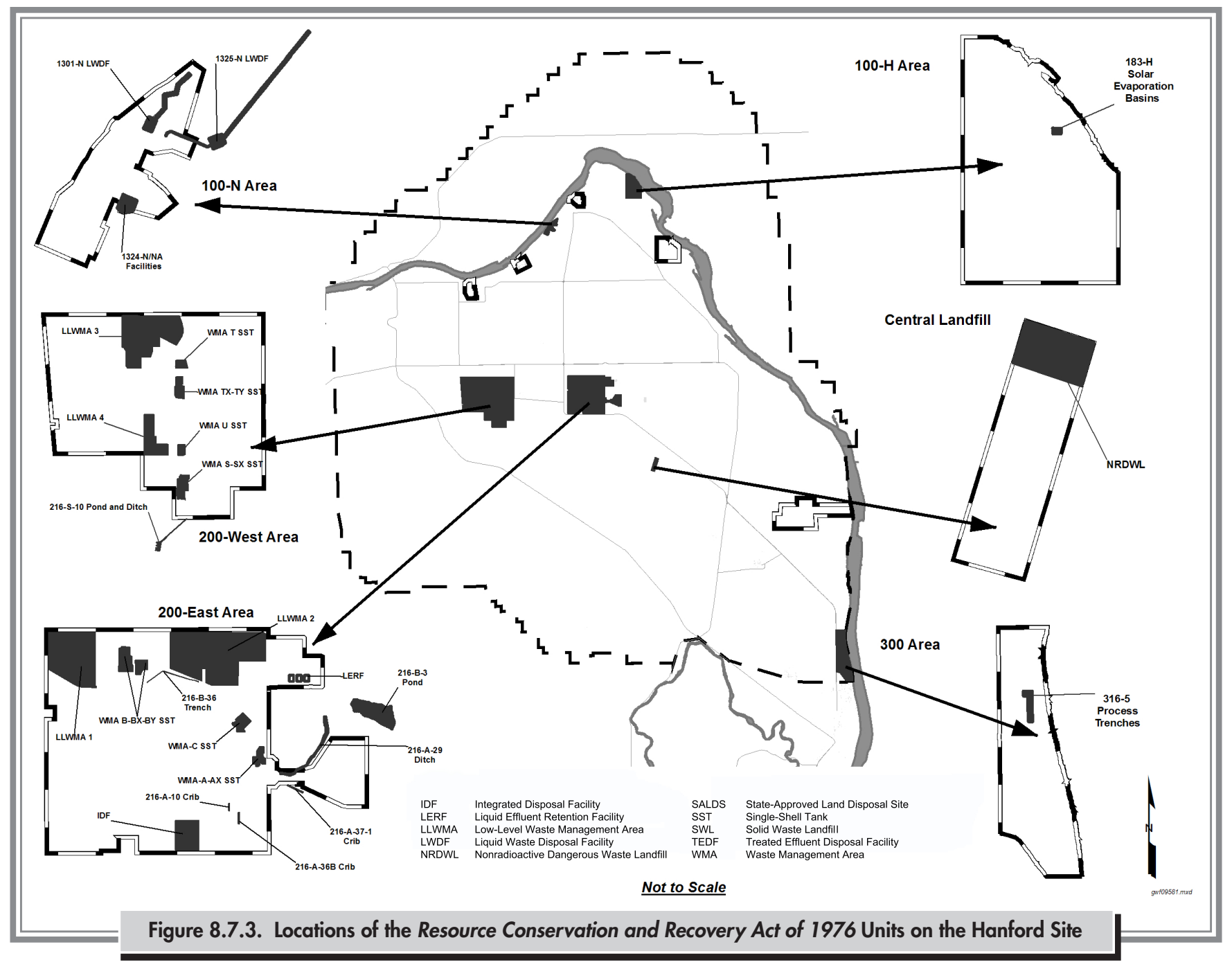

\subsubsection{Overview}

Figure 8.7.4 shows the Hanford Site's principle groundwater contaminant plumes. The total area of contaminant plumes with concentrations above drinking water standards was about 172 square kilometers (66.4 square miles) in 2009 (Table 8.7.4). This area is about $11.3 \%$ of the total area of the Hanford Site and is decreasing with time. Table 8.7.5 lists the highest levels of contaminants by groundwater interest area.

Tritium and iodine-129 plumes have the largest areas with concentrations above drinking water standards. These dominant plumes, which had sources in the 200-East Area, extend toward the east and southeast. Less extensive tritium and iodine-129 plumes are also present in the 200-West
Area. Technetium-99 has much smaller plumes that exceed its drinking water standard in the 200-East and 200-West Areas. One technetium-99 plume extends northward, beyond the 200-East Area. Uranium moves slower in groundwater than tritium, technetium-99, or iodine-129; plumes containing uranium are found in the 200-East, 200-West, and 300 Areas. Strontium-90 exceeds the drinking water standard in the 100 Areas, 200-East Area, and beneath the former Gable Mountain Pond. Cobalt-60, cesium-137, and plutonium exceed drinking water standards, but only in a few wells in the 200-East Area.

Nitrate is the most widespread chemical contaminant in Hanford Site groundwater; plumes originate from the 100 and 200 Areas and from offsite industrial and agricultural activities. Carbon tetrachloride is the most widespread 


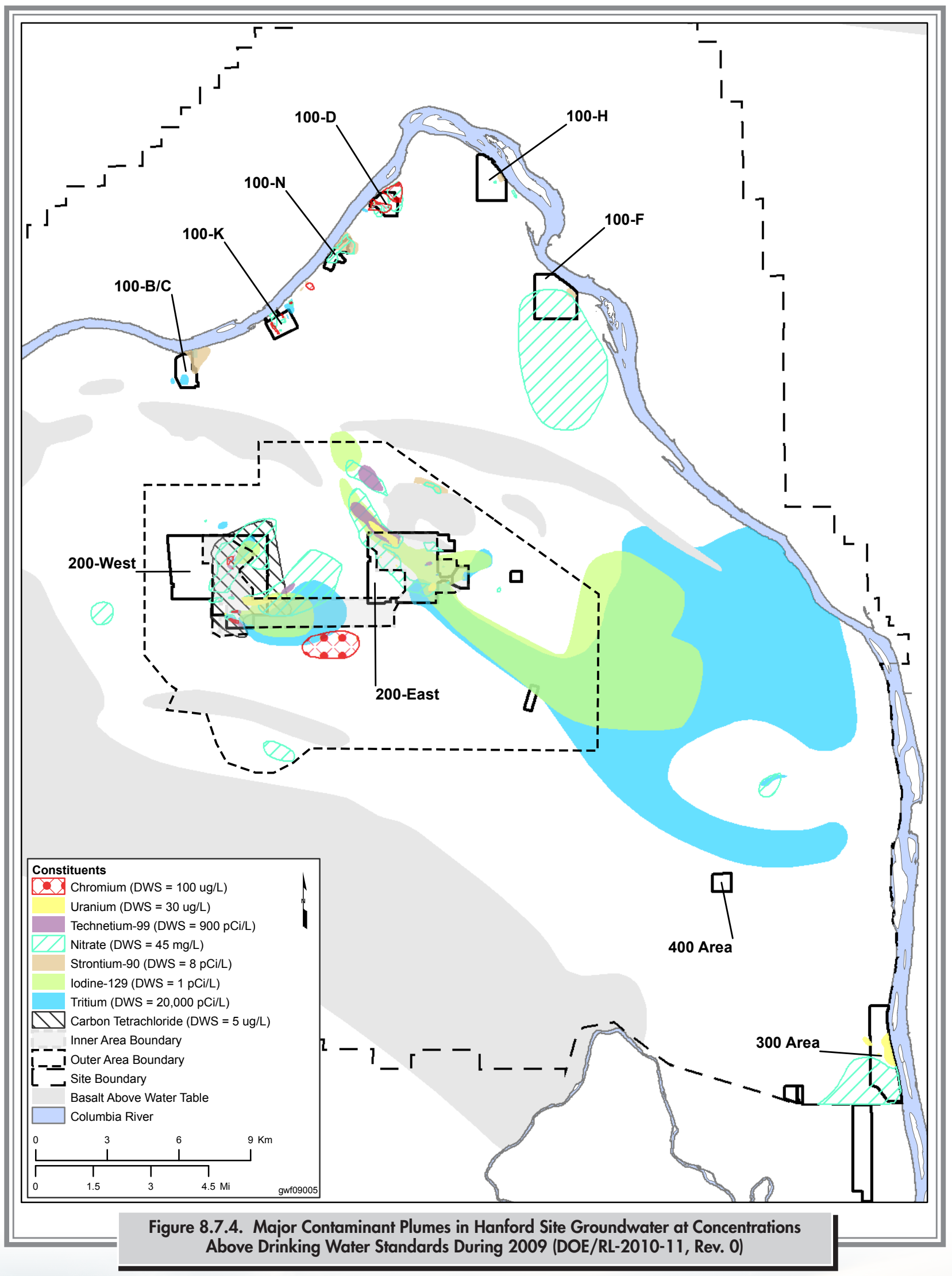


Table 8.7.4. Areas of Contaminant Plumes on the Hanford Site at Levels Above Drinking Water Standards, 2009(a) (DOE/RL-2010-11, Rev. 0)

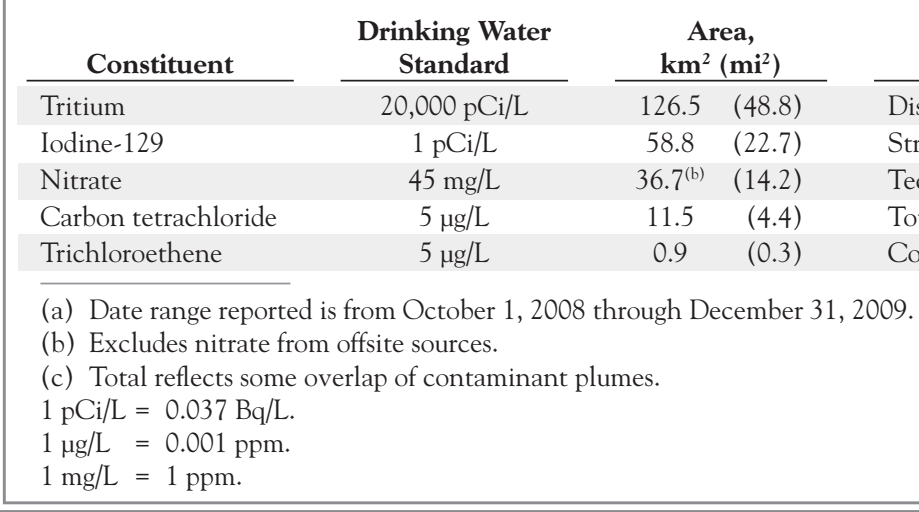

\begin{tabular}{|c|c|c|c|c|c|c|c|}
\hline & \multicolumn{5}{|c|}{$\begin{array}{l}\text { Table 8.7.5. Summary of Maximum Contaminant Concentrations in Hanford Site } \\
\text { Wells by Groundwater Interest Area, 2009(a) (DOE/RL-2010-11, Rev. 0) }\end{array}$} & \multirow[b]{2}{*}{ 00-KR-4 } & \multirow[b]{2}{*}{$100-N R-2$} \\
\hline & Hanford Site & 100-BC-5 & 100-FR-3 & 100-HR-3-D & 100-HR-3-H & & \\
\hline Tritium (pCi/L) & $1,600,000$ & 47,000 & 8,000 & 25,000 & 11,000 & 430,000 & 20,000 \\
\hline Iodine-129 (pCi/L) & 34.5 & NA & NA & NA & NA & NA & NA \\
\hline Nitrate $(\mathrm{mg} / \mathrm{L})$ & 3,410 & 34.1 & 126 & 95.2 & 1,500 & 45.2 & 383 \\
\hline $\begin{array}{l}\text { Carbon tetrachloride } \\
(\mu \mathrm{g} / \mathrm{L})\end{array}$ & 3,900 & NA & ND & 2.7 & 2 & ND & 1.8 \\
\hline $\begin{array}{l}\text { Trichloroethene } \\
(\mu \mathrm{g} / \mathrm{L})\end{array}$ & 14 & NA & NA & NA & NA & 9.2 & 0.21 \\
\hline $\begin{array}{l}\text { Dissolved chromium } \\
(\mu \mathrm{g} / \mathrm{L})\end{array}$ & 55,600 & 56.1 & 53.7 & 55,600 & 117 & 1,230 & 169 \\
\hline Strontium-90 (pCi/L) & 9,000 & 29 & 12 & 6.4 & 110 & 41 & 9,000 \\
\hline Technetium-99 (pCi/L) & 75,000 & NA & NA & NA & 55 & 95 & NA \\
\hline \multirow[t]{2}{*}{ Total uranium $(\mu \mathrm{g} / \mathrm{L})$} & 5,550 & NA & 17.9 & 4.14 & 14.4 & 10.5 & 3.52 \\
\hline & 1100-EM-1 & 200-BP-5 & 200-PO-1 & 200-UP-1 & 200-ZP-1 & 300-FF-5 & \\
\hline Tritium (pCi/L) & 371 & 91,000 & 510,000 & 270,000 & $1,600,000$ & 910,000 & \\
\hline Iodine-129 (pCi/L) & ND & 6.74 & 9.7 & 10.8 & 34.5 & NA & \\
\hline Nitrate $(\mathrm{mg} / \mathrm{L})^{(\mathrm{b})}$ & 80.1 & 1,700 & 158 & 1,080 & 3,410 & 98.7 & \\
\hline $\begin{array}{l}\text { Carbon tetrachloride } \\
(\mu \mathrm{g} / \mathrm{L})\end{array}$ & 2.9 & 5.9 & 2 & 1,300 & 3,900 & 1.3 & \\
\hline $\begin{array}{l}\text { Trichloroethene } \\
(\mu \mathrm{g} / \mathrm{L})\end{array}$ & ND & 3.1 & 3.1 & 9.4 & 14 & 3 & \\
\hline $\begin{array}{l}\text { Dissolved chromium } \\
(\mu \mathrm{g} / \mathrm{L})\end{array}$ & 19 & 89.9 & 124 & 1,090 & 736 & 88.7 & \\
\hline Strontium-90 (pCi/L) & NA & 4,900 & 11 & NA & NA & 1.1 & \\
\hline Technetium-99 (pCi/L) & 75 & 39,000 & 5,700 & 75,000 & 40,000 & 210 & \\
\hline Total uranium $(\mu \mathrm{g} / \mathrm{L})$ & 26.5 & 5,550 & 106 & 416 & 36.6 & 211 & \\
\hline
\end{tabular}


organic contaminant on the Hanford Site, forming a large plume beneath the 200-West Area. Other organic contaminants include chloroform (found in the 200-West Area) and trichloroethene. The 100-F and 200-West Areas have plumes of trichloroethene that show declining concentrations. The 100-K Area has one well that exceeded the trichloroethene drinking water standard. Researchers detected trichloroethene at levels above the drinking water standard at wells completed in a fine-grained layer beneath the 300 Area. Hexavalent chromium at levels above the $100-\mu \mathrm{g} / \mathrm{L}$ drinking water standard underlies portions of the 100-K and 100-D Areas. Chromium also exceeds Washington State's $10-\mu \mathrm{g} / \mathrm{L}$ aquatic standard in these areas and portions of the 100-B/C, 100-H, 100-F, and 600 Areas. Local plumes of chromium contamination are also present in the 200 Areas.

The following section discusses groundwater contamination, monitoring, and remediation for each of the groundwater operable units or interest areas and in the confined aquifers.

\subsubsection{Groundwater Monitoring Results for the 100-BC-5 Operable Unit}

Most of the groundwater contamination in this operable unit is found in the northern portion of the 100-B/C Area, beneath former waste trenches and retention basins. Tritium and strontium-90 concentrations exceeded drinking water standards $(20,000$ and $8 \mathrm{pCi} / \mathrm{L}[740$ and $0.3 \mathrm{~Bq} / \mathrm{L}]$, respectively) in several wells. Chromium and nitrate concentrations continued to be below drinking water standards $(100 \mu \mathrm{g} / \mathrm{L}$ and $45 \mathrm{mg} / \mathrm{L}$, respectively) in recent years, but chromium levels exceed the $10-\mu \mathrm{g} / \mathrm{L}$ aquatic standard.

A record of decision has not yet been developed for the 100-BC-5 Operable Unit, and no active remediation of groundwater is underway. Groundwater monitoring has continued since the initial remedial investigation and while waste site remedial actions are being conducted. In 2009, a draft remedial investigation/feasibility study work plan addendum (DOE/RL-2008-46-ADD3) and sampling and analysis plan (DOE/RL-2009-44) were released for EPA review. The documents are associated with the Integrated 100 Area Remedial Investigation/Feasibility Study Work Plan (DOE/RL-2008-46, Rev. 0).

\subsubsection{Groundwater Monitoring Results for the 100-KR-4 Operable Unit}

The principle groundwater issues in the 100-KR-4 Operable Unit include cleaning up chromium in groundwater, tracking plumes from past-practice sites, and monitoring groundwater near the K-East and $\mathrm{K}$-West Basins. Interim remedial action involves two pump-and-treat systems that remove chromium from groundwater.

Interim Remedial Action. A pump-and-treat system is removing hexavalent chromium from the aquifer beneath the 116-K-2 Trench (Figure 8.7.5). Approximately 347.5 kilograms (766 pounds) of chromium have been removed since startup in 1997. New wells installed in 2009 indicate that one portion of the plume with concentrations above $100 \mu \mathrm{g} / \mathrm{L}$ is larger than previously known. Chromium concentrations in most of the compliance wells near the Columbia River have decreased. The concentration goal for the interim remedial action is $20 \mu \mathrm{g} / \mathrm{L}$. Workers installed new extraction and injection wells and began operation in 2009. The expanded system will increase the amount of contaminated groundwater being treated and will prevent the plume from moving downgradient into the 100-N Area.

Chromium concentrations in groundwater near the K-West Reactor began to rise during 1998. Concentrations in this plume are the highest in the $100-\mathrm{K}$ Area. DOE has operated a pump-and-treat system to clean up the plume since 2007. The system has removed 83.3 kilograms (184 pounds) of chromium from the aquifer, and concentrations in the extraction wells have declined. The K-West system was expanded in 2009. The pump-and-treat system has successfully reduced chromium in the core of the plume.

Monitoring Past-Practice Waste Sites. Other contaminants of potential concern in the 100-KR-4 Operable Unit are carbon-14, strontium-90, nitrate, trichloroethene, and tritium. Levels remained above drinking water standards, and these contaminants will be addressed under the remedial investigation/feasibility study work plan (DOE/RL-2008-46, Rev. 0; DOE/RL-2008-46, ADD2, Rev. 0) and the upcoming final record of decision.

Tritium concentrations in two new wells near the south end of the 116-K-2 Trench are much higher than in surrounding 


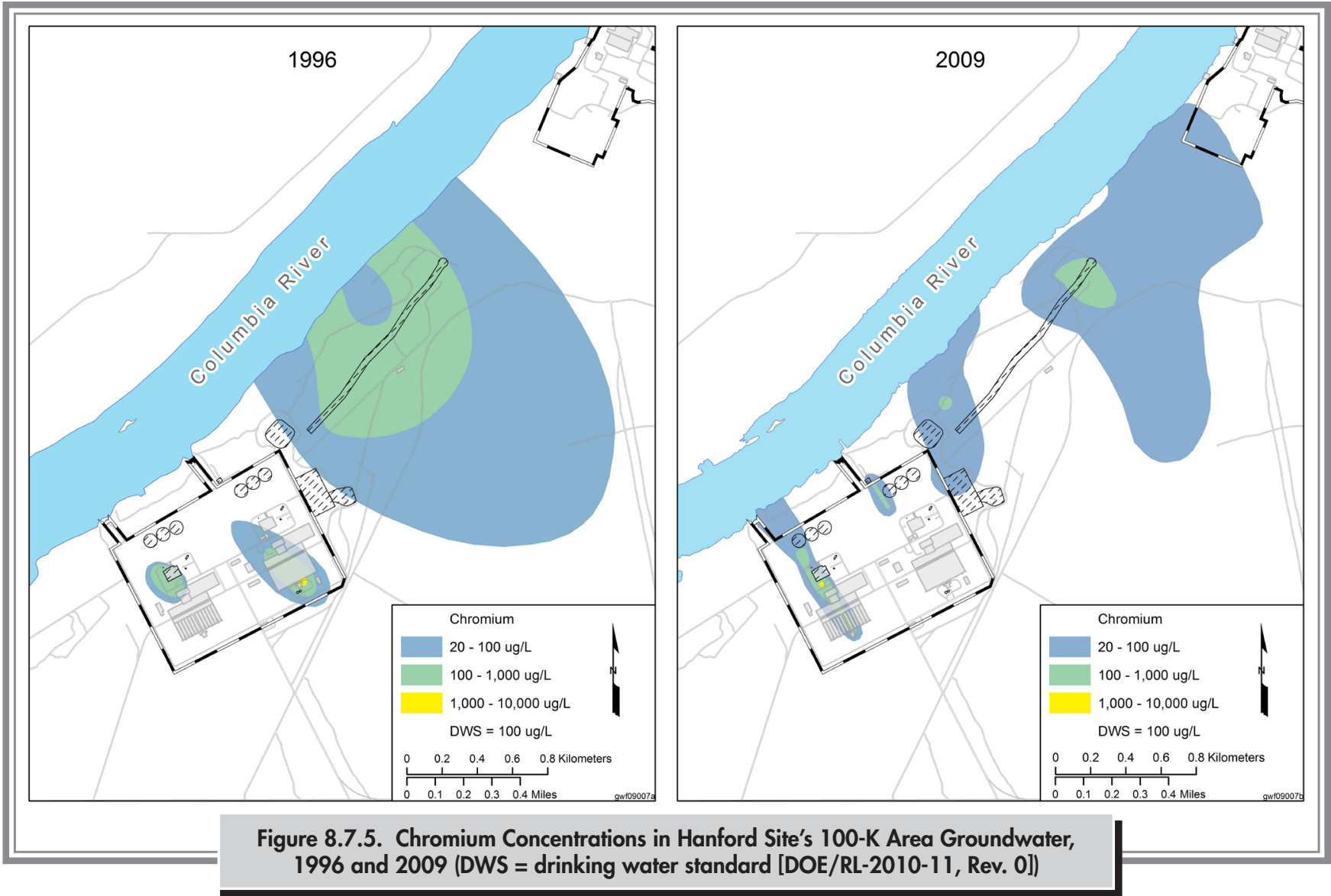

wells. The tritium source at this location is uncertain but appears to be related to the 118-K-1 Burial Ground.

K-East and K-West Basins. These concrete basins are integral parts of each reactor building. From the late 1970s through 2004, they were used to store irradiated fuel from the last run of the 100-N Reactor, as well as miscellaneous fuel fragments recovered during remedial actions at other reactor areas. Shielding water was removed from the K-East Basin, and demolition of the basin was completed in 2009. Remediation of soil and sediments around the former K-East Basin is underway (Section 6.1.2.2), and the groundwater monitoring strategy will be reviewed.

\subsubsection{Groundwater Monitoring} Results for the 100-NR-2 Operable Unit

The primary groundwater contaminant plume in the 100-N Area is strontium-90, which originated at two liquid waste disposal cribs (Figure 8.7.6). Tritium, nitrate, petroleum hydrocarbons, and sulfate also are present in 100-N Area groundwater.

Interim Remedial Action. DOE is applying an in situ technology, apatite sequestration, in the 100-N Area. The goal is to create a permeable, reactive barrier in the aquifer that will capture strontium-90 as groundwater flows through it to the Columbia River. Apatite-forming chemicals were injected into a line of wells along the river shore in 2006, 2007, and 2008. As the injected chemicals reacted with the aquifer and sediments, strontium-90 levels initially increased in downgradient wells and aquifer tubes. However, in the weeks and months after the injections, the chemical reactions progressed, and strontium-90 levels declined. Concentrations in the injection and downgradient wells have been reduced by as much as $90 \%$ at the end of 2009 from pre-injection concentrations. 


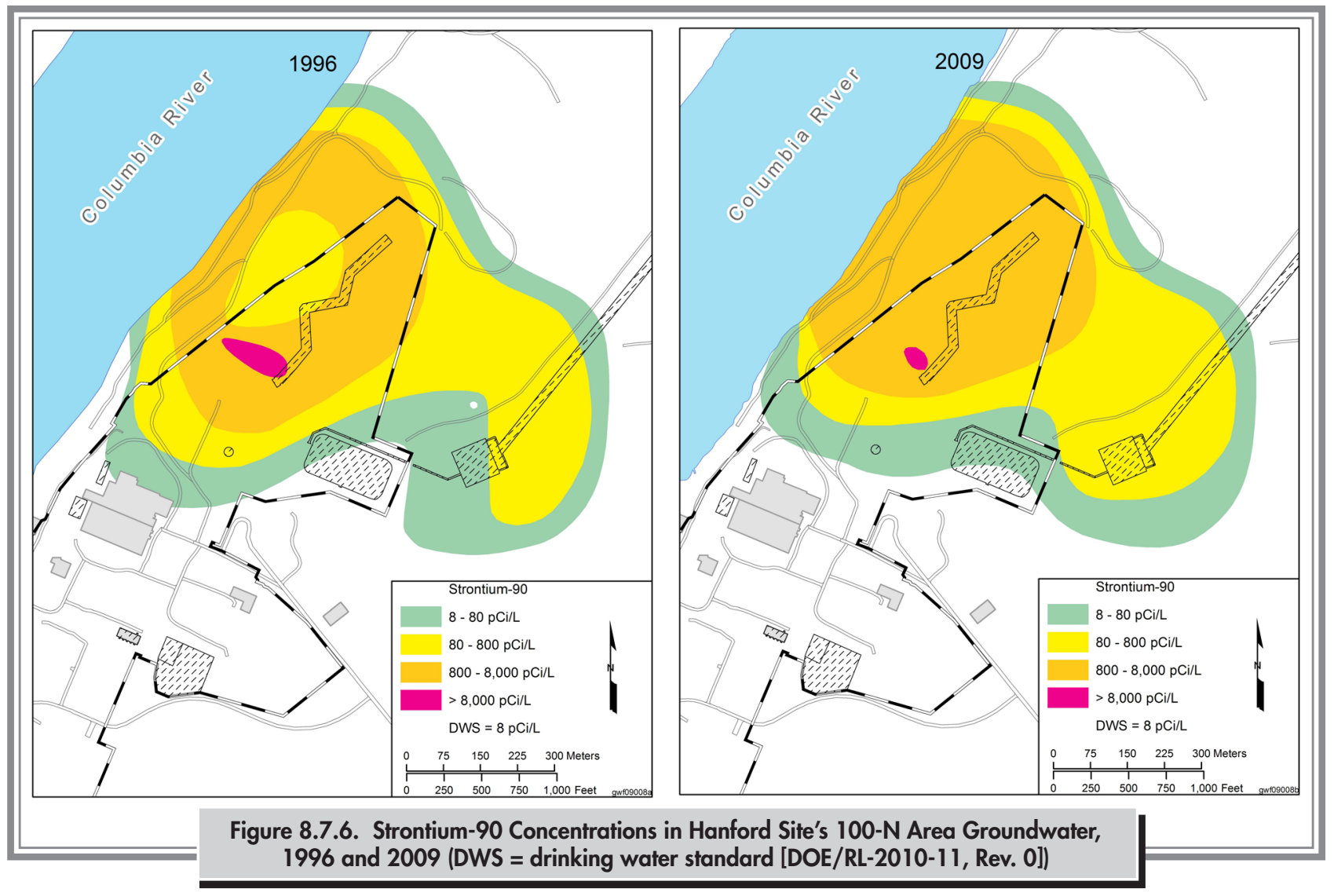

Other forms of remediation being investigated at the 100-N Area include pulse jet injection of apatite-forming chemicals, apatite-forming chemical infiltration, and phytoextraction (using plants) to treat contamination above the average water table (vadose zone) and in shallow groundwater.

1301-N, 1324-N, 1324-NA, and 1325-N Facilities. These four RCRA units are located in the 100-N Area. During 2009, the sites remained in detection monitoring programs. Atomic Energy Act of 1954 and CERCLA monitoring continued to track tritium and strontium-90 plumes from the 1301-N and 1325-N Facilities and sulfate from the 1324-NA Percolation Pond.

\subsubsection{Groundwater Monitoring Results for the 100-HR-3 Operable Unit}

The 100-HR-3 Operable Unit underlies the 100-D Area, 100-H Area, and the region between them. Hexavalent chromium is the principle contaminant of concern in groundwater. A principle cause for this contamination was the routine disposal of reactor coolant, which contained sodium dichromate as a corrosion inhibitor. Periodic spills and leaks of sodium dichromate stock solution to the ground were another source of contamination. Chromium is distributed in northern and southern plumes in the 100-D Area (Figure 8.7.7) and has been reduced to small localized spots in the 100-H Area (Figure 8.7.8). Other contaminants include strontium-90 and sulfate.

Interim Remedial Actions. Hexavalent chromium is the target of two pump-and-treat systems, which are designed to reduce the amount of chromium entering the Columbia River in the 100-D and 100-H Areas. Chromium concentrations remained above the remedial action goal $(20 \mu \mathrm{g} / \mathrm{L}$ for the pump-and-treat systems) in compliance wells during 2009. The two extraction systems the 100-HR-3 and 100-DR-5 pump-and-treat systems have removed 613 kilograms (1,351 pounds) of chromium from the aquifer since 1997. The southern 100-D Area chromium plume is being remediated using a permeable chemical reduction/oxidation ("redox") barrier that immobilizes chromium in the aquifer 


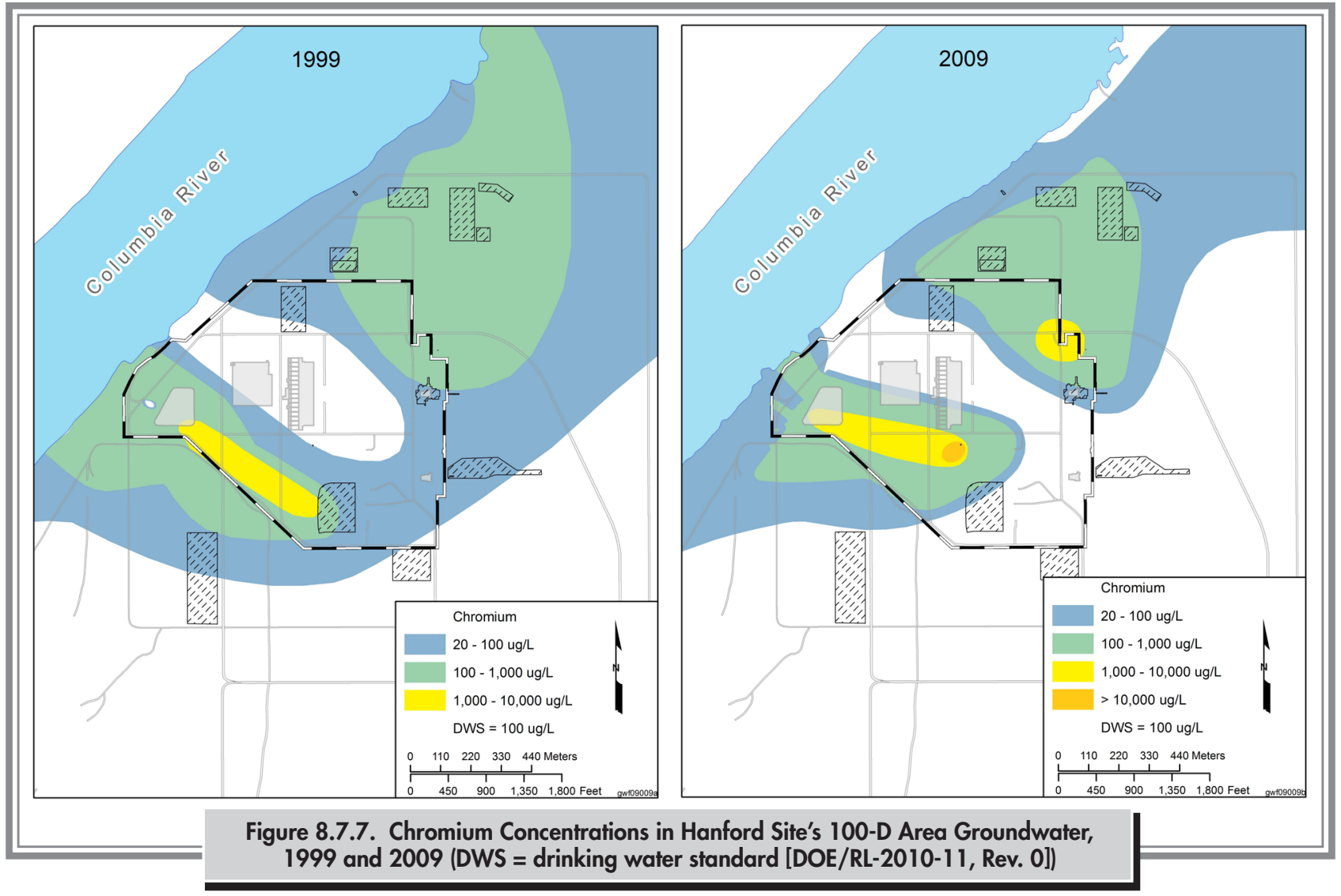

in combination with the pump-and-treat system. Data from recent years indicate that in some locations chromium has migrated through the barrier. At the end of 2009, chromium concentrations in barrier wells ranged from below detection limits to $783 \mu \mathrm{g} / \mathrm{L}$. Most of the elevated concentrations are in the northeastern half of the barrier. The remedial action goal for the permeable barrier of $20 \mu \mathrm{g} / \mathrm{L}$ was met at only two of the seven compliance wells. However, concentrations have declined overall in most of the compliance wells.

Nano-Size Zero-Valent Iron Injection. Scientists think that injecting tiny particles of iron into redox barrier wells will help repair the chromium breach in the permeable chemical barrier. Test injections occurred in August 2008. Initial results show that the groundwater affected by the iron eliminates hexavalent chromium from the aquifer. Injections affected the reduction-oxidation potential and dissolved oxygen in wells 3 meters ( 10 feet) away, but no effects were observed in a well 12.8 meters ( 42 feet) away.
Chromium Source Investigation. The principle objective of the 2009 chromium source investigation was to locate the hexavalent chromium source for the northern contaminant plume. Previous investigations identified some shallow leaks and spills but did not identify a deep vadose zone source. Determining the contaminant source is complicated by daily and seasonal fluctuations of the Columbia River, but a hot spot has been identified that is centered approximately 40 meters (131 feet) southwest of well 199-D5-99. This hot spot occupies less than 1 hectare $(2.5$ acre) and has hexavalent chromium concentrations above 51,000 $\mu \mathrm{g} / \mathrm{L}$.

Chromium in the Ringold Upper Mud Unit. Researchers also performed aquifer tests in 2009 to gather additional data on deep chromium contamination. The aquifer tests were performed using existing monitoring wells in the 100-H Area; wells were grouped into three sets, with each set containing three wells. Each three-well set had wells completed at increasing depths in the unconfined aquifer. Hexavalent 


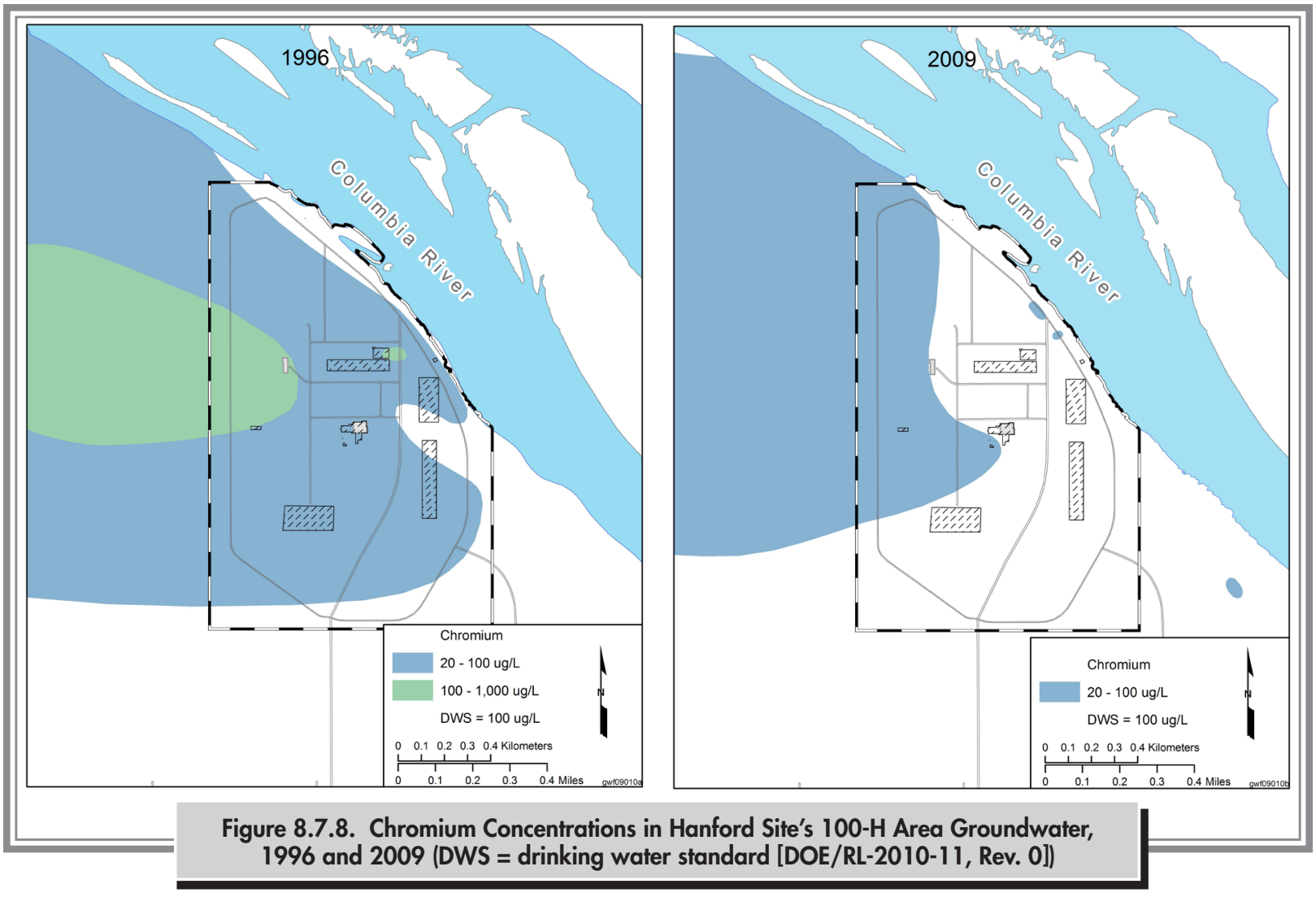

chromium within the tested zone appears to be of a finite extent, which should be amenable to remediation through the pump-and-treat system.

Other Research. Pacific Northwest National Laboratory completed an in situ biostimulation treatability test at the 100-D Area in 2009. Test data indicated that injected substances were successfully distributed to the target radius from the injection well. Microbial activity and the ability to reduce the targeted species were observed throughout the monitored zone, and low oxygen, nitrate, and chromium concentrations were maintained for the duration of monitoring. Reduction of aquifer permeability within the test zone was moderate, while the injected substances and associated organic degradation products persisted for a period of about 1 year.

183-H Solar Evaporation Basins. These former basins are the only RCRA site in the 100-D/H Area. Leaks from the basins contaminated groundwater with chromium, nitrate, technetium-99, and uranium. Concentrations of all four contaminants were below drinking water standards in 2009.
The site is monitored for the post-closure period to track contaminant trends during the operation of the chromium CERCLA interim action.

\subsubsection{Groundwater Monitoring Results for the 100-FR-3 Operable Unit}

Nitrate concentrations in groundwater exceed the $45-\mathrm{mg} / \mathrm{L}$ drinking water standard beneath much of the 100-F Area and the downgradient region. A few wells in the eastern 100-F Area have strontium-90 concentrations above the $8-\mathrm{pCi} / \mathrm{L}(0.3-\mathrm{Bq} / \mathrm{L})$ drinking water standard. Two wells in the southwestern 100-F Area exceeded the drinking water standard for trichloroethene $(5 \mu \mathrm{g} / \mathrm{L})$, but concentrations are declining. Hexavalent chromium concentrations exceeded the $10-\mu \mathrm{g} / \mathrm{L}$ aquatic standard in some wells.

During a study of groundwater upwelling in the Columbia River channel, river bottom sediment porewater samples were collected at 27 locations along the 100-F Area segment. Only one sample contained a detectable level of hexavalent chromium, which was below the aquatic standard. 
A record of decision has not yet been developed for the 100-FR-3 Operable Unit, and no active remediation of groundwater is underway. In 2009, a draft remedial investigation/feasibility study work plan addendum (DOE/ RL-2008-46-ADD4) and draft sampling and analysis plan (DOE/RL-2009-43) were released for EPA review.

\subsubsection{Groundwater Monitoring} Results for the 200-ZP-1 Operable Unit

This operable unit encompasses the northern and central portions of the 200-West Area. The principle contaminant of concern is carbon tetrachloride (Figure 8.7.9). Other contaminants include chloroform, chromium, fluoride, nitrate, trichloroethene, tritium, technetium-99, iodine-129, and uranium.

During 2009, DOE published a remedial design/remedial action work plan (DOE/RL-2008-78) that details the plan and schedule for implementing all tasks for the design, installation, and operation of the final remedy.
Carbon tetrachloride contamination occurs at increasing depth to the east (downgradient) of the known source areas. In this area, natural and artificial recharge may have led to reduced carbon tetrachloride concentrations in the upper portion of the aquifer. Carbon tetrachloride is denser than water, which also affects its vertical distribution. The 200-ZP-1 Operable Unit feasibility study (DOE/RL2007-28, Rev. 0) illustrates the areal extent of carbon tetrachloride at different depths. The maximum extent of the plume at all depths (i.e., the plume footprint) extends beyond the contours shown in Figure 8.7.9.

The 200-ZP-1 groundwater interest area contains one CERCLA interim action for groundwater, one remediation system for the vadose zone, four facilities monitored under RCRA (in conjunction with CERCLA and the Atomic Energy Act of 1954), and one state-permitted unit.

Interim Remedial Action. Since 1994, DOE has operated an interim action pump-and-treat system to prevent carbon tetrachloride in the upper part of the aquifer from spreading.

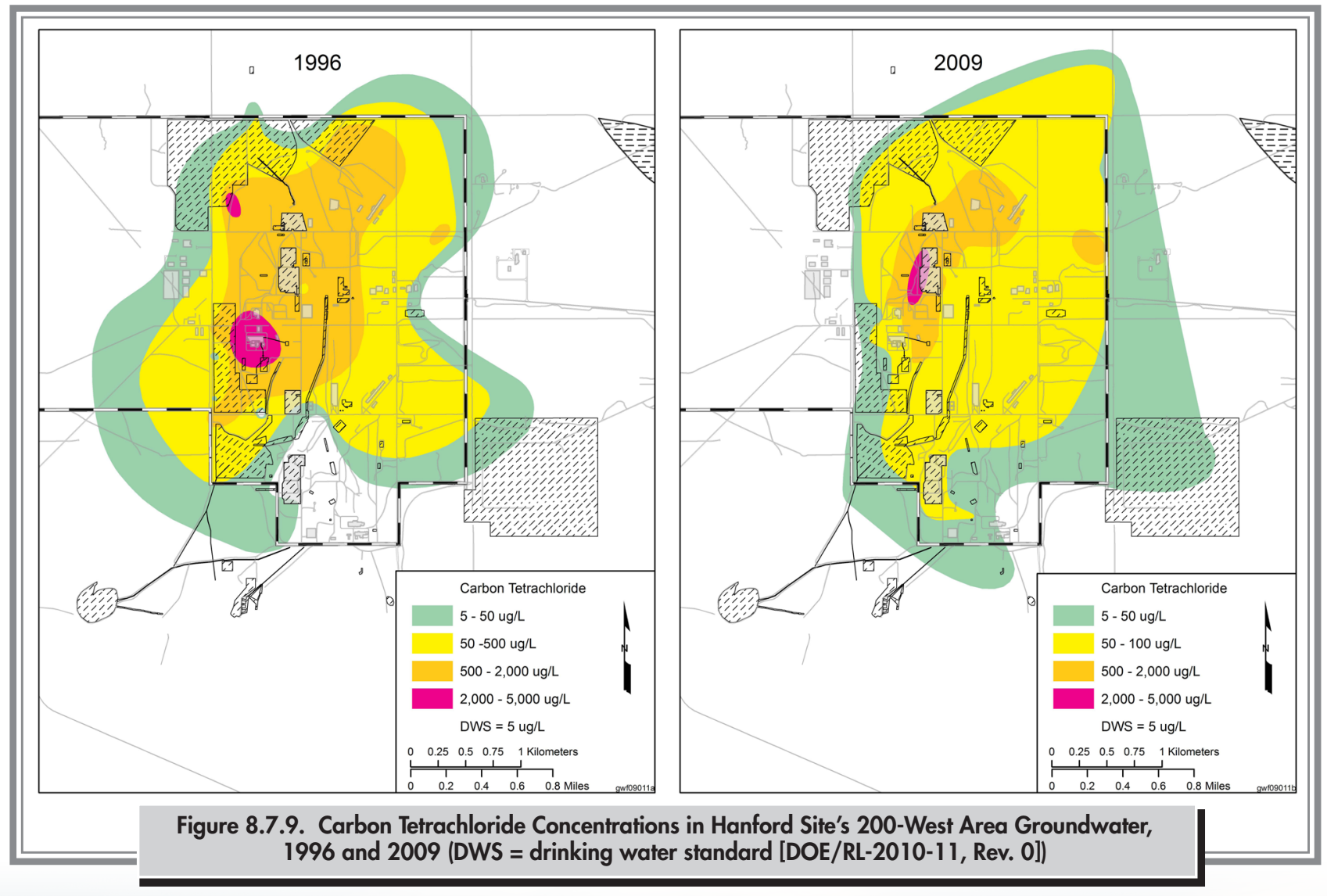


Four monitoring wells were converted to extraction wells during 2008 , bringing the number of extraction wells to 14 , with a combined pumping rate of approximately 1,514 liters (400 gallons) per minute. The system has removed 11,960 kilograms (26,400 pounds) of carbon tetrachloride from groundwater since 1994.

A second pump-and-treat system (241-T) for the removal of technetium-99 at Waste Management Area T came online in 2007. During 2009, the two extraction wells pumped a total of $77,706,000$ liters $(20,528,000$ gallons) at an average pumping rate of 149 liters (39.4 gallons) per minute. The system removed 22.7 grams ( 0.8 ounce) of technetium-99 during the reporting period for a total of 48.3 grams (1.7 ounces) removed since system startup.

Soil-Vapor Extraction. Soil vapor is extracted from the vadose zone and treated to remove carbon tetrachloride. The system has removed approximately 79,600 kilograms (175,000 pounds) of carbon tetrachloride from the vadose zone since operations started in 1991.

Low-Level Burial Grounds Waste Management Area 3. RCRA groundwater monitoring continued under interim status requirements in 2009. Changes to the groundwater flow direction related to the discontinuing liquid effluent discharges in the 200-West Area left Low-Level Waste Management Area 3 without any upgradient wells. Until new upgradient wells are installed and background conditions are established, statistical evaluations have been suspended.

\section{Low-Level Burial Grounds Waste Management Area 4.}

RCRA groundwater monitoring continued under interim status requirements in 2009. The remaining upgradient wells went dry in 2009. Total organic carbon concentrations in one downgradient well exceeded the threshold value in August 2008. In January 2009, a groundwater quality assessment plan was prepared to evaluate the elevated total organic carbon (SGW-40211). Groundwater was monitored under this assessment program from October 2008 through September 2009. In July 2009, the results of the first determination did not find dangerous waste/dangerous waste constituents in the groundwater at Low-Level Burial Grounds Waste Management Area 4. Therefore, monitoring returned to indicator evaluation monitoring.
Waste Management Area T. RCRA assessment monitoring continued in 2009. The waste management area has introduced chromium, nitrate, and technetium-99 to the uppermost aquifer in the area. In September 2007, two downgradient wells on the east side of the tank farms were converted to extraction wells to remove technetium-99 from the aquifer. Technetium-99 concentrations continued to decrease during 2009 in most downgradient wells and increased slightly in others, most likely because of the extraction.

Waste Management Area TX-TY. RCRA assessment monitoring continued in 2009. Sources in the waste management area have contaminated groundwater with chromium, technetium-99, and other tank waste constituents. Groundwater flow beneath Waste Management Area TX-TY is changing due to the operation of the 200-ZP-1 pump-and-treat system. Extraction wells operate south and west (upgradient) of the waste management area.

State-Approved Land Disposal Site. This active disposal facility is regulated under a state waste discharge permit. Groundwater is monitored for tritium and 15 other constituents. Concentrations of all constituents considered in the permit did not exceed enforcement limits during 2009.

\subsubsection{Groundwater Monitoring Results for the 200-UP-1 Operable Unit}

This operable unit underlies the southern portion of the 200-West Area. The principle contaminants of concern are carbon tetrachloride, nitrate, tritium, technetium-99, iodine-129, and uranium. Arsenic, cadmium, chromium, and strontium-90 plumes also have sources in this operable unit. Carbon tetrachloride, chloroform, and trichloroethene in the 200-UP-1 Operable Unit originated from sources in the 200-ZP-1 Operable Unit.

The 200-UP-1 Operable Unit contains one CERCLA interim action, three facilities monitored under RCRA (in conjunction with CERCLA and the Atomic Energy Act of 1954), and one CERCLA disposal site.

Interim Remedial Action. DOE operated an interim remedial action pump-and-treat system for technetium-99 and uranium from 1994 until early 2005. The effort successfully reduced the uranium concentration below the remedial 
action goal of $480 \mu \mathrm{g} / \mathrm{L}$. Since then, EPA established a drinking water standard of $30 \mu \mathrm{g} / \mathrm{L}$. In expectation that the remedial action goal will be revised to $300 \mu \mathrm{g} / \mathrm{L}$ (10 times the current standard), DOE resumed groundwater extraction in April 2007 and continued to operate it in 2009. The system has removed 126.5 grams (4.46 ounces) of technetium-99 and 219 kilograms (483 pounds) of uranium since 1994. Concentrations of technetium-99 and uranium in wells monitoring the pump-and-treat system were below the current remedial action goals by the end of 2009 (Figures 8.7.10 and 8.7.11).

An interim remedial action was implemented at Waste Management Area S-SX for the reduction of technetium-99 through the use of extended purging after routine well sampling. Following sample collection, the pumping rate is increased and the well is pumped until a total of 3,785 liters $(1,000$ gallons $)$ is removed. This activity has removed a total of 0.49 gram ( 0.017 ounce) of technetium- 99 from the aquifer, including the 0.12 gram (0.004 ounce) removed in 2009.
Waste Management Area S-SX. RCRA assessment monitoring continued in 2009. Groundwater beneath this waste management area is contaminated with tank waste constituents, which include chromium, nitrate, and technetium-99, attributed to two general source areas within the waste management area. The concentrations of the contaminants of concern were $280 \mathrm{mg} / \mathrm{L}$ for nitrate, $668 \mu \mathrm{g} / \mathrm{L}$ for total chromium (filtered), and $20,000 \mathrm{pCi} / \mathrm{L}$ (740 Bq/L) for technetium-99. In 2008, selenium-79 was detected in two wells. A total of nine network monitoring wells had at least one detection during the reporting period, with concentrations ranging from 5.5 to $311 \mathrm{pCi} / \mathrm{L}(0.204$ to $11.5 \mathrm{~Bq} / \mathrm{L})$.

Waste Management Area U. RCRA assessment monitoring continued in 2009. The waste management area has been identified as the source of groundwater contamination that is limited to the downgradient (east) side of the site. Plume constituents of interest include nitrate and technetium-99. The maximum concentrations of these two constituents were $43 \mathrm{mg} / \mathrm{L}$ and 2,200 pCi/L (81.4 Bq/L),

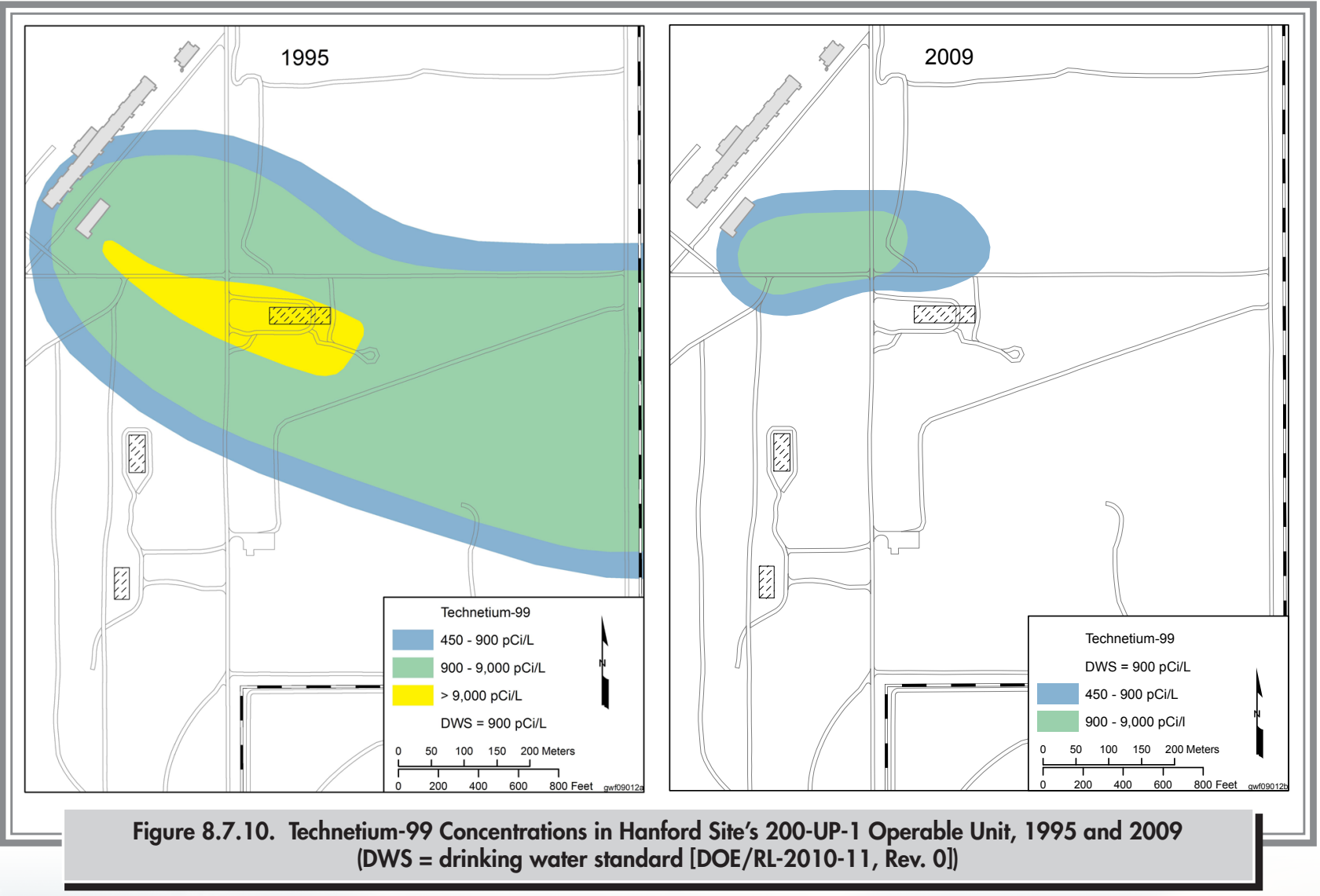




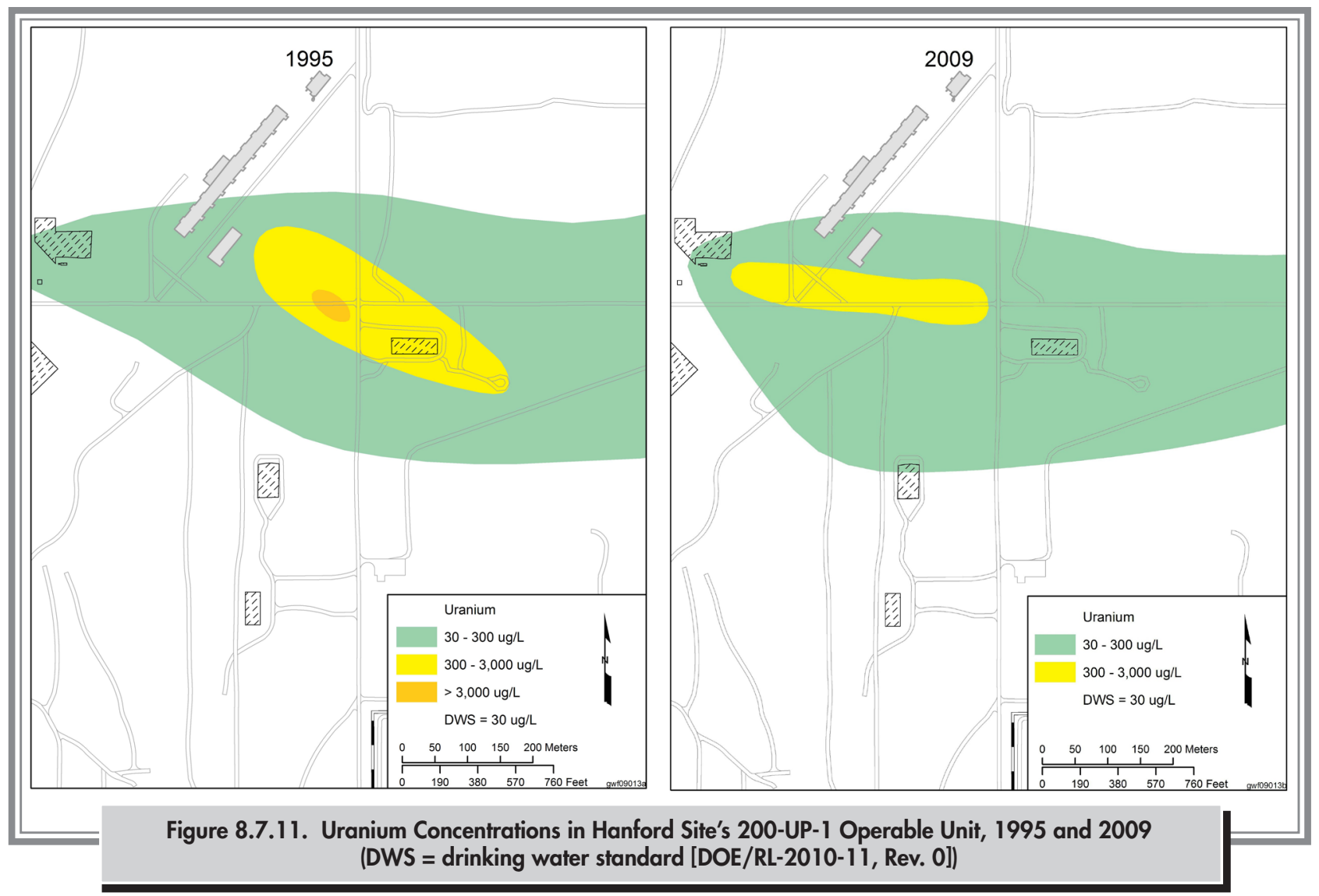

respectively. Selenium-79 was also analyzed in all network wells in July 2009, with all results below the minimum detectable activity.

216-S-10 Pond and Ditch. The 216-S-10 Facility continued to be monitored under a RCRA interim status contamination indicator evaluation program in 2009. One upgradient well and two downgradient wells were installed in 2008 as part of the 200-UP-1 Operable Unit work plan; these were sampled quarterly in 2009 as part of the 216-S-10 unit monitoring wells to reestablish background concentrations for indicator parameters.

Environmental Restoration Disposal Facility. This facility is a low-level, mixed waste disposal facility for waste generated from surface remedial actions and other activities on the Hanford Site. The site was built under CERCLA regulations and is designed to meet all hazardous landfill standards. Results of groundwater monitoring continued to indicate that the facility has not adversely affected groundwater quality.

\subsubsection{Groundwater Monitoring Results for the 200-BP-5 Operable Unit}

This operable unit includes groundwater beneath the northern 200-East Area and the region to the northwest, where mobile contaminants, including tritium and technetium-99, historically moved northward between Gable Mountain and Gable Butte. Most of the groundwater contamination originated in facilities in the northwestern corner of the 200-East Area, known as the B Complex.

The water table in the northern 200-East Area is virtually flat, making it difficult to determine current groundwater flow direction. Studies in recent years suggest that groundwater continues to flow slowly to the northwest from the B Complex area.

Constituents of concern defined in the Groundwater Sampling and Analysis Plan for the 200-BP-5 Operable Unit (DOE/ RL-2001-49, Rev. 1) include cyanide, nitrate, tritium, cobalt-60, strontium-90, technetium-99, iodine-129, 
cesium-137, plutonium-239/240, and uranium. Tritium and technetium-99 plumes extend northward between Gable Mountain and Gable Butte. Uranium forms a narrow plume that also extends northwest of the 200-East Area (Figure 8.7.12). Nitrate forms a plume that extends to the north and likely originated from multiple sources within the 200-East Area. Other contaminants include cyanide and sulfate.

DOE continued to work on the 200-BP-5 Operable Unit remedial investigation/feasibility study (DOE/RL-2007-18) during 2009. Analyses were completed and reported on eight new wells during 2009. Six facilities in the 200-BP-5 Operable Unit are monitored under RCRA in conjunction with CERCLA and the Atomic Energy Act of 1954.

Waste Management Area B-BX-BY. RCRA assessment monitoring continued at this site in 2009. Contaminants near this waste management area include chromium, cyanide, nitrate, technetium-99, and uranium; however, chromium and cyanide (and others) cannot be attributed to the waste management area. Five new wells installed under the 200-BP-5 Operable Unit remedial investigation/ feasibility study were informally added to the network in 2009, and the first year of quarterly sampling was completed. The maximum concentration of contaminants in wells monitoring Waste Management Area B-BX-BY during 2009 were $79.7 \mu \mathrm{g} / \mathrm{L}$ for cyanide, $624 \mathrm{mg} / \mathrm{L}$ for nitrate, 26,000 pCi/L (962 Bq/L) for technetium-99, and 4,850 $\mu \mathrm{g} / \mathrm{L}$ for uranium.

216-B-63 Trench. This RCRA site continued to be monitored under an interim status contamination indicator evaluation monitoring program. With the exception of $\mathrm{pH}$, all indicator parameters were below threshold values. The $\mathrm{pH}$ in one sample exceeded the lower-bound threshold value in October 2008. Verification sampling did not confirm the exceedance, and $\mathrm{pH}$ values returned to within the threshold value range for the remainder of the reporting period.

Low-Level Waste Management Area 1. This site continued to be monitored under RCRA interim status

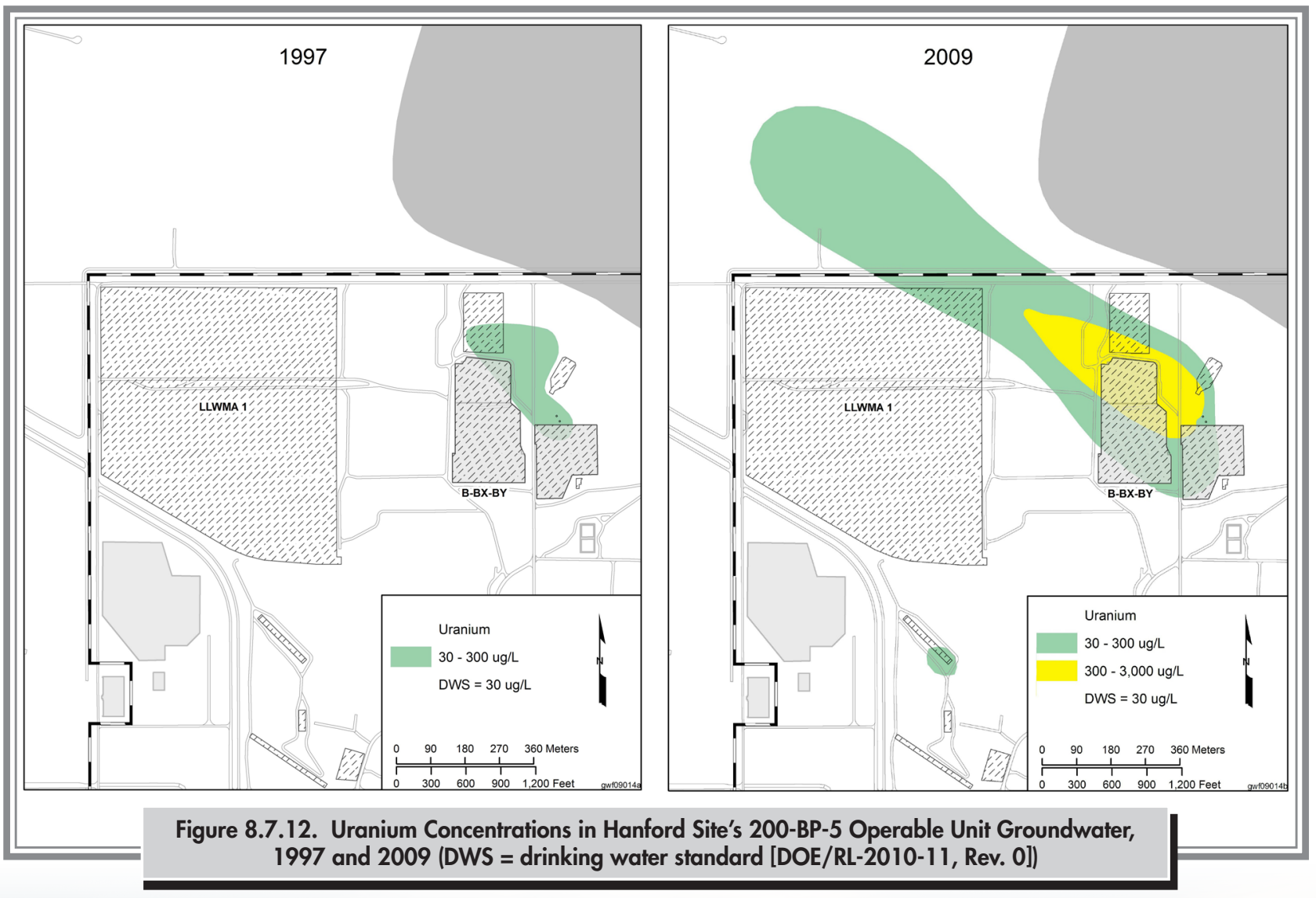


requirements. Specific conductance continued to exceed its threshold value, but exceedances were previously reported and are associated with sources upgradient of the waste management area, not contamination from the waste management area. All other indicator parameters were below their respective threshold values.

Low-Level Waste Management Area 2. This site continued to be monitored under RCRA interim status requirements, with no indication that it has adversely affected groundwater quality.

Liquid Effluent Retention Facility. This facility is operated under final status permit conditions. All four wells in the network were sampled twice during 2009. All permitrequired constituents were either below detection limits or below the operating limits.

Waste Management Area C. This site began the 15-month reporting period under an interim status RCRA contamination indicator evaluation program, but finished the reporting period under a new groundwater quality assessment program. Cyanide has been detected in groundwater beneath this waste management area, and technetium-99 is also present in groundwater.

\subsubsection{Groundwater Monitoring Results for the 200-PO-1 Operable Unit}

This operable unit encompasses the southern portion of the 200-East Area and a large region to the east and southeast that is contaminated with plumes of tritium (Figure 8.7.13) and iodine-129. Concentrations of tritium continued to decline as the plume attenuates naturally because of radioactive decay and dispersion. Nitrate also forms a large plume but typically at levels below the 45-mg/L drinking water standard. Other contaminants include strontium-90 and technetium-99, but these are limited to smaller areas.

During 2009, characterization sampling and routine monitoring continued under Remedial Investigation/Feasibility Study Work Plan for the 200-PO-1 Groundwater Operable Unit (DOE/RL-2007-31, Draft A), which was completed in 2009. Constituents of concern listed in the remedial investigation/

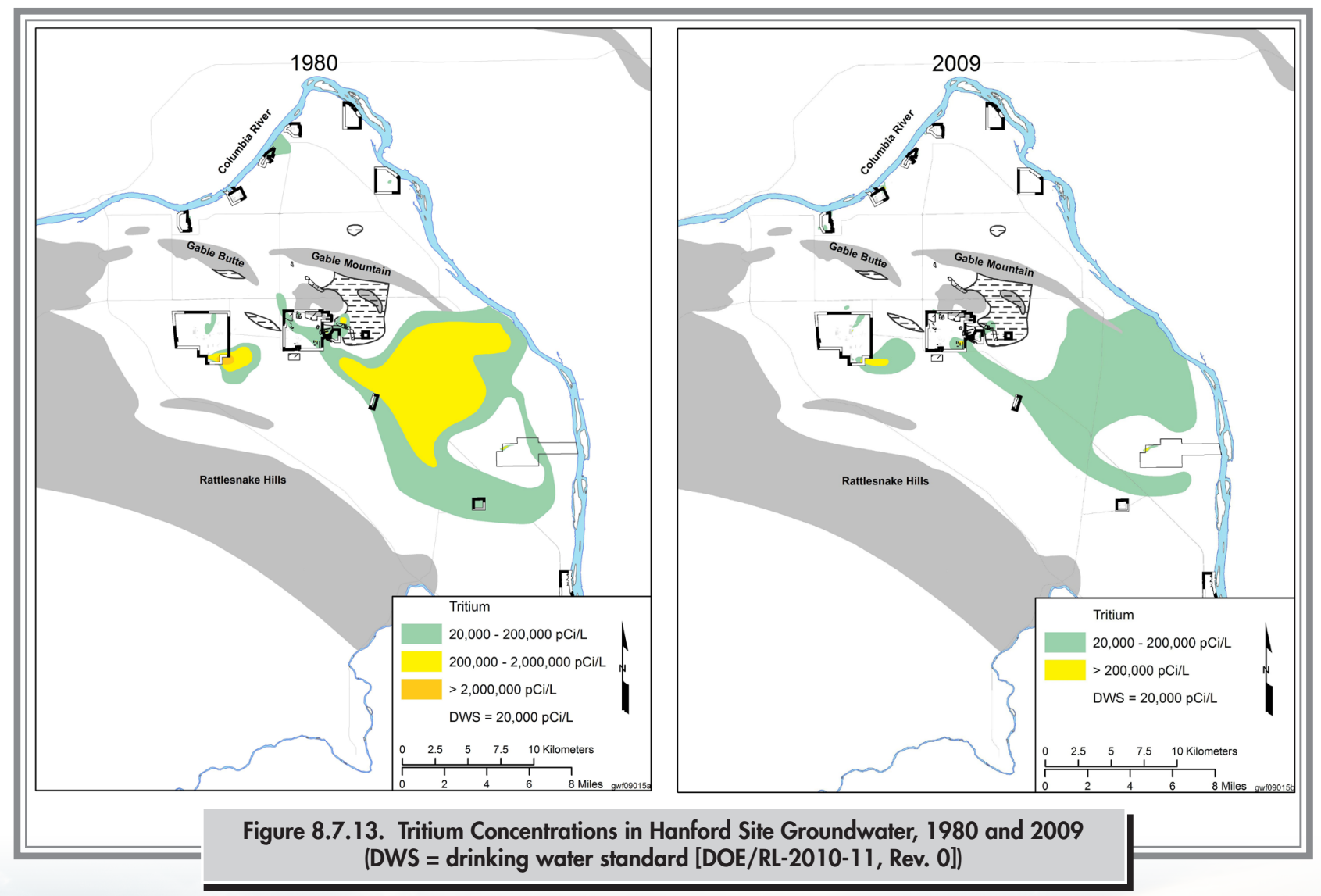


feasibility study work plan include nitrate, tritium, strontium-90, technetium-99, iodine-129, and uranium. Other contaminants of interest are arsenic, chromium, manganese, and vanadium.

Groundwater is monitored at eight regulated units in the 200-PO-1 Operable Unit; six facilities are monitored under RCRA; one wastewater discharge facility is covered by a state waste discharge permit; and one solid waste landfill is regulated under Washington State solid waste regulations. Water supply wells in the 400 Area, which fall within the 200-PO-1 Operable Unit footprint, are also monitored.

Integrated Disposal Facility. This facility is an expandable, lined, RCRA-compliant landfill that will be used for disposal of low-level radioactive waste and hazardous waste. Until the facility begins to operate, results from semiannual monitoring will be added to the baseline data set.

PUREX Cribs. The 216-A-10, 216-A-36B, and 216-A-37-1 Cribs are monitored jointly under a RCRA interim status groundwater quality assessment program, CERCLA, and the Atomic Energy Act of 1954. The cribs have contributed to widespread contaminant plumes in the area, including tritium, iodine-129, and nitrate. The tritium and nitrate plumes are generally attenuating throughout most of their area.

Waste Management Area A-AX. RCRA assessment monitoring continued in 2009. Technetium-99 concentrations continued to exceed the $900 \mathrm{pCi} / \mathrm{L}(33.3 \mathrm{~Bq} / \mathrm{L})$ drinking water standard in two wells.

216-A-29 Ditch. This site continued to be monitored under RCRA interim status requirements, with no indication that it has adversely affected groundwater quality. Specific conductance remains elevated in three downgradient wells, but is consistent with regional groundwater chemistry.

216-B-3 Pond. This site continued to be monitored under RCRA interim status requirements, with no indication that it has adversely affected groundwater quality.

200 Area Treated Effluent Disposal Facility. A state waste discharge permit governs groundwater sampling and analysis in the three monitoring wells at this facility. No permit criteria for constituents in groundwater were exceeded in 2009. Because no unconfined aquifer exists beneath the facility, groundwater monitoring wells are installed in the locally confined aquifer below the Ringold Formation lower mud unit.

Nonradioactive Dangerous Waste Landfill. This RCRA site is located in the 600 Area, within the footprint of the 200-PO-1 Operable Unit regional plume. Interim status contamination indicator evaluation monitoring continued in 2009, after first determination groundwater assessment monitoring was completed. The groundwater assessment monitoring concluded that the elevated total organic carbon detected at the unit was not related to dangerous waste constituents attributable to the facility. Therefore, the site will return to full-time interim status indicator evaluation monitoring in 2010.

Solid Waste Landfill. This facility is adjacent to the Nonradioactive Dangerous Waste Landfill and is regulated under state solid waste regulations. As in previous years, some downgradient wells showed higher chemical oxygen demand, chloride, coliform bacteria, specific conductance, sulfate, total organic carbon, and lower $\mathrm{pH}$ than upgradient wells. Some of these constituents may be related to past disposal of sewage materials to the landfill.

400 Area Water Supply Wells. Three water supply wells provide drinking water and emergency supply water for the 400 Area. Because the 400 Area is in the path of the Hanford Site-wide tritium plume, the wells are routinely monitored for tritium. Tritium concentrations in all samples were below the drinking water standard in 2009.

\subsubsection{Groundwater Monitoring Results for the 300-FF-5 Operable Unit}

This operable unit includes three geographic regions: the 300 Area, the 618-11 Burial Ground region, and the 618-10 Burial Ground/316-4 Cribs region. The operable unit is currently regulated under a record of decision for interim remedial action (EPA/ROD/R10-96/143) that requires groundwater monitoring and institutional controls on groundwater usage.

Contaminants of concern in 300 Area groundwater are uranium, cis-1,2-dichloroethene, and trichloroethene. Monitoring and plume characterization activities indicate 
relatively constant or gradually decreasing levels for these contaminants. Uranium is the principle contaminant of concern and remains above the drinking water standard of $30 \mu \mathrm{g} / \mathrm{L}$ beneath part of the 300 Area (Figure 8.7.14).

Trichloroethene continued to be below the $5-\mu \mathrm{g} / \mathrm{L}$ drinking water standard in wells monitoring the top portion of the unconfined aquifer. However, higher concentrations were detected in a deeper, fine-grained unit in a limited area.

Groundwater downgradient of the 618-11 Burial Ground is contaminated by a high-concentration tritium plume, likely originating from irradiated material in the burial ground. Concentrations at a well adjacent to the burial ground have decreased from the peak values observed in 1999 and 2000.

Remedial Investigation/Feasibility Study. Because the uranium plume beneath the 300 Area has not decreased in concentration as rapidly as predicted by earlier studies, DOE continued a detailed investigation of the natural processes that cause the plume to persist and the residual sources that may supply uranium to the plume. Results obtained in 2009 did not show elevated uranium contamination levels either in the vadose zone or near the water table. In addition, water samples collected from the saturated zone at various depths confirmed that contamination is generally limited to the uppermost hydrologic unit (i.e., saturated Hanford Site gravels). Concentrations in the samples were consistent with those observed during routine groundwater monitoring.

Uranium Treatability Test. Monitoring during 2008 indicated that the addition of polyphosphate did not perform as well as hoped in permanently sequestering uranium on aquifer solids. Results of the aquifer injection test are provided in the 300 Area Uranium Stabilization Through Polyphosphate Injection: Final Report (PNNL-18529). Researchers conducted additional treatability testing using polyphosphate solutions during 2009; testing continues into 2010 at a second test site, where the focus is on immobilizing uranium in the vadose zone.

Integrated Field-Scale Research Challenge. This basic research project has focused on the geochemistry and mobility of uranium in the vadose zone at the 300 Area,

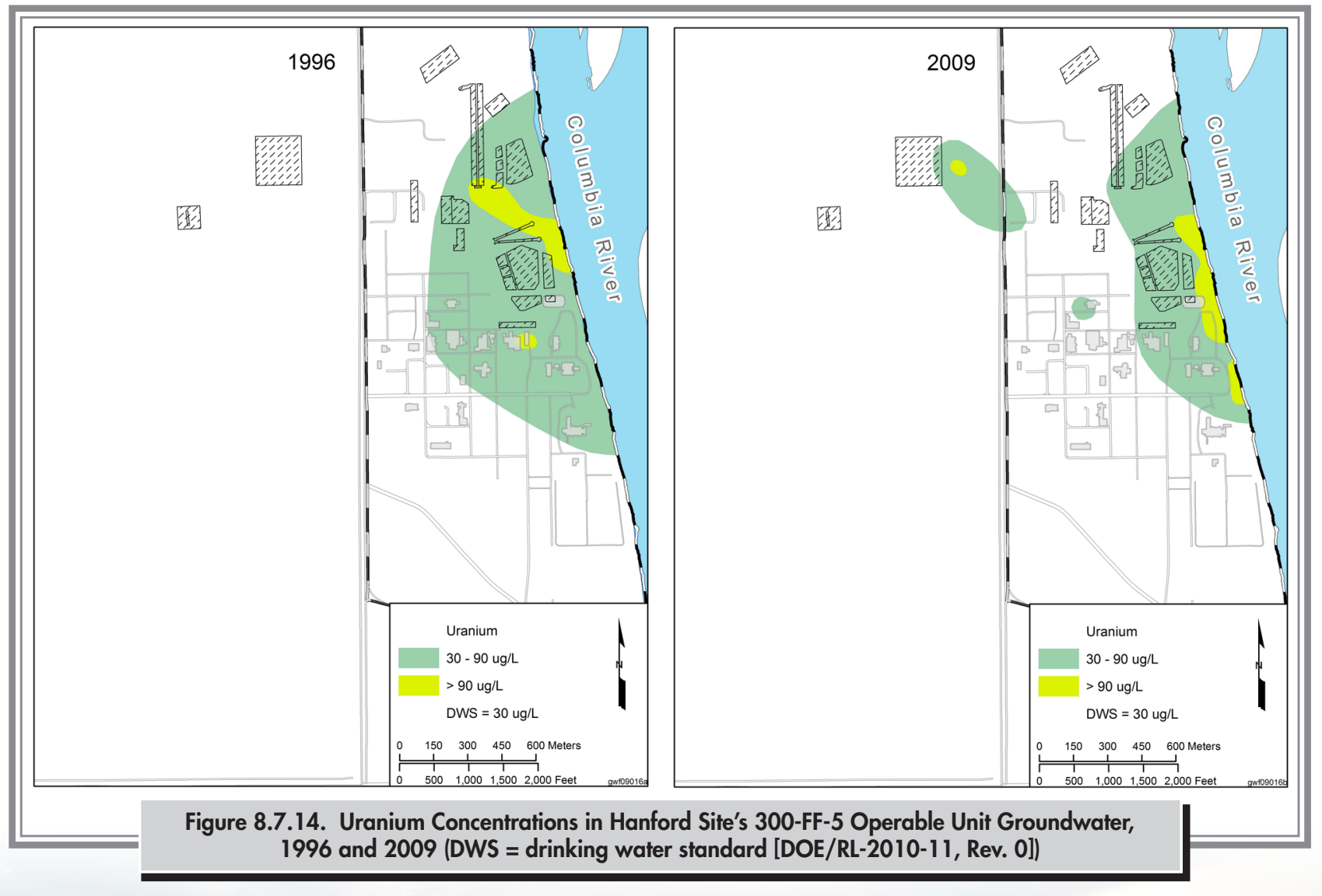


using a variety of near-surface geophysical methods to characterize preferential pathways for groundwater movement and discharge to the Columbia River channel. The project is in its third year, and a final report on the results is expected in 2010.

DOE has also funded a groundwater flow and uranium transport modeling project for the 300 Area through the Scientific Discovery Through Advanced Computing Program. This project involves massively parallel, highspeed computing and conducts calculations that would otherwise require exceedingly long computing times using conventional computer equipment. A report on the initial results of the project is expected during 2010.

316-5 Process Trenches. This former liquid waste disposal site was the last site in the 300 Area to receive uraniumbearing effluent, with discharges ending in the early 1990s. The 316-5 Process Trenches, which have been remediated, are regulated under RCRA in conjunction with CERCLA and the Atomic Energy Act of 1954. Uranium currently exceeds the drinking water standard in wells downgradient from the waste site, although concentrations appear to be decreasing with time. Cis-1,2-dichloroethene concentrations exceed the drinking water standard at only one downgradient well completed at depth in the unconfined aquifer.

\subsubsection{Groundwater Monitoring Results for the 1100-EM-1 Groundwater Interest Area}

The 1100-EM-1 groundwater interest area is located in the southern part of the Hanford Site. It includes the former 1100-EM-1 Operable Unit, which was recently removed from the National Priorities List (40 CFR 300, Appendix B) and is no longer classified as a CERCLA operable unit. Groundwater is also monitored south of the Hanford Site, including the areas formerly designated as the 1100 and 3000 Areas of the site, the city of Richland's landfill, and the North Richland Well Field.

Trichloroethene was the principle contaminant of concern in the former 1100-EM-1 Operable Unit. Concentrations of trichloroethene remained below the $5-\mu \mathrm{g} / \mathrm{L}$ drinking water standard in 2009. Contaminants also flow into the area from offsite sources (e.g., nitrate from agricultural and industrial activities). The final alternative selected for groundwater was monitored natural attenuation of volatile organic compounds.

Wells in the North Richland Well Field are monitored frequently to detect any changes in Hanford Site contaminants near these wells. The tritium plume originating from sources in the 200-East Area has not been detected in these wells. Low levels of tritium, similar to those detected in Columbia River water, continued to be detected in 2009.

Elevated levels of gross alpha occur downgradient of an offsite industrial facility and DOE's inactive Horn Rapids Landfill. Uranium concentrations have been slowly increasing since 1996, but remained below the drinking water standard in 2009.

\subsubsection{Groundwater Monitoring Results for the Confined Aquifers}

Although most of the Hanford Site's groundwater contamination is in the unconfined aquifer, DOE monitors wells in deeper aquifers because of the potential for downward migration of contamination and the potential migration of contamination offsite through the basalt-confined aquifer. No evidence of offsite migration via the confined aquifer has been detected.

The Ringold Formation confined aquifer occurs within fluvial sand and gravel comprising the lowest sedimentary unit of the Ringold Formation. It is confined below by basalt and above by the Ringold Lower Mud Unit. While effluent disposal was occurring at the B Pond System, mounding within the unconfined aquifer in this area led to downward migration of groundwater into the Ringold Formation confined aquifer. During 2009, five wells were sampled that were completed in the Ringold Formation confined aquifer. No contaminants exceeded primary drinking water standards.

Groundwater occurs within basalt fractures and joints, interflow contacts, and sedimentary interbeds within the upper basalt-confined aquifer system. Fifteen basalt-confined aquifer wells were sampled during 2009. Tritium continued to be detected at low levels in some basalt-confined wells. Strontium-90 and gamma-emitting isotopes were not detected above the minimum detection limits in the upper 
basalt-confined aquifer. The elevated cyanide, nitrate, and technetium-99 measured in 2008 in the upper basaltconfined aquifer well located in the northwestern portion of the 200-East Area, declined significantly during 2009. Concentrations are now similar to those found in other upper basalt-confined aquifer wells in the area. Migration of contamination from the vadose zone or unconfined aquifer through the wellbore during well construction was responsible for the elevated levels.

\subsubsection{Shoreline Groundwater Monitoring}

DOE uses aquifer tubes to monitor groundwater near the Columbia River. An aquifer tube is a small diameter, flexible tube with a screened end that is placed in the shallow aquifer and natural seep points or springs along the riverbank.

Concentrations of strontium-90 continued to exceed the $8-\mathrm{pCi} / \mathrm{L}(0.3-\mathrm{Bq} / \mathrm{L})$ drinking water standard in aquifer tubes in the $100-\mathrm{B} / \mathrm{C}, 100-\mathrm{N}$, and $100-\mathrm{H}$ Areas. In the $100-\mathrm{N}$ Area, this high concentration represented a brief spike in response to the nearby injection of apatite-forming chemicals.

Tritium concentrations exceeded the 20,000-pCi/L (740-Bq/L) drinking water standard in one tube in the 100-B/C Area and at the southern end of 100-D Area. The source is believed to be the 100-N Area plume. Tritium also exceeded the standard in springs and aquifer tubes at the Hanford town site.

Uranium concentrations exceeded the 30- $\mu \mathrm{g} / \mathrm{L}$ drinking water standard in the 300 Area aquifer tubes and springs.

Hexavalent chromium concentrations exceeded the $100-\mu \mathrm{g} / \mathrm{L}$ drinking water standard in 100-D Area aquifer tubes. Concentrations in aquifer tubes or springs exceeded the $10-\mu \mathrm{g} / \mathrm{L}$ aquatic standard in the 100-B/C, 100-K, 100-D, 100-H, and 100-F Areas.

Nitrate concentrations exceeded the $45-\mathrm{mg} / \mathrm{L}$ drinking water standard in aquifer tubes in the $100-\mathrm{K}, 100-\mathrm{N}$, and
100-H Areas. An aquifer tube in the southern 300 Area also exceeded the standard; the source of this nitrate is a plume from offsite sources.

Trichloroethene was detected in several aquifer tubes in the 300 Area and continued to exceed the $5-\mu \mathrm{g} / \mathrm{L}$ drinking water standard in some tubes monitoring a deep fine-grained unit.

River Sediment Porewater Sampling. DOE and Washington Closure Hanford, LLC launched an investigation of Hanford Site contaminant releases in the Columbia River in 2008. Researchers collected samples of river bottom sediment porewater (i.e., groundwater that is upwelling beneath the river bottom in the space between rocks and sediment), river sediment, river water, fish, and island soil.

Phase I of the study, a test of the applicability of the Trident ${ }^{(a)}$ probe technology for Hanford Reach conditions, was successfully completed in 2008. Phase II of the study, designed to delineate areas where groundwater was discharging (upwelling) to the river, was completed in 2009. This study was divided into two sub-phases (Phase Ila and Phase IIb). Phase IIa included approximately 675 in situ measurements of specific conductance and temperature to define areas of upwelling. Phase Ila study results indicated areas of preferential upwelling in mappable locations along the Hanford Site shoreline, the opposite shoreline, and in the deep river channel. Results of Phase IIa were used to select sites to be sampled in Phase IIb.

Phase IIb of the study involved collecting samples of groundwater from a subset of Phase Ila locations and analyzing the samples for key Hanford Site contaminants. Contaminants were detected in some of the porewater samples and, in a few cases, were detected at higher concentrations than anticipated.

Phase III of the study was conducted in early 2010 and included additional sampling of approximately five locations in each study area. Samples of porewater, river sediment, and river water were analyzed to provide a more comprehensive list of contaminants.

(a) Trident ${ }^{\mathrm{TM}}$ probe is a trademark of Environmental Sciences, San Diego, California. 


\subsubsection{Well Installation, Maintenance, and Decommissioning}

In 2009, DOE installed 52 new wells. DOE installs new wells when needed for monitoring or characterization, maintains wells to repair problems, and decommissions wells that can no longer be used. DOE, EPA, and the Washington State Department of Ecology (the Tri-Party Agreement agencies) worked together to develop a prioritized list of new wells needed to meet requirements of various groundwater monitoring regulations.

During 2009, 103 temporary characterization boreholes were installed around the Hanford Site to support various projects. The temporary boreholes are installed for subsurface characterization of radiological constituents, volatile organics (e.g., carbon tetrachloride), or hydrogeologic property determination (e.g., moisture, grain size distribution). While typically installed to characterize the vadose zone, boreholes can be drilled to groundwater to obtain a one-time sample and then be decommissioned.

Approximately 10,416 unique well identification numbers have been assigned within the Hanford Site. These include all wells, characterization boreholes, aquifer tubes, soil-gas probes, piezometers, or other subsurface installations. To date, 4,272 of these, or approximately $44 \%$ of the total, have been either administratively removed from the well inventory or decommissioned (sealed with grout). Wells are decommissioned when they are no longer needed; are in poor condition; are in the path of intended remediation or construction activities; or pose an environmental, safety, or public health hazard. DOE maintains a list of wells that are candidates for decommissioning, which must be reviewed and approved by potential well users before a well is decommissioned. A total of 3,498 unique well identification numbers were documented as "in use" through December 2009. One well was physically decommissioned between October 2008 and December 2009.

Staff performed maintenance on 330 wells from October 2008 through December 2009. Surface maintenance included labeling wells, maintaining well caps, and repairing surface casing, wiring, or pump-discharge fittings. Subsurface tasks included repairing and replacing sampling pumps, performing camera surveys, retrieving pumps and equipment, and replacing discharge tubing. 


\title{
8.8 Food and Farm Products Monitoring
}

\author{
BG Fritz
}

Food and farm products (alfalfa, apples, leafy vegetables, milk, potatoes, tomatoes, and wine) were collected at locations near the Hanford Site (Figure 8.8.1) during 2009. Samples were analyzed to determine concentrations of radiological contaminants and were obtained from the following locations:

- Locations generally downwind (east and southeast) of the Hanford Site where airborne emissions or contaminated dust from the site would potentially be deposited

- Locations generally upwind of and distant from the Hanford Site to provide information on reference (background) contaminant levels

- Farms irrigated with water taken from the Columbia River downstream of the Hanford Site.

Results of sample analyses are used to assess the amounts of Hanford Site contaminants in food and farm products by 1) comparing analytical results obtained from similar samples collected from the same regions over long periods of time; 2) comparing analytical results from samples collected at downwind locations to results from samples obtained from generally upwind or distant locations; and 3) comparing analytical results from samples collected in areas irrigated with water withdrawn from the Columbia River downstream from the Hanford Site to analytical results from samples obtained from locations irrigated with water from other regional sources.

Radionuclide concentrations in most food and farm product samples in 2009 were below levels that could be detected by analytical laboratories. However, some contaminants that potentially could have originated from the Hanford Site (e.g., tritium and uranium) were found at low levels in some samples. These findings are presented in the following sections.
Data for naturally occurring potassium-40 are included to show the amounts of this natural radioactive element in food products relative to concentrations of contaminants potentially from the Hanford Site. Radiological doses associated with possible site-produced contaminants are discussed in Section 8.12. Where possible, the measured concentrations are compared to the applicable unusual concentration reporting levels. Unusual concentration reporting levels have been established based on environmental concentrations that would result in a 1-millirem (10-microsievert) dose per year (DOE/RL-91-50, Rev. 4).

\subsubsection{Collection of Food and Farm Product Samples}

Several food and farm product samples are collected each year on quarterly or annual schedules; others are sampled every 2 or 3 years. The rationale for sampling and analyzing some media more frequently than others is discussed in the Hanford Site Environmental Monitoring Plan (DOE/RL91-50, Rev. 4). The types and numbers of samples scheduled for collection in any given year are documented in the annual Hanford Site environmental surveillance master sampling schedule (e.g., PNNL-18177). Typically, enough crop material for two samples is collected at each location. A portion of this material is submitted to a laboratory for analysis, and the remainder is archived at Pacific Northwest National Laboratory if the analytical laboratory needs additional material for confirmatory or follow-up analyses. Table 8.8.1 shows the products, sampling locations, and analytes evaluated during 2009. Most samples were obtained from commercial producers; however, some were obtained from residential gardens because commercial growers could not be located. 


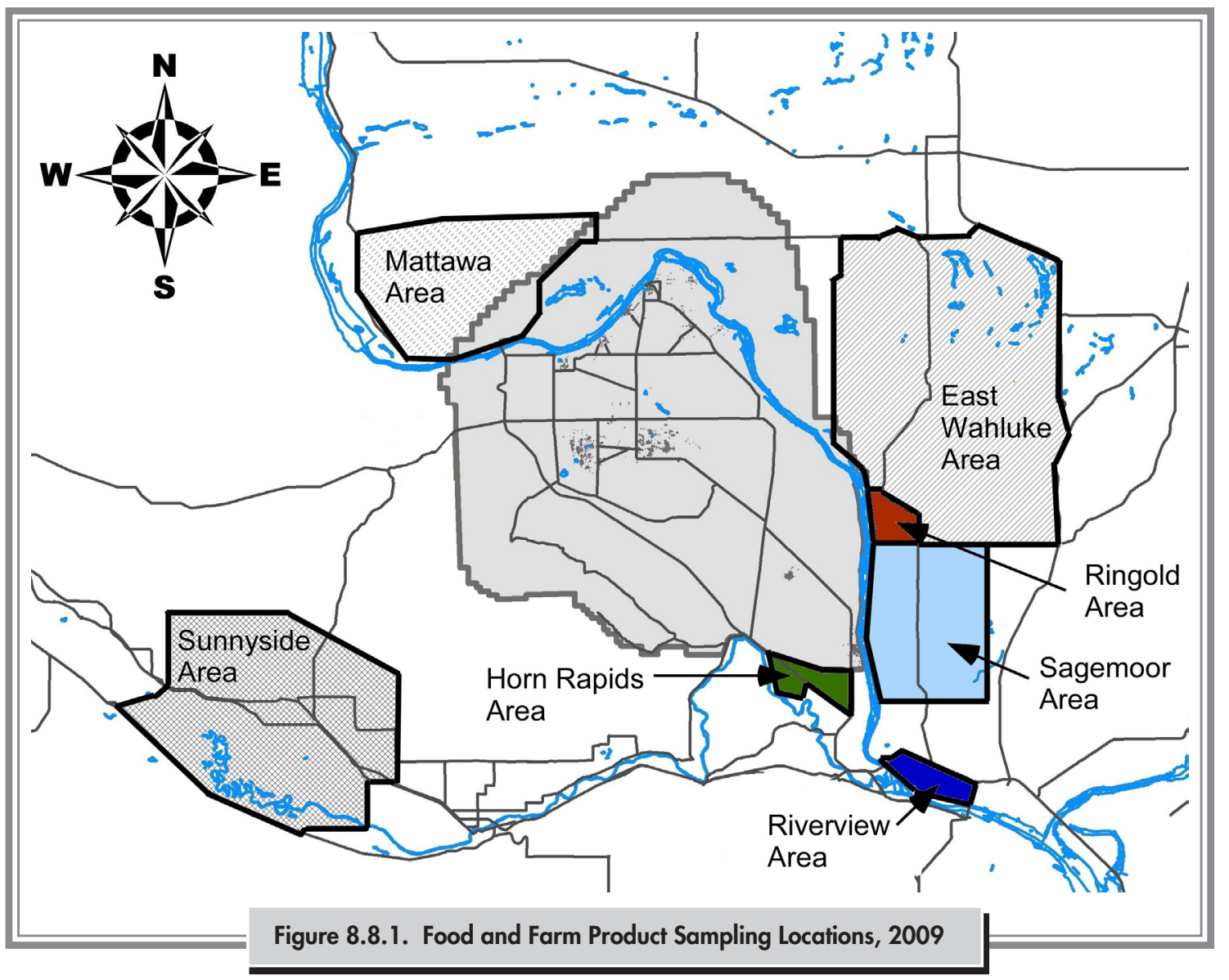

\begin{tabular}{|llc|}
\hline & \multicolumn{1}{|c|}{$\begin{array}{c}\text { Table 8.8.1. Sampling Locations and Analytes for Food and Farm Products } \\
\text { Sampled Around the Hanford Site in 2009 }\end{array}$} \\
\hline $\begin{array}{l}\text { Product } \\
\text { Alfalfa }\end{array}$ & \multicolumn{1}{c}{$\begin{array}{c}\text { Sampling Locations } \\
\text { Apples }\end{array}$} & Morn Rapids, Riverview, Sagemoor, Sunnyside \\
Leafy vegetables & Riverview, Sagemoor, Sunnyside & Gamma, ${ }^{90} \mathrm{Sr}$ \\
$\begin{array}{l}\text { Milk } \\
\text { Potatoes }\end{array}$ & East Wahluke, Sagemoor, Sunnyside & Gamma, ${ }^{90} \mathrm{Sr}$ \\
Tomatoes & East Wahluke, Horn Rapids, Riverview, Sagemoor, Sunnyside & Gamma, ${ }^{90} \mathrm{Sr}$ \\
Wine & Riverview, Sunnyside & Gamma, ${ }^{90} \mathrm{Sr}$ \\
\hline
\end{tabular}

\subsubsection{Milk}

During 2009, milk samples were obtained quarterly from multiple dairies in the East Wahluke sampling area, multiple dairies in the Sagemoor area, and one dairy in the Sunnyside sampling area. The Sagemoor and East Wahluke sampling areas are located near the Hanford Site perimeter and potentially could be affected by airborne contaminants from the site. The Sunnyside area is a reference location generally upwind of the Hanford Site. If milk was obtained from more than one dairy within a sampling area, the milk samples were combined and the sample (composite) was analyzed. All samples were analyzed for gamma-emitting radionuclides, tritium, and strontium-90. Milk sampling was conducted 
because Hanford Site-produced radionuclides have the potential to move through the air-pasture-cow-milk or waterpasture-cow-milk food chains to humans. In recent years, levels of Hanford Site-produced radiological contaminants in milk samples have diminished, and concentrations in samples obtained from dairies downwind of the site are now similar to levels measured in samples obtained from the dairy generally upwind of the site.

Tritium - Tritium was detected in all milk samples collected in 2009. Concentrations ranged from a maximum of $99 \mathrm{pCi} / \mathrm{L}(3.7 \mathrm{~Bq} / \mathrm{L})$ in a Sagemoor area sample to $16 \mathrm{pCi} / \mathrm{L}$ $(0.59 \mathrm{~Bq} / \mathrm{L})$ in an East Wahluke area sample. Annual average concentrations for the three sampling areas were $66 \mathrm{pCi} / \mathrm{L}(2.4 \mathrm{~Bq} / \mathrm{L})$ for Sagemoor $(\mathrm{n}=4) ; 30 \mathrm{pCi} / \mathrm{L}$ $(1.1 \mathrm{~Bq} / \mathrm{L})$ for East Wahluke $(\mathrm{n}=4)$; and $25 \mathrm{pCi} / \mathrm{L}$ $(0.93 \mathrm{~Bq} / \mathrm{L})$ for Sunnyside $(\mathrm{n}=4)$. These concentrations are consistent with concentrations historically measured in these areas. The unusual concentration reporting level for tritium in milk is an annual average of $54,000 \mathrm{pCi} / \mathrm{L}$ $(2,000 \mathrm{~Bq} / \mathrm{L})$.

Potassium-40 - Potassium-40 was detected in all milk samples collected in 2009. Potassium-40 is a naturally occurring radionuclide found in soil and in fertilizers applied to soil. It is the predominant radionuclide in foods and human tissues (Eisenbud 1987). Concentrations ranged between $1,300 \mathrm{pCi} / \mathrm{L}(48 \mathrm{~Bq} / \mathrm{L})$ and 1,600 pCi/L (59 Bq/L).

Strontium-90 - Strontium-90 was not measured at detectable concentrations in any milk samples collected in 2009. The nominal analytical detection limit for strontium-90 in milk was $1.4 \mathrm{pCi} / \mathrm{L}(0.05 \mathrm{~Bq} / \mathrm{L})$, or 19 times below the unusual concentration reporting level for strontium-90 in milk (27 pCi/L [1.0 Bq/L]).

Cesium-137 - No manmade gamma emitters were detected in milk samples collected and analyzed in 2009 (PNNL-19455, APP. 1).

\subsubsection{Fruits and Vegetables}

Apple, leafy vegetable (e.g., lettuce), potato, and tomato samples were collected from upwind and downwind sampling areas during the 2009 growing season (Figure 8.8.1). All samples were analyzed for gamma-emitting radionuclides and strontium-90. Tomato samples were also monitored for tritium (Table 8.8.1). Potassium-40 was detected in all of the fruit and vegetable samples collected. Additionally, one leafy vegetable sample had a detectable concentration of beryllium-7 (a naturally occurring radionuclide), and three leafy vegetable samples had detectable concentrations of strontium-90. The leafy vegetable sample collected in Sunnyside had the highest strontium-90 concentration $(0.011 \mathrm{pCi} / \mathrm{g}[0.41 \mathrm{mBq} / \mathrm{g}])$. This concentration is about 25 times lower than the unusual concentration reporting level for strontium-90 in leafy vegetables $(0.27 \mathrm{pCi} / \mathrm{g}$ $[10 \mathrm{mBq} / \mathrm{g}])$.

\subsubsection{Alfalfa}

Alfalfa samples were collected in the spring from commercial fields in the Horn Rapids, Riverview, Sagemoor, and Sunnyside sampling areas (Figure 8.8.1). Samples were analyzed for gamma-producing radionuclides and strontium-90 (Table 8.8.1). The only radionuclides measured with detectable concentrations were naturally occurring potassium -40 and beryllium-7. The maximum potassium- 40 concentration measured in alfalfa in 2009 was $28 \mathrm{pCi} / \mathrm{g}$ (1 Bq/g).

\subsubsection{Wine}

Red and white wine samples were obtained in November and December 2009 from two wineries near the Hanford Site and at an upwind location. The wines were produced from 2009 vintage grapes that were harvested in the fall from vineyards located in the Columbia Basin area just north of Pasco (downwind of the site), near Mattawa (site perimeter), and just east of Yakima (generally upwind of the site). Each wine was divided (split) into two samples and all samples were analyzed for gamma-emitting radionuclides and tritium (Table 8.8.1).

Cesium-137 - There were no manmade gamma emitters (including cesium-137) detected in wine samples collected and analyzed in 2009 (PNNL-16623, APP. 1).

Potassium-40 - Naturally occurring potassium-40 was measured in all wine samples collected in 2009. Concentrations in all samples ranged from 510 to $1,740 \mathrm{pCi} / \mathrm{L}$ (19 to $64 \mathrm{~Bq} / \mathrm{L})$. Potassium-40 concentrations were higher in red wines than in white wines, probably a result of the skin being included in the processing of red wines. 
Tritium - Tritium was detected at low levels in all wine samples analyzed in 2009. Concentrations in all samples ranged from 1.2 to $23 \mathrm{pCi} / \mathrm{L}(0.04$ to $0.85 \mathrm{~Bq} / \mathrm{L})$. The average concentration for all samples was $15 \mathrm{pCi} / \mathrm{L}(0.56 \mathrm{~Bq} / \mathrm{L})$. Concentrations measured in samples collected in the Yakima Area were slightly lower than concentrations measured in samples collected from the Columbia Basin Area, but the difference was less than the analytical error associated with each result. While there is no health-based standard for tritium in wine, the standard for tritium in drinking water is $20,000 \mathrm{pCi} / \mathrm{L}(740 \mathrm{~Bq} / \mathrm{L})$. 


\subsection{Soil Monitoring}

The following sections summarize soil monitoring efforts conducted in 2009 on and around the Hanford Site. Radiological monitoring of soil is conducted at a variety of locations: onsite near facilities and operations, onsite away from facilities and operations (site-wide), and offsite at perimeter and distant locations and in nearby communities. Contaminant concentration data are used for the following:

- Determining the effectiveness of effluent monitoring and controls within facilities

- Assessing the adequacy of containment at waste disposal sites

- Detecting and monitoring unusual conditions

- Providing information on long-term radionuclide contamination trends in soil at undisturbed locations.

Soil samples have been collected on and around the Hanford Site for more than 50 years. Consequently, a large amount of data exist that document onsite and offsite levels of manmade radionuclides in Hanford Site soils. These data provide a baseline against which unplanned releases can be compared. For further information about the purpose of soil monitoring efforts and the programs that support them, see Section 8.0 and DOE/RL-91-50, Rev. 4.

\subsubsection{Soil Monitoring Near Hanford Site Facilities and Operations}

\section{JW Wilde}

Soil samples are collected near facilities and operations to evaluate long-term trends in the environmental accumulation of radioactive materials, and to detect potential migration and deposition of facility emissions. Soil contamination can occur as the result of direct deposition from facility emissions, resuspension and movement of contaminants from radiologically contaminated surface areas, uptake of contaminants into plants whose roots contact belowground waste, or translocation of buried waste by intruding animals.

\subsubsection{Soil Sampling Near Hanford Site Facilities and Operations}

Soil samples were collected on or adjacent to waste disposal sites and from locations downwind and near or within the boundaries of operating Hanford Site facilities and remedial action sites. The number and locations of soil samples collected during 2009 are summarized in Table 8.9.1. Only

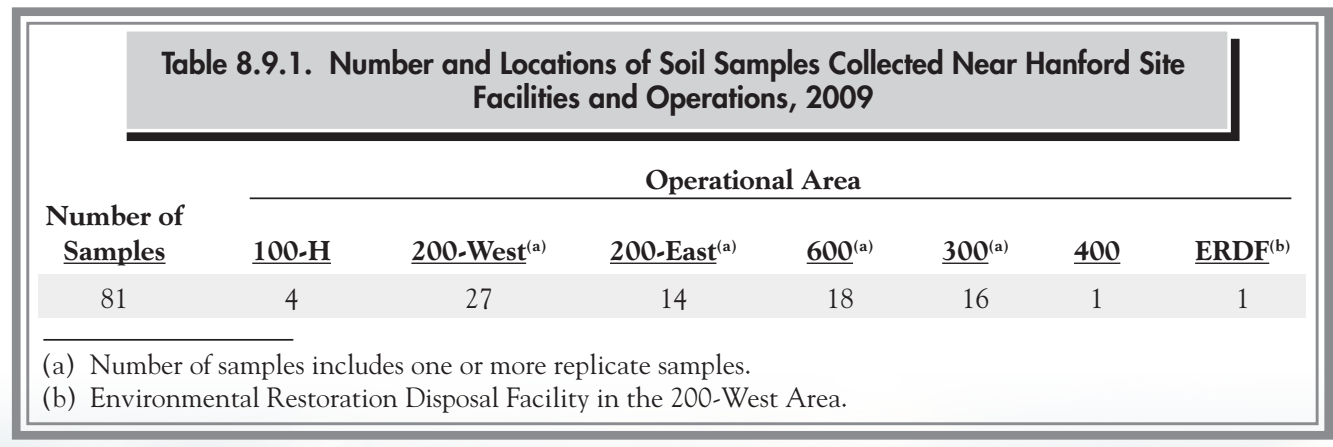


radionuclides with concentrations consistently above analytical detection limits are discussed in this section. A comprehensive presentation of the analytical data from these samples is provided in PNNL-19455, APP. 2.

Each 1-kilogram (2.2-pound) soil sample represented a composite of five plugs of soil, each 2.5 centimeters ( 1 inch) deep and 10 centimeters ( 4 inches) in diameter. Soil samples were sieved in the field to remove rocks and plant debris and then dried in a laboratory before being analyzed to remove residual moisture.

Hanford Site samples were analyzed for radionuclides expected to occur in the areas sampled (i.e., gamma-emitting radionuclides [Appendix F, Table F.1], strontium-90, uranium isotopes, and/or plutonium isotopes). The analytical results from Hanford Site samples were compared to concentrations of radionuclides measured in samples collected offsite in previous years at various sampling locations in Adams, Benton, Franklin, Grant, Walla Walla, and Yakima Counties. These comparisons were used to differentiate concentrations of Hanford Site-produced contaminants from levels resulting from natural sources and worldwide fallout.

Soil sampling results can be compared to the accessible soil (soil that is not behind security fencing) concentrations (WHC-SD-EN-TI-070) developed specifically for use on the Hanford Site. These concentration values for radionuclides were established to ensure effective dose equivalents to the public do not exceed the established limits for any reasonable scenario, such as direct exposure, inadvertent ingestion, inhalation, and consumption of foods, including animal products. The accessible soil concentration values are based on a radiation-dose estimate scenario (WHC-SD-EN-TI-070) in which an individual would have to spend 100 hours per year in direct contact with the contaminated soil. The conservatism inherent in pathway modeling assures the required degrees of protection are in place. These concentrations apply specifically to the Hanford Site with respect to onsite waste disposal operations and cleanup, decontamination, and decommissioning activities. Table 8.9.2 provides a partial listing of these values (see PNNL-19455, APP. 2 for a complete listing of concentrations).

\subsubsection{Analytical Results for Soil Samples Collected Near Hanford Site Facilities and Operations}

Some degree of variability is always associated with the collection and analysis of environmental samples. Therefore, variations in sample concentrations from year to year are expected. In general, radionuclide concentrations in soil samples collected from or adjacent to waste-disposal facilities in 2009 were higher than the concentrations in samples collected farther away, including concentrations measured offsite. The data also show, as expected, that concentrations of certain radionuclides in 2009 were higher within different operational areas when compared to concentrations measured in distant communities in previous years. Generally, the predominant radionuclides detected were activation and fission products in the 100 Areas, fission products in the 200 and 600 Areas, and uranium in the 300 and 400 Areas.

Cesium-134, cesium-137, plutonium-239/240, and uranium were detected consistently in the samples taken in 2009. Concentrations of these radionuclides were elevated near and within facility boundaries when compared to historical concentrations measured offsite at distant communities. Figure 8.9.1 shows the average concentrations of selected radionuclides in soil samples collected during 2009 and the

Table 8.9.2. Accessible Soil Concentration Limits (pCi $/ \mathrm{g}^{[\mathrm{la}]} \mathrm{dry}$ wt.) for Selected Radionuclides

$\underline{\text { Cobalt-60 }} \underline{\text { Strontium-90 }} \underline{\text { Cesium-137 }} \underline{\text { Uranium-234 Uranium-235 }} \underline{\text { Uranium-238 }} \underline{\text { Plutonium-239/240 }}$

Accessible soil ${ }^{(\mathrm{b})}$

concentration limits

(WHC-SD-EN-TI-070)

7.1

2,800

30

630

170

370

190

(a) To convert to international metric system units, multiply $\mathrm{pCi} / \mathrm{g}$ by 0.037 to obtain $\mathrm{Bq} / \mathrm{g}$.

(b) Hanford Site soil that is not behind security fences. 

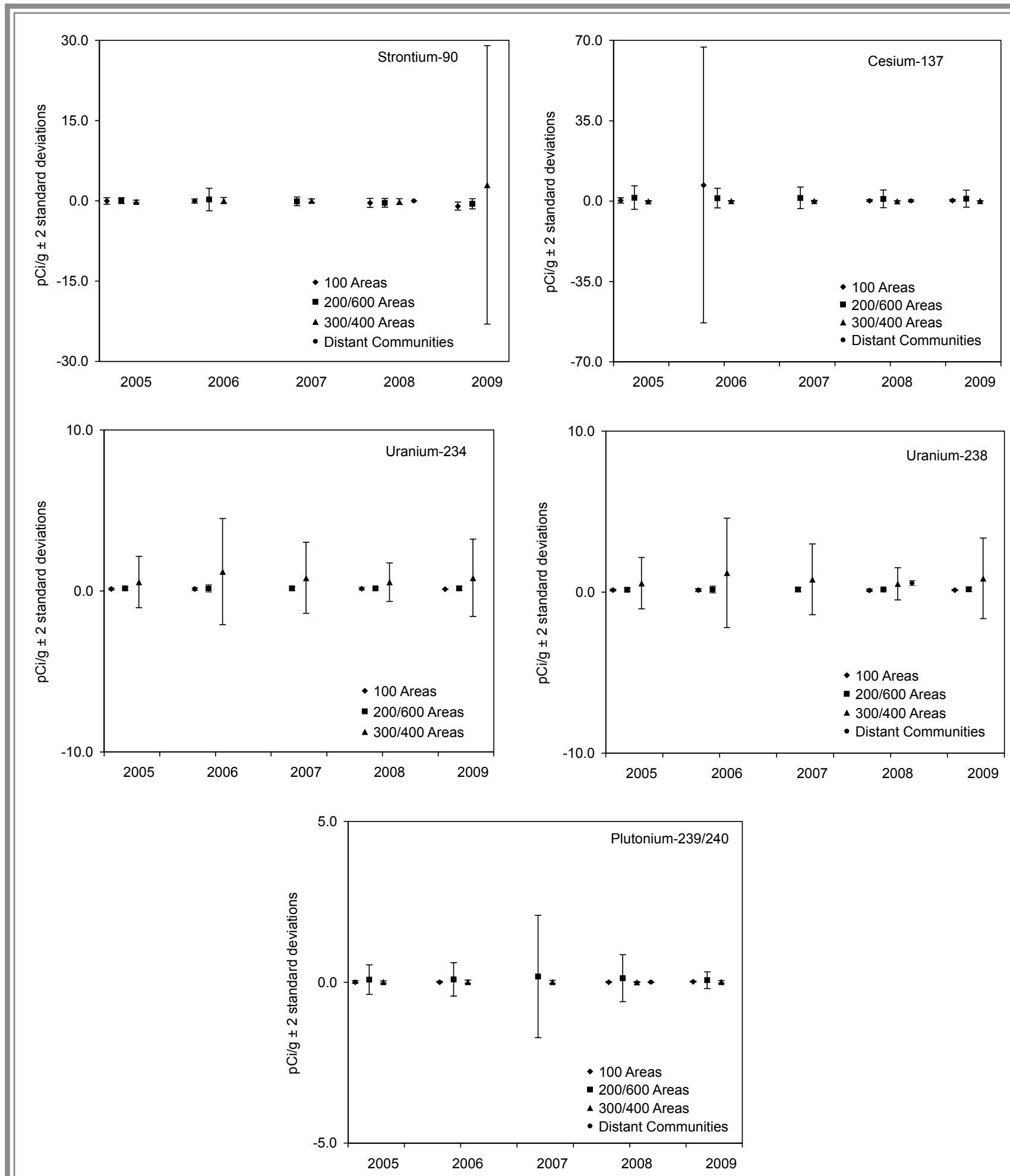

Figure 8.9.1. Average Concentrations of Selected Radionuclides in Soil Samples Collected on the Hanford Site Near Facilities and Operations, 2005 Through 2009, and Those Collected in Distant Communities, 2008.

Radionuclide concentrations below analytical detection limits are not shown. As a result of figure scale, some uncertainties (error bars) are concealed by the point symbol. 
preceding 4 years. Some individual levels demonstrate a high degree of variability, although overall trends are stable.

Table 8.9.3 provides a summary of selected analytical results for near-facility soil samples collected and analyzed in 2009. The average and maximum results are reported for six operational areas, along with comparative data for the preceding 5 years. Complete listings of radionuclide concentrations for all soil samples collected during 2009, as well as sampling location maps, are provided in PNNL-19455, APP. 2.

Soil samples collected in 2009 at locations in the 100, 200-East, 200-West, 400, and 600 Areas were comparable to previous years. Soil samples collected in the 300 Area showed concentrations of uranium-234, uranium-235, and uranium-238 that were comparable to historical data but remained higher than those measured in the 200 Areas. The higher uranium levels in the 300 Area were expected because of uranium releases to the environment during past fuel-fabrication operations in the 300 Area. Plutonium-238 and plutonium-239/240 were found at higher levels in a small number of soil samples in the 200, 600, and 300 Areas.

A single occurrence in one sample in the 300 Area showed an unusually elevated strontium-90 concentration, possibly attributable to ongoing cleanup efforts in the area.

In 2009, four soil samples were collected at the field remediation project in the $100-\mathrm{H}$ Area, and one sample was collected from near the Environmental Restoration Disposal Facility for non-routine soil sampling in support of the environmental restoration contractor projects. Analytical results from each of these locations were comparable to those observed at other near-facility sampling locations at the Hanford Site. Table 8.9.4 provides a summary of selected analytical results for samples from these sites. A complete listing of these data is provided in PNNL-19455, APP. 2.

\subsubsection{Investigations of Radioactive Contamination in Soil Near Hanford Site Facilities and Operations}

\section{SM McKinney, RC Roos, and AR Johnson}

Investigations for radioactive contamination in soil were conducted in and near operational areas to monitor the presence or movement of radioactive materials around areas of known or suspected contamination or to verify radiological conditions at specific project sites. All samples collected during investigations were field surveyed for alpha and beta-gamma radiation. Generally, the predominant radionuclides in samples from the 100 and 200 Areas have been strontium-90, cesium-137, and plutonium-239/240. Uranium-234, uranium-235, and uranium-238 have been routinely found in 300 Area samples.

Twenty-eight instances of radiological contamination in soil samples were collected during investigations in 2009. Of the 28, 18 were identified as speck contamination, and 26 of the 28 were cleaned up and disposed of onsite in licensed burial grounds; the remaining 2 were controlled in a posted area. None of the soil samples were submitted for radioisotopic analysis. The number of soil investigation contamination incidents and range of radiation dose levels in 2009 were generally within historical values (WHC-MR-0418).

Table 8.9.5 summarizes the number and general locations of soil contamination incidents investigated during 2009. Table 8.9.6 provides the number of contamination incidents investigated in 2009 and during the previous 11 years. 
Table 8.9.3. Concentrations of Selected Radionuclides (pCi/g dry wt. ${ }^{(a)}$ in Near-Facility Soil Samples, 2009 Compared to Previous Years

\begin{tabular}{|c|c|c|c|c|c|c|c|c|c|}
\hline \multirow[b]{3}{*}{$\underline{\text { Radionuclide }}$} & \multirow{3}{*}{$\begin{array}{l}\text { Hanford } \\
\text { Site Area }\end{array}$} & \multicolumn{4}{|c|}{2009} & \multicolumn{4}{|c|}{$2004-2008$} \\
\hline & & \multicolumn{2}{|c|}{ Number of } & \multirow[b]{2}{*}{$\underline{\text { Average }}^{(\mathrm{c})}$} & \multirow[b]{2}{*}{$\underline{\text { Maximum }}^{(\mathrm{d})}$} & \multicolumn{2}{|c|}{ Number of } & \multirow[b]{2}{*}{$\underline{\text { Average }}^{(\mathrm{c})}$} & \multirow[b]{2}{*}{$\underline{\text { Maximum }}^{(\mathrm{d})}$} \\
\hline & & Samples & $\underline{\text { Detections }}^{(\mathbf{b})}$ & & & Samples & $\underline{\text { Detections }}^{(\mathbf{b})}$ & & \\
\hline \multirow{4}{*}{ Cobalt-60 } & 200-East & 14 & 0 & $-1.2 \mathrm{E}-03 \pm 6.0 \mathrm{E}-03$ & $4.1 \mathrm{E}-03 \pm 6.3 \mathrm{E}-03^{(\mathrm{e})}$ & 74 & 0 & $7.2 \mathrm{E}-04 \pm 7.4 \mathrm{E}-03$ & $1.0 \mathrm{E}-02 \pm 7.8 \mathrm{E}-03^{(\mathrm{e})}$ \\
\hline & 200-West ${ }^{(f)}$ & 28 & 0 & $-6.0 \mathrm{E}-04 \pm 8.4 \mathrm{E}-03$ & $9.9 \mathrm{E}-03 \pm 7.7 \mathrm{E}-03^{(\mathrm{e})}$ & 137 & 2 & $6.5 \mathrm{E}-04 \pm 9.3 \mathrm{E}-03$ & $2.0 \mathrm{E}-02 \pm 9.1 \mathrm{E}-03$ \\
\hline & 300 & 16 & 0 & $-1.4 \mathrm{E}-03 \pm 6.2 \mathrm{E}-03$ & $4.0 \mathrm{E}-03 \pm 5.2 \mathrm{E}-03^{(\mathrm{e})}$ & 74 & 0 & $-4.5 \mathrm{E}-04 \pm 7.1 \mathrm{E}-03$ & $8.3 \mathrm{E}-03 \pm 6.3 \mathrm{E}-03^{(\mathrm{e})}$ \\
\hline & $400^{(g)}$ & 1 & 0 & $-3.4 \mathrm{E}-03 \pm 9.5 \mathrm{E}-07$ & $-3.4 \mathrm{E}-03 \pm 5.4 \mathrm{E}-03^{(\mathrm{e})}$ & 5 & 0 & $1.8 \mathrm{E}-03 \pm 4.2 \mathrm{E}-03$ & $5.2 \mathrm{E}-03 \pm 6.9 \mathrm{E}-03^{(\mathrm{e})}$ \\
\hline \multirow[t]{6}{*}{ Strontium-90 } & 100 & 4 & 0 & $-9.9 \mathrm{E}-01 \pm 7.5 \mathrm{E}-01$ & $-5.9 \mathrm{E}-01 \pm 5.9 \mathrm{E}-01^{(\mathrm{e})}$ & 75 & 4 & $-1.2 \mathrm{E}-01 \pm 6.6 \mathrm{E}-01$ & $8.3 \mathrm{E}-01 \pm 2.9 \mathrm{E}-01$ \\
\hline & 200-East & 14 & 0 & $-7.4 \mathrm{E}-01 \pm 9.3 \mathrm{E}-01$ & $1.1 \mathrm{E}-01 \pm 5.3 \mathrm{E}-01^{(\mathrm{e})}$ & 74 & 11 & $1.2 \mathrm{E}-02 \pm 8.3 \mathrm{E}-01$ & $1.3 \mathrm{E}+00 \pm 3.2 \mathrm{E}-01$ \\
\hline & 200-West ${ }^{(f)}$ & 28 & 1 & $-5.0 \mathrm{E}-01 \pm 9.4 \mathrm{E}-01$ & $6.7 \mathrm{E}-01 \pm 4.7 \mathrm{E}-01$ & 137 & 17 & $-9.5 \mathrm{E}-03 \pm 1.6 \mathrm{E}+00$ & $8.1 \mathrm{E}+00 \pm 1.6 \mathrm{E}+00$ \\
\hline & 300 & 16 & 3 & $3.2 \mathrm{E}+00 \pm 2.7 \mathrm{E}+01$ & $5.5 \mathrm{E}+01 \pm 7.1 \mathrm{E}+00$ & 74 & 2 & $-6.2 \mathrm{E}-02 \pm 4.8 \mathrm{E}-01$ & $1.0 \mathrm{E}+00 \pm 3.5 \mathrm{E}-01$ \\
\hline & $400^{(g)}$ & 1 & 0 & $4.1 \mathrm{E}-02 \pm 8.4 \mathrm{E}-06$ & $4.1 \mathrm{E}-02 \pm 3.7 \mathrm{E}-01^{(\mathrm{e})}$ & 5 & 0 & $-5.0 \mathrm{E}-02 \pm 4.4 \mathrm{E}-01$ & $2.8 \mathrm{E}-01 \pm 2.6 \mathrm{E}-01^{(\mathrm{e})}$ \\
\hline & 600 & 18 & 1 & $-4.2 \mathrm{E}-01 \pm 8.5 \mathrm{E}-01$ & $5.0 \mathrm{E}-01 \pm 4.8 \mathrm{E}-01$ & 84 & 7 & $-4.8 \mathrm{E}-02 \pm 7.2 \mathrm{E}-01$ & $1.2 \mathrm{E}+00 \pm 5.0 \mathrm{E}-01$ \\
\hline \multirow[t]{5}{*}{ Cesium-137 } & 100 & 4 & 4 & $3.2 \mathrm{E}-01 \pm 4.6 \mathrm{E}-01$ & $6.9 \mathrm{E}-01 \pm 1.2 \mathrm{E}-01$ & 75 & 74 & $2.3 \mathrm{E}+00 \pm 3.3 \mathrm{E}+01$ & $1.4 \mathrm{E}+02 \pm 2.6 \mathrm{E}+01$ \\
\hline & 200-West ${ }^{(f)}$ & 28 & 28 & $1.3 \mathrm{E}+00 \pm 2.7 \mathrm{E}+00$ & $5.4 \mathrm{E}+00 \pm 8.1 \mathrm{E}-01$ & 137 & 133 & $1.5 \mathrm{E}+00 \pm 4.2 \mathrm{E}+00$ & $1.4 \mathrm{E}+01 \pm 2.3 \mathrm{E}+00$ \\
\hline & 300 & 16 & 12 & $5.9 \mathrm{E}-02 \pm 8.9 \mathrm{E}-02$ & $1.5 \mathrm{E}-01 \pm 2.6 \mathrm{E}-02$ & 74 & 66 & $7.6 \mathrm{E}-02 \pm 1.6 \mathrm{E}-01$ & $3.6 \mathrm{E}-01 \pm 6.4 \mathrm{E}-02$ \\
\hline & $400^{(g)}$ & 1 & 1 & $3.2 \mathrm{E}-02$ & $3.2 \mathrm{E}-02 \pm 1.1 \mathrm{E}-02$ & 5 & 5 & $2.1 \mathrm{E}-02 \pm 9.6 \mathrm{E}-03$ & $2.7 \mathrm{E}-02 \pm 1.1 \mathrm{E}-02$ \\
\hline & 600 & 18 & 17 & $2.4 \mathrm{E}-01 \pm 4.5 \mathrm{E}-01$ & $8.9 \mathrm{E}-01 \pm 1.4 \mathrm{E}-01$ & 84 & 80 & $2.3 \mathrm{E}+00 \pm 2.4 \mathrm{E}+01$ & $9.4 \mathrm{E}+01 \pm 1.7 \mathrm{E}+01$ \\
\hline \multirow[t]{6}{*}{ Uranium-234 } & 100 & 4 & 4 & $1.2 \mathrm{E}-01 \pm 2.2 \mathrm{E}-02$ & $1.4 \mathrm{E}-01 \pm 4.8 \mathrm{E}-02$ & 74 & 74 & $1.3 \mathrm{E}-01 \pm 8.1 \mathrm{E}-02$ & $3.2 \mathrm{E}-01 \pm 9.9 \mathrm{E}-02$ \\
\hline & 200-East & 14 & 14 & $1.6 \mathrm{E}-01 \pm 7.4 \mathrm{E}-02$ & $2.5 \mathrm{E}-01 \pm 8.0 \mathrm{E}-02$ & 74 & 74 & $1.6 \mathrm{E}-01 \pm 1.8 \mathrm{E}-01$ & $8.4 \mathrm{E}-01 \pm 2.8 \mathrm{E}-01$ \\
\hline & 200-West ${ }^{(f)}$ & 28 & 28 & $1.9 \mathrm{E}-01 \pm 1.6 \mathrm{E}-01$ & $4.3 \mathrm{E}-01 \pm 1.2 \mathrm{E}-01$ & 137 & 137 & $1.6 \mathrm{E}-01 \pm 1.2 \mathrm{E}-01$ & $5.1 \mathrm{E}-01 \pm 1.4 \mathrm{E}-01$ \\
\hline & 300 & 16 & 16 & $8.6 \mathrm{E}-01 \pm 2.5 \mathrm{E}+00$ & $5.0 \mathrm{E}+00 \pm 1.3 \mathrm{E}+00$ & 74 & 74 & $8.7 \mathrm{E}-01 \pm 2.5 \mathrm{E}+00$ & $5.3 \mathrm{E}+00 \pm 1.4 \mathrm{E}+00$ \\
\hline & $400^{(g)}$ & 1 & 1 & $2.4 \mathrm{E}-01 \pm 8.0 \mathrm{E}-05$ & $2.4 \mathrm{E}-01 \pm 7.4 \mathrm{E}-02$ & 5 & 5 & $1.5 \mathrm{E}-01 \pm 8.3 \mathrm{E}-02$ & $2.2 \mathrm{E}-01 \pm 7.3 \mathrm{E}-02$ \\
\hline & 600 & 18 & 18 & $1.6 \mathrm{E}-01 \pm 8.1 \mathrm{E}-02$ & $2.4 \mathrm{E}-01 \pm 7.7 \mathrm{E}-02$ & 84 & 84 & $1.7 \mathrm{E}-01 \pm 1.8 \mathrm{E}-01$ & $8.4 \mathrm{E}-01 \pm 2.3 \mathrm{E}-01$ \\
\hline \multirow[t]{6}{*}{ Uranium-235 } & 100 & 4 & 2 & $9.6 \mathrm{E}-03 \pm 1.1 \mathrm{E}-02$ & $1.7 \mathrm{E}-02 \pm 1.3 \mathrm{E}-02$ & 72 & 41 & $1.1 \mathrm{E}-02 \pm 1.2 \mathrm{E}-02$ & $2.5 \mathrm{E}-02 \pm 1.7 \mathrm{E}-02$ \\
\hline & 200-East & 14 & 4 & $9.0 \mathrm{E}-03 \pm 9.1 \mathrm{E}-03$ & $1.7 \mathrm{E}-02 \pm 1.4 \mathrm{E}-02$ & 74 & 40 & $1.3 \mathrm{E}-02 \pm 1.2 \mathrm{E}-02$ & $3.3 \mathrm{E}-02 \pm 1.9 \mathrm{E}-02$ \\
\hline & 200-West ${ }^{(f)}$ & 28 & 20 & $2.1 \mathrm{E}-02 \pm 2.4 \mathrm{E}-02$ & $5.1 \mathrm{E}-02 \pm 2.7 \mathrm{E}-02$ & 137 & 68 & $1.3 \mathrm{E}-02 \pm 1.7 \mathrm{E}-02$ & $5.4 \mathrm{E}-02 \pm 2.4 \mathrm{E}-02$ \\
\hline & 300 & 16 & 11 & $5.3 \mathrm{E}-02 \pm 1.3 \mathrm{E}-01$ & $2.7 \mathrm{E}-01 \pm 8.6 \mathrm{E}-02$ & 74 & 59 & $5.7 \mathrm{E}-02 \pm 1.5 \mathrm{E}-01$ & $3.5 \mathrm{E}-01 \pm 1.0 \mathrm{E}-01$ \\
\hline & $400^{(g)}$ & 1 & 1 & $1.8 \mathrm{E}-02$ & $1.8 \mathrm{E}-02 \pm 1.5 \mathrm{E}-02$ & 5 & 2 & $1.3 \mathrm{E}-02 \pm 1.6 \mathrm{E}-02$ & $2.9 \mathrm{E}-02 \pm 1.8 \mathrm{E}-02$ \\
\hline & 600 & 18 & 7 & $1.2 \mathrm{E}-02 \pm 1.1 \mathrm{E}-02$ & $2.1 \mathrm{E}-02 \pm 1.6 \mathrm{E}-02$ & 84 & 47 & $1.5 \mathrm{E}-02 \pm 1.9 \mathrm{E}-02$ & $5.5 \mathrm{E}-02 \pm 2.6 \mathrm{E}-02$ \\
\hline
\end{tabular}


Table 8.9.3. (contd)

2009

\begin{tabular}{|c|c|c|c|c|}
\hline \multirow[b]{2}{*}{ Radionuclide } & \multirow{2}{*}{$\begin{array}{l}\text { Hanford } \\
\text { Site Area }\end{array}$} & \multicolumn{2}{|c|}{ Number of } & \multirow[b]{2}{*}{$\underline{\text { Average }}^{(\mathrm{c})}$} \\
\hline & & Samples & Detections $^{(\mathbf{b})}$ & \\
\hline \multirow[t]{6}{*}{ Plutonium-238 } & 100 & 4 & 0 & $7.7 \mathrm{E}-03 \pm 2.2 \mathrm{E}-02$ \\
\hline & 200-East & 14 & 0 & $2.5 \mathrm{E}-03 \pm 4.4 \mathrm{E}-02$ \\
\hline & 200-West ${ }^{(f)}$ & 28 & 1 & $9.5 \mathrm{E}-03 \pm 3.1 \mathrm{E}-02$ \\
\hline & 300 & 16 & 0 & $-3.1 \mathrm{E}-03 \pm 1.5 \mathrm{E}-02$ \\
\hline & $400^{(g)}$ & 1 & 0 & $1.0 \mathrm{E}-02 \pm 2.8 \mathrm{E}-06$ \\
\hline & 600 & 18 & 0 & $-6.3 \mathrm{E}-04 \pm 1.5 \mathrm{E}-02$ \\
\hline \multirow[t]{6}{*}{ Uranium-238 } & 100 & 4 & 4 & $1.3 \mathrm{E}-01 \pm 3.7 \mathrm{E}-02$ \\
\hline & 200-East & 14 & 14 & $1.7 \mathrm{E}-01 \pm 9.0 \mathrm{E}-02$ \\
\hline & 200-West ${ }^{(f)}$ & 28 & 28 & $1.8 \mathrm{E}-01 \pm 1.8 \mathrm{E}-01$ \\
\hline & 300 & 16 & 16 & $9.1 \mathrm{E}-01 \pm 2.5 \mathrm{E}+00$ \\
\hline & $400^{(g)}$ & 1 & 1 & $2.0 \mathrm{E}-01 \pm 8.1 \mathrm{E}-05$ \\
\hline & 600 & 18 & 18 & $1.7 \mathrm{E}-01 \pm 7.0 \mathrm{E}-02$ \\
\hline \multirow[t]{6}{*}{ Plutonium-239/240 } & 100 & 4 & 3 & $2.2 \mathrm{E}-02 \pm 1.4 \mathrm{E}-02$ \\
\hline & 200-East & 14 & 4 & $1.7 \mathrm{E}-02 \pm 5.0 \mathrm{E}-02$ \\
\hline & 200-West ${ }^{(f)}$ & 28 & 19 & $1.0 \mathrm{E}-01 \pm 3.4 \mathrm{E}-01$ \\
\hline & 300 & 16 & 7 & $1.4 \mathrm{E}-02 \pm 3.8 \mathrm{E}-02$ \\
\hline & $400^{(g)}$ & 1 & 0 & $1.7 \mathrm{E}-03 \pm 4.7 \mathrm{E}-07$ \\
\hline & 600 & 18 & 9 & $4.7 \mathrm{E}-02+1.6 \mathrm{E}-01$ \\
\hline
\end{tabular}

$\underline{\text { Maximum }}^{(\mathrm{d})}$

$2.0 \mathrm{E}-02 \pm 2.1 \mathrm{E}-02^{(\mathrm{e})}$

$3.2 \mathrm{E}-02 \pm 4.0 \mathrm{E}-02^{(\mathrm{e})}$

$5.7 \mathrm{E}-02 \pm 3.6 \mathrm{E}-02$

$8.5 \mathrm{E}-03+1.0 \mathrm{E}-02^{(\mathrm{e})}$

$1.0 \mathrm{E}-02 \pm 1.3 \mathrm{E}-02^{(\mathrm{e})}$

$9.4 \mathrm{E}-03 \pm 4.4 \mathrm{E}-02^{(\mathrm{e})}$

$1.6 \mathrm{E}-01 \pm 5.4 \mathrm{E}-02$

$2.4 \mathrm{E}-01 \pm 7.7 \mathrm{E}-02$

$4.5 \mathrm{E}-01 \pm 1.3 \mathrm{E}-01$

$4.9 \mathrm{E}+00 \pm 1.3 \mathrm{E}+00$

$2.0 \mathrm{E}-01 \pm 6.4 \mathrm{E}-02$

$2.8 \mathrm{E}-01 \pm 8.7 \mathrm{E}-02$

$2.6 \mathrm{E}-02 \pm 1.8 \mathrm{E}-02$

$9.7 \mathrm{E}-02 \pm 3.9 \mathrm{E}-02$

$8.4 \mathrm{E}-01 \pm 2.3 \mathrm{E}-01$

$7.6 \mathrm{E}-02 \pm 2.8 \mathrm{E}-02$

$1.7 \mathrm{E}-03 \pm 3.4 \mathrm{E}-03^{(\mathrm{e})}$

$3.0 \mathrm{E}-01 \pm 8.1 \mathrm{E}-02$
$2004-2008$

\begin{tabular}{|c|c|c|c|}
\hline \multicolumn{2}{|c|}{ Number of } & \multirow[b]{2}{*}{$\underline{\text { Average }}^{(\mathrm{c})}$} & \multirow[b]{2}{*}{$\underline{\text { Maximum }}^{(\mathrm{d})}$} \\
\hline Samples & $\underline{\text { Detections }}^{(\mathrm{b})}$ & & \\
\hline 75 & 0 & $-9.6 \mathrm{E}-04 \pm 3.4 \mathrm{E}-02$ & $3.9 \mathrm{E}-02 \pm 3.9 \mathrm{E}-02^{(\mathrm{e})}$ \\
\hline 74 & 2 & $4.5 \mathrm{E}-03 \pm 4.3 \mathrm{E}-02$ & $1.2 \mathrm{E}-01 \pm 5.5 \mathrm{E}-02$ \\
\hline 137 & 9 & $1.3 \mathrm{E}-02 \pm 6.0 \mathrm{E}-02$ & $2.1 \mathrm{E}-01 \pm 5.9 \mathrm{E}-02$ \\
\hline 74 & 2 & $5.1 \mathrm{E}-03 \pm 4.3 \mathrm{E}-02$ & $1.6 \mathrm{E}-01 \pm 6.1 \mathrm{E}-02$ \\
\hline 5 & 0 & $-4.0 \mathrm{E}-04 \pm 2.7 \mathrm{E}-02$ & $1.1 \mathrm{E}-02 \pm 2.1 \mathrm{E}-02^{(\mathrm{e})}$ \\
\hline 84 & 4 & $1.8 \mathrm{E}-02 \pm 1.8 \mathrm{E}-01$ & $7.7 \mathrm{E}-01 \pm 2.2 \mathrm{E}-01$ \\
\hline 75 & 75 & $1.3 \mathrm{E}-01 \pm 7.3 \mathrm{E}-02$ & $2.9 \mathrm{E}-01 \pm 9.3 \mathrm{E}-02$ \\
\hline 74 & 74 & $1.6 \mathrm{E}-01 \pm 1.6 \mathrm{E}-01$ & $7.7 \mathrm{E}-01 \pm 2.6 \mathrm{E}-01$ \\
\hline 137 & 137 & $1.6 \mathrm{E}-01 \pm 1.2 \mathrm{E}-01$ & $5.3 \mathrm{E}-01 \pm 1.5 \mathrm{E}-01$ \\
\hline 74 & 74 & $8.6 \mathrm{E}-01 \pm 2.5 \mathrm{E}+00$ & $5.3 \mathrm{E}+00 \pm 1.4 \mathrm{E}+00$ \\
\hline 5 & 5 & $1.4 \mathrm{E}-01 \pm 7.3 \mathrm{E}-02$ & $2.1 \mathrm{E}-01 \pm 6.9 \mathrm{E}-02$ \\
\hline 84 & 84 & $1.7 \mathrm{E}-01 \pm 1.4 \mathrm{E}-01$ & $6.8 \mathrm{E}-01 \pm 1.9 \mathrm{E}-01$ \\
\hline 75 & 15 & $2.6 \mathrm{E}-02 \pm 2.5 \mathrm{E}-01$ & $1.1 \mathrm{E}+00 \pm 3.0 \mathrm{E}-01$ \\
\hline 74 & 20 & $1.1 \mathrm{E}-02 \pm 2.4 \mathrm{E}-02$ & $4.6 \mathrm{E}-02 \pm 2.3 \mathrm{E}-02$ \\
\hline 137 & 106 & $2.2 \mathrm{E}-01 \pm 1.4 \mathrm{E}+00$ & $7.3 \mathrm{E}+00 \pm 1.9 \mathrm{E}+00$ \\
\hline 74 & 26 & $1.7 \mathrm{E}-02 \pm 4.8 \mathrm{E}-02$ & $1.2 \mathrm{E}-01 \pm 4.3 \mathrm{E}-02$ \\
\hline 5 & 0 & $2.8 \mathrm{E}-03 \pm 2.3 \mathrm{E}-03$ & $4.7 \mathrm{E}-03 \pm 9.5 \mathrm{E}-03^{(\mathrm{e})}$ \\
\hline 84 & 49 & $2.0 \mathrm{E}-01 \pm 2.6 \mathrm{E}+00$ & $1.2 \mathrm{E}+01 \pm 3.1 \mathrm{E}+00$ \\
\hline
\end{tabular}

(a) $1 \mathrm{pCi}=0.037 \mathrm{~Bq}$

(b) Number of samples with measurable concentrations of contaminant.

(c) Average \pm two standard deviations of all samples analyzed.

(d) Maximum \pm analytical uncertainty.

(e) Maximum value reported is a non-detect.

(f) Includes one sample collected at the Environmental Restoration Disposal Facility.

(g) Average cannot be calculated from a single sample. 
Table 8.9.4. Radionuclide Concentrations (pCi/g $\mathrm{g}^{[a]}$ dry wt.) (b) $^{(i)}$ Environmental Restoration Contractor Field Remediation Projects' Soil Samples, 2009

\begin{tabular}{|c|c|c|c|c|c|c|c|c|}
\hline$\underline{\text { Site }}$ & $\begin{array}{c}\text { Sample } \\
\text { Location }^{(\mathrm{c})}\end{array}$ & $\begin{array}{l}\text { Sample } \\
\text { Date }\end{array}$ & Cobalt -60 & $\underline{\text { Strontium-90 }}$ & Cesium-137 & Uranium-234 & $\underline{\text { Uranium-238 }}$ & Plutonium-239/240 \\
\hline \multirow[t]{4}{*}{$100-\mathrm{H}$} & D152 & 03/27/09 & $-2.1 \mathrm{E}-03 \pm 8.5 \mathrm{E}-03$ & $-8.9 \mathrm{E}-01 \pm 8.9 \mathrm{E}-01$ & $2.8 \mathrm{E}-01 \pm 5.5 \mathrm{E}-02$ & $1.1 \mathrm{E}-01 \pm 4.2 \mathrm{E}-02$ & $1.2 \mathrm{E}-01 \pm 4.4 \mathrm{E}-02$ & $2.6 \mathrm{E}-02 \pm 1.8 \mathrm{E}-02$ \\
\hline & D176 & 03/27/09 & $2.4 \mathrm{E}-03 \pm 8.9 \mathrm{E}-03$ & $-8.7 \mathrm{E}-01 \pm 8.7 \mathrm{E}-01$ & $6.9 \mathrm{E}-01 \pm 1.2 \mathrm{E}-01$ & $1.3 \mathrm{E}-01 \pm 4.7 \mathrm{E}-02$ & $1.1 \mathrm{E}-01 \pm 4.2 \mathrm{E}-02$ & $2.6 \mathrm{E}-02 \pm 1.6 \mathrm{E}-02$ \\
\hline & D177 & $03 / 27 / 09$ & $2.5 \mathrm{E}-04 \pm 2.5 \mathrm{E}-03$ & $-1.6 \mathrm{E}+00 \pm 1.6 \mathrm{E}+00$ & $2.1 \mathrm{E}-01 \pm 4.0 \mathrm{E}-02$ & $1.2 \mathrm{E}-01 \pm 4.4 \mathrm{E}-02$ & $1.3 \mathrm{E}-01 \pm 4.7 \mathrm{E}-02$ & $1.0 \mathrm{E}-02 \pm 1.1 \mathrm{E}-02$ \\
\hline & D178 & $03 / 27 / 09$ & $8.6 \mathrm{E}-03 \pm 8.3 \mathrm{E}-03$ & $-5.9 \mathrm{E}-01 \pm 5.9 \mathrm{E}-01$ & $8.6 \mathrm{E}-02 \pm 2.3 \mathrm{E}-02$ & $1.4 \mathrm{E}-01 \pm 4.8 \mathrm{E}-02$ & $1.6 \mathrm{E}-01 \pm 5.4 \mathrm{E}-02$ & $2.6 \mathrm{E}-02 \pm 1.6 \mathrm{E}-02$ \\
\hline ERDF & D146 & 07/29/09 & $-2.9 \mathrm{E}-03 \pm 7.5 \mathrm{E}-03$ & $-1.6 \mathrm{E}+00 \pm 1.6 \mathrm{E}+00$ & $1.6 \mathrm{E}-02 \pm 9.9 \mathrm{E}-03$ & $1.9 \mathrm{E}-01 \pm 6.7 \mathrm{E}-02$ & $1.6 \mathrm{E}-01 \pm 5.8 \mathrm{E}-02$ & $1.8 \mathrm{E}-03 \pm 1.8 \mathrm{E}-02$ \\
\hline
\end{tabular}

Accessible soil

concentration $^{(d)}$

7.1

2,800

30

630

370

190
(a) $1 \mathrm{pCi}=0.037 \mathrm{~Bq}$
(b) \pm total analytical uncertainty.
(c) Sampling location code. See PNNL-19455, APP. 2.
(d) Hanford Site soil that is not behind security fences (WHC-SD-EN-TI-070).
ERDF $=$ Environmental Restoration Disposal Facility (200-West Area). 


\begin{tabular}{|lc|}
\hline \multicolumn{2}{|c|}{ Table 8.9.5. Number and Locations of Soil } \\
Contamination Incidents Investigated Near \\
Hanford Site Facilities and Operations, 2009
\end{tabular}

\begin{tabular}{|c|c|c|c|}
\hline \multicolumn{4}{|c|}{$\begin{array}{l}\text { Table 8.9.6. Annual Number of Soil Contamination } \\
\text { Incidents Investigated Near Hanford Site Facilities } \\
\text { and Operations, 1998 Through } 2009\end{array}$} \\
\hline Year & $\begin{array}{l}\text { Number of } \\
\text { Incidents }\end{array}$ & Year & $\begin{array}{c}\text { Number of } \\
\text { Incidents }\end{array}$ \\
\hline 1998 & 41 & 2004 & 19 \\
\hline 1999 & 42 & 2005 & 20 \\
\hline 2000 & 25 & 2006 & 25 \\
\hline 2001 & 20 & 2007 & 17 \\
\hline 2002 & 22 & 2008 & 16 \\
\hline 2003 & 30 & 2009 & 28 \\
\hline
\end{tabular}

\subsubsection{Soil Monitoring at Hanford Site-Wide and Offsite Locations}

\section{BG Fritz}

Soil monitoring provides information on long-term contamination trends and baseline environmental radionuclide activities at undisturbed locations both on and off the Hanford Site (DOE/RL-91-50, Rev 4.). Soil samples, collected on and around the Hanford Site for more than 50 years, have been added to a large database documenting onsite and offsite levels of manmade radionuclides in soil at specific locations. This database contains baseline data against which data from unplanned contaminant releases from the Hanford Site can be compared. Soil samples are collected every 3 to 5 years, and were last collected in 2008 (PNNL-18427). 


\subsection{Contaminant Monitoring of Plant and Animal Communities}

Vegetation, fish, and wildlife monitoring conducted on and around the Hanford Site in 2009 are summarized in the following sections. Included are discussions on surveys and monitoring of Hanford Site plant populations, monitoring contaminants in perennial vegetation growing near facilities and operations, control of contaminated or unwanted vegetation, and fish and wildlife monitoring.

Plant populations and habitats that occur on the Hanford Site are surveyed and monitored to assess the abundance, vigor or condition, and distribution of populations and species. These data can be integrated with contaminant monitoring results and used to help characterize potential risks or impacts to biota. Vegetation near onsite facilities and operations is monitored for radiation to determine the effectiveness of effluent monitoring and controls within facilities, assess the adequacy of containment at waste disposal sites, and detect and monitor unusual conditions. Site-wide and offsite vegetation samples are analyzed for information on atmospheric deposition of contaminants in uncultivated areas offsite and around operational areas onsite. These data provide a baseline against which unplanned releases can be compared. Vegetation management activities help prevent, limit, or remove contaminated plants or undesirable plant species. For further information about these monitoring and control efforts, the programs that support them, and their purposes, see Section 8.0 in this report or DOE/RL-91-50, Rev. 4.

Fish and wildlife on and around the Hanford Site are monitored for site-produced contaminants. Monitoring various biota for uptake and exposure to radionuclides both near and distant from Hanford Site operations continues to ensure that consumption of fish and wildlife obtained from the site environs does not pose a threat to humans. Monitoring also provides long-term contamination trends in selected ecosystem components. Fish and wildlife sampled and analyzed during 2009 for radioactive constituents included Canada geese (Branta canadensis) and whitefish (Prosopium williamsoni). The monitored species provide a potential pathway for offsite human consumption.

\subsubsection{Vegetation Monitoring Near Hanford Site Facilities and Operations}

\section{JW Wilde}

Researchers collected vegetation samples on or adjacent to Hanford Site waste disposal sites and from locations downwind and near or within the boundaries of operating facilities and remedial action sites. Samples were collected to evaluate long-term trends in environmental accumulation and potential migration of radioactive material. Contamination in vegetation can occur as the result of surface deposition of radioactive materials from other radiologically contaminated sources or by absorption of radionuclides by the roots of vegetation growing on or near former waste disposal sites.

The number and location of vegetation samples collected near facilities and operations during 2009 are summarized in Table 8.10.1. Only those radionuclides with concentrations consistently above analytical detection limits are presented in this section. A comprehensive presentation of the analytical data from these samples is in PNNL-19455, APP. 2.

\subsubsection{Vegetation Sampling Near Hanford Site Facilities and Operations}

Each sample (approximately 500 grams [17.6 ounces]) consisted of new-growth leaf cuttings taken from the available 


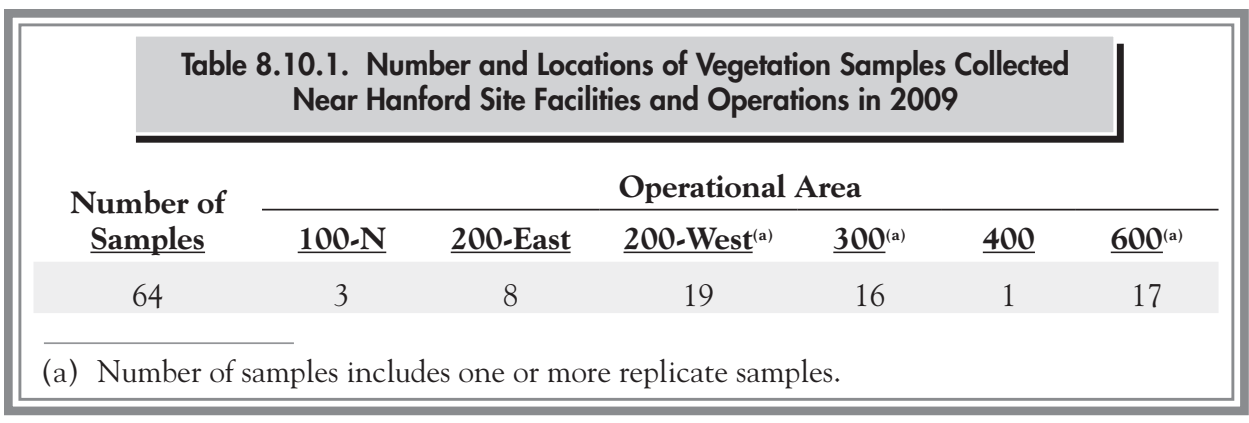

brushy, deep-rooted species (e.g., sagebrush and/or rabbitbrush) at a sampling location. Often, the sample consisted of a composite of several similar members of the samplingsite plant community to avoid decimation of any individual plant through overharvesting. Vegetation samples were dried before analysis, and analytical results were reported on a dry weight basis.

Samples were analyzed for the radionuclides expected to occur in the areas sampled (i.e., gamma-emitting radionuclides [cobalt-60 and cesium-137], strontium-90, uranium isotopes, and/or plutonium isotopes). Selected analytical results were compared to concentrations in samples collected during 2004 by Pacific Northwest National Laboratory personnel at offsite sampling locations in Yakima, Benton, and Franklin Counties (PNNL-15222). Comparisons can be used to determine the differences between contributions from site operations and remedial action sites and contributions from natural sources and worldwide radioactive fallout.

\subsubsection{Analytical Results for Vegetation Samples Collected Near Hanford Site Facilities and Operations}

Some degree of variability is always associated with collecting and analyzing environmental samples. Therefore, variations in sample concentrations from year to year are expected. In general, radionuclide concentrations in vegetation samples collected from, or adjacent to, waste disposal facilities in 2009 were higher than concentrations in samples collected farther away, including concentrations measured offsite. Generally, the predominant radionuclides were activation and fission products in the 100 Areas, fission products in the 200 and 600 Areas, and uranium in the 300 and 400 Areas.
Uranium was detected consistently; strontium-90, cesium-137, plutonium-238, and plutonium-239/240 were detected occasionally in samples taken in 2009. Concentrations of these radionuclides were elevated near and within facility boundaries compared to historic concentrations measured at distant communities. Figure 8.10.1 shows the average concentrations of selected radionuclides in vegetation samples collected near Hanford Site facilities and operations during 2009 and the preceding 4 years, as well as results for 2008 at distant communities. These results demonstrate a high degree of variability in concentrations.

Table 8.10.2 provides a summary of selected radionuclides detected in vegetation samples collected and analyzed in 2009. The average and maximum results are reported for the six primary waste facility/operational areas of interest, along with comparative data for the preceding 5 years. A complete list of 2009 radionuclide concentrations, as well as sampling location maps, are provided in PNNL-19455, APP. 2.

Vegetation samples collected in 2009 at locations in the 100-N, 200-East, 200-West, 400, and 600 Areas were comparable to those collected in previous years. Vegetation samples collected in the 300 Area showed concentrations of uranium-234 and uranium-235 that were comparable to historical data and higher than those measured in the 100 and 200 Areas. The higher uranium levels were expected due to uranium releases to the environment during past fuel-fabrication operations in the 300 Area. Plutonium-238 and plutonium-239/240 were detected at higher levels in a small number of vegetation samples from the 200-West, 600, and 300 Areas. One sample from the 200-West Area showed elevated uranium-234 concentrations over historical levels. These elevations may be a result of facility operations in the area. 

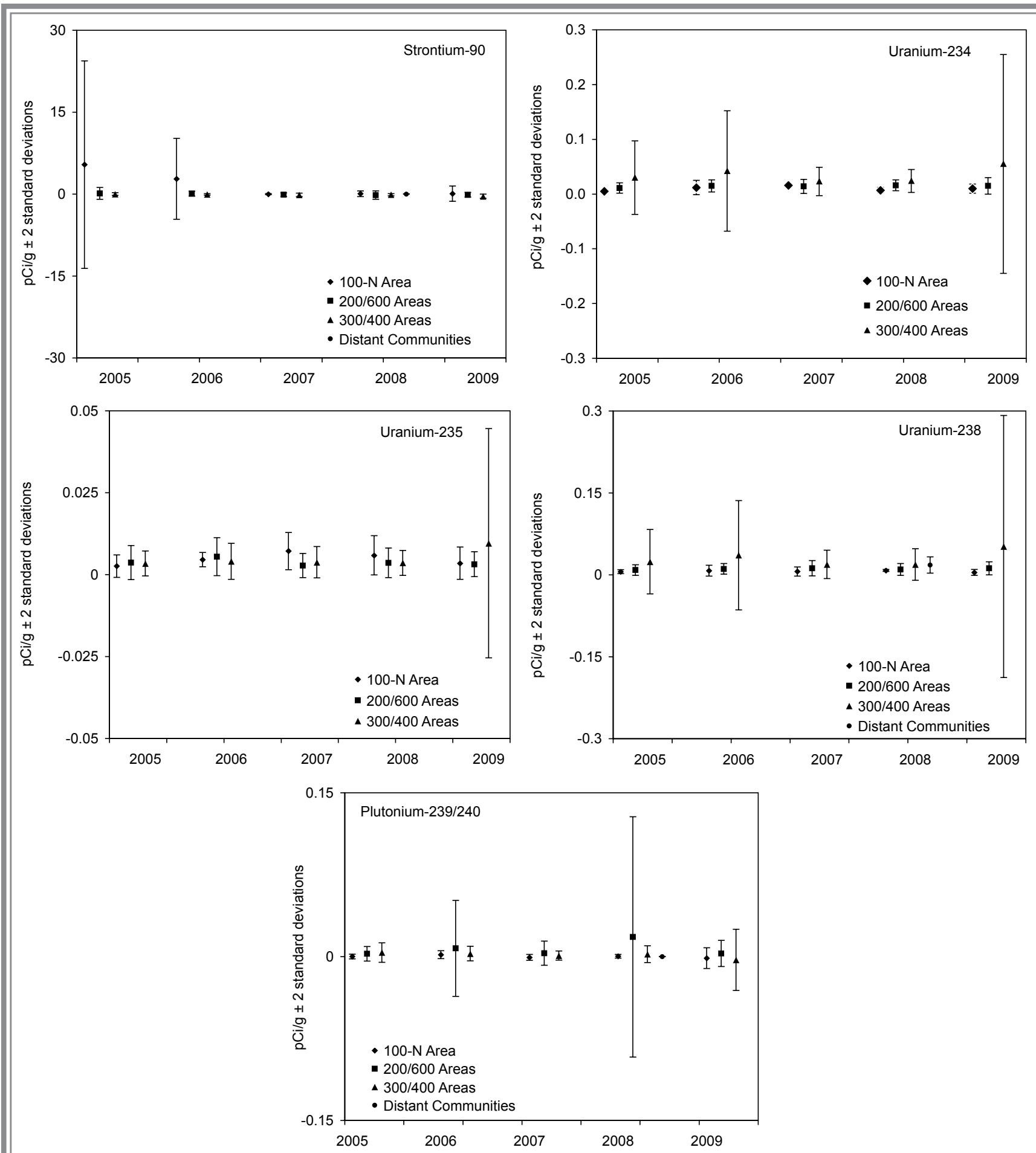

Figure 8.10.1. Average Concentrations of Selected Radionuclides in Vegetation Samples Collected Near Hanford Site Facilities and Operations, 2005 Through 2009, and Those Collected in Distant Communities, 2008. Radionuclide concentrations below analytical detection limits are not shown. As a result of figure scale, some uncertainties (error bars) are concealed by the point symbol. 
Table 8.10.2. Concentrations of Selected Radionuclides (pCi/g dry wt.) (a) in Near-Facility Vegetation Samples, 2009 Compared to Previous Years

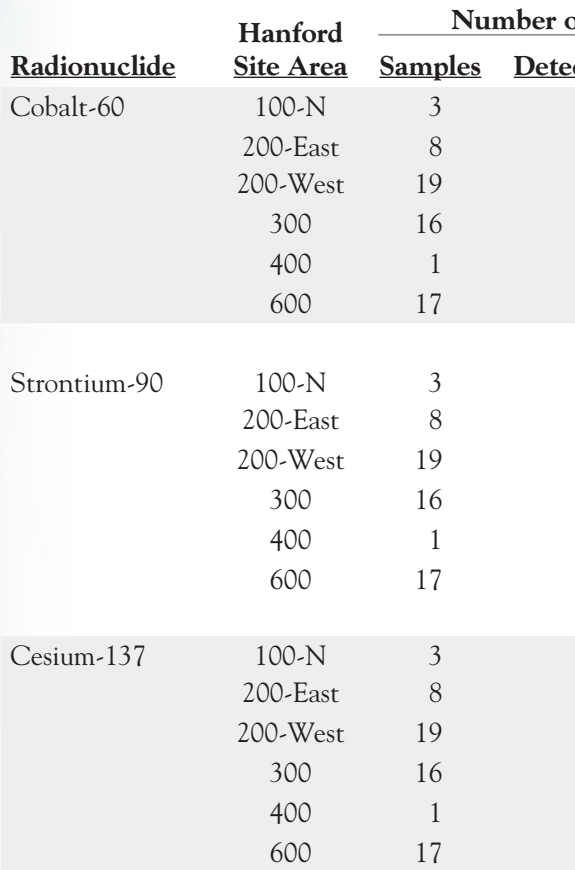

$\begin{array}{cc}\text { Uranium-234 } & 100-\mathrm{N} \\ 200-\text {-East } \\ \text { 200-West } \\ 300 \\ 400 \\ 600\end{array}$

$\begin{array}{ccc}\text { Uranium-235 } & \text { 100-N } & 3 \\ & \text { 200-East } & 8 \\ \text { 200-West } & 19 \\ 300 & 16 \\ 400 & 1 \\ 600 & 17\end{array}$

\section{9}

\section{Average $^{(\mathrm{c})}$}

$2.0 \mathrm{E}-02 \pm 2.9 \mathrm{E}-02$

$4.4 \mathrm{E}-03 \pm 3.9 \mathrm{E}-02$

$-7.3 \mathrm{E}-03 \pm 7.2 \mathrm{E}-02$

$-2.4 \mathrm{E}-03 \pm 7.1 \mathrm{E}-02$ $2.5 \mathrm{E}-02$

$-6.3 \mathrm{E}-03 \pm 7.2 \mathrm{E}-02$

$9.7 \mathrm{E}-02 \pm 1.4 \mathrm{E}+00$

$-6.2 \mathrm{E}-02 \pm 3.3 \mathrm{E}-01$

$-2.2 \mathrm{E}-01 \pm 3.7 \mathrm{E}-01$

$-4.0 \mathrm{E}-01 \pm 4.0 \mathrm{E}-01$

$-3.1 \mathrm{E}-01 \pm 6.5 \mathrm{E}-05$

$-2.7 \mathrm{E}-02 \pm 4.2 \mathrm{E}-01$

\section{$3.8 \mathrm{E}-03 \pm 2.0 \mathrm{E}-02$}

$2.0 \mathrm{E}-02+7.0 \mathrm{E}-02$

$4.9 \mathrm{E}-02 \pm 8.0 \mathrm{E}-02$

$-8.4 \mathrm{E}-03 \pm 6.4 \mathrm{E}-02$

$-4.6 \mathrm{E}-02$

$4.7 \mathrm{E}-03 \pm 1.3 \mathrm{E}-01$

$1.0 \mathrm{E}-02 \pm 8.3 \mathrm{E}-03$

$1.3 \mathrm{E}-02 \pm 1.1 \mathrm{E}-02$

$1.8 \mathrm{E}-02+1.6 \mathrm{E}-02$

$5.7 \mathrm{E}-02 \pm 2.1 \mathrm{E}-01$

$1.6 \mathrm{E}-02 \pm 4.1 \mathrm{E}-06$

$1.4 \mathrm{E}-02 \pm 1.3 \mathrm{E}-02$

$3.5 \mathrm{E}-03 \pm 4.9 \mathrm{E}-03$

$2.8 \mathrm{E}-03 \pm 2.0 \mathrm{E}-03$

$3.2 \mathrm{E}-03 \pm 4.3 \mathrm{E}-03$

$1.0 \mathrm{E}-02 \pm 3.6 \mathrm{E}-02$

$2.2 \mathrm{E}-03$

$3.3 \mathrm{E}-03 \pm 3.7 \mathrm{E}-03$

\section{Maximum $^{(\mathrm{d})}$}

$.1 \mathrm{E}-02 \pm 5.9 \mathrm{E}-02^{(\mathrm{e})}$

$3.7 \mathrm{E}-02 \pm 1.0 \mathrm{E}-01^{(\mathrm{e})}$

$6.9 \mathrm{E}-02 \pm 5.7 \mathrm{E}-02^{(\mathrm{e})}$

$5.6 \mathrm{E}-02 \pm 5.7 \mathrm{E}-02^{(\mathrm{e})}$

$2.5 \mathrm{E}-02 \pm 3.8 \mathrm{E}-02^{(\mathrm{e}}$

$7.1 \mathrm{E}-02 \pm 1.1 \mathrm{E}-01^{(\mathrm{e})}$

$1.1 \mathrm{E}+00 \pm 2.5 \mathrm{E}-01$

$2.4 \mathrm{E}-01 \pm 1.9 \mathrm{E}-01$

$1.4 \mathrm{E}-01 \pm 2.7 \mathrm{E}-01^{(\mathrm{e})}$

$2.3 \mathrm{E}-02 \pm 2.0 \mathrm{E}-01^{(\mathrm{e})}$

$-3.1 \mathrm{E}-01 \pm 3.1 \mathrm{E}-01^{(\mathrm{e})}$

$6.0 \mathrm{E}-01 \pm 2.4 \mathrm{E}-01$

$1.4 \mathrm{E}-02 \pm 3.9 \mathrm{E}-02^{(\mathrm{e})}$

$1.1 \mathrm{E}-01 \pm 1.1 \mathrm{E}-01^{(\mathrm{e})}$

$1.1 \mathrm{E}-01 \pm 1.4 \mathrm{E}-01^{(\mathrm{e})}$

$6.4 \mathrm{E}-02 \pm 1.2 \mathrm{E}-01^{(\mathrm{e})}$

$-4.6 \mathrm{E}-02+4.6 \mathrm{E}-02^{(\mathrm{e})}$

$1.8 \mathrm{E}-01 \pm 1.3 \mathrm{E}-01^{(\mathrm{e})}$

$1.4 \mathrm{E}-02 \pm 8.7 \mathrm{E}-03$

$2.6 \mathrm{E}-02 \pm 1.2 \mathrm{E}-02$

$4.1 \mathrm{E}-02 \pm 1.6 \mathrm{E}-02$

$4.4 \mathrm{E}-01 \pm 1.8 \mathrm{E}-0$

$1.6 \mathrm{E}-02 \pm 9.4 \mathrm{E}-03$

$2.7 \mathrm{E}-02 \pm 1.3 \mathrm{E}-02$

$6.7 \mathrm{E}-03 \pm 6.6 \mathrm{E}-03^{(\mathrm{e})}$

$5.2 \mathrm{E}-03 \pm 6.4 \mathrm{E}-03^{(\mathrm{e}}$

$6.8 \mathrm{E}-03 \pm 5.4 \mathrm{E}-03$

$7.9 \mathrm{E}-02 \pm 7.1 \mathrm{E}-02^{(\mathrm{e})}$

$2.2 \mathrm{E}-03 \pm 3.2 \mathrm{E}-03^{(\mathrm{e})}$

$7.1 \mathrm{E}-03 \pm 6.4 \mathrm{E}-03^{(\mathrm{e})}$
2004-2008

Number of

Samples Detections $^{(\mathbf{b})}$

\section{Average $^{(\mathrm{c})}$}

$8.2 \mathrm{E}-03 \pm 1.0 \mathrm{E}-01$

$-4.8 \mathrm{E}-03 \pm 6.4 \mathrm{E}-02$

$-4.2 \mathrm{E}-04 \pm 7.5 \mathrm{E}-02$

$-2.0 \mathrm{E}-02 \pm 1.5 \mathrm{E}-01$

$3.7 \mathrm{E}-03 \pm 2.1 \mathrm{E}-02$

$-3.0 \mathrm{E}-03 \pm 1.1 \mathrm{E}-01$

$5.1 \mathrm{E}+00 \pm 3.1 \mathrm{E}+01$ $1.4 \mathrm{E}-01 \pm 1.2 \mathrm{E}+00$

$-3.2 \mathrm{E}-02 \pm 5.8 \mathrm{E}+00$

$-8.6 \mathrm{E}-02 \pm 2.3 \mathrm{E}-01$

$4.6 \mathrm{E}-02 \pm 2.0 \mathrm{E}-01$

$4.9 \mathrm{E}-02 \pm 7.7 \mathrm{E}-01$

$9.2 \mathrm{E}-03 \pm 8.9 \mathrm{E}-02$

$4.5 \mathrm{E}-02 \pm 1.8 \mathrm{E}-01$

$4.3 \mathrm{E}-02 \pm 2.5 \mathrm{E}-01$

$-2.1 \mathrm{E}-02 \pm 2.8 \mathrm{E}-0$

$-2.0 \mathrm{E}-02+3.8 \mathrm{E}-02$

$3.9 \mathrm{E}-02 \pm 4.1 \mathrm{E}-01$

Maximum $^{(\mathrm{d})}$

$1.8 \mathrm{E}-01 \pm 4.6 \mathrm{E}-02$

$5.2 \mathrm{E}-02 \pm 7.4 \mathrm{E}-02^{(\mathrm{e})}$

$1.1 \mathrm{E}-01 \pm 9.5 \mathrm{E}-02^{(\mathrm{e})}$

$7.5 \mathrm{E}-02 \pm 5.8 \mathrm{E}-02^{(\mathrm{e})}$

$2.1 \mathrm{E}-02 \pm 3.6 \mathrm{E}-02^{(\mathrm{e})}$

$9.5 \mathrm{E}-02 \pm 7.7 \mathrm{E}-02^{(\mathrm{e})}$

$6.8 \mathrm{E}+01 \pm 8.2 \mathrm{E}+00$ $3.6 \mathrm{E}+00 \pm 5.0 \mathrm{E}-01$

$1.7 \mathrm{E}+01 \pm 3.4 \mathrm{E}+00$

$1.7 \mathrm{E}-01 \pm 2.0 \mathrm{E}-01^{(\mathrm{e})}$

$1.7 \mathrm{E}-01 \pm 1.4 \mathrm{E}-01^{(\mathrm{e})}$

$2.2 \mathrm{E}+00 \pm 4.4 \mathrm{E}-01$

$1.3 \mathrm{E}-01 \pm 6.7 \mathrm{E}-02$

$3.3 \mathrm{E}-01 \pm 9.6 \mathrm{E}-02$

$1.2 \mathrm{E}+00 \pm 2.1 \mathrm{E}+00^{(\mathrm{e})}$

$7.2 \mathrm{E}-02 \pm 8.5 \mathrm{E}-02^{(\mathrm{e})}$

$5.8 \mathrm{E}-04 \pm 5.8 \mathrm{E}-03^{(\mathrm{e})}$

$1.7 \mathrm{E}+00 \pm 2.2 \mathrm{E}+00^{(\mathrm{e})}$

$2.1 \mathrm{E}-02 \pm 1.1 \mathrm{E}-02$

$2.6 \mathrm{E}-02 \pm 1.2 \mathrm{E}-02$

$3.5 \mathrm{E}-02 \pm 1.4 \mathrm{E}-02$

$2.4 \mathrm{E}-01 \pm 6.7 \mathrm{E}-02$

$2.0 \mathrm{E}-02 \pm 1.0 \mathrm{E}-02$

$3.0 \mathrm{E}-02 \pm 1.3 \mathrm{E}-02$

$1.0 \mathrm{E}-02 \pm 7.5 \mathrm{E}-03$

$1.6 \mathrm{E}-02 \pm 9.3 \mathrm{E}-03$

$8.8 \mathrm{E}-03 \pm 6.3 \mathrm{E}-03$

$3.0 \mathrm{E}-02 \pm 2.3 \mathrm{E}-02$

$3.9 \mathrm{E}-03 \pm 4.9 \mathrm{E}-03^{(\mathrm{e})}$

$4.4 \mathrm{E}-03 \pm 8.1 \mathrm{E}-03$

$2.7 \mathrm{E}-03 \pm 2.2 \mathrm{E}-03$

$1.3 \mathrm{E}-02 \pm 8.4 \mathrm{E}-03$ 
Table 8.10.2. (contd)

2009

\begin{tabular}{|c|c|c|c|c|}
\hline \multirow[b]{3}{*}{$\underline{\text { Radionuclide }}$} & \multirow{3}{*}{$\begin{array}{l}\text { Hanford } \\
\text { Site Area }\end{array}$} & \\
\hline & & \multicolumn{2}{|c|}{ Number of } & \multirow[b]{2}{*}{$\underline{\text { Average }}^{(\mathrm{c})}$} \\
\hline & & Samples & $\underline{\text { Detections }}^{(\mathrm{b})}$ & \\
\hline \multirow[t]{6}{*}{ Plutonium-238 } & $100-\mathrm{N}$ & 3 & 0 & $-7.7 \mathrm{E}-03 \pm 2.9 \mathrm{E}-02$ \\
\hline & 200-East & 8 & 0 & $-6.6 \mathrm{E}-04 \pm 1.4 \mathrm{E}-02$ \\
\hline & 200-West & 19 & 0 & $1.5 \mathrm{E}-03 \pm 8.4 \mathrm{E}-03$ \\
\hline & 300 & 16 & 1 & $-9.5 \mathrm{E}-04 \pm 3.8 \mathrm{E}-02$ \\
\hline & 400 & 1 & 0 & $1.3 \mathrm{E}-02$ \\
\hline & 600 & 17 & 1 & $3.8 \mathrm{E}-03 \pm 1.6 \mathrm{E}-02$ \\
\hline \multirow[t]{6}{*}{ Uranium-238 } & $100-\mathrm{N}$ & 3 & 1 & $4.5 \mathrm{E}-03 \pm 5.4 \mathrm{E}-03$ \\
\hline & 200-East & 8 & 7 & $9.3 \mathrm{E}-03 \pm 7.0 \mathrm{E}-03$ \\
\hline & 200-West & 19 & 19 & $1.4 \mathrm{E}-02 \pm 1.6 \mathrm{E}-02$ \\
\hline & 300 & 16 & 15 & $5.5 \mathrm{E}-02 \pm 2.5 \mathrm{E}-01$ \\
\hline & 400 & 1 & 1 & $1.4 \mathrm{E}-02$ \\
\hline & 600 & 17 & 15 & $1.1 \mathrm{E}-02 \pm 7.9 \mathrm{E}-03$ \\
\hline \multirow{6}{*}{$\begin{array}{l}\text { Plutonium- } \\
239 / 240\end{array}$} & $100-\mathrm{N}$ & 3 & 0 & $-1.4 \mathrm{E}-03 \pm 9.5 \mathrm{E}-03$ \\
\hline & 200-East & 8 & 0 & $5.2 \mathrm{E}-04 \pm 3.9 \mathrm{E}-03$ \\
\hline & 200-West & 19 & 5 & $3.6 \mathrm{E}-03 \pm 1.1 \mathrm{E}-02$ \\
\hline & 300 & 16 & 1 & $-3.2 \mathrm{E}-03 \pm 2.9 \mathrm{E}-02$ \\
\hline & 400 & 1 & 0 & $2.8 \mathrm{E}-03 \pm 1.3 \mathrm{E}-06$ \\
\hline & 600 & 17 & 3 & $3.5 \mathrm{E}-03 \pm 1.5 \mathrm{E}-02$ \\
\hline
\end{tabular}

\section{Maximum $^{(\mathrm{d})}$}

$3.9 \mathrm{E}-03 \pm 1.4 \mathrm{E}-02^{(\mathrm{e})}$

$9.8 \mathrm{E}-03 \pm 9.9 \mathrm{E}-03^{(\mathrm{e})}$

$1.2 \mathrm{E}-02 \pm 9.6 \mathrm{E}-03^{(\mathrm{e})}$

$4.6 \mathrm{E}-02 \pm 2.2 \mathrm{E}-02$

$1.3 \mathrm{E}-02 \pm 1.8 \mathrm{E}-02^{(\mathrm{e})}$

$1.7 \mathrm{E}-02 \pm 2.3 \mathrm{E}-02^{(\mathrm{e})}$

Sa

$\frac{\text { Number of }}{\underline{\text { Samples }} \text { Detections }^{(\mathbf{b})}}$

2004-2008

\begin{tabular}{|c|c|c|c|}
\hline & & & \\
\hline 20 & 0 & $1.6 \mathrm{E}-03 \pm 1.5 \mathrm{E}-02$ & $1.9 \mathrm{E}-02 \pm 1.8 \mathrm{E}-02^{(\mathrm{e})}$ \\
\hline 50 & 2 & $-6.3 \mathrm{E}-05 \pm 1.9 \mathrm{E}-02$ & $3.5 \mathrm{E}-02 \pm 1.4 \mathrm{E}-02$ \\
\hline 114 & 6 & $1.2 \mathrm{E}-03 \pm 1.9 \mathrm{E}-02$ & $6.4 \mathrm{E}-02 \pm 2.9 \mathrm{E}-02$ \\
\hline 69 & 4 & $3.9 \mathrm{E}-03 \pm 3.3 \mathrm{E}-02$ & $8.7 \mathrm{E}-02 \pm 4.7 \mathrm{E}-02$ \\
\hline 5 & 0 & $3.0 \mathrm{E}-03 \pm 9.4 \mathrm{E}-03$ & $8.3 \mathrm{E}-03 \pm 1.7 \mathrm{E}-02^{(\mathrm{e})}$ \\
\hline 77 & 0 & $1.2 \mathrm{E}-03 \pm 1.8 \mathrm{E}-02$ & $2.4 \mathrm{E}-02 \pm 2.1 \mathrm{E}-02^{(\mathrm{e})}$ \\
\hline 20 & 12 & $6.3 \mathrm{E}-03 \pm 6.5 \mathrm{E}-03$ & $1.4 \mathrm{E}-02 \pm 8.1 \mathrm{E}-03$ \\
\hline 50 & 37 & $1.0 \mathrm{E}-02 \pm 9.2 \mathrm{E}-03$ & $2.3 \mathrm{E}-02 \pm 1.1 \mathrm{E}-02$ \\
\hline 114 & 95 & $1.1 \mathrm{E}-02 \pm 1.2 \mathrm{E}-02$ & $3.9 \mathrm{E}-02 \pm 1.6 \mathrm{E}-02$ \\
\hline 69 & 63 & $2.6 \mathrm{E}-02 \pm 6.7 \mathrm{E}-02$ & $2.1 \mathrm{E}-01 \pm 5.9 \mathrm{E}-02$ \\
\hline 5 & 5 & $7.8 \mathrm{E}-03 \pm 4.1 \mathrm{E}-03$ & $9.8 \mathrm{E}-03 \pm 6.7 \mathrm{E}-03$ \\
\hline 77 & 54 & $8.5 \mathrm{E}-03 \pm 9.6 \mathrm{E}-03$ & $2.5 \mathrm{E}-02 \pm 1.2 \mathrm{E}-02$ \\
\hline 20 & 0 & $6.9 \mathrm{E}-04 \pm 3.1 \mathrm{E}-03$ & $3.5 \mathrm{E}-03 \pm 4.2 \mathrm{E}-03^{(\mathrm{e})}$ \\
\hline 50 & 4 & $2.2 \mathrm{E}-03 \pm 1.7 \mathrm{E}-02$ & $5.9 \mathrm{E}-02 \pm 2.2 \mathrm{E}-02$ \\
\hline 114 & 34 & $1.2 \mathrm{E}-02 \pm 7.9 \mathrm{E}-02$ & $3.6 \mathrm{E}-01 \pm 9.7 \mathrm{E}-02$ \\
\hline 69 & 4 & $2.0 \mathrm{E}-03 \pm 6.8 \mathrm{E}-03$ & $1.6 \mathrm{E}-02 \pm 1.0 \mathrm{E}-02$ \\
\hline 5 & 1 & $4.0 \mathrm{E}-03 \pm 7.8 \mathrm{E}-03$ & $9.8 \mathrm{E}-03 \pm 6.3 \mathrm{E}-03$ \\
\hline 77 & 7 & $2.4 \mathrm{E}-03 \pm 1.0 \mathrm{E}-02$ & $3.6 \mathrm{E}-02 \pm 1.6 \mathrm{E}-02$ \\
\hline
\end{tabular}

$2.4 \mathrm{E}-03 \pm 1.0 \mathrm{E}-02$

$3.6 \mathrm{E}-02+1.6 \mathrm{E}-02$

(a) $1 \mathrm{pCi}=0.037 \mathrm{~Bq}$.

$7.4 \mathrm{E}-03 \pm 5.3 \mathrm{E}-03$

$1.6 \mathrm{E}-02 \pm 8.6 \mathrm{E}-03$

$4.2 \mathrm{E}-02 \pm 1.7 \mathrm{E}-02$

$5.2 \mathrm{E}-01 \pm 1.9 \mathrm{E}-01$

$1.4 \mathrm{E}-02 \pm 9.2 \mathrm{E}-03$

$2.0 \mathrm{E}-02 \pm 1.0 \mathrm{E}-02$

$3.0 \mathrm{E}-03 \pm 4.5 \mathrm{E}-03^{(\mathrm{e})}$

$2.7 \mathrm{E}-03 \pm 3.2 \mathrm{E}-03^{(\mathrm{e})}$

$2.2 \mathrm{E}-02 \pm 1.3 \mathrm{E}-02$

$1.0 \mathrm{E}-02 \pm 6.5 \mathrm{E}-03$

$2.8 \mathrm{E}-03 \pm 4.2 \mathrm{E}-03^{(\mathrm{e})}$

$2.9 \mathrm{E}-02 \pm 1.2 \mathrm{E}-02$

(b) Number of samples with measurable concentrations of contaminants.

(c) Average \pm two standard deviations.

(d) Maximum \pm analytical uncertainty.

(e) Maximum value reported is a non-detect. 


\subsubsection{Investigations of Radioactive Contamination in Vegetation Near Hanford Site Facilities and Operations}

\section{SM McKinney and RC Roos}

Investigations for radioactive contamination in vegetation were conducted in and near operational areas to monitor the presence or movement of radioactive materials around areas of known or suspected contamination, or to verify radiological conditions at specific project sites. All samples collected during investigations were field-surveyed for alpha and beta-gamma radiation.

During 2009, radiological contamination was found in 109 vegetation samples collected during investigations. One hundred and eight of the samples were tumbleweeds (Russian thistle) or tumbleweed fragments, and one sample was rabbitbrush. None of the samples were analyzed for specific radionuclides, and all were disposed of at a licensed facility.

Table 8.10 .3 summarizes the number and general locations of vegetation contamination incidents investigated during 2009. Table 8.10 .4 provides the numbers of contamination incidents investigated in 2009 and during the previous 11 years. Section 8.10 .3 provides a discussion of vegetation control efforts on the Hanford Site during 2009.

\subsubsection{Vegetation Monitoring at Hanford Site-Wide and Offsite Locations}

\section{BG Fritz}

Monitoring of rabbitbrush and sagebrush leaves and stems provides information on atmospheric deposition of radioactive materials in uncultivated areas and at site-wide locations that could potentially be affected by contaminants from Hanford Site operations. Vegetation samples have been collected on and around the Hanford Site for more than 50 years. Data from these samples are maintained in a database to document onsite and offsite levels of manmade radionuclides in vegetation at specific locations. This
Table 8.10.3. Number of Vegetation Contamination Incidents Investigated Near Hanford Site Facilities and Operations, 2009

\section{Location}

200-East Area

Tank farm

Burial grounds

Cribs, ponds, and ditches

Fence lines

Roads and railroads

Unplanned release sites

Underground pipelines

Miscellaneous

200-West Area

Tank farms

Burial grounds

Cribs, ponds, and ditches

Fence lines

Roads and railroads

Unplanned release sites

Underground pipelines

Miscellaneous

Cross-site transfer line

200-BC cribs and trenches

200-North Area

100 Areas

300 Area

400 Area

600 Area

Former 1100 Area

Total

Table 8.10.4. Annual Number of Vegetation Contamination Incidents Investigated Near Hanford Site Facilities and Operations, 1998 Through 2009

\begin{tabular}{cccc|}
\hline$\underline{\text { Year }}$ & $\begin{array}{c}\text { Number of } \\
\text { Incidents }\end{array}$ & $\underline{\text { Year }}$ & $\begin{array}{c}\text { Number of } \\
\text { Incidents }\end{array}$ \\
1998 & 51 & 2004 & 60 \\
1999 & 85 & 2005 & 66 \\
2000 & 66 & 2006 & 75 \\
2001 & 31 & 2007 & 62 \\
2002 & 16 & 2008 & 127 \\
2003 & 32 & 2009 & 109 \\
\hline
\end{tabular}

database contains baseline data against which data from unplanned contaminant releases from the Hanford Site can be compared. Vegetation samples are collected every 3 to 5 years, and were last collected in 2008 (PNNL-18427). 


\section{Wild Chives}

\section{SD Powell and TM Poston}

Wild chives (Allium schoenoprasum) are edible plants that grow in riparian habitats along the Hanford Reach of the Columbia River. These plants may be used as a cultural resource by local Native American tribes or consumed by wildlife. As part of Hanford Site environmental surveillance, chives growing along the Hanford Reach of the Columbia River were sampled to evaluate the concentrations of metals and radionuclides found in plant tissues.

Wild chives were sampled from shoreline locations near the 100-H Area and Locke Island, and from the reference location at Vernita Bridge. Decayed bulb husk material was removed and all plant samples were thoroughly washed in deionized water and oven dried for analysis of metal and radionuclide concentrations. Each sample was divided into subsamples of root, bulb, and leaf material prior to analysis by inductively coupled plasma mass spectrometry. Radionuclide concentrations monitored included beryllium-7, potassium-40, technetium-99, ruthenium-106, antimony-125, cesium-134, cesium-137, europium-152, europium-155, plutonium-238, and plutonium-239/240. Samples were also monitored for 17 trace metals.

Radionuclide concentrations were not observed above minimum detection limits with the exception of naturally occurring potassium-40, which was found at similar levels in all three samples: $12.3 \mathrm{pCi} / \mathrm{g}$ for the Vernita Bridge sample, $12.4 \mathrm{pCi} / \mathrm{g}$ in the $100-\mathrm{H}$ Area sample, and $13.3 \mathrm{pCi} / \mathrm{g}$ for the Locke Island sample.

Metal concentrations were higher in chives from Locke Island and the 100-H Area than concentrations found in the reference sample, with the exception of boron and iron (Appendix C, Table C.11). Subsample concentrations of cadmium, chromium, and titanium are presented in Figure 8.10.2. Trace metals for which most subsamples had detectable levels (or were above minimum detection limits) are summarized in Appendix C, Table C.11.

Metal concentrations were generally higher in the root subsamples than the bulb and leaf subsamples. Some soil particles may have remained on the roots or adhered to root hairs even though samples were thoroughly washed. (a)

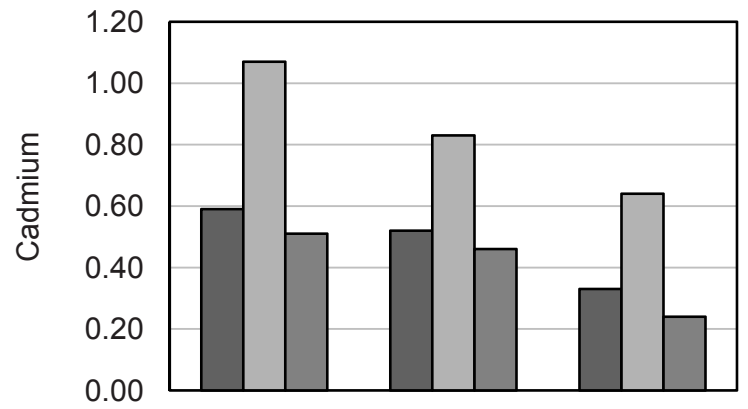

(b)

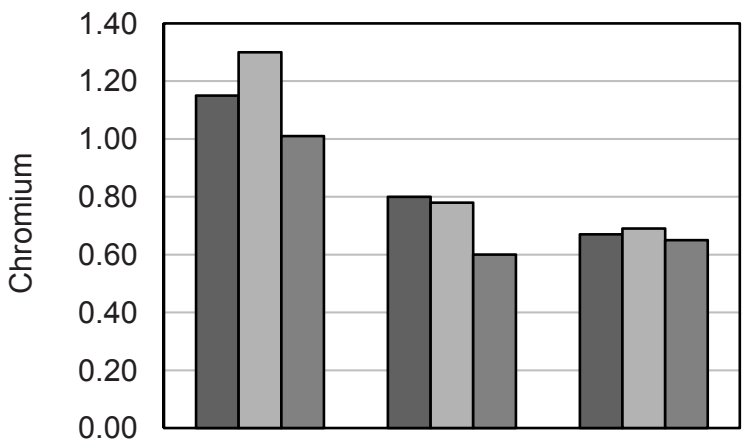

(c)

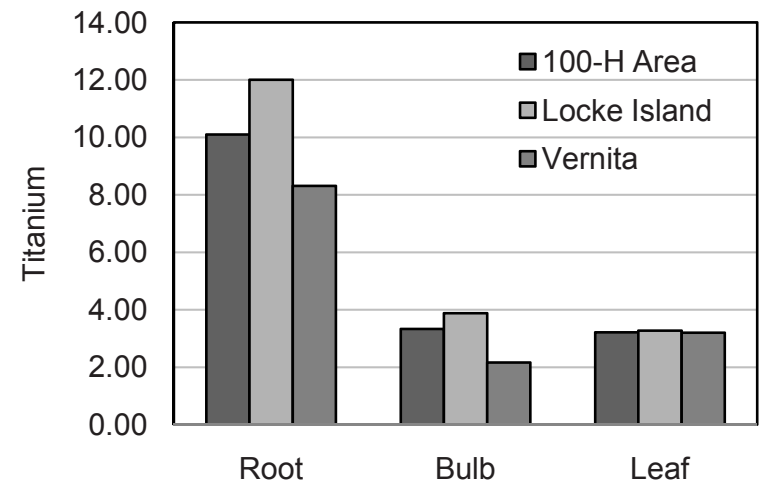

Figure 8.10.2. Concentrations ( $\mu \mathrm{g} / \mathrm{g}$ ) of (a) Cadmium, (b) Chromium, and (c) Titanium in Wild Chive Subsamples of Root, Bulb, and Leaf Material from Shoreline Locations Within the Hanford Reach (near 100-H Area and Locke Island) and a Reference Location Upriver of the Vernita Bridge, Spring 2009 


\subsubsection{Vegetation Control Activities}

\section{AR Johnson, JM Rodriguez, and RC Roos}

Vegetation control on the Hanford Site consists of cleaning up contaminated plants that can be a threat to site workers or the public, controlling or preventing the growth or regrowth of plants in contaminated or potentially contaminated areas on the site, and monitoring and removing unwanted (noxious) plant species.

Approximately 3,200 hectares (7,900 acres) were treated with herbicides in 2009 on radiological waste sites, around operations areas, and along roadways to keep them clean of deep-rooted noxious vegetation (e.g., Russian thistle, also known as tumbleweed). Follow-up treatments are included in the total treated acres; several areas received three or four treatments during the year.

\subsubsection{Waste Site Contamination Control and Revegetation During 2009}

Since 1999, 39 small sites (comprising a total area of approximately 14,000 square meters [151,000 square feet]) were covered with Biobarrier ${ }^{\circledR}$ to prevent invasion by biota. ${ }^{(a)}$ Biobarrier, a herbicide-impregnated engineered fabric used to stop root penetration and serve as a physical barrier to burrowing insects, was placed over areas exhibiting recurring radioactive contamination events caused by deeprooted vegetation or burrowing animals. Tests on the Hanford Site confirm this barrier is effective in preventing the spread of contamination; however, Biobarrier was not used on the Hanford Site in 2009.

Several waste sites were reseeded with bunchgrass to inhibit the growth of deep-rooted vegetation (e.g., tumbleweed). Approximately 200 hectares (500 acres) were overseeded with bunchgrass seed in 2009.

\subsubsection{Noxious Weed Control}

Noxious weeds are controlled on the Hanford Site to prevent their spread and eliminate populations. A noxious weed is a legal and administrative category designated by federal or state regulatory agencies (e.g., U.S. Department of Agriculture or Washington State Department of Agriculture). Noxious weeds are non-native, aggressively invasive, and hard to control. Noxious weeds alter native plant communities and degrade ecosystems unless control measures are taken. Control measures can be mechanical, chemical, cultural, or biological; approximately 200 hectares (500 acres) on the Hanford Site were treated in 2009.

Ten plant species are on a high-priority list for control on the Hanford Site. These species are described in the following paragraphs, along with a summary of 2009 control activities.

Yellow Starthistle (Centaurea solstitialis). Yellow starthistle represents the most rapidly expanding weed infestation in the western United States. Since 1995, yellow starthistle has been the highest priority weed for the Hanford Site noxious-weed control program because yellow starthistle has the potential to invade the entire site and have a dramatic impact on the ecology of the site and neighboring lands.

Control measures for yellow starthistle have included spot treatments and broadcast herbicide applications by ground equipment and aerial sprayers, biological control, and handweeding in critical locations. Major populations near the Hanford town site have been reduced to scattered individual plants, mostly near live trees where aerial herbicide applications were not made.

Yellow starthistle seeds are known to remain viable for 10 years in the soil. The small number of seedlings found over much of the area of infestation indicates the seed bank is being exhausted. Careful control efforts over the next few years should indicate yellow starthistle on the Hanford Site changed from a major infestation to a monitoring and eradication effort.

Biological control agents for yellow starthistle are widely distributed across the infested area and have been highly effective during the early part of the flowering season. However, the adult phase of the control agent's annual life cycle is completed before the end of the flowering season. Consequently, flowers opening late in the season are largely spared the effects of insect predation.

a) Biobarrier is a registered trademark of Fiberweb Inc., Old Hickory, Tennessee. 
Rush Skeletonweed (Chondrilla juncea). Rush skeletonweed is scattered over large areas on the Hanford Site. Areas of dense rush skeletonweed infestation have largely been eliminated. Nevertheless, considerable rush skeletonweed remains as scattered individual plants. Populations of rush skeletonweed have increased in some areas burned by the 24 Command Wildland Fire in June 2000 and can be expected to increase in areas burned by the Wautoma fire in 2007.

In 2009, control of rush skeletonweed focused on individual areas between State Highway 240 and Hanford Route 10. Approximately 175 hectares (350 acres) were treated to remove an infestation that was becoming dense in this area. Rush skeletonweed was also controlled along roadways in the 100 and 600 Areas.

The deep and extensive root system of rush skeletonweed makes it extremely difficult to eliminate. The area north of the Volpentest Hazardous Materials Management and Emergency Response Training and Education Center (HAMMER) facility has been treated with herbicides in the past and will continue to be monitored for sprouts emerging from roots remaining in the ground. Additional aerial applications will likely be needed to reduce the population of rush skeletonweed to the level that ground applications will be able to control the infestation.

Biological control agents are commonly found in rush skeletonweed on the Hanford Site; however, they have not significantly reduced plant populations.

Medusahead (Taeniatherum asperum). No medusahead plants were discovered in 2009. The area where individual plants grew in the past is currently graveled and used as an equipment storage area. It is routinely treated with herbicides to prevent any plant growth. The Hanford Site continues to be monitored to identify further infestation of medusahead.

Babysbreath (Gypsophila paniculata). In 2009, the population of babysbreath at the Hanford town site was sprayed with herbicide or removed by hand. Babysbreath is resistant to control by herbicides; however, the above ground portion of the plant can be killed by some herbicides. Researchers noticed that remaining plants appeared noticeably smaller and weaker than in the past. Although herbicides will not kill healthy babysbreath, herbicides can control flowering and population growth. It is hoped these plants will ultimately be eradicated by continually removing the top portions through herbicide use.

Dalmatian Toadflax (Linaria genistifolia ssp. Dalmatica). In past years, small populations of dalmatian toadflax plants have been found growing at the 100-B/C Area and east of Energy Northwest on the Hanford Site. Sprouts and seedlings of this long-lived perennial plant are eliminated as they are identified. In 2009, no sprouts were identified at the 100-B/C Area, but plants were observed along roads near Energy Northwest and treated with herbicides.

Spotted Knapweed (Centaurea maculosa). Spotted knapweed on the Hanford Site has been controlled so that sprouts or seedlings are rare. No sprouts or seedlings were found in 2009. The site will continue to be monitored to ensure viable seeds and roots have been eliminated from the soil. Cooperative efforts with neighboring landowners continue to eliminate spotted knapweed near the Hanford Site. Knapweed root weevil was released at several sites on and around the Hanford Site in 2009. This weevil prefers spotted knapweed, but will also attack diffuse knapweed.

Diffuse Knapweed (Centaurea diffusa). Aerial applications for control of diffuse knapweed have been effective in the past. In 2009, no areas were sprayed aerially to control diffuse knapweed. Spot treatment of scattered individuals continues. The population of diffuse knapweed near the high-water mark of the Columbia River has not been actively controlled by herbicides because of the biological sensitivity of the area. Researchers monitor established biological controls to observe effectiveness in controlling the weed. Knapweed root weevil was released at two locations along the Columbia River in 2009. If the weevil population establishes, it should help control the weed in the sensitive area along the river.

Russian Knapweed (Acroptilon repens). Biological controls for Russian knapweed are limited, and their success has been poor in the arid climate of the Hanford Site. Chemicals and other control techniques are being developed that promise to be effective with this difficult-to-control species.

Saltcedar (Tamarix spp.). Several individual plants of saltcedar are found on the Hanford Site. Most are remaining 
from ornamental plantings near homes in the early part of the 1900s. A few populations are the result of natural seed dispersal. Most individual plants south and west of the Columbia River have been eliminated. Those remaining alive continue to be treated with herbicide and will be monitored until they are eradicated. In 2009, several individual plants assumed to be dead were not; they sprouted green shoots. When the shoots are large enough to absorb lethal doses of herbicides, they will be sprayed.

Purple Loosestrife (Lythrum salicaria). The Columbia River shorelines and islands on the Hanford Site are monitored for purple loosestrife. Populations are found on many islands and along the north and east bank of the river. Individual plants are found along the south and west bank of the river.

Under favorable ecological conditions, biological controls are effective for controlling purple loosestrife. However, rapidly fluctuating water levels along the Columbia River kill the biological control organisms that overwinter on the ground in the weed populations. Winter mortality prevents an effective population of control agents from developing. Hanford Site personnel are working with neighboring land managers along the Columbia River to identify effective controls for purple loosestrife along the Hanford Reach. No control measures were applied for purple loosestrife in 2009.

\subsubsection{Monitoring of Fish and Wildlife for Hanford Site- Produced Contaminants}

\section{JA Stegen and RE Durham}

In 2009, Canada geese and whitefish were collected at locations on and around the Hanford Site as part of routine monitoring for site-produced contaminants (Figure 8.10.3). Samples from these organisms were analyzed for selected radionuclides and metals that are suspected or known to be present on the Hanford Site (Table 8.10.5). Samples were also collected at locations distant from the site to obtain reference (background) contaminant measurements.

Most fish and wildlife samples collected on or near the Hanford Site for routine human-exposure pathway assessments are obtained annually, but specific species are sampled only every 2 or 3 years. Samples obtained at locations believed to be unaffected by Hanford Site effluents and emissions are collected approximately every 5 years.

In 2009, all fish and wildlife samples collected were monitored for strontium-90 contamination and were analyzed by gamma spectrometry to detect a number of gamma emitters, including cesium-137 (Appendix F). Since the 1990s, strontium-90 and cesium-137 have been the most frequently measured radionuclides in fish and wildlife samples.

Strontium-90 is chemically similar to calcium; consequently, it accumulates in hard tissues rich in calcium such as bones, antlers, and eggshells. Strontium-90 has a biological half-life in hard tissue of 14 to 600 days (PNL-9394). Hard-tissue concentrations may profile an organism's lifetime exposure to strontium-90. However, strontium-90 generally does not contribute much to human dose because it does not accumulate in edible portions of fish and wildlife (National Council on Radiation Protection and Measurements 1991). Strontium-90 is present in the Hanford Site environs as a result of past site operating and waste-disposal practices. Currently, contaminated groundwater entering the Columbia River through shoreline springs in the $100-\mathrm{N}$ and $100-\mathrm{H}$ Areas is the primary source of site-produced strontium-90 measurable in the Columbia River. However, the current contaminant contribution relative to historical fallout from atmospheric weapons testing is small (less than 2\%) (PNL-8817).

Cesium-137 is particularly important to the human food chain because it is chemically similar to potassium and is found in the muscle tissues of fish and wildlife. Having a relatively short biological half-life (less than 200 days in muscle and less than 20 days in the gastrointestinal tract [PNL-9394]), cesium-137 is an indicator of recent exposure to radioactive materials. Cesium-137 is present in the environment as a result of past Hanford Site operating and waste-disposal practices as well as from historical worldwide fallout resulting from nuclear weapons testing.

Gamma spectrometry results for most radionuclides were too low to measure, or measured concentrations were considered artifacts of low background counts. Low background counts occur at random intervals during sample counting and can produce occasional spurious false-positive results. For many radionuclides, concentrations were below levels that could 


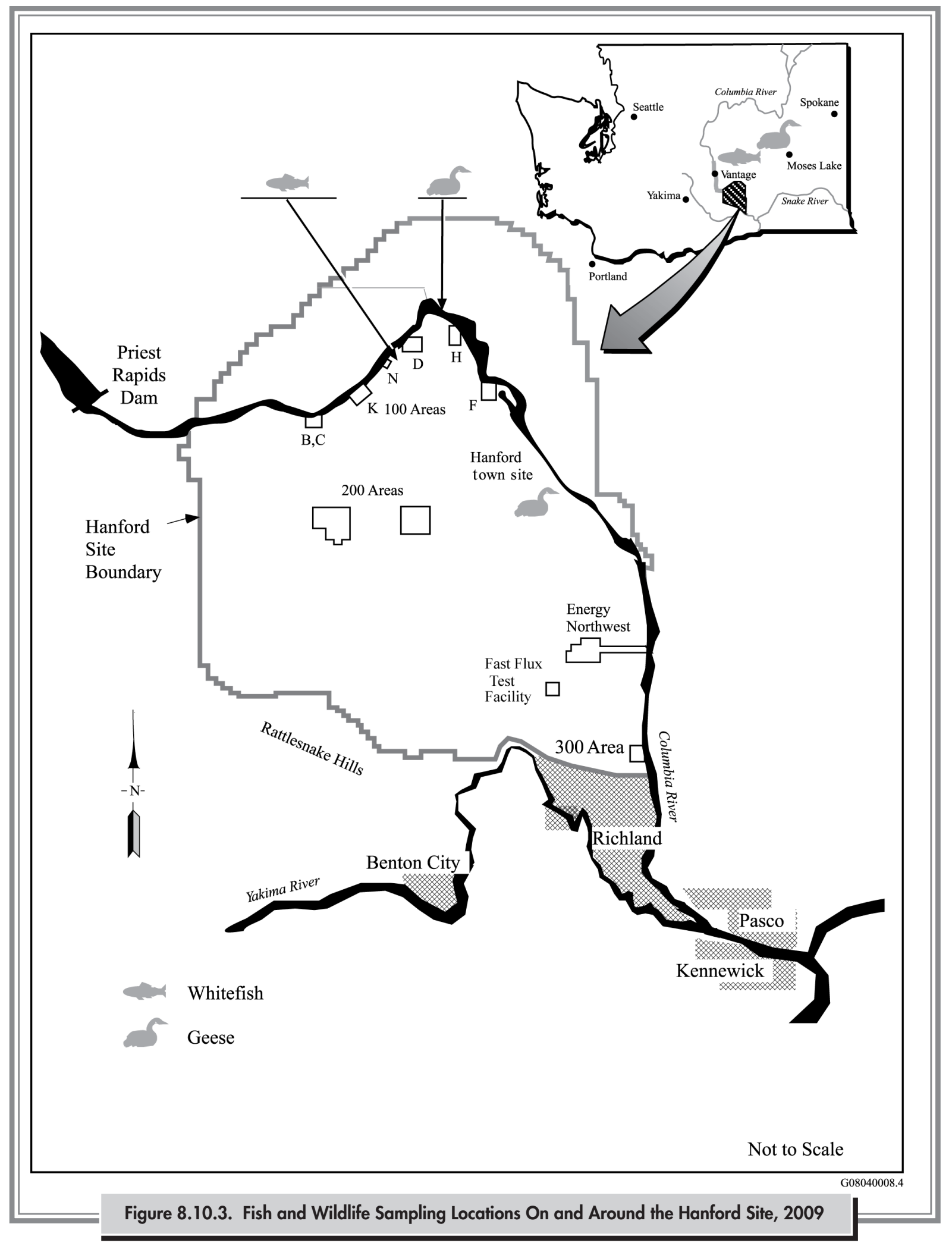




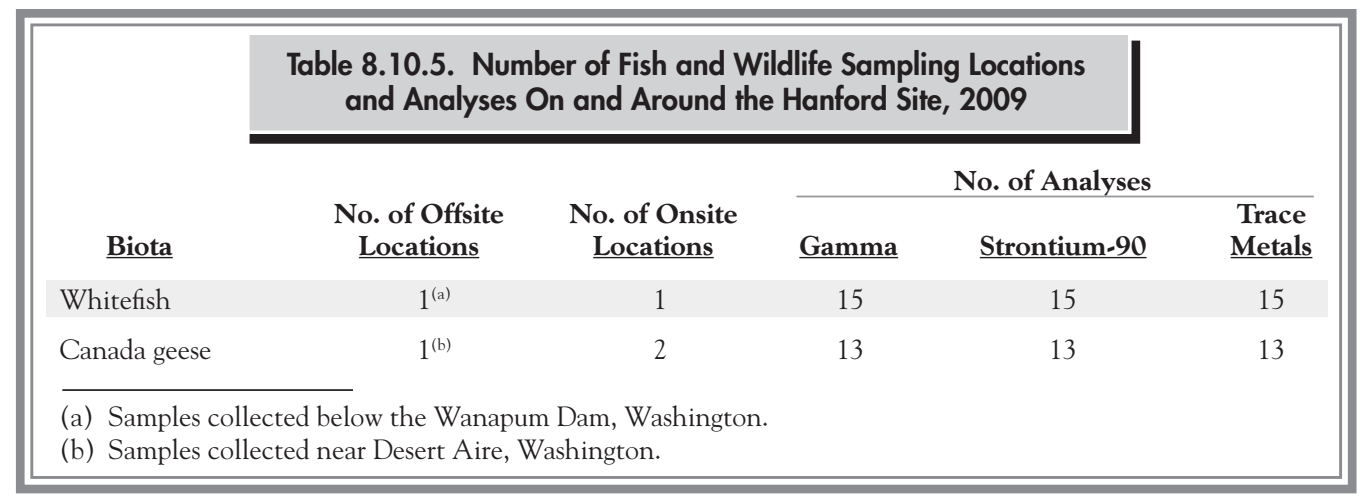

be detected by the analytical laboratory. Results, propagated analytical uncertainties, and minimum detection amounts for all 2009 wildlife samples may be found in PNNL-19455, APP. 1.

A number of trace metals associated with Hanford Site operations have the potential to accumulate in certain fish and wildlife tissues. These metals are potential contaminants of concern (e.g., chromium, copper, lead, and mercury), particularly along Hanford's Columbia River shoreline where contaminated groundwater flows into the river (PNNL-14295). Historical operations at the Hanford Site resulted in the production of both radiological and nonradiological wastes, including metals, in various forms. Liquid and solid wastes were placed in various disposal sites at the site, including trenches, cribs, ditches, ponds, and underground storage tanks (PNNL-13487). Fly ash (ash produced from burning coal) from coal-fired steam/ power plants associated with some reactors was released to the atmosphere. Fly ash contains trace metals and natural radionuclides that may have deposited on the soil around the reactor areas. In addition to trace metals associated with past Hanford Site operations, other sources of contamination have affected the site. Trace metals generated from upriver mining and smelting activities have been transported down the Columbia River and into the Hanford Reach (Johnson et al. 2005). In addition, contaminants associated with past and present agricultural practices have contributed to the metals inventory at the Hanford Site (Yokel and Delistraty 2003). For example, arsenic is likely associated with historical applications of lead arsenate on fruit orchards prior to World War II. Lead arsenate was once the most commonly used insecticide in fruit orchards; studies that examined the extent of arsenic contamination in pre-World
War II orchard soil near the 100 Areas showed elevated levels of arsenic compared to levels in soil from background locations (Yokel and Delistraty 2003).

Organisms can accumulate metals through incidental soil ingestion, by drinking contaminated water, and by consuming contaminated foods. The spatial variability of concentrations of metals in the environment is influenced by the contributions of both natural sources and industrial contaminants, and organisms may range widely over areas influenced to varying degrees by both. Thus, concentrations of metals and organism exposures can vary between locations. This variability can produce some uncertainty in the source of the metals within the sampled organism. To determine the Hanford Site contribution to levels of metals in biota collected onsite or in the Hanford Reach, samples were also collected from the Columbia River upstream of the site and from background areas distant from the site. A comparison of concentrations of metals in upstream and background samples with concentrations in Hanford Reach or Hanford Site samples could ultimately indicate increases in concentrations of metals potentially due to activities on the site. However, currently there is only a relatively small set of metals data for wildlife and fish from the Hanford Reach, the Hanford Site, and from background locations, and the data show some degree of variability. Sample sizes are relatively small for targeted organisms in these areas, and samples have been taken only 4 times within a 7 -year period. The combination of small sample sizes taken over a relatively short period of time and the spatial variability inherent in an organism's exposure underlie to some degree the inconsistency in the metals data evidenced in the discussion that follows. The addition of future monitoring 
data may reduce this variability and enhance the utility of the data in determining Hanford Site contribution to levels of metals in biota.

Trace metal concentrations were monitored in Canada geese and whitefish in 2009, and data results are summarized in the following discussions. Individual results and their associated uncertainties are in PNNL-19455, APP. 1.

\subsubsection{Analytical Results for Fish Samples}

Fishing is a popular activity along the Hanford Reach of the Columbia River. Fish, including whitefish, are harvested for food and could potentially contribute to human exposure. Whitefish are known to migrate seasonally and may be exposed to metals and persistent radionuclides in the river environment. Monitoring fish for uptake and exposure to radionuclides and metals at locations both near to and distant from the Hanford Site continues to be important to track the extent and long-term trends of contamination in the Hanford Reach environment. During 2009, five whitefish were collected between the 100-N and 100-D Areas and five were collected just below Wanapum Dam, upstream of the Hanford Site. Fillets and the eviscerated remains (carcasses) of whitefish were analyzed for a variety of radiological contaminants, and liver samples were analyzed for 17 metals.

Cesium-137. Cesium-137 results were below the analytical detection limit $(0.03 \mathrm{pCi} / \mathrm{g}[0.001 \mathrm{~Bq} / \mathrm{g}]$ wet weight $)$ in the 10 whitefish fillet samples collected during 2009. These results are consistent with results reported throughout the past 10 years (PNNL-13230, PNNL-13910, PNNL-14687, PNNL-15892, PNNL-17603) indicating a gradual decline in cesium-137 levels in fish found both at background locations and near the Hanford Site.

Strontium-90. Strontium-90 results were below the analytical detection limit $(0.05 \mathrm{pCi} / \mathrm{g}[0.002 \mathrm{~Bq} / \mathrm{g}]$ wet weight $)$ in the 10 whitefish carcass samples collected during 2009. These results are consistent with results reported throughout the past 10 years (PNNL-13230, PNNL-13910, PNNL14687, PNNL-15892, PNNL-17603). These results indicate no difference in concentration of strontium-90 in fish found at background locations compared to fish sampled near the Hanford Site.
Trace Metals. Liver samples from four whitefish collected between the 100-N and 100-D Areas were analyzed for 17 trace metals during 2009. Concentrations in the samples were compared to concentrations in five whitefish samples collected upstream of the Hanford Site near Wanapum Dam in 2009. Samples were also compared to previous whitefish samples collected upstream of the site near Wanapum Dam in 2003, 2005, and 2007.

Beryllium was not detected above method detection limits $(0.01 \mu \mathrm{g} / \mathrm{g}$ dry weight) in any samples in 2009 (Appendix C, Table C.13). Maximum concentrations of aluminum, chromium, and mercury were higher in whitefish samples collected near Wanapum Dam than samples collected between the 100-N and 100-D Areas during 2009 (Appendix C, Table C.13). The maximum and median concentrations of antimony, arsenic, cadmium, copper, lead, manganese, nickel, selenium, silver, thallium, thorium, uranium, and zinc were higher in samples collected between the 100-N and 100-D Areas than the maximum and median concentrations of samples collected from the background location in 2009 (Appendix C, Table C.13). With the exception of zinc, selenium, and thallium, concentrations of these metals in whitefish collected between the 100-N and 100-D Areas in 2009 were less than concentrations of these metals in whitefish samples collected at the background location in 2003, 2005, and/or 2007 (Appendix C, Table C.13; PNNL-14687, APP. 1; PNNL-15892, APP. 1; PNNL-17603, APP. 1). The maximum and median concentrations of zinc $(160 \mu \mathrm{g} / \mathrm{g}$ and $140 \mu \mathrm{g} / \mathrm{g}$ dry weight), thallium $(2.2 \mu \mathrm{g} / \mathrm{g}$ and $0.52 \mu \mathrm{g} / \mathrm{g}$ dry weight), and selenium (18 $\mu \mathrm{g} / \mathrm{g}$ and $12 \mu \mathrm{g} / \mathrm{g}$ dry weight) were elevated in the whitefish samples collected between the 100-N and 100-D Areas compared to concentrations in samples collected at the background location near the Wanapum Dam in 2003, 2005, and 2007 (Appendix C, Table C.13; PNNL-14687, APP. 1; PNNL-15892, APP. 1; PNNL-17603, APP. 1). However, whitefish samples collected in 2007 near the Ringold Fish Hatchery had the highest concentrations of selenium ( $21 \mu \mathrm{g} / \mathrm{g}$ dry weight $)$ and zinc ( $238 \mu \mathrm{g} / \mathrm{g}$ dry weight $)$ measured in samples collected between 2003 and 2009 (Appendix C, Table C.13; PNNL-14687, APP. 1; PNNL15892, APP. 1; PNNL-17603, APP. 1). Selenium and zinc are known to occur in fertilizer (WSDA 2007; Takeda et al. 2006) and the area surrounding the Ringold Fish Hatchery is largely agricultural. Fly ash from past reactor activities 
and upriver mining and smelting operations may have contributed to elevated selenium and zinc levels in the Hanford Reach. There are no published ecotoxicological benchmarks for whitefish. However, whitefish are in the family Salmonidae and ecotoxicological benchmarks for liver concentrations of selenium and zinc in salmonids were compared to concentrations of these metals in whitefish sampled along the Hanford Reach in 2009. Ecotoxicological benchmarks are not available for thallium. Decreased growth and increased mortality was reported in juvenile rainbow trout where liver concentrations of selenium were between 29 and $60 \mu \mathrm{g} / \mathrm{g}$ dry weight. Growth, reproduction, and survival were not affected when liver concentrations of zinc in brook trout were between 180 and $204 \mu \mathrm{g} / \mathrm{g}$ dry weight (USACE/ EPA 2005). The maximum observed concentrations of selenium and zinc in Hanford Reach whitefish liver samples were less than published ecotoxicological benchmarks for salmonids (Appendix C, Table C.13; USACE/EPA 2005).

\subsubsection{Analytical Results for Goose Samples}

During spring 2009, 10 Canada geese were collected along the Hanford Reach of the Columbia River: 5 between the Hanford town site and the 300 Area, and 5 near the 100 Areas. Three geese were collected at a background location near Desert Aire, Washington, in spring (Figure 8.10.3). All organisms were analyzed for cesium-137 and other gamma-emitting radionuclides in muscle tissue, strontium-90 in bones, and 17 trace metals in the liver.

Cesium-137. Manmade gamma-emitting radionuclides, including cesium-137, were not found above the detection limit in any of the muscle samples analyzed in 2009. These results were similar to results reported for goose samples collected along the Hanford Reach from 1995 through 2007 (PNNL-11139; PNNL-11795; PNNL-13230; PNNL-13910; PNNL-14687; PNNL-15892; PNNL-17603). The analytical results indicate that Canada geese are not accumulating measurable amounts of cesium-137 along the Hanford Reach of the Columbia River.

Strontium-90. Strontium-90 was detected in two of the goose bone samples collected between the Hanford town site and the 300 Area, and in all three background samples collected near Desert Aire, Washington, during 2009.
Strontium-90 was not detected in any of the goose bone samples collected near the 100 Areas. The maximum concentration in goose bone samples collected between the Hanford town site and the 300 Area $(0.12 \mathrm{pCi} / \mathrm{g}$ [0.004 Bq/g wet weight]) was higher than the maximum concentration in goose bone samples from the geese collected from the background location near Desert Aire, Washington $(0.0711 \mathrm{pCi} / \mathrm{g}[0.026 \mathrm{~Bq} / \mathrm{g}$ wet weight $]$ ) in 2009. The maximum concentration in goose bone samples onsite was less than the maximum concentration in goose bones samples collected in the fall of 2007 from a background location near Moses Lake, Washington $(0.362 \mathrm{pCi} / \mathrm{g}$ [0.013 Bq/g wet weight]; PNNL-17603). The background geese in 2007 were likely fall migrants. The geese collected in July 2009 along the Hanford Reach and near Desert Aire, Washington, are assumed to be residents. If the 2007 background geese migrated from regions that receive more rainfall (and more atmospheric fallout) than the Hanford Site, researchers anticipated the geese may have increased levels of fallout radionuclides, including strontium-90 (Palsson et al. 2006). Maximum and median concentrations in Hanford Reach goose samples in 2009 were similar to or less than results reported since 1999 (Figure 8.10.4; PNNL-13230; PNNL-13910; PNNL-14687; PNNL-15892; PNNL-17603). Strontium-90 concentrations in Hanford Reach goose samples would need to exceed approximately $60 \mathrm{pCi} / \mathrm{g}(2.2 \mathrm{~Bq} / \mathrm{g})$ wet weight to be near the current DOE dose limit of $0.1 \mathrm{rad}(0.001 \mathrm{~Gy})$ per day for terrestrial organisms (Section 8.12).

Trace Metals. Liver samples from geese collected near the 100 Areas, between the Hanford town site and the 300 Area, and near Desert Aire, Washington, were analyzed for 17 trace metals during 2009. Antimony and beryllium were not detected above method detection limits in samples collected from the Hanford Reach or the background location in 2009 (Appendix C, Table C.14). The maximum and median concentrations of chromium, manganese, and silver were elevated in samples collected near Desert Aire, Washington, compared to samples collected in the Hanford Reach (Appendix C, Table C.14). The maximum concentrations of aluminum, arsenic, cadmium, lead, mercury, nickel, selenium, thallium, thorium, uranium, and zinc were elevated in geese collected in the Hanford Reach compared to the maximum concentrations of these 


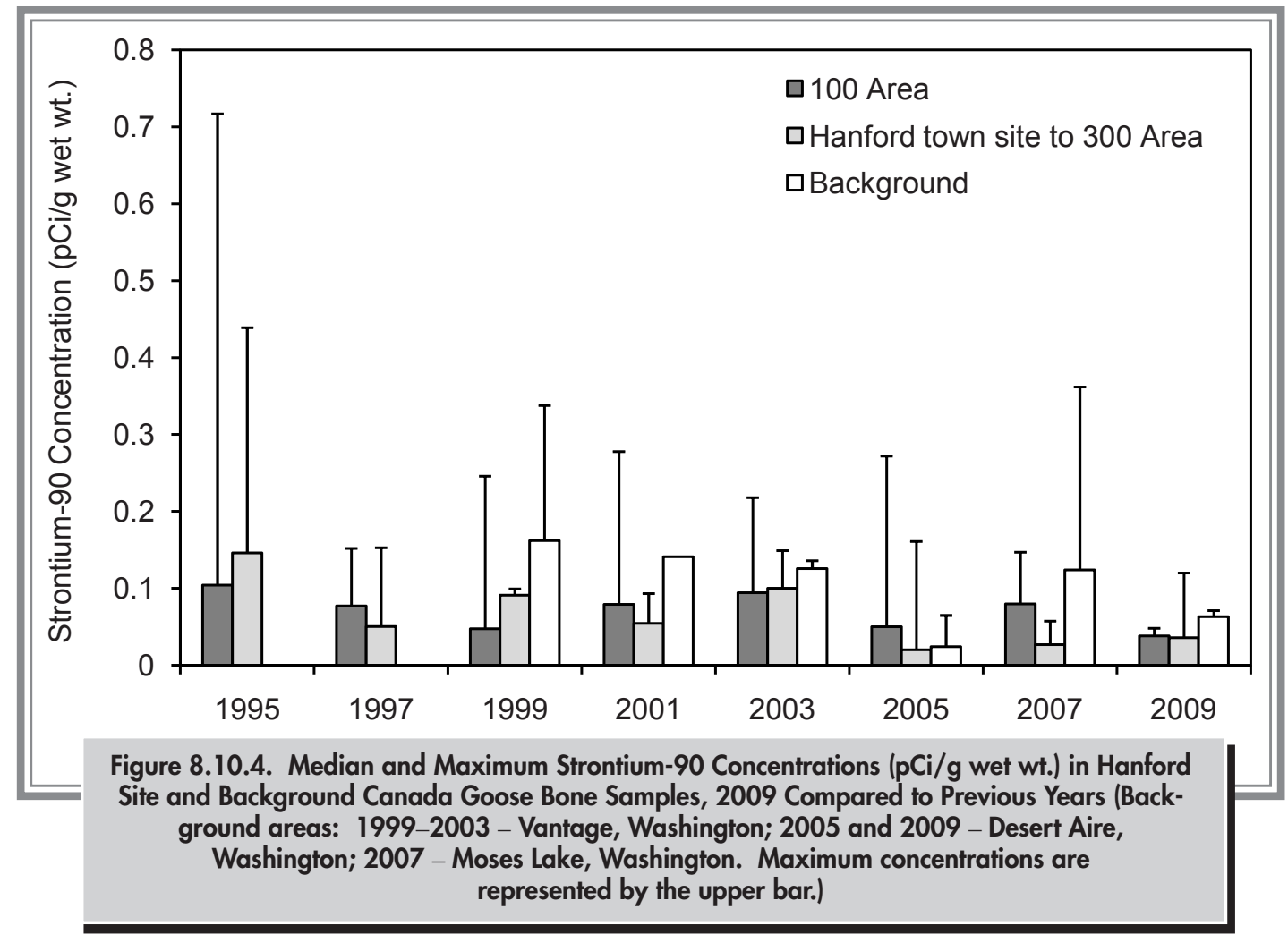

metals found in geese collected near Desert Aire, Washington, in 2009 (Appendix C, Table C.14).

Historical results show a similar trend for arsenic, lead, mercury, selenium, and thallium; for these metals, the mean liver concentrations from geese collected along the Hanford Reach between 2003 and 2007 exceeded the concentration in geese collected offsite during the same timeframe (PNNL-19212). Concentrations of 11 metals (aluminum, arsenic, cadmium, chromium, copper, lead, manganese, mercury, selenium, thallium, and zinc) were analyzed in liver samples from geese, collected from 2003 and 2007 along the Hanford Reach and at background locations (PNNL-19212). Of the metals analyzed, no apparent difference between the Hanford Reach and background data for aluminum, cadmium, manganese, and zinc was found; however, differences were significant $(\mathrm{P}<0.05)$ for arsenic, chromium, copper, lead, mercury, selenium, and thallium (PNNL-19212).

Many of these metals, while toxic at elevated concentrations, are essential micronutrients (e.g., arsenic, chromium, copper, manganese, selenium, and zinc). Aluminum, cadmium, lead, mercury, and thallium are considered non-essential metals with little if any benefit to life forms.

The maximum concentration of arsenic, cadmium, lead, mercury, nickel, selenium, silver, and zinc in samples from geese collected along the Hanford Reach was similar or less than maximum liver metal concentrations reported in waterfowl across the United States (PNNL-19212). Only aluminum and manganese concentrations in Hanford Site goose livers were in excess of literature values for waterfowl, as summarized in PNNL-19212. Literature values for concentrations of antimony, beryllium, thallium, thorium, and uranium in waterfowl liver samples are not available. If ecotoxicological benchmarks for waterfowl were available, liver concentrations of elevated metals in geese sampled along the Hanford Reach in 2009 were compared to these published values (Rattner et al. 2006). The maximum observed concentrations of cadmium, lead, mercury, selenium, and zinc in Hanford Site Canada goose liver samples were less than published ecotoxicological benchmarks and biomarkers for waterfowl, as summarized in PNNL-19212. 


\subsubsection{Control of Pests and Contaminated Biota}

\author{
AR Johnson, RC Roos, JM Rodriguez, \\ RF Giddings, and JW Wilde
}

Animal species such as the domestic pigeon (Columba livia), Northern pocket gopher (Thomomys talpoides), house mouse (Mus musculus), and deer mouse (Peromyscus maniculatus) must be controlled when they become a nuisance or a health problem, or if they become contaminated with radioactivity. Biological control personnel responded to approximately 26,000 animal control requests (ranging from requests to remove animals within radioactive waste facilities to insect invasions of work areas) from Hanford Site employees in 2009. Approximately 3,300 trap or bait stations were used to control animal populations in and near site facilities and offices. In 2009, none of the 1,771 animals captured as part of the Integrated Biological Control Program were radiologically contaminated.

During 2009, 33 contaminated animal-related materials were discovered (e.g., urine or feces). This is approximately
28\% less than the peak number of 46 in 1999 and the same as the total for 2008. Flying insects and insect-related materials (e.g., harvester ants and mud-dauber wasp nests) collected during Hanford Site operations are also monitored for radiological contaminants. One of the contaminated animal samples collected in 2009 was related to insects-an ant mound on an inactive and stabilized process ditch in the 200-East Area. The mound was subsequently treated to eliminate the ants and covered with clean backfill.

Of the 33 animal contamination incidents in 2009, 24 were contaminated rabbit feces. A study to determine the source of radioactive contamination in rabbit feces is ongoing. Black-tailed jackrabbit (Lepus californicus) and mountain (or Nuttall's) cottontail (Sylvilagus nuttallii) have been captured, fitted with collars containing radio transmitters and a global positioning system, and tracked in the 200-West Area in an effort to determine the source of contaminants. Tracking has narrowed contamination boundary parameters and will continue during 2010 to determine the contamination origin. 


\subsection{External Radiation Monitoring}

External radiation is defined as radiation originating from a source external to the human body. In 2009, external radiation on the Hanford Site was monitored onsite in relative proximity to known or potential radiation sources. Sources of external radiation on the Hanford Site include waste materials associated with the historical production of plutonium for defense; residual nuclear inventories in former production and processing facilities; radioactive waste handling, storage, and disposal activities; waste cleanup and remediation activities; atmospheric fallout from historical nuclear weapons testing; and natural sources such as cosmic radiation. During any given year, external radiation levels can vary from $15 \%$ to $25 \%$ at any location because of changes in soil moisture and snow cover (National Council on Radiation Protection and Measurements 1975).

The Harshaw ${ }^{\mathrm{TM}(\mathrm{a})}$ thermoluminescent dosimeter (TLD) system is used to measure external radiation on the Hanford Site. This system includes the Harshaw 8800-series dosimeter and the Harshaw 8800 reader. The Harshaw 8800 -series environmental dosimeter consists of two TLD-700 chips and two TLD-200 chips and provides both shallow- and deep-dose measurement capabilities using filters in the dosimeter. Data obtained from the two TLD-700 chips were used to determine the average total environmental dose at each location during 2009. The two TLD-200 chips were included to determine doses in the event of a radiological emergency and were not used in calculating average total environmental dose. The average daily dose rate was determined by dividing the average total environmental dose by the number of days the dosimeter was exposed. Daily dose equivalent rates (millirem per day) at each location were converted to annual dose equivalent rates (millirem per year) by averaging the daily dose rates and multiplying by 365 days per year. The TLDs were positioned approximately 1 meter ( 3.3 feet) above the ground and were collected and read quarterly.

Radiation surveys with portable instruments are conducted to monitor and detect contamination and to provide a coarse screening for external radiation fields. The types of areas surveyed in 2009 included underground radioactive material areas, contamination areas, soil contamination areas, highcontamination areas, roads, and fence lines.

\subsubsection{External Radiation Monitoring Near Hanford Site Facilities and Operations}

\section{CJ Perkins}

During 2009, external radiation fields were monitored with TLDs at 119 locations near onsite facilities and operations. The TLD results were used individually or averaged to determine dose rates in a given area for a specific sampling period. Table 8.11.1 compares 2008 and 2009 results for TLDs located near waste-handling facilities on the Hanford Site. Individual TLD results and detailed maps of monitoring locations are provided in PNNL-19455, APP. 2.

\subsubsection{External Radiation Measurements Onsite Near Facilities and Operations}

100-K Area. Cleanup activities for the K Basins Closure Project were ongoing during 2009. Removal of contaminated soil beneath the K-East Basin attributed to both a

(a) Harshaw is a trademark of Thermo Fisher Scientific, Inc., Waltham, Massachusetts. 


\begin{tabular}{|c|c|c|c|c|c|c|}
\hline \multirow{3}{*}{$\begin{array}{l}\text { Hanford Site } \\
\text { Locations }\end{array}$} & \multicolumn{5}{|c|}{$\begin{array}{l}\text { Table 8.11.1. Thermoluminescent Dosimeter Results }(\mathrm{mrem} / \mathrm{yr})^{(\mathrm{a})} \text { Near } \\
\text { Hanford Site Operations in } 2008 \text { and } 2009\end{array}$} & \multirow[b]{3}{*}{$\underline{\%}$ Change $^{(\mathrm{e})}$} \\
\hline & \multirow{2}{*}{$\begin{array}{c}\text { No. of } \\
\text { Dosimeters }\end{array}$} & \multicolumn{2}{|c|}{2008} & \multicolumn{2}{|c|}{2009} & \\
\hline & & ${\underline{\text { Maximum }^{(\mathbf{b})}}}$ & Average $^{(\mathrm{c}, \mathrm{d})}$ & ${\underline{\text { Maximum }^{(b)}}}^{(\mathbf{b}}$ & Average $^{(\mathrm{c}, \mathrm{d})}$ & \\
\hline 100-K Area & 14 & $574 \pm 42$ & $192 \pm 255$ & $1,525 \pm 2,814$ & $278 \pm 735$ & 45 \\
\hline 100-N Area & 5 & $106 \pm 9$ & $88 \pm 25$ & $133 \pm 64$ & $96 \pm 47$ & 10 \\
\hline 200-East Area & 42 & $280 \pm 37$ & $103 \pm 80$ & $285 \pm 55$ & $102 \pm 78$ & 0 \\
\hline 200-West Area & 24 & $259 \pm 135$ & $105 \pm 77$ & $189 \pm 21$ & $99 \pm 50$ & -5 \\
\hline \multicolumn{7}{|l|}{ 200-North Area } \\
\hline$(212-R)^{(f)}$ & 1 & $1,663 \pm 250$ & $1,647 \pm 26$ & $1,697 \pm 254$ & $1,552 \pm 323$ & -6 \\
\hline 300 Area & 8 & $103 \pm 7$ & $83 \pm 17$ & $101 \pm 9$ & $82 \pm 17$ & $<1$ \\
\hline 300 Area TEDF & 6 & $83 \pm 7$ & $81 \pm 3$ & $84 \pm 13$ & $80 \pm 5$ & $<1$ \\
\hline 300-FF-2 & 4 & $81 \pm 8$ & $79 \pm 4$ & $81 \pm 12$ & $80 \pm 10$ & $<1$ \\
\hline 400 Area & 7 & $94 \pm 9$ & $81 \pm 12$ & $92 \pm 8$ & $79 \pm 13$ & -2 \\
\hline CVDF & 4 & $302 \pm 18$ & $151 \pm 203$ & $243 \pm 316$ & $138 \pm 149$ & -8 \\
\hline ERDF & 3 & $80 \pm 10$ & $79 \pm 4$ & $91 \pm 23$ & $85 \pm 12$ & 8 \\
\hline $\mathrm{IDF}^{(\mathrm{f})}$ & 1 & $87 \pm 13$ & $85 \pm 5$ & $93 \pm 14$ & $88 \pm 7$ & 4 \\
\hline $\begin{array}{l}\text { (a) To convert tc } \\
\text { (b) Maximum va } \\
\text { (c) } \pm 2 \text { standard } \\
\text { (d) Each dosime } \\
\text { (e) Numbers ind } \\
\text { (f) Maximum va } \\
\text { CVDF = Cold } \\
\text { ERDF = Enviro } \\
\text { IDF = Integr } \\
\text { TEDF = Treate }\end{array}$ & $\begin{array}{l}\text { ernational metric sy } \\
\text { are } \pm \text { analytical un } \\
\text { ations. } \\
\text { collected and read } \\
\text { a decrease or incre } \\
\text { represents highest q } \\
\text { um Drying Facility } \\
\text { ental Restoration Di } \\
\text { Disposal Facility (2 } \\
\text { fluent Disposal Facil }\end{array}$ & $\begin{array}{l}\text { m units, multipl } \\
\text { tainty. } \\
\text { arterly. } \\
\text { from the } 2008 \\
\text { terly value } \pm \text { an } \\
\text { 0-K Area). } \\
\text {-Esal Facility (200 } \\
\text {-East Area). }\end{array}$ & $\begin{array}{l}\mathrm{mrem} / \mathrm{yr} \text { by } 0.0 \\
\text { lean. } \\
\text { lytical uncertai } \\
\text { West Area). }\end{array}$ & to obtain $\mathrm{mSv} /$ & & \\
\hline
\end{tabular}

noticeable increase in the average dose rates at the TLD locations in the immediate vicinity of the cleanup work as well as to a $45 \%$ increase in the overall average dose rate for the 100-K Area in 2009 compared to 2008 (Figure 8.11.1). Dose-rate levels measured in 2009 at monitoring stations in the K-West Area and the Cold Vacuum Drying Facility were, conversely, noticeably decreased compared to 2008 levels.

100-N Area. Average dose-rate levels observed in the 100-N Area during 2009 showed an increase of $10 \%$ compared to 2008 levels.

100-N Area Shoreline (N Springs). Dose rates were measured along the Columbia River shoreline in the $100-\mathrm{N}$ Area (N Springs) to determine potential external radiation doses to onsite workers and to the public accessing the river. Cleanup activities at the retired $116-\mathrm{N}-1$ and $116-\mathrm{N}-3$ Trenches (located near the Columbia River) have decreased dose rates notably over the past few years (Figure 8.11.1).
The 2009 dose rates were approximately 2\% lower than the 2008 dose rates and averaged less than 100 millirem (1 millisievert) per year.

200-East and 200-West Areas. Dose rates measured during 2009 in the 200-East and 200-West Areas were similar to those measured in 2008 (Figure 8.11.1).

Average dose rates measured in 2009 at the Environmental Restoration Disposal Facility (located near the 200-West Area) were approximately 8\% higher than 2008 levels.

200-North Area. One TLD monitoring site, located in the 200-North Area at the contaminated 212-R Railroad Car Disposition Area, showed annual average dose rates in 2009 to slightly decreased compared to 2008 levels. This TLD location was established in 2000 to monitor expected high radiation levels emitted from contaminated railroad cars.

300 and 400 Areas. The average dose rates in the 300 Area at the 300 Area Treated Effluent Disposal 

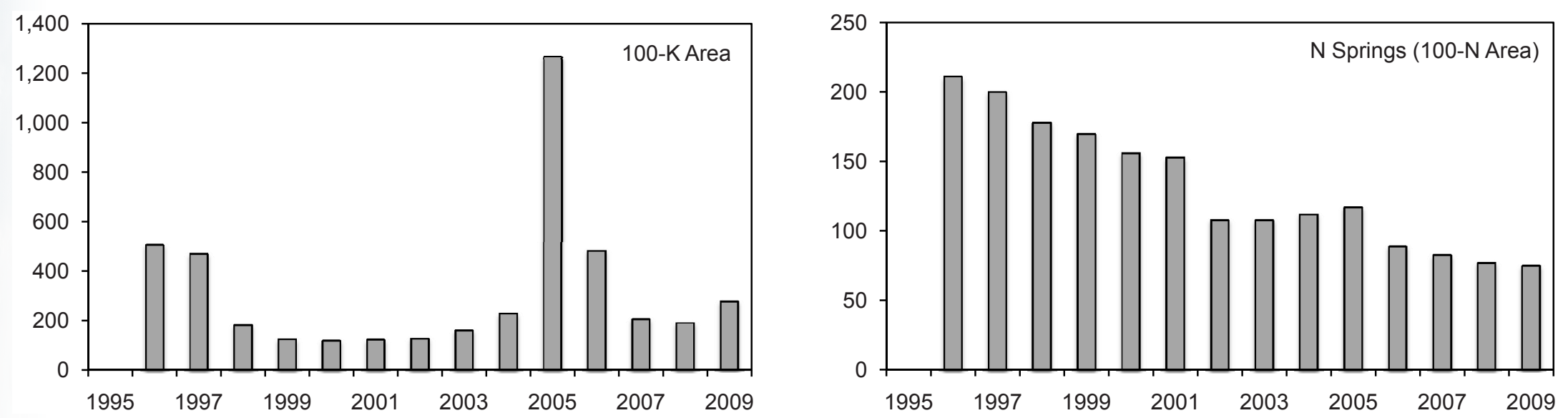

$\stackrel{\infty}{\vec{v}}$
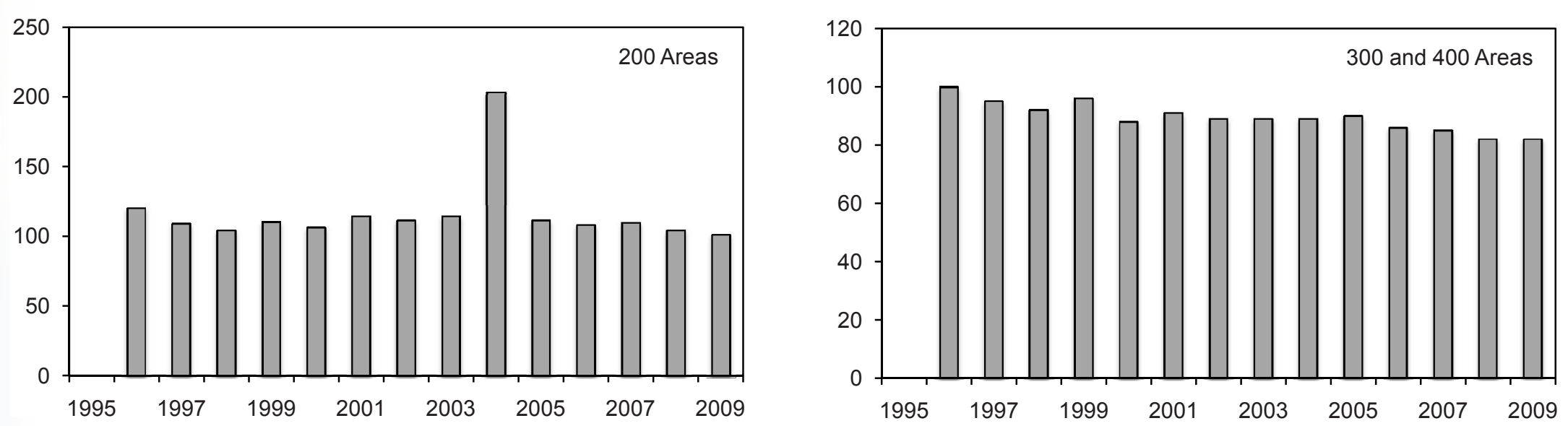

Figure 8.11.1. Annual Average Thermoluminescent Dosimeter Results in Selected Areas Near Facilities and Operations on the Hanford Site, 1996 Through 2009 
Facility and 300-FF-2 field remediation project site, and in the 400 Area in 2009 were comparable to 2008 levels (Figure 8.11.1).

\subsubsection{Radiological Surveys at Active and Inactive Waste Disposal Sites}

\section{SM McKinney}

During 2009, 560 environmental radiological surveys were conducted at active and inactive waste disposal sites and the surrounding terrain to detect and characterize radioactive surface contamination. Vehicles equipped with radiation detection devices and global positioning systems were used to accurately measure the extent of contamination. Area measurements were entered into the Hanford Geographical Information System, a computer database maintained by Mission Support Alliance, LLC. Routine radiological survey locations included former waste disposal cribs and trenches, retention basin perimeters, ditch banks, solid waste disposal sites (e.g., burial grounds), unplanned release sites, tank farm perimeters, stabilized waste disposal sites, roads, and firebreaks in and around the site operational areas. These sites were posted as underground radioactive material areas, contamination areas, and soil contamination areas. The external dose rate at $80 \%$ of the outdoor contamination areas was estimated to be less than 1 millirem (0.01 millisievert) per hour, although direct dose-rate readings from isolated radioactive specks could have been higher.

Underground radioactive material areas are regions where radioactive materials occur below the soil surface. These areas are typically stabilized cribs, burial grounds, covered ponds, trenches, and ditches. Barriers have been placed over the contamination sources to inhibit radionuclide transport to the surface. These areas are surveyed at least annually to assess the effectiveness of the barriers.

Contamination areas and soil contamination areas may or may not be associated with an underground structure containing radioactive material. A breach in the surface barrier of a contaminated underground area may result in the growth of contaminated vegetation. Insects or animals may burrow into the soil and bring contamination to the surface. Vent pipes or risers from an underground structure may be sources of speck contamination (particles with a diameter less than
0.6 centimeter $[0.25 \mathrm{inch}])$. Areas of contamination not related to subsurface structures can include sites contaminated with fallout from effluent stacks or with materials from unplanned releases (e.g., contaminated tumbleweeds and animal feces).

All contaminated areas may be susceptible to contaminant migration and are surveyed at least annually to assess their current radiological status (locations of posted contamination areas are illustrated in PNNL-19455, APP. 2). In addition, onsite paved roadways are surveyed annually, and the intersections along the Environmental Restoration Disposal Facility haul routes are surveyed quarterly.

CH2M HILL Plateau Remediation Company collected radiological data aerially from a 3,900-hectare (9,600-acre) region on the Hanford Site that included the BC Controlled Area and West Lake using a helicopter. Further information concerning this survey is found in Section 6.1.1.

During 2009, the Hanford Site had approximately 3,580 hectares $(8,850$ acres $)$ of outdoor contaminated areas of all types and approximately 580 hectares (1,430 acres) that contained underground radioactive materials, not including active facilities. Table 8.11.2 provides a list of contamination areas, underground radioactive material areas, and interim-closed waste sites as well as their status and general locations. No new areas of significant size were discovered during 2009. Waste sites are "interim-closed" and released from radiation posting when the remedial actions meet the record of decision cleanup requirements for the operable unit. During 2009, approximately 8 hectares (20 acres) of previously posted contamination and/or underground radioactive material areas underwent remediation action and were interim-closed. Table 8.11.3 summarizes the change in status of outdoor contamination areas during 2009.

\subsubsection{External Radiation Monitoring at Hanford Site- Wide and Offsite Locations}

\section{JP Duncan}

External radiation monitoring and radiation surveys at sitewide, offsite, and Columbia River shoreline locations were 
discontinued by Pacific Northwest National Laboratory at the end of calendar year 2005 because of DOE funding reductions. Data collected at these locations for many years indicate that current radiation levels are at or near background levels and are stable or decreasing as onsite cleanup activities progress. Readers interested in reviewing measurement and survey readings obtained in 2005 or earlier should refer to previous Hanford Site environmental reports and their data appendices (see http://hanfordsite.pnl.gov/envreport).

In response to DOE discontinuing the sitewide and offsite monitoring program in 2006, Washington State Department of Health added 26 TLD sites along the Columbia River to the original sites monitored by Pacific Northwest National Laboratory and began an independent monitoring program. Annual environmental radiation monitoring and assessment reports are available at http://www.doh.wa.gov/ehp/rp/rppubl.htm\#envrad.

\begin{tabular}{|c|c|c|c|c|c|c|}
\hline \multirow{3}{*}{$\underline{\text { Area }}$} & \multicolumn{5}{|c|}{$\begin{array}{l}\text { Table 8.11.2. Status of Outdoor Contamination Areas } \\
\text { on the Hanford Site, } 2009\end{array}$} & \\
\hline & \multicolumn{2}{|c|}{$\begin{array}{c}\text { Contamination } \\
\text { Areas, }{ }^{(a)} \text { ha (acres) }\end{array}$} & \multicolumn{2}{|c|}{$\begin{array}{c}\text { Underground } \\
\text { Radioactive Materials } \\
\text { Areas, }{ }^{\left({ }^{b}\right)} \text { ha (acres) } \\
\end{array}$} & $\begin{array}{c}\text { Interim } \\
\text { Closed, } \\
\text { ha (acres) }\end{array}$ & \\
\hline & 0 & (0) & 29 & (72) & 17 & (42) \\
\hline $100-\mathrm{D} / \mathrm{DR}$ & 0 & (0) & 20 & (50) & 8 & (20) \\
\hline $100-\mathrm{F}$ & 0 & (0) & 3 & $(7)$ & 19 & (47) \\
\hline $100-\mathrm{H}$ & 0 & (0) & 7 & (17) & 7 & (17) \\
\hline $100-K$ & 5 & (12) & 45 & (111) & 20 & (49) \\
\hline $100-\mathrm{N}$ & 0.4 & (1) & 16 & $(40)$ & 27 & (66) \\
\hline 200-East ${ }^{(c)}$ & 71 & $(175)$ & 141 & $(348)$ & 0 & (0) \\
\hline 200-West ${ }^{(c)}$ & 27 & $(67)$ & 224 & (554) & 0 & (0) \\
\hline 300 & 0 & $(0)$ & 42 & (104) & 22 & (54) \\
\hline 400 & 0 & (0) & 0 & (0) & 0 & (0) \\
\hline $600^{(\mathrm{d})}$ & 3,478 & $(8,594)$ & 51 & (126) & 4 & (10) \\
\hline Totals & 3,581 & $(8,849)$ & 578 & $(1,429)$ & 124 & (305) \\
\hline \multicolumn{7}{|c|}{$\begin{array}{l}\text { (a) Includes areas posted as contamination/soil contamination or as radiologically } \\
\text { controlled and areas that had both underground radioactive material and } \\
\text { contamination/soil contamination. } \\
\text { (b) Includes areas with only underground contamination. } \\
\text { (c) Includes tank farms. } \\
\text { (d) Includes BC Controlled Area, Environmental Restoration Disposal Facility, and } \\
\text { waste disposal facilities outside the 200-East and 200-West Areas boundaries. }\end{array}$} \\
\hline
\end{tabular}

\begin{tabular}{|c|c|c|c|}
\hline \multirow[b]{2}{*}{$\underline{\text { Areas }}$} & \multicolumn{2}{|c|}{$\begin{array}{l}\text { Table 8.11.3. Change in Status of Outdoor } \\
\text { Contamination Areas on the Hanford Site, } 2009\end{array}$} & \multirow[b]{2}{*}{ (acres) } \\
\hline & Changes & Area, $h$ & \\
\hline 100 & CA/URM to interim closed ${ }^{(\text {a) }}$ & 4 & $(10)$ \\
\hline 200-East & None to report & 0 & $(0)$ \\
\hline 200-North & None to report & 0 & (0) \\
\hline 200-West & None to report & 0 & $(0)$ \\
\hline 300 & None to report & 0 & (0) \\
\hline 400 & None to report & 0 & $(0)$ \\
\hline 600 & CA/URM to interim closed ${ }^{(a)}$ & 4 & $(10)$ \\
\hline Totals & & 8 & $(20)$ \\
\hline \multicolumn{4}{|c|}{$\begin{array}{l}\text { (a) Changes due to remediation activities. } \\
\text { CA = Contamination/soil contamination area. } \\
\text { URM = Underground radioactive material area. }\end{array}$} \\
\hline
\end{tabular}




\title{
8.12 Potential Radiological Doses from 2009 Hanford Site Operations
}

\author{
EJ Antonio, SF Snyder, and K Rhoads
}

During 2009, potential radiological doses to the public and biota from Hanford Site operations were evaluated in detail to determine compliance with pertinent regulations and limits. Potential sources of radionuclide contamination included gaseous emissions from stacks and ventilation exhausts, liquid effluent from operating wastewater treatment facilities, contaminated groundwater seeping into the Columbia River, and fugitive emissions from contaminated soil areas and facilities. The methods used to calculate the potential doses are detailed in Appendix E.

The radiological impacts of 2009 Hanford Site operations were assessed in terms of the following:

- Dose to a hypothetical, maximally exposed individual at an offsite location, evaluated by using a multimedia pathway assessment (DOE Order 5400.5, Chg 2; Section 8.12.1)

- Collective dose to the population residing within 80 kilometers (50 miles) of Hanford Site operation areas (Section 8.12.2)

- Doses for air pathways, evaluated using EPA methods, for comparison to the Clean Air Act standards in 40 CFR 61, Subpart H, "National Emission Standards for Emissions of Radionuclides Other Than Radon from Department of Energy Facilities" (Section 8.12.3)

- Dose to a worker consuming drinking water on the Hanford Site (Section 8.12.4.2)

- Doses from non-DOE industrial sources on and near the Hanford Site (Section 8.12.5)

- Absorbed dose received by organisms exposed to radionuclide releases to the Columbia River and to radionuclides in onsite surface water bodies (Section 8.12.6).
Radiological dose assessments are generally based on direct measurements of radiation dose rates and radionuclide concentrations. However, amounts of most radioactive materials released in 2009 from Hanford Site sources were generally too small to be measured directly after they were dispersed in the offsite environment. For many of the radionuclides present in measurable amounts, it was difficult to separate Hanford Site source contributions from contributions caused by fallout and naturally occurring uranium and its decay products. Therefore, in nearly all instances, offsite doses were estimated using GENII Version 2.09, Software Design Document (PNNL-14584, Rev. 3) and the Hanford Site-specific parameters listed in Appendix E and in PNNL-19455, APP. 1.

Calculations of radiation dose require the use of biological and radiological models of the behavior of radioactive material in the human body and in the environment. Scientific understanding of these processes has improved over time. For many decades, researchers have reported calculated doses for the Hanford Site to the public. In the 1960s, the annual environmental reporting at the Hanford Site used the recommendations and methodologies of the International Commission on Radiological Protection (ICRP) Report 2 (ICRP 1959). Similar techniques were used through the mid-1970s when the annual reports began to follow the newer recommendations of ICRP Reports 26 and 30 (ICRP 1977, 1979), and later incorporated the radiation weighting factors and tissue weighting factors of ICRP Publication 42 (ICRP 1984), along with dose factors from the EPA in Federal Guidance Reports 11 and 12 (EPA 520/1-88-020; EPA 402-R-93-081). The GENII Version 1 computer code, used at the Hanford Site since 1988, uses ICRP 26/30 methods, ICRP 42 weighting factors, 
and EPA dose factors. The computer code instituted with this year's annual report, GENII Version 2.09 (PNNL-14584, Rev. 3), incorporates the internal dosimetry models recommended in ICRP Reports 60 and 72 (ICRP 1990, 1996) and the radiological risk estimating procedures of Federal Guidance Report 13 (EPA 402-R-99-001) along with recently updated versions of environmental pathway analysis models.

Radiological doses from the water pathway were calculated based on known releases to the Columbia River from the 100 Areas (see Table 8.3.2) and the differences in radionuclide concentrations between upstream and downstream sampling points on the Columbia River (considered the contribution from the 200 Areas). During 2009, tritium and uranium isotopes were found in the Columbia River downstream of the Hanford Site at greater levels than predicted, based on direct discharges from the 100-K Area (Section 8.4 and Appendix C). All other radionuclide concentrations in river water were lower than those predicted from known releases. Columbia River shoreline spring water containing radionuclides is known to enter the river along the portion of the site shoreline extending from the $100-\mathrm{B} / \mathrm{C}$ Area downstream to the 300 Area (Sections 8.5 and 8.7). No direct discharge of radioactive materials from the 300 Area to the Columbia River was reported during 2009.

\subsubsection{Maximally Exposed Individual Dose (Offsite Resident)}

The maximally exposed individual is a hypothetical person who lives at a specific location and has a lifestyle that makes it unlikely any member of the public would have received a higher radiological dose from Hanford Site releases during 2009. This individual's exposure pathways were chosen to maximize the combined doses from all reasonable environmental routes of exposure to radionuclides in Hanford Site effluents and emissions using a multimedia pathway assessment (DOE Order 5400.5, Chg 2). In reality, such a combination of maximized exposures to radioactive materials is highly unlikely to apply to any single individual.

The location of the hypothetical, maximally exposed individual varies, depending on the relative contributions of the several sources of radioactive emissions released to the air and liquid effluents released to the Columbia River from Hanford Site facilities (Figure 8.12.1). During 2009, the dose assessment determined that the maximally exposed individual was located across the Columbia River (east of

Historically at the Hanford Site, there has been one primary expression of radiological risk to an offsite individual—this is the maximally exposed individual dose. However, the maximally exposed individual dose is currently calculated by two different methods in response to two different requirements. One maximally exposed individual dose computation is required by DOE Order 5400.5, Chg 2 and is calculated using the GENII computer code. This calculation considers all reasonable environmental pathways (e.g., air, water, and food) that maximize a hypothetical individual's offsite exposure to the Hanford Site's radiological effluent and emissions. A second estimate of maximally exposed individual dose is required by the Clean Air Act and is calculated using an EPA dose modeling computer code (CAP88) or other methods accepted by the EPA for estimating offsite exposure. This offsite dose is based solely on an airborne radionuclide emissions pathway and considers the site's stack emissions and emissions from diffuse and unmonitored sources (e.g., windblown dust).

Because the DOE and EPA computer codes use different input parameters, the location and predicted dose of each agency's maximally exposed individual may be different. However, the estimated doses from both methods have historically been significantly lower than health-based exposure criteria.

Recently, the DOE has allowed private businesses to locate their activities and personnel on the Hanford Site. This has created the need to calculate a maximum dose for an onsite individual who is employed by a non-DOE business and works within the boundary of the Hanford Site. This dose is based on a mix of air-emission modeling data, the individual's exposure at an onsite work location, and the individual's potential offsite exposure.

Another way to estimate risk is to calculate the collective dose. This dose is based on exposure to Hanford Site radiological contaminants through food, water, and air pathways and is calculated for the population residing within 80 kilometers (50 miles) of the Hanford Site operation areas. The collective dose is reported in units of person-rem (person-sievert), which is the sum of doses to all individuals in an exposed population. 


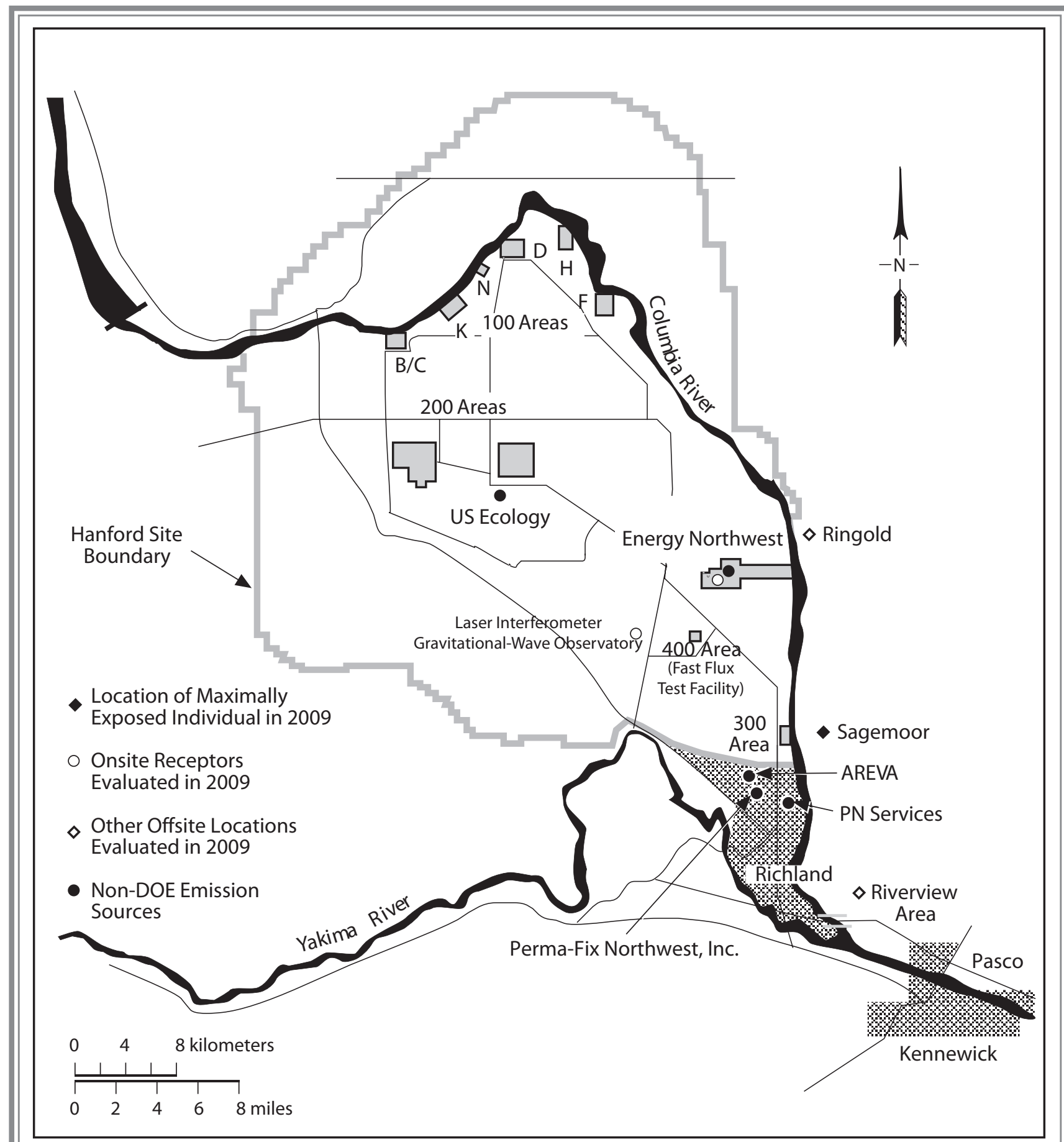

G07040018.96

Figure 8.12.1. Locations Important to Dose Calculations at the Hanford Site, 2009 
the Hanford Site) at Sagemoor. For the calculation, it was assumed this individual had performed the following:

- Inhaled and was immersed in airborne radionuclides

- Received external exposure to radionuclides deposited on the ground

- Ingested locally grown food products irrigated with Columbia River water and/or containing radionuclides deposited from the air

- Used the Columbia River near the Hanford Site for recreational purposes, resulting in direct exposure from radionuclides in water and radionuclides deposited on the shoreline

- Consumed locally caught Columbia River fish.

Doses were calculated using Hanford Site air emissions and liquid effluent data (Tables 8.1.1 and 8.3.2) and the calculated quantities of radionuclides assumed to be present in the Columbia River from site shoreline spring discharges. The estimated radionuclide releases to the Columbia River from these sources were derived from the difference between the upstream and downstream (Appendix C, Tables C.3 and C.4, respectively) radionuclide concentrations in river water. These radionuclides were assumed to originate from historical releases of contaminants to the ground in the 100 and 200 Areas, and to have entered the Columbia River through shoreline groundwater springs between the 100-B/C Area and the 300 Area.

During 2009, the total dose to the maximally exposed individual at Sagemoor (Figure 8.12.1) was calculated to be 0.12 millirem (1.2 microsievert) per year (Table 8.12.1; Figure 8.12 .2 ). This dose was $0.12 \%$ of the 100 -millirem (1,000-microsievert) per-year standard specified in DOE Order 5400.5, Chg 2. The primary pathways (Appendix E, Tables E.1 through E.4) contributing to this dose (and the percentage of all pathways) were as follows:

- The inhalation of air downwind from the Hanford Site (19\%) and the consumption of food products grown downwind from the Hanford Site (approximately 43\%), resulting from exposure to airborne releases of tritium and radon from the 300 Area

- The consumption of food irrigated with Columbia River water withdrawn downstream from the Hanford Site (14\%) and consumption of fish from the Columbia River (23\%), resulting primarily from exposure to uranium isotopes and tritium in the river.

For comparison purposes, the maximally exposed individual dose calculations were also made using the older version

\begin{tabular}{|c|c|c|c|c|c|c|}
\hline \multirow[b]{3}{*}{ Effluent } & \multicolumn{5}{|c|}{$\begin{array}{l}\text { Table 8.12.1. Dose to the Hypothetical, Maximally Exposed Individual Residing } \\
\text { at Sagemoor from 2009 Hanford Site Operations (using GENII Version 2.09) }\end{array}$} & \\
\hline & \multirow[b]{2}{*}{ Pathway } & \multicolumn{5}{|c|}{ Dose Contributions from Operating Areas, mrem $^{(a)}$} \\
\hline & & $\begin{array}{c}100 \\
\underline{\text { Areas }}\end{array}$ & $\begin{array}{c}200 \\
\underline{\text { Areas }}\end{array}$ & $\begin{array}{l}300 \\
\underline{\text { Area }}\end{array}$ & $\begin{array}{l}400 \\
\underline{\text { Area }}\end{array}$ & $\begin{array}{l}\text { Pathway } \\
\text { Total }\end{array}$ \\
\hline \multirow[t]{2}{*}{ Air } & $\begin{array}{l}\text { External } \\
\text { Inhalation } \\
\text { Foods }\end{array}$ & $\begin{array}{l}5.0 \times 10^{-9} \\
4.1 \times 10^{-6} \\
1.4 \times 10^{-6}\end{array}$ & $\begin{array}{l}1.4 \times 10^{-7} \\
5.0 \times 10^{-6} \\
9.9 \times 10^{-5}\end{array}$ & $\begin{array}{l}5.4 \times 10^{-4} \\
2.3 \times 10^{-2} \\
5.4 \times 10^{-2}\end{array}$ & $\begin{array}{l}3.4 \times 10^{-9} \\
4.0 \times 10^{-10} \\
6.5 \times 10^{-8}\end{array}$ & $\begin{array}{l}5.4 \times 10^{-4} \\
2.3 \times 10^{-2} \\
5.4 \times 10^{-2}\end{array}$ \\
\hline & Subtotal air & $5.5 \times 10^{-6}$ & $1.0 \times 10^{-4}$ & $7.7 \times 10^{-2}$ & $6.8 \times 10^{-8}$ & $7.7 \times 10^{-2}$ \\
\hline \multirow[t]{2}{*}{ Water } & $\begin{array}{l}\text { Recreation } \\
\text { Foods } \\
\text { Fish }\end{array}$ & $\begin{array}{l}3.4 \times 10^{-6} \\
7.8 \times 10^{-5} \\
6.5 \times 10^{-4}\end{array}$ & $\begin{array}{l}2.1 \times 10^{-4} \\
1.7 \times 10^{-2} \\
2.8 \times 10^{-2}\end{array}$ & $\begin{array}{l}0.0 \\
0.0 \\
0.0\end{array}$ & $\begin{array}{l}0.0 \\
0.0 \\
0.0\end{array}$ & $\begin{array}{l}2.1 \times 10^{-4} \\
1.7 \times 10^{-2} \\
2.9 \times 10^{-2}\end{array}$ \\
\hline & Subtotal water & $7.3 \times 10^{-4}$ & $4.6 \times 10^{-2}$ & 0.0 & 0.0 & $4.7 \times 10^{-2}$ \\
\hline Combined total & & $7.4 \times 10^{-4}$ & $4.6 \times 10^{-2}$ & $7.7 \times 10^{-2}$ & $6.8 \times 10^{-8}$ & $1.2 \times 10^{-1}$ \\
\hline
\end{tabular}




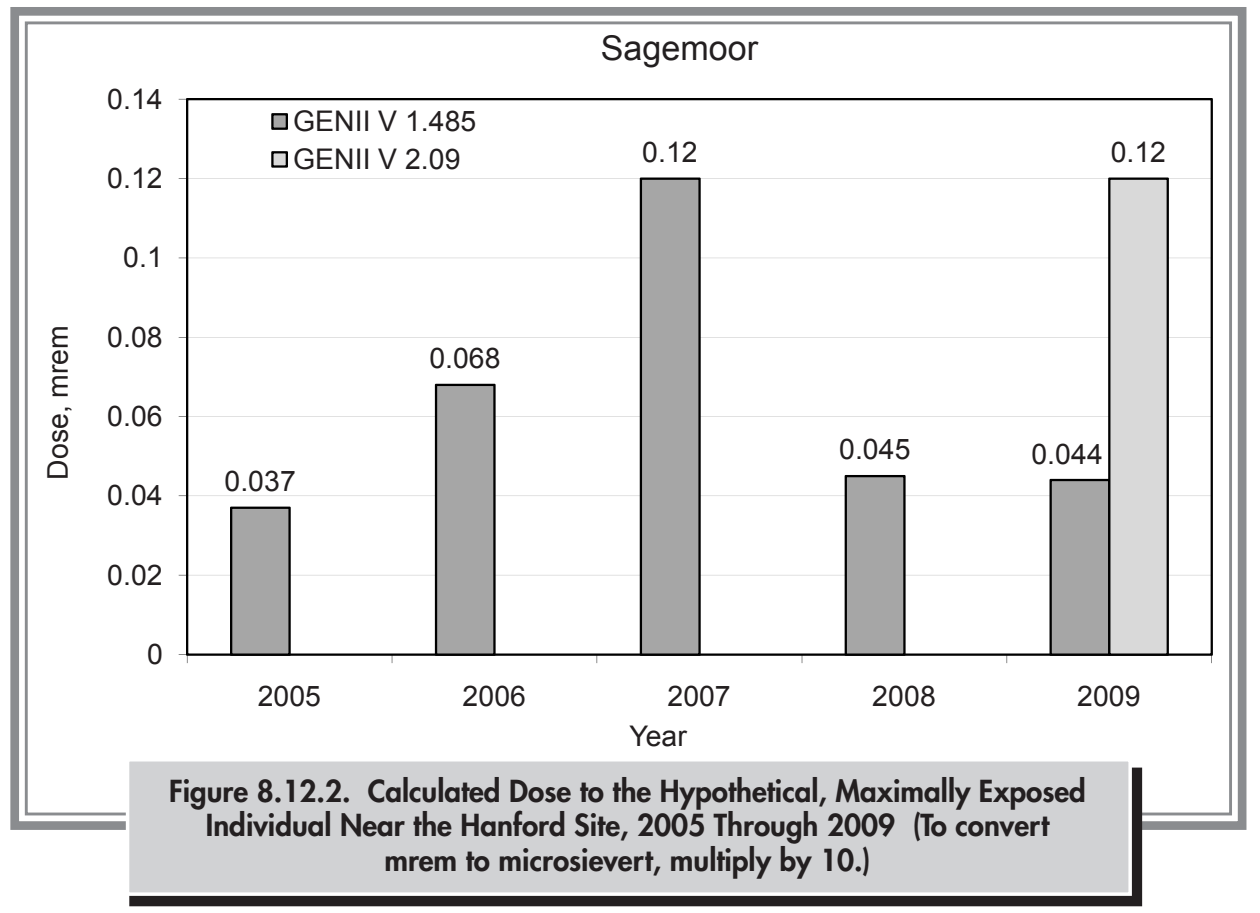

of the GENII 1.485 (Appendix E, Table E.7). GENII Version 2.09 results are approximately 2.5 times higher than those of the older version.

\subsubsection{Collective Dose}

Collective dose is defined as the sum of doses to all individual members of the public within a defined distance of a specific location. The regional collective dose from 2009 Hanford Site operations was estimated by calculating the radiological dose to the population residing within an 80-kilometer (50-mile) radius of onsite operating areas (Appendix E, Tables E.5 and E.6). During 2009, the collective dose calculated for the population using GENII Version 2.09 was 1 person-rem (0.01 person-sievert) per year (Table 8.12.2; Figure 8.12.3), which is about 2.3 times the 2008 collective dose $(0.44$ person-rem $[0.0044$ personsievert] per year), calculated using GENII Version 1.485 (Appendix E, Table E.8). This increase is in the same range seen in the Sagemoor maximally exposed individual dose for GENII Version 2.09 year-2009 calculation and the GENII Version 1.485 year-2008 calculation (see Section 8.12.1). The 2009 population dose calculated using GENII Version 1.485 was 0.47 person-rem $(0.0047$ personsievert) per year (Figure 8.12.3).
Primary pathways contributing to the 2009 collective dose (and the percentage of all pathways) included the following:

- Consumption of food grown downwind of the Hanford Site (approximately 21\%) and inhalation of radionuclides $(11 \%)$ that were released to the air, principally tritium and radon from the 300 Area and iodine-129 from the 200 Areas

- Consumption of water withdrawn from the Columbia River downstream of the Hanford Site $(65 \%)$ and foods irrigated with water withdrawn from the Columbia River downstream of the site (approximately 2\%) containing tritium, uranium-234, and uranium-238.

Collective doses reported for 2009 are based on population data from the 2000 census. The collective dose is reported in units of person-rem (person-sievert), which is the sum of doses to members of the exposed population. Between 1990 and 2000, the population within 80 kilometers (50 miles) of each of the major Hanford Site operating areas increased $24 \%$ to $29 \%$.

The average individual dose from Hanford Site operations, based on a population of 486,000 within 80 kilometers (50 miles) of the site, was approximately 0.002 millirem 


\begin{tabular}{|c|c|c|c|c|c|c|}
\hline \multirow[b]{3}{*}{ Effluent } & \multicolumn{5}{|c|}{$\begin{array}{l}\text { Table 8.12.2. Collective Dose to the Population from } 2009 \text { Hanford } \\
\text { Site Operations (using GENII Version 2.09) }\end{array}$} & \\
\hline & \multirow[b]{2}{*}{ Pathway } & \multicolumn{4}{|c|}{ Dose Contributions from Operating Areas, person-rem ${ }^{(a)}$} & \\
\hline & & $\begin{array}{c}100 \\
\text { Areas }\end{array}$ & $\begin{array}{c}200 \\
\text { Areas }\end{array}$ & $\begin{array}{l}300 \\
\text { Area }\end{array}$ & $\begin{array}{l}400 \\
\text { Area }\end{array}$ & $\begin{array}{l}\text { Pathway } \\
\text { Total }\end{array}$ \\
\hline \multirow[t]{3}{*}{ Air } & External & $1.9 \times 10^{-6}$ & $1.5 \times 10^{-5}$ & $2.8 \times 10^{-3}$ & $1.4 \times 10^{-7}$ & $2.8 \times 10^{-3}$ \\
\hline & Inhalation & $1.1 \times 10^{-3}$ & $8.9 \times 10^{-4}$ & $1.1 \times 10^{-1}$ & $2.5 \times 10^{-8}$ & $1.1 \times 10^{-1}$ \\
\hline & Foods & $1.8 \times 10^{-4}$ & $1.1 \times 10^{-2}$ & $2.0 \times 10^{-1}$ & $2.9 \times 10^{-0}$ & $2.1 \times 10^{-1}$ \\
\hline \multirow{5}{*}{ Water } & Recreation & $1.5 \times 10^{-5}$ & $1.1 \times 10^{-3}$ & 0.0 & 0.0 & $1.2 \times 10^{-3}$ \\
\hline & Foods & $1.1 \times 10^{-4}$ & $1.8 \times 10^{-2}$ & 0.0 & 0.0 & $1.8 \times 10^{-2}$ \\
\hline & Fish & $2.4 \times 10^{-4}$ & $1.1 \times 10^{-2}$ & 0.0 & 0.0 & $1.1 \times 10^{-2}$ \\
\hline & Drinking water & $5.7 \times 10^{-4}$ & $6.5 \times 10^{-1}$ & 0.0 & 0.0 & $6.5 \times 10^{-1}$ \\
\hline & Subtotal water & $9.4 \times 10^{-4}$ & $6.8 \times 10^{-1}$ & 0.0 & 0.0 & $6.8 \times 10^{-1}$ \\
\hline Combined total & & $2.2 \times 10^{-3}$ & $6.9 \times 10^{-1}$ & $3.1 \times 10^{-1}$ & $3.1 \times 10^{-6}$ & $1.0 \times 10^{0}$ \\
\hline
\end{tabular}

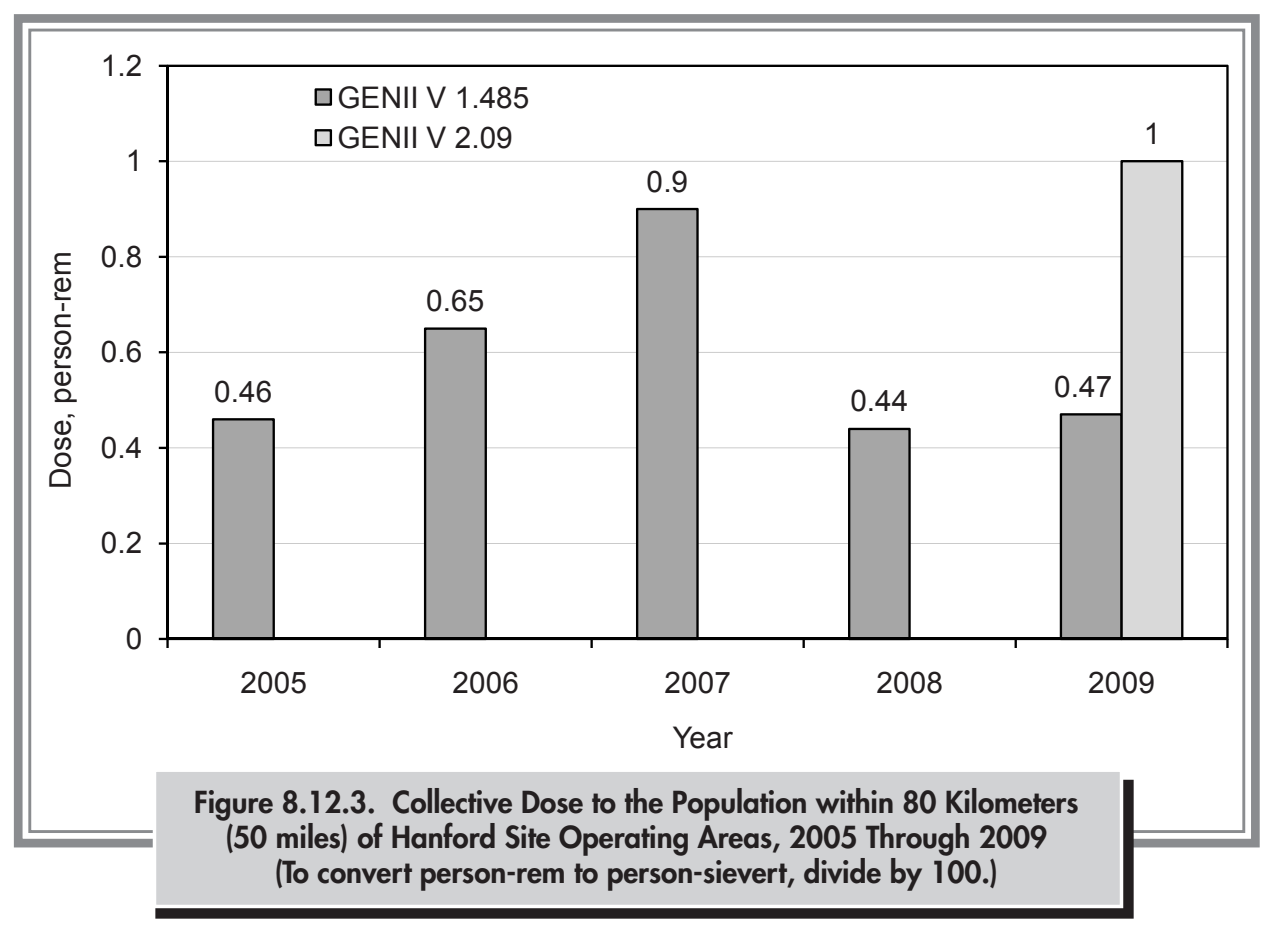

(0.02 microsievert) in 2009. To place this estimated dose into perspective, it may be compared with doses received from other routinely encountered sources of radiation, such as natural terrestrial and cosmic background radiation, medical treatment and $\mathrm{x}$-rays, natural radionuclides in the body, and inhalation of naturally occurring radon
(Figure 8.12.4). In March 2009, the National Council on Radiation Protection issued Report 160, which concluded that Americans were exposed to more than seven times as much ionizing radiation from medical procedures as was the case in the 1980s, causing the overall average exposure to ionizing radiation for the average American to rise from 


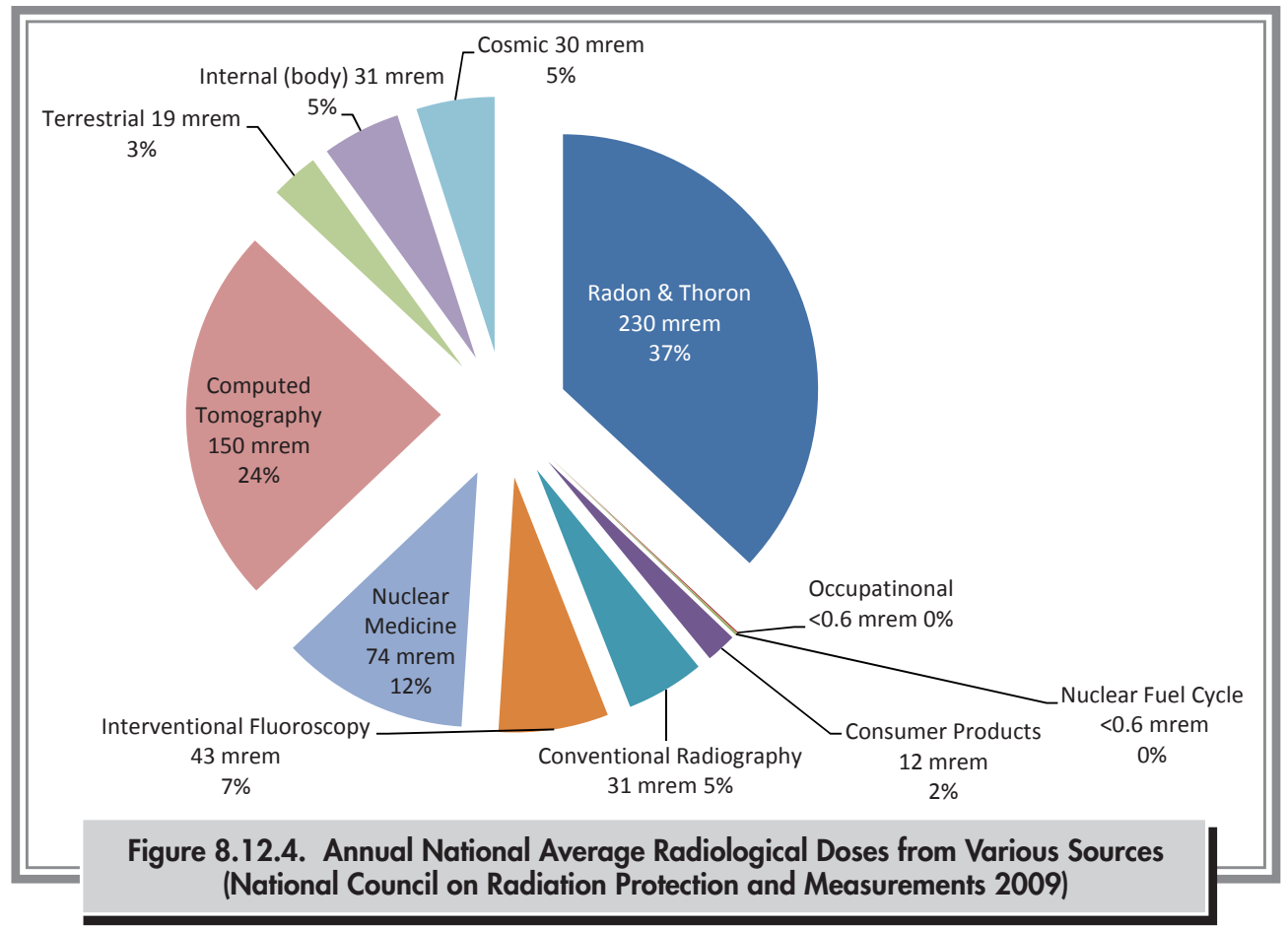

360 to 620 millirem (3,600 to 6,200 microsievert) per year (National Council on Radiation Protection and Measurements 2009). The estimated annual average individual dose to members of the public from Hanford Site sources in 2009 was approximately $0.0007 \%$ of the estimated annual individual dose received from natural background sources (approximately 310 millirem [3,100 microsievert]). The calculated radiological doses from Hanford Site operations in 2009 were a small percentage of the federal standards and of doses from natural background sources (Table 8.12.3).

\subsubsection{Compliance with Clean Air Act Standards}

In addition to complying with the all-pathways dose limits established by DOE Order 5400.5, Chg 2, officials managing DOE facilities are required to demonstrate that their facilities comply with standards established by EPA for airborne radionuclide emissions under the Clean Air Act in 40 CFR 61, Subpart H. This regulation specifies that no member of the public shall receive a dose greater than 10 millirem (100 microsievert) per year from exposure to airborne radionuclide emissions (other than radon) released at DOE facilities. Whereas DOE uses the GENII computer code at the Hanford Site to determine dose to the allpathways maximally exposed individual, EPA requires the use of the CAP-88 computer code (EPA 402-R-00-004) or other EPA-approved computer models to demonstrate compliance with the requirements in 40 CFR 61, Subpart H. The assumptions embodied in the CAP- 88 computer code differ slightly from standard assumptions used with the GENII computer code. Therefore, air-pathway doses calculated by the two codes may differ somewhat. In addition, the maximally exposed individual for air pathways may be evaluated at a different location from the all-pathways maximally exposed individual because of the relative contributions from each exposure pathway (Section 8.12.1).

The EPA regulation also requires that an annual report for each DOE facility be submitted to EPA that supplies information about atmospheric emissions for the preceding year and their potential contributions to offsite dose. For more detailed information about 2009 air emissions at the Hanford Site, refer to the DOE's report to EPA, Radionuclide Air Emissions Report for the Hanford Site, Calendar Year 2009 (DOE/RL-2010-17). 
Table 8.12.3. Comparison of 2009 Doses to the Public from Hanford Site Effluent and Emissions to Federal Standards and Natural Background Levels

\section{Federal Standard}

DOE - $100 \mathrm{mrem} / \mathrm{yr}^{(\mathrm{a})}$ all pathways MEI ${ }^{(b)}$

$\mathrm{EPA}-10 \mathrm{mrem} / \mathrm{yr}^{(\mathrm{a})}$ air pathway $M E I^{(c)}$

\section{Background Dose}

$310 \mathrm{mrem} / \mathrm{yr}$ average from

natural background

U.S. individual ${ }^{(\mathrm{d})}$

150,700 person-rem/yr

to population within

$80 \mathrm{~km}(50 \mathrm{mi})^{(\mathrm{e})}$
Hanford Site Dose

0.12

0.032
Percent of Standard or of Background Dose

0.12

0.032

(a) To convert the dose values to microsievert, multiply by 10 .

(b) DOE Order 5400.5, Chg 2.

(c) 40 CFR 61.

(d) National Council on Radiation Protection and Measurements (2009).

(e) To convert the dose values to person-sievert, divide by 100 .

DOE $=$ U.S. Department of Energy.

$\mathrm{EPA}=$ U.S. Environmental Protection Agency.

MEI = Maximally exposed individual.

\subsubsection{Dose to an Offsite Maximally Exposed Individual}

Using EPA-specified methods, the maximally exposed offsite individual for air pathways in 2009 was in the Sagemoor area of Franklin County, approximately 1.4 kilometers (0.8 mile) east of the 300 Area, across the Columbia River (Figure 8.12.1). The potential air pathway dose from stack emissions (excluding radon) to a maximally exposed individual at that location calculated using the CAP-88 computer code was determined to be 0.032 millirem (0.32 microsievert) per year, which represented less than $1 \%$ of the EPA standard.

The dose from radon-220 and radon-222 was 0.015 millirem (0.15 microsievert) in 2009. Radon is not included in the dose calculated for compliance with the EPA standard in 40 CFR 61, but is regulated by the 10-millirem (100-microsievert) per year standard established by Washington State in WAC 246-247. The total dose from stack emissions was therefore 0.047 millirem ( 0.47 microsievert) per year, including radon, which represented less than $1 \%$ of the Washington State standard. This is similar to the offsite individual doses calculated in previous years and to the air pathway doses for stack emissions in Table 8.12.1.

\subsubsection{Maximum Dose to Non- U.S. Department of Energy Workers at the Hanford Site}

The DOE Richland Operations Office received guidance from the EPA Region 10 office and the Washington State Department of Health that, in demonstrating compliance with 40 CFR 61 standards, it should evaluate potential doses to non-DOE employees who work at facilities within the Hanford Site but who are not under direct DOE control. Accordingly, doses to members of the public employed at non-DOE facilities who were outside access-controlled areas on the Hanford Site (those requiring DOE-access authorization for entry) were evaluated for the $2009 \mathrm{EPA}$ air emissions report (DOE/RL-2010-17). These locations included the Columbia Generating Station operated by Energy Northwest and the Laser Interferometer Gravitational Wave Observatory operated by the University of 
California (Figure 8.12.1). Of those locations, an employee at the Laser Interferometer Gravitational Wave Observatory received the highest dose for non-DOE employees who worked at the Hanford Site. The dose from stack emissions calculated using the CAP-88 computer code was 0.0042 millirem (0.042 microsievert) per year, assuming fulltime occupancy.

EPA guidance does not currently allow for adjustment of doses calculated using the CAP-88 computer code to account for less than full-time occupancy at locations within the Hanford Site boundary. However, if an occupancy period of 2,000 hours per year was assumed for employees at onsite non-DOE facilities, the doses to employees at any of the locations evaluated would be lower than the dose reported for the Laser Interferometer Gravitational Wave Observatory. In 2009, the estimated doses to all nonDOE onsite workers were lower than the dose to an offsite maximally exposed individual.

\subsubsection{Dose from Diffuse and Fugitive Radionuclide Emissions}

The December 15, 1989, revisions to the Clean Air Act (40 CFR 61, Subpart H) required DOE facilities to estimate the dose to a member of the public for radionuclides released from all potential sources of airborne radionuclides. DOE and EPA interpreted the regulation to include diffuse (widespread) and fugitive (unintended) emissions, as well as emissions from monitored point sources (i.e., stacks). EPA has not specified or approved standardized methods to estimate diffuse air-emissions because of the wide variety of sources at DOE sites. The method developed at the Hanford Site to estimate potential diffuse emissions is based on environmental monitoring measurements of airborne radionuclides at the site perimeter (DOE/RL-2010-17).

During 2009, the estimated dose from diffuse emissions to a maximally exposed individual at a location in the Sagemoor area was calculated using the CAP-88 computer code to be 0.021 millirem (0.21 microsievert) per year. This is similar to results for recent years, where the dose from diffuse emissions has been comparable to the dose from stack emissions. The dose to an onsite non-DOE worker from diffuse and fugitive emissions would be similar to, or lower than, the dose at the site perimeter. Therefore, the potential combined dose from stack emissions and diffuse emissions during 2009 was well below the EPA 10-millirem (100-microsievert) per year standard for either onsite or offsite members of the public.

\subsubsection{Special Case Dose Estimates}

The parameters used to calculate the dose to the maximally exposed individual were selected to provide a scenario yielding a reasonable upper (or bounding) dose estimate. However, such a scenario may not have necessarily resulted in the highest conceivable radiological dose. Other lowprobability exposure scenarios existed that could have resulted in somewhat higher doses. Two scenarios that could have potentially led to larger doses included 1) a person who consumed contaminated wildlife that migrated from the Hanford Site, and 2) a person who drank water at the Fast Flux Test Facility in the 400 Area. The potential doses resulting from these scenarios are examined in the following sections.

\subsubsection{Outdoor Recreationalist Dose}

Wildlife have access to Hanford Site areas that are contaminated with radioactive materials and have the potential to acquire radioactive contamination and migrate off the site. Wildlife sampling was conducted on the Hanford Site to estimate the maximum contamination levels that might have existed in animals from the site that were hunted or fished offsite. Because this scenario had a relatively low probability of occurrence, this pathway was not considered in the maximally exposed individual calculation.

Radionuclides detected in routinely collected wildlife samples during 2009 included potassium-40, a primordial radioisotope not of Hanford Site origin, and strontium-90, an anthropogenic radionuclide produced in the fission process and present in worldwide fallout from historic nuclear weapons tests. The maximum detectable concentration of strontium-90 $(0.12 \mathrm{pCi} / \mathrm{g}[4.4 \mathrm{~Bq} / \mathrm{kg}])$ was measured in a Canada goose bone sample collected onsite between the old Hanford town site and the 300 Area, north of the city of Richland. Because bone is not normally consumed by humans, it is not considered further. 


\subsubsection{Onsite Drinking Water}

During 2009, drinking water was sampled and analyzed throughout the year in accordance with applicable regulations (40 CFR 141). Tap water samples were collected from the $100-\mathrm{K}, 100-\mathrm{N}, 200-$ West, and 400 Areas. The annual average radionuclide concentrations measured during 2009 were below applicable drinking water standards. Tritium was the only radionuclide identified above detection limits and only in the 400 Area tap water samples.

Based on the annual average tritium concentration of 2,030 $\mathrm{pCi} / \mathrm{L}(75 \mathrm{~Bq} / \mathrm{L})$, the potential annual dose to a worker at the Fast Flux Test Facility (400 Area) in 2009 would be approximately 0.03 millirem $(0.3$ microsievert) (Appendix E, Table E.9). This dose estimate was derived by assuming a consumption rate of 1 liter ( 0.26 gallon) per day for 250 working days and is well below the drinking water dose limit of 4 millirem (40 microsievert) per year for public drinking water supplies.

\subsubsection{Doses from Non- U.S. Department of Energy Sources}

DOE Order 5400.5, Chg 2, Chapter II, Paragraph 7, has a reporting requirement for a combined dose due to DOE and other manmade sources that exceeds 100 millirem (1,000 microsievert) per year. During 2009, various nonDOE industrial sources of public radiation exposure existed on or near the Hanford Site. These included a commercial, low-level, radioactive waste burial ground at the Hanford Site operated by U.S. Ecology; a nuclear power-generating station at the Hanford Site operated by Energy Northwest; a nuclear-fuel production plant operated near the site by AREVA NP, Inc.; a commercial, low-level, radioactive waste treatment facility operated near the site by Perma-Fix Northwest, Inc.; and a commercial decontamination facility operated near the site by PN Services (Figure 8.12.1).

DOE maintains an awareness of these other sources of radiation, which, if combined with the DOE sources, might have the potential to cause a dose exceeding 10 millirem (100 microsievert) per year to any member of the public. With information gathered from these companies through personal communication and annual reporting, it was conservatively estimated that the total 2009 individual dose from non-DOE source activities was about 0.007 millirem (0.07 microsievert) per year. Therefore, the combined annual dose from non-DOE and DOE sources on and near the site to a member of the public for 2009 was well below any regulatory dose limit.

\subsubsection{Dose to Non-Human Biota}

Upper estimates of the radiological dose to aquatic organisms were made in accordance with the DOE Order 5400.5, Chg 2 interim requirement for management and control of liquid discharges. The current dose limit for native-aquatic animal organisms is $1 \mathrm{rad}$ (10 milligray) per day. The proposed dose limit for terrestrial biota is $0.1 \mathrm{rad}$ ( 1 milligray) per day.

Concentration guides for assessing doses to biota are very different from the DOE-derived concentration guides used to assess radiological doses to humans. A screening method is used to estimate radiological doses to aquatic and terrestrial biota. This method uses the RESRAD-BIOTA computer code (DOE/EH-0676; DOE/STD-1153-2002) to compare radionuclide concentrations measured by routine monitoring programs to a set of conservative biota concentration guides (e.g., the water concentration of a radionuclide that would produce $1 \mathrm{rad}$ [10 milligray] per day for aquatic biota). For samples containing multiple radionuclides, a sum of fractions is calculated to account for the contribution to dose from each radionuclide relative to the dose guideline. If the sum of fractions exceeds 1.0, then the dose guideline has been exceeded. If the initial estimated screening value (Tier 1) exceeds the guideline (sum of fractions more than 1.0), another screening calculation is performed (Tier 2) to more accurately evaluate exposure of the biota to the radionuclides. The process may culminate in a site-specific assessment requiring additional sampling and study of exposure. Biota-dose screening assessments were conducted using surveillance data collected in 2009 from on and around the Hanford Site.

Researchers used the RESRAD-BIOTA computer code to evaluate the maximum concentrations of radionuclides 
measured in sediment, onsite pond water, and Columbia River shoreline spring water as tabulated in Appendix C. Riverbank springs carry groundwater contaminants into the Columbia River at greater concentrations than observed in river water and provide another level of conservatism in the biota dose assessment process. The results of the screening calculations show that the concentrations in nearly all water and sediment samples passed the Tier 1 screen, indicating that the calculated doses were below the dose limits and guidelines (sum of fractions less than 1.0). West Lake, an onsite pond, however, was evaluated by further screening calculations (Tier 2) and its calculated dose was also below the dose limits and guidelines (sum of fractions less than 1.0) (Table 8.12.4).

\subsubsection{Radiological Dose in Perspective}

Scientific studies (National Research Council 1980, 1990; United Nations Science Committee on the Effects of Atomic Radiation 1988) have been performed to estimate the possible risk from exposure to low levels of radiation. These studies provided information to government and scientific organizations and are used to recommend radiological dose limits and standards for public and occupational safety.

Although no increase in the incidence of health effects from low doses of radiation has actually been confirmed by the scientific community, regulatory agencies cautiously assume that the probability of these types of health effects occurring due to exposure to low doses (down to zero dose) is the same per unit dose as the health effects observed after an exposure to much higher doses (e.g., in atomic bomb survivors, individuals receiving medical exposure, or painters of radium dials). This concept is known as the linear no-threshold hypothesis. Under these assumptions, even natural background radiation, which is hundreds of times greater than radiation from current Hanford Site releases, increases each individual's probability or chance of developing a detrimental health effect.

Scientists do not fully agree on how to translate the available data on health effects into the numerical probability

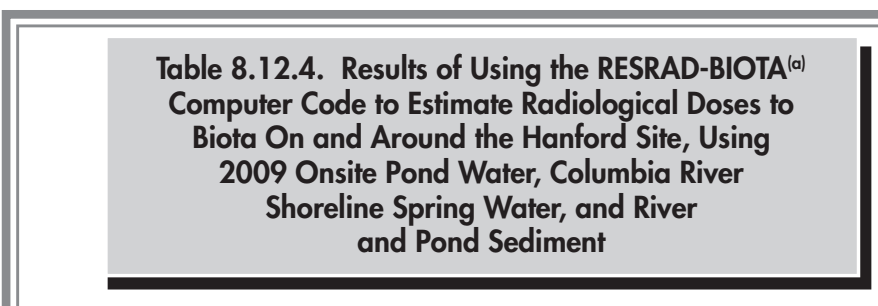

\begin{tabular}{|c|c|c|}
\hline Location & $\begin{array}{c}\text { Tier } 1 \text { Screen, } \\
\text { Sum of Fractions }^{(\mathbf{b})}\end{array}$ & $\underline{\text { Pass or Fail }}$ \\
\hline 100-B Area & 0.007 & Pass \\
\hline 100-D Area & 0.005 & Pass \\
\hline 100-F Area & 0.070 & Pass \\
\hline 100-H Area & 0.014 & Pass \\
\hline 100-K Area & 0.000003 & Pass \\
\hline 100-N Area & 0.000015 & Pass \\
\hline 300 Area Springs & 0.31 & Pass \\
\hline Hanford town site & 0.085 & Pass \\
\hline McNary Dam & 0.29 & Pass \\
\hline Priest Rapids Dam & 0.024 & Pass \\
\hline Richland Spring/River & 0.0091 & Pass \\
\hline West Lake & 1.35 & Fail \\
\hline \multirow[t]{2}{*}{ White Bluffs Slough } & 0.159 & Pass \\
\hline & \multicolumn{2}{|l|}{$\begin{array}{c}\text { Tier } 2 \text { Screen, } \\
\underline{\text { Sum of Fractions }}^{(\mathbf{b})}\end{array}$} \\
\hline West Lake & 0.90 & Pass \\
\hline \multicolumn{3}{|c|}{$\begin{array}{l}\text { (a) A screening method to estimate radiological doses to aquatic and } \\
\text { terrestrial biota. } \\
\text { (b) A sum of fractions is calculated to account for the contribution to dose } \\
\text { from each radionuclide. If the sum of fractions exceeds 1.0, then the dose } \\
\text { guideline has been exceeded and further screening (Tier 2) is required. }\end{array}$} \\
\hline
\end{tabular}

(risk) of detrimental effects from low radiological doses. Some scientific studies have indicated that low radiological doses result in beneficial effects (Sagan 1987). Because cancer and hereditary diseases in the general population are caused by many sources (e.g., genetic defects, sunlight, chemicals, and background radiation), some scientists doubt that the risk from low-level radiation exposure can ever be conclusively proven. In developing Clean Air Act regulations, the EPA used a probability value of approximately 4 per 10 million $\left(4 \times 10^{-7}\right)$ for the risk of developing a fatal cancer after receiving a dose of 1 millirem (10 microsievert) (EPA 520/1-89-005). Additional data (National Research Council 1990) support the reduction of even this small risk value, possibly to zero, for certain types of radiation when the dose is spread over an extended time. Guidance from the Interagency Steering Committee on Radiation Standards (ISCORS 2002) recommends that 
agencies assign a risk factor of 6 per 10 million $\left(6 \times 10^{-7}\right)$ for the risk of developing a fatal cancer after receiving a dose of 1 millirem (10 microsievert).

Government agencies are trying to determine what exposure level is safe for members of the public exposed to pollutants from industrial operations (e.g., DOE facilities, nuclear power plants, chemical plants, and hazardous waste sites). These industries are considered beneficial to the public in some way, such as providing electricity, national defense, waste disposal, and consumer products. Government agencies have a complex task to establish environmental regulations that control levels of risk to the public without unnecessarily reducing needed benefits from industry.
One perspective on risks from industry is to compare them to risks involved in other typical activities. For instance, two risks that an individual experiences when flying on an airplane are added radiological dose (from a stronger cosmic radiation field that exists at higher altitudes) and the possibility of being in an airplane accident. Table 8.12.5 compares the estimated risks from various radiological doses to the risks of some activities encountered in everyday life. Some activities that are estimated to be approximately equal in risk to that from the dose received by the maximally exposed individual from monitored Hanford Site effluents and emissions during 2009 are shown in Table 8.12.6.

Table 8.12.5. Estimated Risk from Various Activities and Exposures ${ }^{(a)}$

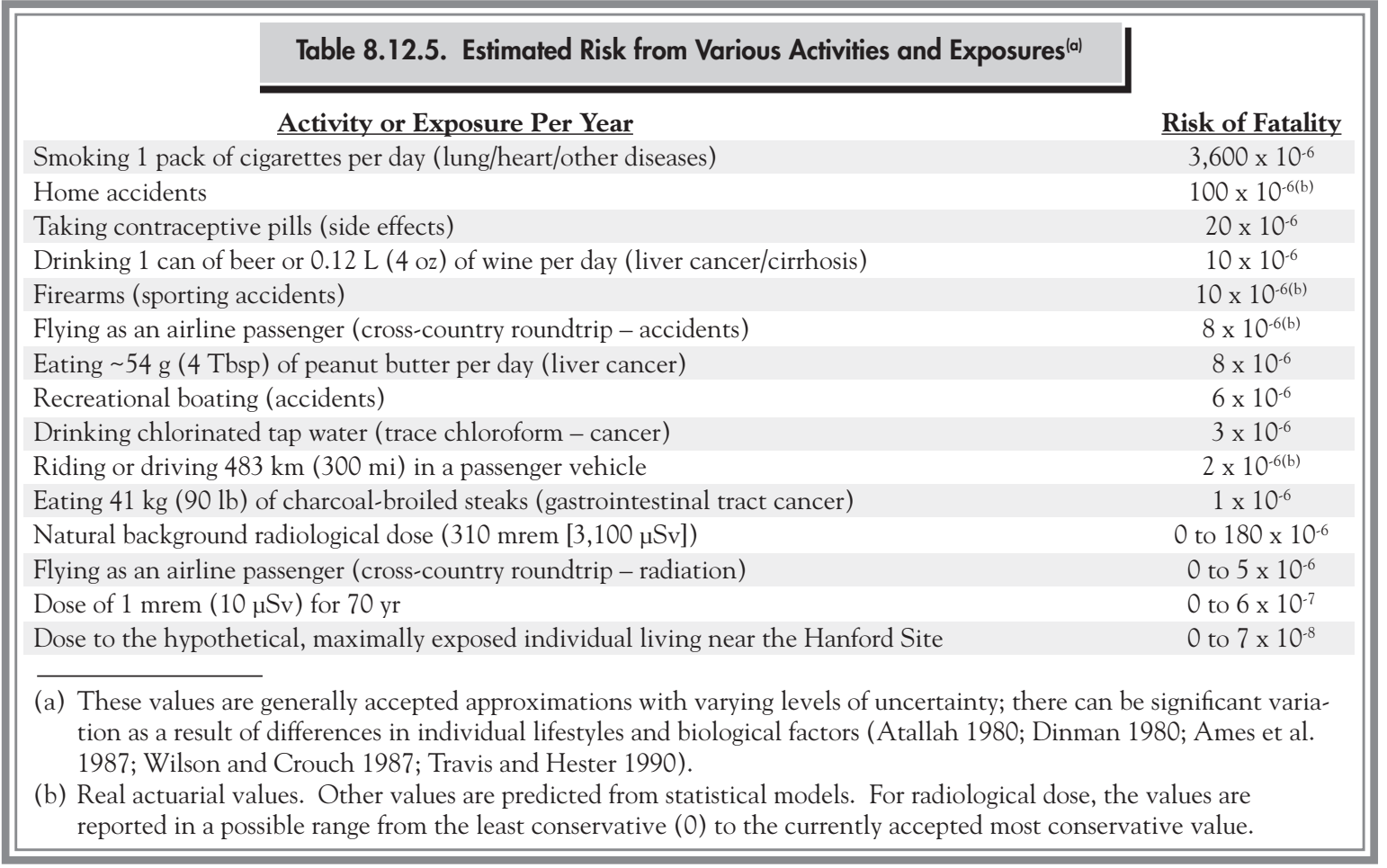

Table 8.12.6. Activities Comparable in Risk to the $0.12-\mathrm{mrem}(0.0012-\mathrm{mSv})$ Dose Calculated for the Hanford Site Maximally Exposed Individual in 2009

Driving or riding $18 \mathrm{~km}(11 \mathrm{mi})$ in a car

Smoking $1 / 7$ of a cigarette

Flying $\sim 95 \mathrm{~km}(59 \mathrm{mi})$ on a commercial airliner

Eating $14 \mathrm{Tbsp}(\sim 200 \mathrm{~mL})$ of peanut butter
Eating 3.1-kg (6.7-lb) of charcoal-broiled steak Drinking $18 \mathrm{~L}$ ( $4.8 \mathrm{gal})$ of chlorinated tap water Drinking $960 \mathrm{~mL}$ ( $33 \mathrm{oz}$ ) of beer or $321 \mathrm{~mL}$ ( $11 \mathrm{oz}$ ) of wine Exposed to the U.S. national average background dose for 3.5 hours 


\title{
8.13 Endangered and Threatened Species on the Hanford Site
}

\author{
MR Sackschewsky and MA Simmons
}

This section describes federal and state endangered and threatened species, candidate or sensitive plant and animal species, and other species of concern potentially found on the Hanford Site. Endangered species are those in danger of extinction within all or a significant portion of their range. Threatened species are those likely to become endangered in the near future. Sensitive species are species that are vulnerable or declining and could become endangered or threatened without active management or removal of threats. The federal list of endangered and threatened species is maintained by the U.S. Fish and Wildlife Service in 50 CFR 17.11 and 50 CFR 17.12. State lists are maintained by the Washington Natural Heritage Program (WNHP 2010) and the Washington Department of Fish and Wildlife (WDFW 2010).

The purposes of the Endangered Species Act of 1973, as amended, are to 1) provide a means to conserve critical ecosystems, 2) provide a program for the conservation of endangered and threatened species, and 3) ensure appropriate steps are taken to achieve the purposes of the treaties and conventions established under the Act. Washington State regulations also list species as endangered and threatened, but such a listing does not carry the protection of the federal Endangered Species Act of 1973. The National Oceanic and Atmospheric Administration's National Marine Fisheries Service (NOAA 2008) has the responsibility for the federal listing of anadromous fish (i.e., fish that require both saltwater and freshwater to complete a life cycle). The U.S. Fish and Wildlife Service has responsibility for all other federally listed species on the Hanford Site. Table 8.13.1 lists the species of plants and animals that occur or potentially occur on the Hanford Site and are listed as endangered, threatened, sensitive, or candidate by either the federal or state governments.
Two fish species (spring-run Chinook salmon [Oncorhynchus tshawytscha] and steelhead [Oncorhynchus mykiss]) on the federal list of endangered and threatened species are known to regularly occur on the Hanford Site (Table 8.13.1). One additional fish species (bull trout [Salvelinus confluentus]) was recorded on the Hanford Site but scientists believe this species is transient. No other plants or animals known to occur on the Hanford Site are currently on the federal list of endangered and threatened species (50 CFR 17), but two plant species, one mammal species, and one bird species are currently candidates for listing under the Endangered Species Act of 1973 (Table 8.13.1). In addition, 13 plant species and 4 bird species have been listed as either endangered or threatened by Washington State. Numerous additional species of animals and plants are listed as candidate or sensitive species by Washington State. There are 32 statelevel sensitive and candidate species of insects and animals and 14 sensitive plant species occurring or potentially occurring on the Hanford Site (Table 8.13.1). The U.S. Fish and Wildlife Service also maintains an informal list of species of concern in the Columbia Basin (USFWS 2010b), which includes species that are being monitored and may be considered for federal candidate status in the future; 17 species that occur on the Hanford Site are included on this list.

Washington State officials maintain additional lower-level lists of species, including a monitor list for animals (WDFW 2010) and review and watch lists for plants (WNHP 2010). Species on the state monitor, watch, and review lists are not considered species of concern, but are monitored for status and distribution. These species are managed by the state, as needed, to prevent them from becoming endangered, threatened, or sensitive. However, an abundance of these species may be indicative of an ecosystem with relatively 
Table 8.13.1. Federal and Washington State Listed Endangered, Threatened, Sensitive, and Candidate Species Occurring or Potentially Occurring on the Hanford Site

\section{Common Name}

Plants

awned halfchaff sedge

beaked spike-rush

Canadian St. John's wort

chaffweed

Columbia milkvetch

Columbia yellowcress

coyote tobacco

desert cryptantha

desert dodder

desert evening-primrose

dwarf evening primrose

fuzzytongue penstemon

Geyer's milkvetch

grand redstem

gray cryptantha

Great Basin gilia

Hoover's desert parsley

loeflingia

lowland toothcup

Piper's daisy

rosy pussypaws

small-flowered evening-primrose

Snake River cryptantha

Suksdorf's monkey flower

Umtanum desert buckwheat

White Bluffs bladderpod

white eatonella

\section{Mollusks}

California floater

great Columbia River spire snail

shortfaced lanx

Insects

Columbia River tiger beetle ${ }^{(b)}$ silver-bordered fritillary

\section{Fish}

bull trout ${ }^{(c)}$

leopard dace ${ }^{(\mathrm{c})}$

mountain sucker ${ }^{(c)}$

river lamprey ${ }^{(\mathrm{c})}$

spring-run Chinook salmon

steelhead

\section{Amphibians and Reptiles}

sagebrush lizard

striped whipsnake

western toad $\underline{\text { Scientific Name }}$

Federal Status $^{(\mathrm{a})}$

State Status $^{(\mathbf{a})}$

Lipocarpha (= Hemicarpha) aristulata

Threatened

Eleocharis rostellata

Hypericum majus

Anagallis (= Centunculus)minimus

Astragalus columbianus

Rorippa columbiae

Nicotiana attenuata

Cryptantha scoparia

Cuscuta denticulata

Oenothera caespitosa

Camissonia (= Oenothera) pygmaea

Penstemon eriantherus whitedii

Astragalus geyeri

Ammannia robusta

Cryptantha leucophaea

Aliciella (= Gilia) leptomeria

Lomatium tuberosum

Loeflingia squarrosa var. squarrosa

Rotala ramosior

Erigeron piperianus

Cistanthe (= Calyptridium) roseum

Camissonia (= Oenothera) minor

Cryptantha spiculifera (= C. interrupta)

Mimulus suksdorfii

Eriogonum codium

Physaria (= Lesquerella) tuplashensis

Eatonella nivea

Anodonta californiensis

Species of concern

Fluminicola columbiana

Species of concern

Candidate

Candidate

Fisherola nuttalli

Cicindela columbica

Boloria selene atrocostalis

Species of concern

Species of concern

Species of concern

Sensitive

Sensitive

Threatened

Sensitive

Endangered

Sensitive

Sensitive

Threatened

Sensitive

Sensitive

Sensitive

Threatened

Threatened

Sensitive

Threatened

Sensitive

Threatened

Threatened

Sensitive

Threatened

Sensitive

Sensitive

Sensitive

Endangered

Threatened

Threatened

Salvelinus confluentus

Rhinichthys flacatus

Catastomus platyrhynchus

Lampetra ayresi

Oncorhynchus tshawytscha

Oncorhynchus mykiss

Sceloporus graciosus

Masticophis taeniatus

Bufo boreas
Threatened

Species of concern

Endangered

Threatened

Species of concern

Species of concern
Candidate

Candidate

Candidate

Candidate

Candidate

Candidate

Candidate

Candidate

Candidate

Candidate

Candidate

Candidate Candidate Candidate 
Table 8.13.1. (contd)

\section{Common Name}

Birds

American white pelican

bald eagle

burrowing owl

common loon

ferruginous hawk

flamulated owl ${ }^{(\mathrm{c})}$

golden eagle

greater sage grouse

Lewis's woodpecker ${ }^{(c)}$

loggerhead shrike

merlin

northern goshawk ${ }^{(c)}$

olive-sided flycatcher

peregrine falcon

sage sparrow

sage thrasher

sandhill crane

western grebe

\section{Mammals}

black-tailed jackrabbit

Merriam's shrew

Townsend's ground squirrel

Washington ground squirrel ${ }^{(c)}$

white-tailed jackrabbit

\section{Scientific Name}

Pelecanus erythrorhynchos

Haliaeetus leucocephalus

Athene cunicularia

Gavia immer

Buteo regalis

Otus flammeolus

Aquila chrysaetos

Centrocercus urophasianus

Melanerpes lewis

Lanius ludovicianus

Falco columbarius

Accipter gentilis

Contopus cooperi

Falco peregrinus

Amphispiza belli

Oreoscoptes montanus

Grus canadensis

Aechmophorus occidentalis

Lepus californicus

Sorex merriami

Spermophilus townsendii

Spermophilus washingtoni

Lepus townsendii $\underline{\text { Federal Status }}^{(\mathrm{a})} \quad \underline{\text { State Status }}^{(\mathrm{a})}$

Endangered

Species of concern Sensitive ${ }^{(\mathrm{d})}$

Species of concern Candidate

Sensitive

Species of concern Threatened

Candidate

Candidate

Candidate Threatened

Candidate

Candidate

Candidate

Candidate

Species of concern

Species of concern

Species of concern

Sensitive

Candidate

Candidate

Endangered

Candidate

Candidate

Candidate

Candidate

Candidate

Candidate

(a) Endangered - Species in danger of extinction within all or a significant portion of its range.

Threatened - Species likely to become endangered in the foreseeable future.

Candidate - Species that are believed to qualify for threatened or endangered species status, but for which listing proposals have not been prepared.

Sensitive - Taxa that are vulnerable or declining and could become endangered or threatened without active management or removal of threats.

Species of concern - Species that are not currently listed or candidates under the Endangered Species Act of 1973, but are of conservation concern within specific U.S. Fish and Wildlife Service regions.

(b) Probable, but not observed, on the Hanford Site.

(c) Reported, but seldom observed, on the Hanford Site.

(d) Reclassified in January 2008.

high native diversity. Approximately 50 Washington State monitor list animal and insect species occur or potentially occur on the Hanford Site (Table 8.13.2), and 23 watch or review list plant species are potentially found on the Hanford Site (Table 8.13.3). 


\begin{tabular}{|c|c|c|c|}
\hline \multirow{3}{*}{$\frac{\text { Common Name }}{\text { Mollusks }}$} & \multicolumn{3}{|c|}{$\begin{array}{l}\text { 2. Washington State Monitor Species Occurring or Potentially Occurring } \\
\text { on the Hanford Site }\end{array}$} \\
\hline & $\underline{\text { Scientific Name }}$ & Common Name & Scientific Name \\
\hline & & Birds & \\
\hline Oregon floater & Anodonta oregonensis & Arctic tern ${ }^{(\mathrm{a})}$ & Sterna paradisaea \\
\hline western floater & Anodonta kennerlyi & ash-throated flycatcher ${ }^{(a)}$ & Myiarchus cinerascens \\
\hline western pearlshell & Margaritifera falcata & black tern $^{(\mathrm{b})}$ & Chlidonias niger \\
\hline Insects & & black-crowned night-heron & Nycticorax nycticorax \\
\hline Bonneville skipper & Ochlodes sylvanoides bonnevilla & black-necked stilt & Himantopus mexicanus \\
\hline canyon green hairstreak & Callophrys sheridanii neoperplexa & bobolink $^{(\mathrm{a})}$ & Dolichonyx oryzivorus \\
\hline coral hairstreak & Harkenclenus titus immaculosus & Caspian tern & Sterna caspia \\
\hline juba skipper & Hesperia juba & Clark's grebe & Aechmophorus clarkii \\
\hline Nevada skipper & Hesperia nevada & Forster's tern & Sterna forsteri \\
\hline northern checkerspot & Chlosyne palla palla & grasshopper sparrow & Ammodramus savannarum \\
\hline Pasco pearl & Phyciodes cocyta pascoensis & gray flycatcher & Empidonax wrightii \\
\hline Persius' duskywing & Erynnis persius & great blue heron & Ardea herodias \\
\hline purplish copper & Lycaena helloides & great egret & Ardea alba \\
\hline ruddy copper & Lycaena rubida perkinsorum & gyrfalcon $^{(\mathrm{a})}$ & Falco rusticolus \\
\hline silver-spotted skipper & Epargyreus clarus californicus & horned grebe & Podiceps auritus \\
\hline viceroy & Limenitis archippus lahontani & lesser goldfinch & Carduelis psaltria \\
\hline Fish & & long-billed curlew & Numenius americanus \\
\hline Pacific lamprey ${ }^{(\mathrm{b})}$ & Lampetra tridentata & osprey & Pandion haliaetus \\
\hline piute sculpin & Cottus beldingi & prairie falcon & Falco mexicanus \\
\hline reticulate sculpin & Cottus perplexus & red-necked grebe $e^{(a)}$ & Podiceps grisegena \\
\hline sand roller & Percopsis transmontana & snowy owl & Nyctea scandiaca \\
\hline Amphibians and Reptiles & & Swainson's hawk & Buteo swainsoni \\
\hline night snake & Hypsiglena torquata & turkey vulture ${ }^{(\mathrm{a})}$ & Cathartes aura \\
\hline short-horned lizard & Phrynosoma douglassii & western bluebird & Sialia mexicana \\
\hline \multirow[t]{8}{*}{ Woodhouse's toad } & Bufo woodhousii & Mammals & \\
\hline & & badger & Taxidea taxus \\
\hline & & long-legged myotis ${ }^{(b)}$ & Myotis volans \\
\hline & & northern grasshopper mouse & Onychomys leucogaster \\
\hline & & pallid bat & Antrozous pallidus \\
\hline & & sagebrush vole & Lagurus curtatus \\
\hline & & small-footed myotis $^{(b)}$ & Myotis leibii \\
\hline & & western pipistrelle & Pipistrellus hesperus \\
\hline
\end{tabular}


Table 8.13.3. Washington State Review and Watch List Plant Species Potentially Found on the Hanford Site

Common Name

annual paintbrush

annual sandwort

basalt milkvetch

bristly combseed

Columbia River mugwort

crouching milkvetch

false pimpernel

giant helleborine

hedgehog cactus

Kittitas larkspur

medic milkvetch

pigmy-weed

porcupine sedge

Robinson's onion

rosy balsamroot

scilla onion

shining flatsedge

small-flowered nama

smooth cliffbrake

southern mudwort

stalked-pod milkvetch

vanilla grass

winged combseed
Scientific Name

Castilleja exilis

Minuartia pusilla var. pusilla

Astragalus conjunctus var. rickardii

Pectocarya setosa

Artemisia lindleyana

Astragalus succumbens

Lindernia dubia var. anagallidea

Epipactis gigantea

Pediocactus simpsonii var. robustior

$=(P$. nigrispinus $)$

Delphinium multiplex

Astragalus speirocarpus

Crassula aquatica

Carex hystericina

Allium robinsonii

Balsamorhiza rosea

Allium scilloides

Cyperus bipartitus (rivularis)

Nama densum var. parviflorum

Pellaea glabella simplex

Limosella acaulis

Astragalus sclerocarpus

Hierchloe odorata $=($ Anthoxanthm hirtum $)$

Pectocarya penicillata
State Listing $^{(a)}$

Watch List

Review Group 1

Watch List

Watch List

Watch List

Watch List

Watch List

Watch List

Review Group 1

Watch List

Watch List

Watch List

Watch List

Watch List

Watch List

Watch List

Watch List

Watch List

Watch List

Watch List

Watch List

Review Group 1

Watch List

(a) Review Group 1 - Taxa for which currently there are insufficient data available to support listing as threatened, endangered, or sensitive.

Watch List - Taxa that are more abundant and/or less threatened than previously assumed. 


\subsection{Ecological Monitoring on the Hanford Site}

The Hanford Site is a relatively undisturbed area of shrub steppe supporting a rich diversity of plant and animal species adapted to the semi-arid environment of the Columbia Plateau. To aid the DOE Richland Operations Office in complying with legal and regulatory requirements for the biological resources found on the Hanford Site, and to protect sensitive resources and habitats, Ecological Monitoring and Compliance Project personnel collect and summarize ecological data and information needed to monitor, assess, and conserve the resources found on the site. Project personnel survey and monitor resources and key biota to assess the abundance, vigor (condition), and distribution of populations and species on the Hanford Site. Data collection and analysis are integrated with environmental monitoring of biotic and abiotic media under the Surface and Environmental Surveillance Project and analytical results are used to characterize any potential risk or impact to the biota. Ecological monitoring and ecological compliance support the Hanford Site's waste management and environmental restoration mission through the following activities:

- Assuring the Hanford Site's operational compliance with laws and regulations including the Endangered Species Act of 1973, the Bald and Golden Eagle Protection Act, and the Migratory Bird Treaty Act, as well as compliance with Executive and DOE Orders

- Providing data for environmental impact and ecological risk assessments

- Providing information and maps of the distribution and condition of biological resources at the Hanford Site

- Supporting the Hanford Site land-use planning and stewardship.
Inventory and monitoring activities conducted under Ecological Monitoring and Compliance Project help protect the natural resources within the DOE-operated portions of the Hanford Site including the DOE-managed portion of the Hanford Reach National Monument. Such activities also provide information useful to the Hanford natural resource stakeholders and the public on the status of some of the Hanford Site's most highly valued biological resources.

This section provides inventory, monitoring, and survey information for species and communities found on the Hanford Site during 2009, and presents this information in context with historical data and trend information. Ecological compliance activities and efforts related to inventory and management of threatened and endangered species are also included in this section.

\subsubsection{Population Monitoring}

The Hanford Site contains biologically diverse shrub-steppe plant communities that have been protected from most disturbances, except for fire, for more than 55 years. This protection has allowed plant and animal species to thrive on the Hanford Site that are displaced elsewhere in the Columbia Basin by agriculture and development. Population level surveys are conducted to monitor fish, wildlife, and plants to develop baseline information and to monitor any changes resulting from Hanford Site operations.

Plant populations monitored on the Hanford Site include taxa classified by Washington State regulations as endangered, threatened, or sensitive (see Section 8.13) and those species listed as Review Group 1 (i.e., taxa in need of additional field work before status can be determined) (WNHP 2008). Species monitored during 2009 included 
Umtanum buckwheat (Eriogonum codium), a candidate for federal listing, and Columbia yellowcress (Rorippa columbiae), a federal species of concern.

Four fish and wildlife species on the Hanford Site are monitored annually by the Ecological Monitoring and Compliance Project: fall Chinook salmon (Oncorhynchus tshawytscha), steelhead (Oncorhynchus mykiss), bald eagles (Haliaeetus leucocephalus), and mule deer (Odocoileus hemionus). These species are of special interest to the public and to stakeholders. Monitoring consists of estimating numbers of fall Chinook salmon redds, surveying for steelhead redds, assessing bald eagle nesting, and conducting an inventory of mule deer. The species are monitored to assess abundance, condition, and distribution. All have the potential to be impacted by Hanford Site operations, and yearly monitoring provides baseline data for ecological assessments. Also included in this section are an assessment of the breeding bird population and an evaluation of the Rocky Mountain elk population's use of the Hanford Site.

\subsubsection{Rare Plant Monitoring JL Downs}

More than 100 plant populations of 53 different taxa listed by the Washington Natural Heritage program as endangered, threatened, sensitive, or on the review or watch list are found on the Hanford Site (PNNL-13688). The U.S. Fish and Wildlife Service has designated 4 of these 53 taxa as species of concern in the Columbia River Basin ecoregion: Columbia milkvetch (Astragalus columbianus), gray cryptantha (Cryptantha leucophaea), Hoover's desert parsley (Lomatium tuberosum), and Columbia yellowcress (Rorippa columbiae). Two species, Umtanum desert buckwheat (Eriogonum codium) and White Bluffs bladderpod (Physaria douglasii ssp. tuplashensis), are candidates for federal listing as endangered and threatened, respectively (WNHP 2008). In addition, several areas on the Hanford Site are designated as special habitats with regard to potential occurrence of plant species of concern listed by Washington State regulations. These areas potentially support populations of rare annual forbs that have been documented in adjacent habitats.

Umtanum desert buckwheat grows only on Umtanum ridge at elevations of 335.3 to 396.2 meters $(1,100$ to
1,300 feet) on pumice-like basalt substrates at the ridge crest. It occurs on exposed basalt from the Lolo Flow of the Wanapum Basalt Formation in patches along a narrow band approximately 2.5 kilometers ( 1.5 miles) long by less than 30 meters (100 feet) wide (Dunwiddie et al. 2001). Monitoring has been conducted over the past 12 years by the Nature Conservancy, the U.S. Fish and Wildlife Service, and the Washington State Department of Natural Resources' Natural Heritage Program as well as volunteers to these agencies. Monitoring data indicate that the population of approximately 5,000 plants is likely in decline (Kaye 2007).

Columbia yellowcress grows in cobbly substrates on the Columbia River shorelines. Surveys for Columbia yellowcress were conducted during 2009 along the Columbia River shoreline and the islands in the downstream stretch of the Hanford Reach (Figure 8.14.1). Data collected during previous years indicate that on the islands in the downstream stretch of the Hanford Reach (such as Island 18 near the 300 Area), the cobble habitats that supported Columbia yellowcress in the previous decade now may be inundated with silts. Data collected in 2009 show little change in the numbers of stems found at the Locke Island and 100-F Beach survey areas (Table 8.14.1). Data that describe trends in plant numbers and the timing of growth for this species are of interest because large variations in population numbers have been observed. Variations in numbers of stems over the past 18 years are believed to be related to river-level fluctuations that inundate habitat for this species during a large part of the growing season. Surveys are conducted during September and early October when water levels are lower than river elevations during spring and summer months. Fewer than $5 \%$ of the stems are found flowering or setting seed, which indicates most of the populations increase through vegetative propagation. During the time period these populations were surveyed, the locations at which the plants were found were at higher elevations along the cobble shorelines than the original survey locations. This indicates that where suitable habitat is available, Columbia yellowcress populations have migrated up the shoreline in response to increased water levels through the growing season. 


\subsubsection{Chinook}

\section{Salmon}

RP Mueller

Chinook salmon are an important resource in the Pacific Northwest; they are caught commercially and for recreation and are culturally important to local Native American tribes. The most important natural spawning area for fall Chinook salmon in the mainstem Columbia River is found in the Hanford Reach (Dauble and Watson 1997). In the early years of the Hanford Site, only a few spawning nests (redds) were found in the Hanford Reach. Between 1943 and 1973, several dams were constructed on the Columbia River, and the formation of reservoirs behind these dams eliminated most mainstem spawning areas. These changes resulted in increased numbers of salmon spawning in the Hanford Reach. Fisheries management strategies aimed at maintaining spawning populations in the mainstem Columbia River also have contributed to the increased number of salmon redds found in the Hanford Reach.

The number of fall Chinook salmon redds in the Hanford Reach is estimated by aerial surveys. Over the years, the number of redds has increased from less than 500 in the early 1950s to nearly 8,800 in 1989 (Figure 8.14.2). In the early 1990s, redd estimates declined to approximately one-third of the 1989 peak. The number of redds peaked again in 1996 and 1997 and then declined before rising again in 2001. This trend continued through 2003 when an estimated 9,400 redds were counted, which was the highest count since monitoring began in 1948 .

The peak redd count for fall Chinook salmon in the Hanford Reach during fall 2009 was estimated at 4,995
(Figure 8.14.2). This count was slightly lower than the 2008 count of 5,588 redds but higher than the 2007 count of 4,018 redds. The 2009 count was 1,430 redds lower than the previous 5 -year average. The main spawning areas observed from the 2009 counts were located at the following sites, listed in order of abundance: Vernita Bar (Area 10), Locke Island complex (Areas 4 and 5), Islands 8-10 (Areas 2 and 3), Island 2 (Area 7), and the Ringold Area (Area 1) (Figure 8.14.3). The general locations of the spawning areas have not changed significantly over the past few years. 
Aerial surveys do not yield absolute salmon redd counts because environmental conditions vary, such as water depth, water turbidity, and sun angle. In addition, the number of redds in high-density locations cannot be counted with absolute accuracy while flying. However, redd survey data are highly correlated with adult salmon

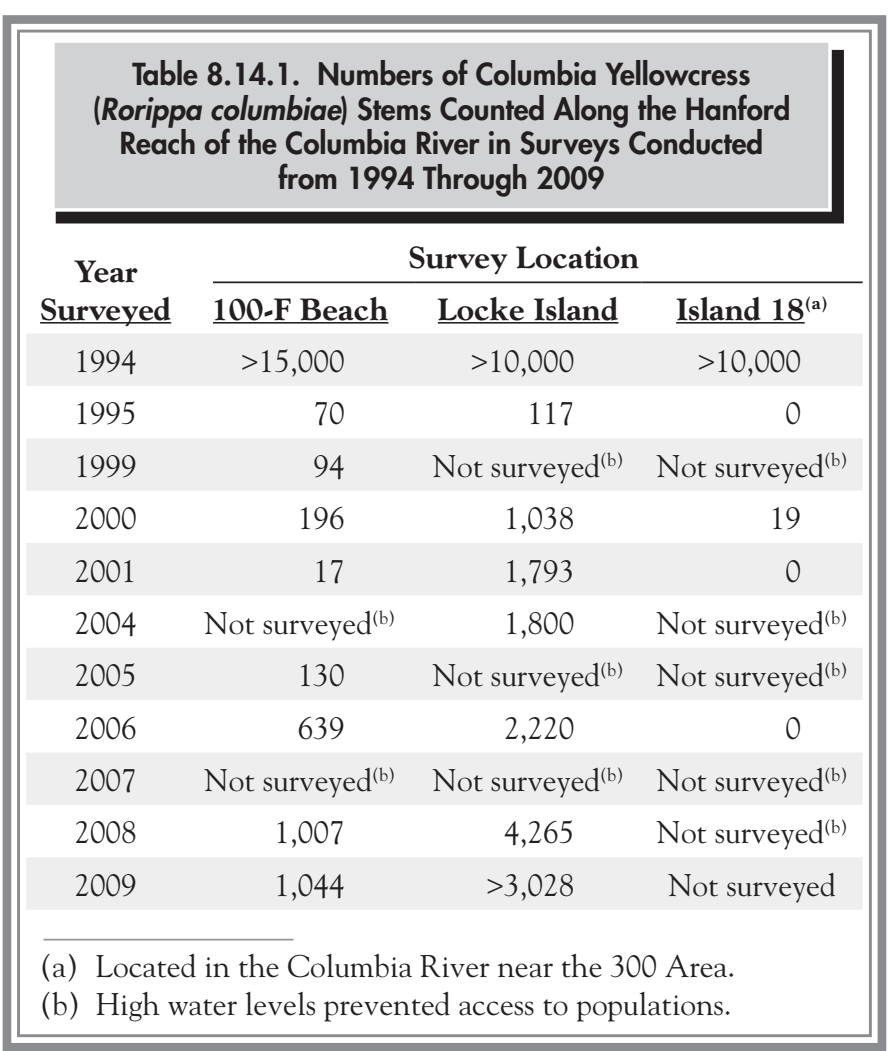

escapement estimates (that portion of the fish population that survives natural mortality and harvest to reach the spawning grounds) obtained by state and federal agencies within the Columbia River Basin by using an expansion factor ( 1 redd $=7$ to 8 adult fish) (for additional information, see the website at http://www.streamnet.org/).

\subsubsection{Steelhead}

\section{RP Mueller}

Steelhead within the Hanford Reach are considered part of the upper Columbia River Evolutionarily Significant Unit and are listed as endangered under the Endangered Species Act of 1973. In April and May 2009, two aerial observation flights were flown on the Hanford Reach from north Richland (river kilometer 547 [river mile 340]) to near Vernita Bridge (river kilometer 624 [river mile 388]) to document the occurrence of any steelhead spawning along the shoreline regions. Flight environmental conditions were very good with clear skies and light winds. River flows ranged from 140,000 cubic feet per second on the first flight to approximately 80,000 cubic feet per second on the second flight. Areas in which steelhead redds were found in previous years were given high priority; several passes were made over these regions to check for the presence of any disturbance of the substrates, which would indicate the possibility of spawning fish. One possible steelhead redd was located east of Island 13 (Figure 8.14.3) during the

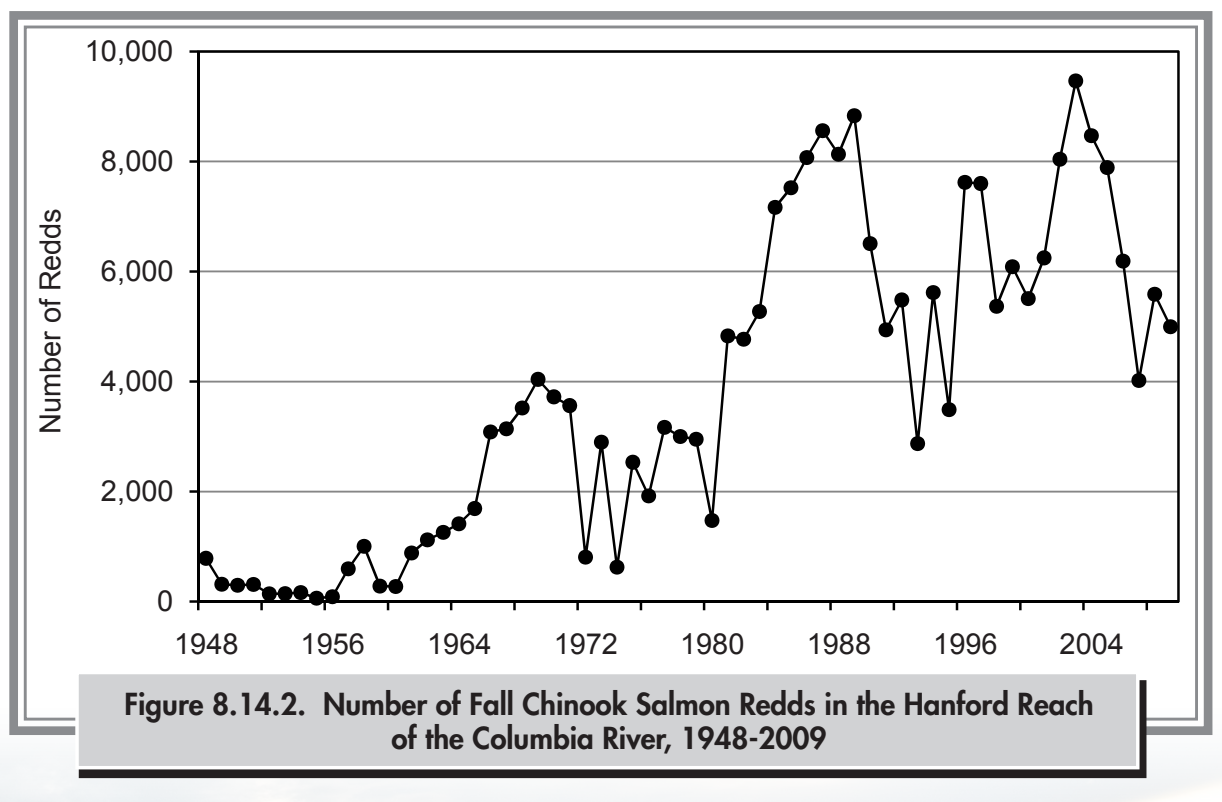

8.142 


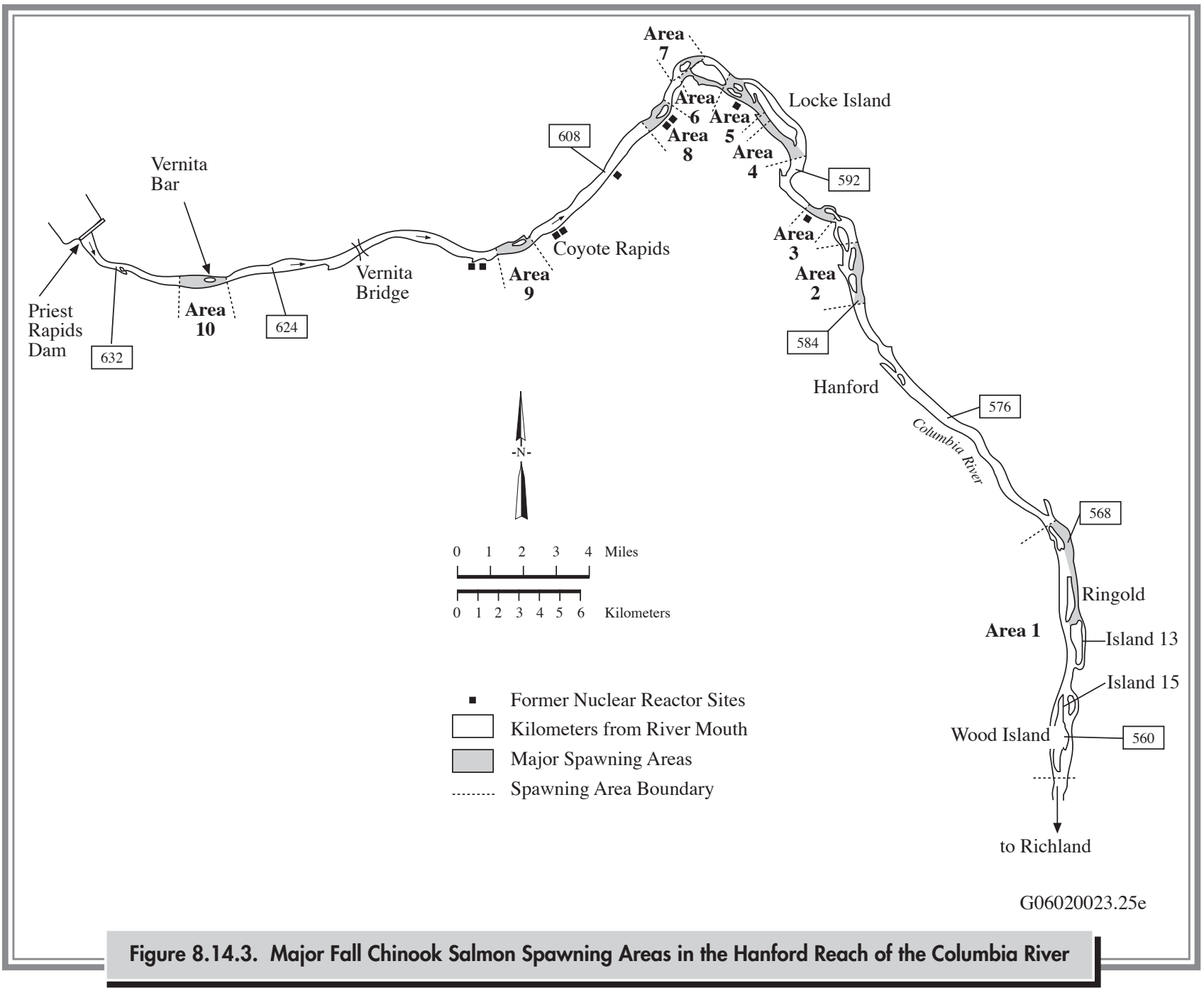

second flight. Researchers examined this region in more detail using a boat-deployed underwater video system and determined the area was not an actual steelhead redd.

\subsubsection{Bald Eagle}

\section{RE Durham, MR Sackschewsky, and CA Duberstein}

The bald eagle was removed from the federal threatened and endangered species list in July 2007 and its status changed from threatened to sensitive in Washington State in January 2008. Federal and state protection is still afforded the bald eagle through the Bald and Golden Eagle Protection Act, the Migratory Bird Treaty Act, and the Washington Administrative Code. A revised Bald Eagle Management Plan for the Hanford Site, South-Central Washington, was published in 2009 to direct Hanford Site activities in accordance with current federal and state regulations and guidelines (DOE/RL-94-150, Rev. 1). This management plan outlines seasonal access restrictions around documented nesting and communal roosting sites at the Hanford Site between November 15 and March 15, and establishes guidelines for the protection of perches, roosts, and alternative nest sites located near the boat launch at the former White Bluffs town site (Figure 8.14.4).

The historical nest site, located in the White Bluffs vicinity, was not occupied in 2009. The lack of territory defense, evidenced during regular perch-site surveys by the presence of more than two adults or a combination of adult and juvenile bald eagles in the vicinity, will mark the second consecutive winter season without an occupied bald eagle 


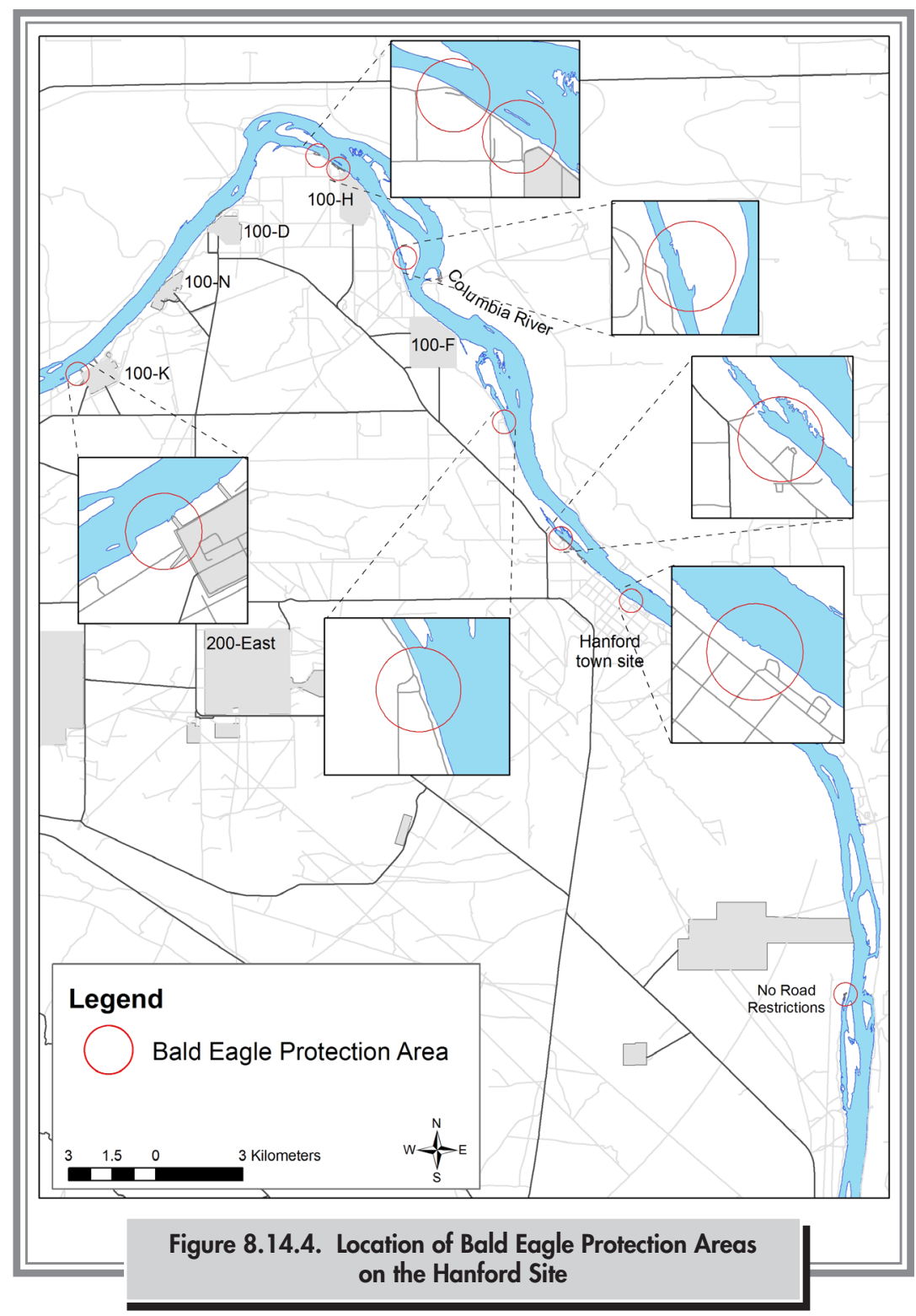

nest on the Hanford Site. Federal guidelines characterize a nest site as active up to 5 years beyond the last occupancy. The causes of eagle nest abandonment along the Hanford Reach have not been examined but may include adverse weather; food availability; increased human activity near the nest site; and inter-specific competition (recorded observations include hazing and harassment by magpies and ravens, and the springtime assertion of great blue herons and Canada geese for nest site possession).

Twelve driving surveys were conducted between late October 2009 and February 2010 to document daytime use of perches by bald eagles during the 2009 wintering season.
Surveys were conducted at the $100-\mathrm{K}$ Area, 100-H Area, Hanford town site, and historic nest territory perch locations. A combined total of 49 adult and 29 juvenile bald eagles were observed during all surveys. Bald eagle numbers were consistently greater per survey at the $100-\mathrm{H}$ Area and historic nest territory perch sites. An age-class ratio was calculated based upon the maximum number of birds observed across all locations at any one time. The ratio of adult to juvenile bald eagles increased from 0.6 in 2008 to 1.6 in 2009. Coincidentally, the same maximum number of bald eagles (18) was observed across the same set of perch locations in both years.

\subsubsection{Breeding Bird Roadside Surveys \\ CA Duberstein and MA Simmons}

Shrub-steppe habitat at one time covered approximately 255,000 square kilometers (98,000 square miles) in western North America (Knick et al. 2003). Much of this land has been transformed as a result of agriculture, grazing, and urbanization. Along with the decrease in habitat, the bird species that depend on this habitat have also declined. Large remnants of shrubsteppe habitat currently exist on the Hanford Site, providing a refugium (an area that has not experienced ecological changes that have affected surrounding regions, providing a habitat for species that were once more widespread) for shrub-steppe birds in the Columbia Plateau. For the past 20 years, roadside point count surveys, patterned after the North American Breeding Bird Survey, have been used to determine which shrub-steppe species use the Hanford Site, evaluate habitat usage and trends in bird abundance, and monitor species of conservation concern.

Nearly 120 species of birds have been observed on the Hanford Site in surveys conducted during the breeding season (April-June) from 1988 through 2009. The most diverse assemblage of species was found along the river (81 species), while fewer species inhabited the shrub areas 
(61 species); bunchgrass habitat had the fewest (42 species). Over the survey period, the number of species observed each year has declined significantly from a high in 1989 of 18.9 species per survey to approximately 7 species per survey in the last 2 years. The abundance of many of the individual species has also declined including the western meadowlark (Sturnella neglecta), one of the most abundant species on the site. Counts for this species have declined from over 100 species per survey to 30 to 50 species per survey. Declines in the numbers of different species observed may be associated with recent wildfires that have reduced available shrub habitat types along the survey route. Explanations for decreases in numbers of individuals of common species, such as western meadowlarks, are less obvious. Many of the breeding bird species are neo-tropical migrants, and the decrease in numbers may reflect habitat loss throughout their range.

Surveys conducted in 2008 and 2009 noted two federal species of concern: the ferruginous hawk (Buteo regalis) and loggerhead shrike (Lanius ludovicianus), and a Washington State candidate species, the sage sparrow (Amphispiza belli). Sage sparrow and loggerhead shrikes are found in shrub habitat; whereas the ferruginous hawk's large hunting territories encompass a variety of habitats.

Trends observed at the Hanford Site appear to mirror regional trends and appear to be associated with an overall decline and fragmentation of shrub-steppe habitat (Knick et al. 2003). For example, a general decline in western meadowlarks has been noted across much of their range (USGS North American Breeding Bird Survey 1980-2007). Thus, while the Hanford Site continues to act as a refugium (Gray and Rickard 1989), the site cannot compensate for the large-scale habitat changes occurring throughout the Columbia Basin and the Intermountain West.

\subsubsection{Mule Deer KD Hand}

Population characteristics of mule deer on the Hanford Site have been monitored since 1994. Roadside surveys are conducted from mid-November to mid-January to assess age and sex ratios and the frequency of testicular atrophy in males. The survey route extends from near the 300 Area in the south to the $100-\mathrm{B} / \mathrm{C}$ Area in the north and is divided at the Hanford town site into northern and southern regions. Tiller and Poston (2000) found little overlap in the home ranges of deer occupying these two regions.

Five surveys were conducted between mid-November 2009 and mid-December 2009. A combined total of 414 deer observations were made over the five repeated surveys, which included multiple observations of the same animals in some cases. Individual animals were identified according to sex and age class (fawn or adult). For male deer, the presence of misshapen, velvet-covered antlers was used as an indicator of testicular atrophy.

Trends in the ratios of fawns to does over time can be used to monitor changes in mule deer population size and health. Over the previous 10 years (1999 through 2008), the fawnto-doe ratios have ranged from 16 to 54 fawns per 100 does $($ mean $=35)$ in the northern region and from 19 to 56 fawns per 100 does $($ mean $=33$ ) in the southern region (Figure 8.14.5). The 2009 fawn-to-doe ratios were higher than those observed in the previous 2 years (Figure 8.14.5). In 2009 , the northern region fawn-to-doe mean estimate was 33 fawns per 100 does. This was approximately twice the 16 fawns per 100 does observed in 2008, but close to the 10-year (1999 through 2008) average of 35 fawns per 100 does. The southern region mean estimate in 2009 was 24 fawns per 100 does. This was slightly higher than the 20 fawns per 100 does observed in 2008, but lower than the 10-year (1999 through 2008) average of 33 fawns per 100 does. In general, the fairly steady trend in fawn-to-doe ratios indicates a stable mule deer population. Hanford Site fawn-to-doe ratios for all survey years (1994 through 2009) are weighted averages, using the total number of fawns and does seen per survey as the weighting factor.

In the early 1990s, testicular atrophy and sterility were observed in some male mule deer on the Hanford Site (Tiller et al. 1997; PNNL-11518). Extensive investigation found no relationships between the presence of testicular atrophy and contaminant levels, diet, disease, or natural conditions such as aging or genetics (Tiller et al. 1997). Testicular atrophy in male mule deer is associated with abnormal antler growth manifested as misshapen, velvet-covered antlers, which can be observed in field surveys. The observed frequency of misshapen antlers in mule deer has ranged from a high of $17 \%$ in the southern region in 1998 to a low of 

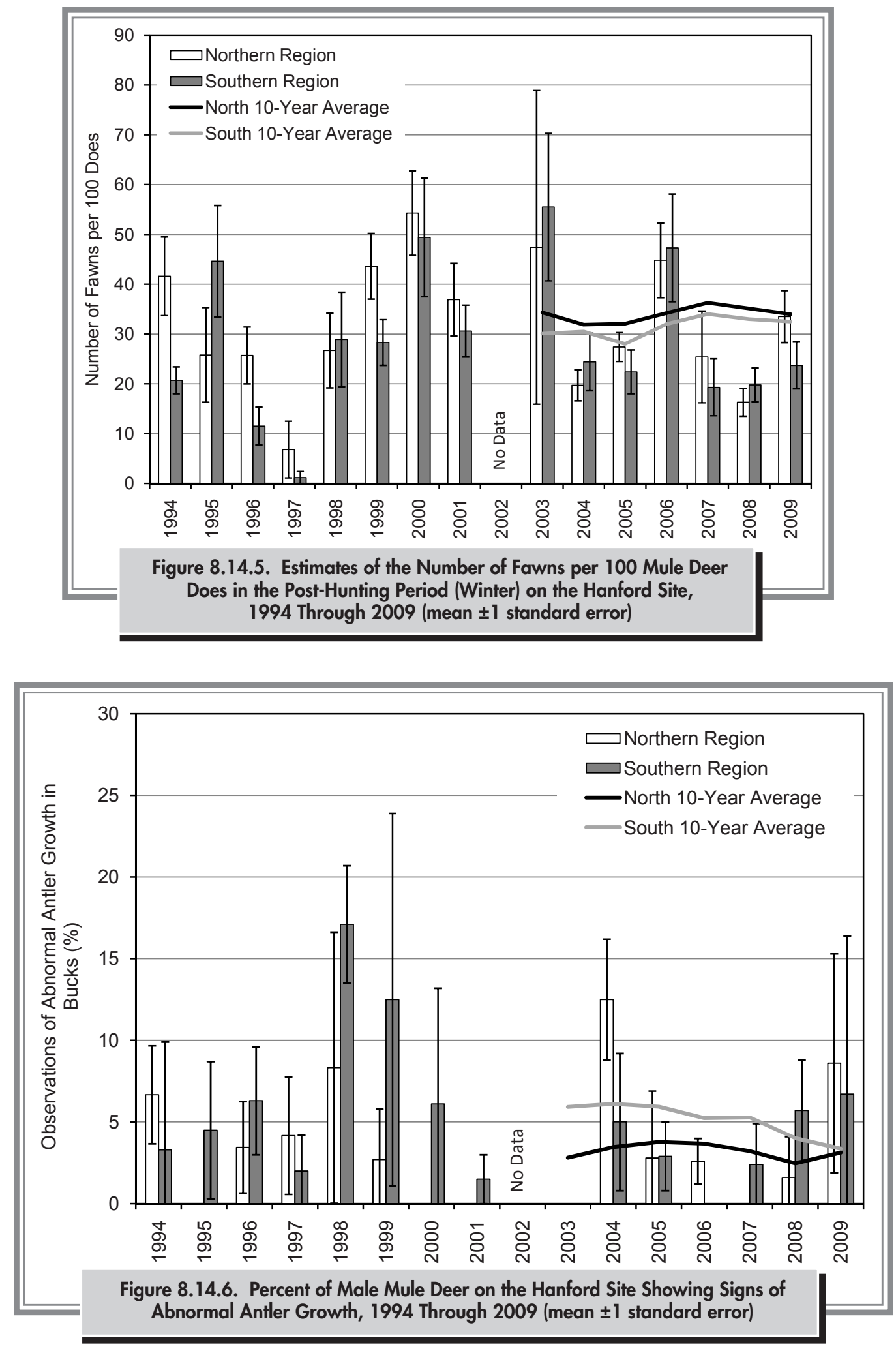
0\% in both regions in 2003 (Figure 8.14.6). Recently, the 10-year averages have shown steady (northern region) or declining (southern region) trends at $6 \%$ or less. In 2009 , observations of affected male deer increased; the observed frequency of antler abnormality was $8.6 \%$ in the northern region and $6.7 \%$ in the southern region. Though higher in 2009 than in recent years, the observations do not appear remarkably different than the overall trends. These frequencies need to be interpreted with caution because the small sample sizes may not fully reflect population conditions. In general, recent data indicate the health of the male mule deer on the Hanford Site has not changed substantially.

\subsubsection{Rocky Mountain Elk KD Hand}

The Rattlesnake Hills elk herd increased from a small group of Rocky Mountain elk (Cervus elaphus nelsoni) that were first observed on the Hanford Site in 1972 to more than 800 animals in 1999. The Washington Department of Fish and Wildlife has primary responsibility for management of the elk herd, and the U.S. Fish and Wildlife Service has primary land management responsibility for the Fitzner/ Eberhardt Arid Lands Ecology Reserve unit of the Hanford Reach National Monument, which makes up the core range for the herd. Elk from the herd also use private lands south and west of the Fitzner/Eberhardt Arid Lands Ecology Reserve, the U.S. Army Yakima Training Center, and portions of the central Hanford Site. Because of concerns about private land crop damage, vehicle collisions, native habitat degradation, and the herd's use of the Hanford Site's radiologically controlled areas, efforts have been undertaken by the Washington Department of Fish and Wildlife and the U.S. Fish and Wildlife Service to reduce the herd's size. The Washington Department of Fish and Wildlife has a target population size of 350 animals (WDFW 2000). Capture/ relocation efforts in 2000 and 2002, increased hunting pressure in recent years, and the effects of wildfires in 2000 and 2007 have reduced the herd size to an average of 641 animals over the last 6 years, based on annual surveys conducted jointly by the Washington Department of Fish and Wildlife and the U.S. Fish and Wildlife Service (USFWS 2010a). The population estimates calculated since the winter of 2004-2005 have been based on a sightability survey and model which allows a confidence interval to be determined. The 2009-2010 population estimate was 677 elk \pm 11 elk (90\% confidence limit) (USFWS 2010a).

Historically, the elk's use of the central area of the Hanford Site (that portion of the site lying north of State Highway 240 and south/west of the Columbia River) has been relatively minor and has consisted mainly of small groups of bulls, primarily during fall and winter. During the 1980s, elk tracking studies indicated elk did not use the central Hanford Site (PNNL-13331). Since then, central Hanford Site elk sightings include a single cow elk in 1997, 42 bull elk in December 1999, and small numbers of bull elk in 2000 (PNNL-13331). During the 2005-2006 annual roadside deer surveys, a group of four bulls was observed near the old Hanford town site and for the past 3 years, a group of bulls (typically seven animals) has been observed in that same general location. In November and December 2009, a group of 20 elk consisting of 15 cows, 4 calves, and 1 bull was sighted on the central Hanford Site approximately 6.5 kilometers (4 miles) north of the Wye Barricade. The reason for this new and perhaps increased use of the central Hanford Site by cows is not known at this time. U.S. Fish and Wildlife Service personnel noticed different spatial patterns of elk on the Fitzner/Eberhardt Arid Lands Ecology Reserve during recent winter surveys and suspect that increased activity by DOE cleanup projects around the old Fitzner/Eberhardt Arid Lands Ecology Reserve headquarters and on Rattlesnake Mountain may be affecting elk movements (USFWS 2010a). Continued monitoring of elk use on the central Hanford Site will be important to assess potential risks related to vehicle safety and radiological contamination.

\subsubsection{Monitoring and Evaluation of Habitat and Species Characterizations}

In 2009, researchers focused their monitoring and assessment efforts on sampling plant communities subject to herbicide application and wildfires, and evaluating habitat features associated with burrowing owl nests. Vegetation surveys were conducted within areas sprayed with herbicides to control noxious weeds and in areas recovering from wildfires that burned in 2007. Surveys in these areas 
included sampling of long-term monitoring plots as well as sampling sites established during 2008 and 2009. Results will aid in evaluating the success of current land management strategies used on the Hanford Site. Sampling and surveys were also conducted to identify the soil texture and burrow availability related to the distribution of burrowing owls on the Hanford Site. The information will be used to identify important breeding habitat for this species, and provide DOE with information regarding burrowing owl nest locations to minimize effects of Hanford Site operations on this priority species.

\subsubsection{Effects of Herbicide on Plant} Communities

\section{JL Downs, MA Chamness, SD Powell, CM Perry, and SA McKee}

Researchers conducted two survey efforts in 2009 to collect information on the condition and status of Hanford Site lands that have been aerially sprayed with herbicides to control noxious weeds. One effort involved sampling two long-term monitoring plots that were located within the areas that had herbicide applied in 2003 and 2006 to compare previous measures of species richness and relative cover with measurements after herbicide applications. The long-term monitoring plots were sampled to provide a "before-and-after" picture of the effects of herbicide on the native plant community. In addition to revisiting long-term monitoring plots, a stratified random design was used to locate sampling transects within areas that had been previously treated with herbicide and in untreated habitats with similar soils and vegetation. Vegetation sampling was conducted on 139 transects during May, June, and early July 2009 to assess canopy cover, species diversity, and frequency of occurrence of native and invasive plants. Results indicate that both native forb richness (i.e., the number of species) and canopy cover is lower in areas that have been subject to aerial applications of the herbicide $\operatorname{Tordon}^{\circledR}$, (a) than in adjacent vegetation associations on the same soil types (Figure 8.14.7). Analysis of data collected on long-term monitoring plots treated with herbicides also indicates that native forb cover decreased significantly after herbicide treatment when compared to measurements of forb cover before treatment of these plots, or compared to changes in forb cover over the same time period on monitoring plots outside the treated areas.

(a) Tordon is a registered trademark of Dow AgroSciences, LLC, Indianapolis, Indiana. 


\subsubsection{Effects of Wildfire on Plant} Communities

\section{JL Downs, MA Chamness, CM Perry, SD Powell, and AM Playter}

Several wildfires have burned across the Hanford Site in the past several decades and pose a potential threat to the health and status of shrub-steppe communities on the site. Burned landscapes are also subject to wind erosion and contribute to dust storms that can affect site operations. In August 2007, the Wautoma wildfire burned approximately 27,100 hectares (67,000 acres) on the Hanford Site. During the fall and early winter months of the same year, approximately 2,830 hectares (6,990 acres) on the central Hanford Site were seeded with perennial bunchgrasses and forbs to provide additional protection from wind erosion. The seed mix consisted of native Sandberg's bluegrass (Poa secunda) and cultivars of Indian ricegrass (Oryzopsis hymenoides), sand dropseed (Sporobolus cryptandrus), bottlebrush squirreltail (Sitanion hystrix), needle and thread grass (Stipa comata), thickspike wheatgrass (Agropyron dasytachyum), and one native forb, yarrow (Achillea millefolium).

To assess plant community recovery after wildfire, 69 sampling transects 50 meters (164 feet) in length were established within the Wautoma burn footprint on the central Hanford Site using a stratified-random design to locate transects in areas that were seeded and areas left to recover naturally based on the different soil types found within the fire footprint on the central Hanford Site. Canopy cover and frequency were measured for individual species on each transect in ten quadrats, each measuring 0.5 square meter (5.4 square feet). Comparison of measurements of native grasses measured in 2009 on seeded and non-seeded areas shows that canopy cover on transects that were not seeded is generally greater than or about the same as that measured on transects that were seeded (Figure 8.14.8). Canopy cover of exotic grasses (primarily cheatgrass) was not significantly different between transects that were seeded and those that were not.

These results should be carefully assessed with respect to the severity of the burn and further evaluated as future recovery and plant growth continues across the Wautoma fire footprint. Patterns of vegetation recovery after fire depend on the severity of the burn and the climatic conditions that ensue during the following growing seasons, as well as the presence of propagules or seeds. Most native perennial grasses and forbs are not killed by a wildfire, but may suffer stress and mortality from ensuing erosion of soils away from roots during the fall and winter after a fire occurs. Observations by Mission Support Alliance, LLC biologists during 2010 indicate further establishment of seeded species on revegetated areas. Additional surveys of monitoring
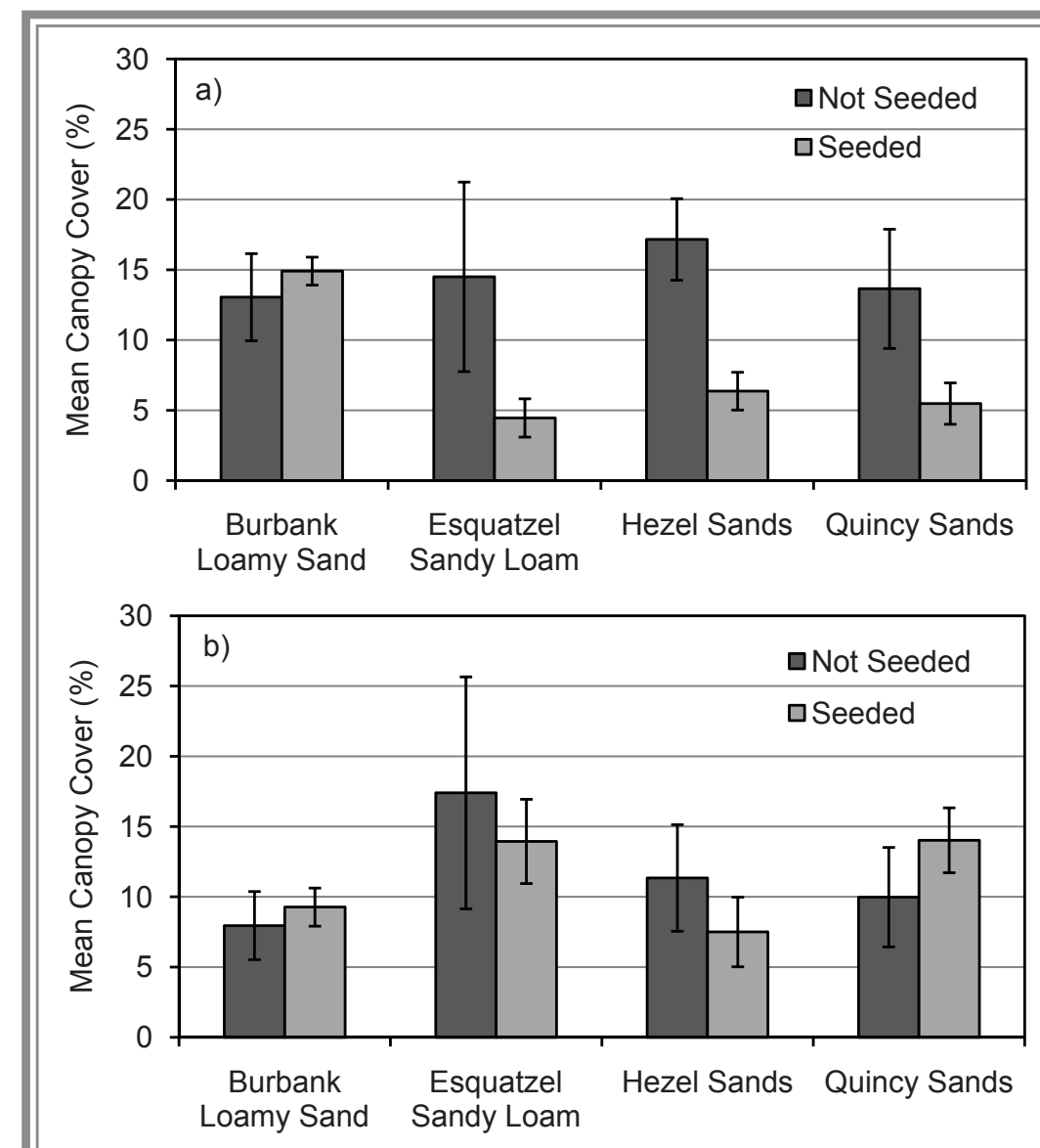

Figure 8.14.8. Comparison of Native (a) and Exotic (b) Grass Cover Within the Wautoma Fire Footprint on Seeded and Not Seeded Transects (error bars are \pm 1 standard error) 
transects are planned to further evaluate the recovery of native bunchgrasses on previously burned sites.

\subsubsection{Burrowing Owls}

\section{KB Larson}

Populations of burrowing owls (Athene cunicularia) are thought to be declining in several portions of their breeding range in North America (Wellicome and Holroyd 2001; Dechant et al. 2002; Klute et al. 2003), including Washington State (Conway and Pardieck 2006). Burrowing owls are federally listed as a Species of National Conservation Concern and listed as either endangered, threatened, or a species of concern in nine states (Klute et al. 2003). Currently in Washington State, burrowing owls are a candidate species for listing as either a state threatened or endangered species. Primary causes for population declines throughout North America include habitat loss and degradation caused by land development and declines of burrowing mammal populations.

Until recently, there was little information regarding population status and habitat use of burrowing owls in eastern Washington State, particularly on the Hanford
Site. Surveys to locate burrowing owls on the site were conducted in 2007 and 2008, and additional data were collected on the habitat use in relation to soil texture and burrow availability. Results available in 2009 indicate that burrowing owls are less abundant on the Hanford Site (0.14 nests per square kilometer [0.4 square mile]; Larson 2009) than in nearby urban $(0.28$ nests per square kilometer [0.4 square mile]) and agricultural ( 0.67 nests per square kilometer [0.4 square mile]) areas in eastern Washington State (Conway et al. 2006). Burrowing owl nests were more common in loamy sand and sandy loam soils compared to silt loams, despite low burrow availability in sandy loams. Most (91\%) burrows that were initially thought to be suitable for burrowing owls based on external examination were approximately 2 meters ( 6.6 feet) shorter than burrows used by burrowing owls. Hence, the availability of burrows several meters long may be an important factor in habitat selection. Seventy-one percent of burrowing owl nests were located in abandoned badger burrows, $26 \%$ in old irrigation pipes, and $3 \%$ in coyote dens. Additional evidence suggests that burrowing owls frequently nest near roadsides, which may have important implications with respect to human activities (Figure 8.14.9).

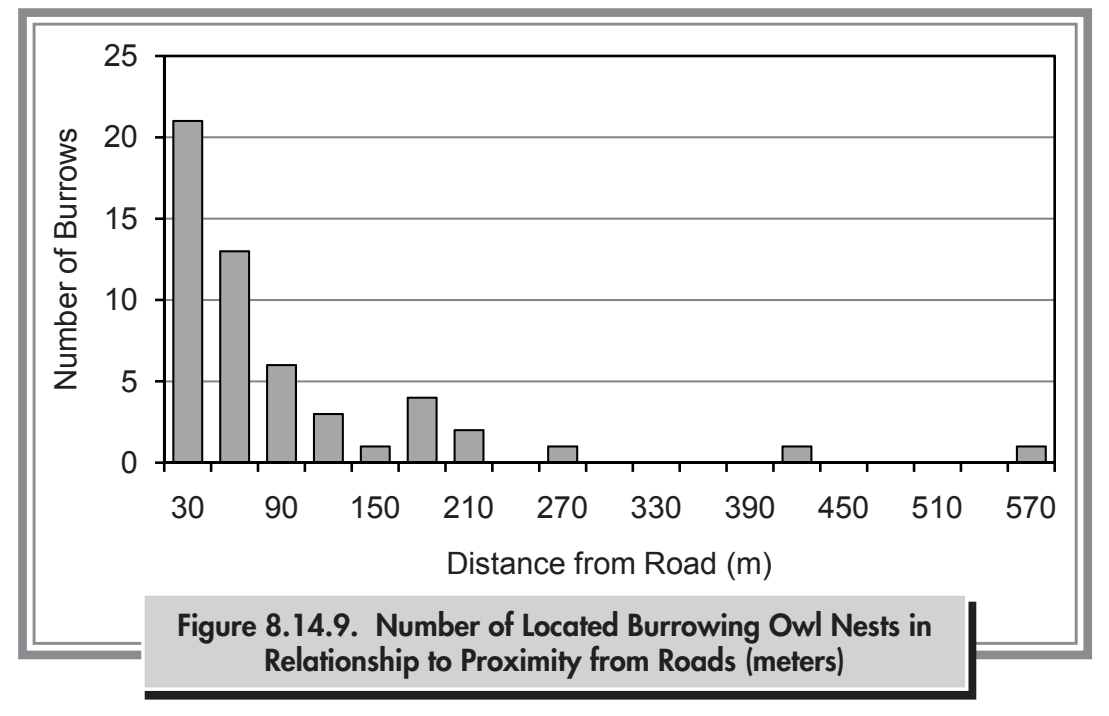




\title{
8.15 Cultural and Historic Resources Monitoring
}

\author{
EP Kennedy and TE Marceau
}

Cultural and historic resources monitoring on DOEmanaged portions of the Hanford Site is conducted under the auspices of the DOE Richland Operations Office's Hanford Cultural and Historic Resources Program to ensure site compliance with federal cultural resources laws and regulations (see Section 5.5.2). Program activities in 2009 included the following:

- Performing cultural resource reviews for all federal activities conducted at the Hanford Site in accordance with Section 106 of the National Historic Preservation Act of 1966 and the National Environmental Policy Act of 1969

- Monitoring cultural resources conditions to ensure important resources were protected

- Maintaining a database of cultural resources site records, project records, and regional ethnohistory

- Maintaining archaeological and historical collections

- Identifying and evaluating new cultural resources so they could be appropriately managed

- Consulting with Native American tribes and stakeholders to gather input on the identification, documentation, and management of cultural resources important to them.

DOE Hanford Cultural and Historic Resources Program personnel oversee all cultural resource activities at the Hanford Site. The majority of technical work is performed for DOE by Pacific Northwest National Laboratory; Washington Closure Hanford, LLC; CH2M HILL Corporate; and the Columbia River Exhibition of History, Science, and Technology Museum.

\subsubsection{Cultural Resources Reviews}

Pursuant to the National Environmental Policy Act of 1969 and Section 106 of the National Historic Preservation Act of 1966, DOE conducts cultural resources reviews of all federal activities at the Hanford Site. Cultural resources reviews ensure that important cultural resources are identified and effects to those resources are evaluated so that mitigation measures can be conducted.

During 2009, 167 cultural resources reviews were completed for Hanford Site contractors. Pacific Northwest National Laboratory completed 83 cultural resource review requests; Washington Closure Hanford, LLC completed 62 cultural resource reviews; and $\mathrm{CH} 2 \mathrm{M}$ HILL Corporate completed 22 cultural resource reviews. Upon initial review, DOE determined that 154 of the activities being reviewed were not the type that had the potential to cause effects and therefore were exempt from full review. Of these, Pacific Northwest National Laboratory received 80; Washington Closure Hanford, LLC received 58; and CH2M HILL Corporate received 16. Examples of these activities included small excavations, such as routine maintenance activities in previously disturbed areas, particularly those located within the fence lines of existing site operable units. The largest number of activities determined to not have the potential to cause effects were in the 100 Area in 2009 (Figure 8.15.1).

The remaining 13 activities required full reviews because these activities involved undisturbed ground, areas that had not been surveyed in the past, or locations in proximity 


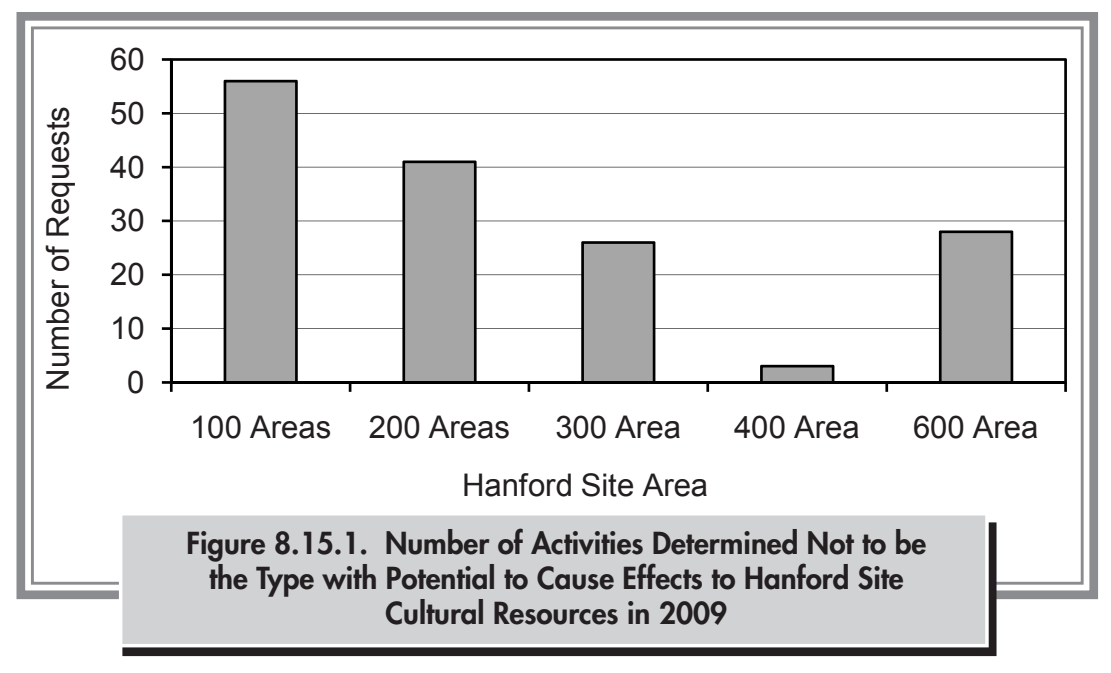

any), and identify protective measures when an impact is significant. In 2009, 51 cultural resource sites were inspected on the Hanford Site.

Cultural resources site visits were conducted with the participation of tribal cultural resources personnel. Although no major impacts were noted at the sites inspected in 2009, minor impacts as a result of natural erosion, and recreational and animal activities were recorded. DOE also visited Locke Island in the Hanford Reach of the Columbia River to measure river-caused erosion so protective measures could be taken if erosion

to known cultural resources. ${ }^{(a)}$ Three were completed by Pacific Northwest National Laboratory; four were completed by Washington Closure Hanford, LLC; and six were completed by CH2M HILL Corporate. The full reviews involved efforts to identify cultural resources that might be affected by the site activity, assess potential impacts, and develop mitigation measures if necessary (Table 8.15.1). Some full reviews required new areas (approximately 1,480 hectares [3,660 acres]) to be surveyed for cultural resources. Others required determination of eligibility evaluations from the National Register of Historic Places, archaeological testing and data recovery, or cultural resources monitoring of project excavations.

\subsubsection{Cultural Resources Protections}

Activities to ensure protection of Hanford Site cultural resources are conducted to comply with Section 110 of the National Historic Preservation Act of 1966, the Native American Graves Protection and Repatriation Act of 1990, and the Archaeological Resources Protection Act of 1979. The Hanford Site has had a monitoring program since 1987 to assess the effects of weathering and erosion or unauthorized excavation and collection upon the site's significant cultural resources. Activities include onsite inspections of important cultural resource sites to monitor site conditions, assess impacts (if rates began to increase. In 2009, there was one erosion trip to Locke Island. The rate of erosion decreased on the island relative to that of 2008. The new concentration of archaeological material exposed through erosion noted in 2008 was recorded in 2009 as HT-2009-001. Examination of eroded areas has revealed there may be two separate causal variables: high water levels and periods of water fluctuation.

In 2009, two incidents of unauthorized excavation were noted within archaeological sites and were documented as Archaeological Resources Protection Act of 1979 violations. The first is located on one of the islands inside archaeological site number 45GR302A and was discovered in January 2009. The second was located in the northern area of the Hanford Site near archaeological site number 45GR306B and was discovered in September 2009. The violations were reported by the DOE Richland Operations Office to the Benton County and Franklin County Sheriff Offices and the U.S. Fish and Wildlife Service. Archaeological Resources Protection Act of 1979 violation forms were completed for each site.

The DOE Richland Operations Office conducted several workshops with four regional Native American tribes to develop strategies for minimizing and reducing impacts to a traditional cultural property located on the Hanford Site. This collaborative planning effort resulted in development

(a) This number does not reflect all of the full cultural resource reviews that were initiated in calendar year 2009. Several others were initiated in 2009, but have not been completed as of March 2010 and therefore are not included in this report. 
Table 8.15.1. Full Cultural Resources Reviews Conducted on the Hanford Site in 2009

\begin{tabular}{|c|c|c|c|c|}
\hline $\begin{array}{c}\text { Reviewing } \\
\text { Organization }\end{array}$ & Proposed Activity & $\begin{array}{c}\text { Field } \\
\text { Activity }\end{array}$ & $\begin{array}{c}\text { Survey Size, } \\
\text { hectares (acres) }\end{array}$ & $\underline{\text { Review Finding }}$ \\
\hline $\begin{array}{l}\text { CH2M HILL } \\
\text { Corporate }\end{array}$ & $\begin{array}{l}\text { BC Cribs south of the 200-East } \\
\text { Area - BC Controlled Area } \\
\text { Northern Zone, } 600 \text { Area }\end{array}$ & $\begin{array}{l}\text { Field survey; recorded } \\
\text { five new sites and } \\
\text { isolated finds }\end{array}$ & $1,441(3,560)$ & No effect to historic properties \\
\hline $\begin{array}{l}\text { CH2M HILL } \\
\text { Corporate }\end{array}$ & $\begin{array}{l}\text { 200-MG-1 Characterization of } \\
\text { Waste Sites 600-40 and 600-262, } \\
600 \text { Area }\end{array}$ & Field reconnaissance & 0 & No effect to historic properties \\
\hline $\begin{array}{l}\text { CH2M HILL } \\
\text { Corporate }\end{array}$ & $\begin{array}{l}\text { 200-MG-1 Characterization of } \\
\text { Waste Sites 600-275 and OCSA } \\
\text { Site 600-518, } 600 \text { Area }\end{array}$ & $\begin{array}{l}\text { Field reconnaissance; } \\
\text { National Register- } \\
\text { eligible site within } \\
\text { project area }\end{array}$ & 0 & No adverse effect to historic properties \\
\hline $\begin{array}{l}\text { CH2M HILL } \\
\text { Corporate }\end{array}$ & $\begin{array}{l}\text { 100-HR-3 Operable Unit, HR-3 } \\
\text { and DR-5 System Enhancement, } \\
600 \text { Area }\end{array}$ & $\begin{array}{l}\text { Field survey; updated } \\
\text { and evaluated eight } \\
\text { previously recorded sites }\end{array}$ & $25.5(63)$ & No adverse effect to historic properties \\
\hline $\begin{array}{l}\text { CH2M HILL } \\
\text { Corporate }\end{array}$ & $\begin{array}{l}\text { Two wells at the } 100-\mathrm{KR}-4 \text { Pump- } \\
\text { and-Treat Project, } 100-\mathrm{K} \text { Area }\end{array}$ & $\begin{array}{l}\text { Field reconnaissance; } \\
\text { updated one traditional } \\
\text { cultural property } \\
\text { boundary }\end{array}$ & 0 & No adverse effect to historic properties \\
\hline $\begin{array}{l}\text { CH2M HILL } \\
\text { Corporate }\end{array}$ & $\begin{array}{l}\text { FY09 100-KR-4 KX Pump-and- } \\
\text { Treat System Phase II Realignment, } \\
\text { 100-K Area }\end{array}$ & Field reconnaissance & 0 & No effect to historic properties \\
\hline PNNL & $\begin{array}{l}\text { Rattlesnake Mountain Combined } \\
\text { Community Communication } \\
\text { Facility and Infrastructure Cleanup } \\
\text { on the Fitzner/Eberhardt Arid } \\
\text { Lands Ecology Reserve, } 600 \text { Area }\end{array}$ & $\begin{array}{l}\text { Field reconnaissance; } \\
12 \text { National Register- } \\
\text { eligible sites, one } \\
\text { National Register- } \\
\text { eligible traditional } \\
\text { cultural property, and } \\
18 \text { National Register- } \\
\text { eligible buildings in } \\
\text { project area }\end{array}$ & 0 & $\begin{array}{l}\text { Adverse effect to traditional cultural } \\
\text { property. Memorandum of Agreement } \\
\text { developed to resolve adverse effects. } \\
\text { Adverse effects to } 18 \text { Manhattan Project/ } \\
\text { Cold War Era Buildings. Mitigation } \\
\text { completed in accordance with } \\
\text { DOE/RL-97-56, Rev. } 1 \text {. No adverse } \\
\text { effect to } 12 \text { archaeological sites. }\end{array}$ \\
\hline PNNL & $\begin{array}{l}\text { Supplemental Cultural Resources } \\
\text { Review for the Infrastructure } \\
\text { Cleanup on the Fitzner/Eberhardt } \\
\text { Arid Lands Ecology Reserve, } \\
600 \text { Area }\end{array}$ & $\begin{array}{l}\text { Field survey; updated } \\
\text { and evaluated one } \\
\text { existing site and } \\
\text { recorded one new site }\end{array}$ & $8.1(20)$ & No adverse effect to historic properties \\
\hline PNNL & $\begin{array}{l}\text { Installation of 200-ZP-1 Injection } \\
\text { Wells and Access Road, } 600 \text { Area }\end{array}$ & $\begin{array}{l}\text { Field survey; National } \\
\text { Register-eligible site } \\
\text { within project area }\end{array}$ & $8.1(20)$ & $\begin{array}{l}\text { Adverse effect to historic properties. } \\
\text { Mitigation completed in accordance } \\
\text { with DOE/RL-97-56, Rev. } 1 .\end{array}$ \\
\hline WCH & $\begin{array}{l}\text { Remediation of Waste Site } 600-151 \\
\text { in the 100-H Area }\end{array}$ & Field reconnaissance & 0 & No effect to historic properties \\
\hline WCH & $\begin{array}{l}\text { Remediation of Waste Site 600-109 } \\
\text { (Hanford Trailer Camp Landfill/ } \\
\text { 45BN1536) in the } 600 \text { Area }\end{array}$ & $\begin{array}{l}\text { Archaeological data } \\
\text { recovery to National } \\
\text { Register-eligible site }\end{array}$ & 0 & $\begin{array}{l}\text { Adverse effect to historic properties. } \\
\text { Memorandum of Agreement developed. } \\
\text { Archaeological excavation mitigation } \\
\text { plan followed. }\end{array}$ \\
\hline WCH & $\begin{array}{l}\text { Remediation of Waste Sites } \\
600-108,600-146 \text {, and } 600-178 \\
\text { Adjacent to Gable Butte }\end{array}$ & $\begin{array}{l}\text { Field reconnaissance; } \\
\text { National Register } \\
\text { traditional cultural } \\
\text { property within project } \\
\text { area }\end{array}$ & 0 & No adverse effect to historic properties \\
\hline
\end{tabular}




\begin{tabular}{|c|c|c|c|c|}
\hline \multirow[b]{2}{*}{$\begin{array}{c}\text { Reviewing } \\
\text { Organization }\end{array}$} & \multirow[b]{2}{*}{ Proposed Activity } & Table 8.15.1. (contd) & & \multirow[b]{2}{*}{$\underline{\text { Review Finding }}$} \\
\hline & & $\begin{array}{c}\text { Field } \\
\text { Activity }\end{array}$ & $\begin{array}{c}\begin{array}{c}\text { Survey Size } \\
\text { hectares (acres) }\end{array} \\
\end{array}$ & \\
\hline WCH & $\begin{array}{l}\text { Remediation of Waste Site } 600-100 \\
\text { in the } 600 \text { Area }\end{array}$ & $\begin{array}{l}\text { Field reconnaissance; } \\
\text { archaeological testing } \\
\text { to evaluate National } \\
\text { Register-eligiblity for } \\
\text { one archaeological site. } \\
\text { Testing confirmed site } \\
\text { was not eligible. }\end{array}$ & 0 & No effect to historic properties \\
\hline $\begin{array}{l}\text { OCSA }=\text { Old } \\
\text { PNNL }=\text { Pacif } \\
\text { WCH }=\text { Wash }\end{array}$ & $\begin{array}{l}\text { entral Shops Area. } \\
\text { Northwest National Laboratory. } \\
\text { ngton Closure Hanford, LLC. }\end{array}$ & & & \\
\hline
\end{tabular}

of a site-wide cultural sensitivity training module for working on traditional cultural properties at the Hanford Site. Workshops were also held with the tribes to develop a Memorandum of Agreement for Historic-Archaeological Data Recovery at 45BN1437 (Hanford Construction Camp Burn Pits) and 45BN1536 (Hanford Trailer Camp Landfill). In addition, two workshops were held with the tribes to begin development of a Programmatic Agreement to handle increased workloads and to accelerate schedules due to DOE's acceptance of American Recovery and Reinvestment Act of 2009 funds.

\subsubsection{Identification and Evaluation Activities}

Identification and evaluation activities are performed to comply with Sections 106 and 110 of the National Historic Preservation Act of 1966. In 2009, 10 new archaeological sites or isolated finds were recorded. Of the 10 newly recorded sites, National Register of Historic Places evaluations were completed on 1 site, 45BN1536. This site was determined to be eligible for inclusion in the National Register of Historic Places. Archaeological site forms for eight previously recorded archaeological sites were updated and evaluated for the National Register: 45BN439, 45BN483, 45BN488, 45BN900, 45BN910, 45BN913, $45 \mathrm{BN} 1052$, and 45BN1053. Of these, three (45BN439, 45BN483, 45BN1052) were determined to be eligible for inclusion in the National Register of Historic Places.

\subsubsection{Data Recovery Activities}

Historic-archaeological data recovery was conducted at the Hanford Construction Camp Burn Pits (45BN1437) and the Hanford Trailer Camp Landfill (45BN1536) during 2009. Both sites were believed to be associated with the Hanford Construction Camp established to house the workers who built Hanford Site facilities between 1943 and 1945. The 45BN1536 site contained only demolition debris relating to the dismantlement of production facilities post-dating the Hanford Construction Camp, so it did not provide information that would be useful in interpreting the lifestyles of the camp workers. However, 45BN1437 produced both a large variety and quantity of artifacts relating to the camp workers including jewelry; ceramic and glassware; decorative items; beer, wine, and soft drink bottles from many locations across the country; medicinal and cosmetic containers; and other materials that will be useful in interpreting the history of the construction period. A report on these excavations and findings is being prepared for release in 2010.

\subsubsection{Management of Artifact and Data Collections}

Pacific Northwest National Laboratory manages Hanford Site archaeological collections, DOE cultural resources records, a reference library, an electronic database of cultural resources reviews, geographical information system data of cultural sites and surveys, and an assortment of supporting 
documentations required to facilitate compliance efforts for the DOE Hanford Cultural and Historic Resources Program. Files from more than 1,500 cultural sites and curated archaeological collections from more than 80 sites are stored in an archive room on the Pacific Northwest National Laboratory campus. During 2009, temperature and humidity levels within the archive room remained within limits for storage of numerous types of archived materials. During 2009, the cultural resources site database was transitioned to a geodatabase, allowing for more accurate depiction of this data set. Additionally, during 2009, database and geographic information systems continued to be used and updated. The Pacific Northwest National Laboratory's Total Records Information Management database (accessible to Pacific Northwest National Laboratory Cultural Resources staff) continues to be used for efficient retrieval of representative site photos, site monitoring photos, historic photos, and archived electronic documents produced by project activities.

The Columbia River Exhibition of History, Science, and Technology Museum manages the Hanford Site Manhattan Project and Cold War artifact collection. Efforts to generate new collections are conducted as stipulated in the programmatic agreement for the built environment on the Hanford Site (DOE/RL-96-77, Rev. 0), which directs DOE to assess the contents of site historical buildings and structures prior to the commencement of deactivation, decontamination, or decommissioning activities. The purpose of the assessments is to identify and preserve any artifacts (e.g., control panels, signs, scale models, machinery) that may have value as interpretive or educational exhibits within national, state, or local museums. During 2009, walkthroughs were completed of six buildings located in the 200 Areas (222-T, 275-E, 276-B, 284-E, 294-A, and
2701-AB). However, no artifacts were observed for retention as exhibits within any of these buildings.

\subsubsection{Cultural Resources Consultations and Public Involvement}

DOE conducts formal consultations with the Washington State Historic Preservation Office, Native American tribes, and interested parties for cultural resources reviews to comply with Section 106 of the National Historic Preservation Act of 1966 and the National Environmental Policy Act of 1969 (see Section 2.0.2). In 2009, DOE consulted with the Washington State Historic Preservation Office and Native American tribes on 13 full cultural reviews (Table 8.15.1).

Hanford Cultural and Historic Resources Program staff held 12 meetings in 2009 with tribal cultural resources staff from the Confederated Tribes of the Umatilla Indian Reservation, the Confederated Tribes and Bands of the Yakama Nation, the Confederated Tribes of the Colville Reservation, the Nez Perce Tribe, and the Wanapum. Discussions focused on the full cultural resources reviews completed and initiated in 2009; development of cultural sensitivity training; implementation of a Memorandum of Agreement for closure projects occurring on Rattlesnake Mountain; results of onsite Archaeological Resources Protection Act of 1979 violations; and approaches to protecting threatened archaeological sites and places containing Native American human remains. No cultural resources meetings were held with non-tribal interested parties in 2009. 


\subsection{Climate and Meteorology}

\section{KW Burk}

Researchers take meteorological measurements to support Hanford Site operations, emergency preparedness and response, and atmospheric dispersion calculations for dose assessments (Appendix E, Table E.5). Support is provided through weather forecasting and by maintaining and distributing climatological data. Forecasting is provided to help manage weather-dependent operations. Climatological data are provided and used to help plan weather-dependent activities, and as a resource to assess the environmental effects of site operations.

Hanford Meteorology Station staff relies on data provided by the Hanford Meteorological Monitoring Network. This network consists of 30 remote monitoring stations that transmit data to the Hanford Meteorology Station through radio telemetry every 15 minutes. There are twenty-seven 9-meter (30-foot) towers and three 61-meter (200-foot) towers. Meteorological information collected at these stations includes wind speed, wind direction, temperature, precipitation, atmospheric pressure, and relative humidity; however, not all of these data are collected at all stations.

Regional temperatures, precipitation, and winds are affected by mountain barriers. The Cascade Range, beyond Yakima to the west, greatly influences the climate of the Hanford Site because of its rain-shadow effect. The Rocky Mountains and ranges in southern British Columbia protect the region from severe, cold polar air masses moving southward across Canada and winter storms associated with them.

Real-time and historical data from the Hanford Meteorology Station can be obtained at http://hms.pnl. gov. Data on this website include hourly weather observations, 15-minute data from the Hanford Meteorological Monitoring Network, monthly climatological summaries, and historical data.
The Hanford Meteorology Station is located on the Hanford Site Central Plateau, where the prevailing wind direction is from the northwest all year long. The secondary wind direction is from the southwest. Summaries of wind directions indicate that winds from the northwestern quadrant occur most often during winter and summer. During spring and fall, the frequency of southwesterly winds increases, with a corresponding decrease in the northwesterly flow. Monthly average wind speeds are lowest during winter months, averaging about 3 meters per second (6 to 7 miles per hour), and highest during summer, averaging about 4 meters per second ( 8 to 9 miles per hour). Wind speeds well above average are usually associated with southwesterly winds. However, summertime drainage winds are generally northwesterly and frequently exceed 13 meters per second ( 30 miles per hour). These winds are most prevalent over the northern portion of the Hanford Site. Figure 8.16.1 shows the 2009 wind roses (i.e., diagrams showing direction and frequencies of wind) measured at a height of 9 meters (30 feet) for the 30 meteorological monitoring stations on and around the Hanford Site.

Atmospheric dispersion is a function of wind speed, wind duration and direction, atmospheric stability, and mixing depth. Dispersion conditions are generally good if winds are moderate to strong, the atmosphere is of neutral or unstable stratification, and there is a deep mixing layer. Good dispersion conditions associated with neutral and unstable stratification exist approximately $57 \%$ of the time during summer. Less-favorable conditions may occur when wind speed is light and the mixing layer is shallow. These conditions are most common during winter, when moderate to extremely stable stratification exists (approximately 66\% of the time). Occasionally, there are extended periods of 


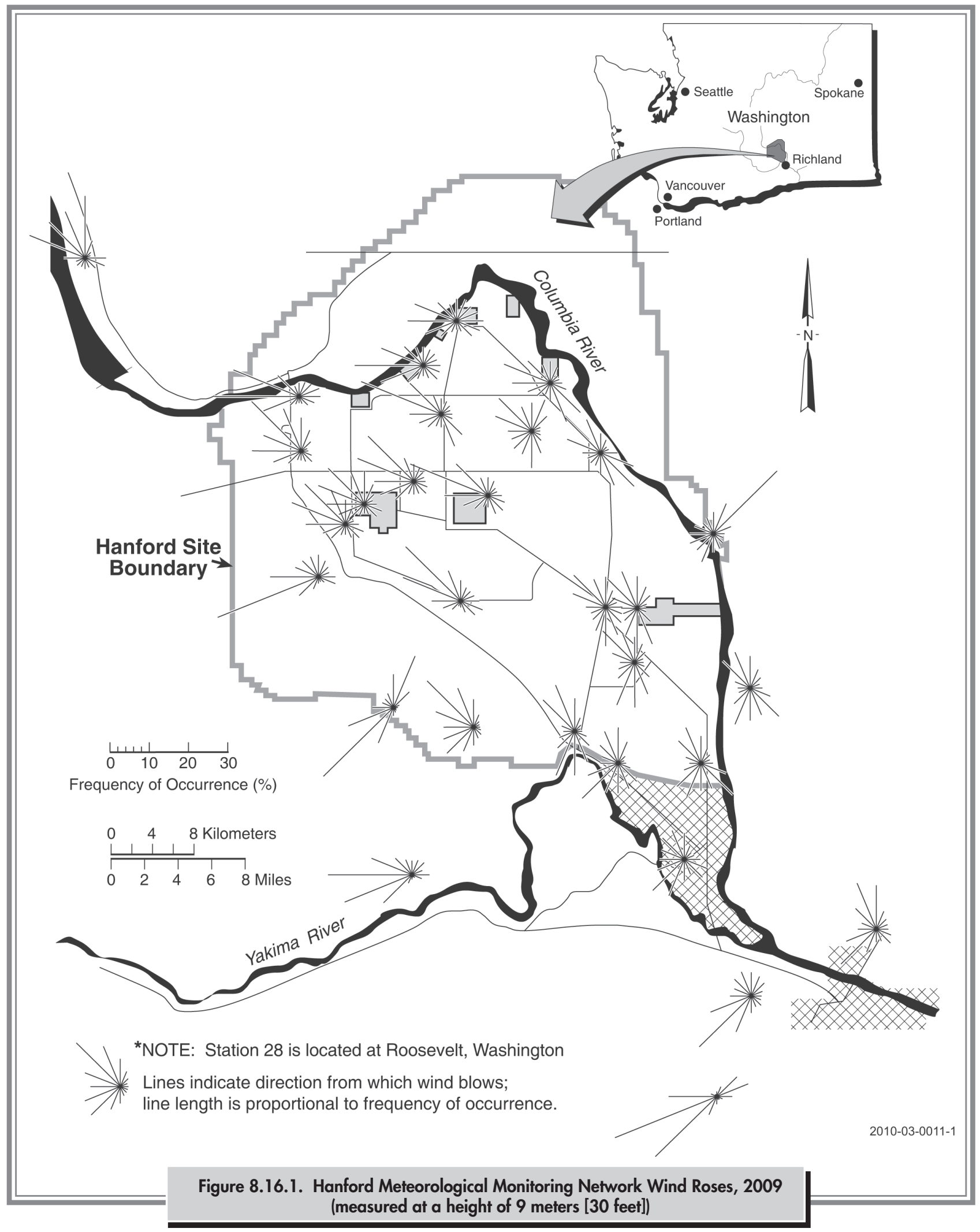


poor dispersion conditions, primarily during winter, that are associated with stagnant air in stationary high-pressure systems.

\subsubsection{Historical Climatological Information}

Daily and monthly averages and extremes of temperature, dew point temperature, and relative humidity for 1945 through 2004 are reported in PNNL-15160. From 1945 through 2009, the record maximum temperature was $45^{\circ} \mathrm{C}$ $\left(113.0^{\circ} \mathrm{F}\right)$ recorded in August 1961, July 2002, and July 2006. The record minimum temperature was $-30.6^{\circ} \mathrm{C}$ $\left(-23.1^{\circ} \mathrm{F}\right)$ in February 1950. Normal monthly average temperatures ranged from a low of $-0.2^{\circ} \mathrm{C}\left(31.7^{\circ} \mathrm{F}\right)$ in December to a high of $24.6^{\circ} \mathrm{C}\left(76.3^{\circ} \mathrm{F}\right)$ in July. During winter, the highest monthly average temperature at the Hanford Meteorology Station was $6.9^{\circ} \mathrm{C}\left(44.4^{\circ} \mathrm{F}\right)$ in February 1991, and the record lowest was $-11.1^{\circ} \mathrm{C}\left(12.1^{\circ} \mathrm{F}\right)$ in January 1950. During summer, the record maximum monthly average temperature was $27.9^{\circ} \mathrm{C}\left(82.2^{\circ} \mathrm{F}\right)$ in July 1985 , and the record minimum was $17.2^{\circ} \mathrm{C}\left(63.0^{\circ} \mathrm{F}\right)$ in June 1953. The normal annual relative humidity at the Hanford Meteorology Station is $54 \%$. Humidity is highest during winter, averaging approximately $76 \%$, and lowest during summer, averaging approximately 36\%. Normal annual precipitation at the Hanford Meteorology Station is 17.7 centimeters (6.98 inches). The wettest year on record, 1995, received 31 centimeters (12.31 inches) of precipitation; the driest, 1976, received 7.6 centimeters ( 2.99 inches). Most precipitation occurs during late autumn and winter, with more than half of the annual amount occurring from November through February. The snowiest winter on record, 1992-1993, received 142.5 centimeters (56.1 inches) of snow.

\subsubsection{Results of 2009 Monitoring}

The 2009 average temperature and precipitation totals were below normal.

The average temperature for 2009 was $11.6^{\circ} \mathrm{C}\left(52.8^{\circ} \mathrm{F}\right)$, which was $0.4^{\circ} \mathrm{C}\left(0.8^{\circ} \mathrm{F}\right)$ below normal $\left(12.0^{\circ} \mathrm{C}\left[53.6^{\circ} \mathrm{F}\right]\right)$. Six months during 2009 were warmer than normal; 6 months were cooler than normal. July had the greatest positive departure at $1.9^{\circ} \mathrm{C}\left(3.4^{\circ} \mathrm{F}\right)$; and December at $3.9^{\circ} \mathrm{C}$ $\left(7.1^{\circ} \mathrm{F}\right)$ below normal, had the greatest negative departure.

Precipitation during 2009 totaled 13.9 centimeters (5.47 inches), which is $78 \%$ of normal precipitation ( 17.7 centimeters [6.98 inches]). Snowfall for 2009 totaled 35.3 centimeters (13.9 inches), compared to normal snowfall of 39.1 centimeters ( 15.4 inches).

The average wind speed during 2009 was 3.4 meters per second (7.8 miles per hour), which was 0.09 meter per second ( 0.2 mile per hour) above normal. The peak gust for the year was 27.3 meters per second (61 miles per hour) on March 15.

Four dust storms were recorded at the Hanford Meteorology Station during 2009. There has been an average of five dust storms per year at the Hanford Meteorology Station during the entire period of record (1945-2009).

Table 8.16.1 provides monthly and annual climatological data collected at the Hanford Meteorology Station during 2009. 
Table 8.16.1. Monthly and Annual Climatological Data for 2009 from the Hanford Meteorology Station

Hanford Meteorology Station, 40 kilometers (25 miles) northwest of Richland, Washington, latitude $46^{\circ} 34^{\prime} \mathrm{N}$, longitude $119^{\circ} 35^{\prime} \mathrm{W}$, elevation 223 meters ( 733 feet)

\begin{tabular}{|c|c|c|c|c|c|c|c|c|c|c|c|c|c|c|c|c|c|c|c|}
\hline \multirow[b]{3}{*}{$\underbrace{\underline{\Xi}}_{\Sigma}$} & \multicolumn{8}{|c|}{ Temperatures, ${ }^{\circ} \mathrm{C}$} & \multicolumn{4}{|c|}{ Precipitation $(\mathbf{c m})$} & \multirow{2}{*}{\multicolumn{2}{|c|}{$\begin{array}{c}\text { Relative } \\
\text { Humidity (\%) }\end{array}$}} & \multicolumn{5}{|c|}{ 15-m Wind ${ }^{(a)}$} \\
\hline & \multicolumn{4}{|c|}{ Averages } & \multicolumn{4}{|c|}{ Extremes } & \multirow[b]{2}{*}{ 营 } & \multirow[b]{2}{*}{ 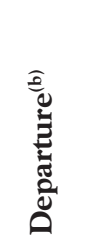 } & \multicolumn{2}{|c|}{ Snowfall } & & & \multirow[b]{2}{*}{ 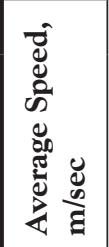 } & \multirow[b]{2}{*}{ 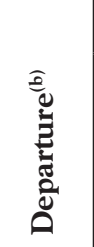 } & \multicolumn{3}{|c|}{ Peak Gusts } \\
\hline & 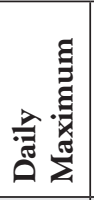 & 氞 & 竞 & 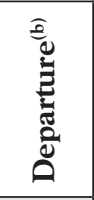 & 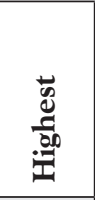 & ص̈ & $\begin{array}{l}4 \\
0 \\
0 \\
0 \\
0 \\
0\end{array}$ & صี & & & సี & 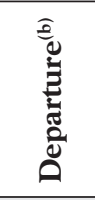 & 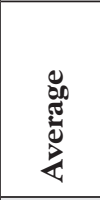 & 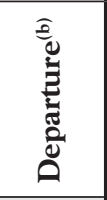 & & & 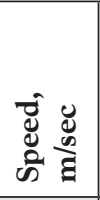 & 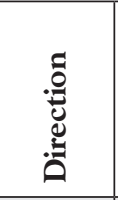 & ڤี๊ \\
\hline $\mathrm{J}$ & 3.0 & -4.4 & -0.7 & -0.6 & 15.6 & 7 & -13.9 & 3 & 2.9 & +0.7 & 20.6 & +9.9 & 80.1 & +2.5 & 2.6 & -0.2 & 22.8 & SSW & 7 \\
\hline $\mathrm{F}$ & 6.1 & -2.8 & 1.7 & -1.6 & 15.0 & 24 & -7.8 & $27^{(c)}$ & 1.6 & -0.1 & 1.8 & -4.8 & 79.3 & +8.6 & 3.0 & -0.1 & 19.2 & SW & 25 \\
\hline M & 11.5 & -0.4 & 5.5 & -2.3 & 20.0 & 20 & -8.9 & 12 & 2.0 & +0.6 & 0.8 & -0.2 & 58.6 & +2.0 & 4.0 & +0.5 & 27.3 & SW & 15 \\
\hline A & 18.4 & 3.5 & 10.9 & -1.0 & 30.6 & 21 & 0 & 2 & 1.0 & -0.1 & $\mathrm{~T}^{(\mathrm{d})}$ & 0 & 47.1 & -0.4 & 3.9 & 0 & 16.1 & WNW & 23 \\
\hline $\mathrm{M}$ & 25.3 & 8.2 & 16.8 & +0.2 & 37.2 & 30 & 2.2 & $13^{(c)}$ & 0.5 & -0.9 & 0 & 0 & 39.7 & -3.3 & 4.1 & +0.1 & 25.5 & $\mathrm{SW}$ & 5 \\
\hline $\mathrm{J}$ & 29.8 & 14.1 & 21.9 & +1.2 & 35.6 & 24 & 8.9 & 23 & 0.4 & -0.6 & 0 & 0 & 37.5 & -2.1 & 4.2 & +0.1 & 19.2 & NW & 17 \\
\hline $\mathrm{J}$ & 35.5 & 17.5 & 26.5 & +1.9 & 40.6 & 31 & 10.6 & 9 & $\mathrm{~T}^{(\mathrm{d})}$ & -0.7 & 0 & 0 & 29.8 & -3.5 & 3.7 & -0.1 & 22.4 & SW & 6 \\
\hline A & 33.3 & 15.9 & 24.6 & +0.5 & 42.8 & 1 & 8.9 & 24 & 0.1 & -0.6 & 0 & 0 & 35.0 & -0.7 & 3.8 & +0.3 & 18.3 & NW & 21 \\
\hline $\mathrm{S}$ & 28.7 & 11.6 & 20.2 & +1.4 & 35.6 & $13^{\text {(c) }}$ & 4.4 & 21 & 0.2 & -0.6 & 0 & 0 & 38.8 & -3.3 & 3.5 & -0.2 & 20.6 & $\mathrm{~W}$ & 6 \\
\hline O & 15.9 & 4.3 & 10.1 & -1.6 & 22.2 & $7^{\text {(c) }}$ & -6.1 & 11 & 2.0 & +0.8 & 0 & -0.3 & 58.8 & +2.7 & 3.8 & +0.9 & 20.6 & $\mathrm{NE}$ & 4 \\
\hline $\mathrm{N}$ & 10.4 & -0.3 & 5.0 & +0.5 & 17.2 & 17 & -6.7 & 12 & 1.4 & -1.1 & $\mathrm{~T}^{(\mathrm{d})}$ & -5.8 & 71.1 & -2.5 & 3.4 & +0.5 & 22.4 & SSW & 22 \\
\hline $\mathrm{D}$ & 0.1 & -8.3 & -4.1 & -3.9 & 8.9 & 21 & -19.4 & 10 & 1.8 & -1.0 & 12.2 & -2.5 & 81.0 & +0.6 & 2.4 & -0.3 & 20.6 & ENE & 6 \\
\hline $\mathrm{Y}^{(\mathrm{e})}$ & 18.2 & 4.9 & 11.5 & -0.4 & 42.8 & Aug 1 & -19.4 & Dec 10 & 13.9 & -3.8 & 35.3 & -3.8 & 54.7 & +0.1 & 3.4 & 0 & 27.3 & $\mathrm{SW}$ & Mar 15 \\
\hline \multicolumn{20}{|c|}{$\begin{array}{l}\text { NOTE: See Appendix A, Table A.2, Conversion Table, in the Helpful Information section for unit conversion information. } \\
\text { (a) Measured on a tower } 15 \text { meters ( } 50 \text { feet) above the ground. } \\
\text { (b) Departure columns indicate positive or negative departure of meteorological parameters from 30-year (1971-2000) climatological normals. } \\
\text { (c) Latest of several occurrences. } \\
\text { (d) Trace. } \\
\text { (e) Yearly averages, extremes, and totals. }\end{array}$} \\
\hline
\end{tabular}




\subsection{Quality Assurance}

Quality assurance and quality control practices encompass all aspects of Hanford Site environmental monitoring and surveillance programs. This section provides information on specific measures taken in 2009 to ensure quality in project management, sample collection, and analytical results.

Samples were collected and analyzed according to documented standard analytical procedures. Analytical data quality was verified by a continuing program of internal laboratory quality control, participation in interlaboratory crosschecks, replicate sampling and analysis, submittal of blind standard samples and blanks, and splitting samples with other laboratories.

Quality assurance/quality control for Hanford Site environmental monitoring and surveillance programs also include procedures and protocols to perform the following:

- Document instrument calibrations

- Conduct program-specific activities in the field

- Maintain groundwater wells to ensure representative samples are collected

- Avoid cross-contamination by using dedicated well sampling pumps.

\subsubsection{Hanford Site-Wide and Offsite Environmental Surveillance and Environmental Monitoring}

\section{EA Lepel and DS Sklarew}

During 2009, comprehensive quality assurance programs, including various quality control practices, were maintained to assure the quality of data collected through the Pacific Northwest National Laboratory Surface Environmental Surveillance Project. The samples collected by project staff were submitted to General Engineering Laboratories, LLC, Charleston, South Carolina, for radiochemical and chemical analyses.

Samples for inorganic analyses were submitted primarily to the Battelle Marine Sciences Laboratory, located at the Pacific Northwest National Laboratory, Sequim Marine Research Operations in Washington State.

\subsubsection{Project Management Quality Assurance}

Site environmental monitoring and related activities (such as performing dose calculations) were subject to an overall quality assurance program. This program implements the requirements of DOE Order 414.1C, "Quality Assurance." Quality assurance plans, which are maintained by project personnel, describe the specific quality assurance elements that apply to each project. These plans were approved by the Pacific Northwest National Laboratory quality assurance organizations that monitor compliance with the plans. Work performed through contracts, such as sample analyses, must meet the same quality assurance requirements. Potential equipment and service suppliers are audited before service contracts are approved and awarded, or materials are purchased that could have a significant impact on quality within the projects.

\subsubsection{Sample Collection Quality Assurance and Quality Control}

Surface Environmental Surveillance Project samples were collected by personnel trained to conduct sampling 
according to approved and documented procedures (PNNL-16744). Continuity of all sampling location identities was maintained through careful documentation. Field duplicate samples were collected for air, biota, vegetation, and water (Tables 8.17.1 and 8.17.2). The water duplicates consisted of three Columbia River water samples and one onsite pond water sample. The biota duplicates were samples of cow's milk and red and white wine. Eleven duplicate vegetation (chive) samples were collected for metals analysis. Fourteen duplicate air samples were collected for tritium analyses. A field duplicate is used to assess sampling and measurement precision. Analytical results were reviewed against the criterion that the result must be greater than the minimum detectable activity value or the method detection limit to be evaluated. To be an acceptable result, the relative percentage difference of the routine sample and

\begin{tabular}{|c|c|c|c|}
\hline \multicolumn{4}{|c|}{$\begin{array}{l}\text { Table 8.17.1. Summary of Field Duplicate Sample Results for Samples } \\
\text { Submitted to General Engineering Laboratories, LLC, Charleston, South } \\
\text { Carolina, for the Surface Environmental Surveillance Project, } 2009\end{array}$} \\
\hline $\begin{array}{l}\text { Media } \\
\text { (Number } \\
\text { of Samples) }\end{array}$ & Analytes & $\begin{array}{l}\text { Number of Results } \\
\text { Reported }^{(a)}\end{array}$ & $\begin{array}{c}\text { Number of } \\
\text { Results Within } \\
\text { Control Limits }^{(b)}\end{array}$ \\
\hline \multicolumn{4}{|c|}{ Radionuclides } \\
\hline Air (14) & ${ }^{3} \mathrm{H}$ & 14 & 8 \\
\hline Water (4) & ${ }^{3} \mathrm{H}$ & 4 & 3 \\
\hline Water (3) & ${ }^{90} \mathrm{Sr}$ & 0 & 0 \\
\hline Water (3) & ${ }^{234} \mathrm{U}$ & 3 & 3 \\
\hline Water (3) & ${ }^{238} \mathrm{U}$ & 3 & 2 \\
\hline Water (1) & Gross beta & 1 & 0 \\
\hline \multirow[t]{3}{*}{ Biota-Milk (2) } & ${ }^{3} \mathrm{H}$ & 2 & 2 \\
\hline & ${ }^{40} \mathrm{~K}$ & 2 & 2 \\
\hline & ${ }^{90} \mathrm{Sr}$ & 0 & 0 \\
\hline \multirow[t]{3}{*}{ Biota-Wine (6) } & ${ }^{3} \mathrm{H}$ & 4 & 4 \\
\hline & ${ }^{40} \mathrm{~K}$ & 6 & 6 \\
\hline & An & & \\
\hline \multirow[t]{4}{*}{ Water (3) } & Chloride & 3 & 3 \\
\hline & Fluoride & 3 & 3 \\
\hline & $\mathrm{NO}_{2}-\mathrm{N}$ & 3 & 3 \\
\hline & $\mathrm{NO}_{3}-\mathrm{N}$ & 3 & 3 \\
\hline \multicolumn{4}{|c|}{ Volatile Organics } \\
\hline Water (1) & Trichloroethene & 1 & 1 \\
\hline \multicolumn{4}{|c|}{ ICP Metals } \\
\hline \multirow[t]{2}{*}{ Vegetation-Chives (11) } & Cadmium & 11 & 9 \\
\hline & Chromium & 11 & 2 \\
\hline \multicolumn{4}{|c|}{$\begin{array}{l}\text { (a) Number of reported results for radiological are those results greater than the minimum } \\
\text { detectable activity. Number of reported results for chemistry are those results greater than } \\
\text { or equal to the method detection limit. } \\
\text { (b) Number of reported results within control limits for radiological analysis are those results } \\
\text { with the relative percent difference value less than } 30 \% \text {, and the result is greater than } \\
\text { the minimum detectable activity. Number of reported results within control limits for } \\
\text { chemical analysis are those results with the relative percent difference value less than } \\
30 \% \text {, and the result is greater than or equal to the method detection limit. } \\
\text { ICP = Inductively coupled plasma. }\end{array}$} \\
\hline
\end{tabular}




\begin{tabular}{|c|c|c|c|}
\hline \multicolumn{4}{|c|}{$\begin{array}{l}\text { Table 8.17.2. Summary of Battelle's Marine Sciences Laboratory Performance on Laboratory Sample Duplicates } \\
\text { for Inductively Coupled Plasma Metals Collected for the Surface Environmental Surveillance Project, } 2009\end{array}$} \\
\hline$\underline{\text { Media }}$ & Metal & $\begin{array}{l}\text { Number of } \\
\text { Results Reported }^{\left({ }^{a}\right)}\end{array}$ & $\begin{array}{l}\text { Number of Results } \\
\text { Within Control Limits }^{(b)}\end{array}$ \\
\hline \multirow[t]{4}{*}{ Water } & As, $\mathrm{Cd}, \mathrm{Cr}, \mathrm{Cu}, \mathrm{Ni}, \mathrm{Pb}, \mathrm{Sb}, \mathrm{Tl}, \mathrm{Zn}$ & 7 & 7 \\
\hline & $\mathrm{Ag}, \mathrm{Be}$ & 1 & 1 \\
\hline & $\mathrm{Hg}$ & 3 & 3 \\
\hline & Se & 6 & 5 \\
\hline Sediment & $\mathrm{Ag}, \mathrm{As}, \mathrm{Be}, \mathrm{Cd}, \mathrm{Cr}, \mathrm{Cu}, \mathrm{Hg}, \mathrm{Mn}, \mathrm{Ni}, \mathrm{Pb}, \mathrm{Sb}, \mathrm{Se}, \mathrm{Tl}, \mathrm{Zn}$ & 1 & 1 \\
\hline \multirow[t]{2}{*}{ Vegetation (Chives) } & $\mathrm{Al}, \mathrm{Cd}, \mathrm{Cr}, \mathrm{Cu}, \mathrm{Mn}, \mathrm{Ni}, \mathrm{Pb}, \mathrm{Tl}, \mathrm{U}, \mathrm{Zn}$ & 1 & 1 \\
\hline & Th & 1 & 0 \\
\hline \multirow[t]{2}{*}{ Biota (Goose) } & $\mathrm{Ag}, \mathrm{Al}, \mathrm{As}, \mathrm{Cd}, \mathrm{Cr}, \mathrm{Cu}, \mathrm{Hg}, \mathrm{Mn}, \mathrm{Ni}, \mathrm{Pb}, \mathrm{Se}, \mathrm{Tl}, \mathrm{Zn}$ & 1 & 1 \\
\hline & Th & 1 & 0 \\
\hline Biota (Whitefish) & $\mathrm{Al}, \mathrm{Cd}, \mathrm{Cr}, \mathrm{Cu}, \mathrm{Hg}, \mathrm{Mn}, \mathrm{Ni}, \mathrm{Pb}, \mathrm{Se}, \mathrm{Tl}, \mathrm{U}, \mathrm{Zn}$ & 1 & 1 \\
\hline \multicolumn{4}{|c|}{$\begin{array}{l}\text { (a) Number of reported results for chemistry are those results greater than or equal to the method detection limit. } \\
\text { (b) Number of reported results within control limits are those results with the relative percent difference value less than } 30 \% \text {, and the } \\
\text { result is greater than or equal to the method detection limit. }\end{array}$} \\
\hline
\end{tabular}

Relative percent difference (RPD) - A measure of the precision of the measurement of a sample (S) and its duplicate (D). The formula is as follows:

$$
R P D=\left(\frac{|S-D|}{\frac{(S+D)}{2}}\right) \times 100
$$

duplicate must be less than $30 \%$. Of the evaluated results, $77 \%$ of the total 2009 field duplicates analyzed by General Engineering Laboratories, LLC for radiochemistry were acceptable. Of the total collected duplicates for chemical analysis and analyzed by the Battelle Marine Sciences Laboratory, $98 \%$ were acceptable.

\subsubsection{Analytical Results Quality Assurance and Quality Control}

Routine chemical analyses of water samples were performed at General Engineering Laboratories, LLC for the Surface Environmental Surveillance Project. Laboratory personnel participated in the EPA-sanctioned Water Pollution and Water Supply Performance Evaluation Studies conducted by
Environmental Resource Associates in Arvada, Colorado. General Engineering Laboratories, LLC maintained an internal quality control program that met the requirements in EPA (1986). The program was audited by the DOE Consolidated Audit Program.

Routine metals analyses were performed by the Battelle Marine Sciences Laboratory. The Battelle Marine Sciences Laboratory participated in the NSI Solutions, Inc. Proficiency Testing Program. NSI Solutions, Inc. in Raleigh, North Carolina, supplied spiked soil and water samples for analyses. Analytical results were provided to NSI Solutions, Inc. and compared to the known concentrations of the spikes. In 2009, water sample results from three general trace metal studies (including mercury) and two additional trace mercury studies (trace mercury only) were reported. The acceptance criteria were met by $100 \%$ of the reported results from the water samples. Results also were reported from two soil studies in 2009; $100 \%$ of these results were acceptable. Results are summarized in Table 8.17.3.

Routine radiochemical analyses of samples for the Environmental Surveillance Monitoring Project were performed by General Engineering Laboratories, LLC, who also 


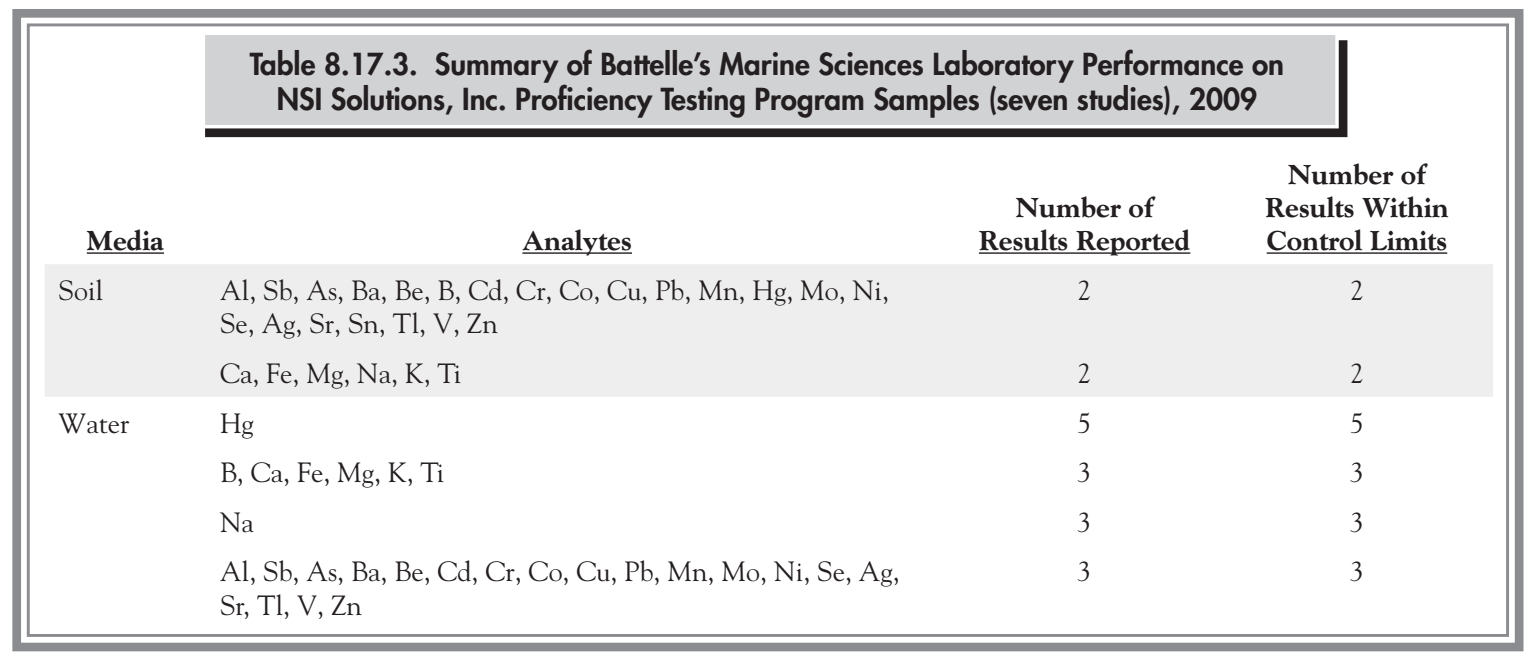

Blind-spiked sample - A sample of known activity and/or concentration submitted to the analytical service laboratory but not necessarily in the same physical geometry as the typical samples submitted.

participated in the DOE Mixed Analyte Performance Evaluation Program (DOE 2004). A quality control blindspiked sample program was also conducted by the Pacific Northwest National Laboratory. General Engineering Laboratories, LLC maintains an internal quality control program. Additional information on these quality control efforts is provided in the following sections.

\subsubsection{U.S. Department of Energy and U.S. Environmental Protection Agency Comparison Studies}

Blind-spiked water samples were distributed to participating laboratories as part of the EPA performance evaluation program. These blind-spiked samples contained specific organic and inorganic analytes that had concentrations unknown to the analyzing laboratories. After analysis, the results for seven different studies were obtained from Environmental Resource Associates, one study from Resource Technology Corporation, and four Environmental Laboratory Accreditation Program studies for comparison with known values and results from other participating laboratories. The acceptance criteria were met by $98 \%$ of the DOE performance assessment sample results (Table 8.17.4).
The DOE Mixed Analyte Performance Evaluation Program conducted by the Radiological and Environmental Sciences Laboratory in Idaho Falls, Idaho, provided standard samples of environmental media (e.g., air filters, soil, vegetation, and water) containing specific amounts of one or more radionuclides unknown to the participating laboratory. After analysis, the results were forwarded to the Radiological and Environmental Sciences Laboratory (two studies) or Environmental Resource Associates (two studies) for comparison with known values and results from other laboratories. The Radiological and Environmental Sciences Laboratory and Environmental Resource Associates established criteria for evaluating the accuracy of results as defined by the National Standards for Water Proficiency Testing Studies, Criteria Document (NERL-Ci-0045). The Radiological and Environmental Sciences Laboratory evaluated the DOE Mixed Analyte Performance Evaluation Program radiological and inorganic samples results for accuracy by determining if each result was within $\pm 30 \%$ of a reference value. Summaries of the 2009 results are provided in Tables 8.17.5 and 8.17.6. The DOE Mixed Analyte Performance Evaluation Program provided General Engineering Laboratories, LLC with two sets of performance evaluation samples for analysis consisting of air filters, soil, vegetation, and water. Acceptable control limits, as defined by the DOE Mixed Analyte Performance Evaluation Program, were met by $98 \%$ of the DOE performance assessment sample results. The acceptable control limit range (NERL-Ci-0045) was met by $78 \%$ of the Environmental Resource Associates samples. 
Table 8.17.4. Summary of Chemical Results for General Engineering Laboratories, LLC, Charleston, South Carolina, Performance on Eight Environmental Resource Associates', One Resource Technology Corporation's, and Four New York State Department of Health Environmental Laboratory Approval Program's Proficiency Testing Samples, 2009

Analyte

Antimony, arsenic, barium, beryllium, cadmium, chromium, copper, molybdenum, nickel, zinc

Silver, vanadium

Lead, manganese, nitrate (as N), selenium, thallium

Aluminum

Cobalt, sodium, tin

Iron, mercury, nitrobenzene

Fluoride, sulfate (as $\left.\mathrm{SO}_{4}\right)$

\section{2,4-Dinitrotoluene}

2,6-Dinitrotoluene; boron; calcium; chloride; methoxychlor; potassium; strontium; titanium

1,4-Dichlorobenzene; endrin; gamma-benzene hexachloride (BHC) (lindane); heptachlor; heptachlor epoxide; hexachlorobutadiene; methyl tert-butyl ether; sulfide

1,1,1-Trichloroethane; 1,1,2,2-tetrachloroethane; 1,1,2-trichloroethane; 1,1-dichloroethane; 1,1-dichloroethene; 1,2,4-trichlorobenzene; 1,2-dichlorobenzene; 1,2-dichloroethane; 1,2-dichloropropane; 1,3,5-trinitrobenzene; 1,3-dichlorobenzene; 1,3-dinitrobenzene; 2,4,6-trinitrotoluene; 2,4-D; 2-amino-4,6-dinitrotoluene; 2-nitrotoluene; 3-nitrotoluene; 4,4'-DDD; 4,4'-DDE; 4,4'-DDT; 4-nitrotoluene; acenaphthene; acenaphthylene; aldrin; alkalinity; alpha-BHC; alphachlordane; anthracene; benzene; benzo(a)anthracene; benzo(a)pyrene; benzo(b)fluroanthene; benzo(g,h,i)perylene; benzo(k)fluoranthene; beta-BHC; bromodichloromethane; bromoform; bromomethane; carbon tetrachloride; chlorobenzene; chloroethane; chloroform; chloromethane chrysene; cis-1,2-dichloroethene; cis-1,3-dichloropropene; delta-BHC; dibromochloromethane; dieldrin; dissolved silica; endosulfan I; endosulfan sulfate; endrin aldehyde; endrin ketone; ethyl benzene; fluoranthene; fluorine; gamma-chlordane; hardness (total, $\mathrm{CaCO}_{3}$ ); HMX; indeno(1,2,3-c,d)pyrene; magnesium; methylene chloride; naphthalene; nitrate + nitrite (as N); nitrite (as N); orthophosphate (as P); pentachlorophenol; phenanthrene; pyrene; hexahydro-1,3,5-trinitro1,3,5-triazine (RDX); silvex (2,4,5-TP); styrene; tetrachloroethene; tetryl; toluene; total xylenes; trans-1,2-dichloroethene; trans-1,3dichloropropene; trichloroethene; trichlorofluoromethane; uranium (nat) mass; vinyl chloride

4-Amino-2,6-dinitrotoluene; dibenzo(a,h)anthracene; endosulfan II

2,4,5-T; 2,4,5-trichlorophenol; 2,4,6-trichlorophenol; 2-methylphenol; 4-methylphenol; bromide; chlordane; dicamba; hexachlorobenzene; hexachloroethane; toxaphene; turbidity

Ammonia (as N); bromochloroacetic acid; dibromoacetic acid; dichloroacetic acid; trichloroacetic acid

Dichlorodifluoromethane

\section{Number of Results Reported}

12

12

10

10

8

7

7

7

7

6

5

4

4

12

11

10

8

7

6

5

6

5
Number of Results Within Control Limits

9

3
3

2

3
1 
Table 8.17.4. (contd)

\section{Analyte}

1,1,1,2-Tetrachloroethane; 1,1-dichloropropene; 1,2,3-trichlorobenzene;

1,2,3-trichloropropane; 1,2,4-trimethylbenzene; 1,2-dibromo-

3-chloropropane; 1,2-dibromoethane; 1,3,5-trimethylbenzene;

1,3-dichloropropane; 2,2-dichloropropane; 2,4-dichlorophenol;

2,4-dimethylphenol; 2,4-dintrophenol; 2,6-dichlorophenol;

2-chloronaphthalene; 2-chlorophenol; 2-chlorotoluene; 2-hexanone;

2-methyl-4,6-dinitrophenol; 2-methylnaphthalene; 2-nitrophenol;

3,3'-dichlorobenzidine; 4-bromophenylphenyl ether; 4-choloro-3-

methylphenol; 4-chlorophenylphenyl ether; 4-chlorotoluene; 4-methyl-2-

pentanone; 4-nitrophenol; benzidine; benzyl butyl phthalate; biochemical oxygen demand; bis(2-chloroethoxy)methane; bis(2-chloroethyl)ether;

bis(2-chloroisopropyl)ether; bis(2-ethylhexyl)phthalate; bromobenzene; bromochloromethane; carbonaceous biological oxygen demand (BOD); chemical oxygen demand (COD); chromium VI; cyanide, dibenzofuran; dibromomethane; diethyl phthalate; dimethyl phthalate; di-n-butyl phthalate; di-n-octyl phthalate; hexachlorocyclopentadiene; isophorone; isopropylbenzene; Kjeldahl nitrogen (total); n-butylbenzene; nitroglycerin; $\mathrm{N}$-nitrosodimethylamine; $\mathrm{N}$-nitroso-n-propylamine; $\mathrm{N}$-nitrosodiphenylamine; $\mathrm{n}$-propylbenzene; oil and grease total recoverable; PCB-1016; PCB-1221; PCB-1232; PCB-1242; PCB-1248; PCB-1254; PCB-1260; pentaerythritoltetranitrate; phenol; phenols; phosphorus (total); p-isopropyltoluene; sec-butylbenzene; settleable solids; specific conductance; tert-butylbenzene; total dissolved solids; total organic carbon (TOC); total residual chlorine; total solids; total suspended solids

Momobromoacetic acid

Monochloroacetic acid

2,4-DB; 3+4-methylphenol; acidity as $\mathrm{CaCO}_{3}$; amenable cyanide bromoacetic acid; chloroacetic acid; $\mathrm{COD}$; conductivity at $25^{\circ} \mathrm{C}$; dichloroprop; diesel range organics; di-isopropyl ether; dinoseb; ethyl-tbutylether; free cyanide; gasoline range organics; lithium; mercury (low level); pyridine; sulfur; t-amylmethylether; tert-butyl alcohol; TOC; total cresol; total cyanide; total petroleum hydrocarbons (TPH); TPH (hexane-extractable material); TPH (silica gel treated hexane-extractable material); volatile solids

Total organic halides

\section{Number of Results Reported}

2
Number of Results Within Control Limits 2
Double-blind spiked sample - A sample of known activity and/or concentration prepared to look like a typical sample submitted to the analytical service laboratory.

\subsubsection{Pacific Northwest National Laboratory Evaluations}

Eight double-blind spiked samples were submitted for analyses by the Surface Environmental Surveillance Project. The samples included air filters, soil, vegetation, and water
(Table 8.17.7). For soil and water blinds, $81 \%$ of General Engineering Laboratories, LLC radiochemistry blind-spiked determinations were within the control limit $( \pm 30 \%$ of the known value). In 2009, the provider of the blinds was changed and analytical procedures for the analysis of vegetation samples were slightly modified. This change was not communicated to General Engineering Laboratories, LLC, which resulted in the observation of sample inhomogenity since a small portion of the total sample was analyzed. Consequently, there was poor agreement (only $13 \%$ of the reported results were acceptable). In addition, the results for the blinds air filters showed poor agreement 


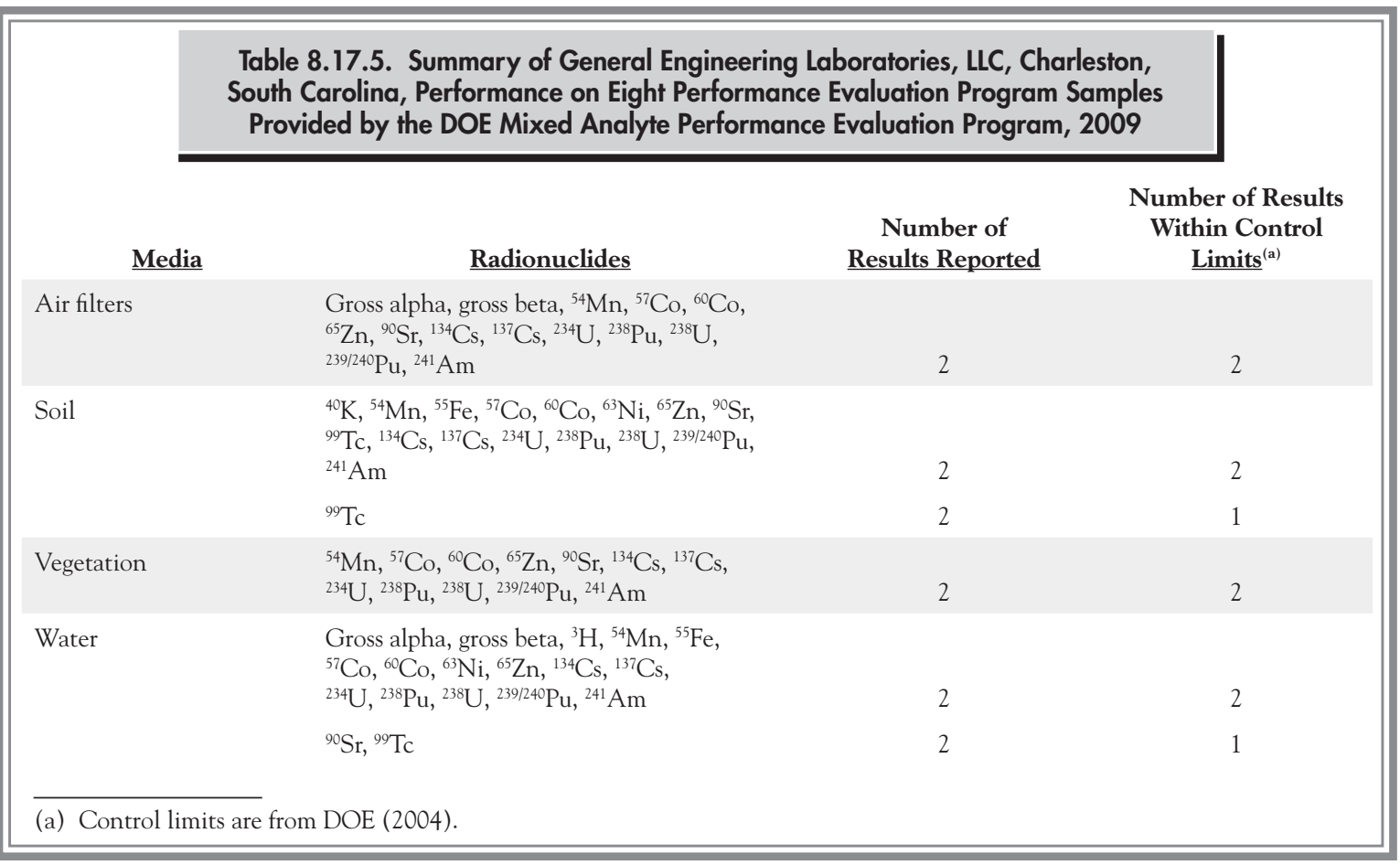

with the known values. Again, the change in the blind sample provider seems to have resulted in analysis results that cannot be explained at this time.

\subsubsection{Laboratory Internal Quality Assurance Programs}

Analytical laboratories are required to maintain an internal quality assurance and control program. Laboratories are audited at least annually for compliance to the quality assurance and control programs. At General Engineering Laboratories, LLC, the quality control program met the quality assurance and control criteria as specified in EPA (1986). The laboratory was also required to maintain a system to review and analyze the results of the quality control samples to detect problems that may have arisen from contamination, inadequate calibrations, calculation errors, or improper procedure performance. Detection levels for each analytical method were determined at least annually.

The internal quality control program at General Engineering Laboratories, LLC involved routine calibrations of counting instruments, yield determinations of radiochemical procedures, frequent radiation-check sources and background counts, replicate and spiked sample analyses, use of matrix and reagent blanks, and maintenance of control charts to indicate analytical deficiencies. Available calibration standards traceable to the National Institute of Standards and Technology were used for radiochemical calibrations. Calculation of minimum detectable concentrations involved the use of factors such as the average counting efficiencies and background counts for detection instruments, length of time for background and sample counts, sample volumes, radiochemical yields, and a predesignated uncertainty multiplier (EPA 520/1-80-012).

The internal quality control program at the Battelle Marine Sciences Laboratory involved routine daily calibrations of analytical instruments, analysis of certified reference materials, replicate and spiked sample analyses, and the use of matrix and reagent blanks. Acceptable results were achieved for more than $98 \%$ of quality control analyses. Most failures were attributed to the results for certified reference materials that were certified at or near the achieved detection limit for that analyte. Available calibration standards traceable to the National Institute of Standards and Technology were used for calibrating instruments used in metal analyses. Calculations of method 


\begin{tabular}{|c|c|c|c|}
\hline \multicolumn{4}{|c|}{$\begin{array}{l}\text { Table 8.17.6. Summary of General Engineering Laboratories, LLC, Charleston, South Carolina, } \\
\text { Performance on One Multimedia Radiochemistry Performance Testing Sample and One } \\
\text { RadChem Proficiency Testing Sample Provided by the Environmental Resource } \\
\text { Associates Proficiency Testing Program, } 2009\end{array}$} \\
\hline$\underline{\text { Media }}$ & $\underline{\text { Radionuclides }}$ & $\begin{array}{c}\text { Number of } \\
\text { Results Reported }\end{array}$ & $\begin{array}{c}\text { Number of Results } \\
\text { Within Control Limits }^{(\mathrm{a})}\end{array}$ \\
\hline \multirow{10}{*}{ Water } & Gross alpha & 5 & 5 \\
\hline & Gross beta, U-total ${ }^{(\mathrm{b})}$ & 5 & 4 \\
\hline & ${ }^{228} \mathrm{Ra}$ & 5 & 3 \\
\hline & U-total (mass) ${ }^{(\mathrm{c})}$ & 5 & 2 \\
\hline & ${ }^{226} \mathrm{Ra}$ & 5 & 1 \\
\hline & ${ }^{131} \mathrm{I}$ & 4 & 4 \\
\hline & $\begin{array}{l}{ }^{60} \mathrm{Co},{ }^{65} \mathrm{Zn},{ }^{90} \mathrm{Sr},{ }^{134} \mathrm{Cs},{ }^{137} \mathrm{Cs}, \\
\text { U-total (mass) }\end{array}$ & 3 & 3 \\
\hline & ${ }^{3} \mathrm{H},{ }^{85} \mathrm{Sr},{ }^{133} \mathrm{Ba},{ }^{241} \mathrm{Am}$ & 2 & 2 \\
\hline & ${ }^{55} \mathrm{Fe},{ }^{54} \mathrm{Mn},{ }^{234} \mathrm{U},{ }^{238} \mathrm{U}, \mathrm{U}$-total & 1 & 1 \\
\hline & ${ }^{238} \mathrm{Pu},{ }^{239} \mathrm{Pu}$ & 1 & 0 \\
\hline \multirow[t]{3}{*}{ Soil } & ${ }^{90} \mathrm{Sr},{ }^{238} \mathrm{U},{ }^{241} \mathrm{Am}$ & 2 & 2 \\
\hline & U-total (mass) & 2 & 0 \\
\hline & $\begin{array}{l}{ }^{40} \mathrm{~K},{ }^{54} \mathrm{Mn},{ }^{60} \mathrm{Co},{ }^{134} \mathrm{Cs},{ }^{137} \mathrm{Cs},{ }^{212} \mathrm{Bi} \\
{ }^{212} \mathrm{~Pb},{ }^{214} \mathrm{Bi},{ }^{214} \mathrm{~Pb},{ }^{228} \mathrm{Ac},{ }^{234} \mathrm{Th},{ }^{234} \mathrm{U} \\
{ }^{238} \mathrm{Pu}, \mathrm{U} \text {-total }\end{array}$ & 1 & 1 \\
\hline \multirow[t]{3}{*}{ Vegetation } & U-total (mass) & 2 & 2 \\
\hline & ${ }^{241} \mathrm{Am}$ & 2 & 1 \\
\hline & $\begin{array}{l}{ }^{40} \mathrm{~K},{ }^{54} \mathrm{Mn},{ }^{60} \mathrm{Co},{ }^{65} \mathrm{Zn},{ }^{90} \mathrm{Sr},{ }^{134} \mathrm{Cs} \\
\text { U-total }\end{array}$ & 2 & 1 \\
\hline \multirow[t]{3}{*}{ Air filters } & Gross beta, ${ }^{241} \mathrm{Am}, \mathrm{U}$-total (mass) & 2 & 2 \\
\hline & Gross alpha & 2 & 0 \\
\hline & $\begin{array}{l}{ }^{54} \mathrm{Mn},{ }^{55} \mathrm{Fe},{ }^{60} \mathrm{Co},{ }^{65} \mathrm{Zn},{ }^{90} \mathrm{Sr},{ }^{134} \mathrm{Cs}, \\
{ }^{137} \mathrm{Cs},{ }^{234} \mathrm{U},{ }^{238} \mathrm{U},{ }^{238} \mathrm{Pu},{ }^{239} \mathrm{Pu} \text {, U-total }\end{array}$ & 1 & 1 \\
\hline \multicolumn{4}{|c|}{$\begin{array}{l}\text { (a) Control limits are from NERL-Ci-0045. } \\
\text { (b) Uranium reported as activity concentration }(\mathrm{pCi} / \mathrm{L}) \text {. } \\
\text { (c) Uranium reported on a mass basis }(\mu \mathrm{g} / \mathrm{L}) \text {. }\end{array}$} \\
\hline
\end{tabular}

detection limits are performed annually according to 40 CFR 136, Appendix B. The Battelle Marine Sciences Laboratory maintained strict adherence to in-house sample handling and chain-of-custody procedures, and all data were fully validated prior to release.

Periodically, inspections of services were performed, and conformance of the analytical facility with its contractual requirements was documented. These inspections provided the framework within which to identify and resolve potential performance problems. Responses to inspection findings were documented by written communication, and corrective actions were verified by follow-up audits and inspections. In 2009, an audit of General Engineering Laboratories, LLC was conducted by the DOE Consolidated Audit Program. 


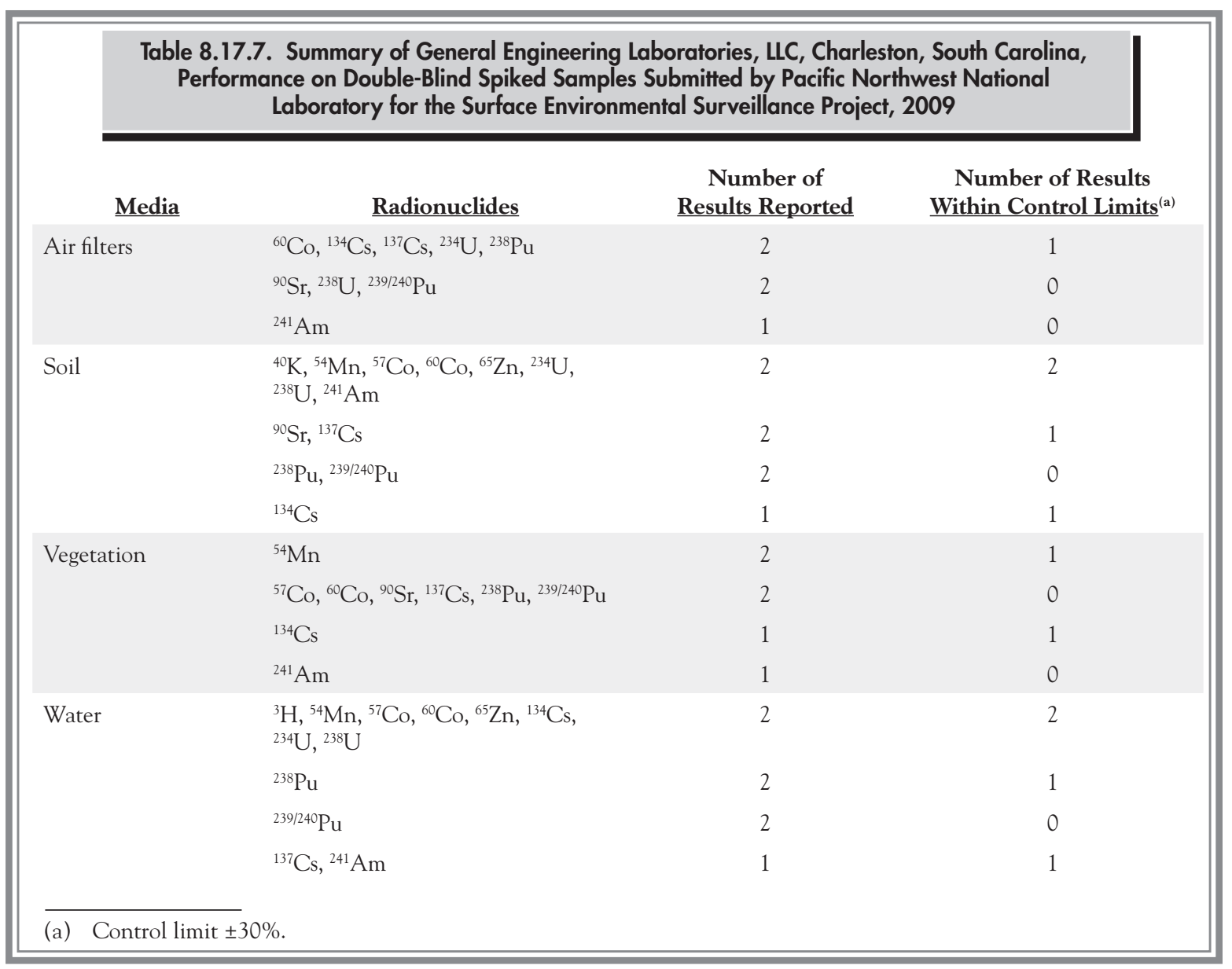

The scope of DOE Consolidated Audit Program audits included the following specific functional areas: 1) quality assurance management systems and general laboratory practices; 2) data quality for organic analyses; 3 ) data quality for inorganic and wet chemistry analyses; 4) data quality for radiochemistry analyses; 5) laboratory information management systems (electronic data management); 6) hazardous and radioactive materials management; and 7) verification of corrective-action implementation from previous audit findings.

One new Priority II finding (requiring some corrective action by the laboratory) and six observations were noted during the DOE Consolidated Audit Program audit of General Engineering Laboratories, LLC. A Priority II finding is defined as the following:

“...factual statement issued from a DOECAP [DOE Consolidated Audit Program] audit to document a deficiency which in of itself does not represent a concern of sufficient magnitude to render the audited facility unacceptable to provide services to DOE. An observation is defined as a factual statement resulting from a DOECAP audit to document an isolated deficiency, deviation from Best Management Practices, or an opportunity for improvement, which does not warrant issuance of a Priority II finding."

Eight previous Priority II finding were closed and none remain open.

The new Priority II finding is as follows:

- Control Charts at a specified frequency for out-ofcontrol conditions was not well defined.

Corrective actions for all the audit findings were accepted, and verification of the corrective actions will be performed in future audits. 
The DOE Consolidated Audit Program internal audit “... found that GEL [General Engineering Laboratories, LLC] meets established requirements necessary to produce data of acceptable and documented quality through analytical operations that follow approved and technically sound methods. DOE samples and analysis-derived waste are handled in a manner that is protective of human health and the environment."

Internal laboratory quality control program data were reported with analytical results. Pacific Northwest National Laboratory scientists summarized results quarterly. For the Surface Environmental Surveillance Project, General Engineering Laboratories, LLC met contract-specified requirements for each quarter in 2009.

\subsubsection{Media Audits and Comparisons}

Additional audits and comparisons were conducted on several specific sample types. The Washington State Department of Health routinely analyzed co-samples of various environmental media during 2009 as part of its oversight monitoring program (see Section 3.0.4). Media that were analyzed for radionuclides included irrigation water from 2 locations, water from 14 locations along and across the Columbia River, water from 10 Columbia River shoreline springs, and water from 2 onsite drinking water locations. Soil samples analyzed were one sample from a pond, five sediment samples taken from the Columbia River, and five from the Columbia River shoreline springs. Biota samples analyzed for radionuclides were two samples of alfalfa, four samples of apples, two samples of leafy vegetables, and four samples of potato tubers. One whitefish was obtained for muscle and carcass analysis. Finally, there were three red and three white wine duplicate samples collected.

No comparison data were available at the time this report was written.

\subsubsection{Effluent Monitoring and Environmental Monitoring Near Facilities and Operations Quality Assurance Programs}

\section{JJ Dorian}

The Effluent Monitoring and Near-Facility Environmental Monitoring Programs were subject to the quality assurance requirements specified in DOE/RL-96-68, Rev. 3. These quality assurance programs complied with DOE Order 414.1C, using standards from the American Society of Mechanical Engineers (ASME NQA-1-2008) as their basis. The program also adhered to the guidelines and objectives in Requirements for Quality Assurance Project Plans for Environmental Data Operations (EPA QA/R-5).

The monitoring programs have a quality assurance program plan describing applicable quality assurance elements. The plan was approved by the contractor quality assurance group, who monitored compliance with the plan. Work, such as sample analyses performed through contracts, had to meet plan requirements. Suppliers were audited before the contract selection was made for equipment and services that may have significantly affected project quality.

\subsubsection{Sample Collection Quality Assurance}

Samples for the Effluent Monitoring and Near-Facility Environmental Monitoring Programs were collected by personnel trained in accordance with approved procedures. Established sampling locations were accurately identified and documented to ensure continuity of data for those sites and are described in PNNL-19455, APP. 2.

\subsubsection{Analytical Results Quality Assurance \\ HK Meznarich and EJ Wyse \\ Samples for the Effluent Monitoring and Near-Facility Environmental Monitoring Programs were analyzed by}


up to four different analytical laboratories. Use of these laboratories depended on the Hanford Site contractor collecting the samples. Table 8.17 .8 provides a summary of the analytical laboratories used for analyzing Hanford Site effluent monitoring and near-facility monitoring samples in 2009.

Analytical data quality was ensured by several means. For instance, counting room instruments were verified to perform within calibration limits through daily checks, the results of which were stored in computer databases. Radiochemical standards used in analyses were measured regularly, and the results were reported and tracked. Formal, written laboratory procedures were followed to analyze samples. Analytical procedural control was ensured through administrative procedures. Chemical technologists at the laboratories are qualified to perform analyses through formal classroom and on-the-job training.

Participation of the Hanford Site analytical laboratories in EPA and DOE laboratory performance evaluation programs also served to ensure the quality of data produced.
Performance of the Waste Sampling and Characterization Facility was evaluated by its participation in the following laboratory performance intercomparison studies in 2009: EPA studies (i.e., soil, water pollution, and water tritium), DOE Mixed Analyte Performance Evaluation Program studies, and the National Institute of Standards and Technology Radiochemistry Intercomparison Program study. Waste Sampling and Characterization Facility laboratory personnel received and analyzed samples containing 447 different analytes and compounds during participation in EPA Water Pollution Studies Nos. 168 and 174 and EPA Soil Studies Nos. 65 and 67. Of the 447 reported analytes, all results were acceptable for a total acceptable rate of $100 \%$. For the EPA Water Tritium studies (RAD 76 and RAD 78), two tritium results were submitted and were acceptable (a 100\% acceptable rate). For the DOE Mixed Analyte Performance Evaluation Program study (MAPEP-09-Study 20 and MAPEP-09Study 21), samples containing 409 different radionuclides and analytes were submitted to the Waste Sampling and Characterization Facility for analysis. Of the 409 reported

\begin{tabular}{|c|c|c|c|c|c|c|c|c|}
\hline \multirow{4}{*}{$\begin{array}{l}\text { Analytical } \\
\text { Laboratory }\end{array}$} & $\begin{array}{l}17.8 . \\
\text { f Efflu }\end{array}$ & $\begin{array}{l}\text { Summar } \\
\text { Monito }\end{array}$ & $\begin{array}{l}\text { of Hanford Site Labo } \\
\text { g and Near-Facility }\end{array}$ & $\begin{array}{l}\text { atories } \\
\text { lonitorir }\end{array}$ & $\begin{array}{l}\text { by Site } C_{c} \\
\text { mples Anc }\end{array}$ & $\begin{array}{l}\text { ractor } \\
\text { zed, }\end{array}$ & $\begin{array}{l}\text { and } \\
09\end{array}$ & \\
\hline & \multicolumn{5}{|c|}{ Effluent Monitoring Samples } & \multirow{2}{*}{\multicolumn{3}{|c|}{$\begin{array}{c}\text { Near-Facility } \\
\text { Environmental } \\
\text { Monitoring Samples } \\
\text { Fluor Hanford, Inc. } \\
\text { and Mission Support } \\
\text { Alliance (R. J. Lee Group) }\end{array}$}} \\
\hline & \multicolumn{2}{|c|}{$\begin{array}{l}\text { Fluor Hanford, } \\
\underline{\text { Inc. }}\end{array}$} & \multirow{2}{*}{$\begin{array}{c}\text { Pacific Northwest } \\
\text { National Laboratory } \\
\underline{\text { Air }}\end{array}$} & \multicolumn{2}{|c|}{$\begin{array}{l}\text { Bechtel National, } \\
\text { Inc. and Washington } \\
\text { Closure Hanford, LLC }\end{array}$} & & & \\
\hline & $\underline{\text { Air }}$ & Water & & $\underline{\text { Air }}$ & $\underline{\text { Water }}$ & $\underline{\text { Air }}$ & $\underline{\text { Water }}$ & Other \\
\hline $\begin{array}{l}\text { Waste Sampling and } \\
\text { Characterization } \\
\text { Facility }^{(a)}\end{array}$ & $\mathrm{X}$ & $\mathrm{X}$ & & $\mathrm{X}$ & $\mathrm{X}$ & $\mathrm{X}$ & $\mathrm{X}$ & $\mathrm{X}$ \\
\hline $\begin{array}{l}\text { Advanced Technologies } \\
\text { and Laboratories Inter- } \\
\text { national, Inc. }\end{array}$ & & & & $\mathrm{X}$ & & & & $\mathrm{X}$ \\
\hline $\begin{array}{l}\text { General Engineering } \\
\text { Laboratories, LLC, } \\
\text { Charleston, } \\
\text { South Carolina }\end{array}$ & $\mathrm{X}$ & $\mathrm{X}$ & $\mathrm{X}$ & $\mathrm{X}$ & $\mathrm{X}$ & & & \\
\hline $\begin{array}{l}\text { Radiochemical } \\
\text { Processing Laboratory }{ }^{(\mathrm{b})}\end{array}$ & $\mathrm{X}$ & $\mathrm{X}$ & $\mathrm{x}$ & & & & & \\
\hline $\begin{array}{l}\text { (a) Operated by Fluor } \\
\text { (b) Operated by Pacif }\end{array}$ & $\begin{array}{l}\text { nford, } \\
\text { orthw }\end{array}$ & $\begin{array}{l}\text { until Au } \\
\text { Jational I }\end{array}$ & $\begin{array}{l}\text { t 23, 2009, and by Missi } \\
\text { oratory. }\end{array}$ & Support & ice (R. J. Le & Group) & nce Augu & 24,2009 \\
\hline
\end{tabular}


radionuclide analytes, 401 results were acceptable while 8 were unacceptable, for a total acceptable rate of $98 \%$. In the National Institute of Standards and Technology Radiochemistry Intercomparison Program study, samples containing strontium-90, americium-241, isotopic plutonium, and isotopic uranium in filters and soils were submitted to the Waste Sampling and Characterization Facility for different analyses (i.e., five samples of each radionuclide for each medium). All radionuclide results for both filters and soils were acceptable, for a total acceptance rate of $100 \%$. Performance evaluation results for the Waste Sampling and Characterization Facility are presented in Table 8.17.9.

Advanced Technologies and Laboratories International, Inc., the Analytical Services Production Contractor at the 222-S Laboratory in the 200-West Area of the Hanford Site, maintains accreditations from the American Industrial
Hygiene Association and the Washington State Department of Ecology. Analytical performance was evaluated by its participation in six different laboratory proficiency testing studies in 2009, which included Environmental Resource Associates Water Pollution Studies 171, 172, and 177 (participation in study 171 was limited only to bromide); Environmental Resource Associates Soil Study 67; and Mixed Analyte Performance Evaluation Program Studies 20 and 21. In addition, the 222-S Analytical Laboratory participated in the American Industrial Hygiene Association Industrial Hygiene Proficiency Analytical Testing, Beryllium Proficiency Analytical Testing, and Workplace Analysis Scheme for Proficiency testing programs to maintain its accreditation.

Advanced Technologies and Laboratories International, Inc.'s 222-S Analytical Laboratory reported 328 different analytes and compounds during participation in the

\begin{tabular}{|c|c|c|c|c|}
\hline \multirow[b]{2}{*}{$\underline{\text { Media }}$} & \multicolumn{4}{|c|}{$\begin{array}{l}\text { Table 8.17.9. The Hanford Site's Waste Sampling and Characterization Facility(a) Performance on } \\
\text { RAD, DOE Mixed Analyte Performance Evaluation Program Samples, and National Institute } \\
\text { of Standards and Technology Radiochemistry Intercomparison Program Samples, } 2009\end{array}$} \\
\hline & $\underline{\text { Program }}$ & $\underline{\text { Radionuclide }}$ & $\begin{array}{c}\text { Number of Results } \\
\text { Reported }\end{array}$ & $\begin{array}{c}\begin{array}{c}\text { Number of Results } \\
\text { Within Control Limits }\end{array} \\
\end{array}$ \\
\hline \multirow[t]{2}{*}{ Air filters } & MAPEP & $\begin{array}{l}{ }^{54} \mathrm{Mn},{ }^{57} \mathrm{Co},{ }^{60} \mathrm{Co},{ }^{65} \mathrm{Zn},{ }^{90} \mathrm{Sr},{ }^{134} \mathrm{Cs},{ }^{137} \mathrm{Cs} \\
\text { alpha, gross beta }\end{array}$ & 28 & $27^{(\mathrm{b})}$ \\
\hline & NRIP & ${ }^{90} \mathrm{Sr},{ }^{233 / 234} \mathrm{U},{ }^{238} \mathrm{Pu},{ }^{238} \mathrm{U},{ }^{240} \mathrm{Pu},{ }^{241} \mathrm{Am}$ & 6 & 6 \\
\hline \multirow[t]{2}{*}{ Soil } & MAPEP & $\begin{array}{l}{ }^{40} \mathrm{~K},{ }^{54} \mathrm{Mn},{ }^{57} \mathrm{Co},{ }^{60} \mathrm{Co},{ }^{65} \mathrm{Zn},{ }^{90} \mathrm{Sr},{ }^{99} \mathrm{Tc},{ }^{134} \mathrm{Cs}, \\
{ }^{137} \mathrm{Cs},{ }^{233 / 234} \mathrm{U},{ }^{238} \mathrm{Pu},{ }^{238} \mathrm{U},{ }^{239 / 240} \mathrm{Pu},{ }^{241} \mathrm{Am}\end{array}$ & 28 & $27^{(\mathrm{c})}$ \\
\hline & NRIP & ${ }^{90} \mathrm{Sr},{ }^{233 / 234} \mathrm{U},{ }^{238} \mathrm{Pu},{ }^{238} \mathrm{U},{ }^{240} \mathrm{Pu},{ }^{241} \mathrm{Am}$ & 6 & 6 \\
\hline Vegetation & MAPEP & $\begin{array}{l}{ }^{54} \mathrm{Mn},{ }^{57} \mathrm{Co},{ }^{60} \mathrm{Co},{ }^{65} \mathrm{Zn},{ }^{90} \mathrm{Sr},{ }^{134} \mathrm{Cs},{ }^{137} \mathrm{Cs}, \\
{ }^{233 / 234} \mathrm{U},{ }^{238} \mathrm{Pu},{ }^{238} \mathrm{U},{ }^{239 / 240} \mathrm{Pu},{ }^{241} \mathrm{Am}\end{array}$ & 24 & $21^{(\mathrm{d})}$ \\
\hline Water & MAPEP & $\begin{array}{l}{ }^{3} \mathrm{H},{ }^{54} \mathrm{Mn},{ }^{57} \mathrm{Co},{ }^{60} \mathrm{Co},{ }^{65} \mathrm{Zn},{ }^{90} \mathrm{Sr},{ }^{99} \mathrm{Tc},{ }^{134} \mathrm{Cs}, \\
\text { gross alpha, gross beta }\end{array}$ & 31 & 31 \\
\hline Water & RAD & ${ }^{3} \mathrm{H}$ & 2 & 2 \\
\hline \multicolumn{5}{|c|}{$\begin{array}{l}\text { (b) }{ }^{90} \mathrm{Sr} \text { failed once. The sample preparation method used for paper filters performed less efficiently using glass filters, as glass fiber filters do } \\
\text { not ash completely. Because the Hanford Site does not use glass fiber filters as specified by MAPEP, the Waste Sampling and Charac- } \\
\text { terization Facility's method (ashing for paper filter) does not work as efficiently for glass fiber filters. } \\
\text { (c) Acceptable }{ }^{99} \mathrm{Tc} \text { in remedial sample. }{ }^{90} \mathrm{Sr} \text { failed once. } \\
\text { (d) }{ }^{57} \mathrm{Co},{ }^{65} \mathrm{Zn} \text {, and }{ }^{90} \mathrm{Sr} \text { each failed once. } \\
\text { MAPEP = Mixed Analyte Performance Evaluation Program. } \\
\text { NRIP } \quad=\text { National Institute of Standards and Technology Radiochemistry Intercomparison Program. } \\
\text { RAD } \quad=\text { Radiochemistry Program provided by Environmental Resource Associates, Inc., a Waters Corporation. }\end{array}$} \\
\hline
\end{tabular}


Environmental Resource Associates water pollution studies in 2009. Of the 328 reported analytes, 324 results were acceptable and 4 were unacceptable, for a total acceptance rate of $98.8 \%$. For the soil study, a total of 160 analytes were reported of which all 160 were acceptable, for an overall score of $100 \%$. For the Mixed Analyte Performance
Evaluation Program studies, 76 of 84 radiological results were acceptable, for an acceptable rate of $90.5 \%$; 168 of 170 non-radiological (i.e., inorganic and organic) results reported on the same studies were acceptable, for a score of $98.8 \%$. Performance evaluation results are presented in Tables 8.17.10 and 8.17.11.

Table 8.17.10. The Hanford Site's 222-S Laboratory (a) Performance on DOE's Mixed Analyte Performance Evaluation Program Samples, 2009(b)

\begin{tabular}{|c|c|c|c|}
\hline \multirow[b]{2}{*}{ Media } & \multicolumn{3}{|c|}{$\begin{array}{l}\text { Table 8.17.10. The Hanford Site's 222-S Laboratory }{ }^{(a)} \text { Performance on DOE's Mixed Analyte } \\
\text { Performance Evaluation Program Samples, 2009(b) }\end{array}$} \\
\hline & $\underline{\text { Radionuclide }}$ & $\begin{array}{l}\text { Number of Results } \\
\text { Reported }\end{array}$ & $\begin{array}{c}\text { Number of Results } \\
\text { Within Control Limits }\end{array}$ \\
\hline \multirow[t]{2}{*}{ Air filters } & $\begin{array}{l}{ }^{54} \mathrm{Mn},{ }^{57} \mathrm{Co},{ }^{60} \mathrm{Co},{ }^{90} \mathrm{Sr},{ }^{134} \mathrm{Cs},{ }^{137} \mathrm{Cs},{ }^{235} \mathrm{U}, \\
\text { gross beta }\end{array}$ & 13 & 13 \\
\hline & $\begin{array}{l}{ }^{54} \mathrm{Mn},{ }^{57} \mathrm{Co},{ }^{60} \mathrm{Co},{ }^{90} \mathrm{Sr},{ }^{134} \mathrm{Cs},{ }^{137} \mathrm{Cs},{ }^{233 / 234} \mathrm{U}, \\
{ }^{235} \mathrm{U},{ }^{238} \mathrm{Pu},{ }^{238} \mathrm{U},{ }^{239 / 240} \mathrm{Pu},{ }^{241} \mathrm{Am} \text {, gross } \\
\text { alpha, gross beta }\end{array}$ & 13 & $11^{(\mathrm{c}, \mathrm{d})}$ \\
\hline Soil & ${ }^{40} \mathrm{~K},{ }^{54} \mathrm{Mn},{ }^{65} \mathrm{Zn},{ }^{90} \mathrm{Sr},{ }^{99} \mathrm{Tc},{ }^{134} \mathrm{Cs},{ }^{137} \mathrm{Cs},{ }^{241} \mathrm{Am}$ & 8 & $7^{(\mathrm{e})}$ \\
\hline \multirow[t]{2}{*}{ Vegetation } & ${ }^{54} \mathrm{Mn},{ }^{57} \mathrm{Co},{ }^{90} \mathrm{Sr},{ }^{134} \mathrm{Cs},{ }^{137} \mathrm{Cs},{ }^{235} \mathrm{U},{ }^{238} \mathrm{U}$ & 7 & $6^{(f)}$ \\
\hline & $\begin{array}{l}{ }^{54} \mathrm{Mn},{ }^{57} \mathrm{Co},{ }^{60} \mathrm{Co},{ }^{65} \mathrm{Zn},{ }^{90} \mathrm{Sr},{ }^{134} \mathrm{Cs},{ }^{137} \mathrm{Cs}, \\
{ }^{23} \mathrm{U}, \mathrm{U} \text {, U-total }\end{array}$ & 10 & $10^{(\mathrm{d})}$ \\
\hline \multirow[t]{2}{*}{ Water } & $\begin{array}{l}{ }^{3} \mathrm{H},{ }^{54} \mathrm{Mn},{ }^{57} \mathrm{Co},{ }^{60} \mathrm{Co},{ }^{63} \mathrm{Ni},{ }^{65} \mathrm{Zn},{ }^{90} \mathrm{Sr},{ }^{99} \mathrm{Tc}, \\
{ }^{134} \mathrm{Cs},{ }^{235} \mathrm{U},{ }^{238} \mathrm{Pu},{ }^{238} \mathrm{U},{ }^{239 / 240} \mathrm{Pu},{ }^{241} \mathrm{Am}, \\
\text { U-total, gross alpha, gross beta }\end{array}$ & 17 & $16^{(\mathrm{g})}$ \\
\hline & $\begin{array}{l}{ }^{3} \mathrm{H},{ }^{54} \mathrm{Mn},{ }^{57} \mathrm{Co},{ }^{60} \mathrm{Co},{ }^{65} \mathrm{Zn},{ }^{90} \mathrm{Sr},{ }^{134} \mathrm{Cs}, \\
{ }^{137} \mathrm{Cs},{ }^{235} \mathrm{U},{ }^{238} \mathrm{Pu},{ }^{238} \mathrm{U},{ }^{239 / 240} \mathrm{Pu},{ }^{241} \mathrm{Am}, \\
\text { U-total, gross alpha, gross beta }\end{array}$ & 16 & $13^{(\mathrm{d}, \mathrm{h})}$ \\
\hline \multicolumn{4}{|c|}{$\begin{array}{l}\text { (a) Onsite laboratory operated by Advanced Technologies and Laboratories International, Inc. (ATL). } \\
\text { (b) These data represent combined values from the MAPEP- } 20 \text { and MAPEP- } 21 \text { studies. } \\
\text { (c) Incorrect value for }{ }^{90} \mathrm{Sr} \text { and }{ }^{233 / 234} \mathrm{U} \text {. }{ }^{234} \mathrm{U} \text { was obtained by ICP-MS and incorrectly reported as }{ }^{233 / 234} \mathrm{U} \text { under } \\
\text { radiological analytes. } \\
\text { (d) Six of the reported results were reported as "less than detection limit," which is consistent with ATL reporting } \\
\text { protocol but not a designation recognized by MAPEP; thus, MAPEP scored the results as unacceptable. For five } \\
\text { of these six results, there was no reference value (i.e., the analyte appeared to be absent from the material). } \\
\text { Because the manner in which the results were reported is consistent with how ATL currently reports } \\
\text { radiological data to customers, ATL considers the five results acceptable. } \\
\text { (e) Incorrect value for }{ }^{90} \mathrm{Sr} \text {. } \\
\text { (f) Incorrect value for }{ }^{134} \mathrm{Cs} \text {. } \\
\text { (g) Incorrect value for }{ }^{99} \mathrm{Tc} \text {. } \\
\text { (h) Incorrect values for gross beta, }{ }^{238} \mathrm{Pu} \text { (a "less than" was reported but there was a reference value assigned), and } \\
\text { U-total (reporting error). } \\
\text { ICP-MS = Inductively coupled plasma mass spectrometry. } \\
\text { MAPEP = Mixed Analyte Performance Evaluation Program. }\end{array}$} \\
\hline
\end{tabular}


Table 8.17.11. The Hanford Site's 222-S Laboratory ${ }^{(a)}$ Performance on EPA Laboratory Water Pollution Inorganic and Organic Studies, 2009

Laboratory

Water Pollution Study (WP-172) July 2009

222-S Laboratory \% Acceptable

Water Pollution Study (WP-177) December 2009

(a) Onsite laboratory operated by Advanced Technologies and Laboratories International, Inc.

(b) 170 of 171 analytes were evaluated as acceptable.

(c) 154 of 156 analytes were evaluated as acceptable. 


\subsection{References}

10 CFR 835. 2009. "Occupational Radiation Protection." Code of Federal Regulations, U.S. Department of Energy. Accessed May 17, 2010, at http:/www.gpoaccess.gov/cfr/ index.html.

40 CFR 61. 2009. "National Emission Standards for Hazardous Air Pollutants." Code of Federal Regulations, U.S. Environmental Protection Agency. Accessed May 17, 2010, at http://www.gpoaccess.gov/cfr/index.html.

40 CFR 61, Appendix E, Table 2. 2009. "National Emission Standards for Hazardous Air Pollutants." Appendix E, "Compliance Procedures Methods for Determining Compliance with Subpart I; Concentration Levels for Environmental Compliance." Code of Federal Regulations, U.S. Environmental Protection Agency. Accessed May 17, 2010, at http://www.gpoaccess.gov/cfr/index.html.

40 CFR 61, Subpart H. 2009. "National Emission Standards for Hazardous Air Pollutants." Subpart H, "National Emission Standards for Emissions of Radionuclides Other Than Radon from Department of Energy Facilities." Code of Federal Regulations, U.S. Environmental Protection Agency. Accessed May 17, 2010, at http://www.gpoaccess. gov/cfr/index.html.

40 CFR 122. 2009. "EPA Administered Permit Programs: The National Pollutant Discharge Elimination System.” Code of Federal Regulations, U.S. Environmental Protection Agency. Accessed May 17, 2010, at http://www.gpoaccess. gov/cfr/index.html.
40 CFR 136, Appendix B. 2009. "Guidelines Establishing Test Procedures for the Analysis of Pollutants." Appendix B, "Definition and Procedure for the Determination of the Method Detection Limit-Revision 1.11." Code of Federal Regulations, U.S. Environmental Protection Agency. Accessed May 17, 2010, at http://www.gpoaccess.gov/cfr/ index.html.

40 CFR 141. 2009. "National Primary Drinking Water Regulations." Code of Federal Regulations, U.S. Environmental Protection Agency. Accessed May 17, 2010, at http://www.gpoaccess.gov/cfr/index.html.

40 CFR 265. 2006. "Interim Status Standards for Owners and Operators of Hazardous Waste Treatment, Storage, and Disposal Facilities." Code of Federal Regulations, U.S. Environmental Protection Agency. Accessed May 17, 2010, at http://www.gpoaccess.gov/cfr/index.html.

40 CFR 300, Appendix B. 2009. "National Oil and Hazardous Substances Pollution Contingency Plan." Appendix B, "National Priorities List." Code of Federal Regulations, U.S. Environmental Protection Agency. Accessed May 17, 2010, at http://www.gpoaccess.gov/cfr/index.html.

50 CFR 17. 2008. "Endangered and Threatened Wildlife and Plants." Code of Federal Regulations, U.S. Department of Interior. Accessed May 17, 2010, at http://www.gpoaccess. gov/cfr/index.html.

50 CFR 17.11. 2008. "Endangered and Threatened Wildlife and Plants; Endangered and Threatened Wildlife." Code of Federal Regulations, U.S. Department of Interior. Accessed May 17, 2010, at http://www.gpoaccess.gov/cfr/index.html. 
50 CFR 17.12. 2008. "Endangered and Threatened Wildlife and Plants; Endangered and Threatened Plants." Code of Federal Regulations, U.S. Department of Interior. Accessed May 17, 2010, at http://www.gpoaccess.gov/cfr/index.html.

American Recovery and Reinvestment Act of 2009. 2009. Public Law 111-5, as amended, 26 USC 1 et seq.

Ames BN, R Magaw, and LS Gold. 1987. "Ranking Possible Carcinogenic Hazards.” Science 236(4799):271-280.

AP-42. 1995. Compilation of Air Pollutant Emission Factors, Volume I: Stationary Point and Area Sources, Fifth Edition. Office of Air Quality Planning and Standards, Office of Air and Radiation, U.S. Environmental Protection Agency, Research Triangle Park, North Carolina.

Archaeological Resources Protection Act of 1979. 1979. Public Law 96-95, as amended, 16 USC 470-470aa et seq.

ARH-CD-775. 1976. Geohydrologic Study of the West Lake Basin. RE Gephart, PA Eddy, RC Arnett, and GA Robinson, Atlantic Richfield Hanford Company, Richland, Washington.

ASME NQA-1-2008. 2008. Quality Assurance Requirements for Nuclear Facility Applications. American Society of Mechanical Engineers, New York.

Atallah S. 1980. "Assessing and Managing Industrial Risk." Chemical Engineering 87(18):94-103.

Atomic Energy Act of 1954. 1954. Chapter 724, 60 Stat. 755, 42 USC 2011 et seq.

Bald and Golden Eagle Protection Act. 1992. Public Law 87-884, as amended, 16 USC 688 et seq.

Beasley TM, LA Ball, and JE Andrews III. 1981. "HanfordDerived Plutonium in Columbia River Sediments." Science 214(20):913-915.

BHI-01153, Rev. 0. 1998. Aquifer Sampling Tube Completion Report: 100 Area and Hanford Townsite Shorelines. RE Peterson, JV Borghese, and DB Erb, Bechtel Hanford, Inc., Richland, Washington.

BNWL-1979. 1976. Environmental Surveillance at Hanford for CY-1975. DR Speer, JJ Fix, and PJ Blumer, Pacific Northwest Laboratory, Richland, Washington.
BNWL-2305. 1977. Association of Hanford Origin Radionuclides with Columbia River Sediment. DE Robertson and JJ Fix, Pacific Northwest Laboratory, Richland, Washington.

Clean Air Act. 1986. Public Law 88-206, as amended, 42 USC 7401 et seq.

Clean Water Act of 1977. 1977. Public Law 95-217, as amended, 33 USC 1251 et seq.

Comprehensive Environmental Response, Compensation, and Liability Act of 1980. 1980. Public Law 96-510, as amended, 42 USC 9601 et seq. Accessed May 17, 2010, at http:// www.epa.gov/lawsregs/laws/cercla.html.

Conway CJ and KL Pardieck. 2006. "Population Trajectory of Burrowing Owls (Athene cunicularia) in Eastern Washington." Northwest Science 80(4):292-297.

Conway CJ, V Garcia, MD Smith, LA Ellis, and JL Whitney. 2006. "Comparative Demography of Burrowing Owls in Agricultural and Urban Landscapes in Southeastern Washington." Journal of Field Ornithology 77:280-290.

Cox SE, PR Bell, JS Lowther, and PC VanMetre. 2004. Vertical Distribution of Trace Element Concentrations and Occurrence of Metallurgical Slag Particles in Accumulated Bed Sediments of Lake Roosevelt, Washington, September 2002. Scientific Investigations Report 2004-2005, U.S. Geological Survey.

Cushing CE, DG Watson, AJ Scott, and JM Gurtisen. 1981. "Decrease of Radionuclides in Columbia River Biota Following Closure of the Hanford Reactors." Health Physics 41(1):59-67.

Dauble DD and DG Watson. 1997. "Status of Fall Chinook Salmon Populations in the Mid-Columbia River: 19481992." North American Journal of Fisheries Management 17(2):283-300.

Dechant JA, ML Sondreal, DH Johnson, LD Igl, CM Goldade, PA Rabie, and BR Euliss. 2002. Effects of Management Practices on Grassland Birds: Burrowing Owl. U.S. Geological Survey Northern Prairie Wildlife Research Center, Jamestown, North Dakota. 
Dinman BD. 1980. "The Reality and Acceptance of Risk." Journal of the American Medical Association (JAMA) 244(11):1226-1228.

DOE. 2004. Handbook for the Department of Energy's Mixed Analyte Performance Evaluation Program (MAPEP). MAPEP Handbook, Rev. 4, U.S. Department of Energy, Idaho Falls, Idaho.

DOE/EH-0173T. 1991. Environmental Regulatory Guide for Radiological Effluent Monitoring and Environmental Surveillance. U.S. Department of Energy, Washington, D.C.

DOE/EH-0676. 2004. User's Guide, Version 1. RESRADBIOTA: A Tool for Implementing a Graded Approach to Biota Dose Evaluation. Interagency Steering Committee on Radiation Standards Technical Report 2004-02, U.S. Department of Energy, Washington, D.C.

DOE Manual 231.1-1A, Chg. 2. 2004. "Environment, Safety and Health Reporting Manual." U.S. Department of Energy, Washington, D.C.

DOE Order 414.1C. 2005. "Quality Assurance." U.S. Department of Energy, Washington, D.C.

DOE Order 435.1, Chg. 1. 1999. "Radioactive Waste Management." U.S. Department of Energy, Washington, D.C.

DOE Order 450.1A. 2008. "Environmental Protection Program.” U.S. Department of Energy, Washington, D.C.

DOE Order 5400.5, Chg. 2. 1993. "Radiation Protection of the Public and the Environment." U.S. Department of Energy, Washington, D.C.

DOE Policy 450.4. 1996. "Safety Management System Policy." U.S. Department of Energy, The Office of Environment, Safety and Health, Washington, D.C.

DOE/RL-91-50, Rev. 4. 2008. Environmental Monitoring Plan, United States Department of Energy, Richland Operations Office. U.S. Department of Energy, Richland Operations Office, Richland, Washington.

DOE/RL-92-12, Rev. 1. 1992. Sampling and Analysis of 100 Area Springs. U.S. Department of Energy, Richland Operations Office, Richland, Washington.
DOE/RL-92-67, Draft B. 1992. Final Remedial Investigation/ Feasibility Study - Environmental Assessment Report for the 1100-EM-1 Operable Unit, Hanford. U.S. Department of Energy, Richland Operations Office, Richland, Washington.

DOE/RL-94-150, Rev. 1. 2009. Bald Eagle Management Plan for the Hanford Site, South-Central Washington. U.S. Department of Energy, Richland Operations Office, Richland, Washington.

DOE/RL-96-68, Rev 3. 2007. Hanford Analytical Services Quality Assurance Requirements Document, Volumes 1, 2, 3, and 4. U.S. Department of Energy, Richland Operations Office, Richland, Washington.

DOE/RL-96-77, Rev 0. 1996. Programmatic Agreement Among the U.S. Department of Energy, Richland Operations Office, the Advisory Council on Historic Preservation, and the Washington State Historic Preservation Office for the Maintenance, Deactivation, Alteration, and Demolition of the Built Environment on the Hanford Site, Washington. U.S. Department of Energy, Richland Operations Office, Richland, Washington.

DOE/RL-97-56, Rev. 1. 1998. Hanford Site Manhattan Project and Cold War Era Historic District Treatment Plan. U.S. Department of Energy, Richland Operation Office, Richland, Washington.

DOE/RL-2001-49, Rev. 1. 2004. Groundwater Sampling and Analysis Plan for the 200-BP-5 Operable Unit. U.S. Department of Energy, Richland Operations Office, Richland, Washington.

DOE/RL-2002-59. 2004. Hanford Site Groundwater Strategy Protection, Monitoring, and Remediation. U.S. Department of Energy, Richland Operations Office, Richland, Washington.

DOE/RL-2005-42, Rev. 1. 2006. 100 Area and 300 Area Component of the RCBRA Sampling and Analysis Plan. U.S. Department of Energy, Richland Operations Office, Richland, Washington.

DOE/RL-2007-18, Rev. 1. 2008. Remedial Investigation/ Feasibility Study Work Plan for the 200-BP-5 Groundwater Operable Unit. U.S. Department of Energy, Richland Operations Office, Richland, Washington. 
DOE/RL-2007-20, Rev 0. 2007. Hanford Integrated Groundwater and Vadose Zone Management Plan. U.S. Department of Energy, Richland Operations Office, Richland, Washington.

DOE/RL-2007-21, Draft A. 2007. River Corridor Baseline Risk Assessment Report. U.S. Department of Energy, Richland Operations Office, Richland, Washington.

DOE/RL-2007-28, Rev. 0. 2008. Feasibility Study Report for the 200-2P-1 Groundwater Operable Unit. U.S. Department of Energy, Richland Operations Office, Richland, Washington.

DOE/RL-2007-31, Draft A. 2007. Remedial Investigation/ Feasibility Study Work Plan for the 200-PO-1 Groundwater Operable Unit. U.S. Department of Energy, Richland Operations Office, Richland, Washington.

DOE/RL-2008-46, Rev 0. 2010. Integrated 100 Area Remedial Investigation/Feasibility Study Work Plan. U.S. Department of Energy, Richland Operations Office, Richland, Washington.

DOE/RL-2008-46-ADD2, Rev. 0. 2010. Integrated 100 Area Remedial Investigation/Feasibility Study Work Plan, Addendum 2: 100-KR-1, 100-KR-2, and 100-KR-4 Operable Units. U.S. Department of Energy, Richland Operations Office, Richland, Washington.

DOE/RL-2008-46-ADD3. 2010. Integrated 100 Area Remedial Investigation/Feasibility Study Work Plan, Addendum 3: 100-BC-1, 100-BC-2, and 100-BC-5 Operable Units. U.S. Department of Energy, Richland Operations Office, Richland, Washington.

DOE/RL-2008-46-ADD4. 2010. Integrated 100 Area Remedial Investigation/Feasibility Study Work Plan, Addendum 4: 100-FR-1, 100-FR-2, 100-FR-3, 100-IU-2, and 100-IU-6 Operable Units. U.S. Department of Energy, Richland Operations Office, Richland, Washington.

DOE/RL-2008-78, Rev. 0. (Reissue). 2009. 200 West Area 200-ZP-1 Pump-and-Treat Remedial Design/Remedial Action Work Plan. U.S. Department of Energy, Richland Operations Office, Richland, Washington.
DOE/RL-2009-43. 2010. Sampling and Analysis Plan for the 100-FR-1, 100-FR-2, 100-FR-3, 100-IU-2, and 100-IU-6 Operable Units Remedial Investigation/Feasibility Study. U.S. Department of Energy, Richland Operations Office, Richland, Washington.

DOE/RL-2009-44. 2010. Sampling and Analysis Plan for the 100-BC-1, 100-BC-2, and 100-BC-5 Operable Units Remedial Investigation/Feasibility Study. U.S. Department of Energy, Richland Operations Office, Richland, Washington.

DOE/RL-2010-11, Rev. 0. 2010. Hanford Site Groundwater Monitoring and Performance Report for Calendar Year 2009. U.S. Department of Energy, Richland Operations Office, Richland, Washington.

DOE/RL-2010-17. 2010. Radionuclide Air Emissions Report for the Hanford Site, Calendar Year 2009. U.S. Department of Energy, Richland Operations Office, Richland, Washington.

DOE-STD-1153-2002. 2002. A Graded Approach for Evaluating Radiation Doses to Aquatic and Terrestrial Biota. Final Technical Standard, U.S. Department of Energy and the Office of Environmental Policy and Guidance, Washington, D.C.

DOH 320-051. 2010. Hanford Environmental Radiation Oversight Program 2008 Data Summary Report. Washington State Department of Health, Olympia, Washington.

Dunwiddie PW, KA Beck, and FE Caplow. 2001. "Demographic Studies of Eriogonum codium Reveal, Caplow \& Beck (Polygonaceae) in Washington." In Conservation of Washington's Rare Plant and Ecosystems, proceedings from a conference of the Rare Plant Care and Conservation Program of the University of Washington, Washington Native Plant Society, Seattle, Washington.

Eisenbud M. 1987. Environmental Radioactivity from Natural, Industrial, and Military Sources. Third Edition, Chapter 5, Academic Press, Inc., New York.

Endangered Species Act of 1973. 1973. Public Law 93-205, as amended, 16 USC 1531 et seq.

EPA. 1986. Test Methods for Evaluating Solid Waste: Physical/ Chemical Methods, SW-846, Third Edition. Office of Solid Waste and Emergency Response, U.S. Environmental Protection Agency, Washington, D.C. 
EPA 402-R-99-001. 1999. Cancer Risk Coefficients for Environmental Exposure to Radionuclides. Federal Guidance Report No. 13, Office of Radiation and Indoor Air, U.S. Environmental Protection Agency, Washington, D.C.

EPA 402-R-00-004. 2000. Updated User's Guide for CAP88-PC, Version 2.0. Office of Radiation and Indoor Air, U.S. Environmental Protection Agency, Washington, D.C.

EPA 402-R-93-081. 1993. External Exposure to Radionuclides in Air, Water, and Soil. Federal Guidance Report No. 12, U.S. Environmental Protection Agency, Washington, D.C.

EPA 520/1-80-012. 1980. Upgrading Environmental Radiation Data: Health Physics Society Committee Report HPSR-1 (1980). U.S. Environmental Protection Agency, Washington, D.C.

EPA 520/1-88-020. 1988. Limiting Values of Radionuclide Intake and Air Concentration and Dose Conversion Factors for Inhalation, Submersion, and Ingestion. Federal Guidance Report No. 11, U.S. Environmental Protection Agency, Washington, D.C.

EPA 520/1-89-005. 1989. Risk Assessment Methodology: Draft Environmental Impact Statement for Proposed NESHAPS for Radionuclides, Vol. 1, Background Information Document. U.S. Environmental Protection Agency, Washington, D.C.

EPA 822-R-96-001. 1996. Drinking Water Regulations and Health Advisories. Office of Water, U.S. Environmental Protection Agency, Washington, D.C.

EPA QA/R-5. 1994. Requirements for Quality Assurance Project Plans for Environmental Data Operations. U.S. Environmental Protection Agency, Washington, D.C.

EPA/ROD/R10-96/143. 1996. EPA Superfund Record of Decision: Hanford 300-Area (USDOE), EPA ID: WA2890090077, OU 01, 02, Benton County, WA. U.S. Environmental Protection Agency, Washington State Department of Ecology, and U.S. Department of Energy, Richland Operations Office, Richland, Washington. Accessed August 17, 2010, at http://www.epa.gov/superfund/ sites/rods/fulltext/r1096143.pdf.

Gibbons GJ. 2000. An Investigation of the Origin of ${ }^{152} \mathrm{Eu}$ in Columbia River Sediments. Master's Thesis, Idaho State University, Department of Physics, Pocatello, Idaho.
Gray RH and WH Rickard. 1989. "The Protected Area of Hanford as a Refugium for Native Plants and Animals." Environmental Conservation 16(3):251-260.

HNF-EP-0527-19. 2010. Environmental Releases for Calendar Year 2009. DJ Rokkan, Mission Support Alliance, LLC, Richland, Washington.

HW-73672. 1962. Dispersion of 300 Area Liquid Effluent in the Columbia River. GE Backman, Hanford Atomic Products Operation, General Electric Company, Richland, Washington.

International Commission on Radiological Protection. 1959. "ICRP Publication 2, Report of Committee II on Permissible Dose for Internal Radiation." Annals of the ICRP, Pergamon Press, Elmsford, New York.

International Commission on Radiological Protection. 1977. "ICRP Publication 26, Recommendations of the International Commission on Radiological Protection." Annals of the ICRP 1(3), Pergamon Press, Elmsford, New York.

International Commission on Radiological Protection. 1979. "ICRP Publication 30, Limits for Intakes of Radionuclides by Workers." Annals of the ICRP 2(3-4), Pergamon Press, Elmsford, New York.

International Commission on Radiological Protection. 1984. "ICRP Publication 42, A Compilation of the Major Concepts and Quantities in Use by ICRP." Annals of the ICRP 14(4), Pergamon Press, Elmsford, New York.

International Commission on Radiological Protection. 1991. "ICRP Publication 60, 1990 Recommendations of the International Commission on Radiological Protection." Annals of the ICRP 21(1-3), Pergamon Press, Elmsford, New York.

International Commission on Radiological Protection. 1996. “ICRP Publication 72, Age-Dependent Doses from Intakes of Radionuclides: Part 5 - Compilation of Ingestion and Inhalation Coefficients." Annals of the ICRP 26(1), Pergamon Press, Elmsford, New York. 
ISCORS. 2002. A Method for Estimating Radiation Risk from TEDE. ISCORS Technical Report No. 1, Interagency Steering Committee on Radiation Standards, Washington, D.C. Accessed May 17, 2010, at http://www.doeal.gov/ SWEIS/DOEDocuments/055\%20iscors.pdf.

Jenkins OP. 1922. Underground Water Supply of the Region About White Bluffs and Hanford. State of Washington Department of Conservation and Development, Olympia, Washington.

Johnson VG, RE Peterson, and KB Olsen. 2005. "Heavy Metal Transport and Behavior in the Lower Columbia River, USA." Environmental Monitoring and Assessment 100(1-3):271-289.

Kaye TN. 2007. Draft Population Viability Analysis for Eriogonum codium (Umtanum buckwheat). Washington Natural Heritage Program, Washington State Department of Natural Resources, Olympia, Washington, 8 pp. plus appendix.

Klute DS, LW Ayers, MT Green, WH Howe, SL Jones, JA Shaffer, SR Sheffield, and TS Zimmerman. 2003. Status Assessment and Conservation Plan for the Western Burrowing Owl in the United States. U.S. Department of Interior, Fish and Wildlife Service, Biological Technical Publication FWS/BTP-R6001-2003, Washington, D.C.

Knick ST, DS Dobkin, JT Rotenberry, MA Schroeder, WM Vander Haegen, and C van Riper III. 2003. "Teetering on the Edge or Too Late? Conservation and Research Issues for Avifauna of Sagebrush Habitats." The Condor 105(4):611-634.

Larsen EM, JM Azerrad, and N Nordstrom (eds.). 2004. Priority Habitat and Species Management Recommendations, Volume IV: Birds. Washington Department of Fish and Wildlife, Olympia, Washington.

Larson KB. 2009. Nest Habitat Selection of Burrowing Owls in Relation to Soils, Burrow Availability, and Burrow Temperature. M.Sc. Thesis, Washington State University, Pullman, Washington.

MAPEP-07 Study 20. 2009. Study 20 Participating Laboratory Reports. U.S. Department of Energy, Mixed Analyte Performance Evaluation Program, Radiological and Environmental Sciences Laboratory, Idaho Falls, Idaho.
MAPEP-08 Study 21. 2009. Study 21 Participating Laboratory Reports. U.S. Department of Energy, Mixed Analyte Performance Evaluation Program, Radiological and Environmental Sciences Laboratory, Idaho Falls, Idaho.

Migratory Bird Treaty Act. 1918. 40 Stat. 755, as amended, 16 USC 710.

National Council on Radiation Protection and Measurements. 1975. Natural Background Radiation in the United States. NCRP Report No. 45, Washington, D.C.

National Council on Radiation Protection and Measurements. 1991. Some Aspects of Strontium Radiobiology. NCRP Report No. 110, Washington, D.C.

National Council on Radiation Protection and Measurements. 2009. Ionizing Radiation Exposure of the Population of the United States. NCRP Report No. 160, Washington, D.C.

National Environmental Policy Act of 1969. 1969. Public Law 91-190, as amended, 42 USC 4321 et seq.

National Historic Preservation Act of 1966. 1966. Public Law 89-665, as amended, 16 USC 470 et seq.

National Oceanic and Atmospheric Administration (NOAA) Fisheries. 2008. Species Under the Endangered Species Act (ESA). Office of Protected Resources, Seattle, Washington. Accessed on May 17, 2010, at http://www. nmfs.noaa.gov/pr/species/esa.

National Research Council. 1980. The Effects on Populations of Exposure to Low Levels of Ionizing Radiation: 1980. Committee on the Biological Effects of Ionizing Radiations, National Academy Press, Washington, D.C.

National Research Council. 1990. Health Effects of Exposure to Low Levels of Ionizing Radiation. Committee on the Biological Effects of Ionizing Radiations, National Academy Press, Washington, D.C.

Native American Graves Protection and Repatriation Act of 1990. 1990. Public Law 101-601, as amended, 25 USC 3001 et seq.

NAVD88. 1988. North American Vertical Datum of 1988. 
NERL-Ci-0045. December 30, 1998. National Standards for Water Proficiency Testing Studies, Criteria Document. U.S. Environmental Protection Agency, Washington, D.C.

Palsson SE, BJ Howard, and SM Wright. 2006. "Prediction of Spatial Variation in Global Fallout of ${ }^{137} \mathrm{Cs}$ Using Precipitation." Science of the Total Environment 367(2-3):745-756.

Patton GW, AT Cooper, and MR Tinker. 1997. “Ambient Air Sampling for Tritium - Determination of Breakthrough Volumes and Collection Efficiencies for Silica-Gel Absorbent." Health Physics 72(3):397-407.

PNL-3127. 1980. Radiological Survey of Exposed Shorelines and Islands of the Columbia River Between Vernita and the Snake River Confluence. MJ Sula, Pacific Northwest Laboratory, Richland, Washington.

PNL-5289. 1984. Investigation of Ground-Water Seepage from the Hanford Shoreline of the Columbia River. WD McCormack and JMV Carlile, Pacific Northwest Laboratory, Richland, Washington.

PNL-7500. 1990. 1988 Hanford Riverbank Springs Characterization Report. RL Dirkes, Pacific Northwest Laboratory, Richland, Washington.

PNL-7662. 1991. An Evaluation of the Chemical, Radiological, and Ecological Conditions of West Lake on the Hanford Site. TM Poston, KR Price, and DR Newcomer, Pacific Northwest Laboratory, Richland, Washington.

PNL-8073. 1992. Hanford Site Ground-Water Monitoring for 1990. JC Evans, RW Bryce, and DJ Bates, Pacific Northwest Laboratory, Richland, Washington.

PNL-8148. 1992. Hanford Site Environmental Report for Calendar Year 1991. RK Woodruff, RW Hanf, and RE Lundgren (eds.), Pacific Northwest Laboratory, Richland, Washington.

PNL-8531. 1993. Columbia River Monitoring: Distribution of Tritium in Columbia River Water at the Richland Pumphouse. RL Dirkes, Pacific Northwest Laboratory, Richland, Washington.
PNL-8580. 1993. Water Level Measurements for Modeling Hydraulic Properties in the 300-FF-5 and 100 Aggregate Area Operable Units. MD Campbell, WJ McMahon, and KR Simpson, Pacific Northwest Laboratory, Richland, Washington.

PNL-8654. 1993. Columbia River Monitoring: Summary of Chemical Monitoring Along Cross Sections at Vernita Bridge and Richland. RL Dirkes, GW Patton, and BL Tiller, Pacific Northwest Laboratory, Richland, Washington.

PNL-8789. 1993. Investigation of Exposure Rates and Radionuclide and Trace Metal Distributions Along the Hanford Reach of the Columbia River. AT Cooper and RK Woodruff, Pacific Northwest Laboratory, Richland, Washington.

PNL-8817. 1993. Contribution of Hanford Liquid Effluents to Strontium-90 Levels in Offsite Soils. RE Jaquish, Pacific Northwest Laboratory, Richland, Washington.

PNL-9394. 1994. Ecotoxicity Literature Review of Selected Hanford Site Contaminants. CJ Driver, Pacific Northwest Laboratory, Richland, Washington.

PNL-10174. 1994. A Qualitative Evaluation of Radionuclide Concentrations in Hanford Site Wildlife, 1983 Through 1992. TM Poston and AT Cooper, Pacific Northwest Laboratory, Richland, Washington.

PNL-10400. 1995. Identification of Contaminants of Concern, Columbia River Comprehensive Impact AssessmentDraft. BA Napier, NC Batishko, DA Heise-Craff, MF Jarvis, and SF Snyder, Pacific Northwest Laboratory, Richland, Washington.

PNL-10535. 1995. Environmental Monitoring of Columbia River Sediments: Grain-Size Distribution and Containment Association. ML Blanton, WW Gardiner, and RL Dirkes, Pacific Northwest Laboratory, Richland, Washington.

PNL-10698. 1995. Hanford Site Ground-Water Monitoring for 1994. PE Dresel, PD Thorne, SP Luttrell, BM Gillespie, WD Webber, JK Merz, JT Rieger, MA Chamness, SK Wurstner, and BE Optiz, Pacific Northwest Laboratory, Richland, Washington. 
PNNL-11139. 1996. Hanford Site Environmental Report for Calendar Year 1995. RL Dirkes and RW Hanf (eds.), Pacific Northwest National Laboratory, Richland, Washington.

PNNL-11518. 1997. Investigation of Anatomical Anomalies in the Hanford Site Mule Deer. BL Tiller, GE Dagle, LL Cadwell, TM Poston, and A Oganesian, Pacific Northwest National Laboratory, Richland, Washington.

PNNL-11175. 1998. Hanford Site Environmental Report for Calendar Year 1997. RW Hanf and RL Dirkes (eds.), Pacific Northwest National Laboratory, Richland, Washington.

PNNL-11933. 1998. Survey of Radiological Contaminants in the Near Shore Environment at the Hanford Site 100-N Reactor Area. SP Van Verst, CL Albin, GW Patton, ML Blanton, TM Poston, AT Cooper, and EJ Antonio, Pacific Northwest National Laboratory, Richland, Washington.

PNNL-13230. 2000. Hanford Site Environmental Report for Calendar Year 1999. TM Poston, RW Hanf, Jr., and RL Dirkes (eds.), Pacific Northwest National Laboratory.

PNNL-13331. 2000. Population Characteristics and Seasonal Movement Patterns of the Rattlesnake Hills Elk Herd - Status Report 2000. BL Tiller, LL Cadwell, RK Zufelt, L Bender, $S$ Turner, and GK Turner, Pacific Northwest National Laboratory, Richland, Washington.

PNNL-13417. 2001. Simultaneously-Extracted Metals/AcidVolatile-Sulfide and Total Metals in Surface Sediment from the Hanford Reach of the Columbia River and the Lower Snake River. GW Patton and EA Crecelius, Pacific Northwest National Laboratory, Richland, Washington.

PNNL-13487. 2001. Hanford Site Environmental Report for Calendar Year 2000. TM Poston, RW Hanf, RL Dirkes, and LF Morasch (eds.), Pacific Northwest National Laboratory, Richland, Washington.

PNNL-13688. 2001. Vascular Plants of the Hanford Site. MR Sackschewsky and JL Downs, Pacific Northwest National Laboratory, Richland, Washington.
PNNL-13692. 2002. Survey of Radiological and Chemical Contaminants in the Near-Shore Environment at the Hanford Site 300 Area. GW Patton, SP Van Verst, BL Tiller, EJ Antonio, and TM Poston, Pacific Northwest National Laboratory, Richland, Washington.

PNNL-13910. 2002. Hanford Site Environmental Report for Calendar Year 2001. RW Hanf, Jr., GP O'Connor, and TM Poston (eds.), Pacific Northwest National Laboratory.

PNNL-14295. 2003. Hanford Site Environmental Report for Calendar Year 2002. TM Poston, RW Hanf, RL Dirkes, and LF Morasch (eds.), Pacific Northwest National Laboratory, Richland, Washington.

PNNL-14444. 2003. Aquifer Sampling Tube Results for Fiscal Year 2003. MJ Hartman and RE Peterson, Pacific Northwest National Laboratory, Richland, Washington.

PNNL-14584, Rev. 3. 2009. GENII Version 2.09, Software Design Document. BA Napier, DL Strenge, JV Ramsdell, Jr., PW Eslinger, and C Fosmire, Pacific Northwest National Laboratory, Richland, Washington.

PNNL-14687. 2004. Hanford Site Environmental Report for Calendar Year 2003. TM Poston, RW Hanf, RL Dirkes, and LF Morasch (eds.), Pacific Northwest National Laboratory, Richland, Washington.

PNNL-14687, APP. 1. 2004. Hanford Site Environmental Surveillance Data Report for Calendar Year 2003. LE Bisping, Pacific Northwest National Laboratory, Richland, Washington.

PNNL-15160. 2005. Hanford Site Climatological Data Summary 2004 with Historical Data. DJ Hoitink, JV Ramsdell Jr., KW Burk, and WJ Shaw, Pacific Northwest National Laboratory, Richland, Washington.

PNNL-15222. 2005. Hanford Site Environmental Report for Calendar Year 2004. TM Poston, RW Hanf, and RL Dirkes (eds.), Pacific Northwest National Laboratory, Richland, Washington.

PNNL-15892. 2006. Hanford Site Environmental Report for Calendar Year 2005. RW Hanf, Jr., LF Morasch, TM Poston, and RL Dirkes (eds.), Pacific Northwest National Laboratory, Richland, Washington. 
PNNL-15892, APP. 1. 2006. Hanford Site Environmental Surveillance Data Report for Calendar Year 2005. LE Bisping, Pacific Northwest National Laboratory, Richland, Washington.

PNNL-16435. 2007. Limited Field Investigation Report for Uranium Contamination in the 300-FF-5 Operable Unit at the 300 Area, Hanford Site, Washington. BA Williams, CF Brown, W Um, MJ Nimmons, RE Peterson, BN Bjornstad, DC Lanigan, RJ Serne, FA Spane, and ML Rockhold, Pacific Northwest National Laboratory, Richland, Washington.

PNNL-16623, APP. 1. 2007. Hanford Site Environmental Surveillance Data Report for Calendar Year 2006. LE Bisping, Pacific Northwest National Laboratory, Richland, Washington.

PNNL-16744. 2007. Surface Environmental Surveillance Procedures Manual, PNL-MA-580, Rev. 5. RW Hanf, TM Poston, and LE Bisping (eds.), Pacific Northwest National Laboratory, Richland, Washington.

PNNL-16805. 2007. Investigation of the Hyporheic Zone at the 300 Area, Hanford Site. BG Fritz, NP Kohn, TJ Gilmore, D McFarland, EV Arntzen, RD Mackley, GW Patton, DP Mendoza, and AL Bunn, Pacific Northwest National Laboratory, Richland, Washington.

PNNL-16894. 2007. Investigation of the Strontium-90 Contaminant Plume along the Shoreline of the Columbia River at the 100-N Area of the Hanford Site. DP Mendoza, BG Fritz, GW Patton, TJ Gilmore, MJ Hartman, R Mackley, FA Spane, BN Bjornstad, MD Sweeney, and RE Clayton, Pacific Northwest National Laboratory, Richland, Washington.

PNNL-16990. 2007. Summary of Radiological Monitoring of Columbia and Snake River Sediment, 1988 Through 2004. GW Patton and RL Dirkes, Pacific Northwest National Laboratory, Richland, Washington.

PNNL-17603. 2008. Hanford Site Environmental Report for Calendar Year 2007. TM Poston, JP Duncan, and RL Dirkes, Pacific Northwest National Laboratory, Richland, Washington.
PNNL-17603, APP. 1. 2008. Hanford Site Environmental Surveillance Data Report for Calendar Year 2007. LE Bisping, Pacific Northwest National Laboratory, Richland, Washington.

PNNL-18177. 2009. Hanford Site Environmental Surveillance Master Sampling Schedule for Calendar Year 2009. LE Bisping, Pacific Northwest National Laboratory, Richland, Washington.

PNNL-18427. 2009. Hanford Site Environmental Report for Calendar Year 2008. TM Poston, JP Duncan, and RL Dirkes, Pacific Northwest National Laboratory, Richland, Washington.

PNNL-18427, APP. 1. 2009. Hanford Site Environmental Surveillance Data Report for Calendar Year 2008. LE Bisping, Pacific Northwest National Laboratory, Richland, Washington.

PNNL-18529. 2009. 300 Area Uranium Stabilization Through Polyphosphate Injection: Final Report. VR Vermeul, BN Bjornstad, BG Fritz, JS Fruchter, RD Mackley, DR Newcomer, DP Mendoza, ML Rockhold, DM Wellman, and MD Williams, Pacific Northwest National Laboratory, Richland, Washington.

PNNL-19212. 2010. Canada Geese at the Hanford Site Trends in Reproductive Success, Migration Patterns, and Contaminant Concentrations. MA Simmons, TM Poston, BL Tiller, A Stegen, KD Hand, and JM Brandenberger, Pacific Northwest National Laboratory, Richland, Washington.

PNNL-19455, APP. 1. 2010. Hanford Site Environmental Surveillance Data Report for Calendar Year 2009. LE Bisping, Pacific Northwest National Laboratory, Richland, Washington.

PNNL-19455, APP. 2. 2010. Hanford Site Near-Facility Environmental Monitoring Data Report for Calendar Year 2009. CJ Perkins, MC Dorsey, SM McKinney, and JW Wilde, EnergySolutions, LLC for Pacific Northwest National Laboratory, Richland, Washington. 
Rattner BA, NH Golden, KM Eisenreich, JB Cohen, LM Loges, LJ Garrett, EA Larsen, EK Henniger, MA McKernan, BK Ackerson, ME Barton, ME Barton, ME Maxey, SE Warner, JE Fallon, PC Toschik, JL Pearson, MA Ottinger, RL Hothem, RL Kershnar, DL Kelly, AM Meckstroth, TW Custer, CR Beckman, KL Lobner, and CW Meeusen. 2010. Contaminant Exposure and EffectsTerrestrial Vertebrates (CEE-TV) Database. Version 9.0. U.S. Geological Survey, Patuxent Wildlife Research Center, Laurel, Maryland. Accessed July 29, 2010, at http://www. pwrc.usgs.gov/contaminants-online/.

Resource Conservation and Recovery Act of 1976. 1976. Public Law 94-580, as amended, 42 USC 6901 et seq. and 42 USC 6927(c) et seq. Accessed May 17, 2010, at http:// www.epa.gov/lawsregs/laws/rcra.html.

ROD. 1996. Record of Decision for the 300-FF-1 and 300-FF-5 Operable Units. Washington State Department of Ecology, U.S. Environmental Protection Agency, and U.S. Department of Energy, Richland Operations Office, Richland, Washington.

Sagan LA. 1987. Health Physics Society Official Journal: Special Issue on Radiation Hormesis 52(5).

SGW-40211. 2009. First Determination RCRA Groundwater Quality Assurance Plan for the Low-Level Burial Grounds Low-Level Waste Management Area 4. CH2M HILL Plateau Remediation Company, Richland, Washington.

SGW-41497, Rev. 0. 2009. Aquifer Tube Optimization Evaluation. MJ Hartman, CH2M HILL Plateau Remediation Company, Richland, Washington.

Takeda A, T Hirofumi, Y Takaku, S Hisamatsu, and N Masami. 2006. "Accumulation of Uranium Derived from Long-Term Fertilizer Applications in a Cultivated Andisol." Total Science of the Environment 367(2-3):924-931.

Tiller BL and TM Poston. 2000. "Mule Deer Antlers as Biomonitors of Sr-90 on the Hanford Site." Journal of Environmental Radioactivity 47(1):29-44.

Tiller BL, GE Dagle, and LL Cadwell. 1997. "Testicular Atrophy in a Mule Deer Population." Journal of Wildlife Management 33(3):420-429.
Travis CC and ST Hester. 1990. "Background Exposure to Chemicals: What Is the Risk?" Risk Analysis 10(4):463-466.

United Nations Science Committee on the Effects of Atomic Radiation. 1988. Sources, Effects and Risks of Ionizing Radiation. Report E.88.1X.7, United Nations, New York.

U.S. Army Corps of Engineers/U.S. Environmental Protection Agency (USACE/EPA). 2005. "The Environmental Residue-Effects Database (ERED)." Accessed on May 17, 2010, at http://el.erdc.usace.army.mil/ered.

U.S. Fish and Wildlife Service (USFWS). 2010a. A Summary and Evaluation of the Sightability Survey for Rocky Mountain Elk on the Arid Lands Ecology Reserve Unit of the Hanford Reach National Monument. H Newsome, U.S. Fish and Wildlife Service, Burbank, Washington.

U.S. Fish and Wildlife Service (USFWS). 2010b. Endangered Species Program. Accessed on May 17, 2010, at http:// www.fws.gov/easternwashington/species/species.html.

U.S. Geological Survey. 1995. Nitrate Concentrations in Ground Water of the Central Columbia Plateau. Open File Report 95-445, U.S. Geological Survey, Tacoma, Washington.

U.S. Geological Survey Circular 1144. 1998. "Water Quality in the Central Columbia Plateau, Washington and Idaho, 1992-95." AK Williamson, MD Munn, SJ Ryker, RJ Wagner, JC Ebbert, and AM Vanderpool, U.S. Geological Survey, Tacoma, Washington. Accessed on May 17, 2010, at http://pubs.usgs.gov/circ/circ1144/.

U.S. Geological Survey, North American Breeding Bird Survey. Accessed May 17, 2010, at http://www.mbr-pwrc. usgs.gov/cgi-bin/atlasa99.pl?05011\&1\&07.

WA-94-1. 1995. Water Resources Data, Washington, Water Year 1994. WD Wiggins, GP Ruppert, RR Smith, LL Reed, LE Hubbard, and ML Courts, U.S. Geological Survey, Tacoma, Washington.

WAC 173-201A. 2006. "Water Quality Standards for Surface Waters of the State of Washington." Washington Administrative Code, Olympia, Washington. Accessed May 17, 2010, at http://apps.leg.wa.gov/wac/. 
WAC 173-201A-240. 2006. "Toxic Substances." Washington Administrative Code, Olympia, Washington. Accessed May 17, 2010, at http://apps.leg.wa.gov/wac/.

WAC 173-216. 2006. "State Waste Discharge Permit Program." Washington Administrative Code, Olympia, Washington. Accessed May 17, 2010, at http://apps.leg.wa.gov/ wac/.

WAC 173-303-400. 2007. "Dangerous Waste Regulations; Interim Status Facility Standards." Washington Administrative Code, Olympia, Washington. Accessed May 17, 2010, at http://apps.leg.wa.gov/wac/.

WAC 173-303-645. 2007. "Dangerous Waste Regulations; Releases from Regulated Units." Washington Administrative Code, Olympia, Washington. Accessed May 17, 2010, at http://apps.leg.wa.gov/wac/.

WAC 173-400. 2009. "General Regulations for Air Pollution Sources." Washington Administrative Code, Olympia, Washington. Accessed May 17, 2010, at http://apps.leg. wa.gov/wac/.

WAC 246-247. 2005. "Radiation Protection - Air Emissions." Washington Administrative Code, Olympia, Washington. Accessed May 17, 2010, at http://apps.leg.wa.gov/ wac/.

WAC 246-290. 2009. "Group A Public Water Supplies.” Washington Administrative Code, Olympia, Washington. Accessed May 17, 2010, at http://apps.leg.wa.gov/wac/.

Washington Department of Fish and Wildlife (WDFW). 2000. The Rattlesnake Hills (Hanford) Elk Strategic Management Plan. Olympia, Washington.

Washington Department of Fish and Wildlife (WDFW). 2010. Species of Concern. Olympia, Washington. Accessed on May 17, 2010, at http://www.wdfw.wa.gov/wildlife/ management/endangered.html.

Washington Natural Heritage Program (WNHP). 2008. Rare Plant Lists by County. Washington State Department of Natural Resources, Olympia, Washington. Accessed on May 17, 2010, at http://www1.dnr.wa.gov/nhp/refdesk/lists/ plantsxco/countyindex.html.
Washington Natural Heritage Program (WNHP). 2010, as amended. Rare Plants Information Available from the Washington Natural Heritage Program. Washington State Department of Natural Resources, Olympia, Washington. Accessed on May 17, 2010, at http://www1.dnr.wa.gov/nhp/ refdesk/plants.html.

Washington State Department of Agriculture (WSDA). 2007. Levels of Nonnutritive Substances in Fertilizers. Report to the Legislature, $249 \mathrm{pp}$.

WCH-91, Rev. 0. 2006. Columbia River Component Data Evaluation Summary Report. Washington Closure Hanford, LLC, Richland, Washington.

WCH-274, Rev. 0. 2008. Inter-Areas Component of the River Corridor Baseline Risk Assessment Sampling Summary. Washington Closure Hanford, LLC, Richland, Washington.

WDR-US-2007. 2007. Water Data Report. U.S. Geological Survey, Tacoma, Washington. Accessed on May 17, 2010, at http://wdr.water.usgs.gov/wy2007/search.jsp. Site Number 12472900 (the Vernita Bridge) and Site Number 12473520 (Columbia River near Richland).

Wellicome TI and GL Holroyd. 2001. "The Second International Burrowing Owl Symposium: Background and Context." Journal of Raptor Research 35:269-273.

WHC-EP-0609. 1992. Riverbank Seepage and Groundwater Along the 100 Areas Shoreline, Hanford Site. RE Peterson and VG Johnson, Westinghouse Hanford Company, Richland, Washington.

WHC-MR-0418. 1994. Historical Records of Radioactive Contamination in Biota at the 200 Areas of the Hanford Site. AR Johnson, BM Markes, JW Schmidt, AN Shah, SG Weiss, and KJ Wilson, Westinghouse Hanford Company, Richland, Washington.

WHC-SD-EN-TI-006. 1992. Hydrologic and Geologic Data Available for the Region North of Gable Mountain, Hanford Site, Washington. RE Peterson, Westinghouse Hanford Company, Richland, Washington.

WHC-SD-EN-TI-070. 1992. Soil Concentration Limits for Accessible and Inaccessible Areas. PD Rittman, Westinghouse Hanford Company, Richland, Washington. 
WHC-SD-EN-TI-125, Rev. 0. 1993. Sampling and Analysis of the 300-FF-5 Operable Unit Springs, Near Shore Sediments and River Water. SL Friant and LC Hulstrom, prepared by Pacific Northwest Laboratory for Westinghouse Hanford Company, Richland, Washington.

WHC-SD-EN-TI-198. 1993. 100 Area Columbia River Sediment Sampling. SG Weiss, Westinghouse Hanford Company, Richland, Washington.
Wilson R and ESC Crouch. 1987. "Risk Assessment and Comparisons: An Introduction.” Science 236(4799):267-270.

Yokel J and DA Delistraty. 2003. "Arsenic, Lead, and Other Trace Elements in Soils Contaminated with Pesticide Residues at the Hanford Site (USA)." Environmental Toxicology 18(2):104-114. 


\title{
Appendix A Helpful Information
}

\author{
JP Duncan
}

The following information is provided to assist the reader in understanding this report. Included here is information on scientific notation, units of measure, radioactivity units, radiological dose units, chemical and elemental nomenclature, understanding data tables and data uncertainty, understanding graphs, and selected mathematical symbols. Definitions of technical terms can be found in Appendix B.

\section{Scientific Notation}

Scientific notation is used to express very large or very small numbers. For example, the number 1 billion could be written as $1,000,000,000$ or, by using scientific or E notation, written as $1 \times 10^{9}$ or $1.0 \mathrm{E}+09$. Translating from scientific notation to a more traditional number requires moving the decimal point either left or right from its current location. If the value given is $2.0 \times 10^{3}$ (or $2.0 \mathrm{E}+03$ ), the decimal point should be moved three places to the right so that the number would then read 2,000. If the value given is $2.0 \times 10^{-5}$ (or 2.0E-05), the decimal point should be moved five places to the left so that the result would be 0.00002 .

\section{Units of Measure}

The primary units of measure used in this report follow the International System of Units and are metric. Table A.1

\begin{tabular}{|c|c|c|c|}
\hline \multirow[b]{2}{*}{$\underline{\text { Symbol }}$} & \multicolumn{3}{|c|}{ Table A.1. Names and Symbols for Units of Measure } \\
\hline & $\underline{\text { Name }}$ & Symbol & $\underline{\text { Name }}$ \\
\hline Temperature & \multirow{3}{*}{$\begin{array}{l}\text { degree Celsius } \\
\text { degree Fahrenheit }\end{array}$} & Concentration & \multirow{4}{*}{$\begin{array}{l}\text { parts per billion } \\
\text { parts per million } \\
\text { parts per million by volume }\end{array}$} \\
\hline${ }^{\circ} \mathrm{C}$ & & $\mathrm{ppb}$ & \\
\hline${ }^{\circ} \mathrm{F}$ & & ppm & \\
\hline Time & \multirow{7}{*}{$\begin{array}{l}\text { day } \\
\text { hour } \\
\text { minute } \\
\text { second } \\
\text { year }\end{array}$} & ppmv & \\
\hline d & & Length & \multirow{10}{*}{$\begin{array}{l}\text { centimeter }\left(1 \times 10^{-2} \mathrm{~m}\right) \\
\text { foot } \\
\text { inch } \\
\text { kilometer }\left(1 \times 10^{3} \mathrm{~m}\right) \\
\text { meter } \\
\text { mile } \\
\text { millimeter }\left(1 \times 10^{-3} \mathrm{~m}\right) \\
\text { micrometer }\left(1 \times 10^{-6} \mathrm{~m}\right)\end{array}$} \\
\hline $\mathrm{hr}$ & & $\mathrm{cm}$ & \\
\hline $\min$ & & $\mathrm{ft}$ & \\
\hline $\sec$ & & in. & \\
\hline yr & & $\mathrm{km}$ & \\
\hline Rate & & $\mathrm{m}$ & \\
\hline cfs $\left(\right.$ or $\left.\mathrm{ft}^{3} / \mathrm{sec}\right)$ & \multirow{6}{*}{$\begin{array}{l}\text { cubic feet per second } \\
\text { counts per minute } \\
\text { gallon per minute } \\
\text { mile per hour } \\
\text { milliroentgen per hour } \\
\text { millirem per year }\end{array}$} & $\mathrm{mi}$ & \\
\hline $\mathrm{cpm}$ & & $\mathrm{mm}$ & \\
\hline gpm & & $\mu \mathrm{m}$ & \\
\hline mph & & Area & \\
\hline $\mathrm{mR} / \mathrm{hr}$ & & ha & hectare $\left(1 \times 10^{4} \mathrm{~m}^{2}\right)$ \\
\hline $\mathrm{mrem} / \mathrm{yr}$ & & $\mathrm{km}^{2}$ & square kilometer \\
\hline Volume & \multirow{8}{*}{$\begin{array}{l}\text { cubic centimeter } \\
\text { cubic foot } \\
\text { gallon } \\
\text { liter } \\
\text { cubic meter } \\
\text { milliliter }\left(1 \times 10^{-3} \mathrm{~L}\right) \\
\text { cubic yard }\end{array}$} & $\mathrm{mi}^{2}$ & square mile \\
\hline $\mathrm{cm}^{3}$ & & $\mathrm{ft}^{2}$ & square foot \\
\hline $\mathrm{ft}^{3}$ & & Mass & \\
\hline gal & & g & gram \\
\hline $\mathrm{L}$ & & $\mathrm{kg}$ & kilogram $\left(1 \times 10^{3} \mathrm{~g}\right)$ \\
\hline $\mathrm{m}^{3}$ & & $\mathrm{mg}$ & milligram $\left(1 \times 10^{-3} \mathrm{~g}\right)$ \\
\hline $\mathrm{mL}$ & & $\mu \mathrm{g}$ & microgram $\left(1 \times 10^{-6} \mathrm{~g}\right)$ \\
\hline$y d^{3}$ & & $\mathrm{lb}$ & pound \\
\hline
\end{tabular}




\begin{tabular}{|c|c|c|c|c|c|}
\hline \multirow[b]{2}{*}{ Multiply } & \multirow[b]{2}{*}{$\underline{\text { By }}$} & \multicolumn{2}{|c|}{ Table A.2. Conversion Table } & \multirow[b]{2}{*}{$\underline{\text { By }}$} & \multirow[b]{2}{*}{ To Obtain } \\
\hline & & To Obtain & Multiply & & \\
\hline $\mathrm{cm}$ & 0.394 & in. & in. & 2.54 & $\mathrm{~cm}$ \\
\hline $\mathrm{m}$ & 3.28 & $\mathrm{ft}$ & $\mathrm{ft}$ & 0.305 & $\mathrm{~m}$ \\
\hline $\mathrm{km}$ & 0.621 & $\mathrm{mi}$ & $\mathrm{mi}$ & 1.61 & $\mathrm{~km}$ \\
\hline $\mathrm{kg}$ & 2.205 & $\mathrm{lb}$ & $\mathrm{lb}$ & 0.454 & $\mathrm{~kg}$ \\
\hline $\mathrm{L}$ & 0.2642 & gal & gal & 3.785 & $\mathrm{~L}$ \\
\hline $\mathrm{m}^{2}$ & 10.76 & $\mathrm{ft}^{2}$ & $\mathrm{ft}^{2}$ & 0.093 & $\mathrm{~m}^{2}$ \\
\hline ha & 2.47 & acres & acre & 0.405 & ha \\
\hline $\mathrm{km}^{2}$ & 0.386 & $\mathrm{mi}^{2}$ & $\mathrm{mi}^{2}$ & 2.59 & $\mathrm{~km}^{2}$ \\
\hline $\mathrm{m}^{3}$ & 35.31 & $\mathrm{ft}^{3}$ & $\mathrm{ft}^{3}$ & 0.0283 & $\mathrm{~m}^{3}$ \\
\hline $\mathrm{m}^{3}$ & 1.308 & $\mathrm{yd}^{3}$ & $\mathrm{yd}^{3}$ & 0.7646 & $\mathrm{~m}^{3}$ \\
\hline $\mathrm{pCi}$ & 1,000 & $\mathrm{nCi}$ & $\mathrm{nCi}$ & 0.001 & $\mathrm{pCi}$ \\
\hline$\mu \mathrm{Ci} / \mathrm{mL}$ & $10^{9}$ & $\mathrm{pCi} / \mathrm{L}$ & $\mathrm{pCi} / \mathrm{L}$ & $10^{-9}$ & $\mu \mathrm{Ci} / \mathrm{mL}$ \\
\hline $\mathrm{Ci} / \mathrm{m}^{3}$ & $10^{12}$ & $\mathrm{pCi} / \mathrm{m}^{3}$ & $\mathrm{pCi} / \mathrm{m}^{3}$ & $10^{-12}$ & $\mathrm{Ci} / \mathrm{m}^{3}$ \\
\hline $\mathrm{mCi} / \mathrm{cm}^{3}$ & $10^{15}$ & $\mathrm{pCi} / \mathrm{m}^{3}$ & $\mathrm{pCi} / \mathrm{m}^{3}$ & $10^{-15}$ & $\mathrm{mCi} / \mathrm{cm}^{3}$ \\
\hline $\mathrm{nCi} / \mathrm{m}^{2}$ & 1.0 & $\mathrm{mCi} / \mathrm{km}^{2}$ & $\mathrm{mCi} / \mathrm{km}^{2}$ & 1.0 & $\mathrm{nCi} / \mathrm{m}^{2}$ \\
\hline $\mathrm{Ci}$ & $3.7 \times 10^{10}$ & $\mathrm{~Bq}$ & $\mathrm{~Bq}$ & $2.7 \times 10^{-11}$ & $\mathrm{Ci}$ \\
\hline $\mathrm{pCi}$ & 0.037 & $\mathrm{~Bq}$ & $\mathrm{~Bq}$ & 27 & $\mathrm{pCi}$ \\
\hline $\mathrm{rad}$ & 0.01 & Gy & Gy & 100 & $\mathrm{rad}$ \\
\hline rem & 0.01 & Sv & $\mathrm{Sv}$ & 100 & rem \\
\hline ppm & 1,000 & $\mathrm{ppb}$ & $\mathrm{ppb}$ & 0.001 & ppm \\
\hline${ }^{\circ} \mathrm{C}$ & $\left({ }^{\circ} \mathrm{C} \times 9 / 5\right)+32$ & ${ }^{\circ} \mathrm{F}$ & ${ }^{\circ} \mathrm{F}$ & $\left({ }^{\circ} \mathrm{F}-32\right) \div 9 / 5$ & ${ }^{\circ} \mathrm{C}$ \\
\hline $\mathrm{Oz}$ & 28.349 & $\mathrm{~g}$ & $\mathrm{~g}$ & 0.035 & $\mathrm{Oz}$ \\
\hline ton & 0.9078 & tonne & tonne & 1.1 & ton \\
\hline
\end{tabular}

summarizes and defines the terms and corresponding symbols (metric and non-metric). A conversion table is also provided in Table A.2.

\section{Radioactivity Units}

Much of this report provides data on levels of radioactivity in various environmental media. Radioactivity in this report is usually discussed in units of curies $(\mathbf{C i})$, with conversions to becquerels $(\mathbf{B q})$, the International System of Units measure (Table A.3). The curie is the basic unit used to describe the amount of activity present, and activities are generally expressed in terms of curies per mass or volume (e.g., picocuries per liter). One curie is equivalent to 37 billion disintegrations per second or is a quantity of any radionuclide that decays at the rate of 37 billion disintegrations per second. One becquerel is equivalent to one disintegration per second. Nuclear disintegrations produce spontaneous emissions of alpha or beta particles, gamma radiation, or combinations of these. Table A.4 includes selected conversions from curies to becquerels.

\begin{tabular}{|c|c|c|c|}
\hline \multirow[b]{2}{*}{ Symbol } & \multicolumn{2}{|c|}{ Table A.3. Names and Symbols for Units of Radioactivity } & activity \\
\hline & $\underline{\text { Name }}$ & Symbol & $\underline{\text { Name }}$ \\
\hline $\mathrm{Ci}$ & curie & $\mathrm{Bq}$ & becquerel $\left(2.7 \times 10^{-11} \mathrm{Ci}\right)$ \\
\hline $\mathrm{mCi}$ & millicurie $\left(1 \times 10^{-3} \mathrm{Ci}\right)$ & $\mathrm{kBq}$ & kilobecquerel $\left(1 \times 10^{3} \mathrm{~Bq}\right)$ \\
\hline$\mu \mathrm{Ci}$ & microcurie $\left(1 \times 10^{-6} \mathrm{Ci}\right)$ & $\mathrm{MBq}$ & megabecquerel $\left(1 \times 10^{6} \mathrm{~Bq}\right)$ \\
\hline $\mathrm{nCi}$ & nanocurie $\left(1 \times 10^{-9} \mathrm{Ci}\right)$ & $\mathrm{mBq}$ & millibecquerel $\left(1 \times 10^{-3} \mathrm{~Bq}\right)$ \\
\hline $\mathrm{pCi}$ & picocurie $\left(1 \times 10^{-12} \mathrm{Ci}\right)$ & GBq & gigabecquerel $\left(1 \times 10^{9} \mathrm{~Bq}\right)$ \\
\hline $\mathrm{fCi}$ & femtocurie $\left(1 \times 10^{-15} \mathrm{Ci}\right)$ & $\mathrm{TBq}$ & terabecquerel $\left(1 \times 10^{12} \mathrm{~Bq}\right)$ \\
\hline $\mathrm{aCi}$ & attocurie $\left(1 \times 10^{-18} \mathrm{Ci}\right)$ & & \\
\hline
\end{tabular}




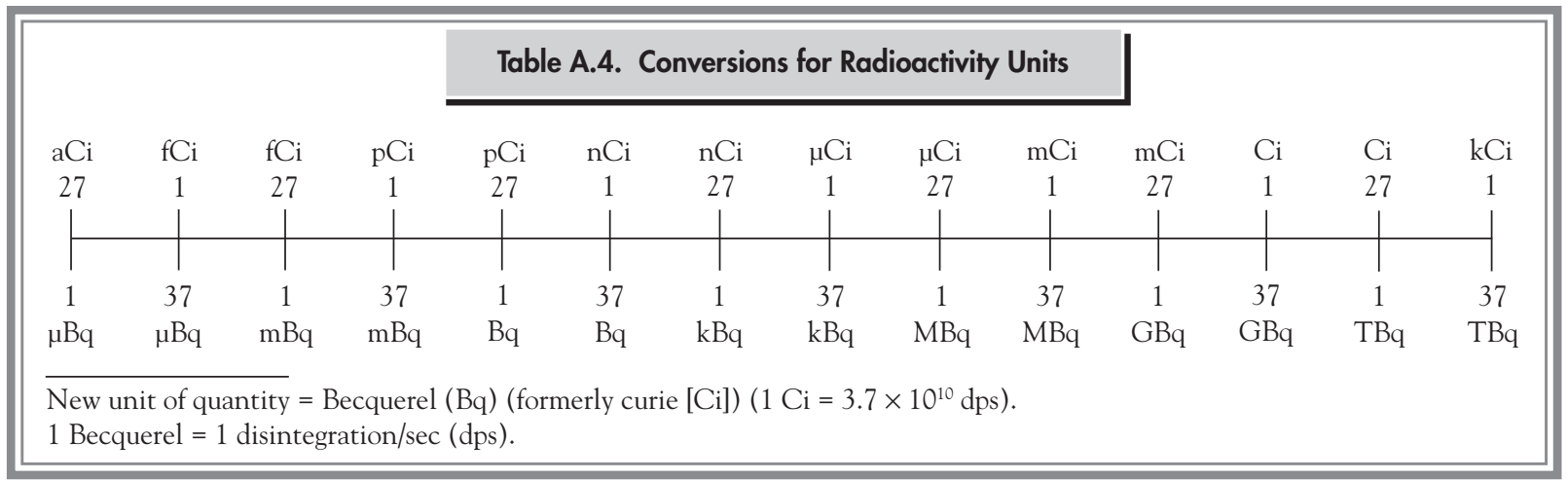

\section{Radiological Dose Units}

Radiological dose in this report is usually written in terms of effective dose equivalent and reported numerically in units of millirem (mrem), with the metric units millisievert $(\mathrm{mSv})$ or microsievert $(\mu \mathrm{Sv})$ following in parenthesis or footnoted.

Millirem (millisievert) is a term that relates a given amount of absorbed radiation energy to its biological effectiveness or risk to humans. For perspective, a dose of 0.01 millirem (1 millisievert) would have a biological effect roughly the same as received from 1 day's exposure to natural background radiation. An acute (short-term) dose to the whole body of 100 rem (1 sievert) would likely cause temporary radiation sickness in some exposed individuals. An acute dose of over 500 rem ( 5 sievert) would soon result in death in approximately $50 \%$ of those exposed. Exposure to lower amounts of radiation $(10 \mathrm{mrem}[100 \mu \mathrm{Sv}]$ or less) produces no immediate observable effects, but long-term (delayed) effects are possible. The average person in the United States receives an annual dose from exposure to naturally produced radiation of approximately $300 \mathrm{mrem}$ (3 mSv). Medical and dental $\mathrm{x}$-rays and air travel add to this total. Table A.5 includes selected conversions from rem to sievert.

Also used in this report is the term rad, with the corresponding unit gray $(\mathbf{G y})$ in parenthesis or footnoted. The rad (gray) is a measure of the energy absorbed by any material, whereas a rem relates to both the amount of radiation energy absorbed by humans and its consequence. The gray can be converted to rad by multiplying by 100 . The conversions in Table A.5 can also be used to convert grays to rads.

A roentgen ( $\mathbf{R})$ is a measure of exposure to electromagnetic radiation (i.e., gamma and $\mathrm{x}$-radiation). One roentgen is equivalent to a charge release of 258 microcoulombs per kilogram of air.

The names and symbols for units of radiation dose used in this report are listed in Table A.6

Additional information on radiation and dose terminology can be found in Appendix B. A list of the radionuclides discussed in this report, their symbols, and their half-lives are included in Table A.7.

\section{Chemical and Elemental Nomenclature}

Many of the chemical contaminants discussed in this report are listed in Table A. 8 along with their chemical (or elemental) names and their corresponding symbols.

Table A.5. Conversions for Radiological Dose Units

\begin{tabular}{|c|c|c|c|c|c|c|c|}
\hline$\mu \mathrm{Sv}$ & $\mu \mathrm{Sv}$ & $\mu \mathrm{Sv}_{\mathrm{v}}$ & $\mu \mathrm{Sv}$ & $\mu \mathrm{Sv}$ & $\mathrm{mSv}$ & $\mathrm{mSv}$ & $\mathrm{mSv}$ \\
\hline 0.01 & 0.1 & 1 & 10 & 100 & 1 & 10 & 100 \\
\hline 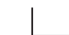 & 1 & 1 & 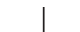 & 1 & 1 & 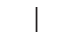 & \\
\hline & & & & & & & \\
\hline $\begin{array}{c}1 \\
\text { arem }\end{array}$ & $\begin{array}{c}10 \\
\mu r e m\end{array}$ & $\begin{array}{c}100 \\
\mu r e m\end{array}$ & $\begin{array}{c}1 \\
\text { mrem }\end{array}$ & $\begin{array}{c}10 \\
\text { mrem }\end{array}$ & $\begin{array}{c}100 \\
\text { mrem }\end{array}$ & $\begin{array}{c}1 \\
\text { rem }\end{array}$ & $\begin{array}{c}10 \\
\text { rem }\end{array}$ \\
\hline
\end{tabular}

Unit of absorbed dose - Gray (Gy) (formerly rad).

Unit of dose equivalent - Sievert (Sv) (formerly rem).

Table also converts Gy to rad. 


\begin{tabular}{|c|c|}
\hline \multicolumn{2}{|c|}{$\begin{array}{l}\text { Table A.6. Names and Symbols for Units } \\
\text { of Radiation Dose or Exposure }\end{array}$} \\
\hline Symbol & $\underline{\text { Name }}$ \\
\hline mrad & millirad $\left(1 \times 10^{-3} \mathrm{rad}\right)$ \\
\hline mrem & millirem $\left(1 \times 10^{-3} \mathrm{rem}\right)$ \\
\hline$\mu r e m$ & microrem $\left(1 \times 10^{-6} \mathrm{rem}\right)$ \\
\hline Sv & sievert (100 rem) \\
\hline $\mathrm{mSv}$ & millisievert $\left(1 \times 10^{-3} \mathrm{~Sv}\right)$ \\
\hline$\mu S v$ & microsievert $\left(1 \times 10^{-6} \mathrm{~Sv}\right)$ \\
\hline $\mathrm{R}$ & roentgen \\
\hline $\mathrm{mR}$ & milliroentgen $\left(1 \times 10^{-3} \mathrm{R}\right)$ \\
\hline$\mu \mathrm{R}$ & microroentgen $\left(1 \times 10^{-6} \mathrm{R}\right)$ \\
\hline Gy & gray $(100 \mathrm{rad})$ \\
\hline mGy & milligray $\left(1 \times 10^{-3} \mathrm{rad}\right)$ \\
\hline
\end{tabular}

\section{Understanding the Data Tables}

Some degree of variability, or uncertainty, is associated with all analytical measurements. This uncertainty is the consequence of random or systematic inaccuracies related to collecting, preparing, and analyzing the samples. These inaccuracies could include errors associated with reading or recording the result, handling or processing the sample, calibrating the counting instrument, and numerical rounding. With radionuclides, inaccuracies can also result from the randomness of radioactive decay. In this report, the uncertainties used include standard deviation, total propagated analytical uncertainty, and standard error of the mean.

\begin{tabular}{|c|c|c|c|c|c|}
\hline \multirow[b]{2}{*}{ Symbol } & \multirow[b]{2}{*}{$\underline{\text { Radionuclide }}$} & \multicolumn{3}{|c|}{ Table A.7. Radionuclides and Their Half-Lives ${ }^{(a)}$} & \multirow[b]{2}{*}{ Half-Life } \\
\hline & & Half-Life & Symbol & $\underline{\text { Radionuclide }}$ & \\
\hline${ }^{3} \mathrm{H}$ & tritium & $12.35 \mathrm{yr}$ & ${ }^{137 \mathrm{~m}} \mathrm{Ba}$ & barium-137m & $2.552 \mathrm{~min}$ \\
\hline${ }^{7} \mathrm{Be}$ & beryllium-7 & $53.3 \mathrm{~d}$ & ${ }^{152} \mathrm{Eu}$ & europium-152 & $13.33 \mathrm{yr}$ \\
\hline${ }^{14} \mathrm{C}$ & carbon-14 & $5,730 \mathrm{yr}$ & ${ }^{154} \mathrm{Eu}$ & europium-154 & $8.8 \mathrm{yr}$ \\
\hline${ }^{40} \mathrm{~K}$ & potassium-40 & $1.28 \times 10^{9} \mathrm{yr}$ & ${ }^{155} \mathrm{Eu}$ & europium-155 & $4.96 \mathrm{yr}$ \\
\hline${ }^{51} \mathrm{Cr}$ & chromium-51 & $27.704 d$ & ${ }^{212} \mathrm{~Pb}$ & lead-212 & $10.64 \mathrm{hr}$ \\
\hline${ }^{54} \mathrm{Mn}$ & manganese-54 & $312.5 \mathrm{~d}$ & ${ }^{220} \mathrm{Rn}$ & radon-220 & $55.6 \mathrm{sec}$ \\
\hline${ }^{55} \mathrm{Fe}$ & iron-55 & $2.7 \mathrm{yr}$ & ${ }^{222} \mathrm{Rn}$ & radon-222 & $3.8235 \mathrm{~d}$ \\
\hline${ }^{59} \mathrm{Fe}$ & iron-59 & $44.529 \mathrm{~d}$ & ${ }^{232} \mathrm{Th}$ & thorium-232 & $1.405 \times 10^{10} \mathrm{yr}$ \\
\hline${ }^{59} \mathrm{Ni}$ & nickel-59 & $7.5 \times 10^{4} \mathrm{yr}$ & $\mathrm{U}$ or uranium & natural uranium & $\sim 4.5 \times 10^{9(b)}$ \\
\hline${ }^{60} \mathrm{Co}$ & cobalt -60 & $5.271 \mathrm{yr}$ & ${ }^{233} \mathrm{U}$ & uranium-233 & $1.585 \times 10^{5} \mathrm{yr}$ \\
\hline${ }^{63} \mathrm{Ni}$ & nickel-63 & $96 \mathrm{yr}$ & ${ }^{234} \mathrm{U}$ & uranium-234 & $2.445 \times 10^{5} \mathrm{yr}$ \\
\hline${ }^{65} \mathrm{Zn}$ & zinc- 65 & $243.9 \mathrm{~d}$ & ${ }^{235} \mathrm{U}$ & uranium-235 & $7.038 \times 10^{8} \mathrm{yr}$ \\
\hline${ }^{85} \mathrm{Kr}$ & krypton-85 & $10.72 \mathrm{yr}$ & ${ }^{237} \mathrm{~Np}$ & neptunium-237 & $2.14 \times 10^{6} \mathrm{yr}$ \\
\hline${ }^{90} \mathrm{Sr}$ & strontium-90 & $29.12 \mathrm{yr}$ & ${ }^{238} \mathrm{U}$ & uranium-238 & $4.468 \times 10^{9} \mathrm{yr}$ \\
\hline${ }^{90} \mathrm{Y}$ & yttrium-90 & $64.0 \mathrm{hr}$ & ${ }^{238} \mathrm{Pu}$ & plutonium-238 & $87.74 \mathrm{yr}$ \\
\hline${ }^{95} \mathrm{Zr}$ & zirconium-95 & $63.98 \mathrm{~d}$ & ${ }^{239} \mathrm{Pu}$ & plutonium-239 & $2.4065 \times 10^{4} \mathrm{yr}$ \\
\hline${ }^{99} \mathrm{Tc}$ & technetium-99 & $2.13 \times 10^{5} \mathrm{yr}$ & ${ }^{240} \mathrm{Pu}$ & plutonium-240 & $6.537 \times 10^{3} \mathrm{yr}$ \\
\hline${ }^{103} \mathrm{Ru}$ & ruthenium-103 & $39.28 \mathrm{~d}$ & ${ }^{241} \mathrm{Pu}$ & plutonium-241 & $14.4 \mathrm{yr}$ \\
\hline${ }^{106} \mathrm{Ru}$ & ruthenium-106 & $368.2 \mathrm{~d}$ & ${ }^{242} \mathrm{Pu}$ & plutonium-242 & $3.763 \times 10^{5} \mathrm{yr}$ \\
\hline${ }^{113} \mathrm{Sn}$ & $\operatorname{tin}-113$ & $115.1 \mathrm{~d}$ & ${ }^{241} \mathrm{Am}$ & americium-241 & $432.2 \mathrm{yr}$ \\
\hline${ }^{125} \mathrm{Sb}$ & antimony-125 & $2.77 \mathrm{yr}$ & ${ }^{243} \mathrm{Am}$ & americium-243 & $7,380 \mathrm{yr}$ \\
\hline${ }^{129} \mathrm{I}$ & iodine-129 & $1.57 \times 10^{7} \mathrm{yr}$ & ${ }^{243} \mathrm{Cm}$ & curium-243 & $28.5 \mathrm{yr}$ \\
\hline${ }^{131} \mathrm{I}$ & iodine-131 & $8.04 \mathrm{~d}$ & ${ }^{244} \mathrm{Cm}$ & curium-244 & $18.11 \mathrm{yr}$ \\
\hline${ }^{134} \mathrm{Cs}$ & cesium-134 & $2.062 \mathrm{yr}$ & \multirow[t]{2}{*}{${ }^{245} \mathrm{Cm}$} & \multirow[t]{2}{*}{ curium-245 } & \multirow[t]{2}{*}{$8,500 \mathrm{yr}$} \\
\hline${ }^{137} \mathrm{Cs}$ & cesium-137 & $30.0 \mathrm{yr}$ & & & \\
\hline \multicolumn{6}{|c|}{ (a) From EPA 402-R-99-001. } \\
\hline \multicolumn{6}{|c|}{ (b) Natural uranium is a mixture dominated by uranium- 238 ; thus, the half-life is $\sim 4.5 \times 10^{9}$ years. } \\
\hline
\end{tabular}




\begin{tabular}{|c|c|c|c|}
\hline \multirow[b]{2}{*}{ Symbol } & \multicolumn{2}{|c|}{ Table A.8. Elemental and Chemical Constituent Nomenclature } & \multirow[b]{2}{*}{$\underline{\text { Constituent }}$} \\
\hline & $\underline{\text { Constituent }}$ & Symbol & \\
\hline $\mathrm{Ag}$ & silver & K & potassium \\
\hline $\mathrm{Al}$ & aluminum & $\mathrm{LiF}$ & lithium fluoride \\
\hline As & arsenic & $\mathrm{Mg}$ & magnesium \\
\hline B & boron & $\mathrm{Mn}$ & manganese \\
\hline $\mathrm{Ba}$ & barium & Mo & molybdenum \\
\hline $\mathrm{Be}$ & beryllium & $\mathrm{NH}_{3}$ & ammonia \\
\hline $\mathrm{Br}$ & bromine & $\mathrm{NH}_{4}^{+}$ & ammonium \\
\hline $\mathrm{C}$ & carbon & $\mathrm{N}$ & nitrogen \\
\hline $\mathrm{Ca}$ & calcium & $\mathrm{Na}$ & sodium \\
\hline $\mathrm{CaF}_{2}$ & calcium fluoride & $\mathrm{Ni}$ & nickel \\
\hline $\mathrm{CCl}_{4}^{2}$ & carbon tetrachloride & $\mathrm{NO}_{2}^{-}$ & nitrite \\
\hline $\mathrm{Cd}^{4}$ & cadmium & $\mathrm{NO}_{3}^{-}$ & nitrate \\
\hline $\mathrm{CHCl}_{3}$ & trichloromethane & $\mathrm{Pb}$ & lead \\
\hline $\mathrm{Cl}^{-}$ & chloride & $\mathrm{PO}_{4}^{-3}$ & phosphate \\
\hline $\mathrm{CN}^{-}$ & cyanide & $\mathrm{P}^{4}$ & phosphorus \\
\hline $\mathrm{Cr}^{+6}$ & chromium (hexavalent) & $\mathrm{Sb}$ & antimony \\
\hline $\mathrm{Cr}$ & chromium (total) & $\mathrm{Se}$ & selenium \\
\hline $\mathrm{CO}_{3}^{-2}$ & carbonate & $\mathrm{Si}$ & silicon \\
\hline Co & cobalt & $\mathrm{Sr}$ & strontium \\
\hline $\mathrm{Cu}$ & copper & $\mathrm{SO}_{4}^{-2}$ & sulfate \\
\hline $\mathrm{F}^{-}$ & fluoride & $\mathrm{Ti}$ & titanium \\
\hline $\mathrm{Fe}$ & iron & $\mathrm{Tl}$ & thallium \\
\hline $\mathrm{HCO}_{3}$ & bicarbonate & V & vanadium \\
\hline $\mathrm{Hg}$ & mercury & & \\
\hline
\end{tabular}

\section{Standard Deviation}

The standard deviation (SD) of sample data relates to the variation around the mean of a set of individual sample results. If differences in analytical results occur among samples, then two times the standard deviation (or $\pm 2 \mathrm{SD}$ ) implies that $95 \%$ of the time, a re-count or re-analysis of the same sample would give a value somewhere between the mean result minus two times the standard deviation and the mean result plus two times the standard deviation.

\section{Total Propagated Analytical Uncertainty}

For samples that are prepared or manipulated in the laboratory prior to counting (counting the rate of radioactive emissions from a sample), the total propagated analytical uncertainty includes both the counting uncertainty and the uncertainty associated with sample preparation and chemical separations. For samples that are not manipulated (e.g., ashed, dried, or chemically treated) in the laboratory before counting, the total propagated analytical uncertainty only accounts for the uncertainty associated with counting the sample. The uncertainty associated with samples that are analyzed but not counted (e.g., chemical or water quality measurements) includes only the analytical process uncertainty. In this situation, the total propagated analytical uncertainty is assumed to be the nominal detection limit.

\section{Standard Error of the Mean}

Just as individual values are accompanied by counting uncertainties, the mean of mean values (averages) is accompanied by \pm 2 times the standard error of the calculated mean. Two times the standard error of the mean implies that approximately $95 \%$ of the time the next calculated mean will fall somewhere between the reported value minus two times the standard error and the reported value plus two times the standard error. 


\section{Median, Maximum, and Minimum Values}

Median, maximum, and minimum values are reported in some sections of this report. A median value is the middle value of an odd numbered set and the average of the two central values in an even numbered set. For example, the median value in the odd numbered series of numbers $-1,2$, $3,3,4,5,5,5,6$ is 4 . The maximum value would be 6 and the minimum value would be 1 . Median, maximum, and minimum values are reported when there are too few analytical results to accurately determine the average with a \pm statistical uncertainty or when the data do not follow a bellshape (i.e., normal) distribution. Figure A.1 provides a graphical representation of median, maximum, and minimum values. The upper line is the maximum value, the center dot is the median value, and the lower line is the minimum value.

\section{Negative Concentrations}

Instruments used in the laboratory to measure radioactivity in Hanford Site environmental samples are sensitive enough to measure natural, or background, radiation along with any

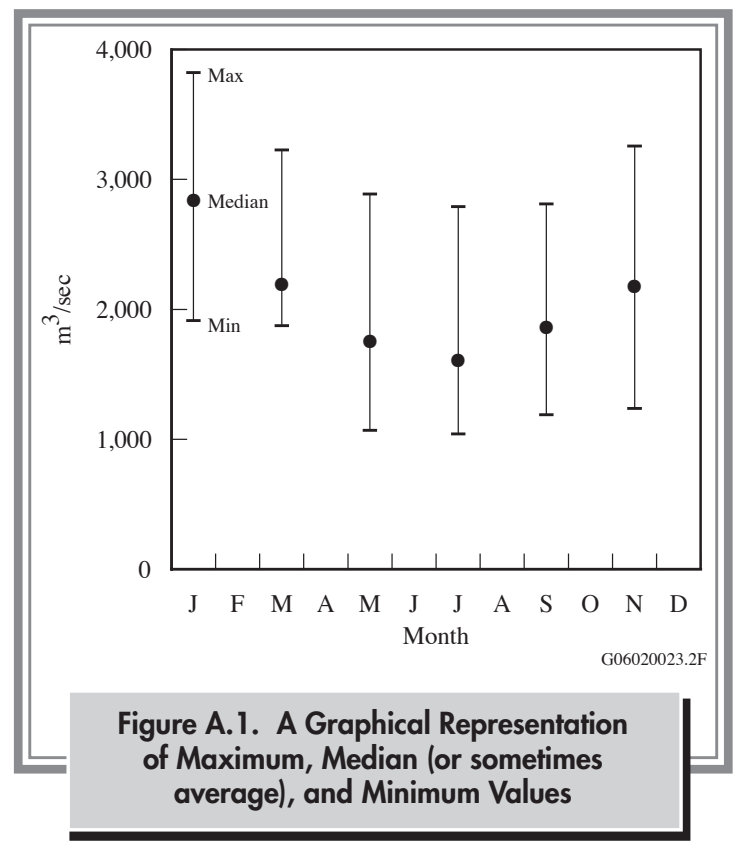

contaminant radiation in a sample. To obtain a true measure of the contaminant level in a sample, the background radiation level must be subtracted from the total amount of radioactivity measured by an instrument. Because of the randomness of radioactive emissions, the very low activities of some contaminants, or the presence of undesirable materials, it is possible to obtain a background measurement that is larger than the actual contaminant measurement. When the larger background measurement is subtracted from the smaller contaminant measurement, a negative result is generated. The negative results are reported because they are essential when conducting statistical evaluations of the data.

\section{Understanding Graphs}

Graphs are useful when comparing numbers collected at several locations or at one location over time. Graphs often make it easy to visualize differences in data where they exist. However, careful consideration should be given to the scale (linear or logarithmic) and units.

Some of the data graphed in this report may be plotted using logarithmic, or compressed, scales. Logarithmic scales are useful when plotting two or more numbers that differ greatly in size or are very close together. For example, a sample with a concentration of 5 grams per liter would get lost at the bottom of the graph if plotted on a linear scale with a sample having a concentration of 1,000 grams per liter (Figure A.2). A logarithmic plot of these same two numbers allows the reader to see both data points clearly (Figure A.3).

The mean (average) and median (defined earlier) values seen in graphics in this report have vertical lines extending above and below the data point. When used with a value, these lines (called error bars) indicate the amount of uncertainty (standard deviation, total propagated analytical uncertainty, or two standard error of the mean) in the reported value. The error bars in this report represent a $95 \%$ chance that the value is between the upper and lower ends of the error bar and a $5 \%$ chance that the true value is either lower or higher than the error bar. ${ }^{(a)}$ For example, in Figure A.4, the first plotted value is $2.0 \pm 1.1$, so there is a $95 \%$ chance that the true value is between

(a) Assuming the data are normally distributed. 

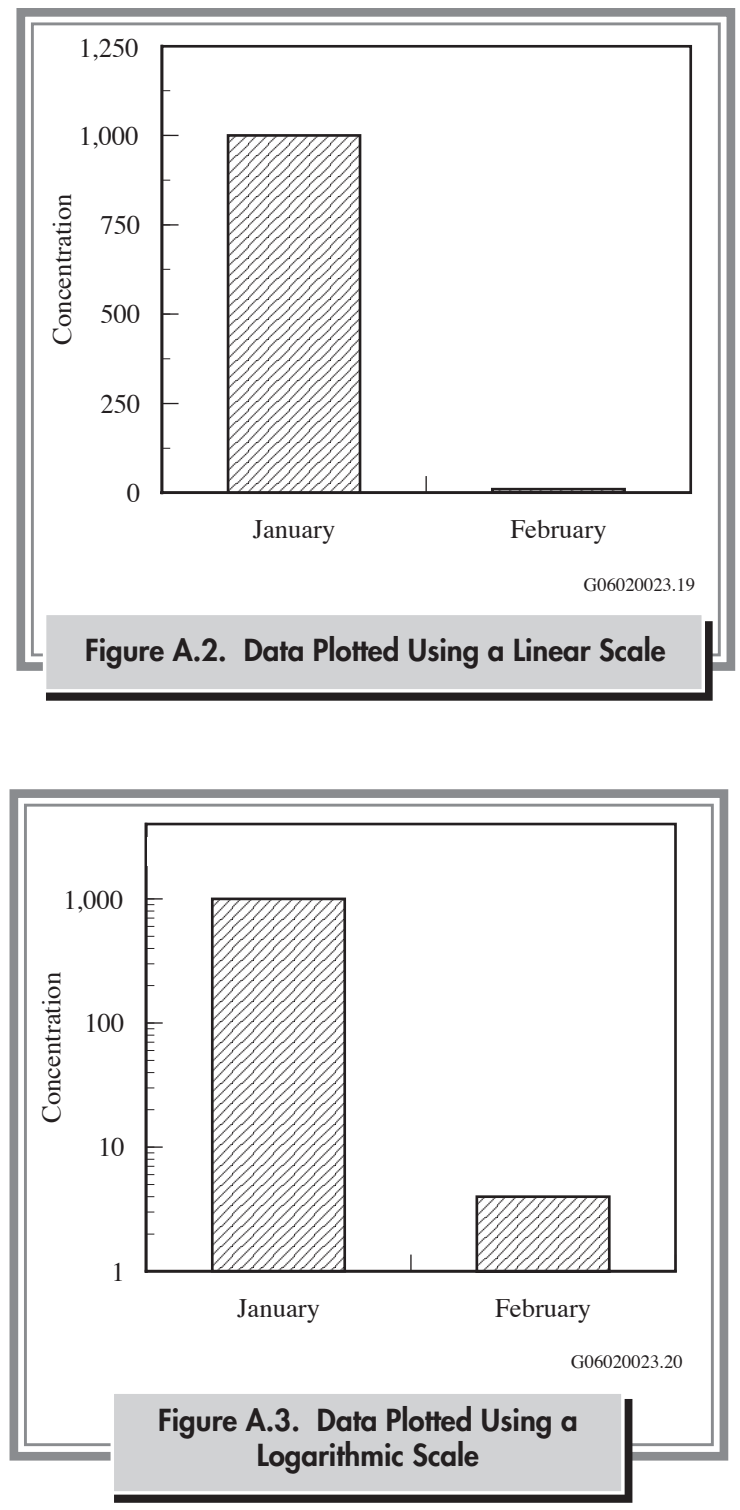

0.9 and 3.1 , a $2.5 \%$ chance that it is less than 0.9 , and a $2.5 \%$ chance that it is greater than 3.1. Error bars are computed statistically, employing all of the information used to generate the value. These bars provide a quick, visual indication that one value may be statistically similar to or different from another value. If the error bars of two or more values overlap, as is the case with values 1 and 3 and values 2 and 3, the values may be statistically similar. If the error bars do not overlap (values 1 and 2), the values may be statistically different. Values that appear to be very different visually (values 2 and 3) may actually be quite similar when compared statistically.

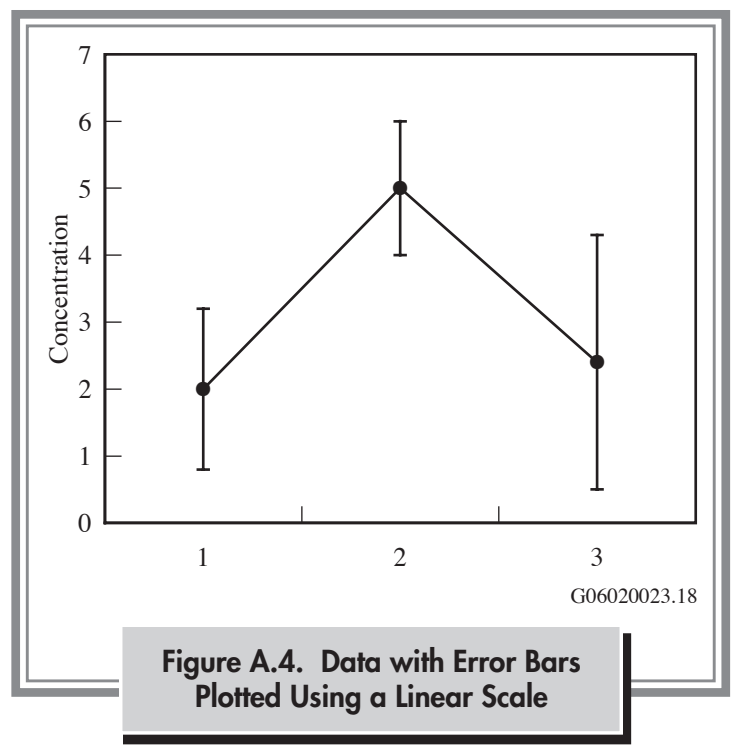

When vertical lines are used with median values, the lower end of each bar represents the minimum concentration measured; the upper end of each bar represents the maximum concentration measured (Figure A.1).

\section{Greater Than (>) or Less Than $(<)$ Symbols}

Greater than $(>)$ or less than $(<)$ symbols are used to indicate that the actual value may either be larger than the number given or smaller than the number given. For example, $>0.09$ would indicate that the actual value is greater than 0.09 . A symbol pointed in the opposite direction $(<0.09)$ would indicate that the number is less than the value presented. A symbol used with an underscore $(\leq$ or $\geq)$ indicates that the actual value is less than or equal to or greater than or equal to the number given, respectively.

\section{Reference}

EPA 402-R-99-001. 1999. "Cancer Risk Coefficients for Environmental Exposure to Radionuclides.” Appendix G in Federal Guidance Report 13, KF Eckerman, RW Leggett, CB Nelson, JS Puskin, and ACB Richardson, Office of Radiation and Indoor Air, U.S. Environmental Protection Agency, Washington, D.C. 


\section{Appendix B Glossary}

This glossary contains selected words and phrases used in this re
in italic type within a definition are also defined in this glossary.

absorbed dose - Energy absorbed per unit mass from any kind of ionizing radiation in any kind of matter. Units: $\mathrm{rad}$, which is equal to the absorption of 100 ergs per gram of material irradiated, or gray, which is the International System of Units (SI) equivalent.

activation product - Material made radioactive by exposure to radiation, principally by neutron radiation as in metals in a nuclear reactor (e.g., cobalt-60 from cobalt-59 in stainless steel).

adsorption - The accumulation of gases, liquids, or solutes on the surface of a solid or liquid.

alpha particle - A positively charged particle composed of two protons and two neutrons ejected spontaneously from the nuclei of some radionuclides. It has low penetrating power and short range. The most energetic alpha will generally fail to penetrate the skin. Alpha particles are hazardous when an alpha-emitting isotope is introduced into the body.

anion - A negatively charged ion.

apatite - A mineral that has the capability to capture and retain radioactive metal contaminants.

aquifer - Underground sediment or rock that stores and/or transmits water.

aquifer tube - A small-diameter, flexible plastic tube used to sample shallow aquifers, natural seepage areas, or springs. background radiation - Radiation in the natural environment, including cosmic rays from space and radiation from naturally occurring radioactive elements in the air, in the earth, and in human bodies. It also includes radiation from global fallout from historical atmospheric nuclear weapons testing. In the United States, the average person receives approximately 300 millirem of background radiation per year.

bank storage - Hydrologic term that describes river water that flows into and is retained in permeable stream banks during periods of high river stage. Flow is reversed during periods of low river stage.

becquerel (Bq) - Unit of activity or amount of a radioactive substance (also radioactivity) equal to one nuclear transformation per second ( $1 \mathrm{~Bq}=1$ disintegration per second). Another unit of radioactivity, the curie, is related to the becquerel: $1 \mathrm{Ci}=3.7 \times 10^{10} \mathrm{~Bq}$.

beta particle - A negatively charged particle (essentially an electron) emitted from a nucleus during radioactive decay. Large amounts of beta particles may cause skin burns and are harmful if they enter the body. Beta particles are easily stopped by a thin sheet of metal or plastic.

biological half-life - The time required for one-half of the amount of a radionuclide to be expelled from the body by natural metabolic processes, excluding radioactive decay, following ingestion, inhalation, or absorption. 
black cell - A section of the Hanford Tank Waste Treatment and Immobilization Plant where high-level nuclear waste will be routed that will never be accessible to humans because of its high radiation levels.

cation - A positively charged ion.

clean closed - A facility is classified as "clean closed" under Resource Conservation and Recovery Act of 1976 regulations when all dangerous waste has been removed and groundwater monitoring is no longer required.

collective total effective dose equivalent - Sum of the total effective dose equivalents for individuals comprising a defined population. Such units are person-rem or personsievert.

committed dose equivalent - The dose equivalent to organs or tissues that will be received from an intake of radioactive material by an individual during the 50-year period following intake.

committed effective dose equivalent - The sum of the committed dose equivalent to various tissues in the body, each multiplied by the appropriate weighting factor.

composite sample - Sample formed by mixing discrete samples taken at different times or from different locations.

confined aquifer - An aquifer bounded above and below by less-permeable layers. Groundwater in the confined aquifer is under a pressure greater than atmospheric pressure.

continuous sample - Sample formed by the continuous collection of the medium or contaminants within the medium during the entire sampling period.

cosmic radiation - High-energy subatomic particles and electromagnetic radiation from outer space that bombard the earth. Cosmic radiation is part of natural background radiation.

crib - An underground structure designed to receive liquid waste that percolates into the soil directly or percolates into the soil after having traveled through a connected tile field. These structures are no longer used at the Hanford Site.

curie (Ci) - A unit of radioactivity equal to 37 billion $\left(3.7 \times 10^{10}\right)$ nuclear transformations per second (becquerels). decay - The decrease in the amount of any radioactive material (disintegration) with the passage of time. See radioactivity.

decay product - The atomic nucleus or nuclei that are left after radioactive transformation of a radioactive material. Decay products may be radioactive or non-radioactive (stable). They are informally referred to as daughter products. See radioactivity.

deep-dose equivalent - The dose equivalent at a tissue depth of 1 centimeter from radiation originating outside of the body.

derived concentration guide (DCG) - Concentrations of radionuclides in air and water that an individual could continuously consume, inhale, or be immersed in at average annual rates and not receive an effective dose equivalent of greater than 100 millirem per year.

desiccation - A process whereby water or moisture is removed, resulting in dryness.

detection level (or limit) - Minimum amount of a substance that can be measured with a specified or implied confidence that the analytical result is greater than a specific value (e.g., zero).

direct-push technology - A cost-effective means of collecting subsurface samples; this technology uses a hydraulic hammer to drive a hollow rod into the soil either vertically or at an angle. Sensors can be deployed within the rod to detect radioactive contaminants, soil moisture, and other sampling criteria.

dispersion - Process whereby effluent or emissions are spread or mixed when they are transported by groundwater, surface water, or air.

dose equivalent - Product of the absorbed dose, a quality factor, and any other modifying factors. The dose equivalent is a quantity for comparing the biological effectiveness of different kinds of radiation on a common scale. The unit of dose equivalent is the rem.

dose rate - The rate at which a dose is delivered over time (e.g., dose equivalent rate in millirem per hour $[\mathrm{mrem} / \mathrm{hr}]$ ). 
dosimeter - Portable device for measuring the accumulated exposure or absorbed dose from specific types or energies of ionizing radiation fields.

effective dose - See effective dose equivalent.

effective dose equivalent - The sum of products of dose equivalent to selected tissues of the body and appropriate tissue weighting factors. The tissue weighting factors put doses to various tissues and organs on an equal basis in terms of health risk.

effluent - Liquid material released from a facility.

effluent monitoring - Sampling or measuring specific liquid effluent streams for the presence of pollutants.

emission - Gaseous stream released from a facility.

exposure - The interaction of an organism with a physical agent (e.g., radiation) or a chemical agent (e.g., arsenic) of interest. Also used as a term for quantifying $\mathrm{x}$ - and gammaradiation fields. See roentgen.

external radiation - Radiation originating from a source outside the body.

fallout - Typically refers to radioactive materials that are released into the earth's atmosphere following a nuclear explosion or atmospheric release and that eventually fall to earth.

fission - The splitting or breaking apart of a nucleus into at least two other nuclei, accompanied with a release of a relatively large amount of energy.

fission products - Nuclides formed from fissioning. Many fission products are radioactive.

found fuel - Incomplete pieces of spent nuclear fuel elements too small to have been located and removed during previous debris removal.

fully institutionalized - To incorporate into a formalized, structured system and be implemented and fully functional.

gamma radiation - High-energy electromagnetic radiation (photons) originating in the nucleus of decaying radionuclides. Gamma radiation is substantially more penetrating than alpha or beta particles. grab sample - A short-duration sample (e.g., air, water, and soil) that is grabbed from the collection site.

ground truth - Direct physical observations that are used to test indirect interpretations.

groundwater - Subsurface water that is in the pores of sand and gravel or in the cracks of fractured rock.

gray (Gy) - Unit of absorbed dose in the International System of Units (SI) equal to the absorption of 1 joule per kilogram. The common unit of absorbed dose, the rad, is equal to $0.01 \mathrm{~Gy}$.

half-life - Length of time in which a radioactive substance will lose one half of its radioactivity by decay. Half-lives range from a fraction of a second to billions of years, and each radionuclide has a unique half-life.

high-activity waste - See high-level waste.

high-level waste - Highly radioactive waste material resulting from the reprocessing of spent nuclear fuel, including liquid waste produced directly in reprocessing and any solid material derived from such liquid waste that contains fission products and other radioisotopes in sufficient concentrations to require permanent isolation.

institutional controls - Long-term actions or restrictions including monitoring, periodic sampling, access controls, and land-use restrictions designed to mitigate any risks posed by contamination following remediation. Institutional controls alone may be sufficient to reduce risks posed by low levels of contamination.

internal radiation - Radiation from radioactive material inside the body.

ion exchange - The reversible exchange of one species of ion for a different species of ion within a medium.

ion exchange resin - High molecular weight insoluble polymers containing functional groups that are capable of undergoing exchange reactions with ions in a solution with which it is in contact.

irradiation - Exposure to radiation.

isotopes - Nuclides of the same chemical element with the same number of protons but a differing number of neutrons. 
isotopic plutonium - Any of two or more atoms of the chemical element plutonium with the same atomic number and position in the periodic table and nearly identical chemical behavior but with differing atomic mass number and different physical properties. Plutonium-239 is produced by neutron irradiation of uranium- 238 .

isotopic uranium - Any of two or more atoms of the chemical element uranium with the same atomic number and position in the periodic table and nearly identical chemical behavior but with differing atomic mass number and different physical properties. Uranium exists naturally as a mixture of three isotopes of mass 234, 235, and 238 in the proportions of $0.006 \%, 0.71 \%$, and $99.27 \%$, respectively.

legacy waste - Waste that was generated before the Hanford Site's nuclear materials production mission was terminated.

low-activity waste - See low-level waste.

low-level waste - Radioactive waste that is not high-level radioactive waste, spent nuclear fuel, transuranic waste, byproduct material, or naturally occurring radioactive material.

material at risk - The inventory of radioactive material that could potentially be released to the environment from an accident.

maximally exposed individual - A hypothetical member of the public residing near the Hanford Site who, by virtue of location and living habits, would reasonably receive the highest possible radiation dose from materials originating from the site.

mean (or average) - Average value of a series of measurements. The mean is computed using the following equation:

$$
\text { mean }=\frac{\sum_{\mathrm{x}}}{\mathrm{n}}
$$

where $\mathrm{n}$ is the number of measurements, and $\Sigma_{\mathrm{x}}$ is the sum of all measurements.

median - Middle value in an odd-numbered set of results when the data are ranked in increasing or decreasing order or the average of two central values in an even number set of results. millirem - A unit of radiation dose equivalent that is equal to one one-thousandth $(1 / 1000)$ of a rem.

minimum detectable amount or concentration Smallest amount or concentration of a chemical or radioactive material that can be reliably detected in a sample.

mitigation - Prevention or reduction of expected risks to workers, the public, or the environment.

mixed waste - A U.S. Environmental Protection Agency or state-designated dangerous, extremely hazardous, or acutely hazardous waste that contains both a nonradioactive hazardous component and a radioactive component.

monitoring - As defined in DOE Order 5400.5, Chg 2, the collection and analysis of samples or measurements of liquid effluent and gaseous emissions for purposes of characterizing and quantifying contaminants, assessing radiation exposure to the public, and demonstrating compliance with regulatory standards.

noble gas - Any of a group of chemically and biologically inert gases that includes argon, krypton, and xenon. These gases are not retained in the body following inhalation. The principle exposure pathway for radioactive noble gases is direct external dose from the surrounding air.

nuclide - A particular combination of neutrons and protons. A radionuclide is a radioactive nuclide.

offsite locations - Sampling and measurement locations outside the Hanford Site boundary.

onsite locations - Sampling and measurement locations within the Hanford Site boundary.

operable unit - A discrete area for which an incremental step can be taken toward comprehensively addressing site problems. The cleanup of a site can be divided into a number of operable units, depending on the complexity of the problems associated with the site.

outfall - End of a drain or pipe that carries wastewater or other effluent into a ditch, pond, or river.

person-rem or person-sievert (person-Sv) - Unit of collective total effective dose equivalent. 1 person-Sv = 100 person-rem. 
photon - A quantum of radiant energy. Gamma radiation and $\mathrm{x}$-radiation ( $\mathrm{x}$-rays) are both composed of photons of varying energy.

phytoremediation - Use of plants to degrade or immobilize pollutants or toxins from the environment.

plume - The cloud of a pollutant in air, surface water, or groundwater formed after the pollutant is released from a source.

plutonium - A heavy, radioactive, metallic element consisting of several isotopes. One important isotope is plutonium-239, which is produced by the irradiation of uranium-238. Routine analysis cannot distinguish between the plutonium-239 and plutonium-240 isotopes; hence, the term plutonium-239/240 as used in this report is symbolic of the presence of one or both of these isotopes in the analytical results.

primordial radionuclide $-A$ radioactive material in the earth's crust that has a very long half-life and has existed since the beginning of the planet.

quality assurance - Actions that provide confidence that an item or process meets or exceeds a user's requirements and expectations.

quality control - Comprises all those actions necessary to control and verify the features and characteristics of a material, process, product, or service to specified requirements. Quality control is an element of quality assurance.

rad - The unit of absorbed dose. $1 \mathrm{rad}=0.01$ gray (Gy).

radiation - The energy emitted in the form of photons or particles (e.g., alpha and beta particles) such as that from transforming radionuclides. For this report, radiation refers to ionizing types of radiation; not radiowaves, microwaves, radiant light, or other types of non-ionizing radiation.

radioactivity - Property possessed by radioisotopes emitting radiation (such as alpha or beta particles, or high-energy photons) spontaneously in their decay process; also, the radiation emitted.

radioisotope - An unstable isotope of an element that decays or disintegrates spontaneously, emitting radiation (Shleien 1992). radiologically controlled area - An area to which access is controlled to protect individuals from exposure to radiation or radioactive materials.

radionuclide - A species of atoms having a particular number of protons $(Z)$, a particular number of neutrons $(A)$, and a particular atomic weight $(\mathrm{N}=\mathrm{Z}+\mathrm{A})$ that happens to emit radiation. Carbon-14 is a radionuclide but carbon-12, which is not radioactive, is referred to simply as a nuclide.

recruitment - Survival from one life form or stage to the next or from one age class to the next.

redox - A chemical reaction involving oxidation and reduction.

refractory - A material that has a high melting point (i.e., heat resistant).

refugium (refugia) - An area that has not experienced ecological changes that have affected surrounding regions, providing a habitat for species that were once more widespread.

rem - A unit of dose equivalent and effective dose equivalent.

remediation - Reduction (or cleanup) of known risks to the public and environment to an agreed-upon level.

risk - The probability that a detrimental health effect will occur.

risk-based disposal approval - A written application to the U.S. Environmental Protection Agency intended to manage and dispose of Toxic Substances Control Actregulated polychlorinated biphenyl waste not addressed suitably within the regulations. The risk-based disposal approval process applies to any person wishing to sample, clean up, or dispose of waste in a manner other than as prescribed in 40 CFR 761. For polychlorinated biphenyl remediation waste, the requirements for a risk-based disposal approval are specified in 40 CFR 761.61(c). A written approval from the U.S. Environmental Protection Agency is required before waste management activities are performed.

roentgen $(\mathbf{R})$ - The unit of $\mathrm{x}$-ray or gamma photon exposure as measured in air, historically used to describe external radiation levels. An exposure of 1 roentgen typically causes an effective dose of 1 rem. 
shrub-steppe - A drought-resistant shrub and grassland ecosystem.

sievert (Sv) - The unit of dose equivalent and its variants in the International System of Units (SI). The common unit for dose equivalent and its variants, the rem, is equal to $0.01 \mathrm{~Sv}$.

special case waste - Waste for which there is an undetermined disposal path because of high levels of radioactivity and difficulties in characterization, classification, and packaging.

specific retention facilities - Historical structures consisting of cribs, ditches, trenches, or holes in the ground that received relatively small volumes of high concentration liquid radioactive waste. The small volume of liquid waste was designed to prevent flushing of the contaminants through the soil column to the groundwater.

spent fuel - Uranium metal or oxide and its metal container that have been used to power a nuclear reactor and for one reason or another has reached the end of its useful life. It is highly radioactive and typically contains fission products, plutonium, and residual uranium.

standard error of the mean - A measure of the precision of a mean of observed values; that is, an estimate of how close a mean of observed values is expected to be to the true mean.

surveillance - As defined in DOE Order 5400.5, Chg 2, the collection and analysis of samples of air, water, soil, foodstuffs, biota, and other media, and the measurement of external radiation for purposes of demonstrating compliance with applicable standards, assessing exposures to the public, and assessing effects, if any, on the local environment.

tank farm - A group of underground waste storage tanks.

thermoluminescent dosimeter - A device containing a material that, after being exposed to beta and/or gamma radiation, emits light when heated. The amount of light emitted is proportional to the absorbed dose to the thermoluminescent dosimeter. total effective dose equivalent - The sum of committed effective dose equivalent from the intake of radioactive material and dose equivalent from exposure to external radiation. Unit: rem or sievert.

total uranium - The sum of concentrations of the isotopes uranium-234, uranium-235, and uranium-238.

transuranic element - An element with an atomic number greater than 92 (92 is the atomic number of uranium).

transuranic waste - Waste containing more than 100 nanocuries $\left(10^{-9}\right.$ curies $)$ per gram of alpha-emitting transuranic isotopes (half-lives greater than 20 years).

tritium - The heaviest radioactive isotope of hydrogen (hydrogen-3) with a 12.3-year half life.

unconfined aquifer - An aquifer containing groundwater that is not confined above by relatively impermeable rocks. The pressure at the top of the unconfined aquifer is equal to that of the atmosphere. At the Hanford Site, the unconfined aquifer is the uppermost aquifer and is most susceptible to contamination from site operations.

vadose zone - Underground area from the ground surface to the top of the water table or aquifer.

volatile organic compounds - Lightweight organic compounds that vaporize easily; used in solvents and degreasing compounds as raw materials.

water table - The top of the unconfined aquifer.

wind rose - A diagram showing how often winds of various speeds blow from different directions, usually based on yearly averages.

\section{References}

40 CFR 761. 2009. "Polychlorinated Biphenyls (PCBs) Manufacturing, Processing, Distribution in Commerce, and Use Prohibitions." Code of Federal Regulations, U.S. Environmental Protection Agency. Accessed May 17, 2010, at http://www.gpoaccess.gov/cfr/index.html. 
40 CFR 761.61(c). 2009. "Polychlorinated Biphenyls (PCBs) Manufacturing, Processing, Distribution in Commerce, and Use Prohibitions; PCB Remediation Waste: Risk-Based Disposal Approval." Code of Federal Regulations, U.S. Environmental Protection Agency. Accessed May 17, 2010, at http://www.gpoaccess.gov/cfr/index.html.

DOE Order 5400.5. Chg 2. 1993. "Radiation Protection of the Public and the Environment." U.S. Department of Energy, Washington, D.C.
Resource Conservation and Recovery Act of 1976. 1976. Public Law 94-580, as amended, 42 USC 6901 et seq. and 42 USC 6927(c) et seq. Accessed May 17, 2010, at http:// www.epa.gov/lawsregs/laws/rcra.html.

Shleien B. (ed.). 1992. The Health Physics and Radiological Health Handbook, Revised Edition. Scinta, Inc., Silver Spring, Maryland.

Toxic Substances Control Act. 1976. Public Law 94-469, as amended, 15 USC 2601 et seq. 


\title{
Appendix C
}

\section{Additional Monitoring Results for 2009}

\author{
GW Patton, CJ Perkins, SD Powell, and JA Stegen
}

This appendix contains additional information on 2009 monitoring results, supplementing data summarized in the main body of the report. More detailed information is available in Hanford Site Environmental Surveillance Data Report for Calendar Year 2009 (PNNL-19455, APP. 1) and Hanford Site Near-Facility Monitoring Data Report for Calendar Year 2009 (PNNL-19455, APP. 2). 
Table C. 1. Concentrations of Selected Radionuclides $\left(\mathrm{pCi} / \mathrm{m}^{3}\right)^{(a)}$ in Near-Facility Air Samples, 2009 Compared to Previous Years

\begin{tabular}{|c|c|c|c|c|c|c|c|c|c|c|c|}
\hline \multirow[b]{2}{*}{$\underline{\text { Radionuclide }}$} & \multirow[b]{2}{*}{$\underline{\text { Site }}$} & \multicolumn{4}{|c|}{2009} & \multirow[b]{2}{*}{$\begin{array}{l}\text { Sampler } \\
\text { Number }\end{array}$} & \multicolumn{4}{|c|}{ 2004-2008 } & \multirow[b]{2}{*}{$\begin{array}{c}\text { EPA } \\
\text { Table 2 }^{(\mathrm{e}, \mathrm{f})}\end{array}$} \\
\hline & & $\begin{array}{r}\text { Nur } \\
\text { Samples }\end{array}$ & $\begin{array}{l}\text { Imber of } \\
\text { Detections }^{(\mathbf{b})}\end{array}$ & $\underline{\text { Average }}^{(\mathrm{c})}$ & $\underline{\text { Maximum }}^{(\mathrm{d})}$ & & $\begin{array}{r}\text { Nun } \\
\text { Samples }\end{array}$ & $\begin{array}{l}\text { mber of } \\
\text { Detections }^{(\mathbf{b})}\end{array}$ & $\underline{\text { Average }}^{(\mathrm{c})}$ & $\underline{\text { Maximum }}^{(\mathrm{d})}$ & \\
\hline \multirow[t]{13}{*}{ Gross alpha } & 100-D FR & 104 & 95 & $1.2 \mathrm{E}-03 \pm 1.0 \mathrm{E}-03$ & $2.6 \mathrm{E}-03 \pm 9.2 \mathrm{E}-04$ & N514 & 197 & 178 & $1.1 \mathrm{E}-03 \pm 1.1 \mathrm{E}-03$ & $3.1 \mathrm{E}-03 \pm 8.5 \mathrm{E}-04$ & 2.0E-02 \\
\hline & 100-H FR & 104 & 98 & $1.2 \mathrm{E}-03 \pm 1.1 \mathrm{E}-03$ & $2.6 \mathrm{E}-03 \pm 7.6 \mathrm{E}-04$ & N574 & 45 & 45 & $1.5 \mathrm{E}-03 \pm 1.0 \mathrm{E}-03$ & $2.8 \mathrm{E}-03 \pm 8.1 \mathrm{E}-04$ & \\
\hline & $100-\mathrm{K} \mathrm{KBC}$ & 208 & 200 & $1.7 \mathrm{E}-03 \pm 3.7 \mathrm{E}-03$ & $2.0 \mathrm{E}-02 \pm 2.5 \mathrm{E}-03$ & $\mathrm{~N} 402$ & 1,040 & 927 & $1.3 \mathrm{E}-03 \pm 2.1 \mathrm{E}-03$ & $1.5 \mathrm{E}-02 \pm 3.9 \mathrm{E}-03$ & \\
\hline & $100-\mathrm{N}$ & 78 & 72 & $1.3 \mathrm{E}-03 \pm 1.2 \mathrm{E}-03$ & $3.0 \mathrm{E}-03 \pm 8.4 \mathrm{E}-04$ & N102 & 393 & 375 & $1.3 \mathrm{E}-03 \pm 1.3 \mathrm{E}-03$ & $4.1 \mathrm{E}-03 \pm 1.1 \mathrm{E}-03$ & \\
\hline & 118-K-1 FR & 40 & 39 & $1.5 \mathrm{E}-03 \pm 2.2 \mathrm{E}-03$ & $6.9 \mathrm{E}-03 \pm 1.3 \mathrm{E}-03$ & $\mathrm{~N} 403$ & 272 & 240 & $1.3 \mathrm{E}-03 \pm 2.1 \mathrm{E}-03$ & $9.4 \mathrm{E}-03 \pm 4.3 \mathrm{E}-03$ & \\
\hline & 200-East & 544 & 521 & $1.3 \mathrm{E}-03 \pm 1.2 \mathrm{E}-03$ & $4.3 \mathrm{E}-03 \pm 1.0 \mathrm{E}-03$ & N499 & 2,658 & 2,436 & $1.2 \mathrm{E}-03 \pm 1.4 \mathrm{E}-03$ & $6.7 \mathrm{E}-03 \pm 1.6 \mathrm{E}-03$ & \\
\hline & 200-North & 68 & 64 & $1.2 \mathrm{E}-03 \pm 1.1 \mathrm{E}-03$ & $2.5 \mathrm{E}-03 \pm 8.0 \mathrm{E}-04$ & N567 & 34 & 28 & $1.1 \mathrm{E}-03 \pm 1.5 \mathrm{E}-03$ & $3.7 \mathrm{E}-03 \pm 1.2 \mathrm{E}-03$ & \\
\hline & 200-UW-1 & 129 & 125 & $1.2 \mathrm{E}-03 \pm 9.1 \mathrm{E}-04$ & $2.4 \mathrm{E}-03 \pm 7.4 \mathrm{E}-04$ & N550 & 536 & 487 & $1.3 \mathrm{E}-03 \pm 1.5 \mathrm{E}-03$ & $6.5 \mathrm{E}-03 \pm 1.6 \mathrm{E}-03$ & \\
\hline & 200-West & 639 & 606 & $1.3 \mathrm{E}-03 \pm 1.3 \mathrm{E}-03$ & $6.9 \mathrm{E}-03 \pm 1.4 \mathrm{E}-03$ & $\mathrm{~N} 433$ & 3,162 & 2,887 & $1.3 \mathrm{E}-03 \pm 1.5 \mathrm{E}-03$ & $1.2 \mathrm{E}-02 \pm 4.6 \mathrm{E}-03$ & \\
\hline & 300 Area $D \& D$ & 26 & 26 & $1.3 \mathrm{E}-03 \pm 1.0 \mathrm{E}-03$ & $2.4 \mathrm{E}-03 \pm 7.6 \mathrm{E}-04$ & N557 & 101 & 92 & $1.2 \mathrm{E}-03 \pm 1.7 \mathrm{E}-03$ & $7.3 \mathrm{E}-03 \pm 1.7 \mathrm{E}-03$ & \\
\hline & 300-FF-2 FR & 64 & 63 & $1.2 \mathrm{E}-03 \pm 1.1 \mathrm{E}-03$ & $3.3 \mathrm{E}-03 \pm 1.3 \mathrm{E}-03$ & N527 & 437 & 406 & $1.2 \mathrm{E}-03 \pm 1.4 \mathrm{E}-03$ & $6.3 \mathrm{E}-03 \pm 7.8 \mathrm{E}-03$ & \\
\hline & BCCA & 73 & 66 & $1.2 \mathrm{E}-03 \pm 1.7 \mathrm{E}-03$ & $3.3 \mathrm{E}-03 \pm 1.2 \mathrm{E}-03$ & N957 & 320 & 293 & $1.3 \mathrm{E}-03 \pm 1.4 \mathrm{E}-03$ & $4.7 \mathrm{E}-03 \pm 3.6 \mathrm{E}-03$ & \\
\hline & ERDF & 130 & 120 & $1.1 \mathrm{E}-03 \pm 1.0 \mathrm{E}-03$ & $2.9 \mathrm{E}-03 \pm 8.1 \mathrm{E}-04$ & N518 & 643 & 548 & $1.1 \mathrm{E}-03 \pm 1.4 \mathrm{E}-03$ & $6.5 \mathrm{E}-03 \pm 1.6 \mathrm{E}-03$ & \\
\hline \multirow[t]{13}{*}{ Gross beta } & 100-D FR & 104 & 104 & $1.8 \mathrm{E}-02 \pm 1.7 \mathrm{E}-02$ & $4.8 \mathrm{E}-02 \pm 4.4 \mathrm{E}-03$ & N515 & 197 & 197 & $1.6 \mathrm{E}-02 \pm 1.8 \mathrm{E}-02$ & $4.9 \mathrm{E}-02 \pm 4.6 \mathrm{E}-03$ & $9.0 \mathrm{E}+00$ \\
\hline & 100-H FR & 104 & 103 & $1.9 \mathrm{E}-02 \pm 2.0 \mathrm{E}-02$ & $5.3 \mathrm{E}-02 \pm 4.9 \mathrm{E}-03$ & N508 & 45 & 45 & $2.4 \mathrm{E}-02 \pm 2.1 \mathrm{E}-02$ & $5.1 \mathrm{E}-02 \pm 4.9 \mathrm{E}-03$ & \\
\hline & $100-\mathrm{K}$ KBC & 208 & 208 & $5.5 \mathrm{E}-02 \pm 2.4 \mathrm{E}-01$ & $1.2 \mathrm{E}+00 \pm 8.4 \mathrm{E}-02$ & $\mathrm{~N} 402$ & 1,040 & 1,040 & $1.9 \mathrm{E}-02 \pm 2.8 \mathrm{E}-02$ & $2.2 \mathrm{E}-01 \pm 3.9 \mathrm{E}-02$ & \\
\hline & $100-\mathrm{N}$ & 78 & 78 & $1.8 \mathrm{E}-02 \pm 1.8 \mathrm{E}-02$ & $4.4 \mathrm{E}-02 \pm 4.7 \mathrm{E}-03$ & N102 & 393 & 393 & $1.7 \mathrm{E}-02 \pm 2.0 \mathrm{E}-02$ & $6.8 \mathrm{E}-02 \pm 6.1 \mathrm{E}-03$ & \\
\hline & $118-\mathrm{K}-1 \mathrm{FR}$ & 40 & 40 & $6.8 \mathrm{E}-02 \pm 2.2 \mathrm{E}-01$ & $5.3 \mathrm{E}-01 \pm 3.9 \mathrm{E}-02$ & $\mathrm{~N} 403$ & 272 & 272 & $1.7 \mathrm{E}-02 \pm 2.4 \mathrm{E}-02$ & $1.2 \mathrm{E}-01 \pm 9.3 \mathrm{E}-03$ & \\
\hline & 200-East & 544 & 544 & $1.9 \mathrm{E}-02 \pm 1.8 \mathrm{E}-02$ & $5.0 \mathrm{E}-02 \pm 4.6 \mathrm{E}-03$ & N999 & 2,658 & 2,658 & $1.7 \mathrm{E}-02 \pm 2.1 \mathrm{E}-02$ & $9.6 \mathrm{E}-02 \pm 7.8 \mathrm{E}-03$ & \\
\hline & 200-North & 68 & 68 & $1.8 \mathrm{E}-02 \pm 1.9 \mathrm{E}-02$ & $5.2 \mathrm{E}-02 \pm 5.5 \mathrm{E}-03$ & N567 & 34 & 34 & $1.1 \mathrm{E}-02 \pm 7.5 \mathrm{E}-03$ & $2.0 \mathrm{E}-02 \pm 3.5 \mathrm{E}-03$ & \\
\hline & 200-UW-1 & 129 & 129 & $1.8 \mathrm{E}-02 \pm 1.7 \mathrm{E}-02$ & $5.0 \mathrm{E}-02 \pm 5.3 \mathrm{E}-03$ & N550 & 536 & 536 & $1.7 \mathrm{E}-02 \pm 2.2 \mathrm{E}-02$ & $7.4 \mathrm{E}-02 \pm 6.9 \mathrm{E}-03$ & \\
\hline & 200-West & 639 & 638 & $1.8 \mathrm{E}-02 \pm 1.7 \mathrm{E}-02$ & $5.0 \mathrm{E}-02 \pm 5.3 \mathrm{E}-03$ & N550 & 3,162 & 3,160 & $1.7 \mathrm{E}-02 \pm 2.2 \mathrm{E}-02$ & $1.7 \mathrm{E}-01 \pm 2.0 \mathrm{E}-02$ & \\
\hline & 300 Area D\&D & 26 & 26 & $1.9 \mathrm{E}-02 \pm 2.0 \mathrm{E}-02$ & $4.7 \mathrm{E}-02 \pm 4.9 \mathrm{E}-03$ & N557 & 101 & 101 & $1.8 \mathrm{E}-02 \pm 2.3 \mathrm{E}-02$ & $6.4 \mathrm{E}-02 \pm 6.8 \mathrm{E}-03$ & \\
\hline & 300-FF-2 FR & 64 & 64 & $2.1 \mathrm{E}-02 \pm 2.4 \mathrm{E}-02$ & $5.4 \mathrm{E}-02 \pm 5.6 \mathrm{E}-03$ & N539 & 437 & 436 & $1.8 \mathrm{E}-02 \pm 2.2 \mathrm{E}-02$ & $8.1 \mathrm{E}-02 \pm 7.2 \mathrm{E}-03$ & \\
\hline & BCCA & 73 & 72 & $2.0 \mathrm{E}-02 \pm 2.0 \mathrm{E}-02$ & $5.0 \mathrm{E}-02 \pm 5.2 \mathrm{E}-03$ & N572 & 320 & 320 & $1.7 \mathrm{E}-02 \pm 2.0 \mathrm{E}-02$ & $6.2 \mathrm{E}-02 \pm 5.8 \mathrm{E}-03$ & \\
\hline & ERDF & 130 & 130 & $1.6 \mathrm{E}-02 \pm 1.9 \mathrm{E}-02$ & $5.0 \mathrm{E}-02 \pm 5.3 \mathrm{E}-03$ & N550 & 643 & 641 & $1.6 \mathrm{E}-02 \pm 2.1 \mathrm{E}-02$ & $7.1 \mathrm{E}-02 \pm 6.8 \mathrm{E}-03$ & \\
\hline
\end{tabular}


Table C.1. (contd)

\begin{tabular}{|c|c|c|c|c|c|c|c|c|c|c|c|}
\hline \multirow[b]{2}{*}{$\underline{\text { Radionuclide }}$} & \multirow[b]{2}{*}{$\underline{\text { Site }}$} & \multicolumn{4}{|c|}{2009} & \multirow[b]{2}{*}{$\begin{array}{l}\text { Sampler } \\
\text { Number }\end{array}$} & \multicolumn{4}{|c|}{$2004-2008$} & \multirow[b]{2}{*}{$\begin{array}{c}\text { EPA } \\
\text { Table } 2^{(\mathrm{e}, \mathrm{f})}\end{array}$} \\
\hline & & $\begin{array}{r}\text { Num } \\
\text { Samples } 1\end{array}$ & $\begin{array}{l}\text { nber of } \\
\text { Detections }^{(b)}\end{array}$ & $\underline{\text { Average }}^{(c)}$ & ${\underline{\text { Maximum }^{(d)}}}^{(2)}$ & & $\begin{array}{r}\mathrm{Nu} \\
\text { Samples } \\
\end{array}$ & $\begin{array}{l}\text { mber of } \\
\text { Detections }^{(b)}\end{array}$ & $\underline{\text { Average }}^{(\mathrm{c})}$ & ${\underline{\text { Maximum }^{(d)}}}$ & \\
\hline \multirow[t]{13}{*}{ Cobalt- 60} & 100-D FR & 8 & 0 & $5.1 \mathrm{E}-07 \pm 5.8 \mathrm{E}-05$ & $3.7 \mathrm{E}-05 \pm 6.3 \mathrm{E}-05$ & N515 & 17 & 0 & $3.9 \mathrm{E}-05 \pm 2.8 \mathrm{E}-04$ & $5.6 \mathrm{E}-04 \pm 1.3 \mathrm{E}-03$ & $1.7 \mathrm{E}-02$ \\
\hline & 100-H FR & 8 & 0 & $8.8 \mathrm{E}-06 \pm 4.8 \mathrm{E}-05$ & $4.7 \mathrm{E}-05 \pm 9.5 \mathrm{E}-05$ & N574 & 4 & 0 & $5.3 \mathrm{E}-05 \pm 1.2 \mathrm{E}-04$ & $1.5 \mathrm{E}-04 \pm 2.0 \mathrm{E}-04$ & \\
\hline & $100-\mathrm{K} \mathrm{KBC}$ & 16 & 1 & $2.0 \mathrm{E}-05 \pm 8.1 \mathrm{E}-05$ & $1.2 \mathrm{E}-04 \pm 1.1 \mathrm{E}-04$ & $\mathrm{~N} 402$ & 80 & 0 & $1.1 \mathrm{E}-05 \pm 8.3 \mathrm{E}-05$ & $1.2 \mathrm{E}-04 \pm 8.5 \mathrm{E}-05$ & \\
\hline & $100-\mathrm{N}$ & 6 & 0 & $-6.7 \mathrm{E}-07 \pm 7.7 \mathrm{E}-05$ & $6.5 \mathrm{E}-05 \pm 7.5 \mathrm{E}-05$ & N103 & 30 & 6 & $4.6 \mathrm{E}-05 \pm 2.0 \mathrm{E}-04$ & $2.8 \mathrm{E}-04 \pm 1.5 \mathrm{E}-04$ & \\
\hline & 118-K-1 FR & 4 & 0 & $-2.4 \mathrm{E}-05 \pm 5.2 \mathrm{E}-06$ & $-2.2 \mathrm{E}-05 \pm 1.7 \mathrm{E}-04$ & N535 & 24 & 0 & $3.6 \mathrm{E}-05 \pm 2.7 \mathrm{E}-04$ & $5.5 \mathrm{E}-04 \pm 5.7 \mathrm{E}-04$ & \\
\hline & 200-East & 42 & 0 & $-4.2 \mathrm{E}-06 \pm 6.6 \mathrm{E}-05$ & $7.5 \mathrm{E}-05 \pm 1.1 \mathrm{E}-04$ & N984 & 204 & 1 & $4.1 \mathrm{E}-06 \pm 9.8 \mathrm{E}-05$ & $1.7 \mathrm{E}-04 \pm 2.7 \mathrm{E}-04$ & \\
\hline & 200-North & 8 & 0 & $1.1 \mathrm{E}-05 \pm 1.0 \mathrm{E}-04$ & $6.9 \mathrm{E}-05 \pm 2.3 \mathrm{E}-04$ & N567 & 4 & 1 & $1.1 \mathrm{E}-04 \pm 1.9 \mathrm{E}-04$ & $2.5 \mathrm{E}-04 \pm 1.2 \mathrm{E}-04$ & \\
\hline & 200-UW-1 & 10 & 0 & $-5.1 \mathrm{E}-06 \pm 3.6 \mathrm{E}-05$ & $2.6 \mathrm{E}-05 \pm 7.8 \mathrm{E}-05$ & N551 & 42 & 0 & $6.4 \mathrm{E}-06 \pm 9.1 \mathrm{E}-05$ & $1.4 \mathrm{E}-04 \pm 2.6 \mathrm{E}-04$ & \\
\hline & 200-West & 50 & 0 & $4.7 \mathrm{E}-06 \pm 9.1 \mathrm{E}-05$ & $1.0 \mathrm{E}-04 \pm 8.7 \mathrm{E}-05$ & N304 & 244 & 1 & $3.1 \mathrm{E}-06 \pm 9.1 \mathrm{E}-05$ & $1.5 \mathrm{E}-04 \pm 1.3 \mathrm{E}-04$ & \\
\hline & 300 Area D\&D & 4 & 0 & $-2.4 \mathrm{E}-06 \pm 1.6 \mathrm{E}-04$ & $1.3 \mathrm{E}-04 \pm 1.4 \mathrm{E}-04$ & N557 & 16 & 0 & $-5.3 \mathrm{E}-05 \pm 2.3 \mathrm{E}-04$ & $8.3 \mathrm{E}-05 \pm 1.5 \mathrm{E}-04$ & \\
\hline & 300-FF-2 FR & 8 & 0 & $-5.5 \mathrm{E}-05 \pm 4.0 \mathrm{E}-04$ & $3.0 \mathrm{E}-04 \pm 4.2 \mathrm{E}-04$ & N538 & 38 & 0 & $-3.6 \mathrm{E}-05 \pm 2.4 \mathrm{E}-04$ & $8.0 \mathrm{E}-05 \pm 9.2 \mathrm{E}-05$ & \\
\hline & BCCA & 6 & 0 & $3.2 \mathrm{E}-06 \pm 5.2 \mathrm{E}-05$ & $3.9 \mathrm{E}-05 \pm 7.9 \mathrm{E}-05$ & N978 & 28 & 0 & $4.2 \mathrm{E}-06 \pm 1.3 \mathrm{E}-04$ & $1.1 \mathrm{E}-04 \pm 1.8 \mathrm{E}-04$ & \\
\hline & ERDF & 10 & 0 & $-3.0 \mathrm{E}-06 \pm 5.1 \mathrm{E}-05$ & $5.7 \mathrm{E}-05 \pm 8.8 \mathrm{E}-05$ & N518 & 49 & 0 & $5.9 \mathrm{E}-06 \pm 1.0 \mathrm{E}-04$ & $1.5 \mathrm{E}-04 \pm 1.2 \mathrm{E}-04$ & \\
\hline \multirow[t]{13}{*}{ Strontium-90 } & 100-D FR & 8 & 0 & $-2.0 \mathrm{E}-04 \pm 3.7 \mathrm{E}-04$ & $1.5 \mathrm{E}-04 \pm 2.4 \mathrm{E}-04$ & N468 & 17 & 1 & $-1.1 \mathrm{E}-04 \pm 4.4 \mathrm{E}-04$ & $2.9 \mathrm{E}-04 \pm 2.4 \mathrm{E}-04$ & $1.9 \mathrm{E}-02$ \\
\hline & 100-H FR & 8 & 0 & $-1.2 \mathrm{E}-04 \pm 3.2 \mathrm{E}-04$ & $2.3 \mathrm{E}-04 \pm 2.4 \mathrm{E}-04$ & N510 & 4 & 0 & $-2.5 \mathrm{E}-04 \pm 7.1 \mathrm{E}-05$ & $-2.1 \mathrm{E}-04 \pm 2.1 \mathrm{E}-04$ & \\
\hline & $100-\mathrm{K} \mathrm{KBC}$ & 16 & 10 & $4.0 \mathrm{E}-03 \pm 9.8 \mathrm{E}-03$ & $1.5 \mathrm{E}-02 \pm 4.4 \mathrm{E}-03$ & N404 & 80 & 5 & $-3.6 \mathrm{E}-05 \pm 2.5 \mathrm{E}-04$ & $2.9 \mathrm{E}-04 \pm 1.7 \mathrm{E}-04$ & \\
\hline & $100-\mathrm{N}$ & 6 & 0 & $-1.5 \mathrm{E}-04 \pm 4.1 \mathrm{E}-04$ & $2.0 \mathrm{E}-04 \pm 2.6 \mathrm{E}-04$ & N106 & 30 & 3 & $-3.9 \mathrm{E}-05 \pm 2.6 \mathrm{E}-04$ & $2.0 \mathrm{E}-04 \pm 1.2 \mathrm{E}-04$ & \\
\hline & 118-K-1 FR & 4 & 2 & $3.7 \mathrm{E}-03 \pm 7.5 \mathrm{E}-03$ & $7.7 \mathrm{E}-03 \pm 2.4 \mathrm{E}-03$ & $\mathrm{~N} 403$ & 24 & 4 & $-1.9 \mathrm{E}-05 \pm 6.5 \mathrm{E}-04$ & $9.5 \mathrm{E}-04 \pm 4.3 \mathrm{E}-04$ & \\
\hline & 200-East & 42 & 0 & $-2.1 \mathrm{E}-04 \pm 2.6 \mathrm{E}-04$ & $7.9 \mathrm{E}-05 \pm 1.6 \mathrm{E}-04$ & N984 & 204 & 11 & $-4.0 \mathrm{E}-05 \pm 2.6 \mathrm{E}-04$ & $5.0 \mathrm{E}-04 \pm 1.8 \mathrm{E}-04$ & \\
\hline & 200-North & 8 & 0 & $-6.0 \mathrm{E}-04 \pm 1.3 \mathrm{E}-03$ & $1.0 \mathrm{E}-04 \pm 1.8 \mathrm{E}-04$ & N568 & 4 & 0 & $-3.1 \mathrm{E}-04 \pm 1.1 \mathrm{E}-04$ & $-2.7 \mathrm{E}-04 \pm 2.8 \mathrm{E}-04$ & \\
\hline & 200-UW-1 & 10 & 0 & $-2.1 \mathrm{E}-04 \pm 2.6 \mathrm{E}-04$ & $-3.2 \mathrm{E}-05 \pm 3.3 \mathrm{E}-05$ & N550 & 42 & 3 & $-4.7 \mathrm{E}-05 \pm 3.5 \mathrm{E}-04$ & $6.6 \mathrm{E}-04 \pm 2.6 \mathrm{E}-04$ & \\
\hline & 200-West & 50 & 1 & $-2.0 \mathrm{E}-04 \pm 3.8 \mathrm{E}-04$ & $2.1 \mathrm{E}-04 \pm 1.9 \mathrm{E}-04$ & N449 & 244 & 7 & $-5.8 \mathrm{E}-05 \pm 2.7 \mathrm{E}-04$ & $6.2 \mathrm{E}-04 \pm 2.2 \mathrm{E}-04$ & \\
\hline & 300 Area D\&D & 4 & 0 & $-5.0 \mathrm{E}-04 \pm 3.4 \mathrm{E}-04$ & $-3.6 \mathrm{E}-04 \pm 3.7 \mathrm{E}-04$ & N557 & 16 & 0 & $-1.1 \mathrm{E}-04 \pm 4.0 \mathrm{E}-04$ & $3.8 \mathrm{E}-04 \pm 4.7 \mathrm{E}-04$ & \\
\hline & 300-FF-2 FR & 2 & 0 & $-2.9 \mathrm{E}-04 \pm 8.1 \mathrm{E}-05$ & $-2.5 \mathrm{E}-04 \pm 2.6 \mathrm{E}-04$ & N130 & 10 & 0 & $-5.8 \mathrm{E}-05 \pm 2.0 \mathrm{E}-04$ & $4.1 \mathrm{E}-05 \pm 1.4 \mathrm{E}-04$ & \\
\hline & BCCA & 6 & 0 & $-2.4 \mathrm{E}-04 \pm 2.5 \mathrm{E}-04$ & $-5.5 \mathrm{E}-06 \pm 5.7 \mathrm{E}-06$ & N573 & 28 & 2 & $-2.1 \mathrm{E}-05 \pm 4.1 \mathrm{E}-04$ & $7.8 \mathrm{E}-04 \pm 3.0 \mathrm{E}-04$ & \\
\hline & ERDF & 10 & 0 & $-1.7 \mathrm{E}-04 \pm 2.9 \mathrm{E}-04$ & $6.8 \mathrm{E}-05 \pm 1.5 \mathrm{E}-04$ & N517 & 49 & 2 & $-2.4 \mathrm{E}-05 \pm 2.8 \mathrm{E}-04$ & $6.7 \mathrm{E}-04 \pm 2.7 \mathrm{E}-04$ & \\
\hline
\end{tabular}


Table C.1. (contd)

\begin{tabular}{|c|c|c|c|c|c|c|c|c|c|c|c|}
\hline \multirow[b]{2}{*}{$\underline{\text { Radionuclide }}$} & \multirow[b]{2}{*}{$\underline{\text { Site }}$} & \multicolumn{4}{|c|}{2009} & \multirow[b]{2}{*}{$\begin{array}{l}\text { Sampler } \\
\text { Number }\end{array}$} & \multicolumn{4}{|c|}{$2004-2008$} & \multirow[b]{2}{*}{$\begin{array}{c}\text { EPA } \\
\text { Table 2 }^{(\mathrm{e}, \mathrm{f}}\end{array}$} \\
\hline & & $\begin{array}{r}\mathrm{Nu} \\
\text { Samples } \\
\end{array}$ & $\begin{array}{l}\text { mber of } \\
\text { Detections }^{(b)}\end{array}$ & $\underline{\text { Average }}^{(\mathrm{c})}$ & $\underline{\text { Maximum }}^{(\mathrm{d})}$ & & $\begin{array}{r}\mathrm{Nu} \\
\text { Samples } \\
\end{array}$ & $\begin{array}{l}\text { mber of } \\
\text { Detections }^{(\mathbf{b})}\end{array}$ & ${\underline{\text { Average }^{(c)}}}^{(\mathrm{s})}$ & $\underline{\text { Maximum }}^{(\mathrm{d})}$ & \\
\hline \multirow[t]{13}{*}{ Cesium-137 } & 100-D FR & 8 & 0 & $4.5 \mathrm{E}-05 \pm 9.5 \mathrm{E}-05$ & $9.6 \mathrm{E}-05 \pm 7.4 \mathrm{E}-05$ & N468 & 17 & 0 & $-8.6 \mathrm{E}-06 \pm 1.6 \mathrm{E}-04$ & $6.5 \mathrm{E}-05 \pm 7.0 \mathrm{E}-05$ & $1.9 \mathrm{E}-02$ \\
\hline & 100-H FR & 8 & 0 & $3.3 \mathrm{E}-05 \pm 6.4 \mathrm{E}-05$ & $9.4 \mathrm{E}-05 \pm 6.2 \mathrm{E}-05$ & N508 & 4 & 0 & $-2.2 \mathrm{E}-05 \pm 2.9 \mathrm{E}-05$ & $-3.0 \mathrm{E}-06 \pm 3.0 \mathrm{E}-05$ & \\
\hline & $100-\mathrm{K} \mathrm{KBC}$ & 16 & 16 & $3.1 \mathrm{E}-02 \pm 7.3 \mathrm{E}-02$ & $1.2 \mathrm{E}-01 \pm 3.9 \mathrm{E}-02$ & $\mathrm{~N} 402$ & 80 & 9 & $1.6 \mathrm{E}-04 \pm 1.7 \mathrm{E}-03$ & $7.4 \mathrm{E}-03 \pm 2.5 \mathrm{E}-03$ & \\
\hline & $100-\mathrm{N}$ & 6 & 3 & $1.4 \mathrm{E}-04 \pm 1.2 \mathrm{E}-04$ & $2.4 \mathrm{E}-04 \pm 1.5 \mathrm{E}-04$ & N103 & 30 & 3 & $3.5 \mathrm{E}-05 \pm 1.1 \mathrm{E}-04$ & $1.8 \mathrm{E}-04 \pm 1.1 \mathrm{E}-04$ & \\
\hline & 118-K-1 FR & 4 & 2 & $3.3 \mathrm{E}-02 \pm 6.8 \mathrm{E}-02$ & $7.5 \mathrm{E}-02 \pm 2.4 \mathrm{E}-02$ & N403 & 24 & 7 & $3.7 \mathrm{E}-04 \pm 2.9 \mathrm{E}-03$ & $7.4 \mathrm{E}-03 \pm 2.5 \mathrm{E}-03$ & \\
\hline & 200-East & 42 & 9 & $1.4 \mathrm{E}-04 \pm 7.1 \mathrm{E}-04$ & $2.3 \mathrm{E}-03 \pm 7.7 \mathrm{E}-04$ & N019 & 204 & 17 & $5.0 \mathrm{E}-05 \pm 2.7 \mathrm{E}-04$ & $9.9 \mathrm{E}-04 \pm 3.9 \mathrm{E}-04$ & \\
\hline & 200-North & 8 & 0 & $6.3 \mathrm{E}-05 \pm 1.1 \mathrm{E}-04$ & $1.2 \mathrm{E}-04 \pm 8.7 \mathrm{E}-05$ & N564 & 4 & 0 & $4.6 \mathrm{E}-05 \pm 1.2 \mathrm{E}-04$ & $1.5 \mathrm{E}-04 \pm 1.6 \mathrm{E}-04$ & \\
\hline & 200-UW-1 & 10 & 5 & $1.1 \mathrm{E}-04 \pm 1.7 \mathrm{E}-04$ & $2.6 \mathrm{E}-04 \pm 1.5 \mathrm{E}-04$ & N551 & 42 & 8 & $9.6 \mathrm{E}-05 \pm 2.2 \mathrm{E}-04$ & $4.5 \mathrm{E}-04 \pm 2.2 \mathrm{E}-04$ & \\
\hline & 200-West & 50 & 5 & $4.7 \mathrm{E}-05 \pm 1.1 \mathrm{E}-04$ & $2.0 \mathrm{E}-04 \pm 1.4 \mathrm{E}-04$ & N974 & 244 & 19 & $4.4 \mathrm{E}-05 \pm 2.2 \mathrm{E}-04$ & $1.3 \mathrm{E}-03 \pm 5.1 \mathrm{E}-04$ & \\
\hline & 300 Area D\&D & 4 & 0 & $2.7 \mathrm{E}-05 \pm 1.5 \mathrm{E}-04$ & $9.8 \mathrm{E}-05 \pm 1.4 \mathrm{E}-04$ & N557 & 16 & 0 & $1.1 \mathrm{E}-05 \pm 1.2 \mathrm{E}-04$ & $1.2 \mathrm{E}-04 \pm 3.1 \mathrm{E}-04$ & \\
\hline & 300-FF-2 FR & 8 & 0 & $-6.5 \mathrm{E}-05 \pm 1.9 \mathrm{E}-04$ & $4.8 \mathrm{E}-05 \pm 3.2 \mathrm{E}-04$ & N539 & 38 & 0 & $2.4 \mathrm{E}-05 \pm 1.8 \mathrm{E}-04$ & $4.6 \mathrm{E}-04 \pm 7.8 \mathrm{E}-04$ & \\
\hline & BCCA & 6 & 2 & $7.8 \mathrm{E}-05 \pm 1.5 \mathrm{E}-04$ & $2.0 \mathrm{E}-04 \pm 1.0 \mathrm{E}-04$ & N978 & 28 & 2 & $1.2 \mathrm{E}-04 \pm 9.3 \mathrm{E}-04$ & $2.5 \mathrm{E}-03 \pm 8.1 \mathrm{E}-04$ & \\
\hline & ERDF & 10 & 3 & $1.2 \mathrm{E}-04 \pm 2.1 \mathrm{E}-04$ & $3.8 \mathrm{E}-04 \pm 1.5 \mathrm{E}-04$ & N517 & 49 & 5 & $6.0 \mathrm{E}-05 \pm 1.4 \mathrm{E}-04$ & $3.2 \mathrm{E}-04 \pm 1.8 \mathrm{E}-04$ & \\
\hline \multirow[t]{13}{*}{ Uranium-234 } & 100-D FR & 8 & 7 & $8.3 \mathrm{E}-06 \pm 4.9 \mathrm{E}-06$ & $1.2 \mathrm{E}-05 \pm 7.9 \mathrm{E}-06$ & N467 & 17 & 14 & $1.6 \mathrm{E}-05 \pm 2.5 \mathrm{E}-05$ & $6.3 \mathrm{E}-05 \pm 7.5 \mathrm{E}-05$ & $7.7 \mathrm{E}-03$ \\
\hline & 100-H FR & 8 & 7 & $9.0 \mathrm{E}-06 \pm 4.1 \mathrm{E}-06$ & $1.2 \mathrm{E}-05 \pm 7.3 \mathrm{E}-06$ & N510 & 4 & 4 & $2.7 \mathrm{E}-05 \pm 1.6 \mathrm{E}-05$ & $4.0 \mathrm{E}-05 \pm 2.1 \mathrm{E}-05$ & \\
\hline & $100-\mathrm{K} \mathrm{KBC}$ & 16 & 15 & $9.7 \mathrm{E}-06 \pm 5.1 \mathrm{E}-06$ & $1.5 \mathrm{E}-05 \pm 8.6 \mathrm{E}-06$ & N478 & 80 & 70 & $1.2 \mathrm{E}-05 \pm 9.5 \mathrm{E}-06$ & $2.4 \mathrm{E}-05 \pm 1.2 \mathrm{E}-05$ & \\
\hline & $100-\mathrm{N}$ & 6 & 4 & $7.7 \mathrm{E}-06 \pm 3.8 \mathrm{E}-06$ & $1.0 \mathrm{E}-05 \pm 6.9 \mathrm{E}-06$ & N106 & 30 & 30 & $1.3 \mathrm{E}-05 \pm 8.8 \mathrm{E}-06$ & $2.2 \mathrm{E}-05 \pm 1.1 \mathrm{E}-05$ & \\
\hline & $118-\mathrm{K}-1 \mathrm{FR}$ & 4 & 3 & $1.1 \mathrm{E}-05 \pm 7.2 \mathrm{E}-06$ & $1.6 \mathrm{E}-05 \pm 1.2 \mathrm{E}-05$ & N535 & 24 & 20 & $1.8 \mathrm{E}-05 \pm 3.2 \mathrm{E}-05$ & $8.4 \mathrm{E}-05 \pm 4.3 \mathrm{E}-05$ & \\
\hline & 200-East & 42 & 35 & $1.0 \mathrm{E}-05 \pm 5.5 \mathrm{E}-06$ & $1.9 \mathrm{E}-05 \pm 1.0 \mathrm{E}-05$ & N498 & 204 & 193 & $1.2 \mathrm{E}-05 \pm 1.0 \mathrm{E}-05$ & $3.9 \mathrm{E}-05 \pm 1.8 \mathrm{E}-05$ & \\
\hline & 200-North & 8 & 8 & $2.2 \mathrm{E}-05 \pm 2.8 \mathrm{E}-05$ & $5.4 \mathrm{E}-05 \pm 2.4 \mathrm{E}-05$ & N564 & 4 & 4 & $1.5 \mathrm{E}-05 \pm 6.7 \mathrm{E}-06$ & $1.8 \mathrm{E}-05 \pm 1.2 \mathrm{E}-05$ & \\
\hline & 200-UW-1 & 10 & 10 & $1.8 \mathrm{E}-05 \pm 1.8 \mathrm{E}-05$ & $4.1 \mathrm{E}-05 \pm 1.9 \mathrm{E}-05$ & N551 & 42 & 38 & $1.8 \mathrm{E}-05 \pm 2.4 \mathrm{E}-05$ & $6.3 \mathrm{E}-05 \pm 2.8 \mathrm{E}-05$ & \\
\hline & 200-West & 50 & 45 & $1.2 \mathrm{E}-05 \pm 9.5 \mathrm{E}-06$ & $2.8 \mathrm{E}-05 \pm 1.4 \mathrm{E}-05$ & $\mathrm{~N} 550$ & 244 & 218 & $1.3 \mathrm{E}-05 \pm 1.3 \mathrm{E}-05$ & $6.0 \mathrm{E}-05 \pm 2.6 \mathrm{E}-05$ & \\
\hline & 300 Area D\&D & 4 & 4 & $2.5 \mathrm{E}-05 \pm 1.0 \mathrm{E}-05$ & $3.3 \mathrm{E}-05 \pm 1.9 \mathrm{E}-05$ & N557 & 16 & 16 & $3.1 \mathrm{E}-05 \pm 4.4 \mathrm{E}-05$ & $1.1 \mathrm{E}-04 \pm 5.3 \mathrm{E}-05$ & \\
\hline & 300-FF-2 FR & 8 & 6 & $2.1 \mathrm{E}-05 \pm 1.8 \mathrm{E}-05$ & $3.9 \mathrm{E}-05 \pm 3.2 \mathrm{E}-05$ & N540 & 38 & 37 & $3.4 \mathrm{E}-05 \pm 9.4 \mathrm{E}-05$ & $1.9 \mathrm{E}-04 \pm 9.7 \mathrm{E}-05$ & \\
\hline & BCCA & 6 & 5 & $1.0 \mathrm{E}-05 \pm 5.3 \mathrm{E}-06$ & $1.4 \mathrm{E}-05 \pm 1.1 \mathrm{E}-05$ & N572 & 28 & 26 & $1.7 \mathrm{E}-05 \pm 2.0 \mathrm{E}-05$ & $3.9 \mathrm{E}-05 \pm 2.7 \mathrm{E}-05$ & \\
\hline & ERDF & 10 & 10 & $2.4 \mathrm{E}-05 \pm 2.4 \mathrm{E}-05$ & $5.3 \mathrm{E}-05 \pm 2.4 \mathrm{E}-05$ & N517 & 49 & 48 & $2.2 \mathrm{E}-05 \pm 2.4 \mathrm{E}-05$ & $6.0 \mathrm{E}-05 \pm 2.6 \mathrm{E}-05$ & \\
\hline
\end{tabular}


Table C.1. (contd)

\begin{tabular}{|c|c|c|c|c|c|c|c|c|c|c|c|}
\hline \multirow[b]{2}{*}{$\underline{\text { Radionuclide }}$} & \multirow[b]{2}{*}{$\underline{\text { Site }}$} & \multicolumn{4}{|c|}{2009} & \multirow[b]{2}{*}{$\begin{array}{l}\text { Sampler } \\
\text { Number }\end{array}$} & \multicolumn{4}{|c|}{$2004-2008$} & \multirow[b]{2}{*}{$\begin{array}{c}\text { EPA } \\
\text { Table 2 }^{(\mathrm{e}, \mathrm{f})}\end{array}$} \\
\hline & & $\begin{array}{r}\mathrm{Nu} \\
\text { Samples } \\
\end{array}$ & $\begin{array}{l}\text { mber of } \\
\text { Detections }^{(b)}\end{array}$ & $\underline{\text { Average }}^{(\mathrm{c})}$ & $\underline{\text { Maximum }}^{(\mathrm{d})}$ & & $\begin{array}{r}\mathrm{Nu} \\
\text { Samples } \\
\end{array}$ & $\begin{array}{l}\text { mber of } \\
\text { Detections }^{(b)}\end{array}$ & $\underline{\text { Average }}^{(\mathfrak{c})}$ & $\underline{\text { Maximum }}^{(\mathrm{d})}$ & \\
\hline \multirow[t]{13}{*}{ Uranium-235 } & 100-D FR & 8 & 1 & $1.7 \mathrm{E}-06 \pm 3.2 \mathrm{E}-06$ & $5.1 \mathrm{E}-06 \pm 4.3 \mathrm{E}-06$ & N515 & 17 & 2 & $6.6 \mathrm{E}-06 \pm 3.1 \mathrm{E}-05$ & $6.7 \mathrm{E}-05 \pm 6.8 \mathrm{E}-05$ & 7.1E-03 \\
\hline & 100-H FR & 8 & 0 & $2.0 \mathrm{E}-06 \pm 3.1 \mathrm{E}-06$ & $5.6 \mathrm{E}-06 \pm 5.3 \mathrm{E}-06$ & N508 & 4 & 0 & $2.4 \mathrm{E}-06 \pm 1.2 \mathrm{E}-06$ & $2.9 \mathrm{E}-06 \pm 3.5 \mathrm{E}-06$ & \\
\hline & $100-\mathrm{K} \mathrm{KBC}$ & 16 & 0 & $1.7 \mathrm{E}-06 \pm 2.1 \mathrm{E}-06$ & $2.9 \mathrm{E}-06 \pm 3.1 \mathrm{E}-06$ & $\mathrm{~N} 402$ & 80 & 17 & $2.7 \mathrm{E}-06 \pm 3.8 \mathrm{E}-06$ & $1.2 \mathrm{E}-05 \pm 7.9 \mathrm{E}-06$ & \\
\hline & $100-\mathrm{N}$ & 6 & 0 & $1.5 \mathrm{E}-06 \pm 8.1 \mathrm{E}-07$ & $2.1 \mathrm{E}-06 \pm 2.6 \mathrm{E}-06$ & N102 & 30 & 11 & $2.9 \mathrm{E}-06 \pm 3.8 \mathrm{E}-06$ & $8.2 \mathrm{E}-06 \pm 6.9 \mathrm{E}-06$ & \\
\hline & 118-K-1 FR & 4 & 0 & $2.0 \mathrm{E}-06 \pm 1.2 \mathrm{E}-06$ & $2.8 \mathrm{E}-06 \pm 3.6 \mathrm{E}-06$ & $\mathrm{~N} 403$ & 24 & 4 & $4.5 \mathrm{E}-06 \pm 9.7 \mathrm{E}-06$ & $2.3 \mathrm{E}-05 \pm 2.3 \mathrm{E}-05$ & \\
\hline & 200-East & 42 & 4 & $1.9 \mathrm{E}-06 \pm 3.4 \mathrm{E}-06$ & $5.9 \mathrm{E}-06 \pm 5.6 \mathrm{E}-06$ & N559 & 204 & 49 & $2.7 \mathrm{E}-06 \pm 4.0 \mathrm{E}-06$ & $1.4 \mathrm{E}-05 \pm 1.7 \mathrm{E}-05$ & \\
\hline & 200-North & 8 & 2 & $5.9 \mathrm{E}-06 \pm 1.4 \mathrm{E}-05$ & $2.1 \mathrm{E}-05 \pm 1.5 \mathrm{E}-05$ & N563 & 4 & 2 & $6.4 \mathrm{E}-06 \pm 3.0 \mathrm{E}-06$ & $8.3 \mathrm{E}-06 \pm 7.9 \mathrm{E}-06$ & \\
\hline & 200-UW-1 & 10 & 3 & $3.4 \mathrm{E}-06 \pm 7.3 \mathrm{E}-06$ & $9.7 \mathrm{E}-06 \pm 7.1 \mathrm{E}-06$ & N550 & 42 & 13 & $3.4 \mathrm{E}-06 \pm 4.6 \mathrm{E}-06$ & $9.7 \mathrm{E}-06 \pm 7.3 \mathrm{E}-06$ & \\
\hline & 200-West & 50 & 7 & $2.0 \mathrm{E}-06 \pm 4.7 \mathrm{E}-06$ & $9.7 \mathrm{E}-06 \pm 7.1 \mathrm{E}-06$ & N550 & 244 & 59 & $3.0 \mathrm{E}-06 \pm 4.9 \mathrm{E}-06$ & $1.9 \mathrm{E}-05 \pm 1.2 \mathrm{E}-05$ & \\
\hline & 300 Area D\&D & 4 & 0 & $4.3 \mathrm{E}-06 \pm 3.5 \mathrm{E}-06$ & $6.5 \mathrm{E}-06 \pm 6.9 \mathrm{E}-06$ & N557 & 16 & 1 & $3.7 \mathrm{E}-06 \pm 5.7 \mathrm{E}-06$ & $8.8 \mathrm{E}-06 \pm 9.8 \mathrm{E}-06$ & \\
\hline & 300-FF-2 FR & 8 & 1 & $6.0 \mathrm{E}-06 \pm 8.9 \mathrm{E}-06$ & $1.7 \mathrm{E}-05 \pm 1.8 \mathrm{E}-05$ & N540 & 38 & 9 & $5.7 \mathrm{E}-06 \pm 2.0 \mathrm{E}-05$ & $4.7 \mathrm{E}-05 \pm 4.6 \mathrm{E}-05$ & \\
\hline & $\mathrm{BCCA}$ & 6 & 0 & $1.9 \mathrm{E}-06 \pm 3.5 \mathrm{E}-06$ & $4.1 \mathrm{E}-06 \pm 4.9 \mathrm{E}-06$ & N572 & 28 & 5 & $3.2 \mathrm{E}-06 \pm 4.8 \mathrm{E}-06$ & $1.0 \mathrm{E}-05 \pm 6.8 \mathrm{E}-06$ & \\
\hline & ERDF & 10 & 3 & $3.3 \mathrm{E}-06 \pm 5.3 \mathrm{E}-06$ & $9.7 \mathrm{E}-06 \pm 7.1 \mathrm{E}-06$ & N550 & 49 & 11 & $3.3 \mathrm{E}-06 \pm 4.6 \mathrm{E}-06$ & $1.0 \mathrm{E}-05 \pm 7.4 \mathrm{E}-06$ & \\
\hline \multirow[t]{13}{*}{ Plutonium-238 } & 100-D FR & 8 & 0 & $1.1 \mathrm{E}-06 \pm 1.9 \mathrm{E}-05$ & $1.8 \mathrm{E}-05 \pm 1.6 \mathrm{E}-05$ & N514 & 17 & 0 & $5.0 \mathrm{E}-06 \pm 5.2 \mathrm{E}-05$ & $1.1 \mathrm{E}-04 \pm 1.9 \mathrm{E}-04$ & $2.1 \mathrm{E}-03$ \\
\hline & 100-H FR & 8 & 0 & $-3.7 \mathrm{E}-06 \pm 8.6 \mathrm{E}-06$ & $5.0 \mathrm{E}-06 \pm 1.4 \mathrm{E}-05$ & N574 & 4 & 0 & $-2.6 \mathrm{E}-06 \pm 2.8 \mathrm{E}-06$ & $-8.4 \mathrm{E}-07 \pm 8.4 \mathrm{E}-06$ & \\
\hline & $100-\mathrm{K} \mathrm{KBC}$ & 16 & 5 & $3.3 \mathrm{E}-05 \pm 9.2 \mathrm{E}-05$ & $1.5 \mathrm{E}-04 \pm 7.1 \mathrm{E}-05$ & N401 & 80 & 5 & $5.5 \mathrm{E}-06 \pm 4.2 \mathrm{E}-05$ & $1.1 \mathrm{E}-04 \pm 5.6 \mathrm{E}-05$ & \\
\hline & $100-\mathrm{N}$ & 6 & 0 & $-2.6 \mathrm{E}-07 \pm 1.8 \mathrm{E}-05$ & $1.9 \mathrm{E}-05 \pm 1.8 \mathrm{E}-05$ & N103 & 30 & 0 & $2.0 \mathrm{E}-06 \pm 1.4 \mathrm{E}-05$ & $2.2 \mathrm{E}-05 \pm 1.5 \mathrm{E}-05$ & \\
\hline & $118-\mathrm{K}-1 \mathrm{FR}$ & 4 & 0 & $2.7 \mathrm{E}-05 \pm 4.6 \mathrm{E}-05$ & $5.4 \mathrm{E}-05 \pm 4.1 \mathrm{E}-05$ & N403 & 24 & 2 & $8.7 \mathrm{E}-06 \pm 5.1 \mathrm{E}-05$ & $1.1 \mathrm{E}-04 \pm 5.6 \mathrm{E}-05$ & \\
\hline & 200-East & 42 & 0 & $3.0 \mathrm{E}-06 \pm 1.4 \mathrm{E}-05$ & $3.6 \mathrm{E}-05 \pm 3.0 \mathrm{E}-05$ & N481 & 203 & 2 & $1.0 \mathrm{E}-06 \pm 2.9 \mathrm{E}-05$ & $1.9 \mathrm{E}-04 \pm 6.8 \mathrm{E}-05$ & \\
\hline & 200-North & 8 & 0 & $-2.2 \mathrm{E}-06 \pm 3.1 \mathrm{E}-05$ & $1.8 \mathrm{E}-05 \pm 5.9 \mathrm{E}-05$ & N568 & 4 & 1 & $1.2 \mathrm{E}-06 \pm 8.1 \mathrm{E}-06$ & $7.7 \mathrm{E}-06 \pm 6.8 \mathrm{E}-06$ & \\
\hline & 200-UW-1 & 10 & 1 & $2.4 \mathrm{E}-06 \pm 1.4 \mathrm{E}-05$ & $1.6 \mathrm{E}-05 \pm 8.3 \mathrm{E}-06$ & N963 & 42 & 1 & $2.4 \mathrm{E}-06 \pm 1.0 \mathrm{E}-05$ & $1.4 \mathrm{E}-05 \pm 1.4 \mathrm{E}-05$ & \\
\hline & 200-West & 50 & 1 & $1.4 \mathrm{E}-06 \pm 1.3 \mathrm{E}-05$ & $2.6 \mathrm{E}-05 \pm 3.3 \mathrm{E}-05$ & N165 & 244 & 3 & $2.1 \mathrm{E}-06 \pm 1.5 \mathrm{E}-05$ & $4.0 \mathrm{E}-05 \pm 2.5 \mathrm{E}-05$ & \\
\hline & 300 Area D\&D & 4 & 0 & $-1.3 \mathrm{E}-06 \pm 1.9 \mathrm{E}-05$ & $1.0 \mathrm{E}-05 \pm 2.1 \mathrm{E}-05$ & N557 & 16 & 2 & $3.6 \mathrm{E}-06 \pm 3.6 \mathrm{E}-05$ & $5.5 \mathrm{E}-05 \pm 4.4 \mathrm{E}-05$ & \\
\hline & 300-FF-2 FR & 8 & 0 & $-6.2 \mathrm{E}-06 \pm 4.6 \mathrm{E}-05$ & $4.6 \mathrm{E}-05 \pm 7.5 \mathrm{E}-05$ & N540 & 34 & 2 & $1.8 \mathrm{E}-06 \pm 8.1 \mathrm{E}-06$ & $1.0 \mathrm{E}-05 \pm 1.3 \mathrm{E}-05$ & \\
\hline & $\mathrm{BCCA}$ & 6 & 0 & $1.2 \mathrm{E}-06 \pm 5.8 \mathrm{E}-06$ & $7.0 \mathrm{E}-06 \pm 1.1 \mathrm{E}-05$ & N978 & 28 & 0 & $7.6 \mathrm{E}-07 \pm 2.8 \mathrm{E}-05$ & $5.6 \mathrm{E}-05 \pm 9.4 \mathrm{E}-05$ & \\
\hline & ERDF & 10 & 1 & $4.2 \mathrm{E}-07 \pm 1.6 \mathrm{E}-05$ & $1.6 \mathrm{E}-05 \pm 8.3 \mathrm{E}-06$ & N963 & 49 & 1 & $2.4 \mathrm{E}-06 \pm 1.1 \mathrm{E}-05$ & $1.6 \mathrm{E}-05 \pm 1.5 \mathrm{E}-05$ & \\
\hline
\end{tabular}


Table C.1. (contd)

\begin{tabular}{|c|c|c|c|c|c|c|c|c|c|c|c|}
\hline \multirow[b]{2}{*}{$\underline{\text { Radionuclide }}$} & \multirow[b]{2}{*}{$\underline{\text { Site }}$} & \multicolumn{4}{|c|}{2009} & \multirow[b]{2}{*}{$\begin{array}{l}\text { Sampler } \\
\text { Number }\end{array}$} & \multicolumn{4}{|c|}{ 2004-2008 } & \multirow[b]{2}{*}{$\begin{array}{c}\text { EPA } \\
\text { Table 2 }^{(\mathrm{e}, \mathrm{f})}\end{array}$} \\
\hline & & $\begin{array}{r}\quad \begin{array}{r}\text { Nur } \\
\text { Samples }\end{array} \\
\end{array}$ & $\begin{array}{l}\text { mber of } \\
\text { Detections }^{(b)}\end{array}$ & $\underline{\text { Average }}^{(\mathrm{c})}$ & $\underline{\text { Maximum }}^{(\mathrm{d})}$ & & $\begin{array}{r}\text { Nu } \\
\text { Samples } \\
\end{array}$ & $\begin{array}{l}\text { mber of } \\
\underline{\text { Detections }}^{(\mathbf{b})}\end{array}$ & $\underline{\text { Average }}^{(\mathfrak{c})}$ & $\underline{\text { Maximum }}^{(\mathrm{d})}$ & \\
\hline \multirow[t]{13}{*}{ Uranium-238 } & 100-D FR & 8 & 7 & $1.0 \mathrm{E}-05 \pm 6.1 \mathrm{E}-06$ & $1.4 \mathrm{E}-05 \pm 8.3 \mathrm{E}-06$ & N514 & 17 & 15 & $1.3 \mathrm{E}-05 \pm 3.3 \mathrm{E}-05$ & $7.8 \mathrm{E}-05 \pm 7.3 \mathrm{E}-05$ & \multirow[t]{13}{*}{$8.3 \mathrm{E}-03$} \\
\hline & 100-H FR & 8 & 7 & $8.6 \mathrm{E}-06 \pm 5.8 \mathrm{E}-06$ & $1.2 \mathrm{E}-05 \pm 7.6 \mathrm{E}-06$ & N509 & 4 & 4 & $1.9 \mathrm{E}-05 \pm 8.6 \mathrm{E}-06$ & $2.4 \mathrm{E}-05 \pm 1.5 \mathrm{E}-05$ & \\
\hline & $100-\mathrm{K} \mathrm{KBC}$ & 16 & 12 & $6.8 \mathrm{E}-06 \pm 5.2 \mathrm{E}-06$ & $1.2 \mathrm{E}-05 \pm 7.1 \mathrm{E}-06$ & N404 & 80 & 74 & $9.0 \mathrm{E}-06 \pm 7.8 \mathrm{E}-06$ & $2.7 \mathrm{E}-05 \pm 1.4 \mathrm{E}-05$ & \\
\hline & $100-\mathrm{N}$ & 6 & 5 & $8.3 \mathrm{E}-06 \pm 3.5 \mathrm{E}-06$ & $1.1 \mathrm{E}-05 \pm 6.9 \mathrm{E}-06$ & N103 & 30 & 25 & $9.0 \mathrm{E}-06 \pm 7.4 \mathrm{E}-06$ & $1.7 \mathrm{E}-05 \pm 9.2 \mathrm{E}-06$ & \\
\hline & 118-K-1 FR & 4 & 2 & $6.2 \mathrm{E}-06 \pm 6.4 \mathrm{E}-06$ & $1.1 \mathrm{E}-05 \pm 7.3 \mathrm{E}-06$ & $\mathrm{~N} 403$ & 24 & 20 & $1.4 \mathrm{E}-05 \pm 1.7 \mathrm{E}-05$ & $3.9 \mathrm{E}-05 \pm 2.6 \mathrm{E}-05$ & \\
\hline & 200-East & 42 & 36 & $8.4 \mathrm{E}-06 \pm 6.4 \mathrm{E}-06$ & $1.8 \mathrm{E}-05 \pm 1.1 \mathrm{E}-05$ & N976 & 204 & 181 & $9.2 \mathrm{E}-06 \pm 8.8 \mathrm{E}-06$ & $3.1 \mathrm{E}-05 \pm 1.5 \mathrm{E}-05$ & \\
\hline & 200-North & 8 & 3 & $9.9 \mathrm{E}-06 \pm 8.8 \mathrm{E}-06$ & $1.7 \mathrm{E}-05 \pm 1.8 \mathrm{E}-05$ & N564 & 4 & 3 & $1.3 \mathrm{E}-05 \pm 5.0 \mathrm{E}-06$ & $1.7 \mathrm{E}-05 \pm 1.0 \mathrm{E}-05$ & \\
\hline & 200-UW-1 & 10 & 10 & $1.6 \mathrm{E}-05 \pm 1.3 \mathrm{E}-05$ & $2.7 \mathrm{E}-05 \pm 1.4 \mathrm{E}-05$ & N551 & 42 & 39 & $1.5 \mathrm{E}-05 \pm 2.1 \mathrm{E}-05$ & $4.7 \mathrm{E}-05 \pm 2.1 \mathrm{E}-05$ & \\
\hline & 200-West & 50 & 43 & $1.0 \mathrm{E}-05 \pm 8.6 \mathrm{E}-06$ & $2.0 \mathrm{E}-05 \pm 1.1 \mathrm{E}-05$ & $\mathrm{~N} 200$ & 244 & 210 & $1.0 \mathrm{E}-05 \pm 1.1 \mathrm{E}-05$ & $4.7 \mathrm{E}-05 \pm 2.1 \mathrm{E}-05$ & \\
\hline & 300 Area D\&D & 4 & 4 & $1.7 \mathrm{E}-05 \pm 1.9 \mathrm{E}-05$ & $3.3 \mathrm{E}-05 \pm 1.8 \mathrm{E}-05$ & N557 & 16 & 11 & $1.6 \mathrm{E}-05 \pm 1.9 \mathrm{E}-05$ & $3.6 \mathrm{E}-05 \pm 2.0 \mathrm{E}-05$ & \\
\hline & 300-FF-2 FR & 8 & 5 & $1.6 \mathrm{E}-05 \pm 2.0 \mathrm{E}-05$ & $3.4 \mathrm{E}-05 \pm 2.9 \mathrm{E}-05$ & N538 & 38 & 36 & $2.5 \mathrm{E}-05 \pm 6.7 \mathrm{E}-05$ & $1.3 \mathrm{E}-04 \pm 7.9 \mathrm{E}-05$ & \\
\hline & BCCA & 6 & 4 & $7.8 \mathrm{E}-06 \pm 6.2 \mathrm{E}-06$ & $1.2 \mathrm{E}-05 \pm 9.0 \mathrm{E}-06$ & N572 & 28 & 24 & $1.1 \mathrm{E}-05 \pm 1.1 \mathrm{E}-05$ & $2.9 \mathrm{E}-05 \pm 1.4 \mathrm{E}-05$ & \\
\hline & ERDF & 10 & 10 & $2.0 \mathrm{E}-05 \pm 1.9 \mathrm{E}-05$ & $3.8 \mathrm{E}-05 \pm 1.8 \mathrm{E}-05$ & N517 & 49 & 47 & $1.9 \mathrm{E}-05 \pm 2.1 \mathrm{E}-05$ & $4.9 \mathrm{E}-05 \pm 2.2 \mathrm{E}-05$ & \\
\hline \multirow[t]{13}{*}{ Plutonium-239/240 } & 100-D FR & 8 & 1 & $3.1 \mathrm{E}-06 \pm 3.1 \mathrm{E}-06$ & $5.9 \mathrm{E}-06 \pm 5.2 \mathrm{E}-06$ & N515 & 17 & 1 & $5.4 \mathrm{E}-06 \pm 3.1 \mathrm{E}-05$ & $6.7 \mathrm{E}-05 \pm 6.3 \mathrm{E}-05$ & \multirow[t]{13}{*}{$2.0 \mathrm{E}-03$} \\
\hline & 100-H FR & 8 & 2 & $1.7 \mathrm{E}-06 \pm 3.7 \mathrm{E}-06$ & $5.8 \mathrm{E}-06 \pm 4.6 \mathrm{E}-06$ & N510 & 4 & 0 & $-2.2 \mathrm{E}-06 \pm 6.6 \mathrm{E}-06$ & $7.3 \mathrm{E}-07 \pm 3.3 \mathrm{E}-06$ & \\
\hline & $100-\mathrm{K} \mathrm{KBC}$ & 16 & 14 & $2.5 \mathrm{E}-04 \pm 7.1 \mathrm{E}-04$ & $1.2 \mathrm{E}-03 \pm 4.7 \mathrm{E}-04$ & $\mathrm{~N} 402$ & 80 & 28 & $3.6 \mathrm{E}-05 \pm 2.6 \mathrm{E}-04$ & $9.4 \mathrm{E}-04 \pm 3.6 \mathrm{E}-04$ & \\
\hline & $100-\mathrm{N}$ & 6 & 2 & $4.0 \mathrm{E}-06 \pm 4.7 \mathrm{E}-06$ & $8.8 \mathrm{E}-06 \pm 6.5 \mathrm{E}-06$ & N103 & 30 & 11 & $4.9 \mathrm{E}-06 \pm 6.9 \mathrm{E}-06$ & $1.8 \mathrm{E}-05 \pm 1.1 \mathrm{E}-05$ & \\
\hline & $118-K-1$ FR & 4 & 2 & $2.0 \mathrm{E}-04 \pm 4.2 \mathrm{E}-04$ & $4.9 \mathrm{E}-04 \pm 1.9 \mathrm{E}-04$ & $\mathrm{~N} 403$ & 24 & 8 & 4.9E-05 $\pm 3.7 \mathrm{E}-04$ & $9.4 \mathrm{E}-04 \pm 3.6 \mathrm{E}-04$ & \\
\hline & 200-East & 42 & 2 & $2.2 \mathrm{E}-06 \pm 1.0 \mathrm{E}-05$ & $3.1 \mathrm{E}-05 \pm 1.5 \mathrm{E}-05$ & N973 & 204 & 19 & $1.2 \mathrm{E}-05 \pm 2.5 \mathrm{E}-04$ & $1.8 \mathrm{E}-03 \pm 6.5 \mathrm{E}-04$ & \\
\hline & 200-North & 8 & 3 & $4.0 \mathrm{E}-06 \pm 8.3 \mathrm{E}-06$ & $1.2 \mathrm{E}-05 \pm 1.5 \mathrm{E}-05$ & N568 & 4 & 0 & $2.5 \mathrm{E}-06 \pm 2.5 \mathrm{E}-06$ & $3.9 \mathrm{E}-06 \pm 4.6 \mathrm{E}-06$ & \\
\hline & 200-UW-1 & 10 & 2 & $4.8 \mathrm{E}-06 \pm 1.0 \mathrm{E}-05$ & $1.8 \mathrm{E}-05 \pm 9.8 \mathrm{E}-06$ & N551 & 42 & 16 & $1.0 \mathrm{E}-05 \pm 4.6 \mathrm{E}-05$ & $1.3 \mathrm{E}-04 \pm 5.2 \mathrm{E}-05$ & \\
\hline & 200-West & 50 & 17 & $1.7 \mathrm{E}-05 \pm 1.0 \mathrm{E}-04$ & $2.8 \mathrm{E}-04 \pm 1.1 \mathrm{E}-04$ & N987 & 244 & 96 & $2.8 \mathrm{E}-05 \pm 1.9 \mathrm{E}-04$ & $7.1 \mathrm{E}-04 \pm 2.7 \mathrm{E}-04$ & \\
\hline & 300 Area D\&D & 4 & 1 & $6.3 \mathrm{E}-06 \pm 2.7 \mathrm{E}-05$ & $2.9 \mathrm{E}-05 \pm 1.7 \mathrm{E}-05$ & N557 & 16 & 2 & $6.3 \mathrm{E}-06 \pm 2.2 \mathrm{E}-05$ & $3.9 \mathrm{E}-05 \pm 2.8 \mathrm{E}-05$ & \\
\hline & 300-FF-2 FR & 8 & 0 & $3.3 \mathrm{E}-06 \pm 4.6 \mathrm{E}-06$ & $8.2 \mathrm{E}-06 \pm 2.3 \mathrm{E}-05$ & N538 & 34 & 1 & $2.0 \mathrm{E}-06 \pm 5.9 \mathrm{E}-06$ & $1.5 \mathrm{E}-05 \pm 9.0 \mathrm{E}-06$ & \\
\hline & BCCA & 6 & 1 & $9.6 \mathrm{E}-07 \pm 4.7 \mathrm{E}-06$ & $4.3 \mathrm{E}-06 \pm 3.6 \mathrm{E}-06$ & N573 & 28 & 1 & $1.7 \mathrm{E}-06 \pm 7.9 \mathrm{E}-06$ & $1.4 \mathrm{E}-05 \pm 1.6 \mathrm{E}-05$ & \\
\hline & ERDF & 10 & 3 & $5.7 \mathrm{E}-06 \pm 9.9 \mathrm{E}-06$ & $1.5 \mathrm{E}-05 \pm 8.7 \mathrm{E}-06$ & N517 & 49 & 19 & $7.7 \mathrm{E}-06 \pm 3.6 \mathrm{E}-05$ & $1.3 \mathrm{E}-04 \pm 5.2 \mathrm{E}-05$ & \\
\hline
\end{tabular}


Table C.1. (contd)

\begin{tabular}{|c|c|c|c|c|c|c|c|c|c|c|c|}
\hline \multirow[b]{2}{*}{ Radionuclide } & \multirow[b]{2}{*}{$\underline{\text { Site }}$} & \multicolumn{4}{|c|}{2009} & \multirow[b]{2}{*}{$\begin{array}{l}\text { Sampler } \\
\text { Number }\end{array}$} & \multicolumn{4}{|c|}{ 2004-2008 } & \multirow[b]{2}{*}{ 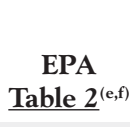 } \\
\hline & & $\begin{array}{r}\mathrm{Nu} \\
\text { Samples } \\
\end{array}$ & $\begin{array}{l}\text { mber of } \\
\text { Detections }^{(b)}\end{array}$ & $\underline{\text { Average }}^{(\mathrm{c})}$ & $\underline{\text { Maximum }}^{(\mathrm{d})}$ & & $\begin{array}{r}\mathrm{Nu} \\
\text { Samples } \\
\end{array}$ & $\begin{array}{l}\text { mber of } \\
\text { Detections } s^{(b)}\end{array}$ & $\underline{\text { Average }}^{(\mathrm{c})}$ & $\underline{\text { Maximum }}^{(\mathrm{d})}$ & \\
\hline \multirow[t]{7}{*}{ Americium-241 } & 100-D FR & 8 & 8 & $9.1 \mathrm{E}-06 \pm 6.0 \mathrm{E}-06$ & $1.4 \mathrm{E}-05 \pm 7.6 \mathrm{E}-06$ & N515 & 8 & 4 & $5.6 \mathrm{E}-06 \pm 2.1 \mathrm{E}-06$ & $6.9 \mathrm{E}-06 \pm 5.0 \mathrm{E}-06$ & $1.9 \mathrm{E}-03$ \\
\hline & 100-H FR & 4 & 3 & $8.5 \mathrm{E}-06 \pm 8.4 \mathrm{E}-06$ & $1.4 \mathrm{E}-05 \pm 7.7 \mathrm{E}-06$ & N509 & 0 & 0 & Not detected & Not detected & \\
\hline & $100-\mathrm{K} \mathrm{KBC}$ & 16 & 16 & $2.2 \mathrm{E}-04 \pm 6.2 \mathrm{E}-04$ & $1.1 \mathrm{E}-03 \pm 3.9 \mathrm{E}-04$ & $\mathrm{~N} 402$ & 80 & 48 & $5.3 \mathrm{E}-05 \pm 3.6 \mathrm{E}-04$ & $1.2 \mathrm{E}-03 \pm 4.4 \mathrm{E}-04$ & \\
\hline & $100-\mathrm{N}$ & 6 & 6 & $1.1 \mathrm{E}-05 \pm 6.2 \mathrm{E}-06$ & $1.7 \mathrm{E}-05 \pm 9.5 \mathrm{E}-06$ & N103 & 18 & 4 & $5.2 \mathrm{E}-06 \pm 9.3 \mathrm{E}-06$ & $1.4 \mathrm{E}-05 \pm 1.0 \mathrm{E}-05$ & \\
\hline & 118-K-1 FR & 2 & 2 & $3.6 \mathrm{E}-04 \pm 2.2 \mathrm{E}-04$ & $4.7 \mathrm{E}-04 \pm 1.7 \mathrm{E}-04$ & N403 & 10 & 8 & $1.8 \mathrm{E}-04 \pm 7.6 \mathrm{E}-04$ & $1.2 \mathrm{E}-03 \pm 4.4 \mathrm{E}-04$ & \\
\hline & 200-East & 4 & 1 & $5.4 \mathrm{E}-06 \pm 4.1 \mathrm{E}-06$ & $8.8 \mathrm{E}-06 \pm 6.1 \mathrm{E}-06$ & N481 & 20 & 7 & $5.9 \mathrm{E}-06 \pm 6.8 \mathrm{E}-06$ & $1.3 \mathrm{E}-05 \pm 1.6 \mathrm{E}-05$ & \\
\hline & 200-West & 2 & 2 & $3.6 \mathrm{E}-05 \pm 1.5 \mathrm{E}-05$ & $4.3 \mathrm{E}-05 \pm 1.9 \mathrm{E}-05$ & N165 & 2 & 1 & $1.7 \mathrm{E}-04 \pm 2.8 \mathrm{E}-04$ & $3.1 \mathrm{E}-04 \pm 1.1 \mathrm{E}-04$ & \\
\hline \multirow[t]{4}{*}{ lutonium-241 } & $100-\mathrm{K} \mathrm{KBC}$ & 16 & 6 & $1.9 \mathrm{E}-03 \pm 5.1 \mathrm{E}-03$ & $9.2 \mathrm{E}-03 \pm 2.9 \mathrm{E}-03$ & $\mathrm{~N} 402$ & 80 & 14 & $3.9 \mathrm{E}-04 \pm 2.3 \mathrm{E}-03$ & $5.8 \mathrm{E}-03 \pm 1.8 \mathrm{E}-03$ & $1.0 \mathrm{E}-01$ \\
\hline & $118-\mathrm{K}-1 \mathrm{FR}$ & 2 & 2 & $2.7 \mathrm{E}-03 \pm 1.6 \mathrm{E}-03$ & $3.5 \mathrm{E}-03 \pm 1.2 \mathrm{E}-03$ & N403 & 10 & 1 & $7.7 \mathrm{E}-04 \pm 3.5 \mathrm{E}-03$ & $5.8 \mathrm{E}-03 \pm 1.8 \mathrm{E}-03$ & \\
\hline & 200-East & 4 & 0 & $-1.1 \mathrm{E}-05 \pm 7.7 \mathrm{E}-04$ & $5.4 \mathrm{E}-04 \pm 8.4 \mathrm{E}-04$ & $\mathrm{~N} 480$ & 20 & 3 & $4.2 \mathrm{E}-05 \pm 1.6 \mathrm{E}-03$ & $1.7 \mathrm{E}-03 \pm 8.7 \mathrm{E}-04$ & \\
\hline & 200-West & 2 & 0 & $3.5 \mathrm{E}-04 \pm 7.4 \mathrm{E}-04$ & $7.2 \mathrm{E}-04 \pm 7.5 \mathrm{E}-04$ & N165 & 2 & 1 & $1.4 \mathrm{E}-03 \pm 5.9 \mathrm{E}-04$ & $1.7 \mathrm{E}-03 \pm 1.5 \mathrm{E}-03$ & \\
\hline
\end{tabular}

(a) $1 \mathrm{pCi}=0.037 \mathrm{~Bq}$.

(b) Number of samples with measurable concentrations of contaminant.

(c) Average \pm two standard deviations of all samples analyzed.

(d) Maximum \pm analytical uncertainty.

(e) DOE-derived concentration guides are shown for gross alpha and gross beta.

(f) EPA values are based on an effective dose equivalent of $10 \mathrm{mrem} / \mathrm{yr}$ (40 CFR 61, Appendix E, Table 2).

$\mathrm{BCCA}=\mathrm{BC}$ Controlled Area.

$D \& D=$ Decontamination and decommissioning.

DOE = U.S. Department of Energy.

EPA = U.S. Environmental Protection Agency.

ERDF = Environmental Restoration Disposal Facility.

$\mathrm{FR} \quad=$ Field Remediation Project.

$\mathrm{KBC}=\mathrm{K}$ Basins closure 
Table C.2. Selected U.S. Geological Survey Columbia River Water Quality Data for Vernita Bridge and Richland, Washington, 2009

\begin{tabular}{|c|c|c|c|c|c|c|c|c|}
\hline \multirow[b]{2}{*}{ Analysis } & \multirow[b]{2}{*}{$\underline{\text { Units }}$} & \multicolumn{3}{|c|}{ Vernita Bridge (upstream) } & \multicolumn{3}{|c|}{ Richland (downstream) } & \multirow{2}{*}{$\begin{array}{l}\text { Washington Ambient } \\
\text { Surface Water } \\
\text { Quality Standard }^{(a)}\end{array}$} \\
\hline & & $\begin{array}{c}\text { No. of } \\
\text { Samples }\end{array}$ & $\underline{\text { Maximum }}$ & $\underline{\text { Minimum }}$ & $\begin{array}{l}\text { No. of } \\
\text { Samples }\end{array}$ & $\underline{\text { Maximum }}$ & $\underline{\text { Minimum }}$ & \\
\hline Temperature & ${ }^{\circ} \mathrm{C}$ & 3 & 20 & 4.5 & 3 & 20 & 3.8 & 20 (maximum) \\
\hline Dissolved oxygen & $\mathrm{mg} / \mathrm{L}$ & 2 & 12.8 & 12.5 & 3 & 12.9 & 9.3 & 8 (minimum) \\
\hline Turbidity & NTU & 3 & $3.7^{(\mathrm{b})}$ & $<2.0$ & 3 & $3.1^{(\mathrm{b})}$ & $<2.0^{(\mathrm{b})}$ & $5+$ background \\
\hline $\mathrm{pH}$ & $\mathrm{pH}$ units & 3 & 8.4 & 7.7 & 3 & 8.4 & 7.6 & $6.5-8.5$ \\
\hline Sulfate, dissolved & $\mathrm{mg} / \mathrm{L}$ & 3 & 9.6 & 8.5 & 3 & 9.5 & 8.7 & .-(c) \\
\hline Dissolved solids, $180^{\circ} \mathrm{C}\left(356^{\circ} \mathrm{F}\right)$ & $\mathrm{mg} / \mathrm{L}$ & 3 & 95 & 74 & 3 & 94 & 76 & -. \\
\hline Specific conductance & $\mu \mathrm{S} / \mathrm{cm}$ & 3 & 143 & 132 & 3 & 140 & 133 & -. \\
\hline Total hardness, as $\mathrm{CaCO}_{3}$ & $\mathrm{mg} / \mathrm{L}$ & 3 & 69 & 62 & 3 & 71 & 62 & -. \\
\hline Alkalinity & $\mathrm{mg} / \mathrm{L}$ & 3 & 55.2 & 53 & 3 & 55 & 55 & -. \\
\hline Phosphorus, total & $\mathrm{mg} / \mathrm{L}$ & 3 & $<0.04$ & $<0.04$ & 3 & $<0.04$ & $<0.04$ & -. \\
\hline Chromium, dissolved & $\mu \mathrm{g} / \mathrm{L}$ & 3 & $0.1^{(\mathrm{b})}$ & $0.08^{(\mathrm{b})}$ & 3 & $0.11^{(\mathrm{b})}$ & $0.09^{(\mathrm{b})}$ & 10 \\
\hline Dissolved organic carbon & $\mathrm{mg} / \mathrm{L}$ & 3 & 1.5 & 1.2 & 3 & 1.7 & 1.4 & -. \\
\hline Iron, dissolved & $\mu g / L$ & 3 & 4 & $3^{(\mathrm{b})}$ & 3 & 6 & $2^{(b)}$ & -. \\
\hline Ammonia, dissolved (as nitrogen) & $\mathrm{mg} / \mathrm{L}$ & 3 & $<0.02$ & $<0.02$ & 3 & $<0.02$ & $<0.02$ & - \\
\hline Nitrite + nitrate, dissolved (as nitrogen) & $\mathrm{mg} / \mathrm{L}$ & 3 & 0.17 & 0.04 & 3 & 0.20 & 0.08 & -. \\
\hline Calcium, dissolved & $\mathrm{mg} / \mathrm{L}$ & 3 & 20 & 18 & 3 & 20 & 18 & .. \\
\hline Magnesium, dissolved & $\mathrm{mg} / \mathrm{L}$ & 3 & 4.8 & 4.2 & 3 & 4.9 & 4.2 & .- \\
\hline Potassium, dissolved & $\mathrm{mg} / \mathrm{L}$ & 3 & 0.87 & 0.74 & 3 & 0.88 & 0.68 & -. \\
\hline Sodium, dissolved & $\mathrm{mg} / \mathrm{L}$ & 3 & 2.6 & 2.0 & 3 & 2.7 & 2.1 & -. \\
\hline Chloride, dissolved & $\mathrm{mg} / \mathrm{L}$ & 3 & 1.4 & 0.92 & 3 & 1.5 & 0.99 & - \\
\hline Suspended sediment & $\mathrm{mg} / \mathrm{L}$ & 3 & 4 & 2 & 3 & 6 & 2 & -. \\
\hline
\end{tabular}

\footnotetext{
(a) From WAC 173-201A.

(b) Estimated value.

(c) Dashes indicate no standard available.

NTU = Nephelometric turbidity units.
} 
Table C.3. Radionuclide Concentrations in Columbia River Water Samples Collected at Priest Rapids Dam, Washington, 2009 Compared to Previous 5 Years

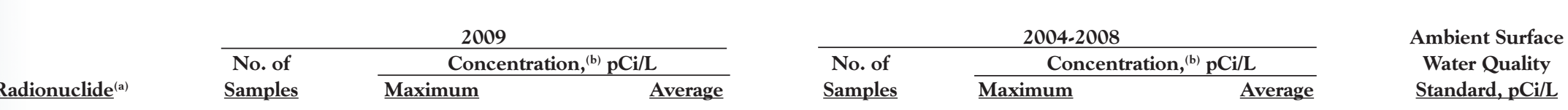

\section{Composite System}

\begin{tabular}{|c|c|c|c|}
\hline Tritium & 12 & $28 \pm 9.0$ & $20 \pm 12$ \\
\hline Alpha (gross) & 12 & $2.3 \pm 1.6$ & $0.66 \pm 2.2$ \\
\hline Beta (gross) & 12 & $4.1 \pm 1.8$ & $1.9 \pm 3.4$ \\
\hline Strontium-90 & 12 & $0.071 \pm 0.035$ & $0.033 \pm 0.041$ \\
\hline Technetium-99 & 12 & $0.40 \pm 0.55^{(f)}$ & $-0.080 \pm 0.39^{(f)}$ \\
\hline Uranium-234 & 12 & $0.26 \pm 0.052$ & $0.22 \pm 0.074$ \\
\hline Uranium-235 & 12 & $0.030 \pm 0.032^{(f)}$ & $6.9 \mathrm{E}-03 \pm 0.021$ \\
\hline Uranium-238 & 12 & $0.23 \pm 0.083$ & $0.17 \pm 0.051$ \\
\hline Uranium (total) & 12 & $0.43 \pm 0.078$ & $0.40 \pm 0.075$ \\
\hline
\end{tabular}

\section{Continuous System}

\begin{tabular}{|c|c|c|c|c|c|c|c|c|}
\hline \multirow[t]{2}{*}{ Cesium-137 } & $\mathrm{P}$ & 12 & $1.6 \mathrm{E}-03 \pm 2.6 \mathrm{E}-03^{(\mathrm{f})}$ & $-1.3 \mathrm{E}-04 \pm 1.9 \mathrm{E}-03^{(f)}$ & 60 & $8.9 \mathrm{E}-03 \pm 6.0 \mathrm{E}-03^{(\mathrm{f})}$ & $7.0 \mathrm{E}-04 \pm 2.8 \mathrm{E}-03$ & $200^{(c)}$ \\
\hline & D & 12 & $4.2 \mathrm{E}-03 \pm 3.7 \mathrm{E}-03^{(\mathrm{f})}$ & $7.1 \mathrm{E}-03 \pm 5.4 \mathrm{E}-03^{(f)}$ & 60 & $7.8 \mathrm{E}-03 \pm 7.0 \mathrm{E}-03^{(f)}$ & $7.9 \mathrm{E}-04 \pm 3.3 \mathrm{E}-03^{(f)}$ & \\
\hline \multirow[t]{2}{*}{ Plutonium-238 } & $\mathrm{P}$ & 4 & $7.4 \mathrm{E}-06 \pm 1.4 \mathrm{E}-05^{(f)}$ & $-1.4 \mathrm{E}-06 \pm 1.7 \mathrm{E}-05^{(\mathrm{f})}$ & 20 & $8.2 \mathrm{E}-05 \pm 4.2 \mathrm{E}-05$ & $6.5 \mathrm{E}-06 \pm 6.0 \mathrm{E}-05$ & $600^{(c)}$ \\
\hline & $\mathrm{D}$ & 4 & $2.0 \mathrm{E}-04 \pm 1.3 \mathrm{E}-04$ & $5.1 \mathrm{E}-05 \pm 2.0 \mathrm{E}-04$ & 20 & $2.3 \mathrm{E}-04 \pm 4.1 \mathrm{E}-04^{(\mathrm{f})}$ & $-2.0 \mathrm{E}-04 \pm 5.0 \mathrm{E}-04^{(\mathrm{f})}$ & \\
\hline \multirow[t]{2}{*}{ Plutonium-239/240 } & $\mathrm{P}$ & 4 & $2.1 \mathrm{E}-05 \pm 5.5 \mathrm{E}-05^{(f)}$ & $8.9 \mathrm{E}-06 \pm 2.1 \mathrm{E}-05^{(\mathrm{f})}$ & 20 & $1.2 \mathrm{E}-04 \pm 4.9 \mathrm{E}-05$ & $2.6 \mathrm{E}-05 \pm 6.3 \mathrm{E}-05$ & -. \\
\hline & D & 4 & $1.1 \mathrm{E}-04 \pm 1.1 \mathrm{E}-04$ & $4.1 \mathrm{E}-05 \pm 9.9 \mathrm{E}-05$ & 20 & $3.2 \mathrm{E}-04 \pm 4.4 \mathrm{E}-04^{(\mathrm{f})}$ & $4.1 \mathrm{E}-05 \pm 1.4 \mathrm{E}-04^{(\mathrm{f})}$ & \\
\hline
\end{tabular}

(a) Radionuclides measured using the continuous system show the particulate (P) and dissolved (D) fractions separately. Other radionuclides are based on unfiltered samples collected by the composite system (see Section 10.4).

(b) Maximum values are \pm total propagated analytical uncertainty ( 2 sigma). Averages are \pm 2 standard deviations of the mean. To convert to the International System of Units, multiply $\mathrm{pCi} / \mathrm{L}$ by 0.037 to obtain $\mathrm{Bq} / \mathrm{L}$.

(c) WAC 173-201A-250 and EPA-570/9-76-003.

(d) WAC 246-290

(e) 40 CFR 141.

(f) Less than the laboratory reported detection limit.

(g) Dashes indicate no concentration guides available. 
Table C.4. Radionuclide Concentrations in Columbia River Water Samples Collected at Richland, Washington, 2009 Compared to Previous 5 Years

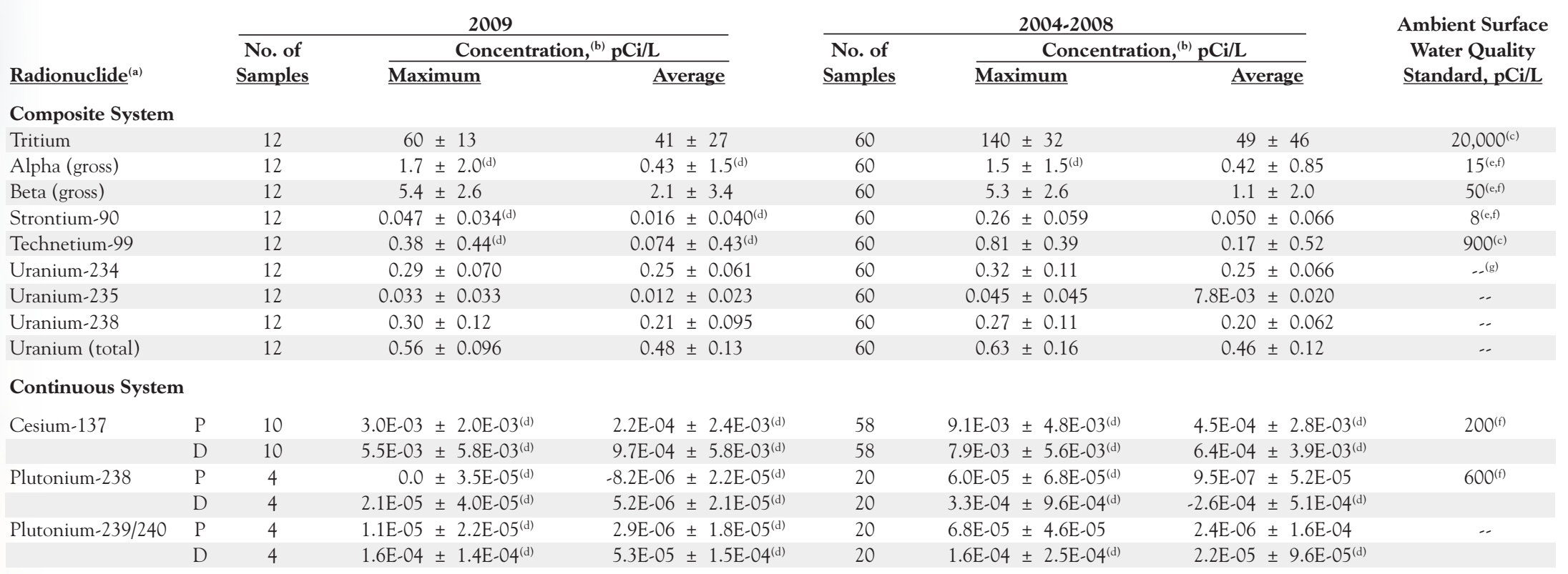

(a) Radionuclides measured using the continuous system show the particulate (P) and dissolved (D) fractions separately. Other radionuclides are based on unfiltered samples collected by the composite system (see Section 8.4).

(b) Maximum values are \pm total propagated analytical uncertainty (2 sigma). Averages are \pm 2 standard deviations of the mean. To convert to the International System of Units, multiply $\mathrm{pCi} / \mathrm{L}$ by 0.037 to obtain $\mathrm{Bq} / \mathrm{L}$.

(c) WAC 173-201A-250 and EPA-570/9-76-003.

(d) Less than the laboratory reported detection limit.

(e) WAC 246-290

(f) 40 CFR 141

(g) Dashes indicate no concentration guides available. 


\begin{tabular}{|c|c|c|c|}
\hline \multirow[b]{3}{*}{ Transect/Radionuclide } & \multirow{3}{*}{$\begin{array}{l}\text { No. of } \\
\text { Samples }\end{array}$} & $\begin{array}{l}\text { sured in Columbia } \\
\text { he Hanford Reach }\end{array}$ & $\begin{array}{l}\text { iver Water } \\
2009\end{array}$ \\
\hline & & \multicolumn{2}{|c|}{ Concentration, ${ }^{(a)} \mathrm{pCi} / \mathrm{L}$} \\
\hline & & Maximum & $\underline{\text { Minimum }}$ \\
\hline \multicolumn{4}{|c|}{ Vernita Bridge (HRM 0.3) } \\
\hline Tritium & 16 & $27 \pm 5.7$ & $12 \pm 6.3$ \\
\hline Strontium-90 & 16 & $0.093 \pm 0.038$ & $0.0062 \pm 0.032^{(\mathrm{b})}$ \\
\hline Uranium (total) & 16 & $0.57 \pm 0.10$ & $0.37 \pm 0.090$ \\
\hline \multicolumn{4}{|l|}{ 100-N Area (HRM 9.5) } \\
\hline Tritium & 7 & $42 \pm 13$ & $21 \pm 8.0$ \\
\hline Strontium-90 & 7 & $0.040 \pm 0.028^{(\mathrm{b})}$ & $0.010 \pm 0.022^{(\mathrm{b})}$ \\
\hline Uranium (total) & 7 & $0.61 \pm 0.089$ & $0.35 \pm 0.073$ \\
\hline \multicolumn{4}{|l|}{$\begin{array}{l}\text { Hanford town site } \\
\text { (HRM 28.7) }\end{array}$} \\
\hline Tritium & 6 & $60 \pm 7.0$ & $12 \pm 6.1$ \\
\hline Strontium-90 & 6 & $0.032 \pm 0.029^{(\mathrm{b})}$ & $-0.0022 \pm 0.032^{(b)}$ \\
\hline Uranium (total) & 6 & $0.45 \pm 0.090$ & $0.34 \pm 0.071$ \\
\hline \multicolumn{4}{|l|}{300 Area (HRM 43.1) } \\
\hline Tritium & 6 & $21 \pm 10$ & $12 \pm 8.9$ \\
\hline Strontium-90 & 6 & $0.053 \pm 0.037^{(\mathrm{b})}$ & $-0.0084 \pm 0.026^{(\mathrm{b})}$ \\
\hline Uranium (total) & 6 & $0.50 \pm 0.090$ & $0.36 \pm 0.071$ \\
\hline \multicolumn{4}{|l|}{ Richland (HRM 46.4) } \\
\hline Tritium & 26 & $58 \pm 9.2$ & $9.8 \pm 6.4$ \\
\hline Strontium-90 & 26 & $0.078 \pm 0.029$ & $-0.014 \pm 0.032^{(\mathrm{b})}$ \\
\hline Uranium (total) & 26 & $1.0 \pm 0.14$ & $0.31 \pm 0.072$ \\
\hline \multicolumn{4}{|c|}{$\begin{array}{l}\text { (a) Maximum and minimum values are } \pm \text { total propagated analytical uncertainty ( } 2 \text { sigma). To } \\
\text { convert to the International System of Units, multiply } \mathrm{pCi} / \mathrm{L} \text { by } 0.037 \text { to obtain } \mathrm{Bq} / \mathrm{L} \text {. } \\
\text { (b) Less than the laboratory-reported detection limit. } \\
\text { HRM = Hanford river marker. }\end{array}$} \\
\hline
\end{tabular}




\begin{tabular}{|c|c|c|c|}
\hline \multirow[b]{3}{*}{ Near-Shore/Radionuclide } & \multirow{3}{*}{$\begin{array}{l}\text { No. of } \\
\text { Samples }\end{array}$} & $\begin{array}{l}\text { sured in Columbic } \\
\text { in the Hanford Re }\end{array}$ & $\begin{array}{l}\text { iver Water } \\
\text { ch, } 2009\end{array}$ \\
\hline & & \multicolumn{2}{|c|}{ Concentration, ${ }^{(a)} \mathrm{pCi} / \mathrm{L}$} \\
\hline & & $\underline{\text { Maximum }}$ & $\underline{\text { Minimum }}$ \\
\hline \multicolumn{4}{|l|}{ Vernita Bridge (HRM 0.3) } \\
\hline Tritium & 4 & $27 \pm 5.7$ & $12 \pm 6.3$ \\
\hline Strontium-90 & 4 & $0.059 \pm 0.035$ & $0.017 \pm 0.034^{(\mathrm{b})}$ \\
\hline Uranium (total) & 4 & $0.47 \pm 0.086$ & $0.37 \pm 0.091$ \\
\hline \multicolumn{4}{|c|}{ 100-N Area (HRM 8.4 to 9.8 ) } \\
\hline Tritium & 6 & $42 \pm 13$ & $20 \pm 5.2$ \\
\hline Strontium-90 & 6 & $0.092 \pm 0.040$ & $0.019 \pm 0.035^{(\mathrm{b})}$ \\
\hline Uranium (total) & 6 & $0.49 \pm 0.091$ & $0.34 \pm 0.077$ \\
\hline \multicolumn{4}{|l|}{$\begin{array}{l}\text { Hanford town site } \\
\text { (HRM } 26 \text { to 30) }\end{array}$} \\
\hline Tritium & 5 & $34 \pm 6.9$ & $16 \pm 5.5$ \\
\hline Strontium-90 & 5 & $0.037 \pm 0.037^{(b)}$ & $-0.0022 \pm 0.032^{(b)}$ \\
\hline Uranium (total) & 5 & $0.43 \pm 0.094$ & $0.34 \pm 0.071$ \\
\hline \multicolumn{4}{|c|}{300 Area (HRM 41.5 to 43.1 ) } \\
\hline Tritium & 5 & $180 \pm 72$ & $15 \pm 11$ \\
\hline Strontium-90 & 5 & $0.043 \pm 0.033^{(b)}$ & $-0.015 \pm 0.031^{(\mathrm{b})}$ \\
\hline Uranium (total) & 5 & $0.46 \pm 0.090$ & $0.35 \pm 0.070$ \\
\hline \multicolumn{4}{|c|}{ Richland (HRM 43.5 to 46.4 ) } \\
\hline Tritium & 22 & $53 \pm 10$ & $15 \pm 7.5$ \\
\hline Strontium-90 & 22 & $0.067 \pm 0.029$ & $-0.014 \pm 0.032^{(b)}$ \\
\hline Uranium (total) & 22 & $0.73 \pm 0.11$ & $0.31 \pm 0.072$ \\
\hline \multicolumn{4}{|c|}{$\begin{array}{l}\text { (a) Maximum and minimum values are } \pm \text { total propagated analytical uncertainty ( } 2 \text { sigma). To } \\
\text { convert to the International System of Units, multiply pCi/L by } 0.037 \text { to obtain } \mathrm{Bq} / \mathrm{L} \text {. } \\
\text { (b) Less than the laboratory-reported detection limit. } \\
\text { HRM = Hanford river marker. }\end{array}$} \\
\hline
\end{tabular}




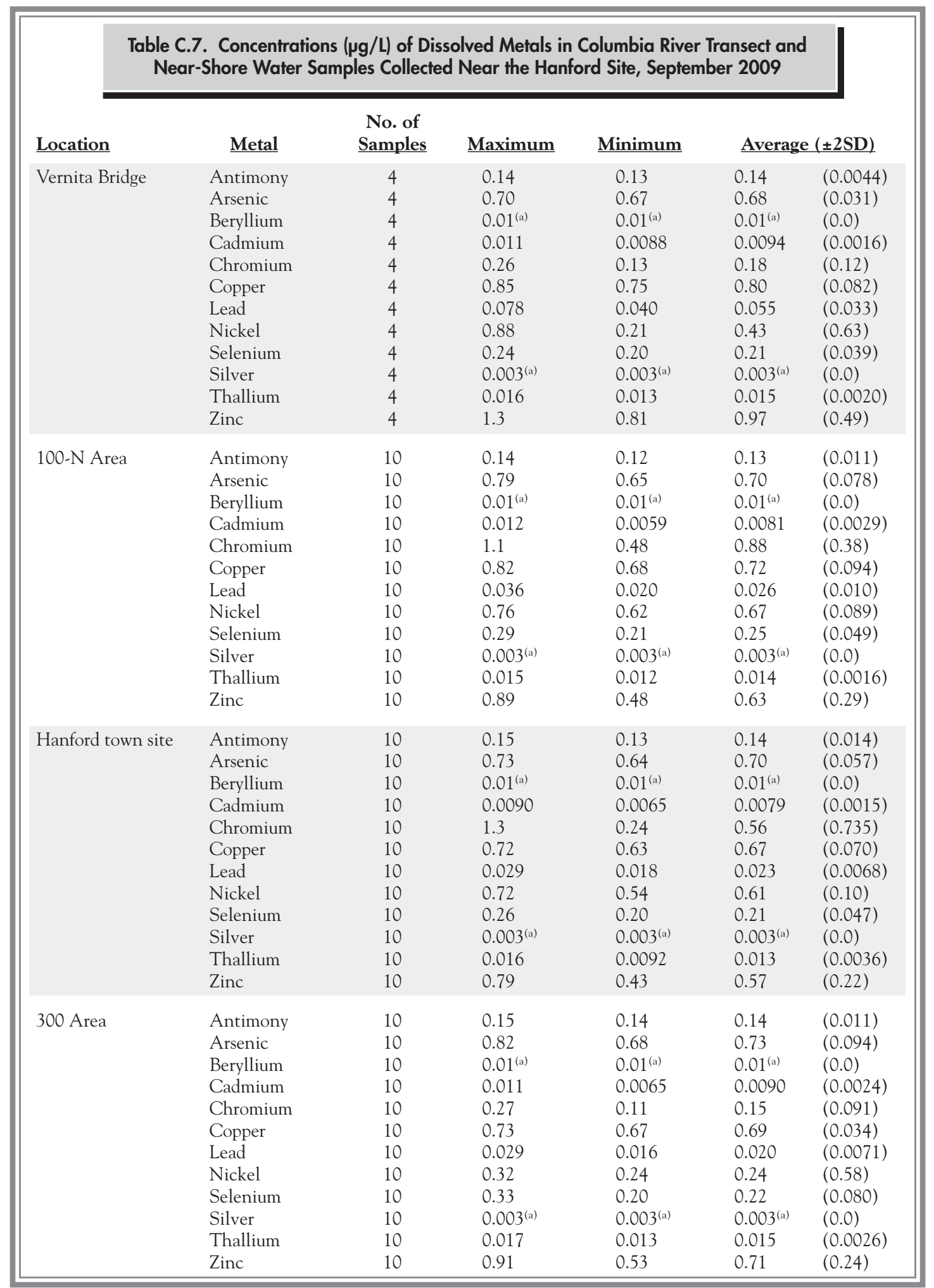




\begin{tabular}{|c|c|c|c|c|c|c|}
\hline \multirow{3}{*}{$\frac{\text { Location }}{\text { Richland }}$} & \multirow{2}{*}{$\frac{\text { Metal }}{\text { Antimony }}$} & \multicolumn{2}{|c|}{ Table C.7. (contd) } & \multirow{2}{*}{$\frac{\text { Minimum }}{0.13}$} & \multirow{2}{*}{\multicolumn{2}{|c|}{ Average $( \pm 2 \mathrm{SD})$}} \\
\hline & & $\begin{array}{c}\begin{array}{c}\text { No. of } \\
\text { Samples }\end{array} \\
\frac{10}{}\end{array}$ & $\frac{\text { Maximum }}{0.15}$ & & & \\
\hline & $\begin{array}{l}\text { Antimony } \\
\text { Arsenic } \\
\text { Beryllium } \\
\text { Cadmium } \\
\text { Chromium } \\
\text { Copper } \\
\text { Lead } \\
\text { Nickel } \\
\text { Selenium } \\
\text { Silver } \\
\text { Thallium } \\
\text { Zinc }\end{array}$ & $\begin{array}{l}10 \\
10 \\
10 \\
10 \\
10 \\
10 \\
10 \\
10 \\
10 \\
10 \\
10 \\
10\end{array}$ & $\begin{array}{l}0.15 \\
0.88 \\
0.01^{\text {(a) }} \\
0.011 \\
0.19 \\
0.81 \\
0.050 \\
0.35 \\
0.26 \\
0.003^{\text {(a) }} \\
0.016 \\
1.4\end{array}$ & $\begin{array}{l}0.13 \\
0.68 \\
0.01^{\text {(a) }} \\
0.0073 \\
0.10 \\
0.67 \\
0.019 \\
0.22 \\
0.20 \\
0.003^{\text {(a) }} \\
0.013 \\
0.63\end{array}$ & $\begin{array}{l}0.14 \\
0.73 \\
0.01^{(a)} \\
0.0093 \\
0.15 \\
0.72 \\
0.027 \\
0.29 \\
0.22 \\
0.003^{(a)} \\
0.014 \\
0.89\end{array}$ & $\begin{array}{l}(0.0075) \\
(0.12) \\
(0.0) \\
(0.0024) \\
(0.067) \\
(0.078) \\
(0.020) \\
(0.084) \\
(0.040) \\
(0.0) \\
(0.0020) \\
(0.50)\end{array}$ \\
\hline
\end{tabular}


Table C.8. Radionuclide and Total Organic Carbon Concentrations in Sediment from the Columbia River Near the Hanford Site, 2009 Compared to Previous 5 Years

\begin{tabular}{|c|c|c|c|c|c|c|c|}
\hline \multirow{3}{*}{$\begin{array}{l}\text { Location and Total } \\
\text { Organic Carbon } \\
\text { Concentrations } \\
(2009 \text { TOC Value })\end{array}$} & \multirow[b]{3}{*}{$\underline{\text { Radionuclide }}$} & \multicolumn{3}{|c|}{2009} & \multicolumn{3}{|c|}{$2004-2008$} \\
\hline & & \multirow{2}{*}{$\begin{array}{c}\text { No. of } \\
\text { Samples }\end{array}$} & \multicolumn{2}{|c|}{ Concentration, pCi/g ${ }^{(a)}$} & \multirow{2}{*}{$\begin{array}{c}\begin{array}{c}\text { No. of } \\
\text { Samples }\end{array} \\
\end{array}$} & \multicolumn{2}{|c|}{ Concentration, pCi/g(a) } \\
\hline & & & Average $^{(\mathbf{b})}$ & $\underline{\text { Maximum }}^{(\mathrm{c})}$ & & Average $^{(\mathbf{b})}$ & $\underline{\text { Maximum }}^{(\mathrm{c})}$ \\
\hline $\begin{array}{l}\text { Priest Rapids Dam } \\
(18,500-24,300 \mathrm{mg} / \mathrm{kg})\end{array}$ & $\begin{array}{l}\text { Cobalt-60 } \\
\text { Strontium-90 } \\
\text { Cesium-137 } \\
\text { Europium-152 } \\
\text { Europium-155 } \\
\text { Uranium-234 } \\
\text { Uranium-235 } \\
\text { Uranium-238 } \\
\text { Plutonium-239/240 }\end{array}$ & $\begin{array}{l}2 \\
2 \\
2 \\
2 \\
2 \\
2 \\
2 \\
2 \\
2\end{array}$ & $\begin{aligned} 2.3 \mathrm{E}-03 & \pm 0.019^{\text {(d) }} \\
0.036 & \pm 0.020^{\text {(d) }} \\
0.27 & \pm 0.065 \\
-0.061 & \pm 0.052^{\text {(d) }} \\
0.071 & \pm 0.037^{(\mathrm{d})} \\
1.2 & \pm 0.099 \\
0.066 & \pm 0.019 \\
1.1 & \pm 0.14 \\
0.011 & \pm 5.3 \mathrm{E}-03\end{aligned}$ & $\begin{aligned} 9.1 \mathrm{E}-03 & \pm 0.023^{(\mathrm{d})} \\
0.043 & \pm 0.028^{(\mathrm{d})} \\
0.29 & \pm 0.050 \\
-0.043 & \pm 0.047^{(\mathrm{d})} \\
0.084 & \pm 0.048^{(\mathrm{d})} \\
1.3 & \pm 0.20 \\
0.073 & \pm 0.027 \\
1.1 & \pm 0.17 \\
0.012 & \pm 3.6 \mathrm{E}-03\end{aligned}$ & $\begin{array}{l}10 \\
10 \\
10 \\
10 \\
10 \\
10 \\
10 \\
10 \\
10\end{array}$ & $\begin{aligned} 3.3 \mathrm{E}-03 & \pm 0.011^{(\mathrm{d})} \\
4.7 \mathrm{E}-03 & \pm 0.028^{(\mathrm{d})} \\
0.29 & \pm 0.077 \\
-0.014 & \pm 0.054^{(\mathrm{d})} \\
0.063 & \pm 0.036^{(\mathrm{d})} \\
0.85 & \pm 0.33 \\
0.041 & \pm 0.054 \\
0.73 & \pm 0.35 \\
8.6 \mathrm{E}-03 & \pm 2.7 \mathrm{E}-03\end{aligned}$ & $\begin{aligned} 0.011 & \pm 0.016^{(\mathrm{d})} \\
0.031 & \pm 0.029^{(\mathrm{d})} \\
0.37 & \pm 0.059 \\
0.014 & \pm 0.029^{(\mathrm{d})} \\
0.093 & \pm 0.045^{(\mathrm{d})} \\
1.1 & \pm 0.14 \\
0.096 & \pm 0.026 \\
1.1 & \pm 0.14 \\
0.010 & \pm 4.3 \mathrm{E}-03\end{aligned}$ \\
\hline $\begin{array}{l}\text { White Bluffs Slough } \\
(6,310 \mathrm{mg} / \mathrm{kg})\end{array}$ & $\begin{array}{l}\text { Cobalt-60 } \\
\text { Strontium-90 } \\
\text { Cesium-137 } \\
\text { Europium-152 } \\
\text { Europium-155 } \\
\text { Uranium-234 } \\
\text { Uranium-235 } \\
\text { Uranium-238 } \\
\text { Plutonium-239/240 }\end{array}$ & $\begin{array}{l}1 \\
1 \\
1 \\
1 \\
1 \\
1 \\
1 \\
1 \\
1 \\
1\end{array}$ & & $\begin{aligned} 6.7 \mathrm{E}-03 & \pm 0.014^{(\mathrm{d})} \\
3.0 \mathrm{E}-03 & \pm 0.023^{(\mathrm{d})} \\
0.44 & \pm 0.044 \\
0.068 & \pm 0.039^{(\mathrm{d})} \\
0.024 & \pm 0.032^{(\mathrm{d})} \\
0.71 & \pm 0.11 \\
0.039 & \pm 0.021 \\
0.71 & \pm 0.12 \\
3.2 \mathrm{E}-03 & \pm 6.4 \mathrm{E}-04\end{aligned}$ & $\begin{array}{l}5 \\
5 \\
5 \\
5 \\
5 \\
5 \\
5 \\
5 \\
5\end{array}$ & $\begin{aligned} 0.019 & \pm 0.023 \\
-2.1 \mathrm{E}-03 & \pm 0.032^{(\mathrm{d})} \\
1.2 & \pm 1.9 \\
0.25 & \pm 0.31 \\
0.061 & \pm 0.037^{(\mathrm{d})} \\
0.48 & \pm 0.20 \\
0.026 & \pm 0.041 \\
0.44 & \pm 0.21 \\
6.5 \mathrm{E}-03 & \pm 4.1 \mathrm{E}-03\end{aligned}$ & $\begin{aligned} 0.038 & \pm 0.028 \\
0.016 & \pm 0.015^{\text {(d) }} \\
2.8 & \pm 0.33 \\
0.51 & \pm 0.099 \\
0.086 & \pm 0.032^{\text {(d) }} \\
0.64 & \pm 0.088 \\
0.061 & \pm 0.020 \\
0.61 & \pm 0.084 \\
0.010 & \pm 1.9 \mathrm{E}-03\end{aligned}$ \\
\hline $\begin{array}{l}\text { 100-F Slough } \\
(5,790 \mathrm{mg} / \mathrm{kg})\end{array}$ & $\begin{array}{l}\text { Cobalt-60 } \\
\text { Strontium-90 } \\
\text { Cesium-137 } \\
\text { Europium-152 } \\
\text { Europium-155 } \\
\text { Uranium-234 } \\
\text { Uranium-235 } \\
\text { Uranium-238 } \\
\text { Plutonium-239/240 }\end{array}$ & $\begin{array}{l}1 \\
1 \\
1 \\
1 \\
1 \\
1 \\
1 \\
1 \\
1\end{array}$ & & $\begin{aligned} 0.014 & \pm 0.011^{(\mathrm{d})} \\
0.027 & \pm 0.025^{(\mathrm{d})} \\
0.24 & \pm 0.024 \\
0.064 & \pm 0.033^{(\mathrm{d})} \\
-2.9 \mathrm{E}-04 & \pm 0.030^{(\mathrm{d})} \\
0.41 & \pm 0.083 \\
0.026 & \pm 0.018 \\
0.39 & \pm 0.079 \\
1.6 \mathrm{E}-03 & \pm 4.6 \mathrm{E}-04^{(\mathrm{d})}\end{aligned}$ & $\begin{array}{l}5 \\
5 \\
5 \\
5 \\
5 \\
5 \\
5 \\
5 \\
4\end{array}$ & $\begin{aligned} 8.1 \mathrm{E}-03 & \pm 7.2 \mathrm{E}-03^{(\mathrm{d})} \\
-1.2 \mathrm{E}-03 & \pm 0.023^{(\mathrm{d})} \\
0.25 & \pm 0.068 \\
0.027 & \pm 0.027^{(\mathrm{d})} \\
0.038 & \pm 0.039^{(\mathrm{d})} \\
0.31 & \pm 0.43 \\
0.018 & \pm 0.049 \\
0.31 & \pm 0.38 \\
1.0 \mathrm{E}-03 & \pm 1.1 \mathrm{E}-03\end{aligned}$ & $\begin{aligned} 0.012 & \pm 0.010^{(\mathrm{d})} \\
9.3 \mathrm{E}-03 & \pm 0.029^{(\mathrm{d})} \\
0.30 & \pm 0.043 \\
0.047 & \pm 0.028^{(\mathrm{d})} \\
0.064 & \pm 0.028^{(\mathrm{d})} \\
0.60 & \pm 0.11 \\
0.061 & \pm 020 \\
0.60 & \pm 0.13 \\
1.6 \mathrm{E}-03 & \pm 6.2 \mathrm{E}-04\end{aligned}$ \\
\hline $\begin{array}{l}\text { Hanford Slough } \\
(4,080 \mathrm{mg} / \mathrm{kg})\end{array}$ & $\begin{array}{l}\text { Cobalt-60 } \\
\text { Strontium-90 } \\
\text { Cesium-137 } \\
\text { Europium-152 } \\
\text { Europium-155 } \\
\text { Uranium-234 } \\
\text { Uranium-235 } \\
\text { Uranium-238 } \\
\text { Plutonium-239/240 }\end{array}$ & $\begin{array}{l}1 \\
1 \\
1 \\
1 \\
1 \\
1 \\
1 \\
1 \\
1 \\
1\end{array}$ & & $\begin{aligned} 1.7 \mathrm{E}-03 & \pm 0.019^{(\mathrm{d})} \\
8.5 \mathrm{E}-03 & \pm 0.020^{(\mathrm{d})} \\
0.046 & \pm 0.025^{(\mathrm{d})} \\
0.011 & \pm 0.055^{(\mathrm{d})} \\
0.023 & \pm 0.041^{(\mathrm{d})} \\
0.73 & \pm 0.12 \\
0.041 & \pm 0.021 \\
0.78 & \pm 0.13 \\
9.4 \mathrm{E}-04 & \pm 2.8 \mathrm{E}-04\end{aligned}$ & $\begin{array}{l}5 \\
5 \\
5 \\
5 \\
5 \\
5 \\
5 \\
5 \\
5\end{array}$ & $\begin{aligned} 8.8 \mathrm{E}-03 & \pm 0.036^{(\mathrm{d})} \\
-6.0 \mathrm{E}-03 & \pm 0.021^{(\mathrm{d})} \\
0.081 & \pm 0.22 \\
8.2 \mathrm{E}-03 & \pm 0.072^{(\mathrm{d})} \\
0.062 & \pm 0.038^{(\mathrm{d})} \\
0.42 & \pm 0.46 \\
0.015 & \pm 0.020 \\
0.41 & \pm 0.43 \\
8.1 \mathrm{E}-04 & \pm 2.1 \mathrm{E}-03\end{aligned}$ & $\begin{aligned} 0.040 & \pm 0.026^{(\mathrm{d})} \\
3.4 \mathrm{E}-03 & \pm 0.015^{(\mathrm{d})} \\
0.28 & \pm 0.041 \\
0.069 & \pm 0.028^{(\mathrm{d})} \\
0.091 & \pm 0.044^{(\mathrm{d})} \\
0.74 & \pm 0.11 \\
0.031 & \pm 0.017 \\
0.73 & \pm 0.11 \\
2.6 \mathrm{E}-03 & \pm 5.8 \mathrm{E}-04\end{aligned}$ \\
\hline
\end{tabular}


Table C.8. (contd)

\begin{tabular}{|c|c|c|c|c|c|c|c|}
\hline \multirow{3}{*}{$\begin{array}{l}\text { Location and Total } \\
\text { Organic Carbon } \\
\text { Concentrations } \\
\text { (2009 TOC Value) }\end{array}$} & \multirow[b]{3}{*}{$\underline{\text { Radionuclide }}$} & \multicolumn{3}{|c|}{2009} & \multicolumn{3}{|c|}{$2004-2008$} \\
\hline & & \multirow{2}{*}{$\begin{array}{l}\text { No. of } \\
\text { Samples } \\
\end{array}$} & \multicolumn{2}{|c|}{ Concentration, $\mathrm{pCi} / \mathrm{g}^{(\mathrm{a})}$} & \multirow{2}{*}{$\begin{array}{c}\text { No. of } \\
\text { Samples } \\
\end{array}$} & \multicolumn{2}{|c|}{ Concentration, $\mathrm{pCi} / \mathrm{g}^{(\mathrm{a})}$} \\
\hline & & & Average $^{(\mathrm{b})}$ & $\underline{\text { Maximum }}^{(\mathrm{c})}$ & & Average $^{(\mathbf{b})}$ & $\underline{\text { Maximum }}^{(\mathrm{c})}$ \\
\hline \multirow{9}{*}{$\begin{array}{l}\text { Richland } \\
(3,270 \mathrm{mg} / \mathrm{kg})\end{array}$} & Cobalt -60 & 1 & & $-0.020 \pm 0.018^{(\mathrm{d})}$ & 5 & $3.6 \mathrm{E}-03 \pm 7.7 \mathrm{E}-03^{(\mathrm{d})}$ & $9.2 \mathrm{E}-03 \pm 0.011^{(\mathrm{d})}$ \\
\hline & Strontium-90 & 1 & & $-9.4 \mathrm{E}-03 \pm 0.025^{(\mathrm{d})}$ & 5 & $-1.2 \mathrm{E}-03 \pm 0.023^{(\mathrm{d})}$ & $0.015 \pm 0.020^{(\mathrm{d})}$ \\
\hline & Cesium-137 & 1 & & $0.12 \pm 0.025$ & 5 & $0.16 \pm 0.063$ & $0.19 \pm 0.033$ \\
\hline & Europium-152 & 1 & & $-5.3 \mathrm{E}-03 \pm 0.054^{(\mathrm{d})}$ & 5 & $0.043 \pm 0.022^{(\mathrm{d})}$ & $0.057 \pm 0.033^{(\mathrm{d})}$ \\
\hline & Europium-155 & 1 & & $0.080 \pm 0.055^{(\mathrm{d})}$ & 5 & $0.068 \pm 0.050^{(\mathrm{d})}$ & $0.10 \pm 0.053^{(\mathrm{d})}$ \\
\hline & Uranium-234 & 1 & & $0.79 \pm 0.12$ & 5 & $0.29 \pm 0.20$ & $0.41 \pm 0.073$ \\
\hline & Uranium-235 & 1 & & $0.024 \pm 0.016$ & 5 & $0.011 \pm 0.019$ & $0.026 \pm 0.016$ \\
\hline & Uranium-238 & 1 & & $0.80 \pm 0.13$ & 5 & $0.30 \pm 0.25$ & $0.47 \pm 0.080$ \\
\hline & Plutonium-239/240 & 1 & & $7.8 \mathrm{E}-04 \pm 3.6 \mathrm{E}-04^{(\mathrm{d})}$ & 4 & $1.3 \mathrm{E}-03 \pm 7.4 \mathrm{E}-04$ & $1.6 \mathrm{E}-03 \pm 4.6 \mathrm{E}-04$ \\
\hline \multirow{9}{*}{$\begin{array}{l}\text { McNary Dam } \\
(7,790-9,420 \mathrm{mg} / \mathrm{kg})\end{array}$} & Cobalt-60 & 2 & $7.4 \mathrm{E}-03 \pm 2.5 \mathrm{E}-03^{(\mathrm{d})}$ & $8.2 \mathrm{E}-03 \pm 0.023^{(\mathrm{d})}$ & 10 & $0.012 \pm 0.023^{(\mathrm{d})}$ & $0.029 \pm 0.011^{(\mathrm{d})}$ \\
\hline & Strontium-90 & 2 & $-0.011 \pm 0.022^{(\mathrm{d})}$ & $-3.6 \mathrm{E}-03 \pm 0.027^{(\mathrm{d})}$ & 10 & $6.9 \mathrm{E}-03 \pm 0.035$ & $0.034 \pm 0.047^{(\mathrm{d})}$ \\
\hline & Cesium-137 & 2 & $0.25 \pm 0.055$ & $0.26 \pm 0.038$ & 10 & $0.27 \pm 0.095$ & $0.33 \pm 0.054$ \\
\hline & Europium-152 & 2 & $0.045 \pm 0.055^{(\mathrm{d})}$ & $0.064 \pm 0.047^{(\mathrm{d})}$ & 10 & $0.080 \pm 0.15^{(\mathrm{d})}$ & $0.17 \pm 0.068^{(\mathrm{d})}$ \\
\hline & Europium-155 & 2 & $0.033 \pm 0.029^{(\mathrm{d})}$ & $0.043 \pm 0.048^{(\mathrm{d})}$ & 10 & $0.059 \pm 0.045^{(\mathrm{d})}$ & $0.082 \pm 0.055^{(\mathrm{d})}$ \\
\hline & Uranium-234 & 2 & $1.5 \pm 0.17$ & $1.6 \pm 0.23$ & 10 & $1.1 \pm 0.35$ & $1.4 \pm 0.24$ \\
\hline & Uranium-235 & 2 & $0.069 \pm 0.011$ & $0.073 \pm 0.027$ & 10 & $0.049 \pm 0.059$ & $0.12 \pm 0.030$ \\
\hline & Uranium-238 & 2 & $1.2 \pm 0.028$ & $1.2 \pm 0.18$ & 10 & $0.85 \pm 0.32$ & $1.1 \pm 0.14$ \\
\hline & Plutonium-239/240 & 2 & $6.7 \mathrm{E}-03 \pm 1.8 \mathrm{E}-03$ & $7.4 \mathrm{E}-03 \pm 9.6 \mathrm{E}-04$ & 10 & $8.2 \mathrm{E}-03 \pm 3.5 \mathrm{E}-03$ & $0.012 \pm 3.3 \mathrm{E}-03$ \\
\hline
\end{tabular}

(a) To convert to the International System of Units, multiply pCi/g by 0.037 to obtain $\mathrm{Bq} / \mathrm{g}$. All values are dry weight.

(b) Average values are not provided when only one sample was analyzed.

(c) Values are \pm total propagated analytical uncertainty (2 sigma).

(d) Below detection limit.

TOC $=$ Total organic carbon 
Table C.9. Range of Metal Concentrations ( $\mathrm{mg} / \mathrm{kg}$ dry wt.) in Sediment Samples Collected from the Columbia River Near the Hanford Site, 2009

\begin{tabular}{|c|c|c|c|c|}
\hline Metal & $\begin{array}{l}(\mathrm{n}=2) \\
\text { Priest Rapids } \\
\quad \underline{\text { Dam }}\end{array}$ & $\begin{array}{l}(n=4) \\
\text { Hanford } \\
\underline{\text { Reach }}^{(a)}\end{array}$ & $\begin{array}{l}(\mathrm{n}=2) \\
\text { McNary } \\
\underline{\text { Dam }}\end{array}$ & $\begin{array}{l}\quad(n=7) \\
\text { Shoreline } \\
\text { Springs }^{(b)}\end{array}$ \\
\hline Antimony & $0.93-0.95$ & $0.39-1.5$ & $0.78-0.84$ & $0.42-1.2$ \\
\hline Arsenic & $9.2-10$ & $3.7-18$ & $8.7-9.3$ & $3.8-15$ \\
\hline Beryllium & $1.3-1.4$ & $1.2-1.7$ & $1.5-1.5$ & $1.2-1.5$ \\
\hline Cadmium & $4.1-6.3$ & $0.29-0.80$ & $1.4-1.8$ & $0.39-1.5$ \\
\hline Chromium & $65-69$ & $40-65$ & $61-63$ & $40-130$ \\
\hline Copper & $52-60$ & $19-40$ & $40-41$ & $18-39$ \\
\hline Lead & $45-49$ & $16-120$ & $27-29$ & $20-94$ \\
\hline Mercury & $0.14-0.14$ & $0.012-0.034$ & $0.089-0.091$ & $0.012-0.040$ \\
\hline Nickel & $45-48$ & $14-22$ & $29-30$ & $16-29$ \\
\hline Selenium & $0.47-0.53$ & $0.30-0.30$ & $0.30-0.52$ & $0.30-0.30$ \\
\hline Silver & $0.60-0.64$ & $0.46-0.67$ & $0.62-0.65$ & $0.38-0.79$ \\
\hline Thallium & $0.76-1.0$ & $0.43-0.58$ & $0.62-0.64$ & $0.43-0.61$ \\
\hline Zinc & $400-480$ & $90-400$ & $230-250$ & $100-390$ \\
\hline \multicolumn{5}{|c|}{$\begin{array}{l}\text { (a) White Bluffs Slough, 100-F Slough, Hanford Slough, and Richland. } \\
\text { (b) } 100-\text { B Area }(n=1), 100-F \text { Area }(n=1), 100-\text { H Area }(n=1) \text {, Hanford town site }(n=2) \text {, and } \\
300 \text { Area }(n=2) \text {. } \\
n=\text { Number of samples. }\end{array}$} \\
\hline
\end{tabular}


Table C.10. Radionuclide Concentrations Measured in Columbia River Water Samples Collected from Shoreline Springs Along the Hanford Site, 2009 Compared to Previous 5 Years

\begin{tabular}{|c|c|c|c|c|c|c|c|}
\hline \multirow[b]{3}{*}{ Location/Radionuclide } & \multicolumn{3}{|c|}{2009} & \multicolumn{3}{|c|}{$2004-2008$} & \multirow{3}{*}{$\begin{array}{c}\text { Washington State } \\
\text { Ambient Surface } \\
\text { Water Quality } \\
\text { Standard, }{ }^{(b)} \text { pCi/L }\end{array}$} \\
\hline & \multirow{2}{*}{$\begin{array}{c}\begin{array}{c}\text { No. of } \\
\text { Samples }\end{array} \\
\end{array}$} & \multicolumn{2}{|c|}{ Concentration, ${ }^{(\mathrm{a})} \mathrm{pCi} / \mathrm{L}$} & \multirow{2}{*}{$\begin{array}{c}\text { No. of } \\
\text { Samples }\end{array}$} & \multicolumn{2}{|c|}{ Concentration, ${ }^{(a)} \mathrm{pCi} / \mathrm{L}$} & \\
\hline & & $\underline{\text { Maximum }}$ & Average & & $\underline{\text { Maximum }}$ & Average & \\
\hline \multicolumn{8}{|l|}{ 100-B Area } \\
\hline Alpha (gross) & 2 & $6.6 \pm 1.4$ & $5.0 \pm 4.4$ & 8 & $14 \pm 5.6$ & $3.1 \pm 9.3$ & 15 \\
\hline Beta (gross) & 2 & $13 \pm 1.3$ & $8.6 \pm 12$ & 8 & $23 \pm 5.1$ & $10 \pm 12$ & 50 \\
\hline Strontium-90 & 2 & $1.8 \pm 0.30$ & $0.90 \pm 2.6$ & 8 & $3.1 \pm 0.47$ & $1.3 \pm 2.7$ & 8 \\
\hline Technetium-99 & 2 & $4.7 \pm 0.81$ & $2.5 \pm 6.1$ & 8 & $12 \pm 0.95$ & $4.9 \pm 7.6$ & $900^{(\mathrm{d})}$ \\
\hline Tritium & 2 & $1,800 \pm 400$ & $1,600 \pm 190$ & 8 & $5,200 \pm 470$ & $3,200 \pm 2,600$ & 20,000 \\
\hline
\end{tabular}

\section{0-K Area}

Alpha (gross)

Beta (gross)

Strontium-90

Tritium

$1.1 \pm 1.7^{(\mathrm{c})}$

$7.1 \pm 2.8$

$0.027 \pm 0.032^{(c)}$

$680 \pm 260$

$13 \pm 4.8$

$19 \pm 5.2$

$2.7 \pm 0.41$

$3.1 \pm 9.9$

$\begin{array}{ll}8.4 & 1.3 \pm 2.3 \\ .41 & 1,300 \pm 3,900\end{array}$

15

\section{0-N Area}

Alpha (gross)

Beta (gross)

Strontium-90

Tritium

$\begin{aligned} 0.68 & \pm 1.1^{(c)} \\ 4.0 & \pm 2.4 \\ 0.048 & \pm 0.032^{(c)} \\ 4,000 & \pm 820\end{aligned}$

$2.3 \pm$

$2.3 \pm$
$5.9 \pm$

,300 $\pm 3,900$

\section{0-D Area}

\section{Alpha (gross)}

Beta (gross)

Strontium-90

Tritium

\begin{tabular}{|c|c|c|}
\hline 2 & $1.8 \pm 2.0^{(\mathrm{c})}$ & $1.0 \pm 2.2^{(c)}$ \\
\hline 2 & $6.1 \pm 2.8$ & $3.9 \pm 6.2$ \\
\hline 2 & $1.3 \pm 0.24$ & $0.83 \pm 1.3$ \\
\hline 2 & $6,200 \pm 1,300$ & $3,600 \pm 7,500$ \\
\hline
\end{tabular}

$0.035 \pm$

$10,000 \pm$

$\begin{array}{rlr}1.3 & \pm 1.6 & 15 \\ 3.8 & \pm 3.7 & 50 \\ 0.016 & \pm 0.025^{\text {(c) }} & 8 \\ 7,700 & \pm 3,900 & 20,000\end{array}$

\section{0-H Area}

\section{Alpha (gross)}

Beta (gross)

Strontium-90

Technetium-99

Tritium

Uranium (total)

$7.5 \pm 3.1$

$9.3 \pm 4.1$

$0.40 \pm 0.074$

$2.1 \pm 4.9$

$3.9 \pm 5.5$

$\begin{array}{ll}480 \pm 140 & 130 \pm 350\end{array}$

50

9
9

20,000

\begin{tabular}{|c|c|}
\hline & $3.8 \pm 2.6$ \\
\hline 2 & $7.3 \pm 3.3$ \\
\hline 2 & $3.0 \pm 0.48$ \\
\hline & $1.7 \pm 0.86$ \\
\hline & $1,600 \pm 380$ \\
\hline
\end{tabular}

$\begin{aligned} 3.2 & \pm 1.7 \\ 5.4 & \pm 5.5 \\ 1.5 & \pm 4.3 \\ 0.92 & \pm 2.3 \\ 850 & \pm 2,200 \\ 0.44 & \pm 0.52\end{aligned}$

$3.8 \pm 1.3$

$22 \pm 3.0$

$1.7 \pm 2.5$

$6.8 \pm 1.1$

$9.4 \pm 15$

$0.52 \pm 0.42$

$2.6+6.4$

$4,100 \pm 250$

$0.26 \pm 0.31^{(\mathrm{c})}$

$5.0 \pm 0.56$

$1,400 \pm 2,600$

15
50
8
$900^{(d)}$
20,000




\section{Table C.10. (contd)}

\begin{tabular}{|c|c|c|c|c|c|c|c|}
\hline \multirow[b]{3}{*}{ Location/Radionuclide } & \multicolumn{3}{|c|}{2009} & \multicolumn{3}{|c|}{$2004-2008$} & \multirow{3}{*}{$\begin{array}{c}\text { Washington State } \\
\text { Ambient Surface } \\
\text { Water Quality } \\
\text { Standard, }{ }^{(\mathrm{b})} \mathrm{pCi} / \mathrm{L} \\
\end{array}$} \\
\hline & \multirow{2}{*}{$\begin{array}{c}\text { No. of } \\
\text { Samples }\end{array}$} & \multicolumn{2}{|c|}{ Concentration, ${ }^{(\mathrm{a})} \mathrm{pCi} / \mathrm{L}$} & \multirow{2}{*}{$\begin{array}{c}\text { No. of } \\
\text { Samples }\end{array}$} & \multicolumn{2}{|c|}{ Concentration, ${ }^{(\mathrm{a})} \mathrm{pCi} / \mathrm{L}$} & \\
\hline & & Maximum & Average & & Maximum & Average & \\
\hline \multicolumn{8}{|l|}{ 100-F Area } \\
\hline Alpha (gross) & 1 & $5.0 \pm 3.2$ & & 5 & $28 \pm 8.8$ & $12 \pm 20$ & 15 \\
\hline Beta (gross) & 1 & $6.4 \pm 3.1$ & & 5 & $43 \pm 9.6$ & $15 \pm 32$ & 50 \\
\hline Strontium-90 & 1 & $-0.023 \pm 0.022^{(c)}$ & & 5 & $0.12 \pm 0.050$ & $0.033 \pm 0.10$ & 8 \\
\hline Tritium & 1 & $880 \pm 240$ & & 5 & $1,400 \pm 190$ & $1,100 \pm 720$ & 20,000 \\
\hline Uranium (total) & 1 & $3.5 \pm 0.38$ & & 5 & $20 \pm 2.1$ & $7.6 \pm 14$ & .-(e) \\
\hline \multicolumn{8}{|l|}{ Hanford town site } \\
\hline Alpha (gross) & 3 & $3.6 \pm 2.6$ & $2.4 \pm 2.3$ & 15 & $14 \pm 5.6$ & $2.7 \pm 6.6$ & 15 \\
\hline Beta (gross) & 3 & $22 \pm 4.6$ & $15 \pm 12$ & 15 & $47 \pm 12$ & $18 \pm 21$ & 50 \\
\hline lodine- $129^{(f)}$ & 3 & $0.056 \pm 0.19^{(\mathrm{c})}$ & $-0.054 \pm 0.28^{(\mathrm{c})}$ & 6 & $0.65 \pm 0.27^{(\mathrm{c})}$ & $0.21 \pm 0.45^{(c)}$ & 1 \\
\hline Technetium-99 & 3 & $35 \pm 4.0$ & $25 \pm 19$ & 15 & $78 \pm 4.5$ & $30 \pm 43$ & $900^{(\mathrm{d})}$ \\
\hline Tritium & 3 & $20,000 \pm 4,000$ & $16,000 \pm 7,000$ & 15 & $67,000 \pm 4,800$ & $26,000 \pm 36,000$ & 20,000 \\
\hline Uranium (total) & 3 & $1.8 \pm 0.22$ & $1.2 \pm 1.8$ & 14 & $5.6 \pm 0.69$ & $2.0 \pm 2.4$ & - (e) \\
\hline \multicolumn{8}{|l|}{300 Area } \\
\hline Beta (gross) & 4 & $20 \pm 4.3$ & $18 \pm 5.3$ & 18 & $40 \pm 3.6$ & $21 \pm 19$ & 50 \\
\hline Iodine-129(f) & 2 & $0.26 \pm 0.39^{\text {(c) }}$ & $0.081 \pm 0.49^{(\mathrm{c})}$ & 4 & $0.045 \pm 0.10^{(\mathrm{c})}$ & $-0.039 \pm 0.15^{(\mathrm{c})}$ & 1 \\
\hline Strontium-90 & 4 & $0.13 \pm 0.042$ & $0.059 \pm 0.16$ & 18 & $0.26 \pm 0.061$ & $0.10 \pm 0.14$ & 8 \\
\hline Tritium & 4 & $9,000 \pm 1,800$ & $6,200 \pm 4,100$ & 19 & $12,000 \pm 920$ & $7,000 \pm 6,200$ & 20,000 \\
\hline Uranium (total) & 4 & $70 \pm 6.8$ & $27 \pm 63$ & 19 & $120 \pm 13$ & $54 \pm 76$ & .- (e) \\
\hline
\end{tabular}

(a) Maximum values are \pm total propagated analytical uncertainty. Averages are \pm 2 standard deviations of the mean. To convert to the International System of Units, multiply $\mathrm{pCi} / \mathrm{L}$ by 0.037 to obtain $\mathrm{Bq} / \mathrm{L}$.

(b) WAC 246-290, 40 CFR 141, and Appendix D, Table D.4

(c) Value below the laboratory-reported detection limit.

(d) WAC 173-201A-250 and EPA-570/9-76-003.

(e) Dashes indicate no concentration guides available.

(f) $2001-2004$ results; no results were available for 2005 and 2006. Note: For 2007, iodine-129 was analyzed by the gamma spectroscopy method, which has higher detection limits than the previous method. 
Table C.11. Radionuclide Concentrations in Columbia River Shoreline Sediment for 2009 Compared to Previous 5 Years

\begin{tabular}{|c|c|c|c|c|c|c|c|}
\hline \multirow[b]{3}{*}{ Location } & \multirow[b]{3}{*}{$\underline{\text { Radionuclide }}$} & \multicolumn{3}{|c|}{2009} & \multicolumn{3}{|c|}{$2004-2008$} \\
\hline & & \multirow{2}{*}{$\begin{array}{c}\text { No. of } \\
\text { Samples }\end{array}$} & \multicolumn{2}{|c|}{ Concentration, $\mathrm{pCi} / \mathrm{g}^{(\mathrm{a})}$} & \multirow{2}{*}{$\begin{array}{c}\text { No. of } \\
\text { Samples }\end{array}$} & \multicolumn{2}{|c|}{ Concentration, $\mathrm{pCi} / \mathrm{g}^{(\mathrm{a})}$} \\
\hline & & & Average $^{(\mathbf{b})}$ & $\underline{\text { Maximum }}^{(\mathrm{c})}$ & & Average $^{(\mathbf{b})}$ & $\underline{\text { Maximum }}^{(\mathrm{c})}$ \\
\hline 100-B Spring & $\begin{array}{l}\text { Cobalt-60 } \\
\text { Strontium-90 } \\
\text { Cesium-137 } \\
\text { Europium-152 } \\
\text { Europium-155 } \\
\text { Uranium-234 } \\
\text { Uranium-235 } \\
\text { Uranium-238 }\end{array}$ & $\begin{array}{l}1 \\
1 \\
1 \\
1 \\
1 \\
1 \\
1 \\
1\end{array}$ & & $\begin{aligned}-1.2 \mathrm{E}-03 & \pm 0.018^{(\mathrm{d})} \\
6.5 \mathrm{E}-03 & \pm 0.026^{(\mathrm{d})} \\
0.077 & \pm 0.032 \\
0.011 & \pm 0.046^{(\mathrm{d})} \\
0.088 & \pm 0.063^{(\mathrm{d})} \\
0.51 & \pm 0.088 \\
0.035 & \pm 0.016 \\
0.48 & \pm 0.085\end{aligned}$ & $\begin{array}{l}4 \\
4 \\
4 \\
4 \\
4 \\
4 \\
4 \\
4\end{array}$ & $\begin{aligned} 2.9 \mathrm{E}-03 & \pm 0.016^{(\mathrm{d})} \\
-4.0 \mathrm{E}-03 & \pm 0.031^{(\mathrm{d})} \\
0.045 & \pm 0.023 \\
-0.013 & \pm 0.037^{(\mathrm{d})} \\
0.068 & \pm 0.025^{(\mathrm{d})} \\
0.26 & \pm 0.28 \\
0.012 & \pm 0.029 \\
0.25 & \pm 0.33\end{aligned}$ & $\begin{aligned} 0.010 & \pm 8.9 \mathrm{E}-03^{(\mathrm{d})} \\
8.0 \mathrm{E}-03 & \pm 0.020^{(\mathrm{d})} \\
0.055 & \pm 0.012 \\
9.7 \mathrm{E}-03 & \pm 0.045^{(\mathrm{d})} \\
0.082 & \pm 0.033^{(\mathrm{d})} \\
0.47 & \pm 0.093 \\
0.034 & \pm 0.022 \\
0.49 & \pm 0.094\end{aligned}$ \\
\hline 100-K Spring & $\begin{array}{l}\text { Cobalt-60 } \\
\text { Strontium-90 } \\
\text { Cesium-137 } \\
\text { Europium-152 } \\
\text { Europium-155 } \\
\text { Uranium-234 } \\
\text { Uranium-235 } \\
\text { Uranium-238 }\end{array}$ & $\begin{array}{l}0 \\
0 \\
0 \\
0 \\
0 \\
0 \\
0 \\
0\end{array}$ & & & $\begin{array}{l}2 \\
2 \\
2 \\
2 \\
2 \\
2 \\
2 \\
2\end{array}$ & $\begin{aligned} 5.4 \mathrm{E}-03 & \pm 0.020^{(\mathrm{d})} \\
-7.4 \mathrm{E}-04 & \pm 9.7 \mathrm{E}-03^{(\mathrm{d})} \\
0.094 & \pm 1.1 \mathrm{E}-03 \\
3.4 \mathrm{E}-03 & \pm 0.061^{(\mathrm{d})} \\
0.051 & \pm 0.016^{(\mathrm{d})} \\
0.78 & \pm 1.5 \\
0.064 & \pm 0.16 \\
0.76 & \pm 1.6\end{aligned}$ & $\begin{aligned} 0.013 & \pm 8.5 \mathrm{E}-03^{(\mathrm{d})} \\
2.7 \mathrm{E}-03 & \pm 4.5 \mathrm{E}-03^{(\mathrm{d})} \\
0.094 & \pm 0.016 \\
0.025 & \pm 0.028^{(\mathrm{d})} \\
0.057 & \pm 0.035^{(\mathrm{d})} \\
1.3 & \pm 0.17 \\
0.12 & \pm 0.031 \\
1.3 & \pm 0.17\end{aligned}$ \\
\hline 100-H Spring & $\begin{array}{l}\text { Cobalt-60 } \\
\text { Strontium-90 } \\
\text { Cesium-137 } \\
\text { Europium-152 } \\
\text { Europium-155 } \\
\text { Uranium-234 } \\
\text { Uranium-235 } \\
\text { Uranium-238 }\end{array}$ & $\begin{array}{l}1 \\
1 \\
1 \\
1 \\
1 \\
1 \\
1 \\
1\end{array}$ & & $\begin{aligned} 0.019 & \pm 0.021^{(\mathrm{d})} \\
0.021 & \pm 0.024^{(\mathrm{d})} \\
0.17 & \pm 0.033 \\
0.021 & \pm 0.056^{(\mathrm{d})} \\
0.051 & \pm 0.047^{(\mathrm{d})} \\
0.64 & \pm 0.13 \\
0.022 & \pm 0.018 \\
0.52 & \pm 0.11\end{aligned}$ & $\begin{array}{l}5 \\
5 \\
5 \\
5 \\
5 \\
5 \\
5 \\
5\end{array}$ & $\begin{aligned} 5.1 \mathrm{E}-03 & \pm 0.011^{(\mathrm{d})} \\
0.031 & \pm 0.087 \\
0.15 & \pm 0.082 \\
0.048 & \pm 0.030^{(\mathrm{d})} \\
0.050 & \pm 0.035^{(\mathrm{d})} \\
0.47 & \pm 0.63 \\
0.021 & \pm 0.051 \\
0.43 & \pm 0.58\end{aligned}$ & $\begin{aligned} 0.011 & \pm 0.012^{(\mathrm{d})} \\
0.10 & \pm 0.017 \\
0.20 & \pm 0.029 \\
0.066 & \pm 0.037^{(\mathrm{d})} \\
0.074 & \pm 0.034^{(\mathrm{d})} \\
1.0 & \pm 0.14 \\
0.067 & \pm 0.025 \\
0.93 & \pm 0.13\end{aligned}$ \\
\hline 100-F Spring & $\begin{array}{l}\text { Cobalt-60 } \\
\text { Strontium-90 } \\
\text { Cesium-137 } \\
\text { Europium-152 } \\
\text { Europium-155 } \\
\text { Uranium-234 } \\
\text { Uranium-235 } \\
\text { Uranium-238 }\end{array}$ & $\begin{array}{l}1 \\
1 \\
1 \\
1 \\
1 \\
1 \\
1 \\
1\end{array}$ & & $\begin{aligned} 6.8 \mathrm{E}-03 & \pm 0.020^{(\mathrm{d})} \\
0.020 & \pm 0.026^{(\mathrm{d})} \\
0.12 & \pm 0.033 \\
9.4 \mathrm{E}-03 & \pm 0.067^{(\mathrm{d})} \\
0.048 & \pm 0.062^{(\mathrm{d})} \\
0.98 & \pm 0.18 \\
0.033 & \pm 0.022 \\
0.97 & \pm 0.17\end{aligned}$ & $\begin{array}{l}5 \\
5 \\
4 \\
5 \\
5 \\
5 \\
5 \\
5\end{array}$ & $\begin{aligned} 3.5 \mathrm{E}-03 & \pm 8.5 \mathrm{E}-03^{(\mathrm{d})} \\
-7.5 \mathrm{E}-04 & \pm 0.024^{(\mathrm{d})} \\
0.10 & \pm 0.015 \\
0.020 & \pm 0.029^{(\mathrm{d})} \\
0.046 & \pm 0.029^{(\mathrm{d})} \\
0.58 & \pm 0.53 \\
0.030 & \pm 0.057 \\
0.52 & \pm 0.57\end{aligned}$ & $\begin{aligned} 8.5 \mathrm{E}-03 & \pm 0.014^{(\mathrm{d})} \\
0.014 & \pm 0.027^{(\mathrm{d})} \\
0.11 & \pm 0.021 \\
0.038 & \pm 0.031^{(\mathrm{d})} \\
0.070 & \pm 0.034^{(\mathrm{d})} \\
0.98 & \pm 0.13 \\
0.081 & \pm 0.024 \\
1.0 & \pm 0.13\end{aligned}$ \\
\hline
\end{tabular}


Table C.11. (contd)

\begin{tabular}{|ll}
\multicolumn{1}{|l}{ Location } & Radionuclide \\
\hline Hanford Spring & Cobalt-60 \\
& Strontium-90 \\
& Cesium-137 \\
& Europium-152 \\
& Europium-155 \\
& Uranium-234 \\
& Uranium-235 \\
& Uranium-238
\end{tabular}

\begin{tabular}{|c|c|c|}
\hline \multirow{3}{*}{$\begin{array}{l}\text { No. of } \\
\text { Samples }\end{array}$} & \multicolumn{2}{|l|}{2009} \\
\hline & \multicolumn{2}{|c|}{ Concentration, $\mathrm{pCi} / \mathrm{g}^{(\mathrm{a})}$} \\
\hline & ${\underline{\text { Average }^{(\mathbf{b})}}}$ & $\underline{\text { Maximum }}^{(\mathrm{c})}$ \\
\hline 2 & $1.7 \mathrm{E}-03 \pm 3.6 \mathrm{E}-03^{(\mathrm{d})}$ & $3.0 \mathrm{E}-03 \pm 0.014^{(\mathrm{d})}$ \\
\hline 2 & $8.6 \mathrm{E}-03 \pm 0.014^{(\mathrm{d})}$ & $0.014 \pm 0.022^{(\mathrm{d})}$ \\
\hline 2 & $0.15 \pm 0.18$ & $0.21 \pm 0.040$ \\
\hline 2 & $0.049 \pm 0.12^{\text {(d) }}$ & $0.092 \pm 0.063^{(\mathrm{d})}$ \\
\hline 2 & $0.079 \pm 0.047^{(\mathrm{d})}$ & $0.095 \pm 0.050^{(\mathrm{d})}$ \\
\hline 2 & $1.2 \pm 0.014$ & $1.2 \pm 0.20$ \\
\hline 2 & $0.053 \pm 5.5 \mathrm{E}-03$ & $0.055 \pm 0.023$ \\
\hline 2 & $0.97 \pm 0.052$ & $0.99 \pm 0.16$ \\
\hline
\end{tabular}

\begin{tabular}{crr}
\multicolumn{3}{c}{$\mathbf{2 0 0 4 - 2 0 0 8}$} \\
\hline $\begin{array}{c}\text { No. of } \\
\text { Samples }\end{array}$ & \multicolumn{2}{c}{ Concentration, pCi/g $\mathbf{g}^{(\mathrm{a})}$} \\
\cline { 2 - 3 } Average $^{(\mathbf{b})}$ & $\underline{\text { Maximum }}^{(\mathrm{c})}$ \\
9 & $0.012 \pm 0.015^{(\mathrm{d})}$ & $0.025 \pm 0.013^{(\mathrm{d})}$ \\
9 & $1.4 \mathrm{E}-03 \pm 0.057$ & $0.074 \pm 0.013$ \\
9 & $0.15 \pm 0.13$ & $0.26 \pm 0.041$ \\
9 & $0.075 \pm 0.083^{(\mathrm{d})}$ & $0.15 \pm 0.058^{(\mathrm{d})}$ \\
9 & $0.077 \pm 0.048^{(\mathrm{d})}$ & $0.12 \pm 0.11^{(\mathrm{d})}$ \\
9 & $0.68 \pm 0.66$ & $1.3 \pm 0.19$ \\
9 & $0.024 \pm 0.041$ & $0.066 \pm 0.021$ \\
9 & $0.56 \pm 0.63$ & $1.1 \pm 0.16$
\end{tabular}

300 Area Spring

Cobalt-60
$4.6 \mathrm{E}-03 \pm 9.9 \mathrm{E}-03^{(\mathrm{d})}$
$0.018 \pm 0.018^{(\mathrm{d})}$
$0.42 \pm 0.040$
$0.19 \pm 0.064^{(\mathrm{d})}$
$3.7 \pm 0.59$
$0.18 \pm 0.060$
$3.4 \pm 0.54$

$0.016 \pm 6.4 \mathrm{E}-03$

$0.16 \pm 0.35$

Cesium-137

Europium-152

Europium-155

Uranium-234

Uranium-235

Uranium-238

$0.068 \pm 0.17^{(\mathrm{d})}$

$0.047 \pm 0.034^{\text {(d) }} \quad 0.064 \pm 0.050^{\text {(d) }}$

$1.7 \pm 2.8$

$0.087 \pm 0.13$

$1.6 \pm 2.6$

18
10
18
18
18
18
18
18

$3.0 \mathrm{E}-03 \pm 8.1 \mathrm{E}-03^{(\mathrm{d})}$

$9.2 \mathrm{E}-03 \pm 0.012^{(\mathrm{d})}$

$2.5 \mathrm{E}-03 \pm 0.028 \quad 0.027 \pm 0.021^{(\mathrm{d})}$

$0.11 \pm 0.17$

$0.026 \pm 0.067^{(\mathrm{d})}$

$0.33 \pm 0.029$

$0.051 \pm 0.035^{\text {(d) }}$

$0.11 \pm 0.037$

$1.4 \pm 2.2$

$\begin{aligned} 0.074 & \pm 0.028 \\ 4.1 & \pm 0.66\end{aligned}$

$0.074 \pm 0.11$

$0.21 \pm 0.042$

(a) To convert to the International System of Units, multiply pCi/g by 0.037 to obtain $\mathrm{Bq} / \mathrm{g}$. All values are dry weight.

(b) Averages are \pm 2 standard deviations of the mean. Average values are not provided when only one sample was analyzed.

(c) Values are \pm total propagated analytical uncertainty (2 sigma).

(d) Below detection limit. 


\begin{tabular}{|c|c|c|c|c|}
\hline \multirow{3}{*}{$\begin{array}{l}\text { Sample } \\
\text { Description }\end{array}$} & \multirow{3}{*}{$\begin{array}{l}\text { Sample } \\
\text { Location }\end{array}$} & $\begin{array}{l}\mathrm{g} / \mathrm{g} \text { ) of } \\
\mathrm{s} / \mathrm{bu} \text { bus } \\
\text { Compa } \\
\text { ita Brid }\end{array}$ & $\begin{array}{l}\text { ical Con } \\
\text { s) from } \\
\text { Referen } \\
\text { ing } 200\end{array}$ & \\
\hline & & \multicolumn{3}{|c|}{ Concentration $(\mu \mathrm{g} / \mathrm{g})$} \\
\hline & & $\underline{\text { Root }}$ & $\underline{\text { Bulb }}$ & $\underline{\text { Leaf }}$ \\
\hline \multirow[t]{3}{*}{ Aluminum } & 100-H Area & 203 & 43 & 19.2 \\
\hline & Locke Island & 216 & 78.1 & 25.4 \\
\hline & Vernita Bridge & 172 & 11.3 & 34.9 \\
\hline \multirow[t]{3}{*}{ Barium } & 100-H Area & 22.6 & 20.3 & 13.1 \\
\hline & Locke Island & 25 & 17.7 & 14.1 \\
\hline & Vernita Bridge & 20.5 & 13.5 & 10.3 \\
\hline \multirow[t]{3}{*}{ Boron } & 100-H Area & 11.3 & 13.3 & 12.7 \\
\hline & Locke Island & 11.5 & 9.86 & 9.54 \\
\hline & Vernita Bridge & 12.2 & 13.3 & 11.5 \\
\hline \multirow[t]{3}{*}{ Cadmium } & 100-H Area & 0.59 & 0.52 & 0.33 \\
\hline & Locke Island & 1.07 & 0.83 & 0.64 \\
\hline & Vernita Bridge & 0.51 & 0.46 & 0.24 \\
\hline \multirow[t]{3}{*}{ Calcium } & 100-H Area & 4,010 & 8,680 & 4,180 \\
\hline & Locke Island & 3,510 & 6,480 & 4,420 \\
\hline & Vernita Bridge & 3,230 & 6,150 & 3,780 \\
\hline \multirow[t]{3}{*}{ Chromium } & 100-H Area & 1.15 & 0.8 & 0.67 \\
\hline & Locke Island & 1.3 & 0.78 & 0.69 \\
\hline & Vernita Bridge & 1.01 & 0.6 & 0.65 \\
\hline \multirow[t]{3}{*}{ Copper } & 100-H Area & 16.6 & 2.53 & 2.8 \\
\hline & Locke Island & 37.6 & 2.76 & 2.67 \\
\hline & Vernita Bridge & 9.35 & 2.08 & 2.18 \\
\hline \multirow[t]{3}{*}{ Iron } & 100-H Area & 298 & 83.8 & 56.3 \\
\hline & Locke Island & 497 & 80.7 & 68.6 \\
\hline & Vernita Bridge & 364 & 53.2 & 77.2 \\
\hline \multirow[t]{3}{*}{ Magnesium } & 100-H Area & 1,700 & 806 & 830 \\
\hline & Locke Island & 1,710 & 657 & 968 \\
\hline & Vernita Bridge & 1,410 & 559 & 742 \\
\hline \multirow[t]{3}{*}{ Manganese } & 100-H Area & 22.9 & 9.7 & 8.9 \\
\hline & Locke Island & 30.8 & 9.35 & 11.5 \\
\hline & Vernita Bridge & 13.7 & 3.99 & 7.01 \\
\hline \multirow[t]{3}{*}{ Molybdenum } & 100-H Area & 0.23 & 0.22 & 0.42 \\
\hline & Locke Island & 0.18 & 0.32 & 0.34 \\
\hline & Vernita Bridge & 0.12 & 0.14 & 0.4 \\
\hline \multirow[t]{3}{*}{ Nickel } & 100-H Area & 1.34 & 1.29 & 0.86 \\
\hline & Locke Island & 2.83 & 3.77 & 1.93 \\
\hline & Vernita Bridge & 0.99 & 0.98 & 0.6 \\
\hline \multirow[t]{3}{*}{ Sodium } & 100-H Area & 832 & 115 & $50^{(a)}$ \\
\hline & Locke Island & 1,210 & 121 & $50^{(a)}$ \\
\hline & Vernita Bridge & 421 & 67.1 & $50^{(a)}$ \\
\hline \multirow[t]{3}{*}{ Strontium } & 100-H Area & 30.7 & 49.8 & 25.3 \\
\hline & Locke Island & 29.3 & 36.1 & 24.6 \\
\hline & Vernita Bridge & 26.9 & 33.6 & 20.2 \\
\hline \multirow[t]{3}{*}{ Thallium } & 100-H Area & 0.34 & $0.20^{\text {(a) }}$ & 0.24 \\
\hline & Locke Island & 0.44 & 0.23 & 0.51 \\
\hline & Vernita Bridge & 0.22 & $0.20^{(\mathrm{a})}$ & 0.24 \\
\hline
\end{tabular}




\begin{tabular}{|c|c|c|c|c|}
\hline \multirow{3}{*}{$\begin{array}{l}\text { Sample } \\
\text { Description }\end{array}$} & \multicolumn{2}{|c|}{ Table C.12. (contd) } & & \\
\hline & \multirow{2}{*}{$\begin{array}{l}\text { Sample } \\
\text { Location }\end{array}$} & \multicolumn{3}{|c|}{ Concentration $(\mu \mathrm{g} / \mathrm{g})$} \\
\hline & & $\underline{\text { Root }}$ & $\underline{\text { Bulb }}$ & Leaf \\
\hline \multirow[t]{3}{*}{ Titanium } & 100-H Area & 10.1 & 3.33 & 3.21 \\
\hline & Locke Island & 12 & 3.88 & 3.27 \\
\hline & Vernita Bridge & 8.31 & 2.16 & 3.2 \\
\hline \multirow[t]{3}{*}{ Zinc } & 100-H Area & 39.9 & 24.1 & 17.4 \\
\hline & Locke Island & 58.8 & 23.9 & 25.7 \\
\hline & Vernita Bridge & 26.6 & 20.6 & 17.6 \\
\hline
\end{tabular}

Table C.13. Concentrations ( $\mu \mathrm{g} / \mathrm{g}$ dry wt.) of Metals in Livers from Whitefish Collected from the Hanford Reach of the Columbia River and at an Upriver Reference Location Below Wanapum Dam in 2009(a)

\begin{tabular}{|c|c|c|c|c|c|c|}
\hline \multirow[b]{2}{*}{$\underline{\text { Metal }}$} & \multicolumn{3}{|c|}{$\begin{array}{c}100-\mathrm{N} \text { to } 100-\mathrm{D} \text { Area } \\
(\mathrm{n}=5)\end{array}$} & \multicolumn{3}{|c|}{$\begin{array}{c}\text { Upriver, Priest Rapids Pool } \\
(\mathbf{n}=5)\end{array}$} \\
\hline & $\underline{\text { Maximum }}$ & $\underline{\text { Minimum }}$ & $\underline{\text { Median }}$ & Maximum & $\underline{\text { Minimum }}$ & $\underline{\text { Median }}$ \\
\hline Aluminum & $2.6^{(\mathrm{b})}$ & $1.0^{(c)}$ & 1.1 & $3.9^{(\mathrm{b})}$ & $1.0^{(c)}$ & 1.1 \\
\hline Antimony & 0.028 & $0.01^{(\mathrm{c})}$ & 0.01 & 0.019 & $0.01^{(\mathrm{c})}$ & 0.01 \\
\hline Arsenic & 0.84 & $0.15^{(\mathrm{d})}$ & 0.42 & 0.61 & $0.1^{(\mathrm{c})}$ & 0.37 \\
\hline Beryllium & $0.01^{(c)}$ & $0.01^{(\mathrm{c})}$ & 0.01 & $0.01^{(\mathrm{c})}$ & $0.01^{(\mathrm{c})}$ & 0.01 \\
\hline Cadmium & 1.1 & 0.27 & 0.87 & 0.86 & 0.19 & 0.80 \\
\hline Chromium & 0.35 & 0.27 & 0.30 & 0.44 & 0.23 & 0.27 \\
\hline Copper & 18 & 7.1 & 8.5 & 14 & 5.7 & 6.9 \\
\hline Lead & 0.14 & $0.020^{(b)}$ & 0.049 & 0.086 & $0.010^{(b)}$ & 0.019 \\
\hline Manganese & 6.9 & 4.5 & 5.5 & 9.7 & 3.6 & 4.0 \\
\hline Mercury & 0.39 & 0.11 & 0.19 & 1.0 & 0.29 & 0.47 \\
\hline Nickel & 0.072 & $0.044^{(\mathrm{b})}$ & 0.053 & 0.066 & $0.025^{(b)}$ & 0.052 \\
\hline Selenium & 18 & 1.2 & 12 & 15 & 0.31 & 3.5 \\
\hline Silver & 0.14 & $0.0052^{(\mathrm{b})}$ & 0.011 & 0.066 & $0.003^{(c)}$ & 0.0048 \\
\hline Thallium & 2.2 & 0.29 & 0.52 & 0.52 & 0.34 & 0.38 \\
\hline Thorium & 0.016 & $0.01^{(\mathrm{c})}$ & 0.01 & $0.01^{(\mathrm{c})}$ & $0.01^{(\mathrm{c})}$ & 0.01 \\
\hline Uranium & 0.064 & $0.0033^{(b)}$ & 0.010 & 0.051 & $0.0041^{(\mathrm{b})}$ & 0.017 \\
\hline Zinc & 160 & 100 & 140 & 98 & 83 & 94 \\
\hline \multicolumn{7}{|c|}{$\begin{array}{l}\text { (a) Data are not blank corrected. } \\
\text { (b) Analyte not detected above the method detection limit. } \\
\text { (c) Value less than required detection limit and greater than method detection limit. } \\
\text { (d) Analyte detected in both the sample and associated quality control blank, and the sample concentration was less than or equal to } \\
\text { five times the blank. } \\
\mathrm{n}=\text { Number of samples. }\end{array}$} \\
\hline
\end{tabular}




\begin{tabular}{|c|c|c|c|c|c|c|c|c|c|}
\hline \multirow[b]{3}{*}{ Metal } & \multicolumn{9}{|c|}{$\begin{array}{l}\text { Table C. 14. Concentrations ( } \mu \mathrm{g} / \mathrm{g} \text { dry wt.) of Metals in Livers from Canada Geese Collected from the Hanford Reach } \\
\text { of the Columbia River and at a Reference Location Near Desert Aire, Washington, in 2009(a) }\end{array}$} \\
\hline & \multicolumn{3}{|c|}{$\begin{array}{l}100 \text { Areas } \\
(\mathbf{n}=5)\end{array}$} & \multicolumn{3}{|c|}{$\begin{array}{l}\text { Hanford town site to } 300 \text { Area } \\
\qquad(\mathrm{n}=5)\end{array}$} & \multicolumn{3}{|c|}{$\begin{array}{l}\text { Desert Aire, Washington } \\
(\mathbf{n}=3)\end{array}$} \\
\hline & Maximum & Minimum & Median & Maximum & $\underline{\text { Minimum }}$ & Median & Maximum & $\underline{\text { Minimum }}$ & Median \\
\hline Aluminum & $2.2^{(\mathrm{b}, \mathrm{c})}$ & $1.5^{(\mathrm{b}, \mathrm{c})}$ & 2.1 & $4^{(b, c)}$ & $1.6^{(\mathrm{b}, \mathrm{c})}$ & 3.1 & $1.6^{(\mathrm{b}, \mathrm{c})}$ & $1.2^{(\mathrm{b}, \mathrm{c})}$ & 1.2 \\
\hline Antimony & $0.01^{(\mathrm{d})}$ & $0.01^{(\mathrm{d})}$ & 0.01 & $0.01^{(\mathrm{d})}$ & $0.01^{(\mathrm{d})}$ & 0.01 & $0.01^{(\mathrm{d})}$ & $0.01^{(\mathrm{d})}$ & 0.01 \\
\hline Arsenic & 0.42 & 0.24 & 0.34 & 0.48 & 0.31 & 0.36 & 0.41 & 0.24 & 0.34 \\
\hline Beryllium & $0.01^{(\mathrm{d})}$ & $0.01^{(\mathrm{d})}$ & 0.01 & $0.01^{(\mathrm{d})}$ & $0.01^{(\mathrm{d})}$ & 0.01 & $0.01^{(\mathrm{d})}$ & $0.01^{(\mathrm{d})}$ & 0.01 \\
\hline Cadmium & 2.4 & 0.37 & 1.6 & 4.3 & 0.28 & 0.58 & 4.2 & 0.51 & 1.0 \\
\hline Chromium & 0.15 & 0.13 & 0.14 & 0.22 & 0.14 & 0.16 & 0.23 & 0.17 & 0.19 \\
\hline Copper & 34 & 15 & 20 & 53 & 19 & 23 & 56 & 51 & 52 \\
\hline Lead & 0.10 & $0.037^{(c)}$ & 0.083 & 0.29 & $0.027^{(\mathrm{b}, \mathrm{c})}$ & 0.045 & 0.28 & $0.058^{(c)}$ & 0.073 \\
\hline Manganese & 7.8 & 7.2 & 7.7 & 8.9 & 6.2 & 8.4 & 13 & 8.7 & 9.2 \\
\hline Mercury & 0.066 & 0.049 & 0.058 & 0.053 & 0.038 & 0.049 & 0.030 & 0.022 & 0.023 \\
\hline Nickel & $0.046^{(b, c)}$ & $0.017^{(b, c)}$ & 0.021 & $0.044^{(b, c)}$ & $0.016^{(b, c)}$ & 0.024 & $0.030^{(b, c)}$ & $0.023^{(b, c)}$ & 0.028 \\
\hline Selenium & 2.6 & 1.0 & 2.3 & 3.0 & 1.2 & 1.5 & 2.6 & 1.6 & 1.7 \\
\hline Silver & $0.017^{(c)}$ & $0.0056^{(\mathrm{b}, \mathrm{c})}$ & 0.0079 & $0.014^{(c)}$ & $0.0056^{(b, c)}$ & 0.0085 & $0.018^{(\mathrm{c})}$ & $0.010^{(c)}$ & 0.015 \\
\hline Thallium & 0.018 & 0.010 & 0.015 & 0.058 & $0.01^{(\mathrm{d})}$ & 0.015 & 0.046 & 0.039 & 0.044 \\
\hline Thorium & $0.048^{(\mathrm{c})}$ & $0.01^{(\mathrm{d})}$ & 0.021 & $0.02^{(\mathrm{c})}$ & $0.01^{(\mathrm{d})}$ & 0.011 & $0.021^{(\mathrm{c})}$ & $0.01^{(\mathrm{d})}$ & 0.01 \\
\hline Uranium & $0.002^{(\mathrm{d})}$ & $0.002^{(\mathrm{d})}$ & 0.002 & $0.0056^{(\mathrm{b})}$ & $0.002^{(\mathrm{d})}$ & 0.0021 & $0.002^{(\mathrm{d})}$ & $0.002^{(\mathrm{d})}$ & 0.002 \\
\hline Zinc & 105 & 85 & 97 & 230 & 100 & 110 & 180 & 130 & 160 \\
\hline \multicolumn{10}{|c|}{$\begin{array}{l}\text { (a) Data are not blank corrected. } \\
\text { (b) Value less than required detection limit and greater than method detection limit. } \\
\text { (c) Analyte detected in both the samples and associated quality control blank, and the sample concentration was less than or equal to five times the } \\
\text { (d) Analyte not detected above the method detection limit. } \\
\text { n = Number of samples. }\end{array}$} \\
\hline
\end{tabular}




\section{References}

40 CFR 61, Appendix E, Table 2. 2009. "National Emission Standards for Hazardous Air Pollutants." Appendix E, "Compliance Procedures Methods for Determining Compliance with Subpart I; Concentration Levels for Environmental Compliance." Code of Federal Regulations, U.S. Environmental Protection Agency. Accessed May 17, 2010, at http://www.gpoaccess.gov/cfr/index.html.

40 CFR 141. 2009. "National Primary Drinking Water Regulations." Code of Federal Regulations, U.S. Environmental Protection Agency. Accessed May 17, 2010, at http://www.gpoaccess.gov/cfr/index.html.

EPA-570/9-76-003. 1976. National Interim Primary Drinking Water Regulations. Office of Water Supply, U.S. Environmental Protection Agency, Washington, D.C.

PNNL-19455, APP. 1. 2010. Hanford Site Environmental Surveillance Data Report for Calendar Year 2009. LE Bisping, Pacific Northwest National Laboratory, Richland, Washington.
PNNL-19455, APP. 2. 2010. Hanford Site Near-Facility Monitoring Data Report for Calendar Year 2009. CJ Perkins, MC Dorsey, SM McKinney, and JW Wilde, EnergySolutions, LLC for Pacific Northwest National Laboratory, Richland, Washington.

WAC 173-201A. 2006. "Water Quality Standards for Surface Waters of the State of Washington." Washington Administrative Code, Olympia, Washington. Accessed May 17, 2010, at http://apps.leg.wa.gov/wac/.

WAC 173-201A-250. 2006. "Radioactive Substances." Washington Administrative Code, Olympia, Washington. Accessed May 17, 2010, at http://apps.leg.wa.gov/wac/.

WAC 246-290. 2009. "Group A Public Water Supplies." Washington Administrative Code, Olympia, Washington. Accessed May 17, 2010, at http://apps.leg.wa.gov/wac/. 


\section{Appendix D Standards and Permits}

\section{GW Patton and JP Duncan}

Permits required for regulated releases to water and air have been issued by the U.S. Environmental Agency (EPA) under the National Pollutant Discharge Elimination System of the Clean Water Act of 1977 and the "Prevention of Significant Deterioration" requirements of the Clean Air Act. In addition, under authority granted through the Clean Air Act, the Washington State Department of Health issued a permit for Hanford Site radioactive air emissions. Permits to collect wildlife for environmental sampling are issued by the Washington Department of Fish and Wildlife and the U.S. Fish and Wildlife Service. Current permits are discussed in Table D.1.

\section{U.S. Department of Energy (DOE) Order 5400.5, Chg 2} established derived concentration guides that reflect the concentrations of radionuclides in water and air that an individual could continuously consume, inhale, or be immersed in at average annual levels without exceeding an effective dose equivalent of 100 millirem (1 millisievert) per year. Derived concentration guides are not exposure limits but are simply reference values that are provided to allow for comparisons of radionuclide concentrations in environmental media. Table D.2 lists selected DOE-derived concentration guides for radionuclides of particular interest at the Hanford Site. These guides are useful reference values but do not generally represent concentrations in the environment that assure compliance with DOE, the Clean Air Act, or drinking water dose standards.

Hanford Site operations must conform to a variety of government standards and permits. The primary environmental quality standards and permits applicable to Hanford Site operations in 2009 are listed in the following tables. Washington State has water quality standards for the Columbia River, as defined in WAC 173-201A, "Water
Quality Standards for Surface Waters of the State of Washington." The Hanford Reach of the Columbia River has been designated as Class A (Excellent). This designation requires that the water be usable for substantially all needs, including drinking water, recreation, and wildlife. In 2003, the Washington State Department of Ecology revised the surface-water quality standards and submitted them to the EPA for approval. As the new standards are approved, the Class A (Excellent) designation uses are being replaced by other-use designations. Four use-designations have been identified for water bodies in Washington State: 1) Aquatic Life Uses, 2) Recreational Uses, 3) Water Supply Uses, and 4) Miscellaneous Uses. Within each designation are categories that apply to specific bodies of water. For the Hanford Reach of the Columbia River, the category for Aquatic Life Uses is noncore salmon and trout; for the protection of spawning, noncore rearing and migration of salmon and trout, and other associated aquatic life. The category for Recreational Uses is primary contact, which refers to the amount of fecal-coliform bacteria allowed in the water. Designated water-supply uses and miscellaneous uses include domestic water, industrial water, agricultural water, stock water, wildlife habitat, harvesting, commerce and navigation, boating, and aesthetics. Some of the newuse designations and associated criteria have been approved and some have not. For those not yet approved, the old criteria are still in effect. A summary of currently applicable Hanford Reach water criteria is provided in Table D.3. Table D.4 summarizes federal and state drinking water standards in 40 CFR 141, "National Primary Drinking Water Regulations" and WAC 246-290, "Group A Public Water Systems." Select surface freshwater quality criteria for toxic pollutants are included in Table D.5. 
Table D.1. Environmental Permits

\section{Clean Air Act Permits}

Prevention of Significant Deterioration Permit No. PSD-X80-14, issued to the U.S. Department of Energy, Richland Operations Office by the U.S. Environmental Protection Agency, Region 10, covers emission of $\mathrm{NO}_{\mathrm{x}}$ to the atmosphere from the Plutonium Uranium Extraction Plant and the Uranium-Trioxide Plant. No expiration date.

Hanford Site Air Operating Permit 00-05-006, Renewal 1, covers operations on the Hanford Site having a potential to emit airborne emissions. This permit was effective on January 1, 2007, and expires January 1, 2012. The permit is intended to provide a compilation of applicable Clean Air Act requirements for both radioactive and non-radioactive emissions at the Hanford Site. It will be implemented through federal and state programs.

State License FF-01 was incorporated into the Hanford Site Air Operating Permit.

\section{Clean Water Act of 1977 - National Pollutant Discharge Elimination System Permits}

Permit WA-002591-7 (governing effluent discharges to the Columbia River) includes the outfall for the 300 Area Treated Effluent Disposal Facility and two outfalls in the 100-K Area. The 300 Area Treated Effluent Disposal Facility was removed from the permit during 2009, as the facility has been shut down.

Permit WAR05A57F governs storm water discharges. This permit expired October 30, 2005, and a new permit has not yet been issued. However, facilities covered by this permit are automatically granted an administrative continuance of permit coverage until a new permit is issued. $\mathrm{CH} 2 \mathrm{M}$ HILL Plateau Remediation Company terminated coverage under this permit on June 22, 2009.

Permit WAR10B90F is a National Pollutant Discharge Elimination System Construction General Permit granted to CH2M HILL Plateau Remediation Company that became effective on June 3, 2009. It replaces permit WAR05A57F and governs storm water discharges.

Permit CR-IU005 allows wastewater from the Environmental Molecular Sciences Laboratory to be discharged to the city of Richland's wastewater treatment facility.

\section{Washington State Department of Ecology - State Wastewater Permits}

Permit ST 4500 allows treated wastewater from the Effluent Treatment Facility to be discharged to the State-Approved Land Disposal Site. This permit expired August 1, 2005, and has not been reissued. The old permit will remain in effect until the new permit is issued.

Permit ST 4501 allows for the discharge of cooling water and other primarily uncontaminated wastewater from 400 Area facilities to two ponds located north-northeast of the 400 Area perimeter fence. This permit was effective October 1, 2003, and expired on October 1, 2008. It will remain in effect until a new permit is issued.

Permit ST 4502 allows treated effluent from the 200-East and 200-West Areas to be discharged to the 200 Area Treated Effluent Disposal Facility. This permit expired in May 2005 and has not been reissued. The old permit will remain in effect until the new permit is issued.

Permit ST 4507 allows domestic wastewater to be discharged to the 100-N Area sewage lagoon. This permit expired in May 2002. A renewal application has been submitted. The old permit will remain in effect until a new permit is issued.

Permit ST 4511 is a consolidation of permits: ST 4508, ST 4509, and ST 4510. This Categorical State Waste Discharge Permit authorizes the discharge of wastewater from maintenance, construction, and hydrotesting activities and allows for cooling water, condensate, and industrial storm water discharges at the Hanford Site. This permit was issued February 16, 2005, and expires February 16, 2010. A permit renewal application for ST 4511 was filed with the Washington State Department of Ecology in August 2009.

Permit WAG-50-5180 (General Sand and Gravel) for the Concrete Batch Plant in the 200-East Area. Reissued in May 2006.

Permit WAG-50-5181 for Gravel Pit 30 in the 200-East Area. Reissued in May 2006.

\section{Washington State Department of Ecology - Resource Conservation and Recovery Act of 1976 Permit}

Permit WA7890008967 was issued on September 27, 1994, and has undergone several revisions. The permit expired on September 27, 2004, and a draft of Revision 9 of the permit is in progress, incorporating the Hanford Site's 43 treatment, storage, and disposal units. The current permit remains in effect until a new permit is issued.

\section{Wildlife Sampling Permits}

Scientific Collection Permit 08-425, issued by the Washington Department of Fish and Wildlife to Pacific Northwest National Laboratory for 2009; covered the collection of food fish, shellfish, game fish, and wildlife for research purposes. This permit is renewed annually.

Federal Fish and Wildlife Permit No. MB671877-0, issued by the U.S. Fish and Wildlife Service to Pacific Northwest National Laboratory; covers the collection of migratory wildlife. This permit expires March 31, 2012.

Copies of the regulations concerning these permits may be obtained from the following organizations:

State of Washington

Department of Ecology

P.O. Box 47600

Olympia, WA $98504-7600$
U.S. Environmental Protection Agency

Region 10

1200 Sixth Avenue

Seattle, WA 98101
U.S. Department of Energy

Richland Operations Office

825 Jadwin Avenue

Richland, WA 99352 


\begin{tabular}{|c|c|c|c|c|c|}
\hline \multirow{2}{*}{\multicolumn{2}{|c|}{ Radionuclide }} & \multicolumn{3}{|c|}{ Table D.2. Selected DOE-Derived Concentration Guides ${ }^{(a, b, c)}$} & \multirow{2}{*}{$\begin{array}{l}\left.\mathrm{Bq} / \mathrm{m}^{3}\right) \\
\mathrm{Air}\end{array}$} \\
\hline & & \multicolumn{2}{|c|}{$\begin{array}{l}\text { Consumed Water, } \\
\text { pCi/L }(\mathbf{B q} / \mathbf{L})\end{array}$} & $\begin{array}{c}\text { Inhaled Air, } \\
\mathrm{pCi} / \mathrm{m}^{3}\left(\mathrm{~Bq} / \mathrm{m}^{3}\right)\end{array}$ & \\
\hline \multicolumn{2}{|c|}{ Tritium } & $2,000,000$ & $(74,000)$ & 100,000 & $(3,700)$ \\
\hline \multicolumn{2}{|c|}{ Carbon-14 } & 70,000 & $(2,590)$ & 500,000 & $(18,500)$ \\
\hline \multicolumn{2}{|c|}{ Chromium-51 } & $1,000,000$ & $(37,000)$ & 60,000 & $(2,220)$ \\
\hline \multicolumn{2}{|c|}{ Cobalt-60 } & 5,000 & (185) & 80 & $(2.96)$ \\
\hline \multicolumn{2}{|c|}{ Strontium-90 } & 1,000 & $(37)$ & 9 & $(0.333)$ \\
\hline \multicolumn{2}{|c|}{ Technetium-99 } & 100,000 & $(3,700)$ & 2,000 & (74) \\
\hline \multicolumn{2}{|c|}{ Ruthenium-103 } & 50,000 & $(1,850)$ & 2,000 & (74) \\
\hline \multicolumn{2}{|c|}{ Ruthenium-106 } & 6,000 & $(222)$ & 30 & $(1.11)$ \\
\hline \multicolumn{2}{|c|}{ Iodine-129 } & 500 & $(18.5)$ & 70 & (2.59) \\
\hline \multicolumn{2}{|c|}{ Iodine-131 } & 3,000 & $(111)$ & 400 & $(14.8)$ \\
\hline \multicolumn{2}{|c|}{ Cesium-137 } & 3,000 & (111) & 400 & $(14.8)$ \\
\hline \multicolumn{2}{|c|}{ Uranium-234 } & 500 & $(18.5)$ & 0.09 & $(0.00333)$ \\
\hline \multicolumn{2}{|c|}{ Uranium-235 } & 600 & (22.2) & 0.1 & $(0.0037)$ \\
\hline \multicolumn{2}{|c|}{ Uranium-238 } & 600 & (22.2) & 0.1 & $(0.0037)$ \\
\hline \multicolumn{2}{|c|}{ Plutonium-238 } & 40 & (1.48) & 0.03 & $(0.00111)$ \\
\hline \multicolumn{2}{|c|}{ Plutonium-239 } & 30 & (1.11) & 0.02 & $(0.00074)$ \\
\hline \multicolumn{2}{|c|}{ Plutonium-240 } & 30 & (1.11) & 0.02 & $(0.00074)$ \\
\hline \multicolumn{2}{|c|}{ Americium-241 } & 30 & (1.11) & 0.02 & $(0.00074)$ \\
\hline \multicolumn{6}{|c|}{$\begin{array}{l}\text { (a) Concentration of a specific radionuclide in water or air that could be continuously } \\
\text { consumed or inhaled at average annual rates and not exceed an effective dose } \\
\text { equivalent of } 100 \text { mrem }(1 \mathrm{mSv} \text { ) per year. } \\
\text { (b) Values in this table represent the lowest, most-conservative, derived concentration } \\
\text { guides considered potentially applicable to Hanford Site operations and may be } \\
\text { adjusted upward (larger) if accurate solubility information is available. } \\
\text { (c) From DOE Order } 5400.5 \text {, Chg } 2 \text {. }\end{array}$} \\
\hline
\end{tabular}




\begin{tabular}{|c|c|}
\hline Parameter & $\underline{\text { Permissible Levels }}$ \\
\hline Fecal coliform & $\begin{array}{l}\text { (1) Geometric mean value less than or equal to } 100 \text { colonies } / 100 \text { milliliters }(0.026 \text { gallons }) \\
\text { (2) Not more than or equal to } 10 \% \text { of samples may exceed the geometric mean value of } \\
200 \text { colonies } / 100 \text { milliliters ( } 0.026 \text { gallons) }\end{array}$ \\
\hline Dissolved oxygen & Greater than $8 \mathrm{mg} / \mathrm{L}$ (8 ppm) \\
\hline Temperature & $\begin{array}{l}\text { (1) Less than or equal to } 18^{\circ} \mathrm{C}\left(64^{\circ} \mathrm{F}\right) \text { as a result of human activities } \\
\text { (2) When natural conditions exceed } 18^{\circ} \mathrm{C}\left(64^{\circ} \mathrm{F}\right) \text {, no temperature increases will be allowed } \\
\text { that will raise the temperature of the receiving water by more than } 0.3^{\circ} \mathrm{C}\left(0.54^{\circ} \mathrm{F}\right) \\
\text { (3) Incremental temperature increases resulting from point sources shall not at any time } \\
\text { exceed } \mathrm{t}=28 /(\mathrm{T}+7) \text {, where } \mathrm{t}=\text { maximum permissible temperature increase measured at } \\
\text { a mixing zone boundary and } \mathrm{T}=\text { background temperature. Incremental temperature } \\
\text { increases resulting from non-point sources shall not exceed } 2.8^{\circ} \mathrm{C}\left(5.04^{\circ} \mathrm{F}\right) \text {. }\end{array}$ \\
\hline $\mathrm{pH}$ & $\begin{array}{l}\text { (1) } 6.5 \text { to } 8.5 \text { range } \\
\text { (2) Less than } 0.5 \text {-unit induced variation }\end{array}$ \\
\hline Turbidity & $\begin{array}{l}\text { Turbidity shall be less than or equal to } 5 \text { nephelometric turbidity units over background } \\
\text { turbidity when the background turbidity is } 50 \text { nephelometric units or less, and shall not } \\
\text { increase more than } 10 \% \text { when the background turbidity is }>50 \text { nephelometric units }\end{array}$ \\
\hline Aesthetic value & $\begin{array}{l}\text { Shall not be impaired by the presence of materials or their effects, excluding those of natural } \\
\text { origin, which offend the senses of sight, smell, touch, or taste }\end{array}$ \\
\hline Radioactive substances & $\begin{array}{l}\text { Deleterious concentrations of radioactive materials for all classes shall be as determined by } \\
\text { the lowest practicable level attainable and in no case shall exceed } 1 / 12.5 \text { of the values listed } \\
\text { in WAC 246-221-290 or exceed EPA drinking water regulations for radionuclides, as pub- } \\
\text { lished in EPA-570/9-76-003 or subsequent revisions thereto (see Table D.2) }\end{array}$ \\
\hline Toxic substances & $\begin{array}{l}\text { Shall not be introduced above natural background levels in waters of the state that have the } \\
\text { potential either singularly or cumulatively to adversely affect characteristic water uses, cause } \\
\text { acute or chronic toxicity to the most sensitive biota dependent on those waters, or adversely } \\
\text { affect public health, as determined by the department (see Table D.5) }\end{array}$ \\
\hline \multicolumn{2}{|c|}{$\begin{array}{l}\text { (a) WAC 173-201A. } \\
\text { EPA = U.S. Environmental Protection Agency. } \\
\text { WAC = Washington Administrative Code. }\end{array}$} \\
\hline
\end{tabular}


Table D.4. Selected Drinking Water Standards

\begin{tabular}{|c|c|c|c|}
\hline \multirow{2}{*}{$\begin{array}{l}\text { Constituent } \\
\text { Antimony }\end{array}$} & \multicolumn{2}{|c|}{ Drinking Water Standard ${ }^{(\mathrm{a})}$} & \multirow{2}{*}{$\begin{array}{l}\underline{\text { Agency }}^{(\mathbf{b})} \\
\text { EPA, DOH }\end{array}$} \\
\hline & $6 \mu \mathrm{g} / \mathrm{L}$ & $(0.006 \mathrm{ppm})$ & \\
\hline Arsenic & $10 \mu g / \mathrm{L}$ & $(0.01 \mathrm{ppm})$ & $\mathrm{EPA}, \mathrm{DOH}$ \\
\hline Barium & $2,000 \mu \mathrm{g} / \mathrm{L}$ & $(2 \mathrm{ppm})$ & EPA, DOH \\
\hline Cadmium & $5 \mu \mathrm{g} / \mathrm{L}$ & $(0.005 \mathrm{ppm})$ & EPA \\
\hline Carbon tetrachloride & $5 \mu \mathrm{g} / \mathrm{L}$ & $(0.005 \mathrm{ppm})$ & EPA, DOH \\
\hline Chloroform (THM) $)^{(\mathrm{c})}$ & $80 \mu g / L$ & $(0.08 \mathrm{ppm})$ & EPA \\
\hline Chromium & $100 \mu \mathrm{g} / \mathrm{L}$ & $(0.1 \mathrm{ppm})$ & EPA, DOH \\
\hline cis-1,2-Dichloroethene & $70 \mu g / L$ & $(0.07 \mathrm{ppm})$ & EPA, DOH \\
\hline Copper & $1,300 \mu g / L$ & $(1.3 \mathrm{ppm})$ & EPA \\
\hline Cyanide & $200 \mu g / L$ & $(0.2 \mathrm{ppm})$ & $\mathrm{EPA}, \mathrm{DOH}$ \\
\hline Fluoride & $4 \mathrm{mg} / \mathrm{L}$ & $(4 \mathrm{ppm})$ & EPA, DOH \\
\hline Lead & $15 \mu \mathrm{g} / \mathrm{L}$ & $(0.015 \mathrm{ppm})$ & EPA \\
\hline Mercury (inorganic) & $2 \mu \mathrm{g} / \mathrm{L}$ & $(0.002 \mathrm{ppm})$ & EPA, DOH \\
\hline Methylene chloride & $5 \mu \mathrm{g} / \mathrm{L}$ & $(0.005 \mathrm{ppm})$ & EPA, DOH \\
\hline Nitrate, as $\mathrm{NO}_{3}$ & $45 \mathrm{mg} / \mathrm{L}$ & $(45 \mathrm{ppm})$ & $\mathrm{EPA}, \mathrm{DOH}$ \\
\hline Nitrite, as $\mathrm{NO}_{2}^{-}$ & $3.3 \mathrm{mg} / \mathrm{L}$ & $(3.3 \mathrm{ppm})$ & $\mathrm{EPA}, \mathrm{DOH}$ \\
\hline Selenium & $50 \mu \mathrm{g} / \mathrm{L}$ & $(0.05 \mathrm{ppm})$ & EPA, DOH \\
\hline Tetrachloroethene & $5 \mu \mathrm{g} / \mathrm{L}$ & $(0.005 \mathrm{ppm})$ & $\mathrm{EPA}, \mathrm{DOH}$ \\
\hline Thallium & $2 \mu \mathrm{g} / \mathrm{L}$ & $(0.002 \mathrm{ppm})$ & $\mathrm{EPA}, \mathrm{DOH}$ \\
\hline Trichloroethene & $5 \mu \mathrm{g} / \mathrm{L}$ & $(0.005 \mathrm{ppm})$ & $\mathrm{EPA}, \mathrm{DOH}$ \\
\hline Antimony-125 & $300 \mathrm{pi} / \mathrm{L}^{(\mathrm{d})}$ & $(11.1 \mathrm{~Bq} / \mathrm{L})$ & EPA \\
\hline Beta particle and photon activity & $4 \mathrm{mrem} / \mathrm{yr}^{(\mathrm{e})}$ & $(40 \mu \mathrm{Sv} / \mathrm{yr})$ & $\mathrm{EPA}, \mathrm{DOH}$ \\
\hline Carbon-14 & $2,000 \mathrm{pCi} / \mathrm{L}^{(\mathrm{d})}$ & $(74.1 \mathrm{~Bq} / \mathrm{L})$ & EPA \\
\hline Cesium-137 & $200 \mathrm{pCi} / \mathrm{L}^{(\mathrm{d})}$ & $(7.4 \mathrm{~Bq} / \mathrm{L})$ & EPA \\
\hline Cobalt -60 & $100 \mathrm{pCi} / \mathrm{L}^{(\mathrm{d})}$ & $(3.7 \mathrm{~Bq} / \mathrm{L})$ & EPA \\
\hline Iodine-129 & $1 \mathrm{pCi} / \mathrm{L}^{(\mathrm{d})}$ & $(0.037 \mathrm{~Bq} / \mathrm{L})$ & EPA \\
\hline Ruthenium-106 & $30 \mathrm{pCi} / \mathrm{L}^{(\mathrm{d})}$ & $(1.11 \mathrm{~Bq} / \mathrm{L})$ & EPA \\
\hline Strontium-90 & $8 \mathrm{pCi} / \mathrm{L}^{(\mathrm{d})}$ & $(0.296 \mathrm{~Bq} / \mathrm{L})$ & $\mathrm{EPA}, \mathrm{DOH}$ \\
\hline Technetium-99 & 900 pCi/L $/ \mathrm{L}^{(\mathrm{d})}$ & $(33.3 \mathrm{~Bq} / \mathrm{L})$ & EPA \\
\hline Total alpha (excluding uranium) & $15 \mathrm{pCi} / \mathrm{L}^{(\mathrm{d})}$ & $(0.56 \mathrm{~Bq} / \mathrm{L})$ & EPA, DOH \\
\hline Tritium & $20,000 \mathrm{pCi} / \mathrm{L}^{(\mathrm{d})}$ & $(740 \mathrm{~Bq} / \mathrm{L})$ & EPA, DOH \\
\hline Uranium & $30 \mu \mathrm{g} / \mathrm{L}$ & $(0.03 \mathrm{ppm})$ & $\mathrm{EPA}, \mathrm{DOH}$ \\
\hline
\end{tabular}

(a) Maximum contaminant level for drinking water supplies.

(b) $\mathrm{DOH}=$ Washington State Department of Health at WAC 246-290.

EPA $=$ U.S. Environmental Protection Agency at 40 CFR 141, 40 CFR 143, and EPA 822-R-96-001.

(c) Standard is for total trihalomethanes (THM).

(d) EPA drinking water standards for radionuclides were derived based on a 4-mrem/yr dose standard using maximum permissible concentrations in water specified in National Bureau of Standards Handbook 69 (U.S. Department of Commerce, August 1963, as amended).

(e) Beta and gamma radioactivity from anthropogenic radionuclides. Annual average concentration shall not produce an annual dose from anthropogenic radionuclides equivalent to the total body or any internal organ dose $>4 \mathrm{mrem} / \mathrm{yr}$. If two or more radionuclides are present, the sum of their annual dose equivalents shall not exceed $4 \mathrm{mrem} / \mathrm{yr}$. Compliance may be assumed if annual average concentrations of total beta, tritium, and strontium- -90 are $<50,20,000$, and $8 \mathrm{pCi} / \mathrm{L}$, respectively. 
Table D.5. Selected Surface Freshwater Quality Criteria for Toxic Pollutants

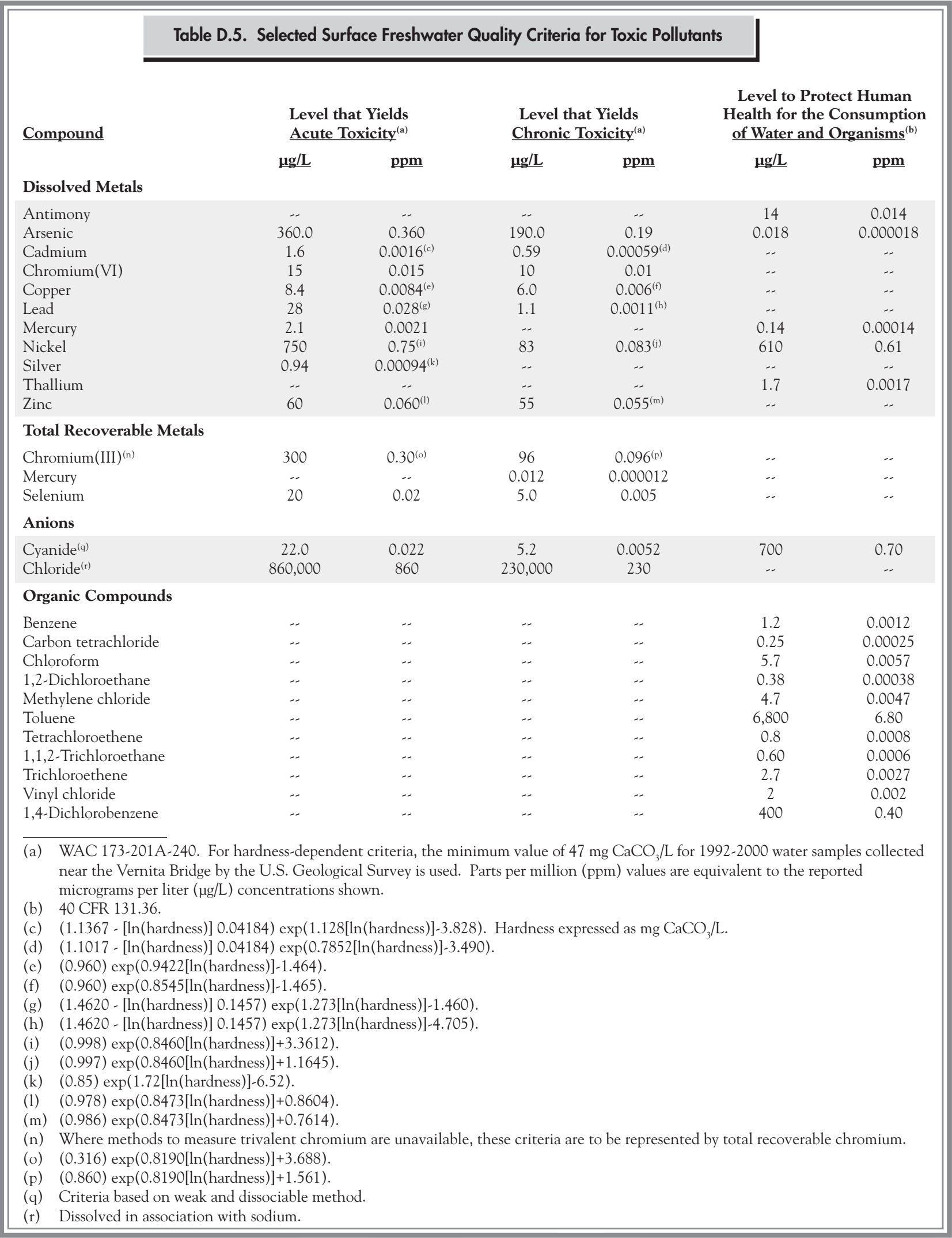


Table D.6. Radiation Standards (Dose Limits[a]) for Protection of the Public from all Routine DOE Concentrations

All Pathways (limits from DOE Order 5400.5, Chg 2)

The effective dose equivalent for any member of the public from all routine DOE operations ${ }^{(b)}$ shall not exceed the values given below.

Routine public dose

Potential authorized temporary public dose $\mathrm{e}^{(\mathrm{d})}$

$$
\begin{aligned}
& \text { Effective Dose Equivalent }{ }^{(c)} \\
& \underline{\mathrm{mrem} / \mathrm{yr}} \underline{\mathrm{mSv} / \mathrm{yr}}
\end{aligned}
$$

$\begin{array}{ll}100 & 1 \\ 500 & 5\end{array}$

Dose to Native Aquatic Animal Organisms from Liquid Discharges (interim limits from DOE Order 5400.5, Chg 2)

Radioactive material in liquid waste discharged to natural waterways shall not cause an absorbed dose ${ }^{(e)}$ to native aquatic animal organisms that exceeds $1 \mathrm{rad}(10 \mathrm{mGy})$ per day.

Drinking Water Pathway Only (limits from 40 CFR Parts 9, 141, and 142; WAC 246-290; and DOE Order 5400.5, Chg 2)

Radionuclide concentrations in DOE-operated public drinking water supplies shall not cause persons consuming the water to receive an effective dose equivalent greater than $4 \mathrm{mrem}(0.04 \mathrm{mSv})$ per year. DOE operations shall not cause private or public drinking water systems downstream of the facility discharge to exceed the radiological drinking water limits in 40 CFR Parts 9, 141, and 142 (see Table D.2).

Air Pathways Only (limits from 40 CFR 61)

Public dose limit at location of maximum annual air concentration as a consequence of routine DOE operations ${ }^{(b)}$

$\begin{array}{cc}\frac{2}{2} \text { Effective Dose Equivalent } \\ \text { mrem/yr } \\ 10 & \underline{\mathrm{mSv} / \mathrm{yr}} \\ & 0.1\end{array}$

(a) Radiation doses received from natural background, residual weapons testing and nuclear accident fallout, medical exposure, and consumer products are excluded from the implementation of these dose limits.

(b) "Routine DOE operations" implies normal, planned activities and does not include actual or potential accidental or unplanned releases.

(c) Effective dose equivalent is expressed in rem (or millirem) and sievert (or millisievert).

(d) Authorized temporary annual dose limits may be greater than 100 mrem (1 mSv) per year (but cannot exceed 500 mrem [5 mSv]) per year if unusual circumstances exist that make avoidance of doses greater than $100 \mathrm{mrem}(1 \mathrm{mSv})$ per year to the public impracticable. The DOE Richland Operations Office is required to request and receive specific authorization from DOE Headquarters for an increase from the routine public dose limit to a temporary annual dose limit.

(e) Absorbed dose is expressed in rad (or millirad) with the corresponding value in gray (or milligray) in parentheses. 


\section{References}

40 CFR 61. 2009. "National Emission Standards for Hazardous Air Pollutants." Code of Federal Regulations, U.S. Environmental Protection Agency. Accessed May 17, 2010, at http://www.gpoaccess.gov/cfr/index.html.

40 CFR 131.36. 2009. "Toxics Criteria for Those States Not Complying with Clean Water Act Section 303(c) (2)(B)." Code of Federal Regulations, U.S. Environmental Protection Agency. Accessed May 17, 2010, at http://www. gpoaccess.gov/cfr/index.html.

40 CFR 141. 2009. "National Primary Drinking Water Regulations." Code of Federal Regulations, U.S. Environmental Protection Agency. Accessed May 17, 2010, at http:// www.gpoaccess.gov/cfr/index.html.

40 CFR 143. 2009. "National Secondary Drinking Water Regulations." Code of Federal Regulations, U.S. Environmental Protection Agency. Accessed May 17, 2010, at http:// www.gpoaccess.gov/cfr/index.html.

65 FR 76707. December 7, 2000. "National Primary Drinking Water Regulations; Radionuclides; Final Rule. 40 CFR Parts 9, 141, and 142." Federal Register, U.S. Environmental Protection Agency.

Clean Air Act. 1986. Public Law 88-206, as amended, 42 USC 7401 et seq.

Clean Water Act of 1977. 1977. Public Law 95-217, as amended, 33 USC 1251 et seq.

DOE Order 5400.5, Chg 2. 1993. "Radiation Protection of the Public and the Environment." U.S. Department of Energy, Washington, D.C.

EPA-570/9-76-003. 1976. National Interim Primary Drinking Water Regulations. Office of Water Supply, U.S. Environmental Protection Agency, Washington, D.C.
EPA 822-R-96-001. 1996. Drinking Water Regulations and Health Advisories. Office of Water, U.S. Environmental Protection Agency, Washington, D.C.

Resource Conservation and Recovery Act of 1976. 1976. Public Law 94-580, as amended, 42 USC 6901 et seq. and 42 USC 6927(c) et seq. Accessed May 17, 2010, at http:// www.epa.gov/lawsregs/laws/rcra.html.

U.S. Department of Commerce. 1959, as amended in 1963. "Maximum Permissible Body Burdens and Maximum Permissible Concentrations of Radionuclides in Air and Water for Occupational Exposure." In National Bureau of Standards Handbook 69, National Bureau of Standards, Washington, D.C. (This document is available from the Hilton M. Briggs Library, South Dakota State University, Brookings, South Dakota.)

WAC 173-201A. 2006. "Water Quality Standards for Surface Waters of the State of Washington." Washington Administrative Code, Olympia, Washington. Accessed May 17, 2010, at http://apps.leg.wa.gov/wac/.

WAC 173-201A-240. 2006. "Toxic Substances." Washington Administrative Code, Olympia, Washington. Accessed May 17, 2010, at http://apps.leg.wa.gov/wac/.

WAC 246-221-290. 2009. "Appendix A - Annual Limits on Intake (ALI) and Derived Air Concentrations (DAC) of Radionuclides for Occupational Exposure; Effluent Concentrations; Concentrations for Release to Sanitary Sewerage." Washington Administrative Code, Olympia, Washington. Accessed May 17, 2010, at http://apps.leg. wa.gov/wac/.

WAC 246-290. 2009. "Group A Public Water Systems." Washington Administrative Code, Olympia, Washington. Accessed May 17, 2010, at http://apps.leg.wa.gov/wac/. 


\section{Appendix E Dose Calculations}

\section{EJ Antonio and SF Snyder}

The radiological dose that the public could have received in 2009 from Hanford Site cleanup operations was calculated in terms of the "total effective dose equivalent." The total effective dose equivalent is the sum of the effective dose equivalent from external sources and the committed effective dose equivalent for internal exposure. Effective dose equivalent is a weighted sum of doses to organs and tissues that accounts for the sensitivity of the tissue and the nature of the radiation causing the dose. It is expressed in units of rem (sievert), or more typically the sub-unit millirem (millisievert) ${ }^{(a)}$ for individuals, and in units of personrem for the collective dose received by the total population within an 80 -kilometer (50-mile) radius of the site operations areas. This appendix describes how the doses in this report were calculated.

Calculation of the effective dose equivalent takes into account the long-term (50 years) internal exposure from radionuclides absorbed into the body during the current year. The effective dose equivalent is the sum of individual committed (50 years) organ doses multiplied by weighting factors $^{(b)}$ that represent the proportion of the total health effect risk that each organ would contribute following uniform irradiation of the whole body. Internal organs may also be irradiated from external sources of radiation. The external exposure received during the current year is added to the committed internal dose to obtain the total effective dose equivalent. The transfer factors used for pathway and dose calculations are documented in PNL-3777, PNL-6584, and PNNL-14583, Rev. 3.
Releases of radionuclides from Hanford Site facilities are usually too small to be measured. Therefore, the air dose calculations were based on measurements made at the point of release (stacks and vents). The water pathway dose calculations were based on measurements of releases to the Columbia River (from the 100 Areas) and the difference in detectable radionuclide concentrations measured upstream and downstream of the site. Environmental radionuclide concentrations were estimated from the effluent measurements by using environmental transport models.

The transport of radionuclides in the environment to the point of exposure is predicted by empirically derived models of exposure pathways. These models calculate radionuclide levels in air, water, and foods. Radionuclides taken into the body by inhalation or ingestion may be distributed among different organs and retained for various times. In addition, long-lived radionuclides deposited on the ground become possible sources for long-term external exposure and uptake by agricultural products. Dietary and exposure parameters were applied to calculate radionuclide intakes and radiological doses to the public. Standardized computer programs were used to perform the calculations. These programs contain internally consistent mathematical models that use site-specific dispersion and uptake parameters. These programs are incorporated in a master code, GENII - The Hanford Environmental Radiation Dosimetry Software System, Version 1.485 (PNL-6584), which employs the dosimetry methodology described in International Commission on Radiological Protection reports (1979a,

(a) 1 rem $(0.01$ sievert $)=1,000$ millirem (10 millisievert).

(b) The more recent International Commission on Radiological Protection 60 weighting factors were used in this year's calculations (ICRP 1991). International Commission on Radiological Protection 30 weighting factors had been used previously (ICRP 1979a, 1979b, 1980, 1981a, 1981b, 1982a, 1982b, 1988). 
1979b, 1980, 1981a, 1981b, 1982a, 1982b, 1988). For calendar year 2009, GENII Version 2.09 was used (PNNL14583; PNNL-14584). GENII Version 2.09 is a Microsoft Windows ${ }^{\circledR}$-based version that incorporates some environmental modeling improvements (e.g., plume depletion during atmospheric transport). The assumptions and data used in the GENII calculations are in the following paragraphs. To bridge the change from one GENII version to another, the results of GENII Version 1.485 calculations are provided in this appendix for comparison (see Tables E.7 and E.8).

The RESRAD-BIOTA computer code was used to screen the 2009 radionuclide concentrations in water and sediment to see if they exceeded the established biota concentration guides (e.g., concentrations that could result in a dose rate of $1 \mathrm{rad}$ per day for aquatic biota or $0.1 \mathrm{rad}$ per day for terrestrial organisms). Both internal and external doses to aquatic, riparian, and terrestrial animals as well as to terrestrial plants are included in the screening process. For analyses with multiple media and multiple radionuclides, a sum of fractions is calculated to account for the contribution to dose from each radionuclide relative to its corresponding biota concentration guide. In the initial screening assessment, researchers compare maximum measured concentrations to the biota concentration guides. If the sum of fractions does not exceed 1 , no further analysis is required. However, if the sum of fractions does exceed 1, a second analysis is performed using average concentrations. The screening process is further described in A Graded Approach for Evaluating Radiation Doses to Aquatic and Terrestrial Biota (DOE-STD-1153-2002).

The computer program, CAP88-PC, was used to calculate an air pathway dose to a maximally exposed individual as required by the U.S. Environmental Protection Agency (EPA) through 40 CFR 61, Subpart $\mathrm{H}$ from airborne radionuclide effluent (other than radon) released at U.S. Department of Energy (DOE) facilities. Technical details of the CAP88-PC calculations are provided in the 2009 air emissions report (DOE/RL-2010-17).

\section{Types of Dose Calculations Performed}

Calculations of radiological doses to the public from radionuclides released into the environment are performed to demonstrate compliance with applicable standards and regulations.

DOE Order 5400.5, Chg. 2 requires the following:

- Effective dose equivalent must be used in estimating public doses.

- Calculations of doses to the public from exposures resulting from both routine and unplanned activities must be performed using EPA or DOE dose conversion factors or analytical models prescribed in regulations applicable to DOE operations.

- Doses to the public must be calculated using facility effluent data when environmental concentrations are too low to measure accurately.

The following types of radiological doses were estimated.

Maximally Exposed Individual Dose (mrem $[\mu \mathrm{Sv}]$ ). The maximally exposed individual is a hypothetical member of the public who lives at a location and has a lifestyle that makes it unlikely other individuals would receive higher doses. All potentially significant exposure pathways to this hypothetical individual were considered, including the following:

- Inhalation of airborne radionuclides

- Submersion in airborne radionuclides

- Ingestion of foodstuffs contaminated by radionuclides deposited on vegetation and the ground by both airborne deposition and irrigation water drawn from the Columbia River downstream of the 100-K Area

- Exposure to ground contaminated by both airborne deposition and irrigation water

- Consumption of fish from the Hanford Reach of the Columbia River

- Recreation along the Hanford Reach of the Columbia River, including boating, swimming, and other shoreline activities. 
Determination of the Location of the Maximally Exposed Individual. The location of the hypothetical, maximally exposed individual can vary from year to year, depending on the relative contributions of the several sources of radioactive emissions released to the air and effluent released to the Columbia River from Hanford Site facilities. Based on experience since 1990, three separate locations (Figure 8.12.1) have been used to assess the dose to the maximally exposed individual: 1) the Ringold area, along the east shoreline of the Columbia River 26 kilometers (16 miles) east of separations facilities in the 200 Areas; 2) the Sagemoor area, across the Columbia River from the 300 Area; and 3) the Riverview area, across the Columbia River from Richland. Although the Ringold area is closer than the Riverview area to Hanford Site facilities that historically released airborne emissions, at Riverview the maximally exposed individual receives a higher dose rate from radionuclides in the Columbia River than a Ringold resident. The applicable exposure pathways for Ringold and Sagemoor are described in the following paragraphs. In 2002, the maximally exposed individual was located in the Riverview area. However, from 2003 through 2009, the hypothetical, maximally exposed individual was located across the Columbia River from the 300 Area in the Sagemoor area (Figure 8.12.1).

Ringold Maximally Exposed Individual. Because of its location, an individual in the Ringold area has the potential to receive the maximum exposure to airborne emissions from the 200 Areas, including direct exposure to a contaminated plume, inhalation, external exposure to radionuclides that deposit on the ground, and ingestion of contaminated locally grown food products. In addition, it is assumed that individuals in the Ringold area irrigate their crops with water from the Columbia River downstream of where contaminated groundwater originating from the 100 and 200-East Areas enters the river. This results in additional exposure from ingestion of potentially contaminated irrigated food products and potential external irradiation from radionuclides deposited on the ground by irrigation. Recreational use of the Columbia River is also considered for this individual, resulting in direct exposure from water, and radionuclides deposited on the shoreline, and doses from ingestion of locally caught Columbia River fish.
Riverview Maximally Exposed Individual. Because of its location, an individual in the Riverview area has the potential to receive the maximum exposure to waterborne effluent from Hanford Site facilities. For the calculation, it was assumed the Riverview area maximally exposed individual obtained domestic water from a local water treatment system that pumped from the Columbia River just downstream of the Hanford Site. In addition, it was assumed that individuals in the Riverview area irrigate their crops with water taken from the Columbia River. This results in additional exposure from ingestion of potentially contaminated irrigated food products and potential external irradiation from radionuclides deposited on the ground by irrigation. Recreational use of the Columbia River was also considered, resulting in direct exposure from water, and radionuclides deposited on the shoreline, and doses from ingestion of locally caught Columbia River fish. This individual also receives exposure via the air pathways, including direct exposure to a contaminated plume, inhalation, external exposure to radionuclides that deposit on the ground, and ingestion of locally grown food products contaminated by air deposition.

Sagemoor Maximally Exposed Individual. Because of the shift in Hanford Site operations from nuclear weapons production to the current mission of managing waste products, cleaning up the site, and researching new ideas and technologies for waste disposal and cleanup, the significance of air emissions from production facilities in the 200 Areas has decreased compared to emissions from research facilities in the 300 Area.

An individual in the Sagemoor area, located approximately 1.4 kilometers $(0.87$ mile) directly across the Columbia River from the 300 Area, receives the maximum exposure to airborne emissions from the 300 Area. However, domestic water at this location comes from wells rather than from the river, and wells in this region are not directly contaminated by radionuclides of Hanford Site origin (EPS-87-367A). Because the farms located across from the 300 Area obtain irrigation water from the Columbia River upstream of the Hanford Site, researchers conservatively assumed that the diet of the Sagemoor area individual consisted entirely of food purchased from the Riverview area, which could contain radionuclides present in both 
the liquid effluent and air emissions pathways. The added contribution of radionuclides in the Riverview area irrigation water maximizes the calculated dose from the air and water pathways combined.

Eighty-kilometer (50-mile) Collective Population Doses (person-rem [person-sievert]). Regulatory limits have not been established for population doses. However, evaluation of the collective population doses to all residents within an 80-kilometer (50-mile) radius of Hanford Site operations is required by DOE Order 5400.5, Chg 2. The radiological dose to the collective population within 80 kilometers (50 miles) of the site operations areas was calculated to confirm adherence to DOE environmental protection policies, and provide information to the public. The 80-kilometer (50-mile) collective dose is the sum of doses to all individual members of the public within 80 kilometers ( 50 miles) of Hanford Site operations areas.

Pathways similar to those used for the maximally exposed individual were used to calculate doses to the offsite population. In calculating the effective dose, an estimate was made of the fraction of the offsite population expected to be affected by each pathway. The exposure pathways for the population are as follows:

- Drinking water - The cities of Richland and Pasco obtain all or part of their municipal water directly from the Columbia River downstream from the Hanford Site; Kennewick obtains their municipal water indirectly from the river from nearby wells. Approximately 130,000 people in the Tri-Cities ${ }^{(c)}$ are assumed to obtain all of their drinking water directly from the Columbia River or from wells adjacent to the river.

- Irrigated food - Columbia River water is withdrawn for irrigation of small vegetable gardens and farms in the Riverview area of Pasco in Franklin County. It is assumed that enough food is grown in this area to feed an estimated 2,000 people. Commercial crops are also irrigated by Columbia River water in the Horn Rapids area of Benton County. These crops are widely distributed.

- Columbia River recreation - These activities include swimming, boating, and shoreline recreation. Specific pathways include external exposure from radionuclides in the water or on the shoreline and ingestion of river water while swimming. An estimated 125,000 people who reside within 80 kilometers (50 miles) of the Hanford Site operations areas are assumed to be affected by these pathways.

- Fish consumption - Population doses from the consumption of fish obtained locally from the Columbia River were calculated from an estimated total annual catch of 15,000 kilograms (33,075 pounds) per year without reference to a specified human group of consumers.

\section{Data for Dose Calculations}

The data that are needed to perform dose calculations are based on either measured upstream or downstream differences or measured effluent releases, and include information on initial transport through the atmosphere or river, transfer or accumulation in terrestrial and aquatic pathways, and public exposure. By comparison, radiological dose calculations based on measured activities of radionuclides in food require data describing only dietary and recreational activities and exposure times. These data are discussed below.

\section{Population Distribution and Atmospheric Dispersion}

Geographic distributions of the population residing within an 80-kilometer (50-mile) radius of the Hanford Site operating areas are shown in PNNL-19455, APP. 1. These distributions are based on 2000 Bureau of the Census data (PNNL-14428). These data influence the population dose by providing estimates of the number of people exposed to radioactive effluent and their proximity to the points of release.

\section{Terrestrial and Aquatic Pathways}

Important parameters affecting the movement of radionuclides within exposure pathways such as irrigation rates, growing periods, and holdup periods are listed in Table E.1.

(c) The cities of Pasco, Kennewick, and Richland are known as the Tri-Cities. 


\begin{tabular}{|c|c|c|c|c|c|c|c|}
\hline \multirow{4}{*}{$\frac{\text { Medium }}{\text { Leafy vegetables }}$} & \multicolumn{7}{|c|}{ Table E.1. Food Pathway Parameters Used in Hanford Site Dose Calculations, 2009} \\
\hline & \multicolumn{2}{|c|}{ Holdup (days) $^{(a)}$} & \multirow[b]{2}{*}{$\begin{array}{c}\text { Growing } \\
\text { Period (days) } \\
\end{array}$} & \multirow{2}{*}{\multicolumn{2}{|c|}{$\begin{array}{c}\text { Yield } \\
\mathrm{kg} / \mathrm{m}^{2}\left(\mathrm{lb} / \mathrm{yd}^{2}\right) \\
\end{array}$}} & \multirow{2}{*}{\multicolumn{2}{|c|}{$\begin{array}{c}\text { Irrigation Rate } \\
\mathrm{L} / \mathrm{m}^{2} / \mathrm{mo}\left(\mathrm{gal} / \mathrm{yd}^{2} / \mathrm{mo}\right)\end{array}$}} \\
\hline & $\begin{array}{l}\text { Maximally Exposed } \\
\text { Individual }\end{array}$ & $\begin{array}{c}\text { Average } \\
\text { Individual }\end{array}$ & & & & & \\
\hline & $\frac{1}{1}$ & 14 & 90 & 1.5 & $(3.3)$ & 150 & $(40)$ \\
\hline Other vegetables & 5 & 14 & 90 & 4 & $(8.2)$ & 170 & $(45)$ \\
\hline Fruit & 5 & 14 & 90 & 2 & $(4.41)$ & 150 & $(40)$ \\
\hline Cereal & 180 & 180 & 90 & 0.8 & $(1.76)$ & 0 & \\
\hline Eggs & 1 & 18 & 90 & 0.8 & $(1.76)$ & 0 & \\
\hline Milk & 1 & 4 & -. & -. & & .. & \\
\hline Hay & $100^{(\mathrm{b})}$ & $100^{(b)}$ & 45 & 2 & $(4.41)$ & 200 & (53) \\
\hline Pasture & 0 & 0 & 30 & 1.5 & $(3.3)$ & 200 & (53) \\
\hline Red meat & 15 & 34 & -. & -. & & -. & \\
\hline Hay & $100^{(b)}$ & $100^{(b)}$ & 45 & 2 & $(4.41)$ & 200 & (53) \\
\hline Grain & $180^{(\mathrm{b})}$ & $180^{(\mathrm{b})}$ & 90 & 0.8 & $(1.76)$ & 0 & \\
\hline Poultry & 1 & 34 & 90 & 0.8 & $(1.76)$ & 0 & \\
\hline Fish & 1 & 1 & .. & .. & & .. & \\
\hline Drinking water ${ }^{(c)}$ & 1 & 1 & -. & .. & & .. & \\
\hline $\begin{array}{l}\text { (a) Holdup is the } \\
\text { (b) Holdup in da } \\
\text { (c) Drinking wat }\end{array}$ & $\begin{array}{l}\text { ne between harvest and c } \\
\text { etween harvest and cons } \\
\text { ooldup in calculations is } 1\end{array}$ & $\begin{array}{l}\text { sumption. } \\
\text { ption by farm } \\
\text { days for } 100\end{array}$ & $\begin{array}{l}\text { als. } \\
\text { eleases and } 1.0 \mathrm{~d} \text {. }\end{array}$ & $00 \mathrm{Are}$ & releases. & & \\
\hline
\end{tabular}

Certain parameters are specific to the lifestyles of either the DOE or EPA maximally exposed individuals or individuals for whom average parameter values were used.

\section{Public Exposure}

The offsite radiological dose is related to the extent of external exposure to or intake of radionuclides released from Hanford Site operations. Tables E.2 through E.4 give the parameters describing the diet, residency, and river recreation parameters assumed for maximally exposed and average individuals.

\section{Dose Calculation Documentation}

DOE established the Hanford Dose Overview Panel to promote consistency and defensibility of environmental dose calculations at the Hanford Site. The panel was responsible for defining standards, documented computer codes, and input parameters used for radiological dose calculations for the public in the vicinity of the Hanford Site. This panel is no longer functional. Procedures, models, and parameters previously defined by the panel were used to calculate the radiological doses (PNL-3777). The inputs previously used in GENII Version 1.485 were implemented in GENII Version 2 for the maximally exposed individual dose calculations, as described in PNNL-19168. Population doses were calculated in a similar manner and then reviewed. Summaries of dose calculation technical details for this report are shown in Tables E.5 and E.6 and in PNNL-19455, APP. 1.

To reveal the impact of using the updated version of GENII, the maximally exposed individual and population dose impacts were also calculated in the historic manner using GENII Version 1.485. Dose impact results are presented in Tables E.7 and E.8. These tables can be evaluated against Tables 8.12.1 and 8.12.2, which implement GENII Version 2.09 calculations.

\section{Area Drinking Water}

Drinking water at the Fast Flux Test Facility contained slightly elevated levels of tritium. The potential doses to 400 Area workers consuming this water in 2009 are provided in Table E.9. 


\begin{tabular}{|c|c|c|c|c|}
\hline \multirow{3}{*}{$\frac{\text { Medium }}{\text { Leafy vegetables }}$} & \multicolumn{4}{|c|}{ Consumption } \\
\hline & \multicolumn{2}{|c|}{$\begin{array}{l}\text { Maximally Exposed } \\
\text { Individual }\end{array}$} & \multicolumn{2}{|c|}{$\begin{array}{c}\text { Average } \\
\text { Individual }\end{array}$} \\
\hline & 30 kg/yr & (66 lb/yr) & $15 \mathrm{~kg} / \mathrm{yr}$ & (33 lb/yr) \\
\hline Other vegetables & $220 \mathrm{~kg} / \mathrm{yr}$ & (485 lb/yr) & $140 \mathrm{~kg} / \mathrm{yr}$ & $(310 \mathrm{lb} / \mathrm{yr})$ \\
\hline Fruit & $330 \mathrm{~kg} / \mathrm{yr}$ & (728 lb/yr) & $64 \mathrm{~kg} / \mathrm{yr}$ & $(140 \mathrm{lb} / \mathrm{yr})$ \\
\hline Grain & 80 kg/yr & $(180 \mathrm{lb} / \mathrm{yr})$ & $72 \mathrm{~kg} / \mathrm{yr}$ & $(160 \mathrm{lb} / \mathrm{yr})$ \\
\hline Eggs & $30 \mathrm{~kg} / \mathrm{yr}$ & $(66$ lb/yr) & $20 \mathrm{~kg} / \mathrm{yr}$ & (44 lb/yr) \\
\hline Milk & $270 \mathrm{~L} / \mathrm{yr}$ & (71 gal/yr) & $230 \mathrm{~L} / \mathrm{yr}$ & $(61 \mathrm{gal} / \mathrm{yr})$ \\
\hline Red meat & $80 \mathrm{~kg} / \mathrm{yr}$ & $(180 \mathrm{lb} / \mathrm{yr})$ & $70 \mathrm{~kg} / \mathrm{yr}$ & $(150 \mathrm{lb} / \mathrm{yr})$ \\
\hline Poultry & $18 \mathrm{~kg} / \mathrm{yr}$ & $(40$ lb/yr) & $8.5 \mathrm{~kg} / \mathrm{yr}$ & $(19 \mathrm{lb} / \mathrm{yr})$ \\
\hline Fish & $40 \mathrm{~kg} / \mathrm{yr}$ & (88 lb/yr) & ..(a) & \\
\hline Drinking water & $730 \mathrm{~L} / \mathrm{yr}$ & (193 gal/yr) & $440 \mathrm{~L} / \mathrm{yr}$ & $(116 \mathrm{gal} / \mathrm{yr})$ \\
\hline \multicolumn{5}{|c|}{$\begin{array}{l}\text { (a) Average individual consumption not identified; radiation doses were calculated based } \\
\text { on estimated total annual catch of } 15,000 \mathrm{~kg} / \mathrm{yr}(33,075 \mathrm{lb} / \mathrm{yr}) \text {. }\end{array}$} \\
\hline
\end{tabular}

\begin{tabular}{|c|c|c|}
\hline \multirow[b]{3}{*}{ Parameter } & $\begin{array}{l}\text { sidency Parameters U } \\
\text { Dose Calculations, } 2\end{array}$ & $\begin{array}{l}d \text { in } \\
99\end{array}$ \\
\hline & \multicolumn{2}{|c|}{ Exposure (hr/yr) } \\
\hline & $\begin{array}{l}\text { Maximally Exposed } \\
\text { Individual }\end{array}$ & $\begin{array}{c}\text { Average } \\
\text { Individual }\end{array}$ \\
\hline Ground contamination & 4,383 & 2,920 \\
\hline Air submersion & 8,766 & 8,766 \\
\hline Inhalation $^{(a)}$ & 8,766 & 8,766 \\
\hline
\end{tabular}

\begin{tabular}{|c|c|c|}
\hline \multicolumn{3}{|c|}{$\begin{array}{l}\text { Table E.4. Columbia River Recreational Parameters } \\
\text { Used in Hanford Site Dose Calculations, } 2009\end{array}$} \\
\hline \multirow[b]{2}{*}{ Parameter } & \multicolumn{2}{|c|}{ Exposure $(\mathbf{h r} / \mathbf{y r})^{(\mathrm{a})}$} \\
\hline & $\begin{array}{l}\text { Maximally Exposed } \\
\text { Individual }\end{array}$ & $\begin{array}{l}\text { Average } \\
\text { Individual }\end{array}$ \\
\hline Shoreline & 500 & 17 \\
\hline Boating & 100 & 5 \\
\hline Swimming & 100 & 10 \\
\hline \multicolumn{3}{|c|}{$\begin{array}{l}\text { (a) Transit times for water to irrigation and recreation sites vary } \\
\text { by release and receptor locations. }\end{array}$} \\
\hline
\end{tabular}




\begin{tabular}{|c|c|c|c|}
\hline \multicolumn{3}{|c|}{ Table E.5. Technical Details of Airborne Release Dose Calculations for the Hanford Site, 2009} & \\
\hline Emission facilities & \multicolumn{3}{|l|}{ 100-K Area, 200 Areas, 300 Area, 400 Area } \\
\hline Releases (Ci) & \multicolumn{3}{|l|}{ See Table 8.1.1 } \\
\hline Computer code & \multicolumn{3}{|c|}{ GENII, Version 2.09, December 2009 (PNNL-14583) } \\
\hline Meteorological conditions & \multicolumn{3}{|c|}{$\begin{array}{l}2009 \text { hourly data collected from 100-K Area, } 200 \text { Area Hanford Meteorological Station (HMS) } \\
300 \text { Area, and } 400 \text { Area stations }\end{array}$} \\
\hline \multirow[t]{2}{*}{ Particulate $\overline{\mathrm{X}} / \mathrm{Q}$ dispersion factors } & & $\begin{array}{l}\text { Maximally Exposed Individual } \\
\qquad\left(\mathrm{sec} / \mathrm{m}^{3}\right)\end{array}$ & $\begin{array}{c}\text { Population } \\
\left(\text { person-sec } / \mathrm{m}^{3}\right)\end{array}$ \\
\hline & $\begin{array}{l}\text { 100-K Area }(10-\mathrm{m}[33-\mathrm{ft}] \text { release height }) \\
200 \text { HMS }(89 \mathrm{~m}[292-\mathrm{ft}] \text { release height }) \\
300 \text { Area }(10 \mathrm{~m}[33-\mathrm{ft}] \text { release height }) \\
400 \text { Area }(10 \mathrm{~m}[33-\mathrm{ft}] \text { release height })\end{array}$ & $\begin{array}{l}4.61 \times 10^{-9} \\
7.33 \times 10^{-9} \\
1.74 \times 10^{-6} \\
5.32 \times 10^{-8}\end{array}$ & $\begin{array}{l}1.20 \times 10^{-3} \\
1.32 \times 10^{-3} \\
5.70 \times 10^{-3} \\
3.31 \times 10^{-3}\end{array}$ \\
\hline Population, 80 km (50 mi) & \multicolumn{3}{|c|}{$\begin{array}{l}100-\text { K Area }(\sim 482,000), 200 \text { HMS }(\sim 486,000), 300 \text { Area }(\sim 349,000), 400 \text { Area }(\sim 354,000) \\
\text { (PNNL-14428) }\end{array}$} \\
\hline Doses calculated & \multicolumn{3}{|c|}{$\begin{array}{l}\text { Chronic, } 1 \text {-yr exposure, } 50 \text {-yr committed internal dose equivalent, and annual effective dose } \\
\text { equivalent to individual and population }\end{array}$} \\
\hline Pathways considered & \multicolumn{3}{|c|}{$\begin{array}{l}\text { External exposure to contaminant plume and atmospheric contaminants deposited on the } \\
\text { ground } \\
\text { Inhalation } \\
\text { Ingestion of foods produced locally }\end{array}$} \\
\hline Dose calculations details & \multicolumn{3}{|c|}{$\begin{array}{l}\text { GENII, Version 1.485, Food Transfer Library (Rev 8/28/88) transcribed to GENII, Version } 2.09 \\
\text { GENII, Version } 2.09 \text { with ICRP } 60 \text { (ICRP 1991) weighting factors }\end{array}$} \\
\hline
\end{tabular}

\begin{tabular}{|c|c|}
\hline Tabl & Details of Liquid Release Dose Calculations for the Hanford Site, 2009 \\
\hline Release facilities & 100-K Area, 200 Areas \\
\hline Releases $(\mathrm{Ci})$ & $\begin{array}{l}\text { 100-K Area - see Table } 8.3 .2 \\
200 \text { Areas - see Tables C. } 2 \text { and C. } 3\end{array}$ \\
\hline Computer code & GENII, Version 2.09, December 2009 (PNNL-14583) \\
\hline Mean river flow & $2,657 \mathrm{~m}^{3} / \mathrm{sec}\left(93,830 \mathrm{ft}^{3} / \mathrm{sec}\right)$ \\
\hline Exposed population & $\begin{array}{l}130,000 \text { for drinking water pathway } \\
125,000 \text { for aquatic recreation pathway } \\
2,000 \text { for irrigated food consumption pathway }\end{array}$ \\
\hline Doses calculated & $\begin{array}{l}\text { Chronic, } 1 \text {-yr exposure, } 50 \text {-yr committed internal dose equivalent, and annual effective dose } \\
\text { equivalent to individual and population }\end{array}$ \\
\hline Pathways considered & $\begin{array}{l}\text { External exposure to irrigated soil, river water, and shoreline sediments } \\
\text { Ingestion of irrigated farm products and aquatic foods }(15,000 \mathrm{~kg} / \mathrm{yr}[33,075 \mathrm{lb} / \mathrm{yr}] \text { total harvest } \\
\text { of Columbia River fish) }\end{array}$ \\
\hline Dose calculation details & $\begin{array}{l}\text { GENII, Version 1.485, Food Transfer Library (Rev 8/28/88) transcribed to GENII, Version } 2.09 \\
\text { GENII, Version 2.09, GENII, Version } 2.09 \text { with ICRP } 60 \text { (ICRP 1991) weighting factors }\end{array}$ \\
\hline
\end{tabular}




\begin{tabular}{|c|c|c|c|c|c|c|}
\hline \multirow[b]{3}{*}{ Effluent } & \multicolumn{5}{|c|}{$\begin{array}{l}\text { Table E.7. Dose (mrem) to the Hypothetical, Maximally Exposed Individual Residing } \\
\text { at Sagemoor from } 2009 \text { Hanford Site Operations (using GENII Version 1.485) }\end{array}$} & \multirow{3}{*}{$\begin{array}{l}\mathbf{1} \\
\begin{array}{c}\text { Pathway } \\
\text { Total }\end{array}\end{array}$} \\
\hline & \multirow[b]{2}{*}{$\underline{\text { Pathway }}$} & \multicolumn{4}{|c|}{ Operating Area Contribution Doses, mrem } & \\
\hline & & $\begin{array}{c}100 \\
\underline{\text { Areas }}\end{array}$ & $\begin{array}{l}200 \\
\underline{\text { Areas }}\end{array}$ & $\begin{array}{l}300 \\
\text { Area }\end{array}$ & $\begin{array}{l}400 \\
\text { Area }\end{array}$ & \\
\hline \multirow[t]{2}{*}{ Air } & $\begin{array}{l}\text { External } \\
\text { Inhalation } \\
\text { Foods }\end{array}$ & $\begin{array}{l}1.5 \times 10^{-8} \\
6.5 \times 10^{-5} \\
1.4 \times 10^{-6}\end{array}$ & $\begin{array}{l}4.1 \times 10^{-7} \\
5.3 \times 10^{-5} \\
2.9 \times 10^{-4}\end{array}$ & $\begin{array}{l}2.7 \times 10^{-4} \\
6.7 \times 10^{-3} \\
2.8 \times 10^{-2}\end{array}$ & $\begin{array}{l}3.6 \times 10^{-9} \\
2.0 \times 10^{-9} \\
3.8 \times 10^{-8}\end{array}$ & $\begin{array}{l}2.7 \times 10^{-4} \\
6.8 \times 10^{-3} \\
2.8 \times 10^{-2}\end{array}$ \\
\hline & Subtotal air & $6.6 \times 10^{-5}$ & $3.4 \times 10^{-4}$ & $3.5 \times 10^{-2}$ & $4.4 \times 10^{-8}$ & $3.5 \times 10^{-2}$ \\
\hline \multirow[t]{2}{*}{ Water } & $\begin{array}{l}\text { Recreation } \\
\text { Foods } \\
\text { Fish }\end{array}$ & $\begin{array}{l}3.4 \times 10^{-6} \\
9.1 \times 10^{-5} \\
6.0 \times 10^{-4}\end{array}$ & $\begin{array}{l}8.2 \times 10^{-5} \\
4.0 \times 10^{-3} \\
4.1 \times 10^{-3}\end{array}$ & $\begin{array}{l}0.0 \\
0.0 \\
0.0\end{array}$ & $\begin{array}{l}0.0 \\
0.0 \\
0.0\end{array}$ & $\begin{array}{l}8.5 \times 10^{-5} \\
4.1 \times 10^{-3} \\
4.7 \times 10^{-3}\end{array}$ \\
\hline & Subtotal water & $6.9 \times 10^{-4}$ & $8.2 \times 10^{-3}$ & 0.0 & 0.0 & $8.9 \times 10^{-3}$ \\
\hline Combined total & & $7.6 \times 10^{-4}$ & $8.5 \times 10^{-3}$ & $3.5 \times 10^{-2}$ & $4.4 \times 10^{-8}$ & $4.4 \times 10^{-2}$ \\
\hline
\end{tabular}

Table E.8. Collective Dose (person-rem) to the Population from 2009 Hanford Site Operations (using GENII Version 1.485)

\begin{tabular}{|c|c|c|c|c|c|c|}
\hline \multirow[b]{3}{*}{ Effluent } & \multicolumn{5}{|c|}{$\begin{array}{l}\text { Table E.8. Collective Dose (person-rem) to the Population from } 2009 \text { Hanford Site } \\
\text { Operations (using GENII Version 1.485) }\end{array}$} & \\
\hline & \multirow[b]{2}{*}{ Pathway } & \multicolumn{5}{|c|}{ Operating Area Contribution Doses, person-rem } \\
\hline & & $\begin{array}{l}100 \\
\underline{\text { Areas }}\end{array}$ & $\begin{array}{c}200 \\
\text { Areas }\end{array}$ & $\begin{array}{l}300 \\
\text { Area }\end{array}$ & $\begin{array}{c}400 \\
\text { Area }\end{array}$ & $\begin{array}{l}\text { Pathway } \\
\text { Total }\end{array}$ \\
\hline \multirow[t]{2}{*}{ Air } & $\begin{array}{l}\text { External } \\
\text { Inhalation } \\
\text { Foods }\end{array}$ & $\begin{array}{l}3.0 \times 10^{-6} \\
2.0 \times 10^{-2} \\
2.2 \times 10^{-4}\end{array}$ & $\begin{array}{l}3.5 \times 10^{-5} \\
7.0 \times 10^{-3} \\
2.6 \times 10^{-2}\end{array}$ & $\begin{array}{l}3.0 \times 10^{-3} \\
7.3 \times 10^{-2} \\
1.8 \times 10^{-1}\end{array}$ & $\begin{array}{l}1.6 \times 10^{-7} \\
1.3 \times 10^{-7} \\
1.8 \times 10^{-6}\end{array}$ & $\begin{array}{l}3.0 \times 10^{-3} \\
1.0 \times 10^{-1} \\
2.1 \times 10^{-1}\end{array}$ \\
\hline & Subtotal air & $2.0 \times 10^{-2}$ & $3.3 \times 10^{-2}$ & $2.6 \times 10^{-1}$ & $2.1 \times 10^{-6}$ & $3.1 \times 10^{-1}$ \\
\hline \multirow[t]{2}{*}{ Water } & $\begin{array}{l}\text { Recreation } \\
\text { Foods } \\
\text { Fish } \\
\text { Drinking water }\end{array}$ & $\begin{array}{l}1.5 \times 10^{-5} \\
1.2 \times 10^{-4} \\
2.3 \times 10^{-4} \\
5.7 \times 10^{-4}\end{array}$ & $\begin{array}{l}4.0 \times 10^{-4} \\
4.3 \times 10^{-3} \\
1.5 \times 10^{-3} \\
1.5 \times 10^{-1}\end{array}$ & $\begin{array}{l}0.0 \\
0.0 \\
0.0 \\
0.0\end{array}$ & $\begin{array}{l}0.0 \\
0.0 \\
0.0 \\
0.0\end{array}$ & $\begin{array}{l}4.1 \times 10^{-4} \\
4.4 \times 10^{-3} \\
1.7 \times 10^{-3} \\
1.5 \times 10^{-1}\end{array}$ \\
\hline & Subtotal water & $9.3 \times 10^{-4}$ & $1.6 \times 10^{-1}$ & 0.0 & 0.0 & $1.6 \times 10^{-1}$ \\
\hline \multicolumn{2}{|c|}{ Combined total } & $2.1 \times 10^{-2}$ & $1.9 \times 10^{-1}$ & $2.6 \times 10^{-1}$ & $2.1 \times 10^{-6}$ & $4.7 \times 10^{-1}$ \\
\hline
\end{tabular}

\begin{tabular}{|c|c|c|c|}
\hline Table E.9. Annual Dose to 400 Area Workers from Ingestion \\
of Onsite Drinking Water, 2009
\end{tabular}




\section{References}

40 CFR 61, Subpart H. 2009. "National Emission Standards for Hazardous Air Pollutants." Subpart H, "National Emission Standards for Emissions of Radionuclides Other Than Radon from Department of Energy Facilities." Code of Federal Regulations, U.S. Environmental Protection Agency. Accessed May 17, 2010, at http://www.gpoaccess.gov/cfr/ index.html.

DOE Order 5400.5, Chg 2. 1993. "Radiation Protection of the Public and the Environment." U.S. Department of Energy, Washington, D.C.

DOE/RL-2010-17. 2010. Radionuclide Air Emissions Report for the Hanford Site, Calendar Year 2009. U.S. Department of Energy, Richland Operations Office, Richland, Washington.

DOE-STD-1153-2002. 2002. A Graded Approach for Evaluating Radiation Doses to Aquatic and Terrestrial Biota. Final Technical Standard, U.S. Department of Energy and the Office of Environmental Policy and Guidance, Washington, D.C.

EPS-87-367A. 1988. Investigation Report: Radiological Evaluation of Well Water in Franklin County. Washington State Department of Social and Health Services, Environmental Protection Section, Olympia, Washington.

International Commission on Radiological Protection. 1979a. "ICRP Publication 30, Part 1, Limits for Intakes of Radionuclides by Workers." Annals of the ICRP 2(3/4), Pergamon Press, Elmsford, New York.

International Commission on Radiological Protection. 1979b. "ICRP Publication 30, Supplement to Part 1, Limits for Intakes of Radionuclides by Workers." Annals of the ICRP 3(1-4), Pergamon Press, Elmsford, New York.

International Commission on Radiological Protection. 1980. "ICRP Publication 30, Part 2, Limits for Intakes of Radionuclides by Workers." Annals of the ICRP 4(3-4), Pergamon Press, Elmsford, New York.

International Commission on Radiological Protection. 1981a. "ICRP Publication 30, Supplement to Part 2, Limits for Intakes of Radionuclides by Workers." Annals of the ICRP 5(1-6), Pergamon Press, Elmsford, New York.
International Commission on Radiological Protection. 1981b. "ICRP Publication 30, Part 3 Including Addendum to Parts 1 and 2, Limits for Intakes of Radionuclides by Workers." Annals of the ICRP 6(2-3), Pergamon Press, Elmsford, New York.

International Commission on Radiological Protection. 1982a. "ICRP Publication 30, Supplement A to Part 3, Limits for Intakes of Radionuclides by Workers." Annals of the ICRP 7(1-3), Pergamon Press, Elmsford, New York.

International Commission on Radiological Protection. 1982b. "ICRP Publication 30, Supplement B to Part 3 Including Addendum to Supplements to Parts 1 and 2, Limits for Intakes of Radionuclides by Workers." Annals of the ICRP 8(1-3), Pergamon Press, Elmsford, New York.

International Commission on Radiological Protection. 1988. "ICRP Publication 30, Part 4, Limits for Intakes of Radionuclides by Workers: an Addendum." Annals of the ICRP 19(4), Pergamon Press, Elmsford, New York.

International Commission on Radiological Protection. 1991. "ICRP Publication 60, 1990 Recommendations of the International Commission on Radiological Protection." Annals of the ICRP 21(1-3), Pergamon Press, Elmsford, New York.

PNL-3777, Rev. 2. 1993. Recommended Environmental Dose Calculation Methods and Hanford-Specific Parameters. RG Schreckhise, K Rhoads, JS Davis, BA Napier, and JV Ramsdell, Pacific Northwest Laboratory, Richland, Washington.

PNL-6584. 1988. GENII - The Hanford Environmental Radiation Dosimetry Software System, 3 vols. BA Napier, RA Peloquin, DL Strenge, and JV Ramsdell, Pacific Northwest Laboratory, Richland, Washington.

PNNL-14428. 2004. Hanford Area 2000 Population. DB Elliott, MJ Scott, EJ Antonio, and K Rhoads, Pacific Northwest National Laboratory, Richland, Washington.

PNNL-14583, Rev 3, 2009. GENII Version 2 Users' Guide. BA Napier, Pacific Northwest National Laboratory, Richland, Washington. 
PNNL-14584, Rev. 3. 2009. GENII Version 2.09 Software Design Document. BA Napier, DL Strenge, JV Ramsdell Jr., PW Eslinger, and C Fosmire, Pacific Northwest National Laboratory, Richland, Washington.

PNL-19168. 2010. Hanford Site Annual Report Radiological Dose Calculation Upgrade Evaluation. SF Snyder, Pacific Northwest National Laboratory, Richland, Washington.
PNNL-19455, APP. 1. 2010. Hanford Site Environmental Surveillance Data for Calendar Year 2009. LE Bisping, Pacific Northwest National Laboratory, Richland, Washington. 


\section{Appendix F}

\section{Radionuclides Measured by Gamma Spectroscopy (Gamma Scan)}

\section{EJ Antonio}

Gamma rays, a form of high energy electromagnetic radiation that originate from the nucleus of an atom, have very short wavelengths and can easily penetrate all but the most dense materials. Gamma-emitting radionuclides may be natural in origin, result from Hanford Site operations, or be related to fallout from historic nuclear weapons testing.
Gamma rays can be detected and quantified by inorganic scintillators, which convert energy into visible light. Scintillators may include thallium-activated sodium iodide crystals $(\mathrm{NaI}[\mathrm{Tl}])$ or germanium semiconductor detectors and their associated electronics (gamma spectroscopy). A partial list of radionuclides whose activity is measurable using gamma spectroscopy is provided in Table F.1.

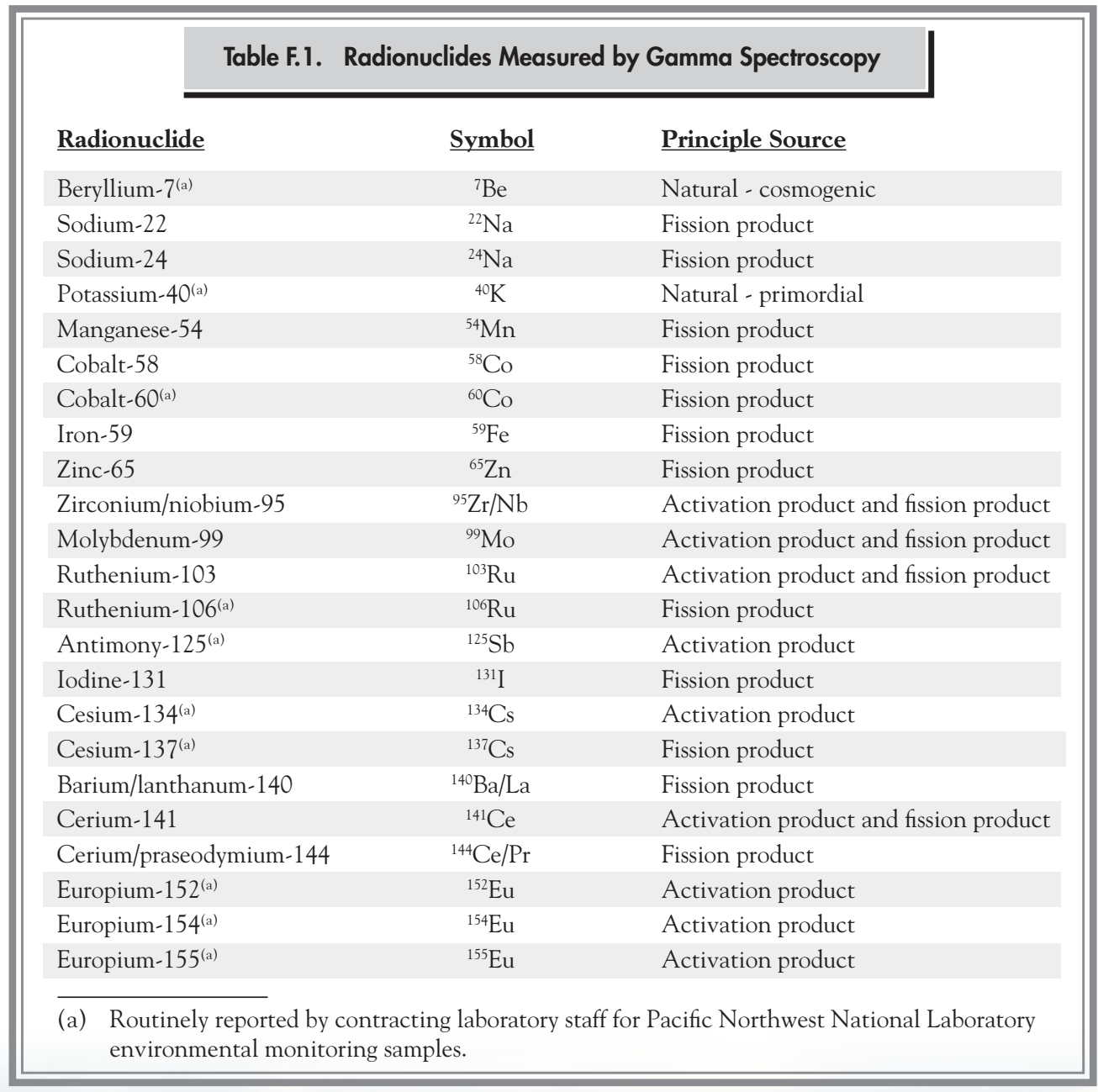




\section{Distribution List}

\section{Format/Number}

\section{OFFSITE}

CD Mary T. Adams, MS E2 C40

U.S. Nuclear Regulatory Commission

Washington, DC 20555

CD Lynn Albin, MS 7827

Division of Radiation Protection

Washington State Department of Health

P.O. Box 47827

Olympia, WA 98504-7827

CD Bradley D. Andersen

Idaho National Laboratory

P.O. Box 1625, Mail Stop 6194

Idaho Falls, ID 83415

P Charlene Andrade

Hanford Natural Resource Trustee Council

Washington Department of Fish and Wildlife

600 Capitol Way North

Olympia, WA 98501-1091

P/S Candace Andrews

Richland Public Information Office

550 Swift Boulevard

Richland, WA 99352

CD John Andrews

Regional Director

Washington Department of Fish and Wildlife 2315 N. Discovery Place

Spokane, WA 99216-1566
CD Mike R. Ault

Facility Manager

US Ecology, Inc.

1777 Terminal Drive

Richland, WA 99352

P Mary C. Baker

NOAA Northwest Regional Office

Hanford Natural Resource Trustee Council

7600 Sand Point Way N.E.

Seattle, WA 98115

CD Mary M. Baranek

U.S. Department of Energy

Savannah River Site

P.O. Box A, Building 730-B

Aiken, SC 29802

CD John Bargar, MS-69

Stanford Linear Accelerator Center

2575 Sand Hill Road, Building 137, Room 221

Menlo Park, CA 94025

P/CD/S Basin City Branch of Mid-Columbia Library

50-A N. Canal Boulevard

Basin City, WA 99343

P/S Robert W. Batty, President

Washington State Chapter

Republicans for Environmental Protection

South 14017 Merriney Road

Cheney, WA 99004

$\mathrm{CD} / \mathrm{S}$ James Beaver

Benton County Commissioner, District 3

Benton County Courthouse

P.O. Box 190

Prosser, WA 99350

P Cassandra Begay

Los Alamos Site Office

528 35th Street

Los Alamos, NM 87544 
CD/S Max Benitz, Jr.

Benton County Commissioner, District 2

Benton County Courthouse

P.O. Box 190

Prosser, WA 99350

$\mathrm{P} / \mathrm{CD} / \mathrm{S}$ Benton City Branch of the Mid-Columbia Library

810 Horne Drive

Benton City, WA 99320

CD Benton Clean Air Authority

526 S. Clodfelter Road

Kennewick, WA 99336-9594

CD Gabriel Bohnee, Director

Environmental Restoration and Waste

Management

Nez Perce Tribe

P.O. Box 365

Lapwai, ID 83540

2P Carol M. Borgstrom, Director

Office of NEPA Policy and Compliance

U.S. Department of Energy, GC-20

1000 Independence Avenue S.W.

Washington, DC 20585

CD/S Leo Bowman

Benton County Commissioner, District 1

Benton County Courthouse

P.O. Box 190

Prosser, WA 99350

P/CD/S Burbank Library

875 S. Lake Road

Burbank, WA 99323

CD John Burns, Operations Manager

Franklin County Irrigation District No. 1

P.O. Box 3907

Pasco, WA 99302

CD Norm Buske, Director

The RadioActivist Campaign

7312 N.E. North Shore Road

Belfair, WA 98528

CD Paula Call

U.S. Fish and Wildlife Service

64 Maple Street

Burbank, WA 99323-0521
P/S Senator Maria Cantwell

United States Senate

511 Dirkson Senate Office Building

Washington, DC 20510

CD/S Representative Bruce Chandler

15th Legislative District

427B Legislative Building

P.O. Box 40600

Olympia, WA 98504-0600

CD Coeur d'Alene Tribe

850 A. Street

P.O. Box 409

Plummer, ID 83851

CD Columbia National Wildlife Refuge

U.S. Fish and Wildlife Service

735 E. Main Street

P.O. Drawer F

Othello, WA 99344

CD/S The Columbian

P.O. Box 180

Vancouver, WA 98666-0180

CD The Confederated Tribes of the Umatilla Indian

Reservation

Department of Natural Resources

P.O. Box 638

Pendleton, OR 97801

$\mathrm{P} / \mathrm{CD} / \mathrm{S}$ Connell Branch of the Mid-Columbia Library

118 N. Columbia

Connell, WA 99326

CD John Cox

The Confederated Tribes of the Umatilla Indian

Reservation

P.O. Box 638

Pendleton, OR 97801

CD/S CREHST Museum

95 Lee Boulevard

Richland, WA 99352

CD Damon Delistraty

Washington State Department of Ecology

N. 4601 Monroe

Spokane, WA 99205-1295

$\mathrm{P} / \mathrm{S}$ Senator Jerome Delvin

8th Legislative District

201 Irv Newhouse Building

P.O. Box 40408

Olympia, WA 98504-0408 
P/CD Stephen L. Domotor

U.S. Department of Energy, HS-22

Office of Nuclear Safety and Environmental Assistance

1000 Independence Avenue S.W.

Washington, DC 20585

CD David Einan

Hanford Project Office

U.S. Environmental Protection Agency

Region 10

309 Bradley Boulevard, Suite 115

Richland, WA 99352

P Bill Elkins, Project Director

Bechtel National, Inc.

2435 Stevens Center Place

Richland, WA 99352

P/CD/S Energy Northwest Library

P.O. Box 968

Mailstop PE-20

Richland, WA 99352

CD Dennis Faulk

U.S. Environmental Protection Agency,

Region 10, Hanford Project Office

309 Bradley Boulevard, Suite 115

Richland, WA 99352

CD Federal Emergency Management Agency

Region X

130 228th Street S.W.

Bothell, WA 98021-8627

P/CD Pete Fledderman

Savannah River Site

Building 735-B

Aiken, SC 29808

CD Brent Foster

Executive Director

Columbia Riverkeeper

724 Oak Street

Hood River, OR 97031

CD/S John Fox, Mayor

City of Richland

P.O. Box 190

Richland, WA 99352

P/CD Mike Fox

7336 129th Avenue NE

Kirkland, WA 98033
CD/S Adam Fyall

Community Development Coordinator

Benton County Commissioner's Office

7122 West Okanogan Place, Building A

Kennewick, WA 99336

CD Andrew X. Gamache

Winemaker

Hyatt Vineyards

2020 Gilbert Road

Zillah, WA 98953

$\mathrm{P} / \mathrm{CD} / \mathrm{S}$ Norbert W. Golchert

Argonne National Laboratory - East

9700 S. Cass Avenue

Argonne, IL 60439

CD Larry Goldstein

Washington State Department of Ecology

P.O. Box 47600

Olympia, WA 98504-7600

CD Dibakar Goswami

Washington State Department of Ecology

Hanford Project Office

3100 Port of Benton Boulevard, H0-57

Richland, WA 99354

CD Government Accountability Project

1511 Third Avenue, Suite 321

Seattle, WA 98101

P/S Governor Christine Gregoire

Office of the Governor

P.O. Box 40002

Olympia, WA 98504-0002

P/S Representative Larry Haler

8th Legislative District

122D Legislative Building

P.O. Box 40600

Olympia, WA 98504-0600

CD David M. Hamby, Professor

Nuclear Engineering and Radiation Health

Physics

E120 Radiation Center

Oregon State University

Corvallis, OR 97331-5902

P/S Robert (Bill) W. Hanf

4103 South Fisher Street

Kennewick, WA 99337 
CD Barbara Harper

Manager, Environmental Health

The Confederated Tribes of the Umatilla Indian

Reservation

Hanford Natural Resource Trustee Council

P.O. Box 638

Pendleton, OR 97801

CD/S Stuart Harris, Director

The Confederated Tribes of the Umatilla Indian

Reservation

Department of Science and Engineering

Hanford Natural Resource Trustee Council

P.O. Box 638

Pendleton, OR 97801

P/S Congressman Richard (Doc) Hastings

4th Congressional District

2715 St. Andrews Loop, Suite D

Pasco, WA 99301

CD Heart of America Northwest

1314 56th Street NE, Suite 100

Seattle, WA 98105

CD Jim D. Heffner

Washington SRS

Building 735-B

Aiken, SC 29808

CD/S Representative Bill Hinkle

13th Legislative District

122C Legislative Building

P.O. Box 40600

Olympia, WA 98504-0600

CD/S Carl Holder

P.O. Box 1316

Pasco, WA 99301

CD Betsy S. Holmes

DOE Idaho Operations Office

1955 Fremont Avenue, MS-1216

Idaho Falls, ID 83415

CD/S Senator Janéa Holmquist

13th Legislative District

106B Irv Newhouse Building

P.O. Box 40413

Olympia, WA 98504-0413

CD/S Senator Jim Honeyford

15th Legislative District

107 Irv Newhouse Building

P.O. Box 40415

Olympia, WA 98504-0415
CD Balwan Hooda, MS-120

Environmental and Waste Management Services Division

Brookhaven National Laboratory

Building 120

P.O. Box 5000

Upton, NY 11973-5000

P Joan F. Hughes, MS-6137

Oak Ridge National Laboratory

P.O. Box 2008

Oak Ridge, TN 37831-6137

P/CD Susan C. Hughs

Hanford Natural Resource Trustee Council

Environmental Specialist

Oregon Department of Energy

Nuclear Safety and Engineering Siting

625 Marion Street NE, Suite 1

Salem, OR 97301-3742

CD Tracy A. Ikenberry

Dade Moeller \& Associates

1835 Terminal Drive, Suite 200

Richland, WA 99354

CD Russell Jim, Manager

Environmental Restoration and Waste Management Program

The Confederated Tribes and Bands of the Yakama Nation

2808 Main Street

Union Gap, WA 98903

P Matthew P. Johansen

Los Alamos Site Office

528 35th Street

Los Alamos, NM 87544

P/S Cindy Johnson

Interim City Manager

City Hall

505 Swift Boulevard

Richland, WA 99352

$\mathrm{P} / \mathrm{CD} / \mathrm{S}$ Kahlotus Branch of the Mid-Columbia Library

E. 255 Weston

Kahlotus, WA 99335

$\mathrm{P} / \mathrm{CD} / \mathrm{S}$ Keewaydin Park Branch of the Mid-Columbia

Library

405 S. Dayton

Kennewick, WA 99336 
CD William E. Kennedy

Dade Moeller \& Associates

1835 Terminal Drive, Suite 200, MS B8-24

Richland, WA 99354

P/CD/S Kennewick Branch of the Mid-Columbia Library

1620 S. Union Street

Kennewick, WA 99338

CD Paul M. Kesich

FERMI National Accelerator Laboratory

ESH, Environmental Team, MS 119 (WH 7E)

Wilson and Kirk Road

P.O. Box 500

Batavia, IL 60510-0500

P/S Representative Brad Klippert

8th Legislative District

122D Legislative Building

P.O. Box 40600

Olympia, WA 98504-0600

CD Paige Knight, President

Hanford Watch

4549 N.E. 39th Avenue

Portland, OR 97211

P/CD/S Knight Library

University of Oregon

1501 Kincaid

Eugene, OR 97403-1299

CD/S Robert Koch

Franklin County Commissioner, District 2

90 Access Road

Connell, WA 99326

P Dan Landeen

Hanford Natural Resource Trustee Council

Nez Perce Tribe

ERWM Program

P.O. Box 365

Lapwai, ID 83540

CD Barbara L. Larsen

Sandia National Laboratories, California

P.O. Box 969, MS 9221

Livermore, CA 94551-0969

CD Jerry D. Levine

Environment, Safety \& Health

MSO1 C-Site MOD VI 1

Princeton Physics Laboratory

P.O. Box 451

Princeton, NJ 08543-0451
P Charles B. Lewis

Acting Director, Office of Corporate Safety

Analysis

U.S. Department of Energy, HS-30

1000 Independence Avenue S.W.

Washington, DC 20585

CD Albert R. Mamatey

Savannah River Site

P.O. Box 616

Building 730-1B, Room 3021

Aiken, SC 29808

$\mathrm{P} / \mathrm{CD} / \mathrm{S}$ Brian Marquez

251 Lisa Lane

Pasco, WA 99301

CD Debra McBaugh

Division of Radiation Protection, MS 7827

Washington State Department of Health

P.O. Box 47827

Olympia, WA 98504-7827

CD Jay McConnaughey

Hanford Natural Resource Trustee Council

P.O. Box 6066

Kennewick, WA 99336-0066

P/CD/S Merrill's Corner Branch of the Mid-Columbia Library

5240 Eltopia West

Eltopia, WA 99330

P Caryle B. Miller

U.S. Department of Energy, SC-31.2

Germantown Building, Room G-236

1000 Independence Avenue S.W.

Washington, DC 20585-1290

CD/S Rick Miller

Franklin County Commissioner, District 3

4704 Mesquite Drive

Pasco, WA 99301

CD Armand Minthorn

The Confederated Tribes of the Umatilla Indian

Reservation

P.O. Box 638

Pendleton, OR 97801

P Beth A. Moore

U.S. Department of Energy, EM-22

Forrestal Building, Room 3E-066

1000 Independence Avenue S.W.

Washington, DC 20585 
P/S Senator Patty Murray

United States Senate

173 Russell Senate Office Building

Washington, DC 20510

2P/ Rosario L. Natoli

3CD/ Office of Analysis

3S U.S. Department of Energy, HS-32

1000 Independence Avenue S.W.

Washington, DC 20585

P/S Representative Terry Nealey

16th Legislative District

402 John L. O’Brien Building

P.O. Box 40600

Olympia, WA 98504-0600

CD The News Tribune

P.O. Box 11000

1950 S. State Street

Tacoma, WA 98411

CD/S Donna Noski, Mayor

City of West Richland

3801 W. Van Giesen

West Richland, WA 99353

CD The Oregonian

ATTN: Editor

1320 SW Broadway

Portland, OR 97201

P/CD/S Othello Branch of the Mid-Columbia Library

101 East Main

Othello, WA 99344

$\mathrm{P} / \mathrm{CD} / \mathrm{S}$ Pasco Branch of the Mid-Columbia Library

1320 W. Hopkins

Pasco, WA 99301

CD/S Brad Peck

Franklin County Commissioner, District 1

200 N. Road 34

Pasco, WA 99301

P/CD Valarie Peery

Washington State Department of Ecology

3100 Port of Benton Boulevard

Richland, WA 99354

CD Perma-Fix Northwest, Inc.

2025 Battelle Boulevard

Richland, WA 99354
P Bradley A. Peterson

Director, Office of Independent Oversight

U.S. Department of Energy, HS-60

1000 Independence Avenue S.W.

Washington, DC 20585

P Ed Picazo, URS

West Valley Demonstration Project

10282 Rock Springs Road

West Valley, NY 14171

CD Mike Priddy

Washington State Department of Health

309 Bradley Boulevard, Suite 201

Richland, WA 99352

$\mathrm{P} / \mathrm{CD} / \mathrm{S}$ Prosser Branch of the Mid-Columbia Library

902 7th Street

Prosser, WA 99350

CD Public Affairs Office

Walla Walla District

U.S. Army Corps of Engineers

201 N. 3rd Avenue

Walla Walla, WA 99362

CD Karen Ratel

Brookhaven National Laboratory

Environmental and Waste Management

Services Division, MS 120

81 Cornell Avenue, Building 120

Upton, NY 11973-5000

CD Records Manager

Bureau of Land Management

Spokane District Office

1103 N. Fancher Road

Spokane, WA 99212

2P Ms. Joy Redman, MS 7827

Office of Radiation Protection

Washington State Department of Health

P.O. Box 47827

111 Israel Road

Olympia, WA 98504-7827

CD Regional Administrator's Office, RA-140

U.S. Environmental Protection Agency,

Region 10

1200 Sixth Avenue

Seattle, WA 98101

P/CD/S Richland Public Library

955 Northgate Drive

Richland, WA 99352 
CD Philip Rigdon

The Confederated Tribes and Bands of the Yakama Nation

Department of Natural Resources

P.O. Box 151

Toppenish, WA 98948

CD Wade Riggsbee

The Confederated Tribes and Bands of the Yakama Nation

6304 Collins Road

West Richland, WA 99353

CD Robert E. Safay

Agency for Toxic Substances and Disease Registry

Senior Regional Representative

Atlanta Federal Center

61 Forsyth Street, SW

Atlanta, GA 30303

CD Cheri A. Sawyer

SAIC, NA-261

20201 Century Building, 3rd Floor

Germantown, MD 20874

CD Seattle Post-Intelligencer

101 Elliott Avenue W.

Seattle, WA 98119

CD The Seattle Times

P.O. Box 70

Seattle, WA 98111

P/3CD Paul Shaffer

Department of Nuclear Safety and Energy Siting

Oregon Department of Energy

625 Marion Street NE, Suite 1

Salem, OR 97301-3742

CD Robert S. Sheneman

MS01 C-Site Mod IV 123

Princeton Plasma Physics Laboratory

P.O. Box 451

Princeton, NJ 08543-0451

CD/S Frederique Spencer

Winemaker, Sagelands Vineyard

71 Gangl Road

Wapato, WA 98951

CD Spokesman Review

P.O. Box 2160

Spokane, WA 99210
CD M. D. Squeochs

Department of Natural Resources

Environmental Program

Yakama Nation

P.O. Box 151

Toppenish, WA 98948

P/CD Don Steffeck

Hanford Natural Resources Trustee Council

U.S. Fish and Wildlife Services (ES/EC)

Chief, Environmental Contaminants, Region 1

911 NE 11th Avenue

Portland, OR 97232-4181

CD Lisa Stiffler

Seattle Post-Intelligencer

101 Elliott Avenue W.

Seattle, WA 98119

CD/S William J. Stokes, President

Columbia Basin Consulting Group

1235 Gage Boulevard, Suite 100

Richland, WA 99352

CD Ronald Suppah, Council Chairman

Confederated Tribes of the Warm Springs

Reservation

1233 Veterans Street

Warm Springs, OR 97761

CD Jeff Tayer

Regional Director

Washington Department of Fish and Wildlife

1701 S. 24th Avenue

Yakima, WA 98902-5720

P Priscilla Thompson

Pantex Plant

Building 12-132

P.O. Box 30020

Amarillo, TX 79120-0020

CD Brett L. Tiller

Environmental Assessment Services, LLC

P.O. Box 265

Richland, WA 99352

CD Lisa C. Treichel

13541 Taylorstown Road

Leesburg, VA 20176-6165

CD/S Tri-City Herald

P.O. Box 2608

Tri-Cities, WA 99302 
$\mathrm{P} / \mathrm{CD} / \mathrm{S}$ University of Washington

Government Publications

Suzzallo Library

Box 352900

Seattle, WA 98195-2900

CD U.S. Fish and Wildlife Service

Mid-Columbia NWRC

64 Maple Street

Burbank, WA 99323-0521

CD U.S. Geological Survey

Washington Water Science Center

934 Broadway, Suite 300

Tacoma, WA 98402

P/CD/S U.S. Geological Survey Library 950 National Center, Room 1D100

12201 Sunrise Valley Drive

Reston, VA 20192

CD Scott Van Verst, MS 7827

Washington State Department of Health

Office of Radiation Protection

P.O. Box 47827

Olympia, WA 98504-7827

$\mathrm{P} / \mathrm{CD} / \mathrm{S}$ Walla Walla University

Peterson Memorial Library

104 S. College Avenue

College Place, WA 99324-1159

P/CD/S Andrew Wallo, III

Office of Nuclear Safety and Environment

U.S. Department of Energy, HS-20

1000 Independence Avenue S.W.

Washington, DC 20585

P/S Representative Maureen Walsh

16th Legislative District

423 John L. O'Brien Building

P.O. Box 40600

Olympia, WA 98504-0600

$\mathrm{P} / \mathrm{CD} / \mathrm{S}$ Washington State Department of Ecology Library

P.O. Box 47600

Olympia, WA 98504-7600

P/CD/S Washington State Department of Health

Environmental Section Library

Division of Radiation Protection

P.O. Box 47827

Olympia, WA 98504-7827
CD/S Matt Watkins, Mayor

City of Pasco

8616 Massey Drive

Pasco, WA 99301

CD Charles B. Watson

The MITRE Corporation

7515 Colshire Drive

McLean, VA 22102-7539

$\mathrm{P} / \mathrm{CD} / \mathrm{S}$ West Richland Branch of the Mid-Columbia Library

3803 W. Van Giesen

West Richland, WA 99353

CD Gail R. Whitney, Physical Scientist (ENV)

Savannah River Operations Office, 730-B

Department of Energy

P.O. Box A

Aiken, SC 29802

P Mike Wilson

Congressional Liaison/Policy Analyst

Nuclear Waste Program

Washington State Department of Ecology

P.O. Box 47600

Olympia, WA 98504-7600

CD Yakama Agency

Bureau of Indian Affairs

P.O. Box 632

Toppenish, WA 98948

CD Yakima Herald-Republic

114 N. 4th Street

Yakima, WA 98901

CD Jerel W. Yokel

Washington State Department of Ecology

3100 Port of Benton Boulevard

Richland, WA 99354

CD/S Steve Young, Mayor

City of Kennewick

418 W. Kennewick Avenue

Kennewick, WA 99336

CD Rhett Zufelt

1208 N. Road 64

Pasco, WA 99301

\section{ONSITE}

Rosanne L. Aaberg (CD)

K3-54

Kelle M. Airhart (CD) 
Heather L. Anastos (CD)

Al R. Ankrum (CD)

Ernest J. Antonio (P)

Stuart G. Arnold (CD)

John F. Bagley (2P/4CD)

Brett M. Barnes (CD)

J. Matthew Barnett (CD)

Steven R. Baum (CD)

Thomas G. Beam (CD)

Mark W. Benecke (CD)

Clark P. Beus (CD)

Lynn E. Bisping (P/CD)

Bruce N. Bjornstad (CD/S)

L. Ty Blackford (CD)

Douglas L. Bowers (CD)

Elizabeth M. Bowers (CD)

Harlan C. Boynton (CD)

Paul R. Bredt (CD)

C. Roger Briggs (CD)

David A. Brockman (P/CD/S)

Thomas M. Brouns (CD)

Jan F. Brown (CD)

Ronald C. Brunke (CD)

Robert W. Bryce (CD)

Amoret L. Bunn (CD)

Mary E. Burandt (CD)

Ken W. Burk (CD)

Scott Butner (CD/S)

Paula K. Call (CD)

Jerry W. Cammann (CD)

Mike A. Casbon (CD)

Joe G. Caudill (CD)

Christopher S. Cearlock (CD)

Mickie A. Chamness (CD)

Briant L. Charboneau (CD)

Sherree A. Christman (CD)

Scott R. Clark (CD)

Steven W. Clark (CD)

Suzanne E. Clarke (CD)

Alan J. Colburn (CD)

Mary E. Cole (CD)

Michael S. Collins (CD)

Shannon B. Colson (CD/S)

Carl W. Connell (CD)

Rhonda R. Connolly (CD)

Jill A. Conrad (CD)

Ray J. Corey (P)

William G. Cox (CD)

Gary M. Crummel (CD)

Gloria D. Cummins (CD)

Roger L. Dirkes (P)

Jack W. Donnelly (P/CD)

John J. Dorian (P/CD)
R3-60

K9-69

K3-54

T4-04

BWO

X4-01

J2-25

P7-22

H7-28

R3-60

J2-56

K6-75

K6-81

T4-09

X3-16

A2-15

S5-31

K9-09

K9-42

H6-60

K9-69

H4-02

H8-15

K6-75

K3-61

H6-60

S3-91

K7-28

A7-75

H7- 28

T2-03

R3-31

H4-22

K6-85

A6-33

H8-51

K6-52

H4-23

A6-33

A5-17

A0-26

A6-38

P8-55

H8-51

T4-04

A7-75

A5-14

T5-61

R1-51

H8-15

K6-75

H4-22

H7-28
Janelle L. Downs (P) K6-85

Corey A. Duberstein (CD) K6-85

Joanne P. Duncan (125P/200CD/1,000S) K6-85

Robin E. Durham (CD) K6-85

Dale L. Dyekman (CD) R3-60

Jerry L. Eby (12S)

Richard M. Ecker (CD)

Robert S. Edrington (CD)

Richard H. Engelmann (P/CD)

David B. Erb (CD)

Leif Erickson (CD)

Jon D. Fancher (CD)

Diane E. Faulk (CD)

Toni L. Faust (CD)

Michael J. Fayer (CD)

T4-04

Sequim

R3-50

H8-45

R3-60

A4-19

L6-06

N2-01

H4-23

K9-33

A5-15

P7-50

R3-60

A6-38

R3-60

A3-04

A7-75

K9-33

K6-75

K6-96

H6-60

H4-26

H7- 28

P7-22

K6-84

K6-96

K9-30

A5-17

A6-35

T4-53

H4- 21

A3-04

S5-32

H7-28

A 5-17

S5-31

K6-85

R3-50

K1-36

S2-42

A2-15

T1-21

N3-10

K8-98

K3-55

A6-38

B1-55

H4-22 
Edward R. Jacobs (CD)

Paul H. Jacobsen (CD)

Duane D. Jacques (CD)

Mary Jarvis $(\mathrm{CD} / \mathrm{S})$

Bradley D. Johns (CD/S)

Austin Ray Johnson (CD)

Russell E. Johnson (CD)

Wayne F. Johnson (CD)

Jim D. Kautzky (CD)

Lynn M. Kelly (P/CD)

Ellen P. Kennedy (P/CD)

Charles T. Kincaid (CD)

Deanna L. Klages (CD)

Michael Kluse (P/CD/S)

Greg L. Koller (P/CD/S)

Roger J. Landon (P/CD)

David C. Lanigan (CD)

Kyle B. Larson (CD/S)

Brenda K. Lasorsa (CD/S)

George V. Last (P)

Greg J. LeBaron (CD)

Elwood A. Lepel (P)

Jeffrey A. Lerch (CD)

Michael J. Lindberg (CD)

Steven S. Lowe (CD)

John D. Ludowise (CD)

Kristi J. Lueck (CD)

Stuart P. Luttrell (CD)

Fred M. Mann (CD)

Tom E. Marceau (CD)

Candice E. Marple (CD)

Christopher J. Martin (CD)

Paul W. Martin (CD)

Brian W. Mathis (CD)

Hope E. Matthews (P/CD/S)

Rick G. McCain (CD)

Adrian L. McCall (P/CD)

Matthew S. McCormack (P/CD/S)

Clay D. McCurley (CD)

John P. McDonald (CD)

Doug McFarland (S)

Steve M. McKinney (CD)

Geoffrey A. McMichael (CD/S)

Huei K. Meznarich (CD)

William J. Millsap (CD)

Ron D. Morrison (CD)

John G. Morse (CD)

Robert P. Mueller (CD/S)

Ellyn M. Murphy (CD)

David A. Myers (CD)

Anthony S. Nagel (CD)

Bruce A. Napier (CD)

Susan M. Narbutovskih (CD)
T1-41

G3-31

H4-22

A5-15

K6-75

R3-12

H7 -28

H $4-22$

A3-04

R3-15

K6-75

K9-33

$\mathrm{X} 4-12$

K1-46

K1-33

H4-21

K6-75

K6-85

Sequim

K6-81

S2-42

P8-01

H4-22

P7-22

R3-60

L6-06

T4-10

R3-50

S7-66

H7-28

N1-21

R3-50

T4-52

T2-07

K6-86

B2-62

K1-68

A5-70

X $5-50$

R3-50

K6-75

H7-28

K6-85

S3-30

A1-14

A5-11

A5-11

K6-85

K9-02

E6-31

H7 -28

K3-54

R3-50
Gae M. Neath (CD)

Kathy R. Neiderhiser (P/S)

Dean E. Nester (CD)

Darrell R. Newcomer (CD)

Karin L. Nickola (CD)

Terry W. Noland (CD)

Steve M. O'Toole (CD)

Jennifer F. Ollero (CD)

Brian E. Opitz (P/CD/S)

Gregory W. Patton (P)

Craig J. Perkins (P/CD)

Chris Perry $(\mathrm{CD} / \mathrm{S})$

Jon K. Perry (CD)

Linda C. Petersen (CD)

Scott W. Petersen (CD)

Kirk A. Peterson (2P/13CD)

Robert E. Peterson (CD)

Ted M. Poston (P/4CD/S)

Sylvia D. Powell (CD)

John B. Price (CD)

Raja Ranade (CD)

Bruce A. Rathbone (CD)

Kathleen Rhoads (CD)

Julie R. Robertson (CD)

Annabelle L. Rodriguez (CD/S)

Juan M. Rodriguez (CD)

Virginia J. Rohay (CD)

Donald J. Rokkan (P/CD)

Richard C. Roos (CD)

Fred A. Ruck, III (CD)

R. Woody Russell (CD)

Michael R. Sackschewsky (CD)

John P. Sands (CD)

Daniel G. Saueressig (CD)

Stephen N. Schlahta (P/CD)

Jeffrey P. Shearer (CD)

Fen M. Simmons (CD)

Mary Ann Simmons (CD)

Gregory L. Sinton (CD)

Ray J. Skwarek (P/CD)

Connie V. Smith (CD)

Ronald M. Smith (CD)

Sandra F. Snyder (CD)

Chris Sorensen (CD)

Paul S. Stansbury (CD)

Amanda Stegen (CD)

Robert D. Stenner (CD)

Christopher P. Strand (CD)

Scott D. Stubblebine (CD)

Monte J. Sula (CD)

L. Craig Swanson (CD)

Mark D. Sweeney (CD)

Alex E. Teimouri (CD)
H6-60

K6-90

T4-08

K6-96

H8-75

H7 -28

S7-90

H7 -28

K6-75

K6-75

H7-28

K6-85

H7-28

T4-04

R3-50

H7-28

K6-75

K6-75

K6-85

$\mathrm{HO}-57$

H7-28

P7-01

K3-54

E6-31

A5-15

T1-32

H8-15

H7-28

R3-12

H8-45

H6-60

K6-85

A3-04

N3-30

K6-83

H8-51

H8-45

K6-85

A6-38

R2-50

A4-52

K6-96

K3-54

H6-60

K3-54

K3-66

K3-54

L7-10

H6-60

Sequim

R3-50

K6-75

A3-04 
William Thackaberry (CD)

K. Mike Thompson (CD)

Suzette A. Thompson (CD)

Harold T. Tilden II (CD)

Wayne E. Toebe (CD)

Arlene C. Tortoso (CD)

Steve Trent (CD)

Geoffrey T. Tyree (CD/S)

Wooyong Um (CD)

Barry L. Vedder (CD)

Jeffry A. Voogd (CD)

Curt B. Walker (CD)

Dana C. Ward (30P/50CD/50S)

Dave Watson (CD)

Christine R. Webb (CD)

Kriss E. Weeks (CD)

Regan S. Weeks (CD)

Michael J. Weis (P/CD/S)

Nancy L. Weston (CD)

Dana L. Widrig (CD)

Debra J. Wilcox (CD)

Justin W. Wilde (CD)
R3-60

A6-38

H7 -28

K3-75

H8-45

A6-38

R3-50

A7-75

P7-22

H4-21

R1-51

S2-51

A5-15

X4-01

H8-51

S5-31

K3-75

K9-42

T4-10

R3-50

A4 452

H7 -28
Bruce A. Williams (CD)

H8-51

Janice D. Williams (CD)

$\mathrm{H} 8-43$

A4-52

R3-60

A3-03

H8- 15

S7-34

H7 -28

H8- 51

P7-28

H4-21

K9-36

T6-10

H6-60

K8-96

A3-04

G3-70

$\mathrm{H} 2-53$

DOE Public Reading Room (2P/2CD/2S)

Hanford Site Administrative

Record $(2 \mathrm{P} / 2 \mathrm{CD} / 2 \mathrm{~S})$

H6-08

Hanford Technical Library $(2 \mathrm{P} / 2 \mathrm{CD} / 2 \mathrm{~S})$

P8-55

Historical File-J. P. Duncan (P/CD/S)

K6-85 
Prepared for the U.S. Department of Energy under Contract DE-AC05-76RL01830 by 